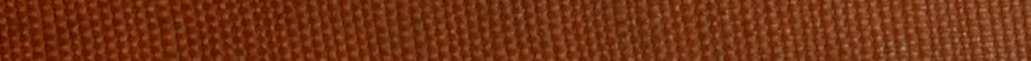
E.6. 5.

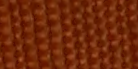









\section{AZ FÖLOSZTVA ALKOTẢSA SZERINT \\ AXAPUZ SZOLGALANDó

\section{AZ ÁLLATOK TERMÉSZETLEIRÁSAHOZ}

6 BEVEZETÉSỨL AZ ÖSSZEHASONLITÓ BONCTANHOZ.

\section{Heprais}

\section{CUUIER BÁRÓ}

A BECSÜLETREND NAGYKER. OHSZÁgTANÁcsos a KÖZ OKTATÁs KIR. TANÁCSíbaN, Egr a

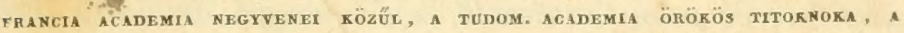
LONDON, BERLINI, TÉTERVÁRI, STOCKHOLMI, EDINBURGI, KOPPENHÁGAI, GÖTTINGAI. TURINI, BAJOR, MODENAI, NÉMETALFöLdi, CALCUTTAI ACADEMÍ́K ÉS KYR. TÁRSASÁgoK, s a rondoni linnéi társaság taga stb. f́ltal.

TERMÉSZET UTÁN RAJZOLT ÁBRÁKKAL.

A MÁSODIK ÁTNÉZETT ÉS ÖREGBÍTETT KIADÁS SZERINT

YoRDíToTA

\section{y J D P T R,}

in. acad. levelezó tag.

\section{KÖTET.}

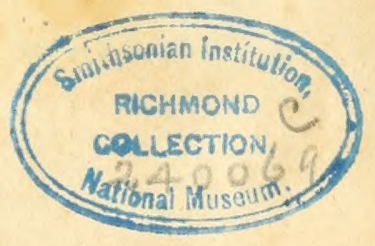

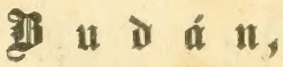

A. MAGYAR KIRÁLYI EGYETEM BETÚIVEL.

A M. ACADEM. KÖLTSÉGEIN.

81. 
Sogè

arsols ous s.

b.

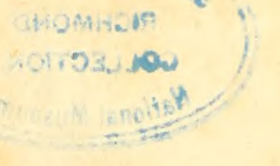




\section{T U D N I U A L Ó K.}

1. A' nugyar Ludós társasíg ezen munkának csak ki adoja lévén, nem kezeskedik a’ benne követett nyelvsza. bályokról, sem irásmúdról, sem végre akármi nemü nyelvet s irást illetö elvekról: egyedül arra kivánt a’ kéziratok' birálatában ügyclni, $\log y$ az ellogadott és sajto ala bocsátandó munka, mint egész, egy vagy más tekintelböl, ajúnlható legyen, 's a' literatura' jelen állapotjában kiadásra méltónak tartalhassék.

2. Nem vizsgálhatrín meg a' benyújtolt kéziratokat a lársaság fejenként és egészben; ez u. m. ,AZ ÁLLATORSZÁG, fölosztva alkotása szerint, b. Cuvier Györgytöl, fordíva Vajda Péter íltal," Schedel Ferencz r. \&s Pólya József l. tagok', mint e végre hivatalosan megbizoltak’ ajánlására aditotl sajtó alá.

3. E’ munka azon 61 közuil való, mellyek' forditására a' társaság 1832-ben martiusban a' magyar irokit felszólította.

4. A' társaság által kiadott kéziratolsnak ez LXX-dl. kölcte.

Pesten, martius' 15-d. 1841.

\section{Scheder Ferencz, titoknok.}





\section{A FORDÍTÓ RLÖSZAVA.}

Kuïönbözö okokbul s\%ïlséges mergemlitenem axon körälményeket, mellyek kozöt jelen munka magyarrá saületék, föképen pedig axint, hogy ar. olvasó közonség vagy inkábl, a lumuló oszatily hiundja, mit kelljen benne nekem érdemiil és ellenérdemäl fölrónia. Rin részemrial annyival készeblen teszem azt, mett nem tudom, mikor adjat maghit alkatom eki), hol illy édemes leme szimot admom literaturai mukálkodísomrul.

A természetiránti sacretet sok kebello be van olva, - én imádtam a rermészeted. lis hat nem mondhatom is, a mit sajuosan cryek, hogy életem nagyobb részé a természench áldozással töldhelóm, annyit állsthatok, hogy kémlöje mindenkor valék s öromeim legszebl részét az ö kebelóbuil szivtam. A sor's is ugy latszott akarni, hogy kiolhhatlan rokonszenvel viselessem a természethez, mert fogékonyságot ada egy részrul bajai iránt, és sok tásas

$$
a^{i f}
$$


oromöl megtagadva tólem, egyenesen ó hozzát mutatí hi utamat. Már a gyermek a természeté vala. İoolyaígyak szolgáltak pamlagául a honi kertekben és kertek alatt, zöld pázsit vonult el számára majel minden világrész folé az árnyas erdökig; rétek virultak neki Flora czer gyernekével s a levegö dalosithal pezsgett körtile. Wind ezekre a bakonyi szép nap mosolyga le s a gyermek örömét legtisztább kek ig lakará. Hogyan feledhette volna ezt el a falı egyszerü fia, midőn az apai tüzhelytül tívozék s magát az oskolai falak közé zárandó, Sopronba ment? A tanulmányok minden bájai között nem felejthezék el szerelmesérül s midön a jövendö szimára kincseket iparkodék gyüjteni, a jelent egész tcljében éldelé. - Kéjfalotája a szabad természet maradt.

De a tanulás is éldelete volt: mert mindent a tanulástul reméle. Kopár jelenét, ellagyatotságát megorvosolhatni gondolá s midön oskolíkba ment, szebb jövendönek vélt elébe menni. Szomjas keble remegre szitta magába az oskolák hincseit s feje napot gondola kifejteni magában, tükrét azon szép napnak, melly gyermeksége szép egén mosolyga. Niut a hold-kóros kedves csillaga után vándorol, ugy ment ö remélı világának ellenébe. Györött az Academia derék embereit hallgatá s Pestre jöt részint a koszorút tenni föl törekvéseire, részint bajokkal küzdeni, hogy száz göröngy között egy virágot szakaszthasson. 
Természethezi vouzódásom huzotl az orvosi pályára, melly közben igazlalanság történt velem. nagy, és fölkiáltó a jog istenéhez. De errül ne többet. Hagyva pályám egyik felét, annál otthonosabbnak gondolám magamat a másik félen, mellyre erómet szentelni szándékozám. S eröt gyaniték érezni lelkemben némi dolgok végrehajtására. Hiszen az ifjú kebele olly teli, akarata olly szent: hazájának, nemzetének munkálkodni! Hagyva a korúzö istennét, az ép természet papjíví akarím magamat szentelni. Ekkor volt azon szép idö, mikor literaturánk álmábul ébredve, czer remények közt éldelé ébredése elsö perceit. Az Academia fölállt és minden módot megkisérte a hatásra. Munkára szólíta föl az elmei törekvés egész mezején minden erót. Cuvier ki lön tüzve lefordítás végetı, az Állatország híres, remek leirója. Ezen óriási munkára én bátorkodtam; hihetó sem én, sem az Academia nem gondoltuk, hogy olly sokára érjünk czélt.

Cuviert társul fogadva látogatám és használtam a londoni zoologicus kerteket, hol az elsó osztályokbul élö példányokban láttam a fajok nagy részét s midön haza jöttem, az emlösek le voltak fordítva. Reményem volt ekkor, állatvizsgálóvá képeznem ki magamat. De a tudományos literatura nem gyümölcsözött. A nap szükségei beszélyt kivántak s beszély, rege, költeményiróvá lettem. Elzengém a Nap szakaszait s azóta sokszor gondolám: bár ki- 
zengtem volna benne keblem egész érzetét, bár leirtam volna minden irandót, mert az irói pálya, mint keresetmezö, iggen sovány és rosszul jutalmazó. Jobb lett volna elhuzódnom a haza bármellyik szegletébe $s$ a nap alatl dolgoznom, mig itt a hálátalan munka négy fial közé szorít. És ha nagyszerú dologhoz láthattam volna! de aprólékokra kellett veszlegetni a drága idöt, szabadalomért küzdve a sorssal, hogy irhassak néhíny lelkes sort, - elöadni kénytelen, mik nem lelkembül fakadtak.

De a túrgyhoz térek. Mig az irigylendö sorsu Cuvier a sok szép alkalmat számlálja eló, mellyek öt képessé tevék illy embereröt haladó munka elöállitására; mig ö barátokat soroz elö, lik a pályát egyengeték vele s kezére dolgoztak, addig nekem azt kell mondanom: segéd intézet volt is számomra nem is, segítö barátom volt is nem is, és mig egyszer dolgozék mellettem a sors, addig szárzzor volt ellenem. Azért barátsángosan kérlek, ne csudáljátok, ha hiínyokat talíltok a munkában: minél nemesebb a gyümöles, annát melegebb napot kivín érésére, én melog naprul keveset mondhatok. De at. volna rendkivüli s azon ïlközhetnétek meg, ha hiányokra illy hímyos korrülményeknél nem akadnátok.

Kérdezitek: honnan vellem nevet e sok emlös és madir-nemnek és fajnak, midön elöttem olly kevés vala megneverve és most mindnyáfínak kell magvar nevének lenni. Erre azt felelem: a minek 
népi közönséges neve nem volt tudva elöttem s a minek Földi Jánosnál nem találtam nevét, annak minden vonakodás nélkül keresztapja lettem. Irtóztató sokba került volna ugyan - és részemrïl vég. re lajuható nem lett volna - ha minden fiú keresztcléscuél csak garast kellett volna is fizetnem: de az a jó, hogy magam voltam minden egy személyben s igy a díj zsebemben maradt sôt méğ toldatik is. Keresztfiaim nem igen hányhatják, vethetik ugyan emlékpénzeiket, mert irtóztató sokan vanuak, de más részrül meg kell ebben is nyugodni; a sze gény szerenese is szerencse, - $s$ olcsó munka mellett csak a nagy közönség nyer. Azt az egyet ohajtottam volna, hogy a balsors ne gátolja dijan fölvételét 1\$35-tül, 1\$41-ig, mert ha az el nem marad illy sokíig, választott mezőmön igen és igen elöre volnék.

De ezen idö még sem folyt le minden jó nélküil. Javultak körülményeim, bejuték az Acade-miába és igy társok lettem sok olly férfiaknak, kik a tudomány diszei s kikre a haza büszke lehet. Az. Academiában és kivül ösmerôseim, barátaim lettek nagyobb részint mind, kik a természeti tudományol mezején buzgalommal és sükerrel munkálkoduak. Egyike ezeknek a madarak osztályánál viva ki magának diesôséget, a másik rovarok tekintetében Europaszerte ismeretes, egy harmadik az egés\% tudományt öleli at és müszavakat alkot és rendez, negyedik ötödik a fïvészet mellett szinte allatvizsgála- 
lokat is gyakorol, és igy tovább. Ezen f'érfiakal naponként közlekedve, egészen új tér nyilik elöttem s váratlan ut a kritikaibb dolgozásra. Azon ponton vagyunk és vagyok, logy a muzeum és egyetem tárainak bilincsei is egyre jobban szakadoznak s a tudományé lesz az, mi eddig a poré rala. Ezek végetleniil jobb körülmények, mint mellyekben hat év elölt valék.

A mumka folytatását illetólegr megvallom, logy örömömre szolgálua végre hajtani azt, mibe kezdellem, de az mégsem tólem, hanem az Academiátul függ. Ha ez szíves lesz gyámolítani: ij eróvel, s ismeretségem egész használatával látandok munkához. Es ha meggondolom hogy az osztályonként kidolgozott állatlan, melly Cuvier szerencsés fölfogása szerint ciupa lényegességeken alapul, kor és nemzet szuiksége minálunk, hogy oskolák, tanilúk és tanulók érezik hianyát, s végre fontolora vévén azon szerenciés fordulatot, melly a latin nyelv helyébe magyar nemzeti nyelvïnket teszi az oskolákban: nem akarok kételkedni, miszerint Academiánk a megkezdett munkitt buzgún folytatni kivánandja s a mit részérül az ügyben tehet, megteendi. Az állattudomány ę̧ ges osztályainak nem kevés mívelöje van nálunk, ezeknek pedigg, hogy alaposan dolgozzanak, épen Cuvier munkájáura van szükségök, mert è az összehasonlito boncolatot adja, melly nélkiil ma a tan épülete nevét sem érdemli. Cuvier almulatasai szerint kömnyen fejlöd- 
hetnek ki hazánkban állattudúsok, egyes osztályokat kimerítók, kiknek nyomdokain egyes lángész. vagy lársulat könnyen adandhatja az egész allatországot.

Hazánkban a sok teendők között bizonyosan igen magas helyen állván a természeti tudományok mívelése, s ezeknek olly ágaik lévén, mellyek korunk dicsöségét teszik, ezereknek örömöt szereznek $s$ a köz boldogságot hathatósan elömozdítják: nem szükség mondanom, hogy hozzájok, hogy mívelésökhez lelkesen kellenc fogni, mert azt kiki tudja, az Academia pedig mindenek fölött. Részemıül csak azt ohajtom : bár minél elöbb gondoskodjék a nemzet elegendö erőrül és pénzalaprul, mellyel a tudományok mélyébe lehessen nyulni, különösen pedig ezen tudományokéba, mellyek a legnagyobb visszahatással vannak a közéletre s mint a termékeny szántó föld, sokszorosan fizetik vissza a beléjek vetetí magvakat.

Midőn pedig elöszavambani eltéréseimért olvasóimtul bocsánatot, a nemzettül pedig a munka becse tekintetében kegyes elnézést kérnék, midön tudósainkat arra szólitanám föl, mérjék szorgalmam gyümölcsét a körülményekhez, és a kritikusokat. hogy keljenek ki a munkáshiány ellen, melly nem állita föl concurrentiát illy nagy munkában s róják meg az erösebb válluakat, miért nem vállalák magokra e nagy terhet: átadom az állatország két első osztályát hazám és nemzetemnek, hiányai érzése 
XIV

A Forditó ETöszava.

mellett azon egy vigasztalással, hogy szent volt nálam az akarat és szent is marada, $s$ ha a süker. annak felele meg, semmi kivínandó nem marad vala hátra.

Pesten Tavaszelö 2-d. 1841.

VIJDA. 


\section{A SZERZÖ ELÖSZAVA}

\section{AZ ELSÖ KIADÁSHOZ.}

Hajlandóságbul, első ifjuságom óta az összehasonlitó bonctudomány tanulására szánván magamat, azaz az állatok müszeressége törvényeinek és azon módosílások kiösmerésére, mellyek e múszerességgel történnek a kölönböző fajoknál, és majd harminc év óta e tudományra szánván mind azon perceket, mellyek kötelességeim teljesítése mellett szabad rendelkezésem alá estek: munkáimnál állandó célom volt, visszavezetni őket általános szabályokra s legegyszerübb kifejezésü tételyek alá. Első kisérleteim azonnal észrevetették velem, hogy azt elóbb, el nem érem, mig azon állatok, mellyek alkatát meg akarom ismertetni, nem lesznek épen ez alkatás szerint elrendezve, olly módon, hogy az osztály, rend, nem stb. egyetlen neve alatt mind azon fajokat össze lehessen foglalni, mellyek mind belsö mind külső alkotásokra nézve általánosabb vagy részletesebb hasonlatosságot birnak. De épen ezt nem törekedett tenni a korunkbeli természetvizsgálók na- 
gyobb száma, söt közülök igen kevés tehette volna, még akarva is, mert az illyen elrendelés eléggé kiterjedt ismeretét teszi föl azon alkotásnak, mellyet némileg ábrázolni akar.

Taló ugyan, hogy Daubenton és Camper adatokkal léptek eló, hogy Pallas nézeteket állíta föl: de ezen tudományos emberek eszméi még nem gyakorlottak olly befolyást kortársaikra, minót érdemlettek. Az állatok egyetlen általános sorjegyzéke, melly akkor létezett és ma is megvan, Linné rendszere egy szerencsétlen kiadó által elidomtalaníttaték, ki még nem is fáradozott azon, hogy ezen elmés rendszerkészitönek elveibe béhasson, és a ki akárhol talála némelly rendetlenséget, törekedni látszék azt még oldozhatlanabbá tenni.

Igaz ugyan, hogy egyes osztályokrul nagyon kiterjedt munkák voltak, mellyekbül számos új fajt lehetne megismerni; de szerzöik többnyire csak külsó viszonyait tekinték e fajoknak, és senki nem foglalatoskodék azzal, az osztályokat és rendeket az alkotás egyeteme szerint állítani össze; több osztályok bélyegei hamisak vagy hiányosak maradtak, még a méltán híres bonctani munkákban is; a rendek egy része önkényti volt s a fölosztások majd egyikében sem voltak a nemek természetszerüleg egymáshoz sorozva.

Kellett tehát - és ezen kellés sok időmbe került - a bonctant és állattudományt, a boncolást és osztályozást kézen fogva járatnom; elsô vizsgála- 
taimban a müszeresség felül, jobb elosztásokat keresnem; ezeket használnom, hogy új észrevételek hez jussak; ezen észrevételeket is alkalmaznom, hogy az elosztás tökéletesíttessék; végre a mint ezen két tudomány közül eģyik a másikat kölcsönösen termékenyité, egy állattani rendszert kelle elöállítanom, melly bevezetésül és kalauzúl szolgáljon a bonctudomány mezején, és boncolati tant fỏlállítanom, melly fejlődést szerezzen és magyarázatot adjon az állattani rendszernek.

Ezen kettős munka első eredményei 1795 ben jelentek meg egy emlékiratban a fehérvérü állatok egy új fölosztásárul. Megkisértém őket a nemekre alkalmazni s ezek alnemekre való fölsztásánál használni illy munkámban: Tableau élémentaire des Animaux, melly 1798-ban nyomaték; kijavítám e munkámat Dumeril ur segedelmével azon tabellákban, mellyeket a „Leçons d' anatomie comparée, $1500^{66}$ elaő kötetéhez csatoltam.

Meglehet hogy beértem volna ezen tabellák tökéletesitésével s azonnal, közvetlenül nagy bonctudományom közrebocsátásához fogtam volna, ha fürkészeteim folytában igen gyakran meg nem botlottam volna ez állattudomány általános vagy részletes rendszerei nagyobb számának más hiányában; azon zavart értem, mellyben a kritika hiánya számos fajokat, sőt nemeket is hagya.

Nem csak az osztályok és rendek nem voltak megegyezésben az állatok bensó természetével, hogy 
kényelmes alapul szolgáltak volna az összehasonlitó bonctant fejlegető iratnak; de a nemek magok is, ámbár rendesen jobban voltak alkotva, csak ki nem elégitő segédforrást nyujtának az elnevezésben, mert a fajok nem a bélyeghez alkalmazottan voltak egymás alá állogatva. Igy a kézceteket a rozmárok nemébe, a syrént az angolnákéba tévén, Gmelin lehetellenné tön minden íltalános magyarázatot ezen nemek alkotására nézve; midön ugyan azon osztúlyba, rendbe s egymás oldalára vezeté össze a sepia-t (Téntaféreg F.) s az édes vizbeli polypusokat, lehetetlenné tevé valami közönségeset mondani azon osztályrul és rendrül, mellyben olly különböző lények foglaltatnak.

Itt a legszembeszököbb példákbul választottam; azonban számtalan van még, melly clsó látásra keresebbé ötlik föl, de következményeiben nem kevesbbé alkalmatlan.

Nem vala tehát elég, hogy új osztályokat és rendeket állitsak föls oda illendöleg helyeztessem a nemeket; szükséges vala még a fajok mindnyáját is megvizsgálnom, hogy kitudjam, ha valóban azon nemekhez tartoznak-e, mellyekhez adattak.

Midón pedig ehez fogtam, látám hogy nem csak fajok halmoztaltak össze vagy hányattak szét minden elv nélkül, de észrevevém, hogy némellyek nem is tevóleges módon állittattak föl, azaz sem a rájok fogott bélyegeknél, sem azon ábrák és leirásoknál fogva, mellyek mellettek fölhozattak. 
Egyik közülök, a hasonnevezeteknél fogva, egy név alatt töbljeket is ad, és néha annyira különbözóket, hogy még azon nem alá sem tartoznak; néha egy faj kettőztetve, hármaztatva van és egymás után több alnemben, több nemben és néha különböz:ö rendben is fölhozatik.

Mit mondjunk p. o. Gmelin Trichechus manatus-árul, melly egyetlen faj-név alatt három fajat és két nemet, két majd mindenben különböző nemet foglal magában? Mi néven szóljunk, ,Velella“_ járul melly kétszer jö elő a meclusá-k között és egyszer a holothuriá-knál? Hogyan gyüjtsük össze a biphorákat, mellyek közül némellyek dagysa, a legnagyobb szám salpa néven neveztetik, sok pedig a holothuriá-k közé téteték át.

Illy módon a cél teljes elérése végett nem vala elegendő, átvizsgálni a fajakat: szükséges volt még hasonneveiket is átfürkészni ; azaz újra kellett alkotni az állatok rendszerét.

Illy vállalat, azon bámulatos kifejlödés mellett, minőt e tudomány nehány év óta tön, teljes kiterjedésében minden magános férfiutól végrehajthatlan vala, még akkor is, ha neki leghosszabb életet és teljes függetlenséget tulajdonítunk is; én magam sem lettem volna képes ezen jelenleg átadandó rajzot elkészíteni, ha tulajdon saját segédszereimre lettem volna szoritva; de helyezetem eszközöket szolgáltata kezembe, mellyek pótolhaták időm és tehetségemel. Olly sok ügyes természetvizsgálók kö- 
zött lakván; használván munkáikat a mint megjelentek; olly szabadon haszuálva gyüjteményeiket mint ök magok; magam is alakítván illyen elég nevezeteseket, saját szükségemhez alkalmazottakat: munkám nagyobb része nęm állott másban mint illy gazdag anyagok használatában. Nem vala lehetséges, hogy sok tenni valúm maradjon, például a conchyliáknál, mellyeket Lamark ur kimeríte, sem a négylábuaknál, mellyeket Geoffroi úr irt le. Levaillant úr a minden oldahrul összegyüjtött szép madarakon észrevette a müszcresség azon részleteit, mellyeket én fogadék el tervemben. Saját fürkészeteim más természetvizsgálók által használva s termékenyítve, olly gyümölcsöket terménck számomra, mellyeket magam kezei között nem teremhettek volna. Igy Blainville és Oppel urak megvizsgálván a csináltam mülárban a bonctuni készítményeket, mellyekre hüllöim fölosztását szándékozám alapitani, abbul elölegesen s talín jobban mint magam képes lettem volna, olly eredményeket vontak ki, mellyeket magam csak sejditék stb. stb.

Ezeket meggondolván, fölbátorodtam s elhatározám, hogy összehasonlító bonctanom elött az állatok némi rendszerét adom ki, mellyben osztályaikat minden fokon elóaduám, közegyenüleg építve azt belsố és külsố alkotásokra; hol kimutatnám a valódi fajokat, mellyek bizonyosan ezen alosztályok valamellyikéhez tartoznak, és a hol az érdeket nevelendö, bemerülnék a részletességhe is azon fijok- 
nál, mellyeket vidékeinken való bövelkedésök, a belólök háramló haszon, az általok okozott kár, szokásaik s életmódjok különössége, redkivüli idomaik, szépségök vagy nagyságok nevezetesebbekké tesznek.

Ez által hasznossá remélék lenni a fiatal természetvizsgálók elött, kik nagyobb részint keveset sejtenek a zavarbul és a kritika hibáibul, mellyekkel a leghitelesebb munkák is hemzsegnek, s a kik, kivált idegen országokban, nem foglalatoskodnak eléggé a lények alkotásának valódi viszonyaival; még egyenesebb szolgálatot remélék tenni a bonctanároknak, kik elöre kötelesek tudni, melly osztályokés rendekre fordítsák kémlelődésöket, midön azt teszik föl magokban, hogy az összehasonlitó bonctan által az emberi bonc- vagy élettan valamellyik föladatát világosítják föl, de kik rendes fugglalatosságaik miatt nem készültek eléggé, hogy sükerrel dolgozások e lényeges föltételét jól betöllhessék.

Mindazáltal nem törekvém e kettős nézetet az ország minden osztályaira egyenlöképen kiterjeszteıi; a gerinces állatokkal kellett fóképen foglalatoskodnom, mint minden szempontbul érdekescbljekkel. A csontváztalanok között részletesebben kclle tanulnom a csupasz puhángokat és a nagy állatagácsokat; de a kagylók és korallok külsô alakainak számtalau különbségei, a nagyító állatai, és azon családok, mellyek a természetben nem játszanak igen kitünő szerepet, vagy mellyek alkata kevés

CUVIER I. K. 
zsákmányt szolgáltat a bonckésnek, nem kivántak olly nagy részletességü előadást. Különben pedig, a kagglók-és korallokra nézve az épen kiadott Lamarck munkájára hivatkozhatám, mellyben mind azt e@̣ütl taláhni, mit a legforróbl) tudásrágy követelhet.

A rovarokra nézve, mellyek külsö alakjok, alkotások, szokíssiik s az egész élö természetre gyakorlolt befolyások által olly érdekesek, szerencsém vala oll r segedelmet találni, melly végetlenül tökélelesebbé tevé munkámat, mint az tollam alul jöhele ki, s egyszersmind közzé télelét is nagyon sietteté. Tiszúrsam és barátom Latreille úr, Europa embere, ki legnagyobb alipossággal tamulá ezen állatohat, szíves vala egy kötechen adni s majdnem azon rendben, mellyet a többi részekben követék, végetlen vizsgílatai eredményét és azon számtalan nemek rendszerét, mellyet a rovaríszok nem szünnek meg fölállítani.

Különben, ha némely helyeken kisebb terjedelmet adok az alnemek és fajoknak, ezen egyenetlenségnek nincs helye abban, mi a fölsöbb elosztásokat illeti és a viszonyok kijelelését, mellyeket mindenhol egrenlóleg szilárd alapra álliték, mindenfelé hasonlóliıg szorgalmasan vizsgálódván.

Egyrúl egyre kivizsgáltam minden fajt, melylyet a természetben meg tudtam szerezni; közelre hozám egymáshoz azokat, mellyek nem különböznek egrmústul egyébben mint a nagyságban, szin- 
ben vagy némelly kevesebbé fontus részek számában, s ezen módon csináltam az alnemet.

Mind annyiszor, midön lehete, fölboncolék legalább egy fajt mindenik alnembül; s ha kiveszszük azokat, mellyeknél a bonckést alkalmazni lehetlen, igen kevés csoport van könyvemben ezen fokrul, mellynek müszereibül legalább nevezetes részt ne tudnék elömutatni.

Miután ezen fajak nevcit meghatározám, melylyeket magam vizsgáltam meg, s mellyek már az elött jól ábrázoltatlak vagy leirattak, ugyan azon alnembe rakám azokat, mellyeket nem láték, de mellyeknek az iróknál eléggé pontos ábráját találtam vagy eléggé szigorú leirásokat, annyira, hogy a természeti viszonyokrul semmi kétség nem marada fön; de hallgatással mellözém azon ingatag jelelmények nagy számát, mellyekkel véleményem. szerint nagyon is törekedtek fajokat fölállítani, és mellyek elfogadása okozá leginkább, hogy a lények névsorába azon zavar csuszott be, melly hasznosságának igen nagy részét elveszi.

Majd mindenütt nevezetes mennyiségben hozhattam volna föl új fajokat; de minthogy ábrákhoz nem adhaték utasítást, szükséges lett volna leirásokat többre kiterjeszteni, mint a hely megengedé; tehát inkább meg akarám fosztani munkámat ezen dísztól, és csak azon fajokat jelelém ki, mellyek különös alkotás miatı új alnemeknek szolgáltatnak alapot. 
Midön alucmeimet bizonyos iszunyokra alko-tám és valólag meghatározolt fajolibul össze állitám, nem marada más hátra, mint a nemek, törzsökök, családok, rendek, osztalyok és ágozatok azon nagy alkotmányát készíteni el, melly az állatország egyeiemét teszi.

Itten részint azon múdot tartím meg, hogy az itsó elosztísoktul a fölsöbbehhez haladék a közelités c's összehasonlitís utján, részint megfordítva a felsöbbbektül bocsátkozva az alsóblakhoz a bélyegek alírendelésének elve szerint; gondosan összehasonlítra a két módszer eredményeil, egyiket a másik allal igazitva ki, s mindig arra törekedve, hogy a belsö idomok megfeleljenek a külsöknek, mellyek mindenike minden állat lényegének kiegészitö részét teszi.

Igy látlam mindany iszor a dologhoz, midön sziiksóges és lehetö vila új elrendezést csinálni; de nem szuikséges azt mondanom, hogy az ország több részeilben azon eredmények, mellyekhez jutulam volna, már olly kielégitö fokon voltak elöállitva, logy más baj nem marada számomra hátra, mint elödcim nyomdokát követni. Mindazáltal még ezen esetben is, midön nem kelle többet tennem miut ök tettek, új észrevételek által igazolám és bizonyitám azt be, a mit elöttem ismertek meg, és nem fogadám clöbb el, mint miután szigorú vizsgúlatnak vetém alája.

A hözonség fogalmal szerezhcte magának a vizs- 
gálat e nemérül a puhángok bonctanárul szóló értekezésben, melly a Museum évkönyveiben jelent meg s mellynek mostanában külön és öreģbített. gyüjteményét adom ki. Merem állítani, hogy szinte olly terjedelmes munkát tettem a gerinceseknél, annelidá-knál, állatnövényeknél és a rovarok és héjángok nagy számánál. 'Nem tartám szükségesnek, hogy ezeket hasonló részletességgel adjam; de minden készitményem ki van téve a füvészkert össıehasonlító bonctani teremében, s ljonctudományi munkámhoz fog hisszáltatni.

Egy másik eléggé nevezeles munka, de mellynek pontjait nem lehet annyira kutfósiteni, a fajok kritikai megvizsgálása. Én az irók által fölhozott képeket mind megnéztem és mindeniket, a mennyire tudtam, valódi fajához helyezém, mielótt kiválasztottam volna azokat, mellyek $\mathrm{ki}$ vannak jelelve; és csak csupán ezen valódisitás utản, soha sem az elóttem irt módszeresek osztályozása szerint sorozám alnemeimhez az oda tartozó fajokat. Innét láthatni minden csodálkozás nélkül azt, hogy Gmelin illy neme különbözö nemek és ágazatokba van szétrakva, hogy több fölhozott faj egyetlen egyre vonaték össze, s hogy a közönséges nevek egészen különbözöleg vannak használva mint az elótt. Ezen változtatások között nincs egy is, mellyet nem volnćk képes igazolni s mellynek az olvasó maga is meg nem találná bizonyságát, ha a fölhordandó kutfókhöz kész folyamodni. 
légre hogy e bajon segitsek, gondoskodva vítlaszlék minden oszály számára egy fö auctort, rendesen azt, ki leginkább bövelkedik jo eredeti ábrákkal s a másodrangu munkákat csak akkor hozom föl, ha ez nem szolgáltat mil sem kezemre, vagy ha célszerú lett némi összehasonlitíst tenni at hasonnevek jobb meghatározása végett.

Tárgyammal köteteket tölthetlem volna meg, de kötelességemnek tarlúm azt összehuzni, szerkesztésbeli röviditö módokat gondolva hi hozzá A fokozatos általínossángok álal érlem ezt el. Soha nem ismételve azt a fajnál, a mil az egész alnemroil lehet mondani, nem a nemnél azt, mi az egész rendrül elmondható, iły jutunk el a szóbcli legnagyobb gazdátkodáshoz. Ide törekedtem mindenck elótt, amnyival inkább, mivel valósággal e vala munkám fó célja. Mindazonáltal észre lehet vemi, hogy nem sok múszavat használok, hogy eszméimet a gyártott szavak mind azon barbar készülete nélkül törekvém elöadni, melly olly sok mostani természetvizsgátók munkáiban alkalmallankodik. Ugy hiszem, hogy e törekrés által mit sem veszték el a pontosság és értelmességbül.

Sajnos, hogy sok új nevet kelle életbe hoznom, noha leguagyobb gondot fordíték az elöttem irtak neveinek megtartására; de az általam fölállított sok alnem új elnevezést kivána; mert az illy tarkázott tárgyban az emlék ezó tehelség nem éri be csupa szémbeli megjegyzéssel. Ezeket ugy választám, hogy vagy 
némi bélyeget fejezzenek ki, vagy a szokott nevet latinosítám, vagy végre Linné példáját követve, a mythologiábul kölcsönzék neveket, mellyek kedvesen hangzanak a fülben és még közel sincsenek kimerítve.

Mindazáltal azt tanácslom, hogy midón a fajt akarja valaki megnevezni, csak a fönem fönevét használja és a fajét. Az alnemek nevei csak arra vannak szánva, hogy az emlékezö tehetséget segitsék, midön ezen alsó elosztásokat akarjuk részletesen kimutatni. Különben, miluelyt a már is számos alnemek idövel még tovább fognak szaporodni, kénytelenck lévén több föneveket jelehni meg, utoljára annak leszünk kitéve, hogy elvesztjük a Limé által olly szerencséser kigoondolt kettös elnevezés hasznait.

Ezt minél nagyobb tisztelerben akarván tartani, a mennyire lehete, el nem daraboltam a tudomány e nagy reformatorának fönemeit. Valahínyszor az alnemek, mellyekre öket elosztom, nem voltak különbözö családokba átteendők, együtı hagyám óket régi nemi nevök alatt. Ez nem csak azon tiszteletbül törtéut, mellyel Linné emlékének tartozom, de szükséges figyelem is volt, hogy megtartassék a traditió s a különbözö országok ter'mészelvizsgálóinak kölcsönös egymást értése.

E köny v tanulását még tovább akarván könynyíteni, mert inkább tanulás mint olvasás számára van készítve, különbféle fiju betüket használtam a nyomtatáshoz olly módon, hogy azok az eszmék ál- 
talánossága fokainak megfeleljenek. Mind az, mit a fölsö elosztásokrul lehete mondani, bezárólag a törzsökök- vagy alcsaládokig, ciceróbul van szedve; mind az, mi a nemeket illeti, philosophiábul; az alnemek és más elosztások, apró romanabul vannak; de röridehb sorokban vagy négyszöghe foglalva; régre a lap aljára helyezett jegyzemények, mellyek a kevesbbé fontos fajok elösorozását, a hasonnevïség hörüli észrevételeket, vagy elödeim munkáiban talált hibák elöadását loglalják magokhan, petilbül vannak szedve. A fölsö closztások nevei mindenütt nagy majusculák; a csalídok, nemek és alnemekéi apró majusculák, megfelelve a textusban használt három fajta betúknek; a fajakéi italicák; a latin név követi a franciát *), de záró jeģy között $s$ majdnem hasonló szabály tartaték meg a minden kötelet megelözö rendszeres névjegyzékben s mellyek arra szánvák, hogy vezetöül szolgáljanak a kezdőknek. Igy a szem elöre megkülönbözteti minden dolog fontosságát s minden eszme rendét, s a nyomtató mind azon mesterséggel kezére járt az irónak, mellyet a mnemonica számára adhat.

Ezen szokás, mellyet természetleirás tanulása

*) A magyar munka, sajtói tehinletben, egćszen a\% eredeti szerint van elintézve; mi pedig a neveket illeti, legelül a magyar ludományos nèv áll, azután a közönséges vagy Földi által használt, azután jónck a francia, latín s $\mathbf{3}$ madaraknál a német nevek is, hol Voigt bönyvében 'z utolsók nen hibáznak. 
közben tulajdonává tesz az ember, midón elméjében számos eszméket osztályoz, ezen tudománynak azon hasznát teszi, mellyrül legkevesebbet szólottak, s a melly meglehet elsó rangot nyer, ha általában elfogadtatik a közönséges nevelés számára; általa a logica azon részében gyakoroljuk magunkat, melly methodicanak (rendszerességnek) neveztetik, majdnem miként a mértan tanulásánál az ugy nevezett syllogismusban gyakoroljuk elménket, azon okbul, mert a természetleirás azon tudomány, melly legpontosabb rendszert kiván, valamint a mértan legszigorúbb okoskodást. De a rendszer ezen mestersége, milelyt egyszer jól birtokunkban van, végetlen haszonnal alkalmazható a természetleirástul legidegenebb tanulmányokra is. Minden vitatkozás, melly a cselekmények osztályozását teszi föl, minden fürkészés, melly az anyagok elosztását kivánja, ugyan azon törvények szerint történik; s azon ifjú, ki csak azt vélte, hogy csak nulatsága tárgyaul szolgáland e tudomány, maga is bámulni fog, tapasztalván mi könnyüséget szerze magának mindemnemú dolgok fölfogására.

Tudományunk nem kevesebbé hasznos a magányban. Eléggé kiterjedt, hogy a legterjedelmesb észt is foglalatoskodtassa, eléggé változatos, eléggé érdekes, hogy a leghányottabbak lelkét is mulassa, vigasztalja a boldogtalanokat, csillapítja a gyülölséget. Mihelyt fölemelkedénk a természet azon öszhangzalának vizsgálatához, melly a gondviselés által ellen- 
állhatlanul van szabályozva, mi gyöngék és csekélyeknek találjuk azon mozgalmakat, mellyeket az emberek szabad önkényétül hagyott függeni! Menynyire bámulunk, olly sok szép észt látva emésztödni, olly haszontalanúl a magok és mások boldogságára nézve, hiú tervek koholísában, mellyeknek nehány év elegendö, még nyomait is eltörölni.

Igen is, nyilván megrallom, ezen eszmék soha sem voltak idegenek munkáimtul, és ha minden erömbül iparkodám terjeszteni e békés tanulmányt, onnan volı, hogy, véleményem szerint, ez minden egyéb fölött alkalmatos táplálni azon foglalatossági szükséget, melly századunk zavaraira olly nagy befolyásu volt; de ideje visszatérni tárgyamhoz.

Hátra van számot adnom azon fö változtatásokrul, mellyeket a legíjabban elfogadott rendszereknél tettem, és tanusitanom azt, mivel tartozom azon természetrizsgaloknak, kiknek munkáibul azt átvevém vagy részben kölcsönzöttem.

Hogy a kritikának elejét vegyem, melly természetesen sokaknál fog jelentkezni, meg kell jegyeznem elölegesen, hogy sem törekvésem, sem vágyam nem rala olly módon osztályozni a lényeket, hogy magános vonalt képezzek belölök vagy kölcsönös fölsöblségöket kijegyezzem. Sö́t minden illy nemi megkisértést végrehajthatlannak tekintek; nem is akarom azt értetni, hogy az emlösek és a madarak között a legutolsó helyre állitotlak a legtökéletlenebbek volnának osztályokban, annál ke- 
vesbbé állitom, hogy az utolsó emlős tökéletesebb az elsö madárnál, az utolsó puháng tökéletesebb az első annelidnál vagy az állat-agácsoknál; még akkor is ha ezen ingatag szót ,tökéletesebb“ azon értelemben veszszük, hogy ,müszerekkel teljesebben megáldott. ‘ك Én osztályaim és alosztályaimat csak ugy tekintém, mint az egymásba átmenö lények hasonlatosságának fokozatos kitételét; és ámbár megtörténik, hogy némi aljasodás és átmenetel vetetik észre egyik fajtul a másikhoz, mellyet tagadni lehetlen, de sok hiányzik még, hogy ezen elrendelés általános volna. A lények követelt hágcsója nem egyéb hibás alkalmazásánál a teremtés összegéhez azon részinli észrevételeknek, mellyek csak akkor igazak, ha azon határok közé vannak zárva, a hol tetettek, - és ezen alkalmazás, véleményem szerint, alig képzelhetö fokon ártott mai idókben a termeszetleirás elómenetelének.

Ezen nézetteli összehangzás szerint alapitám én általános fölosztásomat négy ágozatra, melly már egy külön értekezésben ki volt fejıve; mindegyre azt gondolom, hogy ez az állatok valódi viszonyait pontosabban fejezi ki mint a régi fölosztás gerincesekés gerinctelenekre, azon okbul, hogy a gerinces állatok sokkal inkább hasonlítanaḱ egymás között mint a gerinctelenek, és szükséges volna e különbséget a viszonyok egész terjedelmében kimutatni.

Virey ur, a Nouveau Dictionnaire d' Histoire naturelle egyik cikkében, már ezen fölosztás alap- 
jainak egy részét fölfogta és fơképen azt, melly az ideg-rendszeren alapul.

A tojó gerincesek rúszinti közeledése egymás-hoz, eredetét azon különös észrevételektül kapta, mellyeket Geoffroy úr a csontos fejek összetételében tapasztalt és azoktul, mellyeket a váz többi részére s az izomtanra nézve hozzá adtam.

Az emlösek osztályánál a patásokat a vastagbórüekhez adám; ezeket új nézetek szerint osztám családokra; a kérödzóket a négylátbuak végére helyezém; a kézceteket a celekhez atám; a ragadozók rendét egy kissé máskép oszlium el; az ingadúkat. egészen elválasztám a majmokıul; némi közegyenességet mutaték ki az erszényes és a többi ujjas emlósek közölt, mind ezt saját bonctani vizsgálataim szerint. Geoffroy de Saint-Hilaire barátom és tiszltársam új és alapos munkálatai szolgáltattak talpkövet mind ahoz, mit a négykezüek és denevérekrül mondok. Testvérem, Cuvier Fridrik vizsgálatai a ragadozók és órlök fogai között, nagy hasznot hajtoltak e két rend alnemeire nézve. Boldogult Iliger nemei aligha egyebek, mint ugyan ezen és némelly külföldi természetvizsgálók törekvéseinek eredménye; mindazáltal mindig elfogadám neveit, ha nemei megegyeztek alnemeimmel. De Lacépède úr is több jeles fölosztást fogott föl és mutata ki e fokon, mellyeket szinte iparkodtam elfogadni; de minden fokok bélyegei s a fajok egész. leirása a természet 
után adalék, vagy a bonctani teremben vagy a museum karzatában.

Hasonló történt a madarakkal, legnagyobb figyelemmel vizsgáltam meg több mint 4000 egyént a museumban; saját nézeteim szerint rendelém el a közönséges teremben már 5 év óta, és innen vettem mind azt, mit munkám e részében ezen oszályrul mondok. Illy módon, ha fölosztásaim hasonlítanak némelly újabb tabellákhoz, az részemrül, egészen történetes. ${ }^{1}$ ).

Remélem hogy a természetvizsgálók helyben hagyandják azon számos alnemeket, mellyeket a ragadozó madarak a verebek és a gázlók között fölállílandóknak véltem; ugy !átszik, hogy ezek a legnagyobb világosságot szerzék meg ezen elóbb igen zavart nemeknek. A mennyire tehetségemben állt, szinte pontosan kijegyzém ezen alosztások megegyezését de Lacépède, Meyer, Wolf, Temming és Savigny nemeivel, s mindenikhez oda sorolám mind a fajokat, mellyekrül elég biztos ismeretet szerez-

1) Ezen észrevétel nem lévén clég szeınbe szökó, némelly külföldick elött, újra kell itt clmondanom és hangosan nyilvánítnom egy tettet, mellynek Párisban több ezer tanúja van: hogy a Museum közös karzatának minden madarai az én rendszerem szerint voltak megnevezve, eloszlva 1811 óta. Sỏt alosztásaim közñl azok is, mellyeknek nevet nem adék, saját jegyekkel jegyeztettek meg. Itt az adatom. Különben elso köteten 1816 eleje óta kezdődött nyomatni. Négy kötetet nem nyomathatni ki olly hamar, mint néhány lapbul álló fïzetel. Nem szólandok többct. (Ezen jegyzet a 2-dik kiadáshoz mellékeltetett. 
heték. E fárasztó munka kedres lesz azok elöı, kik jövendöben a madarak valúdi történetével foglalatoskodnak. A szép madártani muskák, mellyek néhány év elött adatıak ki, fóleğ le Vaillantéi, telve annyi érdekes észrevétellel, és Vieillotéi, mellyek igen hasznosak voltak azon fajok pontos kijelelésére, mellyeket ábrázolnak.

Ezen osztály fö elosztása ollyan marada, minöt 179S-ban közlöttem a „Tableau élémentaire“ ben. $\left.{ }^{1}\right)$.

A hüllókre nézve is megtartandónak véltem Brongniárt barátom általános fölosztását; de nagy bonctani munkákat kelle végeznem, hogy továbbá alsú osztásokhoz jussak. Oppel úr, mint mondám, részint elöre használá ezen elökészületi munkákat; és mind annyiszor, midön nemeim egészen megegyeznek az övéivel, azt megjegyzem. Daudin munkája, bármilly középszerú, hasznos volt elöttem a részlet elöadísához; de a részinti fölosztások, mellyeket a monilor és gecko nemekben adok, saját észrevételeim szüleménye, számos hüllökön csináltaké, mellyeket Péron és Goffroy hoztak a museumnak.

A halakrul szóló munkám, ugy vélem, legfon-

1) Ezt csak azért jelelem meg, mert egy érdemes természetvizsgáló, (Vieillott uiı) magának tulajdonitá egy ę̣́szen új munkában a a Picae és Passeres egyesitését. Én már 1798-ban kinyomatám öket épen mint töhbi folosztásaimat, hogy 1811 és 1812-dik évhen a a Muscum-ban kiadjam. 
tosabb mind azok között, mellyeket a gerinces állatoknál végrehajték. Museumunk iggen számos halakat kapván, mióta de Lacépède hires munkája közzé téteték, én több alosztályokat adhaték ezen tudós természetvizsgálóéihoz, sok fajt különbözó módon állíthaték össze s szaporithatám a bonctani kémleleteket. Szinte tehetségemben volı Commerson fajait és más utazókét jobban meghatározni, és én e tárgyban igen sokat köszönhetek azon átnézésnek, melylyeket ezen ur magával hozott, de mellyek csak nem rég fedeztettek föl, melly segédforrásokhoz én azokat is toldám, mellyeket a Péron által a Nagytengerbül s az indiai szigetsokbul hozott halak nyujtának, és azon halak, mellyeket a Középtengeren magam szedék, boldogult Sonnerat gyüjteményei a coromandeli partokon, Matthieu-éi az Isle de France-nál, Geoffroi-éi a Nilusban és Verestengerben stb. Illy módon megvalósíthatám Bloch, Russel és mások fajainak nagyobb részét, majd minden alnemek vázát és beleit elkészíthetém olly módon, hogy e rész, reményem szerint, sok újat adand a haltudósaknak.

A mi ezen osztály fölosztását illeti, mellyet adék, megvallom, hogy a használatra kevessé alkalmatos, kevessé kényelmes, de legalább természetesebbnek hiszem minden eddig adottaknál; midön kevéssel ezelótt közzé tevém, nem adám más gyanánt mint a mit ér; és ha valaki a felosztásra 
célszerübb elvet talál föl, de az alkotással szintugy megegyezót, sietni fogok azt elfogadıi.

Ismeretes, hogy mind azon munkák, mellyek a gerinctelen állatok általános felosztásáirul megjelentek, csak módosítísai annak, mellyet 1795-ben terjeszlék elö a legrégibb értckezésben s az is tudva van különösen mennyi gondot és idöt áldozék föl általában a puhángok bonctanának és különösen a csupasz puhángok ismeretének. Ezen osztály megohatírozísa, valamint osztályai s alosztályai az én észrevételeimen alapulnak; Poli úr pompás munkája egyedül vága csak clémbe, célomat elómozdító leirás és boncolatok által, de csupás a sok-és kétkávásakat. Bebizonyitám mind azon észrevételeket, mellyeket ez ügyes boncolótul kaptam, és ugy hiszem, hogy naggyob igazsággal jegyzém ki némelly müszerek hatását. Szinte törekedtem meghatározni azon állatokat, mellyekhez tartoznak a csigahéjak és kagylóhéjak föidomai, és ezeket ezen vizs-gálat szerint rendelni el; de mi a csigahéjak (coquilles) további fölosztását illeti, hol az állatok egymáshoz hasonlók, nem iparkodtam másra, mint elegendőleg kifejezni tudni azt, mit Lamark és de Montfort fölállítottak; és még a nemek és alnemek azon csekély száma is, melly enyém, az állatok kémlésébül eredtek fóleg. Arra szoritkoztam, hogy példaképen Martini, Chemnitz, Lister és Soldani fajainak egy részét idézém és ezt is csupán azért, mivel azon kötet, mellyben de Lamark úr ezen részt 
merítendi ki, még nem jelent meg s igy én köteles valék olvasóim figyelmét szabott tárgyakra vezetni. De nem szándéklottam ezen fajok megválasztása-s meghatározásánál azon kritikát használni, mellyet a gerinces állatoknál és a csupasz puhángoknảl alkalmaztam.

Savigny, Lesueur és Desmarets urak szép kémletei az összetett ascidiákrul, a puhángok ezen utolsó családát közel vezetik az állatuövények bizonyos rendeihez; ez érdekes rokonság és tanúbizonyság, hogy az állatokat nem sorozhatni egy vonal hosszában.

Ugy hiszem, én emelém ki az annelidcikat, noha nevöket nem gondolám ki, azon tömegbül hol clöbb össze voltak zavarva, a puhángok, hejancok és állatnövények között és a természeti rendben összeállitám őket; nemeik csak azon meghatározások által kaptak világosságot, mellyet én adék nekik a ,Természeti tudományok szótárában (Diclionnaire des sciences naturelles)" és egyebütt.

Nem szólandok a harmadik kỏtetben lévő hírom osztályrul; Latreille úr, ezen rész saját szerzöje, ha némelly boncolati részleteket kiveszünk, mellyeket munkajába szövék saját tapasztalásom és Ramdohr uréi szerint, az elószóban kimerítendi, a mi különössel bir munkája.

Az állatországot bezáró állatnövényekre nézve, a* echinodermák tekintetében de Lamarck új munkaját használám : a belférgeknél hudolphi ,Entozoa“ cuvier 1. $k$. 
cinü könyvét; de magam tevék boncolast minden nemben s ezekbül néhány csak én általam határoztaték meg. Végre az echinodermák boncolatárul jeles munka van Tiédemann urtól, melly nem sokára meg fog jelenni. Minthogy a korallok és azalagok alig szolgáltatnak oldalt a bonctan számára, iggen röviden bintam velck. De Lamarck új muskája pótolni fogja azt, a mi nálam hiányzik. ')

Itten csak azon auctorokat idézhetém, kik általános nézeteket adtak vagy költöttek föl bennem ${ }^{2}$ ) Sok mások vannak, kiknek részletes adatokat koszönök és kiket ganondosan megnevezék azon cikkeknél hol kémleteiket használom. Neveiket könyvem minden lapján láthatni. Ha elfeledtem volna valakinck közülök igasságot szolgáltatni, akarat elleni feledékenység volna, s elöré bocsánatot kérek érte; szemeimben nincs szentebb tulajdon, mint a lélek észrevételei, müivei, s azon közönségessé lett szokás a természetvizsgálóknál: a lopasokat névesere által takarni be, elótem mindig valódi bünnek tetszett.

Ezen túl fáradatlanul fogok foglalatoskodni öszszchasonlító bonctanon kiadásával; az anyagok készek hozzá, a készitmények és rajzok nagy része be-

3) Épen most kapom meg Lamouronx úrtól: „Histoire des Polipiers corullegertes flexibles," melly ignen jeles potlékul szolgáland Lamarch irnak.

$\left.1{ }^{2}\right)$ Blainville ú legújahban tabellákat ad ki az egész állattudományról, mellyeket nem használhatnoun igen sajnosan esik, - azon idobben jelentek meg, midön munhám majd cgészen hi voit nyomva. 


\section{AZ ELSÓ KIADÁSHOZ. XXXIX}

végzeték, osztályoztaték, gondom volt e munkát részekre osztani, hogy mindenik egészet tegyen, és igy, ha eróm elegendó nem lenne egész tervem végrehajtására, a mit a közönségnels adék, mégis bevégzett sort képezzen, mindenik a maga tárgyára nézve, és hogy az anyagok, mellyeket összegyüjtöttem, közvethetlenül használhatók legyenek azok által, kik munkáim folytatását magokra válalandják.

A kiraily kertében, octoberben, 1816. 


\section{FIG YELMEZTETÉS}

\section{A MÁSODIK KIAD ÍSHOZ.}

Az elöbbi elöbeszéd híven látlatja azon állapo10t, mellyben az állatok történetirását találtam e hönyr elsö kiadása idejében. E tudomány az azóta lefolyt tizenkét év alatt szörnyü haladást tön, részint számos, épen olly tudús mint bátor utazók gyüjtései által, kik a földteke minden vidékeit kikémlették, részint gazdag természeti tárak által, mellyeket különbözö kormínyok állitottak föl és a közönségnek megnyitottak, részint régre azon undós és szép munkák által, mellyeliben ábrázolva s leirra vannak az új fijak s mellyekben az irók törekedtek kölcsönỏs viszonyaikat fölfogni és öket minden szempont alatt megvizsgálni. ${ }^{2)}$

Iparkodtam e fölfedezésckbül annyi hasznol huzni, a mennyit tervem engede, elöször is természet után vizsgálva a király gyüjteményébe jött számtalan tárgyakat és összehasonlítwa azokkal, mellyek

1) Lísd e táigyban azon beszédet, mellyet az Institut egyik ulésében olvastam föl "e természetleirás haladásárul a tengeri bék c ósa, emlékbeszédeim harmadik hötetének végén lenyomatra. 
első kiadásomnak alapul szolgálıak, hogy ủj összeköttetéseket vagy uij alosztásokat állitsak elö, és végre fölkeresve azon munkákhan, mellyeket megszerezhettem, a természetvizsgálók által alapított nemeket vagy alnemeket $s$ a fajok azon leirását, mellyekre e különbözö összetéteket építették.

A hasonszavak e kidolgozása sokkal könuyübb lett mint elsó kiadásomkor vala; a francia és az idegen természetvizsgálók megismerni látszának azon szükséget, hogy osztályokat kell azon igen nagy nemekben fölállítani, hol az elótı egészen különböző fajak összetömettek; csoportaik jelenleg poniosan és jól határozottak, leirások eléggé részletes, ábráik pontosak, egész a legkisebb bélyegekig, és gyakran a müvészet tekintetében a legnagyobb szépséget birják. Nem egy könnyen van többé nehézség, hogy a fajok azonsáģárul meggyőőődjünk és csak tölünk függene az elnevezésekben is megegyezni. Szerencsétlenségre ez a legellhan yagoltabb gond: ugyan azon nemek, azon fajak nevei mind annyiszor szaporodnak, valahányszor valamelly auctor alkalmat kap róla szólani, és ha ezen egyet-nem-értés folytallatik, a régi chaos megújuland, nem kevesebbé zavarosan mint az elöu, ámbár más okbul.

Én megtettem a mi lehetséges volt, hogy ezen fölösleges elnevezéseket összehasonlitsam és közel vezessem egymáshoz, sőt még felejtve auctori kis érdekemet, gyakian azon neveket is fölhozám melylyek a végre látszanak kigondolva lenni, hogy elta- 
gadtassék miképen az én folosztásaim kölcsönöztettek el. De hogy illy munka teljesen végrehajtassék, az állatország e névkalauza (Pinax), melly naprul napra szuikségesebb lesz, hogy a bizonyító okok megviszgáltassanak $s$ hogy az elfogadandó névöszveg (elnevezés, nomenclature) elhatározottan tüzessék ki, azt elegettevö leirások-és ábrákra támasztva, - sokkal nagyobb helyet foglal el, mint a mekliorít én engedhetek neki, és idöt, mig enyémet más munkák paranesolólag foglalják el. A halak leirásánál, mellyet Valenciennes segedelmével kezdék közzé tenni, törekszem eszmét adni arrul, a mit jónak látok, hogy a tudomány minden részeiben hasonló történnék. Itten esak rövid képét vagy is egyszerú rajzát akarom adni : boldog ha e tervrajzot tisztába hozhatom minden részeire nézve.

Hasonló nemü különböző tabellák adatlak ki némelly osztályokrul és én gondosan tanulám azokat, általok a magamét tökéletesitendö. Desmaret úr Mammologie-ja, ugyan az Lessontul, Cuvier Fridrik értekezése A négylábuak fogairul, elsö kiadásom angolra fordítása Griffith által, hozzáadással megtoldva, fóleg Smith Hamiltontul, Temmink úr "Manuel d' ornithologie-jának“ új kiadása; Wagler Madártani töredékei, A hüllók rajzlapjai boldogult Merremtül, s Fitsinger úr értekezése ugyan azon tárgyrul, - voltak föleg hasznosak számomra a gerinces állatok tekintetében. De Lamark úr természetirása a csontváztalan állatokrul, Blainville úr, 
"Malacologie-ja" szinte sokat segiletlek rajlam a puhángoknál. Ide mellékezém azon ü nézcteket és adatokat, mellyck találhatók Geoflroy Saint-Hilaice atya és fiú, Savigny, T'emmink, Lichteustein, Kuhl, Wilson, Horsfield, Vigors, Swaison, Gray, Ord, Say, Harlan, Bonaparte Károly, Lamouroux, Mitchill, Lesueur úrak és más ïgyes és munkás emberek számos és tudós irataiban találtatnak, kiket gondosan idézendek azon helyeken, hol a vizsáálták és leirták tárgyakrul szólandok.

Azon szép rajzgyïjtemények, mellyek ezen utolsó tizenkél évben jelentek meğ, képessé tettek számosabb fajok megnevezésére s ezen alkalmat bóven is használtam. Föképen köszönettel kell azt megemlítenem, a mit e nemben következó urak ide jegyzendö munkáinak köszönök: Geoffroy Saint-Hilaire és Cuvier Fridrik ,Emlösek történetének," Temmink és Laugier Szinzett rajzainak, Vieillot Madarak irattárának (Galerie des Oisecux), Naumann úr Németországi madarai iu kiadásának, Wilson, Ord és Bonaparte Károly Egyesült tartományokbeli madarainak ('), Spix úr és Wied Maximilián herceg fönsége nagy munkáinak Brazilia madarairul, és Ferussac-ćinak A puhángokrul. - Freycinet és Duperrey urak uijainak képrajzai s állattani leirásai, mellyeket az elsónél Quoy és Gaymard adtak, az ulolsónál Lesson és Garnot uu., szinte sok új tárgyat adnak. Hasonlót kell mondani Java állatairul Horsfield által. - Kisebl minta szerint rit- 
ka fajak új ábríit adják még: a Memoires du Museum, a Les Annales des sciences naturelles és más francia, időszaki iratok, a különbféle természetleirási szótárak (Dictionncires d' histoire naturelle) az Illustralions zoologiques Swainsontul és az Allaltani hirlap, mellyet ïgyes természetvizsgálók adnak ki Londonban. Az ujyorki Lyceum és a philadelphiai természettudományi Academiának hirlapjai nem kevesebbé becsesek; de azon fokon, a mint a természeltudomány izlése terjed és e tudomány több országokban míveltetik, elfoglalásainak száma mértani fokozattal halad elöre és egyre nehezebb és nehezebb lesz a természetvizsgálók minden iratát öszszcgyüjteni és az eredmények tábláját kiegészíteni; bátorkodom tehát azok bocsánatára számitani, kiknek kémletei elkeriülék figyelmemet, vagy kiknek munkíit nem tanulám olly nagy gonddal, hogy belölök kihuzıam volna minden kinálkozó hasznot.

Latrcille urr, húres barátom és tiszttársam itt szinte mint az elsó liadásban szíves vala a crustaceák, arachnideák, és rovarok nevezetes osztályaival foglalkozni, ö maga elmondja elószavában azon menetelt; mellyet követe, s igy nekem nem szükséges e tárgyba bocsátkoznom.

Csak azt tartom megjegyzendőnek, miszerint munkáj̧a aunyira megszaporodván hogy két kötetet elfoglalna, a könyvnyomtatási csin kiváná hogy az állatnövények leirását harmadik kötetembe tegyem a puhángokéhoz s az auctorok névsorához. E cse- 


\section{A MÁSODTK KIADÁSHOZ. XT,Y}

kély változtatás nem okozand semmi zavart a\% értesült olvasónak.

Az első füzet végén különféle adatokat és némelly elnevezési részleteket gyüjték össze az emlösek és madarak tekintetében, mellyek különbözö okokbul csak a nyomás vége felé jöltek értésemre; kérem odafolyamadni az olvasót, a mint azon cikkekkel foglalatoskodik, mellyekkel ez új tanúságok viszonyban állanak. 


\title{
RENDSZERES TARTALOMMUTAT'́́
}

\author{
AZ ELSÖ KUTTFTHFZ.
}

(Egyszersmind magyar-német saotoira as omlissetnek.)

\section{BÉVEZETES .}

A termiszelleirís- is annak irányzalairol általában . 1

Az élö lények- és a múszeressigekról áltakában . . . 11

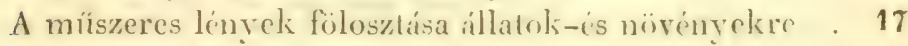

Az állati lest miaszeri elememel saját idomairil is regy-

tani elemeinek fơ vegyületéról . . . . . . 21

Az állati testben mủködö erókrúl . . . . . . . 25

$\mathrm{A} z$ állati test müreletei s müszereinelis s azok bonyo-

lata különbözö fokainak összes álnézete • . . 29

Az állatok extr.mi mumkálatainak rörid átuczése . . . 38

Az irányzatril, ammak az állatorszácra viló alkalmaz-

tatísában . . . . . . 44

Az illatorszígnals általínos négy nagy oszlályra szaliaszlúsa . . . . . . . . . . . 45

A csontvázas állatok általában . . . . . . . . 49

Ezek fölosztása négy nagy oszlályra . . . . . . 54

EMLÖEK . $\quad$\begin{tabular}{r|rr} 
Lap. & Lap. \\
59 & Az emberi fajnak fajtái & $\mathbf{7 5}$
\end{tabular}

Ezeł rendekre szakadása 62 11. NÉGYKEZÜEK * . 80

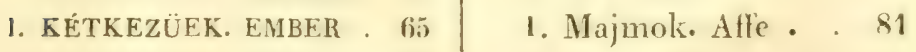

Annak különös alkotása . 66 A tulajdonképi majmok 82

Természeti s erkölcsi kifej-

lése .... . 81

a. Eml8rök. Orang. Wald-

mensch. 
Homlokmagas E. Der eig. Orang Outang. . . . 82 Homloklapos E. Der Schim. pansce . .... 84

b. Karnyúk. Gibbon . . 85

c. Pofürük. Meerkatzen .. 86 Ajkcímes P. Der blaumäulige Affe . . . 89

Orrfehér. P. Die Weissnase d. Farkanyúk . . . . - -

Imádott F. Der Hulman 990

Búbos F. Der Kruh. ‘ . 91

Fekete F. Budeng .. .. . -

e. Tömkar . . . . -

Sórényes T. S. silenus et leonia: Nil Bandar . . 92

Kalapos T. Der chinesische Hutaffe . . . . . -

Makogó T. Der Makako -

Kukordu. Bruh ... . 93

f. Fargagomók. . . . . -

Közönséges F. Der gemeine Affe . . ... . -

g. Ebfejömek. Der Pavian 94

Öırhosszú E. Der Perückenaffe.

h. Duzajkok

Az ujvilág majmai.

A. Göndörüls . 96

a. Bơgöncök. Heulaffen , 97

Közöns. göndörúk . . . . 98

b. Dugujjak. Spinnenaffe,

Klammeraffe . . . . -

c. Gömbcsupok . . ... 99

d. Kúcsfödek . . 100

e. Majmókok ...... 101

B. a. Kucslanok. . -

Vereshasu K. Der rothbau- chige Nachtaffe. .. 101

※. Kurtászak . . . . 102

b. Fogarejtek . . . - -

Álarcos F. Der maskirte Affe Özvegy F. Der Traueraffe . 103

c. Éjszemömek. Schlafaffe - Sujtásos E. Kuszi-Kuszi

Mirikina

2. Ingadúk

Aranysörényü I. Das Löven-

äffchen ... . 105

3. Málkik ...... 106

a: Tulajdonképi mákik , 107

b. Indrik . . . . . .

c. Lórik . . . . 108

Lassu L. der Faulthier :- -

d. Talpanyúk . . . . . -

`. Sarkanyúk . . . . 109

RAGADOZÓK ... 110

1. KÉZSZÁRNYUAK: Fledernıäuse . . . 111

a. Denevérek. Fledermaus : 112

1. Szárnyoncok ‥ -

a) Farktalan Sz. . . 113

Fekete Sz. Kalong . . . -

Közönséges Sz. Die gemeine

Ressette . .. 114

b) Kisfarkuak . . . -

2. Hátragok . ...... -

Tulajdonképi denẹérek : 115

3. Fülgék . . . -

4. Szürkülészek .

5. Éjjelészek ? . 116

6. Lábakéz • . . - -

7. Szárnypikkelönc . -

8. Nyulajkócok. ....117 
9. Hártyorrok. Blattnasc . . . . 117

Lidérc H. Der Vampyr - 10. Nyelvöltök . . . 118 11. Tömbúröls . . 119

12. Patkócok. Hufeisennase

Nagy P. Die grosse H.

Kis P. Die kleine H. . -

13. Gödörorrak • • . 120

14. 'Tálori. . . . -

15. Kezénzsebek . 121

16. Meredfök

17. Közöns. denevérek.

Szárnyasegér D. Die Fledermaus $12^{6}$

Éjjelezö D. Die Speckmaus Törpe D. Die Zwergfledermats . . . . 123

18. Öszfülel Dic Grossolren

Nagy Ö. Die grassohrige Fledermaus

19. F́.jröpök 124

b. Majmugrászok. Fliegender Máki

II. BOGÁREVÖK. Insectenfiesser . . . . 125

a. Sünök. Igel .

Közönséges S. Der gem. Igel 126

b. Süncsutok

Tövises S. Der Tenrec . 127

Sörtés S. Der Tendrac . c. Ször-sünök . . . . . -

d. Cickányok. Spitzmaiis 128

Közönséges C. Die gem. Sp. -
Vizi C. Die Wassersp. . 129

e. Cicúszok. Bisamratte . 130

f. Aranydokok. Goldmaulmaulwurf : : . . 131

g. Valondokok, Maulwurf 132

h. Sugárdokok. Sternmaulwurf . . . . 133

i. Cictúrók. Wassermaulwuif 134

III. HÚSEVÖK. Reissende Thicre . .. . . 135 a. Talponjárók . . 136

k. Medvék. Der Bïr. . 137 Erdei M. Der braune europäische B....... Éjszakamerikai M. Der Baribal . . . . . 138 Ékes. M. Der südamerikanische B.

Tengeri M. der.Eisbär . 139 l. Talpályok . . . . ... Mosó T. Waschbär ' 140 m. Talpajárók. Dee Pandal n. Talpacsok. Benturong - 141 Fekeie T. Der schwarze Benturong . . . . - o. Orramozgók.. Cuati . - Veres O. Der gesellige C. Barna O. Der einsame C. 142 p. Fogódzák . . . . . Mézezઠ F. Der Kinkaju . q. Borzok. Dachs … -

Közönséges B. Der Dachs . I4: Amerikai B. Der amerikanische D. . . . . r. Falókok. Vielfrass : . - Torkos F. Der Vielfrass. Barna F. Der Galera . 114 s. Borzone 
Lap.

Méhész B. Der Honigdachs 145 B. Ujjonjátók . . . -

¿. Menyétek

1. Menyétek különösen -

Görény M. Der gemeine Iltis 146

Furó M. Das Frett .. . -

Lengyel M. Der Peruaska -

Sibiriai M. Der sibirische Iltis

Közönséges M. Das kleine Wiesel

Hölgy. M. Das Hermelin . Vidıa M. Der Nörz, Mink,

Norek . . . . 147

Jávai M. Der javanische lltis -

Csikolt M, Das gestreifte

IViesel . . . . . -

Reményfoki M. Der Cap'sche Iltis . . . 148

2. Nyusztok

Közönsẻges Ny. Der Edelmarder.

Nyest $\mathrm{Ny}$. Der Steinmarder Cobỏly Ny. Der Zobel : -

Fehẻr Ny. Der weisze Vison 149

Kanadai Ny. Der Pekan : -

3. Görények. Stinkthier -

Szagos G. Das Stinkthicr, der Skunk . . . . 150

Bùzös G. Der Chinche . -

4. Büzényel ‘. . • -

Jávại B. Der Telagon ... -

5. Vidrák Die Ottern -

Közönséges V. Dei Fisch-

Otter ...... . 151

Tengeri V. Der Meer-Otter 4. Ebek. Hunde .... . 152
Lap.

1. 'Tulajdonképi Ebek 152 Szelid E. Der Hund . . -

2. Farkasok, Der Wolf 154

Közönséges F. Der Wolf -

Feketc F. Der schwarze Wolf -

Mexikói F. Der mexikanische W.

Amerikai F. Der amerikanische W. . . . 155

Sakál. Goldwolf . . . . -

3. Rókák, Füchse

Közönséges R. Der gemeine $F$.

Braziliai R. Der brasilische F. . . . . 156

Sárga R. Der kleine gelbe $\mathrm{F}$.

IHáromszinü R. Der dreifarbige F......... -

Fekete R. Der schwarze Silberfuchs . . . . 157

Ejszaki R. Der Steppenfuchs, Steinfuchs . . ... -

Reményfoki R. Der Cap'sche F. . . . -

Nagyfülü R. Der Ambukol 4. Seregeb. Simir, Der wilde Hund : . . 158 2. Petymegek . . . . .

1. Tulajdonképi petymegek

Közönséges P. Zibethkatze. 159 Cibét P. Das Zibetthier - 2. Janólok . . . . Közönséges. J. Die Genette 3. Kúkorok .... 16 I Indiai $\mathrm{K}$. 
4. Petyzsebek ‥ $\begin{array}{r}\text { Lap. } \\ 162\end{array}$

Aegytomi P. Die Manguste von Aegypten . . . . -

5. Ösznyilak . . 163

6. Mangols

7. Petyürek .

w. Hienák. Hyäne

Csikus H. Die gestreifte H. 165 Barna H. Die braune H. : Foltos H. Die gefleckte H. x. Macskák. Katzen . . Orozlán. Der Löve ‥ 160 Rohanóc, tigris. Der Königstieger

Onka. Der Jaguar, Der amerikanishe Tiger . . 167

Párduc. Der Panther . -

Leopárd Der Leopard : -

Puma. Cuguar. Der amerikanische Löwe . . 168

1. Hiúzok. Luchse

Közönséges H. Der Luchs, Rothluchs. 169

Verhenyes H. Luchskatze Mocsári H. Sumpfluchs . óhiúz (karakál) Der Karakal . . . 170

Szemge der Ozclot .

Házi M. Die eigenthliche Katze

$\gamma$. Kétlábuak: Schwimmfüsser

y. Fókák, Robben

1) Külfültelen fókák Borju F. Der gemeine Seehund 172 Szakállas F. Die Bartrobbe 173 Nyulfarku. F. R. mit deu
Hasenschwanz $\cdot . \quad 174$

2) Váganégyek . . -

3) Tomkúpok . . . -

Fehérhasú F. Die Mönchsroble

4.) Zápanyom . . . 175

Tarajos F. Die Kappenrobbe

5) Ormányók

Orozlán F. die Rüsselrobbe -

6) Külfülesfókák . 176

Törényes F. Der Seelöwe -

Medve F. Der Seebär . - -

z' Rozmárok. Wallrosse . . -

Közönséges R. Das WallIUSS . . . . . . 177

IV. ERSZENYESEK' : 178

A. 1. Fijahordók. Beutelratte ... . 180

Fülekétszínü F. Das B. mit

Zweifarbigen Ohren . 181

Fekete arcorru F. Die grosse

B. von Paraguay

182

Csecsiszákos. Fo. Die grosse

B. von Brasilien .

Foltszemes F. Das Vierauge .

Hátas F. Der surinamische Acneas . . . 183

Szürke F. Schupati .

Rövidfarku F. Der Tuan.

(Buff: Supll. VII, 61) . -

a. Usztalpak : : .. -

b. Kétméhüek .. . $\mathbf{1 8 4}$

c. Iszákok … . . . ... -

2. Mezfarkak @ 185

3. Körömkúlyök ? 186 
B. 4. Perckúlyök. Phalanger

a) Tulajdonképi perckülyök 188

b) Repülo̊ perckülyök, Fliegende Fhalanger 190

C. 5. Fönfarok. Potoru 191

D. 6. Vetfarkok; Ugrányok. Känguruh 192 Ugrány V. Das Känguruh ' E. 7. Csútok. Der Kuala F. 8. Erszék . ‘. 195 Barna E. Das Wombat . 196 v. ÖRLÖK

\section{A mókusok.Eichhorn 198}

Evet MI. Das Eichhörnchen 199 a. Hörcsevetek .

Csikolt H. Das Erdeichhorn 200

b. Farkvetek . . . . 201

c. Röpevetek. Fliegendes Eichhorn

Lengyel R. Das gem。 flieg. E. Szigetsoki R. Der Taguan 202 d. Ájájak .

Madagaskári A. Das AyeAye

2. Patkányok'. . 203

a. Mormogák

Havasi M. Das Murmelthier Lengyel M. Der Bobak. . -

b. Ürgék . . . . . Ürge. Das Zicsel . . . c. Pelék . . . . 205

Ennivaló P. Der Siebenschläfer, Rellmaus . . 206

Cser P. Die grosse Hasel. unaus
Lap.

Mogyoró P. Die kleine Haselmaus . . . . 206 d. Töris-egerek, Stachelratte.

e. Vizegerek : . . 207

f. Nyul-egerek . . • . 208

g. Tulajdonképi patkányok

Egèr, Die Hausmaus • . 209

Patkány. Die Ratte . . -

Vándor' P. Die Wanderratte

Szörnyă P. Die Bisamratte 210

๙. Egerek. Mäuse . . . - -

Kahirói E. Die M. von Kahiro

Mezei E. Die Waldmaus - h. Örölkék . . . . . 212 i. Reszclkék . . . . 213

k. Hörcsökek, Hamster . - -

Közönséges H. Der H. - l. Mezőtanyászok . . . 214 $m$. Habtanyászok. Ondatra . Kanadai H. Die canadische Bisamratte .

n. Közönséges Mezötanyászok. Feldmäuse . . 215

Poc. Die Wasserratte

Földi M. Die Schermaus, Erdmaus

Mezei M. Die kleine Feld-

maus o. Lemmingek. Lemminge 216 Közönséges L. Der Lemming

Sziberiai L. Der Zokor... p. Szittanyászok . . . 217

Reményfoki Sz. Die Ohrma1s 
Lap. q. Ugregerek, Springıäuse 218

3. Szơkegerek Springhase . . . . 219

Kaffer Sz. Der Berghase . -

4. Vaksilk. Blindmäuse Vak V. Die Blindmaus. . 220 5. Pislogíli . . . Zátonyi P. Der Sandmoll 221 Fehérfoltos P. Der cap'sche Maulwurf . . . -

6. Zsebegerek, Beutelmaus . . . . -

7. Csútegerek . . 222

8. Hódok. Biber . Kanadai H. Der Biber . 223

9. Szilhridok . . . 224

10. Súlök. Stachelschwcin

a. Tulajłlonképi súlök . . 225

Tarajos S. Das gemeine Stachelschwein .... -

b. Szitsük . . . . . -

c. Túrejtsủk . . . . . 226

d. Göndesúlek . . . . . -

11. Nyulak. Hasen a. Tulajdonképi Nyulak . 227 Mezei Ny. Dex gem. Hase Változó Ny. Der Alpenhase Tengeri Ny.Das Kaminchen $22 \mathrm{~S}$ Siberiai Ny. Das Sibitische

Kaniuchen . . . . Afrikai Ny. . . . . -

b. Sípörlék. Pfeifhase • . 229 Apró S. Der Zwerghase ‥ Havasi S. Das Schoberthicr 230 12. Hártyőrlék . . . Guyanai H. Der Capybara -
Lap.

13. Orlecsek, Meerschweinchen 231 Tengeri Ö. Ferkelkaninchen 14. Mokok . . . 15. Agulik. Aguli Farkas A. Akuchi . . . 232 Pampasz A. Pampashase . 16. Pakák. Paka . - (?.) Csinkörle, Chinchilla . . . 233 VI. FOGHIJASAK • • $A$. L a s a n júrók. Faulthiere . . .234

1. Lajhárok. Faulthiere a. Áj-ok . . . . 235 b. Lajhárok tulajdonképen 236 Közönséges L. Der Unau * IIal-áj . . . . 237 B. Rendes Foghijasok.

2. Tatuk. Gürtelthier

a. 'Tatuhetek . . . 238

b. Tatutizek . . . . 239

c. Tatupikkek . . . . -

d. Tatuvájak . . . 240

e. Tatukirmok . . . 241

Szörnyü T. Der Riesentatu f. Hátavértesek . . . Csonka H. Das Cürassthicr 3. Tijlábals. . . 212 Reményfoki V. Erdferkel 4. Hangyászak. Ameisenfresser

Sörényes H. Yurumi . - Fogódzó H. Caguaré . . 5. 'Tobzoskák. Schup- 
Lap.

penthier . $\quad 244$

C. Egyvékuak, együrüek.

6. Gömbölyek. Stachelameisenfresser 247

7. Kacsaszájuak. Schnabelthier

Képtelen K. . . . . 248 VII. VASTAGBÖRÜEK . . A. O rmán y o s a k $\mathbf{2 4 9}$ 1. Elefántok. Elephant. 250 a. Kupfoguak . . . 252 B. Vastagbő r ü ek, szorosb értelemben $\mathbf{2 5 3}$

2. Vizilovak. Flusspferd $\mathbf{2 5 4}$ Kétéltü V. Das Nilpferd . 3. Disznók. Schweine 255 ^ Rendes disznók . . . Sertés D. Das Schwein - Alarcos D. Das Larvensehwein . . . . 256

Babirssza D. Hirscheber . $a b$. Szömơcspofok. Warzenschwein .

c. Hátanyilak. Nabelschwein $\mathbf{2 5 7}$ Örvös H. Patira . . . Ajakas H. Tajassu . . . 258 * Fegylenósd

4. Orrszarvialk. Nashorn 259

5. Sziklabúk. Klippschliefer . . . 260

* Hajdanóc . . . . 261

* Tarajfog . . . . 262

6. Tapirok Tapir . . Indiai 'T. Der Maiba . . 263

C. Merókörmuiek. CUVIER $\mathrm{r}$. $\mathrm{K}$.
Lap.

7. Lovak . . . . 264

Közönséges Ló. Das Pferd Dsagatáj, Dschiggetai . 265 Szamár. Der Esel . . . Zebra. das Zebra . . 266 Kúaga. Der Quagga .... Bércló. Der wilde Pard VIII. KÉRÖDZÖK . . . . A. Szarvatlanok $\cdot 267$ 1. Tevék @ . . 269 a. Tulajdonképi Tevék $\cdot 270$ Kétpúpu T. Kaneel . . Egypúpu T. Dromedar . l. Lámák . . . . . 271 Szörös L. Das Lama : : Gyapjas L. Das Vigognethice.

2. Pésmále. 271 Tatár P. Das Moschusthier 272 B. Szarvasak

3. Szarvasok. Hirsch 274 Jávor Sz. Das Elenn. Elk. lrám Sz. Das Rennthier - Dámvad. Der Damhirsch 275 Közönséges Sz. Der Edelhixsch a. Özek 278

Európai Öz. Das Reh Tatár Öz .

4. Hegyelí. Giraffe ?27!

C. Oduszarvasak . 5. Zergék . . . 280 Gazilla. Gazelle : . . 281 Korinna. Die Corinne' . Kevel. Kevel . . . . Dseren. Der Dscheiran : Szökócz. Der Springhock . 282 d. 
Lap.

Nubiai Z. Mondes-Antilope 283

Sziklaugró. Klippspringer 284

Törpe Z. Die Zwergantilope -

Horgelőcz. Der Mbill . 285

Szarvalıoszzn. Der Gemsbock -

Algazel. Algazel . . -

Kék Z. Der Blaubock . 286

Ló Z. Der Koba . . -

Szakállas, Z. Der Kudu . 287

Szarvanégy. Der Tschaku 288

Nyakszakállas.Z.DerNylgan 289

Kőszáli Z. Die Gems • . -

Gnu. Das Gnu. Niu . . -

6. Kecskék.Bock.Ziege 290

Törzsök K. Die IVilde Ziege -

Vad K. Der Steinbock . 291

Kaukazi K. Der Steinbock von Kaukazus . . -

7. Juhok. Schaafe .292 Argali J. Der Argali . Sardiniai. J. Der Muflon - -

8. Marlıálc. Ochse . 294

Közönséges. M. Der Stier. Bölény. Der Auerochs . Amerikai B. Der Bison . 295 Bival. Der Büffel . . . Gival. Der Gyall

Röfögo̊ Ökör. Der grunzende Ochs . . . . 296

Pésma Ö. Bisamochs . . -

IX. CETEK . . . . 297

A. Fúucetek . . . 298

1. Kézcetek. Manati . 299

2. Habilánok . . . -

3. Legelcetek . . 300

B. Rendes cetek (hisevök)
4. Suhanúszók. Delphine . . . . 302 a. Tulajdonképi delphinck -

b. Károrúszok . . . . 304

c. Ajkaboltok. Meerschwein 305

d. Hátasikak . . . . . 307

e. Padlatfoguak : . . 308

5. Kétfoguak. Narval -

6. Szöketólk. Caschelot 310

C. Szöketelyek . . 312

7. Cethal. Walfisch : -

a. Szárnyucetek . . . 314

b. Simahasu Szárayucetek -

c. Árkucetek . . . . 315

Tojó csontvázas állatok általában . . . 316

MADARAK : . . 318

Madárosztály rendei . . 327

1. RAGADOZÓ MADARAK . 329

A. Nappaliak . -

1. Keselyúk . . . 330

Tulajdonképi keselyűk -

Tarajkesely . . . . . 332

Tyukkesely . : . . 333

Dögkesely . . . . -

2. Keselysas, Saskeselyü . . . . 335

3. Sólymok •... 336 Sólyom

Kerecsen .. . . . 340

Nemtelen ragadozók:

1. Sasok . . . 341

Tulajdonkepi sasok . . 342

Halászsasok . . . .344

Folyamsasok . . . 345

Kigyósasok * : : : 346

Karakárak ‥ . 347 


\begin{tabular}{|c|c|}
\hline & Lap. \\
\hline Karomsasok. R & Rövröpök 347 \\
\hline Héjasasok : & • . . 348 \\
\hline Horogsasok & - : $\quad 350$ \\
\hline Héjak. & . . . . 351 \\
\hline Karvaly . . & . . 352 \\
\hline Kányák . & . . . .354 \\
\hline Darázs-ölyvek & \&... 355 \\
\hline Ölyãk • . & $\cdot .356$ \\
\hline Örvölyảk · . & $\cdot \quad \cdot \quad 358$ \\
\hline Titkár kigyósa & as . 359 \\
\hline B. Éjjeli ra & agadozók- \\
\hline 5. Bagoly & . . . 361 \\
\hline Fülesbaglyok . & . . . . . - \\
\hline Huholyok . & . . . . 362 \\
\hline Fátyolbaglyok & . . 363 \\
\hline Reszgölyök . & . . . 364 \\
\hline Suholyok . & . $\quad \therefore . .-$ \\
\hline Éjbaglyok. . & . . . . . 365 \\
\hline Karval-baglyol & ok . : - \\
\hline Parabaglyok & $\therefore . \quad$. \\
\hline 11. VEREBFÉLÉ & ÉK - . \\
\hline A. Cs orrfo & g a s ak. \\
\hline
\end{tabular}

1. Gébicsek . . -

a. Túlajdonképi gébicsek 371

Felso̊ csorrlemezök ivelt : 371

Felsó csorrlemezök egyenes . . . . . 374

Csorrok duzadt : . . 375

Fejök bubos . : . -

b. Karolyga . . . . . -

Fecskegebicsek . . . 376

Varjugebicsek . . 376

Açélgébek . : : . 377

Verébgebicsek . . .. -

Hollógébek . . . 378

Szarkagébek . . . 379

Cinkegébek . . . . -

Paragébek
2. Légylsapólk .... 380

Zsarolyak . . . . . -

Légycsipék . . ...381

Lapcsorrok . . . . 382

Tulajdonképi ségykapók • 383

Zsarolycsup . . 385

Csőrröp . . . . . . -

3. Selyemfarkuak $\quad 386$

Piohó

Rendes selyemfarkuak -

Szárnyadisz @ . . 387

Farkagok . . . . -

Locska . . . . 388

Szelecsör . . . . . . . . 389

Tulajdonképi szelecső: : - -

Torkacsup . . . . -

Nyakacsupasz : . 390

4. Bogárkapók .... -

Bogfogár . . . 391

5. Verebélyek : . - -

Hangajók . . . . . -

Nagycsorru verebélyek $\quad 392$

Tulajdonképi verebélyek -

Rióverebélyek ... -

Sarkály . . . . . . 393

Kávaduz

6. Rigók .

Túlajdonképi rigók $\quad .394$

Hurosok . . . . 395

Ragyok . . . . 398

Hurics

Riógébek: •

Hurigáz • . 399

Csórönször

7. Hangyárok @ . -

Hangyöröly : . . . Zuzgár 
8. Viztengélyek, v. Arriók 402

9. Húrszilk

10. Tarirók: 404

11. Csacslárok : . 405

Csacsogák : . . . 406

12. Zajgálok • . 407

13. Valódi Loriók • 408

14. Loricsupok $\quad .409$

* Tropidorhynchus. -

15. Lantárok

16. Billegtetók. Bilok 410

Sziklar

Dalár .... . . 412

Zenér . . . . . 413

* Dalabáj . . . . -

Csattogány ......4 417

* Csalogány . . . -

Ǒköıszem; Parányka. . 418

Gyepükér. Csaláncsatto-

gató . . . . . 420

Billegérek

Tulajdonképi billegérek . 421

Bilcsirták . . .... -

Pipárok

17. Piprák . ... 423

Kötanyárok . . . . -

Kottengek . . . . -

Valódi Piprák . . 424

18. Csőrbók. Csoratágok -

B. Szelt csoruak -

19. Fecskék . .425

Fellengü . . . . -

Tulajdonképi fecskék * 426

20. Lappantyúk @ 428

Lappoga
Lap.

C. Kupos csorruak. -

21. Pacsirták . . 431

22. Cinegélk . . 433

Tulajdonképi cinege . . 434

Szakállcin

435

Csügecin

23. Sármányok • 436

Sárma 438

24. Pintyek

439

a. Fonár . . . . -

b. Veréb. . . . 441

c. Pinty . . . . . 442

d. Tengelic . : . . . 443

c. Kenderike . . . .444

f. Csiz . . . . 445

६. Özvegypinty . . . 446

h. Kupály. . . . .447

i. Magzuzár • . . 448

k. Pirók . . . . 449

25. Kereszlorrály . -

26. Kupahorg . . .450

27. Hajlakup • . 451

28. Vúgárok . . -

29. Csoportály . . 452

Csapatály . ....... -

Falkảr. . . . 453

Gyülér . . .... .454

Csordály

30. Seregélyek

31. Holló: Varjuk

455

Tulajdonképi hollók és varjuk : . . . . 456

Szarka . . . 458

Szajkó

Diótöro̊

459

Hollár . . . . . 460

Harju 


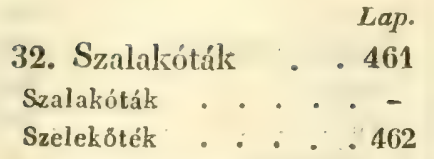

33. Paradizárok ‘... -

D. Vékony c sorruak.

34. Favágárok .... 466

Vágcsár . ... . -

Vergély .. . . 467

Kopogár . . . . . . -

35. Fakúszok . . -

Valódi fakúsż $。$. 468

Facsúsz . . . . - -

Falkúsz . . . . 469

Édszipol . . . . . -

Szipár . . . . .470

Kúszlan . . . . . -

Mézszip . . . .471

Diszkúsz . . . . -

Pókfalár . . . . 473

36. Pompály . . - -

Pompály . . . .474

Diszcsér . . . . 475

37. Babuták . . 476

Banka . . . . . -

Tulajdonképi babuták .477

Gyurgya . . . . 478

Bankaragy . . . . -

E. Öszujjuak . -

38. Gyurgyalagok . 480

39. Gyürgyelegek @ 482

40. Jegérek . . . . -

* Dacelo . . . . 483

41. Ujjhijárok ... 484

42. Tódok . . . -

43. Szarvályok $\quad-$

111. KÚszóK
1. Kapasz. Galbula . 487

Gyurgyakúsz .. . . . -

2. Harkályok @ 488

a. Harkálycsa , v. harka. ‘491

3. Nyaktekercsek . . 492

Tekerăcsek . . . 493

4. Kalsukok

Valódi kakuk

Kuály . . . . 495

Kukály . . . . . -

Kuroly . . . . . 496

Mézkallauz

Szakállkukuk . . . . -

5. Hajlakúszok . 497

6. Borsalkúszok . . -

7. Pofókúsz . . . 498

Szakállnagy . . . . -

Szakállár . . . . 499

Szakállkúsz

8. Kurukuruk . . 500

9. Nyüvészek ... 501

10. Borsályok . . 502

Tulajd. borsályok : . . -

Csorrályok . : . . 503

11. Papagály .' . -

Papara . . . . .504

Papakúsz

a. Papacsup .

b. Papanyil

c. Papaterj . . . . 505

d. Papakúsz . .... . 506

Papadú. Csacsogály . . -

Papaga . . . . 508

Papatár .. . . 50!

Papujár

12. Turakúsz

510 


\begin{tabular}{|c|c|}
\hline & \\
\hline Bana- & Rendes Galambok. \\
\hline . . . . 511 & oene \\
\hline FÉLIEK . . - - & Tuba \\
\hline lygó . . . 513 & V. GÁZLÓK \\
\hline . . . . - & A. Rövid szál- \\
\hline . . . . . .514 & nyuak... \\
\hline .Jaku , . . . . 5 & 1. Szaladárok . \\
\hline $\begin{array}{l}\text { 7. Jakutárs } \\
\text {. Uijváltyuk }\end{array}$ & 2. Kazuárok . \\
\hline 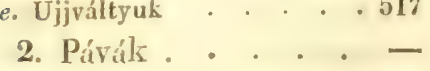 & * Dudn . . \\
\hline Pávacs. . . . . .510 & B. Nyomott csor \\
\hline kálk . . . . - & ruals \\
\hline gytyukok . 520 & 3. Túzokolk. \\
\hline 5. Fácánok • · . . 521 & 4. Lilék . . \\
\hline Kakas. v. Tyuk . . . - & Lábtömér . \\
\hline Fúcán . . . . . 522 & . . . \\
\hline . . . . . 524 & 5. Libuc . . . . \\
\hline ér. • · · 52 & Bíbicek, Libucok, Libuc- \\
\hline nhijár $\cdot \cdot \cdot \cdot \cdot-$ & \\
\hline 6. Fajdok · . . 526 & Libucok \\
\hline$\cdot \cdot \cdot \cdot-$ & 6. \\
\hline $\mathrm{d} \cdot \cdot \cdot \cdot \cdot .520$ & 7. $\mathrm{U}$ \\
\hline Csupfajd . . . . . . & S. Bubapárols \\
\hline $\begin{array}{l}\text { Fogoly. . } \\
\text { Fogolyszi . }\end{array}$ & u a k \\
\hline Rendes fogoly . . . 531 & 9. Daruk \\
\hline Fürj . . . . . . 532 & . . . \\
\hline$\cdot . \quad . \quad . \quad .533$ & . . . . $5 t$ \\
\hline 7. Hármujjak . . 534 & . . . \\
\hline Féll: & 10. Rákrászak \\
\hline zlyok $\cdot \cdot \cdot \cdot-$ & 11. Ge \\
\hline 8. Farklanok . . . 535 & gém \\
\hline . . . $\quad-$ & . . . . . \\
\hline . . . . 536 & a..... . \\
\hline & . . . . . \\
\hline 9. Galambok • . & . \\
\hline Tubatyuk . . . & 13. Orrondik . . \\
\hline
\end{tabular}


\begin{tabular}{ll} 
14. Nyomgólyák & $\begin{array}{r}\text { Lap. } \\
\text { 15. Hiúcsorrak }\end{array} \quad$. 568 \\
\hline 569
\end{tabular} a. Kereporr

16. Tantalok . 570

17. Kalámosak , 571

D. Hosszcsoruak $\mathbf{5 7 2}$

18. Lebenke . .... 573

Batla . . . . . -

Ugaríly . . . . 575

Tulajdonképi Lebenke .576

Szemenke . . . . 578

Iszapgåz . . . . 579

Partiram . . . . 580

Ulomokgúzz . . . . 581

Árpacsirta . . . . 582

Hajlár. . . . . -

Kaszacsorr . . . .583

Vibic . . . . . -

Iramúsz . . . . . 584

Lapútrsorr . . . . -

Szilics-iram . . . . .585

Köhengér . . . . . -

Viziram . . . . .586

Karélyláb . . . . . 589

Szijláb . . . . . . -

19. Kardorruak . .590

E. Nagyujjuak . 20. Parrák . . . 591

21. Palmédok . . 593

Örgáz . . . . . . 594

Lábnagy

22. Guvatok . . .595

Hatis . . . . . .596

23. Fúk . . . . 597

Nádfí . . . . . . -

Biborfu
Tulajdonképi Szárcsák . 598 24. Hüvelyér. 'Tokgáz 599 25. Porondály .

26. Lảngály

600

V1. USZHÁRTYÁSAK _. . . 602

A. B ukárok Rövidszárnyuak.

1. Hosszanbukók . . 603

Vöcsök . . . . . -

Szárcsavöcsök . . 605

Bukdár . . . . . -

Bukjó . . . . . 606

Bukdacs . . . . 607

2. Alkík . . . 608

Bábusz . . . . . -

Tulajdonképi Alka . . . 609

3. Reptelenek • . 610

Reptelen . . . . -

Replenúsz . . . .611

C'sakúsz . . . . . . -

B. 'Távolrepülök.

4. Hojszák . . . 612 Hojsza . . . . .613

Vészjús . . . . 614

Széltárs . . . . -

Tengerör . . . . 615

Hojhúsz

5. Diomédek . . -

6. Csüllök . $\quad 616$

Csülls . . . . . .017

Sirály . . . . . 618

Ganály . . . . 619

7. Halíszák . . .620

Bangók . . . .621

8. Gólicok . . 622 
T.X TARTATOMMUTATÓ, A\% ET,Sï KÖTETHEZ.

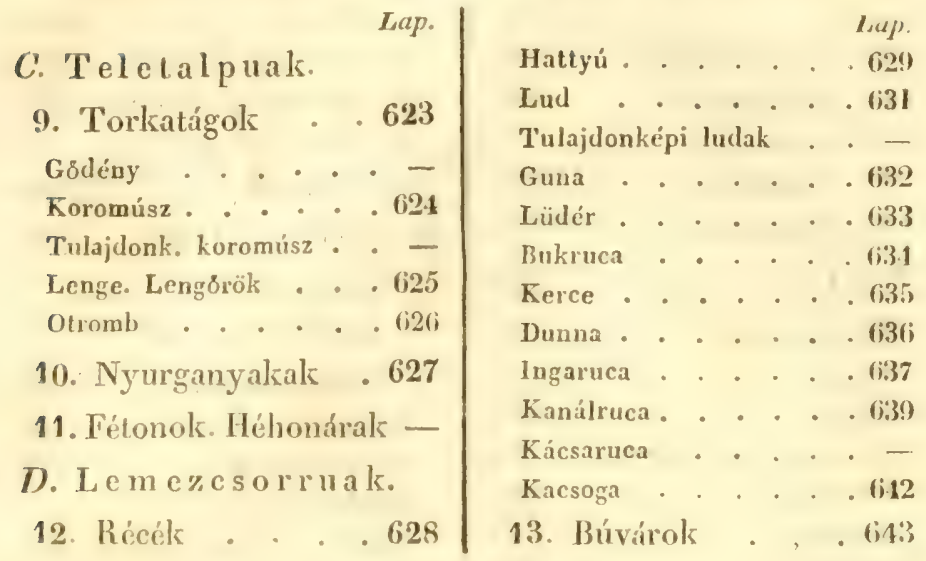




\section{A $\%$}

\section{Á L L A T - ORSZÁ G,}

FöloszTVA ALKOTÁSA SZERINT.

\section{BÉVEZETÉS.}

A' TERMÉSZEET LEIRíSRUL 's ANNAK IRÁNYZATAIRÚL, MÓDSZERÉrÜL, ÁLTALÁBAN.

\section{K}

evés embernek lévén a' természetleirásrul igaz képzelete, szükségesnek láttuk munkánkat azon tárgynak szoros meghatározásával kezdeni, mellyet ezen tudomány maga elébe fölvesz, és szigorú határokat rendelni ezen és a' határos tudományok között.

A' franczia nyelvben és a' többiek nagyobb számában is a' TERMÉszeT szó alatt értetnek: majd azon tulajdonságok, mellyeket valamelly Jény eredeténél (születésénél) fogva bir, ellenökbe téve a' talám mív által nyerteknek; majd a' mindenséget alkotó lények egyeteme; majd végre az ezen lényeket igazgató törvények. 'S leginkább ezen utolsó értelemben szokás a' természetet személyesíteni 's nevét tiszteletbül alkotojáé helyett használni.

OUVIER T. K。 
A' természeltudomainy (physica) ezen háurom tekintetben vizsgálja a’ természelet. Ö általino vagy ḳülönös. Az viltalcinos természetludornciny elvonólag vizsgálja a’ testeknek nevezett, mozogható 's kiterjedı lények mindenik tulajdonságát. Erötudománynak nevezelt része tömeghben veszi a' testeket ügyelöre, és igren csekély szímu vizsgálatoknál kezdre, számolatosan meghatározza a' súlyegren, a' mozgás és annak közlése törvénycit; különbozố osztályailoan myguattuclomciny (statica), erömivtan (mechanica), viznyugvat- (hydrostatica) vizeró(hydrodynamica), legrnyugvat-tudomainy (aërostati(a), stb. nevezeteket kap, azon testek természete szexint, mellyeknek mozgásail fürkészi. Á läcistudomainy (optica) a' világrosságg tulajdlon szabályaival foglalatoskodik; és itt a' csak csupán lapasztalís által meghatírozható tünemények számosabbak lesznek.

A'vegy-tudominy (chemia), az álıalános természéltudomány másik része, azon törvényeket magyarizza, mellyek szerint az elemrészecskék egymásıª hatuak közel helyezetben, azon egyesïleteket és clválísokat, mellyek ezen részecskék általános vergyïlésre vágyásábul erednek, azon módosításokat, mellyek az öket eltávoztatni vagy közelebbre vezetni képes különbféle körülállások által okoztatnak ezen törekvésnél. Liz csaknem egészen tapasztalgatasi tudomány, mellyel nem lehete számolatra vonni. 
A'héség és villanyosság elmélete (theoriája), a' mint egyik vagy másik oldalrúl tekintjük, majdnem egyenlöen tartozik az erö- 's vegytudományhoz.

$\Lambda z$ általános természettudomány minden részében uralkodó ircinyzat (módszer) a' testek elszigetelésében (isolatio) áll, és a' legnagyobb egyszerüségre való hozatalokban, mindenik tulajdonságuk különös munkásságra ébresztésében akár fontolgatás akár tapasztalás által; azok sikerének megismerésében vagy kiszámolásában, végre ezen tulajdonságok általánosításában 's öszvekötésében, hogy belólök tudomány-épület képeztessék és, ha lehetséges, mindnyája olly egyetlen törvény alá vonassék, melly valamennyinek általános kifejezése volna.

A' különös természettudomány vagy is a'természet-leirás (mert ezen két kifejezés egyértelmü) tárgyúl ismeri az általános természettudomány különbözó ágai által kitanult törvényeknek a’ természetben létezó különbféle számos lényekre való különös alkalmaztatását 's végre az ezen lények mindenikétül mutatott tünemények magyarázását.

Ezen kiterjedt értelemben a' csillagászságot (égtudományt, astronomia) is magában foglalná; hanem ezen tudomány magának az erómívtudománynak világai által eléggé földeríttetvén 's annak törvényei alá teljesen bocsátva lévén, azon irányzatoktúl, mellyeket a' rendes természetleirás meg- 
enged, különbözóbbeket kiván, mint sem loggy azon személyek által míveltethetnék.

Ezen utolsót tehát a' szoros számolatot 's minden részökben pontos mérést meg nem engedö tárgyokra szorítják, még rendesen az idoöjoircis tudománycit (meteorologia) elvonják tóle, az általímos természettudomínyhoz kötendöt: a' természetleirás nem visgál tchait élettelen testeknél egyebet, mellyek ásványoknak neveztetnek, és még az éló lények különbözö fajtáit, mellyek közül mindeniken tapasztalhatni a' mozgás és elemi vonszódás, valamint az általínos természettudomány által föloldott minden más okok törvényeinek többé kevesebbé különbözö sikereit.

Szigoruan véve a' természetleirásnak is azon bánásmódot kellene követnie, mellyet az általímos undományok hasznának, és valóban köveli is azt, ha visgálódásának tárgyai amnak megengedésére plécgré egyszerüek. Ilanem sok hibázik még, hogy azt mindig tehesse.

Valójában valódi különbözés az az általános tudományok és a' természetleirás között, hogy az. elsöknél csak azon tüneményeket visgáljuk, mellyeknek minden körülményét szabályozhatjuk, föloldások által közönséges törvényeket lelendök; a’ másodikban pedig a’ tünemények olly föltételek alatt forognak le, mellyek nem függnek az öket visgálótul, ki bonyolódásukban a’ már ismert általános törvények hatásil kifejteni törekszik. Meg sincs 
ennek (a’ figyelónek) engedve hogy apródonkint minden föltételek alul elvonja azokat 's a' föladást (problema) elemcire hozza, mint a' tapasztalgató tesz; hanem azokat öszvesen köteles venni, egyszerre minden föltételökkel, föloldásokat csak elméjében tehetve. Kezdje, például, valaki azon tüneményeket elszigetelni, mellyekbül a' fejlésfokon egy kevéssé fölemelt állatnak élete áll; csak egynek elnyomásával is, elenyészend az egész élet.

E’képen az erőtan majd egészen számolati tudomány lön, a’ vegytan még csupán visgálati tudomány; a’ természetleirás részei nagy számában soká csupán figyeleti tudomány maradand.

Ezen három mellékjelezet eléggé jól kimutatja azon bánásmódot, melly a' természeti tudományok három ágában uralkodik; hanem köztök a' bizonyosság igen különböző fokait allítván föl, egyszersmind azon czélt is láttatja, mellyhez a' két utolsónak törekednic kell, hogy a' tökély felé fölebb 's fölebb emelkedjék.

A' számolás, úgy szólva, kormányozza a’ természetet; pontosabban határozza meg tüneményeit mint őket a' figyelés képes megismertetni; a’ visgálás (tapasztalás) oot maga föltakarására kényszeríti; a’ figyelés kémleli öt, zavargásakor, 's meglepni törekszik.

A' természetleirásnak azouban van egy különös észbeli okfeje, mellyet sok alkalomnál haszon- 
nal vesz elö, ez a' létel föltétele, melly közönségesen végokok nevét kapja. Semmi nem létezhetvén, ha lehetöségének föltételeit nem hordja magában, minden lény különbözö részeinek ugy kell öszve-rendeltetniek, hoggy létezhetóvé tegyék az egész. lényt, nem csak maǵíra hanem az azt körülvevó dolgokra nézve is; és ezen föltélelek szítbontása gyakran általínos törvényekre vezet, olly bebizonyítottakra, millyenek a' szímolat-és tapasztalásbul száamazottak.

Csak akkor szorulunk a’ figyelet egyszerü törvényeire, midőn az általános természettudomány és a' létel föltételeinek törvényei kimerítettek.

Ennck megnyerésćhez legsikeresebb pálya az öszvehasonlításé. Ez abban áll, hogy ugyan azon testekre folyvíst figyelünk, a' mint azokat különbözö helyezetbe teszi a' természet, ragy a' különbféle testeket addig hasonlítjuk öszve, mig állandó viszonyokat lelünk alk otásuk és azon tïnemények között, mellyeket mutatnak. Ezen különbözö testek megannyi tapasztalás fajok, a' természet által készíttetve, melly köztök mindeniknek ád vagy tagad meg különbféle részeket, mint mi azt múhelyeinkben kivánhatnók, 's ö maga megmutatja azon hozzá toldás vagy elvétel hatását.

Illyenképen bizonyos törrényekhez jutni, melylyek ezen viszonyokat szabályozzák és ugy használtat nak, mint az általános tudományok által meghatároztattak. 
$\Lambda$ 'figyelés ezen törvényeinek az altalánosakkal való egybekötése, akár egyenesen, akár a’ lét föltételeinek okfeje szerint történvén, a' természeti tudományok rendszerét teljessé tenné, minden részeiben minden lények kölcsönös egymásra hatását éreztetve. És ide kell az ezen tudományokat mivelók törekedésének irányoztatnia.

Hanem mind ezen féle visgálódások fölteszik azt, hogy erönkben van azon testeknek, melylyekkel bánunk, ön magunk - 's mások általi biztos megkülönböztetése; különben untalan kitétetünk a' természet nyujtotta számtalan lények öszvezavarásának. Tehát a' természetleirás alapul birja az ugy nevezett természet rendszerét, vagy egy nagy névsort, mellyben mindenik lény illö nevet bir, megkülönböztető jegyek által ismerhető, el van szakasztva osztályokra és alosztályokra, mellyek szinte megneveztettek 's bélyegezve vannak, - mellyben végre fölkereshetö.

Hogy ezen névsorban mindenik lény ismerhetö legyen, szükséges hogy bélyegét magával hordozza; tehát a' bélyegek nem kölcsönözhetők a’ pillantatokig gyakorolt tulajłonsárgoktúl vagy minöségektül, hanem az alkotásbul kell vetetniek.

Majd alig van valami lény, melly egyszerü bé-lyeget birna, vagy alkotása vonatainak egyike által megismertethetnék; majd mindig több illy vonatokat kell egyesítenünk, hogy valamelly lény a' szomszédoktúl megkülönböztessék, mellyek azok közül 


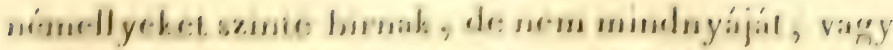

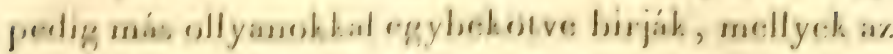

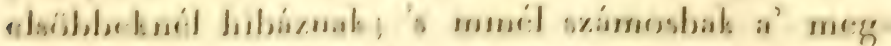

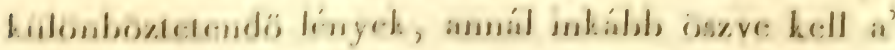

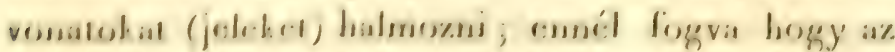

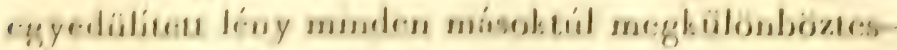

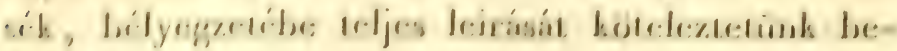
ikturui.

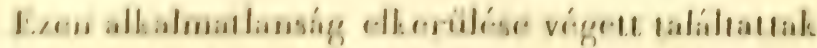

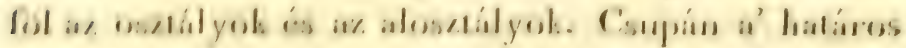

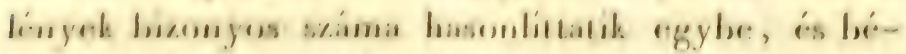

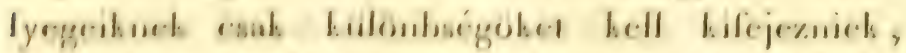

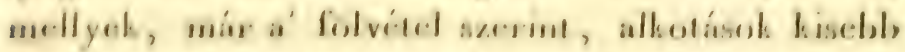

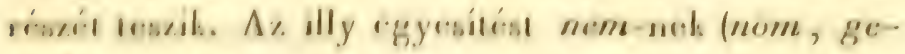
mess) neverziak.

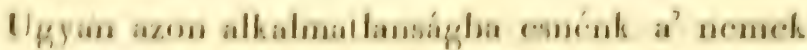

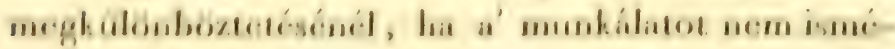

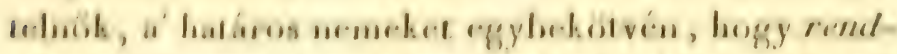

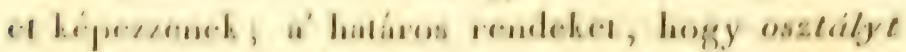

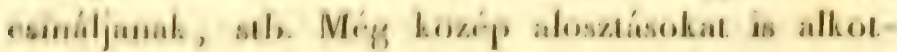
latuit.

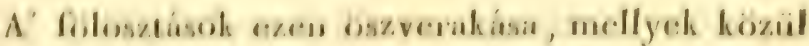

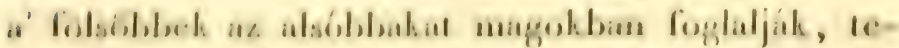

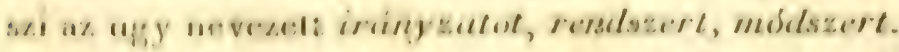

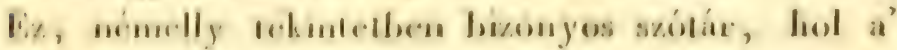

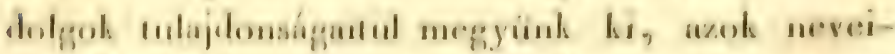

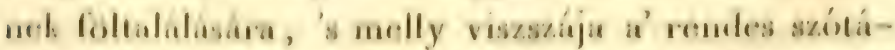
rohnal, lnol a' nevehriol imdulumh n' inlajelonsigek m16. 
De ha az irányzal jó, nem szorulkozik csak a’ nevek tanítására. Ha az alosztások nem önkény szerint állapíttattak meg, hanem valóságos alapos tulajdonságokra, a’ lények valódi hasonlatosságára alkottattak, akkor az irányzat legbiztosabb eszköz ezen lények önségeinek általános szabályokra vonására, azoknak legkevesebb (rövidebb) szavakkal való kifejezésére és könnyủ megtartásokra az emlékezetben.

Annak illyenné tevése végett, a' lényeket szorgalmatosan egybehasonlítjuk, a’ bélyegek alárendelésének elvétül kormányoztatva, melly maga is a' létel föltételeiétül származik. A' lény részeinek kölcsönös viszonyban kellvén egymás iránt lenniek, vannak olly alkotási vonatok (jegyek), mellyek másokat kizárnak; vannak ellenben másokat szükségképen megkivánók is; midőn tehát illyen vagy olylyan vonatokat ismerünk valamelly lényben, kiszámolhatni a' vélek együtt létezóket, vagy a' mellettök meg nem állhatókat; azon részek, tulajdonságok vagy alkotási vonatok, mellyek legnagyobb számban birják ezen meg nem szívelhetés (sziveletlenség) vagy együtt létezés jeleit, vagy más szavakkal, mellyek legkijeleltebb befolyást gyakorolnak a' lények egyesítésére, neveztetnek fontos jellemeknek, uralkodó sajátságok-nak, mások alárendelt bélyegek, és illyenek hasonlókép különböző fokuak vannak.

A' bélyegek ezen befolyása néha okos módon meghatározható a' müszer természetének visgálata 
által; ha ez nem lehetö, az egyszerú figyelést hasz:náljuk, és a' súlyos bélyegek megismerésének biztos és magábul természetökbül származó módja az, hogy ezck a' legállandúbbak; és liogy a’ különbözö lények hoszú sorában, a’ hasonlatossáng fokai szerint egymáshoz közelítókében, ezen bélyegek legutószor változnak.

Befolyásoktul és állandóságoktul egyenlöen származik azon szabály, hogy öket a’ nagy fölosztások megkülönböztetésére kell méltatni; 's hogy azon mórtékben, a’ mint alsóbb fölosztásokra bocsátkozunk, szinte alárendelt változó bélyegekre is ereszkedhetni.

('sak egy irányzat (methodus) lehet tökélyetes, ez a' természeti ircinyzat, módszer (természeti rendszer); igy neveztetik azon elrendelés, mellyben az azon nembeli lények egymúshoz közelebb állanak mint minden más nembeliek; az azon rendbeli nemek, közelebb, nuint minden más rendbeliek, és ugy tovább. Ezen irányzat, azon tökélykép, mellyhez a' természetleirásnak iparkodnia kell; mert világos hogy a'hoz eljutván, az egész természet pontos és teljes kifejezését birnók. Valóban minden lény másokhoz való hasonlatossága és azoktul különhözése által határoztatik meg, és mind ezen viszonyok tökélyesen helyeztetnek az általunk kijelelt elrendeléshen.

Egy szóval, a’ természeti irányzat magává az egész tudománnyá lesz 's a'véle tétetett mindenils lépés czéljához közclebbre vezeti a’ tudományt. 
$\Lambda z$ élet lévén a' lények minden tulajdonságai közt a' legfontosabb's minden bélyegök legmagasal-bika, épen nem csudálatos, hogy minden idóben ezt tették legáltalánosabbá a' megkülönböztetés elveinél 's hogy a' természeti lényeket mindig két végetlen osztályra szakaszták, az èlö 's élettelen lényekére.

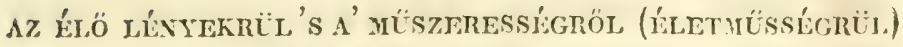
ÁLTLLÁBAN.

Ha, hogy az élet valóságárul igaz képzeletet nyerjünk, azt azon lényekben vizsgáljuk, hol hatásai legegyszerübbek, hamar észreveendjük, hogy azon tehetségben áll, mellynél fogva némelly testegyesületek bizonyos ideig 's határozott idom alatt fömmaradni képesek, az őket körülvevő testekbül egy részt szünetlenül fölvéve magokba, ’s önanyagukból az elemeknek némelly részt visszaadva.

Az élet tehát olly örvény, többé kevesebbé gyors, többé kevesebbé bonyolt, mellynek iránya állandó 's mindig azon nemü részecskéket von maga után; hanem hol az egyéni részecsek nyugtalanul be és kimennek, olly módon, hogy az élö testnél az idom valódibb az anyagnál.

Mig ezen mozgás tart, addig azon test, mellyben gyakoroltatik, élö, él. Mihelyt a' mozgás, viszszajövendés nélkül, megsziún, a' test meghal. A' ha- 
lál után az elemek, fölszabadíttatván à rendes elemtörvények alá, hamar bontakozni kezdenek, a' honnan hamarább vagy késóbben beálland az élt test eloszlása. Tehát az életi mozgás volt az, a' mi ezen eloszlást korlátozá, 's a' test elemeit pillantatokig egyesíté.

Minden élö test meghal egy idő után, mellynek véghatára mindenik faj számára kiszabatott, 's a' halál az élet szükséges következésének lemni látszik, melly munkálása által is megváltoztatja észievétlenül azon testek alkotását, mellyekben gyakoroltatik, olly módon, hogy annak folytatása lehetetlen lesz.

Valóban az élö test fokonkinti, hanem állandó változásokat tapasztal, egész tartása alatt. Eleinte a' kiterjedésekben nöl, a' mindenik fajnak 's az mindenik részének kiszabott viszonyokat követve, 's a' kijelelt határok között maradva; utóbib részei nagyobb számának tömöttsége nevekszik, és úgy látszik, hogy a' változás ezen második neme teszi természetes halála okát.

Ha a' különböző élö testeket közelebhrül visgáljuk, bennök egy közös alkotást találunk, melylyet egy kis gondolkozással is hamar valódilag szükségesnek itélünk azon forgataghoz, millyen az életi mozgás.

És valóban kivántatnak a' testeknél merő részek, hogy az idomot biztosítsák, és folyó részek, a’ mozgást föntartandók. Szövetök tehát hálós és 
kászmás, rostokbúl álló és merö lemezekbül, melylyek a’ folyó részeket téreikben tartják, ezen folyókban legállandóbb és legkiterjedtebb a' mozgás; az idegen anyagok a' testek belszövetébe hatnak, azokkal egyesülendők; ezek táplálják a' meróket, közbe szállítva részecskéiket; ezek fosztják meg fölösleges részeiktül a' meróket, a' kivetendö anyagok folyó vagy gáz idomban hatják ált az élö testek gőzelőit, likacsait (porus); hanem ellenben a' merók foglalják magokban a' folyó részeket és öszvehuzódások által mozgások egy részét szerzik.

A' merö 's folyó részek ezen kölcsönös hatása, a' részecsek ezen egyikekbül a' másikakba menetele, nagy hasonlatosságot tesz szükségessé azoknak elemi öszvetételében; és valóban a' müszeres testek merő részei nagy részint könyen folyó vagy gázidomba általmehető elemekbül tétettek öszve.

A' folyó részek mozgása szinte egyre ismételt hatást kivánván a' merók részérül, 's ők is ollyast osztván, megkivántatik, hogy a' merők egyszersmind hajlékonyak és kitágíthatók legyenek; és valóban, ez majdnem közönséges bélyege a' müszeres merő részeknek.

Ezen minden élö testtel közös alkotás, ezen hálószövet, mellynek többé kevesebbé hajlékony rostja 's lemezei többé kevesebbé bővelkedő nedveket tartanak, neveztetik müszerességnek, életmüsségnek (organisatio); 's következöleg a' mondottak szerint csak a' müszeres (életmüs) testek élhetnek. 
A müsseressign, a’ mint látók, nagy szímu chendelésekbül (dispositio) áll, mellyek meg amnyi föltételei az életnck; 's megfogható, hogy az élet általános mozgáza megállani kénytelen, mihelyt hatása arra megy ki, hogy föltételeinek egyike megválıztassék, olly módon, hogy csak egyike akadjon is föl azon részinties mozgásoknak, mellyekbül össze van téve.

Minden müszeres testuck, szövete közös minöségein kivïl, tulajdon idoma is van, nem csak illababan és külsöképen, hanem mindenik része alkotásának belsejéig, 's ezen idom hatúrozza meg az álala gryatiorolt részinties mozgások mindenikének tulajdon ixányát, mellytül élete általámos mozgásának bonyolata függ, a’ fajt kifejezö 's ót azzá tevö, ¿' mi valóban. Ezen általános mozgást mindenik rész elösegíti tulajdon cselekvés últal's annak különös hatását érezi, olly módon, hogy mindenik lényben az élet olly öszveség, melly részei kölcsöuös hatásábul és viszszahatásábul származik.

Tchát az élet általában müszerességet tesz föl, 's mindenik lény tulajdon élete, azon lény tulajdon müszerességét föltételezi, valamint az órajaráis az órát; - 's innét életet csak a’ müszeres és az egészen azzal birásiá alkotott lényekben látunk, 's a' természeutudósok minden törekvése nem mutathatá még az alkotó anyagot meg, a’ magátul vaggy akármelly más külsö okbúl munkálkodót. Valóban, az élet à rendes elemi rohonságok íltal szülendä 
hatással egészen ellenkezót gyakorolván az elemeken, mellyck mindig részei az éló testnek, 's azokon, mellyeket abba fölvesz, innét a' józan észszel ellenkezik, hogy az maga is ezen rokonsígok által volna teremtve, 's azonban még sem ismerünk a' a' természethen semmi más erót, melly az elóbls válva volt részecseket egyesíteni képes volna.

A' müszeres lények születése tehát legnagyobb titok a' müszeres hatósághan és az egész természetben; egész mostanig csak fejlódni látjuk azokat, de nem képezódni; sót mégr többet, - mind azok, mellyeknek eredetéig föl leheteıt hatni, egy hozzájok hasonló idomu, de elóttök kifejlett testhez, szóval, szülöhöz, nemzöhöz voltak ragadva. Mig a' nemzendőnek nincs tulajdon élete, hanem nemzöjébül vesz részt, $c$ sirá-nak mondatik.

Azon hely hova a' csira tapad, az ót elválasztó 's neki tulajdon éltet adó alkalmi ok különbözó, hanem ezen ösi eleintei hozzáragadás a' hasonló lényhez, kivételtelen szabály. A’ csira elválása nem$z e ́ s-n e k$ mondatik.

Minden müszeres lény magához hasonlót nemz, különben, a’ halál az élet sziilkséges következése lévén, a’ fajak nem állhatnának fön.

A' müszeres lényeknek bizonyos, elvesztett részeiket újra tenyésztó crejök is van, fajaik sze-rint, különbözó fokon. Lz az ugy nevezett rijra tenyésztés ereje. 
A'múszeres lények kifejlödése többé kevesebbe gyors, többé kevesebbé kiterjedt, az inkább vagy szükebben kedvezö körülmények szerint. A' melegség, az eledelek bösége 's neme és még más okok is vannak reá befolyással, 's ezen befolyás általános lehet az egész testre vagy különös, bizonyos müszerekre; innét jö hogy a' nemzettek hasonlatossága nemzöikhez nem lehet mindig tökéletes.

A' múszeres lények e'féle különbözéseit nevezzük fajtcik-nak.

Nincs semmi tanúnk, hogy a' müszeres lényeket már kijelelö különbözések olly természetïek volnának, hogy illy módon a' körülmények által hozattak volna elö. Mind az föltételes, a’ mit e’ tárgyrul állitottak. Söt a’ tapasztalás ellenkezót látszik bizonyitani, hogy t. i. föld golyonk mostani létében a' fajták igen keskeny határok közé szorítattak, és a’ mennyire csak vissza tudunk hatni a’ régiségbe, azon határokat a’ maiakkal egyeknek látjuk.

Tehát bizonyos idomokat köteleztetünk föl-venni, a’ dolgok eredete olta fönn állókat, ezen határokon túl nem lépöket; és minden, ezen idomok egyikéhez tartozó egyének teszik az úgy nevezett fajt (espèce). A' fajták a' faj történetbeli elosztásai.

A' nemzés lévén egyedül azon határok megismerhetésének eszköze, mellyekig a’ fajták kiterjedhetnek, imnét a' fajt igy határozzuk meg: $\alpha z$ egymástul, vagy közös, ès hozzajok annyira, mint 
ök magokhoz hasonlitó nemzöktül származott egyènek egyesülete; de, noha szigoru ezen meghatározás, érezhető hogy igen nehezen alkalmaztatható a' meghatározott egyénekre, ha szükséges tapasztalások nem tétettek.

Újra mondva, a’ beszívás, önnönítés, kigőzölgés, kifejlödés és a' nemzés minden éló testtel közös munkálatok; a' születés és a' halál lételök általános határai; a' háló idomu, öszvehuzható, téreiben mozogható nedvet vagy gázt tartó szövet, alkotások fó valósága; nedüvé vagy gázzá majd egészen átváltozható anyagok 's egybül másokba könynyen átmehető öszveköttetések, elemi alkotások alapjai. Határzott és a' nemzés által örökítendő idomok különböztetik meg fajaikat, határozzák meg a’ másod munkálatok bonyolatát a' mint az közülök mindeniknek tulajdona, kimutatják az általok a' mindenség egyetemében játszandó szerepet. Ezen idomok magok nem teremtik elö 's nem változtatják magokat; az élet fölteszi lételöket; az csak az egészen előkészített müszerzetekben gyúlhat meg; és a' legmélyebb gondolkozás, a' legfinomabb figyelés nem ér elöre a' csirák elölétezéseig.

A MỨszeles LÉNYeK Fölosztása Állatokra 's NövéNYEKRE.

$\mathrm{Az}$ élö vagy is müszcres lények a' legôsibb idök óta lelkesekre, azaz érzékenyekre 's mozgókra, CUVIER I. $k$. 
és lelketlenekre azaz ezen tehetsígek egyikével sem birokra osztattak föl. Noha több növény öszvegöndöríti megérintett leveleit, a’ gyökerek mindig a' nedv felé irányzódnak, a' levelek a' lég és vilíg fe-lé, 's noha némelly növényi részek minden észrevehetö külsö ok nélküli rezgéseket is mutatnak, de ezen különbféle mozgások kevesebbé hasonlitanak az állatokéhoz, hogy sem bennök érezés és akaral tanuságát lehetne találni.

Az állatok mozgásainak önkényessége valódi módositásokat kiván meg mégg azoknak csupán növényi múszerciben is. Grökereik nem hatván a' a' földbe, képeseknek kell lenniek magokba helyheztemi a' táplálandó eledeleket, és a' raktárt magokkal hordozni. Innćt származik az állatok elsó jelleme, vagy bélcsatornájok, mellybül a' tápredv egyób) részeikbe hat a' gớzclökön, (likacsokon, góziireken) vagy edényeken által, mellyek mintegy belsó gyökerek.

Ezen csatorna 's toldalćkai müszerzetének különböznie kell az eledelek természete's azon munkálatok szerint, mellyeknek azok alá vettetnek, miclölt a' beszivásıa alkalmatos nedveket nyujtanának, migg azonban a' légkör 's a' föld már kész nedveket aduak a' növényeknek 's mindjárt a' bešivásra alkalmatosakat.

$\Lambda z$ állati test, melly számosabb és különbözöbl, munkálatokat kénytelen temni a' növényinél, követketkezóleg sokkal bonyoltabb müszerzetet is bir- 
hat; részei nem tarthatván egymás közt különben állandó helyzetet, nem vala más mód, minthogy nedveik mozgása külsó okok által létesítteték, 's annak a' melegtül és légkörtül függetlennek kelle lenni; illyen az állatok második búlyegének, vagy kerengési rendszeröknek, oka, melly az emésztésinél kevesebbé valódi, minthogy nem szükséges a’ legegyszerübb állatoknál.

Az állati múveletek müszeres rendszereket kivánnak, mellyekre a' növények nem szorulnak; az izmokét az akarat szerinti mozgásra, az idegekét az érzés végett; es ezen két rendszer nem múvelkedvén, mint mind a' többiek, egyéb, mint a' nedvek vagy folyórészek mozgása és átképzödése által, szükséges, hogy ezek inkább bövelkedjenek az állatokban, 's az állati test elem-öszvetétele bonyoltabb legyen mint a' növényé; e'képen azoknál egy anyaggal (a’ fojtóval, azotum) több valódi elem van, melly a' növényeknél a’ müszerzet közönséges három eleméhez: a’ savítóhoz, gyúlóhoz és szenőhöz csak történetbül köttetik. Ez az állatok harmadik jelleme.

A' föld és a' légkör eledelül vizet adnak a' növényeknek, melly savítóbul és gyúlóbul áll, és levegöt, melly savítóbul és fojtóbul tétetik öszve, és szénösavanyat, melly a' szénő és savitó vegyülete. Hogy ezen élelmekbül tulajdon állományt alkossanak, a' gyúlót és szénót megg kelle tartaniok, a’ fölösleges savítót kigoózölögniek, a’ fojtribul keveset vagr sem- 
mit fölvenniek. És illyen a' növényi élet menetele, a' valódi múveletül a’ savitó kigözölgését ismeröé, melly a' világ segedelmével történik.

Az állatoknak, inkább mint a' növényeknek, közvetett vagy közvetetlen táplálatul a növényi öszszctétel szolgál, mellỵhen a’ gyúló és szenő förészek gyanánt léteznek. Hogy ezeket tulajdon vegyủletökké dolgozzák ált, meg kell a’ sok gyúlótul, kiváltképen pedig a' szenötül szabadítaniok, - a' fojtót pedig föl kell halmozniok; ezt a' lélekzés által teszik, a' levegö savítojának segedelmével, melly a' vér gyulójával és szenöjével egyesül, és ezekkel együtt viz és szénsavany idom alatt kilöketik. $A z$ akármelly uton testökbe ható fojtó ott lítszik maradni.

A' növények és állatok tehát megfordított viszonyban vannak a' levegöhöz; az elsök fölszíják a' vizet és a' szénsavanyt, az utolsók azt újra nemzik. A' lélekzés valódi müvelet az állati test alkotásáníl; ez állatisítja azt némiképen, 's ez okbul látjuk hogy az állatok annál tökéletesebben gyakorolják állati müveleteiket, minél tökélyesebben lélekzenek. $\Lambda$ 'viszonyok ezen különbségében áll az állatok negyedik bélyege. 
AZ ÁLIATI TEST MÜSZERI ELEMEINEK TULAJDON IDOMAIRUL, 'S VEGYTANI ELEMEINEK FöVEGYÚLETEIRÜL.

A' koczkás (hálós) szövet 's a' három vég-elem minden élö testtel közös, egy negyedik elem különösen az állatoké; hanem ezen szövet különbféle kúszma idomokbul tétetik öszve, és elemei változó vegyülés utján egyesülnek.

A' müszeres anyagoknak vagy szöveteknek három neme van, a' sejtszövet, az izomrost és a' velö; és mindenik idomhoz tulajdon végelem-vegyület és tulajdon müvelkezés tartozik.

A' sejtszövet számtalan apró lemezekbül tétetik öszve, mellyek vaktában hányattak el és apró sejteket vesznek közbe, egymással mind közösülőket. Ez egy bizonyos szivacs-nem, az egész testtel egyidomú, minden többi részek által betöltető vagy átvágató. Tulajdonsága a' végetlenül öszvehuzódás, ha az öt kiterjesztve tartott okok megszünnek; ezen eró tartja a' testet kiszabott idomban és határok között.

A' tömött sejtszövet a' hairtycik-nak nevezett 's többé kevesebbé kiterjedt lemezeket képzi; a' hengeresen öszvehajlott hártyák az edények-nek nevezett, többé kevesebbé ágos csőket teszik; a’ rostok-nak nevezett szálak, sejtszövetté olvadnak föl; a' csontok nem egyebek földanyagok öszvehalmoźasa álıal megkeményedett sejtszövetnél. 


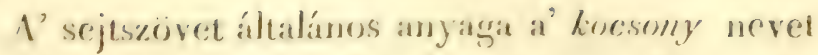

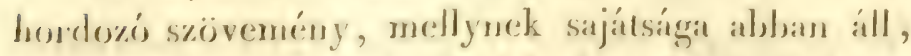
longy a' forró vizlon fölolvad's a' meghülés által remegö kocsonyává lesz.

$\Lambda$ 'velït (relïanyagot) nem tudtuk mind eddig míszeres relemende oldani, ez valami lágy kása gyanäu tün a' szem elóbe, esak végetlemiil apróo golírsolat kïlönböztedscliank meg benne; föletszö mozúsuliat alkatmatlan, hanem benne alapodik azon csurlálistos crö, melly a' kïlérzékek fölvett be川jonnásait az ön-nek ön-rin nok (an Moi) áltadja, is az akarat paraucsolatait az izmokkal közli. $\Lambda$ agy 's a' gerincoagy nagy részint e'bül állanak; és a' mindrn éroékeny müszerbe clterjedö idegek valójokra nézve az ö elágozásainak grïgyüi (pamaljai). $\Lambda$ ' hus-vaggy izomrost a' sáálakuak tulajdon neme, mellynek meghiilumbözletö sajálsága az, hogy az élet lartisat alatt redökbe szedetve öszvehuzódik, ha valanelly test altal érintetik vagy löketik megg, vagy hat az ileig lözluejurasa allal az akarat mumkálkodását érezi.

Az izmok a' hészakinatus mozgás kozvellen müsะerei nem eğ. elok izommostok gügyüinél; minden ahámelly oissvenjománt g. akorlandó edények illy rostokhal vammak feggrerkezve; ezek mindig belhíven eggesiiluk ar ideguzáloklal; de a' csupoun növé-

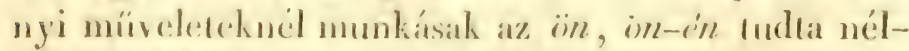

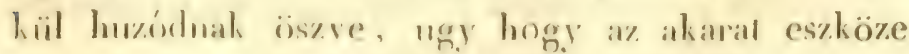


ugyan a' rost hatásának, hanem ezen eszköz sem általános, sem egyedüli.

Az izomrostnak egy rostó-nak (fibrine) nevezett tulajdon anyag szolgál alapul, a' forró vízben el nem olvadó, mellynek természete az ezen szálidom fölvételében látszik helyheztetve lenni.

A tápláló nedv (tápnedï) vagy is a' vér, a' mint a' keringés edényeiben létez, nem csak legna-gyobb részint föloldható az állati test közönséges elemeire: a' szenőre, gyulóra, savítóra 's fojtóra, hanem magában hordozza a' rostót és kocsonyt is , majd egészen elkészültten az öszvehuzódásra és a' hártyák's szálak tulajdon idomainak fölvételére, legalább kevés nyugalom elég ezeknek benne mutatkozhatására. A' vér szinte egy sok folyó és meró állati részekben találtató szöveményt is láttat, a' tojuisfehe'rt (fehérnyét), mellynek bélyege az, hogy a' forró vízben öszveáll; bennne majd mind azon elemeket föllelni, mellyek akármelly állat alkotásába béjuthatnak, mint a' meszet és villót, a' csontvázosak csontjait megkeményítöket, a' vasat mint a' vér és más részek színesítőjét, a’ zsirt vagy állati olajt melly a' sejtszövetbe gyül, azt lágyítandó, stb. Az állati test mind ezen folyó 's meró része a'vérben létezett végelemekbül képzödik, 's mindenik csak az által különbözik, hogy némelly elemekbül kevesebbet vagy más viszonyt bir, honnan látható, hogy képződésök csak a' vér egy vagy több eleme egész vagy részintes elvonásátul függ, és igen kevés 
számu esetben, más honnan jött néhány elem hozzíadásátul.

Ezen müveletek, mellyek által a' tápnedü a' test minden részének merö 's folyó anyagát megtartja, általában elvcilasztcis (secretio) nevet kaphatnak. Azonban e' nevet gyakran a' nedvek elötermesztésére szorítjuk, és különösebben tciplcilásnak nevezzük a' meró részek eltartására 's nevekedésére szükséges anyagok képzését és lerakását.

Minden merö müszernek, minden folyó anyagnak, játszandó szerepéhez alkalmatos vegyülete van, mellyet mind addig megtart, mig egészsége fönáll, minthogy a' vér azt meguijitja, mennyire elváltozott. Az azt kipótoló vér önvegyületét is egyre változtatja; hanem viszont súlyegyenbe tétetik az anyagát megújitó emésztés, a’ fölösleges szénő- és gyúlótul megszabadító lélekzés, a' kigózölgés és más különbféle ürületek által, mellyek a' többi túlbövelkedó anyagelemektül szabadítják meg.

A' vegytani összetételnek ezen untalanos átváltozásai nem kevesebbé valúdi részét teszik az élet-örvénynek, életforgatagnak, mint a' látható és áttételes, (akarattalan) mozgások sőt ezeknek is csak azon átváltoztatás szolgál tárgyul. 
AZ ÁLLA'TT TESTBEN MƯKöDö ERöKRÜL.

Az izomrost nem csak a' készakaratos, önkénytes mozgás müszere; láttuk hogy egyszersmind leghatalmasabb azon eszközök közt, mellyeket a' természet a' növényi élethez szükséges mozgások előhozására fordít. E'képen a' bélcsatorna rostai a' féregmozgást szülik, melly az eledeleket áthajtja ezen csőn; a’ sziv és üterek rostjai a' vérkeringés éltetői 's ez által minden elválasztásokéi is.

$\mathrm{Az}$ akarat öszvehuzódtatja a' rostot az ideg közbehatása által; és az akarattul független rostok, millyeneket már megjegyzénk, szinte mind a' beléjök ható idegek által eleveníttetnek, tehát hihetó, hogy az idegek birják őket öszvehuzódásra.

Minden öszvehuzás és általában minden kiterjedésheli változás a' természetben az elemi vegyülés változása által történik, ha nem másképen is, mint egy súlymérhetetlen folyóanyag be vagy kifolyása által, millyen p.o. a’ hevő (caloricum); igy történnek a' legerószakosabb, ismert mozgások a' földön, a’ gyúladások, eldurranások, stb.

Tehát igen meglehető, hogy az ideg sulymérhetetlen folyó anyag által hat a' rostra, annál inkább, mivel bebizonyíttatott, hogy tömeghatást reá nem gyakorol.

Az egész idegrendszer velósanyaga egynemü, és valahol találtatik, képesnek kell lennie a' termé- 
szetéhez tartozó müvelcteket gyakorlani; minden ágazata nagy böségben kap vérhordó edényeket.

Minden állati nedv a' vérbül vétetvén elválasztás által, nem kételhető, hogy az idegnedv szinte ezen eselben van, ha csak a’ velö maga nem válaszıja el.

Más oldalrul az bizonyos, hogy a' velö anyag egyedüli vezetöje az idegnedvnek; a’ többi müszeres elemek mind megannyi korlátozúi 's elrekesztöi, mint az üveg a’ villanyé.

A’ külsó okok, mellyek érzéseket képesek szülni, vagy is öszvehuzódásokat tudnak a' rostban teremteni, mind elemi hatók, a’ föloldásnál munkálkodhatók, mint p.o. a’ viláğ, a’ hevö, savak, illatos gőzek, ütés, nyomás, stb.

Igen ugy látszik tehát hogy ezen okok elemzetes módon hatnak az idegnedüre's annak vegyületét változtatva; és ez annál inkább hihetó, mint hogy azoknak hatása ellankad ha soká folytattatik, mintha az idegnedvnek elödi vegyúletének viszszavételére volna szüksége az újonan átváltozandás végett.

Az érzékek külső müszerei mintegy ollyan rosták, mellyek az idegre csak azon hatás fajt bocsátják, mellynek reája minden módon hatni kell, de mellyet gyakorta öszve is halmoznak, benyomását nevelendök: a’ nyelvnek szivacsos szömölcsei vannak, hogy azok a' sós olvadatokat beigyák; a’ fülnek kocsonyás bele, a' hangrezgés által remegésbe jövendö; a’ szemnek átlátszó lencséi, mellyeket csak sugár járhat által, stb. 
Az ugy nevezett ingerlök vagy a’ rost öszveJuzódásait okozó hatók, ezen munkát hihetőleg ugy gyakorolják, hogy az ideg által ugyanazon sikert hozzák a’ rostnál elö, mellyet az akarat szok elóteremteni, azaz, az ideg nedvet a' befolyása alatt lévó rost kiterjedéseinek elváltoztatásához szükséges módon cserélgetik; hanem az akarat semmit nem folyhat be munkájokra, az én gyakran épen semmi ismerettel sincs rúla. A' testül elválasztott izmok még ingerelhetök, míg a’ velök maradt idegdarab a' rájok hathatás erejét megtartja, - az akárat pedig világosan idegen ezen tüneménynél.

Az ideg nedv olly igen változik az izom-ingellés mint az érzékenység, és mint a' készakaratos mozgás által, 's néki is szüksége van arra, hogy szöveményében helyre pótoltassék.

A' növevény élethez szükséges akarattalan mozgások az ingerlés által határoztatnak meg; az élelmek a' beleket ingerlik, a' vér a' szívet. stb. Ezen mozgások mind elvétettek az akarat 's általában (míg az egészség (art) az én ismerete elül; az óket nemző idegeknek is több részekben azon, az érzékek hatását tapasztaló, vagy az akaratnak alája vetett idegekétül különbözó elosztások van, mellynek tárgyául éppen azoknak elöle elvonása látszik kitéve lenni.

Az idegmüveletek, azaz az érzékenység és izomi ingerlékenység, annál erósebbek minden helyen, minél bóvelkedóbb a' hatójok ; és valamint ezen ható vagy is az idegnedü elválasztás által nemződik, an- 
nál inkább kell bövelkednie, minél több velös vagy elválasztó anyaga van 's minél több vért kap. ezen anyag.

$A^{\prime}$ vérkeringéses állatoknál az üterek által jut a' vér a' test részeihez, mellyek azt ön ingerlésök és a' szívének segedelmével járatják. Ha az üterek ingereltetnek, erősebben munkálkodnak és több vért vezetnek; az idegnedü bövelkedöbb lesz, a' helyi érzékenységet neveli; az üterek ingerlékenységét is fölmagaszalalja, 's ezen kölcsönös hatás igen meszsze haladhat. Neve torlódićs, dagcily, (orgasme), 's midön fájdalmas és állandó lesz, gyuiladcis, (gyie, lob). Az ingerlést az ideg is kezdheti, ha érzései élénkek.

Az idegek és rostok ezen kölcsönös befolyása, mind a' bél, mind az ér-rendszerben, teszi a' növényi élet valódi rugóját az állatoknál.

Valamint a' külsö érzék csak bizonyos érzetö, érzésre gerjesztő anyagnak ád által menetelt, ugy a’ belsö müszerekre is esak bizonyos inger hathat. Illy módon a’ higany (kénesö) a' nyálmirígyeket ingerli, a' körösbogás a' hugyhólyagot, stb.... Ezek az úgy nevezett tulajdon, fajszerü hatók.

Az idegrendszer egynemü és huzamos lévén, a' helybeli érzések és ingerek az egészet elfárasztják 's mindenik, igen messze vitt müvelet meggyöngítheti a' többieket. A' sok eledel gátolja a' gondolkozást 's az igen hosszan nyujtott gondolkozás gyengíti az emésztést, stb. 
A' mértéket haladó helyi ingerlés az egész testet gyöngítheti, mintha az élet minden ereje egy pontra volna gyüjtve.

Más helyen egy másik ingerlés tétetvén, ez az elsót kisebbíteni, vagy a' mint mondatik, elvezetni képes, illyen a' hajtók 's hólyagszívók, stb. sikere.

Bár melly rövid is ezen magyarázatunk, elegendő azon lehetóség megállapítására, hogy a’ természeti élet tüneményeirül számot adhatunk egy olly nedv fölvétele mellett, mellyet azon tulajdonságok szerint meghatározánk, mellyeket mutat.

AZ ÁLLATI TEST MÚVELETEINEK ÉS MÜSZEREINEK, 'S AZOK BONYOLATA' KÜLÖNBÖZÖ FOKAINAK ÖsZVES ÁTNÉZŹ́sE.

Azok után a' mit a' test müszeri elemeirül, végrészeirül és a' bennek munkálkodó erókrül mondtunk, még csak azon különös múveletekrül, mellyekbül az élet öszvetétetik, és a' hozzájok tartozó müszerekrül, kell öszves ábrázolatot adnunk.

Az állati test múveletei két osztályra szakadnak.

$\mathrm{Az}$ állati vagy az állatoknak tulajdon müveleteire, azaz, az érzésre és készakaratos mozgásra.

A' növényi (tenyészeti) vagy az állatokkal és növényekkel közös müveletekre, millyen a' táplálkozás és nemzés.

Az érzékenység az idegrendszerben helyezüdik. 
Legáltalánosabb külsö érzés a tapintás; helye a' bör, ezen az egész testet betakaró hártya, idegekkel mindenütt keresztiil szöve, mellyeknek végszálai annak színén szömölcsökbe végzödnek a’hám és más érzéketlen takarók által védetve, millyenek a' haj, ször, pikkelek, stb. Az izlés és szaglás csak finomabb tapintások, mellyeknek számáxa a' nyelv és orr böre különösen müıserezett, az elsö, emeltebb és szivacsosabb szömölcsök által, a’ másik mindig nedves fölszinének rendkivïli finomsága és sokszorozása által. A' szemrül és fülrül már szóltunk általában. A' nemzés müszere egy hatodik érzéssel van megajándékozva, belsö böréluen létezövel; a’ gyomor és belek érzéke szinte tulajdon érzetek által tudatja ezen belrészek állapolját. Végre a’ test minden részében támodhatnak történetbül vagy betegségek által többé kevesebbé fájdalmas érzések.

Sok állatnál hibámnak a’ fülek és az orrok, többeknél a’ szemek; vamnak mellyeknél csak a’ tapintás létez, a’ soha nem hibázó.

A' külső érzékek által fölvett hatás az idegek álıal az idegrendszer középtömegéig elterjed, melly a’ fölsőbb állatoknál az agybul és gerinczagybul all. Minél emeltebb természetii az állat, annál tömegesebl, az agy, az érzó eró annál gyüjtvébb benne; olly módon, a’ mint az állat alább van a' sorfokon, velós anyaga is eloszlik; a' legtökéletlenebb nemek nél az egész ideg - anyag össze-vegyülni látszik a’ lest közoos anyagával. 
Fejnek nevezik a' test azon részét melly az agyat 's az érzékek fó müszereit foglalja magában.

Midón az állat valamelly érzést fel fog, 's benne akarat támad, ezen akaratot szinte az idegek által közli az izmokkal.

Az izmok hús-rostok gügyüi, pamatai, melylyeknek öszvehuzódása szúli az állati test minden mozgását. A' tagok kinyujtása, a’ részek minden hosszabbítása megannyi eredménye az izom öszvehuzódásnak, nem különben mint meghajtások és megrövidülések. Mindenik állat izmai számra 's irányra nézve az általok teendő mozgásokhoz képest rendelvék el; 's midón ezen mozgásoknak hatalmasan kell történniek, akkor az izmok kemény, egymással ízesült, megannyi emelö rud gyanánt tekínthető részekhez ragadnak. Ezen részek csontnak neveztetnek a' vázos állatoknál, hol ők belülsők, villósavas mész végrészekkel átjárt kocsonyos anyagbul képzettek. Tekenyóknek, hejaknak, pikkelyeknek mondatnak a' puhányoknál, hejasoknál 's bogaraknál, hol kivülsők és mész vagy szarv-anyagbul a' bör és hám közé átizzadóbul, tétetnek öszve.

Az izomrostok más kocsonya nemü rostok segítségével tapadnak a' kemény részekhez, - 's ezek amazok folytatása gyanánt látszanak 's az úgy nevezett inakat képzik.

A' kemény részek iz - (izesülési) színének idoma kiszabja a’ mozgások határait, az izszínek pedig megerósíttetnek az ízesülés oldalaira ragadt giï- 
syük vagy takarók által, mellyek szalagoknak neveztetnek.

Ezen csont és izom készületek különbféle elrendelései 's a' tagoknak azokbul szármozó idoma 's 's viszonya szerint, képesek az állatok számtalan mozgásokat tenni, mellyekbül járások, ugrások, repülésök és uszások tétetik öszve.

Az emésztésnél 's körfutásnál munkás izomrostok nincsenek az akarat alá vetve; azonban idegeket még is kapnak, hanem mint mondók, azok közül a' jelesbek olly fölosztásokat és csomósodást tapasztalnak, mellyeknek az látszik czélul kitüzve lenni, hogy azokat az én hatalma alul elvonják, És csak az indulatok, vagy az elme más erós mozdúlata idején haladja ált az én hatalma ezen gátszéleket 's majd mindig háborítva a' növényi múveletek rendét. Érzéstül csak beteg állapotban kisértetnek ezen müveletek. Az emésztés rendesen az állat észrevétele nélkül történik.

Az eledelek, az álkapcsok és fogak által elapritva, vagy, ha csak higat nyel az állat, fölszíva, a’ száj hátulának és toroknak izmai által lenyomatnak 's letétetnek az ételcső elsô részeibe, a' rendesen vagy több gyomorrá fölfújtakba, hol a' föloldó nedvektül átjáratnak.

A' csatorna többi részébe vezettetvén, ott még más nedveket is kapnak, elökészitésöket végrehajtandókat. A' csatorna falai gözlöket, likacsokat, birnak, mellyek ezen tömeghül a' táplálásra alkalmas 
részı fölszíják, a hasztalan maradékot pedig ürülmény (ganaj) gyanánt kivetik.

A csö, mellyben a táplálás ezen első munkálata történik, a bör folytatása, és ezéihez hasonló lemezekbül áll; az ezt körülvevő rostok is hasonlók a bör belső színét lepókhöz, nevök izoming (pannicule charnu); az egész csatorna belsejében átizzadás történik, nagyon megegyező a bör kigözölgésével, s amannak elnyomása mellett bövebbé leendö; maga a bör egy a belcsóéhez igen hasonlító fölszivást gyakorol.

Az ürülmények csak az utolsó állatoknál jönek a szájon által vissza, mellyeknek bele vak zsákot képez.

Még a két végnyilásu ételcsövel biró állatok közl is sok van, hol a tápnedü, a bél oldalai által fölvéve, egyenesen elterjed a test szivacsossígába; a bogarak egész osztálya ide látszik tartozni.

De a pókoktul és férgektül számítva (kezdve), zárt edényrendszerben kering a tápláló nedv, mellynek csak utolsó ágai osztják el a táprészecseket a táplálandó részekbe; a tápláló nedvet a részekhez eképen vivö edények üterek-nek mondatnak, a mellyek pedig a keringés középpontjához vissza viszik, vérerek-nek; a keringés örvénye majd egyszerü, majd kettős, majd még hírmas is (a verócz vagy kapuerét ide számolva), mozgásának gyorsasága gyakrau, szív-nck nẹczeu, izmos készuiletek öszvehuzodása által rezéreltedik.

CUVIER J, K. 
melly a keringésnek egyik vagy mísik, néha mind a két közepére helyeztetett.

A bel-vázos és piros vérü állatoknál a tápláló nedv fehér vagy útlítszó, midőn a belekbül tovább megy s ekkor t(ip) a neve; tulajdon, úgy nevezett téjedények által a véreres rendszerbe ömlik, itt a vérrel vegy vilendö. A téjedényekhez hasonló, és azokkal az ligy hivott nyirkrendszert képezö edények szinte a vérbe viszik a részek táplálatának maradékát $\mathrm{s}$ a bör fölszívásának szüleményét.

Ilogy a' vér alkalmatos legyen a részek táp láláśura, szuilkséges hogy a körülvevö folyósíg részérül a lélekzés által a fölebb említett módositást tapasztalja. A körfutásu állatoknál az edények egy része a vérnek azon müszerekbe vezetésére rendeltetet, hol ażok nagy fölszínen eloszlanak, hogy a körülvevö folyóság hatísa cróscbb legyen. Midön azon folyósíg levegö, akkor a szín üreges és neve tüdö, ha pedig víz, akkor a szín fölemelt, s neve kopótyu. Mindig vannak itt mozgási müszerek, a körülvevö folyóságot a lélekzö müszerbe vagy reá vezetendők.

A keringéstelen állatoknál a levegö vezetöknek (léglyukaknak, tracheae) nevezett rugékony edények által terjed el a test minden részére; vagy a víz munkálkodik, majd az edények által behatva, majd csak a bör fölszínét fürösztve.

A lélekzett vér minden részek vegyületének vissza pótolíśía alkalmatos, valamint a tulajdon- 
képen úgy nevezett táplálás eszközlésére is. Igen csuda az a könnyüség mellyel minden ponton ugy oldatik föl, hogy épen a szükséges elemeket adja ált; de ezen csuda is teszi az egész növény életet. A merô részek táplálata végett csak igen elosztva látjuk az üterek végssö ágacsait, hanem a nedvek elöhozása végett a készületek különbözőbbek és bonyoltabbak; az edények utolsó végei majd egyszerüen terjednek ki a nagy fölszíneken, honnan a' szült nedv kigőzöölg; majd apró üregek fenekén történik ez, honnan azon nedv kiizzad; leggyakrabban pedig, minekelötte vérerekké változnának ezen ütérvégek, különös edényeknek adnak lételt, mellyek a nedvet áltvezetik, a két edény-nem egyesületi pontjánál származni látszót; majd a vér és az ugy nevezett tulajdon edények összekeverednek és a torlott vagy is elválasztó mirígyeket képezik.

A vérkeringéssel nem biró állatoknál, nevezetesen a bogaraknál, a tápnedú minden részt füröszt; ezeknek mindenike belöle veszi a táplálatá-. hoz szükséges részecseket; s ha itt valamelly nedvet kell elökészíteni, a tulajdon edények a tápláló nedvben usznak s gózelöik által a nedü vegyületéhez megkivántató elemeket szívják belöle.

Igy tartja meg a vér szünetlenül minden részek vegyületét és kipótolja a változásokat, mint müveleteik folyvásti és szüikséges következéseit. Ezen munkálatrul szerezhetó általúuns képzeleteink elég- 
gé világosak, noha nincs megkülönböztetett s poutos ismeretünk arrul, a mi minden ponton történik; és mivel mindenik rész elemi öszvetételét elég pontosan nem ismerjük, nem is adhatunk szigoruan szímot az annak elöteremtésére szükséges átváltoztatásokrul.

Azon mirígyeken kivül, mellyek a belsö gazdasághan szerepet játszandó nedveket választanak el a vérbül, vannak mások, a testbül kivetendö nedveket. készitök, történjék az bár fölöslegesség mialt, mint a vese nemzette hugry-nál, vagy az állatnak valamelly hasznára, mint a tus a tintaféregnél, a bibor-nedv más puhángoknál.

A mi a nemzést illeti, itt egy munkálat vagy tïnemény van, melly az elválasztásoknál, más módon, nchezebb megfogásu, - ez a csira elótermése. Még azt is littuk, hogy ezt majinem megfoghatlannak kell tckinteni; hanem a csira lételét egyszer megengedve, a nemzésre nézve semmi kuilönös nehézség nincs. Mig az anyához ragad, ugy tápláltatik, mintha annak müszere volna; attúl elválván pedig, tulajdon életet bir, melly a fölüdlültéhez hasonló.

A csira (állatpete), az ébrény (embryo), a magzat, az újdonszült soha sem birják tökéletesen a fölüdült idomát s különbözésök néha olly nagy, hogy hasonlósulások átváltozás nevet érdemle gyakorta. [IIy módon senki sem gyanítaná, ha észre nem vette vagy nem hallotta volna, hogy a hernyóbul pille lesz. 
Nevekedése folytában minden éló lény változik, azaz bizonyos részeket elveszt, más elöbb tekintetbe kevessé jött részei pedig kifcjlődn€k. A' pillangó csápjai, szárnyai s minden része a hernyó bóre alá volt rejtve; ezen bőr eltún az álkapcsokkal, lábakkal s más a pillangónál nem találtató müszerekkel együtt. A béka lábai az úgy nevezett ebihal (ebhal, ebbék) börébe zárvák, s hogy az ebihal béká vá változzék, elveszti farkát, száját, kopótyuit. A csecsemő is születésekor elveszti lepényét és burkait; bizonyos korra majd egész paizsmirígyét elveszti, lasankint hajat, fogakat, szakállat kap ; müszerei nagyságának arányai változnak, teste a fejéhez képest inkább nól, feje inkább mint belfüle stb.

Azon hely, hol a csirák (peték) mutatkoznak, s ezen csirák öszvegyültsége, petefészek-nek, csirarejtö-nek mondatik; azon csatorna, mellyen az elválasztott pete alá ereszkedik, petevezér-nek; azon üreg, mellyben születése elótt némelly fajoknál hosszabb, rövidebb ideig kell tartózkodnia, méhnek; a külsô nyilás, mellyen elöjő, vailag-nak. Ha kettő a nem, akkor a hím termékenyít (fogamtat), a nő (nőstény)-nél a csirák jelennek meg. $\Lambda$ fogamtató nedv neve: mag (himmag), az ezt elválaszió mirígyeké: tök (here); és midón a mag a nó testébe bélövendó, az ezt végre hajtó múszer a vesszö (mony). 


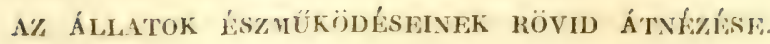

A külsö tárgyak benyomása az ḱN-re, az érzés és kép elöhozísa áthathatlan titok lelkünknek, az anyagászság (materialismus) pedig annál merészlettebb föltétemény, minthogy a' bölcselkedés az anyag valódi lételének semmi egyenes tanúbizonyságát nem ludta adni. Hanem a termózetésznek, természeltudósnak, vizsgálnia kell, mellyek ez érzés anyagi föltételei; követuic kell az elme további munkálatait; megismernie: melly pontra emelkedik az mindenik lényben, s meggyözödnie: nincsenek-e azoknál tökélletességi föltételek, mindenik faj müszerzetétül vagy mindenik egyén testének jelen állapotjátul fügçők.

Hogy az év érezhessen, szükséges hogy szakadatlan idegi közösülés legyen a külsü érzék és a velö rendszer középtöınegei között. $\Lambda z$ én tehát csak az ezen tömegek által tapasztalt módosítást veszi észre; azonban igen valóságos érzetei lehetnek a nélkïl, hogy a kïlsó múszer hatást szenvedne, azok pedig majd az ideg átmenetelben, majd magában a középtömegben erednek; illyenek a látomások, álmok s némelly történetbeli bizonyos érzetek.

A középtömeg alatt az idegrendszer annál korlátoztabb részét értjük, minél tökéletesebb az állat. Az embernél ez csupán csak az agynak határok közé szorílott része; a mászóknál máx az agy és az egés. velö 's ezcknek mindenik része magánosan véve, 
olly módon, hogy az egész agy hibázata sem gátolja meg az érezést. Az alsóbb osztályokban még jóval nagyobb ezen kiterjedés.

Az én kapta észrevétel az érzett tárgy képét teremti elö. Az érzet okát magunkon kivülre helyheztetjük, s így az azt nemzette tárgyrul képzelményt, eszmét, ideát, szerzünk magunknak. Értelmességünk szükséges törvénye szerint, az anyagi tárgyak minden képzelményei időben és térben léteznek.

$\Lambda$ velötömegek által tapasztalt módosítások benyomást hagynak hátra, megújulandót s az elme elé képeket és képzelményeket hozandót vissza: ez az emlékezet, a kor és egészség szerint igen változó testi tehetség.

Az egymáshoz hasonlító vagy egy időben nyert képzelmények egymást fölkeltik: ez az eszmekeltés, képzelményszövetkezés. Ezen szövetkezés rende, kiterjedése és gyorsasága teszik az emlékezet tökélyét.

Minden tárgy minden minöségével vagy minden mellékes képzelményeivel együtt jö az emlékezetbe.

Az értelem-nek ereje van ezen mellékes képzelményeknek elválasztására a tárgyaktul s a több tárgyakban együtt találkozóknak egy ciltalános képzelménybe kötésére, mellynek tárgya a valóságban nem létez és egyedüli tetten nem mutatkozik: ez, a\% elvonás (abstractio). 
Minden éroés töblé kevesebbé kedves vigg kellemetlen lévén, a tapasztalás és ismételt vizsgálatok gyorsan kijegyzik azon mozgásokat, mellyeket azoknak megszerzésére, ezeknck pedig kikeriilésére tenni kell, s az értelem e tekintetben általános szabályohat von ki magának, az akuraratot kormányozandó.

A' kellemes érzésnek következései lchetvén, mell cek nem ollyanok, és megfordítva, - a kövelkezö érzések az elsö érzés képzelményéhez csacolódnak, és az értelem kivonta szabílyokat ezen tekintelben módosítják : ez az okosság.

I’szabályoknak általános képzelményekre való alkalmaztatásábul bizonyos idomok (minták) származnak, ezután az egyes esetekre könnyen illeszthetók: ez az okoskodcis.

Az elö és keltett érzísek, a hozzájok csatolt gyönyör és fajjdalom élénk emlékezete, teszik: a képzelödést.

Egy elöjogozott lény, az ember, azon tehelséggel bir, loggy általinos eszméit, részinti s többé kevesblée önkényes, az emlékezetnek könnyen áltadható s az általok ábrázolt általános képzelmények fölkeliésére szolgáló képekhez csatolhatja. Ezen csatoló képeket jelek-nek nevezik; öszveségök a nyelvet teszi. Midón a nyelv a hallás érzékére tartozó képekbül vagy is hangok-bul áll, beszéd-nek mondatik. Midön a képek a szemérzéket illetik, hieroglyphciknak mondatnak. Az ircis a szemérzékhez tartozí képek sora, mellyek által az elem- 
hangokat képzeljük magunk elé $s$, azokat öszvefiiggesztve, mind, a hallás érzékét illető képeket is, mellyekbül a beszéd áll, tehát ez nẹ egyéb mint a képzelmények közvetett ábrázolata.

Az általános eszméket jelek vagy részinti képek által viszontábrázoló tehetség, azokat világosan segiti az emlékezetben megtartani, s végetlen számukat hozni zavar nélkül az emlékezetbe vissza; az okoskodásnak és képzelödésnek számtalan anyagot ad, egy'éneknek pedig közösülési eszközt, melly az egész fajt részelteti minden egyik tapasztalásában; olly módon, hogy századok folytával az ismeretek határtalanul emelkedhetnek; - ez az emberi értelem különböztető bélyege.

A' legtökéletesebb állatok is végetlenül alább vaunak, elme tehetségökre nézve, az embernél; anynyi mégis bizonyos, hogy értelmességök hasonló nemü munkálatokat visz végbe. A vet: érzetek következésében mozognak, tartós indulatokra alkalmasok, tapasztalás által a dolgokrul bizonyos ismereteket nyernek, mellyek szerint alkalmaztatják magokat, függetlenül a jelen fájdalomtul vagy gyönyörtül és csupán a következések elöre látása szerint. A háziasításban érezik alávetettségöket, tudják hogy az öket megbüntetö lény szabadságában van azt nem tenni, könyörgỏ képet öltenek föl midőn bünösnek érzik magokat, vagy urokat haragudva látják. Az ember társaságában tökélyesülnek vagy romlanak; versenygés és féltésre alkalmasok; 
magok közt természeti nyelvvel birók, melly, igazán, nem egyéb mint pilantatkori érzetök kifejezése; de az ember egy sokkal bonyoltabb nyelv érzésére is tanithatja óket, melly által akaratját tudtokra ejti s öket annak teljesítésére ösztönzi.

Egyszóval, a fölsóbb állatcknál az okoskodás bizonyos fokát láthatni minden jó s rosz sikerével, s melly majdnem épen ollyannak tetszik, mint a csecsemóké, mikor még szólani nem tanultak meg. A mint az embertül távolabb esó állatokhoz ereszkedünk, ezen tehetségek is gyengülnek; és az utolsó osztályokban az érzékenység némelly s még ez is hatalmatlan jeleire, azaz némelly kevessé hatható mozgísra, a fájdalom kikerülése végett, szorulkozva végzödnek. Ezen két szél közt számtalanok a' fokok.

De az állatok nagy szímánál az értelemtül különbözö tehetség van; ez az ugy nevezett ösztön. Ez velök szükséges munkílatot tetet, a faj föntarLására, az egyén "gy látszó szükségétül gyakran egészen különbözöt, sokszor igen bonyoltat, s melly, hogy az értelmességnek tulajdoníttassék, végetlenül több elörelátást és ösmeretet tenne föl annál, mellyet az azt gyakorló fajnál megengedhetünk. Ezen ösztön szülte munkák épen nem majmolás következései, mert az azokat gyakorló egyének másoktul tenni azt soha sem látták; azok viszonyban sincsenek a rendes értelmességgel, hanem annál különösebbek, bölesebbek és érdek-mellékezöbbek 
lesznek, minél alacsonyabb osztályhoz tartozik az állat, s különben minél ostobább. Annyira a faj tulajdona az, hogy az egyének mindnyájan hasonlóképen gyakorolják, rajta semmit nem tökélyesítve.

E szerint a munkás (mézgyüjtö) méhek, a világ kezdete óta, igen elmés, a legmagasabb méréstudomány szerint kiszámolt tanyákat építenek, egy olly jövendóség lakására s táplálatára szántakat, melly nem is az övék. $\Lambda$ magános méhek és darázsok szinte igen bonyolt fészkeket raknak, tojásaikat azokba teendők. E tojásbul féreg jö ki, melly anyját soha sem látta, melly volt tömlöcze alkotását nem ismerte, $s$ áltváltozva ön tojása számára ahoz még is tökéletesen hasonlót épít.

$\mathrm{Az}$ ösztönrül nem nyerhetni világos képzelményt, mint fölvévén, hogy ez állatoknak velök született állandó képeik vagy érzeteik vannak érzéjökben (sensorium), őket cselekvésre határozók, mint a rendes és történetes érzések rendesen határoznak. Ez egy nöme az álomnak és látomásnak, óket egyre üzó, s mindenre nézve, a mi ösztönükkel viszonyban van, holdasoknak (irányálmosaknak) tekinthetni őket.

Az ösztön értelem-pótolás gyanánt adaték az állatoknak, s hogy általa s az eró és a termékenység által, illó fokon gondviseltessék mindenik faj fönmaradásárul.

Az ösztönnek nincs semmi látható jegye az állat alkatásában; de az értelem, a' mennyire tapasz- 
talni lehetett, állandó viszony ban van az agynak, s kivált féltekéinek aránylagoos nagyságával.

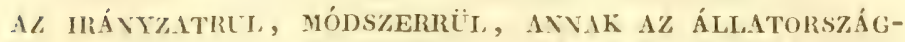
Ra VALó ALKaLMAZTATÁsábaN.

$\Lambda z$ irányzatokrul általában mondottak után, ammak tudása van még hátıa, mellyek a legbefolyóbb bélyegek az állatoknál, mellyekbül az elsö fölosztások alapját lehessen csinálni. Világos, hogy ezeknek az állati múveletektül, azaz, az érzéstiil s mozgásoktul retteknek kell lemiek, mert nem csak ök teszik állattá a lényt, hanem némiképen állatisága fokát is határozzák.

A' figyelés megerösíti ezen okoskodást, megmutatva hogy kifejlódésök és bonyolatok fokai megegyeznek a növényi míveletek müszereivel.

$\Lambda$ 'szív és a' vérkeringés müszerei mintegy közepei a növényi müveleteknek valamint az agy és az idegrendszer törzsökül szolgál az állati munkálatoknak. Most egymással enyészni s végre eltünni látjuk ezen két rendszert. Az utolsó állatoknál, a’hol nem láthatók az idegek, a rostok sem különböztethetök meg, s az emésztés müszerei egyszerüen vájattak a test azonnemü tömegébe. Sót az edényrendszer az idegrendszernél elöbb eltün a bogarak nál, hanem általában a velös tömegek elszéledése megfelel az izom hatásáénak; a gerinczagy, mely- 
lyen a csomók vagy dúczok megannyi agyat ábrázolnak, a számos gyürükre osztott és hosszában elrendelt tagpárokon hordozott testnek felel meg, stb.

Az általános idomok ezen megegyezése, melly at mozgás müszereinek elrendelésétül az ideg tömegek elosıtásátul és a keringési rendszer hatalmátul származik, szolgáland tehát az állat-országban csinálandó első föl osztások alapjául.

Utóbb, ezen osztásık mindenikénél megvizsgálandjuk, melly bélyegekuek kell ezcket egyenesen követniek s helyet (alapot) adniok az elsó alosztályoknak.

AZ ÁtLATORSZÁGNAK ÁLTALÁNOS NÉGY NAGY OSZTÁLIRI SZAKASZTÁSA.

Ha az állatországot az alapított okfók, elvek szerint vizsgáljuk, kiburkolódzva a régi fölosztásokra épített balitéletekbül, tekintettel csak alkotások és természetök iránt lévén az állatoknak, nem pedig nagyságokra, hasznokra, rólok való több kevesebb ismeretünkre, sem semmi más mellékes körülményre nem nézve, azt találandjuk, hogy négy fó idom (minta), s ha szabad a kifejezéssel élni, négy általános terv létez, mellyek szerint az állatok mindnyája képezettnek látszik, s mellyeknek további osztásai, akármi czímekkel ajándékozták légyen is ezeket meg a természettudósak, nem egre-- 
bek igen csekély módosítísoknál, némelly részek kifejlödésén vagy hozzá toldatásán alapulva, mely.lyek a terv valóján semmit nem változtatnak.

Ezen idomok elsöjénél, melly az emberé s a hozzá leghasonlatosabb állatoké, az agy és az idegrrendszer fötörzsöke csonthüvelybe zárattak, a kaponyábul és csigolákbul állóba; ezen középoszlop' oldalaihoz tapadnak a bordák és a végtagok csontjai, a test állóját képezve; az izmok általában födözik a csontokat, és mozgatják; a belrészek a fejbe és törzsökbe csukattak.

Mi az illy idomu állatokat csontvcizosak-nak (Animaux vertébres) nevezzük.

Mindnyájának vére veres, szívök izmos, szájok két egymás fölött vagy elött helyezödö álkapesu; különmüszereik a látásra, hallássa s izlésre, mind az arez üregeibe tévék; négy végtaguknál több soha sincs; a nöm mindig különvált; a velós tömegek s az idegrendszer fö ágainak elosztása igen egyidomu.

Az ezen nagy állatsorbeli állatok mindegyik részét közelebbrül vizsgálván, abban mindig lelni valamelly szabály-azonosságot, még az egymástul legeltávozottabb fajoknál is, s ugyan azon terv alálépéseit követui lehet az embertül a halak utolsajáig.

A második idomban nincs töblé váz; az izmok csak a bö́höz tapadtak, a lágy, különbfélekép öszvehuzhato takaróhoz, mellyben tohb fajok- 
nál sziklanemü lapok, tekeny, csigaház nevezetüek, nemzödnek, mellyeknek helyzete s termése hasonlít a nyálkás testekéhez; az idegrendszer a belekkel egyült ezen közös takaróban van és több elszéledt tömegbül áll, idegsszálak által öszvekötöttekbül, mellyek között a legfóbbek a torkon vannak s agynak neveztetnek. A tulajdon négy érzékbül csak az izlés és látás különböztetik meg; az utolsó hibázik is néha. Csak egyetlen egy család láttat halló müszereket. Különben mindig teljes vérkeringési rendszerök van, s a lélekzésre tulajdon múszerök. Az emésztésé s az elválasztásókéi majd olly bonyoltak mint a vázosaknál.

Mi az ezen második idomu állatokat puhángoknak nevezzük (Animaux mollusques).

Noha müszerzetök általános terve nem olly egyidomu, részeik külső tekintetére nézve, mint a vízosaké, de e részek között mindig van hasonlatosság, legalább egy fokon álló az alkotásban s müveletekben.

A harmadik idom az, melly a bogarakban, férgekben, stb. vétetik észre. Idegrendszerök két, a has hosszában folyó s térrül térre csomókba vagy dúczokba dagadt idegzsinegbül áll. Ezen dúczok elseje, a bárzsing fölött helyeződő, agy-nak nevezett, alig nagyobb a has hosszában lévóknél melylyekkel a bárzsingot gallér (nyakkörv) gyanánt körülvevơ szálak által közösúl. Törzsökük takaroja keresztredőkkel bizonyos számı gyürükre osztolt, 
mellyuck förlelei majd kemények majd lágyak, hitnem az izmok mindig a belsö félhez tapadnak. A törzsök gyakran izes tagokat bir oldalain; hanemi gyakran azok hijával is van.

Mi ezen állatohà izesültek-nek hivandjuk (Animaux articulés).

Nálok láuni az átlépést a zárt (vak) edényekbeli vérforgístul a beszírís általi táplálathoz, az ennek megfelelö átmenetelt a körülkorlátozott múszerekbeli lélekzéstül a vezetök vagy is az egész testhen elterjedı légedények által történöhoz. Az izlés és láttás müszerei legkitünóbbek ezeknél, a hallásét csak egy család mutatja. Álkapesaik, mikor vamnak, mindig oldaliak.

Végre a negyedik idom, melly minden az állatuövény (zoophỵtes) név alatt ismeretes állatot magában. foglal, szinte a sugaras cilicatok (Animaux rayonnés) nevét hordozhatja.

Vinden elöbbiekuél szépidomulag (öszméresen) rendelteltek el a mozgás és az érzékek müszerei egy tengel két oldalára. Hasontalan hátulsó és melülsö oldalok (melüleıök és hátulatok) van. Ezeknél mintegy sugarak azok egy középpont köriil, és az még akkor is igaz, mikor ezck csak két sorban vannak, mert két színök hasonlatos. A növények egynemüségéhez közelítenek; nem látni sem jó kifejtett idegrendszeröket, sem különös érzćk müszeröket; alig vehotni némellyekben a vérforgás nyomait észe: lélekzö) múszereik majdnem mindig tes- 
tiik lölızinén vamnak; a legnagyobb szám csak egy vak erszényt bir az egész bél helyett, és a legutolsó családok csak egy azonnemü, mozgó s érzékeny tömegnemet mutatnak. (1)

\section{AZ ÁLLATORSZÁG ELSÖ NAGYOSZTÁİYA.}

\section{ISONTVAZAS (GERINCES) ALLATUK.}

Testök és ragjaik egymás fölé rakott és mozogható darabokbul öszvetett csontrakvány által tartatván egyenesen, több pontossággal és vidorsággal birnak mozgásaikban; ezen támasznak keménysége nagy termetre hagyja öket jutni, s közöttük is találtatnak az állatok legnagyobbai.

(') Jegyz, Én elöltem a mostani természettudósak minden Yizlalan állatokat hét osztályra szakaszlottak, bogarakra s férgrekre. Én kezlém ezon nézetet elöszòr megtámadni s̀ más föl-osztást javasoltam egy emlekirásban, melly a párisi természetleirási társaság elött fölolvastatik a 111 . év virinyhava (floréal) 21-kén, vagy május 10. 1705., s hinyomaték a Décade plifosophique-ban, hol mrgjesyzem a puhángok, líjasok, férgek, tövisho̊riek és állatnơvényeh hatirait. Megkülönböztetén a verrs - vérï fẻrohet vagy is gyürönöket egy az Institut elött a X. év 11-kén, vagy dec. 31. 1801. fölolvasotl cmlékirásban. Utólbb ezen különböző osztályokat három ágozatra, a csontrizasukénah egyikéhez hasonlitóra osztáın egy értekezésben, melly az Instıtut elött fölolvastatéh jul. 1812, s kinyouaték az Aurales du mus. d' Hist. nat. XIX kototétion.

CUTIEA I. $\mathrm{K}$. 
Jobban központosított idegreudszerök, enuek bövelkedöbb középponti részei, nagyobb hathatóságot és tartósságot adnak érzéseiknek, a honan fölebh való értelmesség és nagyol,b tökélyesedhetés szírmazik.

Testök mindig föbül, törzsökbrïl és végtagokbul-tétetik öszve.

Fejöket a kaponya, melly az agyat rejti, és az arce képzi, melly a két álkapocsbul és az érzés müszcreibül tétetik öszve

Törsökök a hägerinc és bordcik által tartatik.

A' hátgerinc egymás fölött mozogható gerincekbäl, csigolyákbul all, mellyek közül az elsö a fejet tarlja, "ggil részök gyürüs, s együt véve esatornát képzenek, mellyben azon velö-nyulat helyezüdik, honan az idegek származnak, s melly gerincagynak neveztetik.

Igen gyakı:an nyulik ki a hátgerinc az alsó végtagokon túlra.

$\Lambda$ bordák fél körüek, mellyek a törzsök üregénck oldalát rédik, egyik végöknél fogva a gerincekkel izesülnek és rendesen a melcsonthoz érnek elöl; hanem néha nem veszik körül a törzsöket egészen, s vannak nemek, mellyeknél alig láthatók.

Soha sincs két párnál több végtagok, de ezek közül néha egyik vagy másik vargy mindenik is hibít- 
zik; idomuk különbözö az általok teendö mozgások szerint. Az elsö végtagok kezek, lábak szárnyak és uszonyok (ormók) lehetnek; a hátulsók lábak vagy uszonyok.

Vérök mindig piros és az érzés vidorságára és az izom-eróre szükséges öszvetétellel vagy is vegyülettel látszik birni, hanem különbözö fokon, a lélekzet menyiségének megfelelve, melly a csontvázas állatok négy osztályra szakasztásának szolgál alapul.

$A$ kül érzékek száma mindig öt, és két szembül, két orrlyukbul, a nyelv és az egész test födözöjébül állanak. Némelly fajoknál azonban a szemek kifejletlenek.

Az idegek a gerincagyhoz futnak a csigolák vagy a kaponya lyukain íltal; mind ezen gerincang gral látszanak egyesülni, melly ön szálait vagy is rostjait keresztül csapván elnyul, földagad, azon különböző karélyokat képzendö, mellyekbül az agy áll, s a féltekének nevezelt két agyboltba végzödendö, mellynek nagysága az értelem kiterjedésének felel meg.

Alkapcsuk mindig kettö van, fó mozgást az alsó bir, melly emelkedik ragy esik; a fölső néha egészen íkelt: egrik vagy másik majd mindig föl van fogakkal fegyverkezve, tulajdon természetü kinövésekkel, elemi vegyületekre nézve a csontokhoz iggen hasonlókkal, sorban és kiizzadás által nölökkel; egy teljes oszititl azouban (a madaraké) szaruva 
fedett álkapcsokat bir: a takenös békák neme a mászók osztályában hasonló esetü.

A bélesö a szájul a seggig megy, különbféle csavarulásı, kïlönbözoö kilágulásı és megszúkülést tapasztalva, toldalékokat nyerve és oldó nedveket kapva, mellyek közül a szájbeli nyáhnak mondatik, a többick, rsak a bélcsöbe menendök, különbözö neviiek: két föbl, a hasnyol (mint a hasnyál-mirigy nedve) és az epe. melly egy másik nagy, és májnak mondott mirigy által késziltetik.

Mig a megemésztell eledelek áltmennek aw étcsön, a líplálat-adós stap-nak mondott részö fölszivatik tulajdon ugy nevezelt tej-edények által és a vérerekbe vitetik; a részek líplalékának maradványa szinte a tejedényekhez hasonló edények által átadatik a vérereknek; ezen edények pedig egyïtt a nyirkedények rendssèrét képerik.

$A$ véredények a szívhöz viszik a részek táplalítsára szolgált, és a táp s nyirk által megríjítandó vért; hanem ezen vér egészen, vagy csak egy része, köteles a lélekzés múszerein álmenni, hogy olt üteres természetet ölsön magára, minekelötte az üterek által a testrészekhez elvitemék. Az elsö három osztályban ezen lélekzési müszer a lïclö, azaz sejtek öszvesége, hova a levegó behat. ('sak a hat laknál és némelly mászóknál, elsö horokban, kopótyu az, melly nem egréb lemez-sorokuál, melylyek közé viz hat. 
Minden csontvízas állatuál az epe anyagát a míjban azon véreres vér adja, melly résziut a belek falaiban, részint egy tulajdon, lép nevezetü testben keringelt már, és a melly minekutána egy veróc vagy is kapuéenek mondott törzsökben öszvegyült, újonan eloszlik a májban.

Mind ezen állatok még egy tulajdon elválaszlással birnak, a hugyéval, melly két nagy, a hát gerinc oldalain feküvö, s vesék-nek neveztetett mirigg ben történik; az ezen mirigyek szülték nedv többnyire egy hólyagnak nevezett tartóban gyülekezik öszve.

A nemek elválasztottak; a nö (nöstény) mindig egy vagy két petefészket bir, honnan a peték elválnak a fogamzás pillanatában.

A him azokat a mag-nedv által megtermékenyíti vagy is fogamtatja, de ezen fogamtatás módja igen különböző.

Az első három osztály legtöbb neménél megkivántatik a nedv belökése, némelly mászóknál és a halak legtöbbénél akkor történik megg, mikor a cojás már tojva van. 


\section{$\triangle$ CSONTVÁZAS ÁLLATOK \\ NÉGY OSZTÁLYRA SZAKASZTÍSA.}

Láttuk mennyire hasonlitanak egymáshoz a csontvázas állatok; mégis négy oszályt adnak, mozgásaik neme vagy eróssége által jelelkezöt, melly lélekzésök mennyiségétül függ, megjegyezve, hogy az izom-rostok ingerlékenységök erejét a lélekzéstül kapják.

A lélekzés memnyisége két tevötuil vagy is faccortul függ; elsö a vér aránylagos memy yiséçe, melly meghatírozott idó alatt a lélekzés múszereibe jut; második a savitú arányos memujisége, melly a körülömló nedv vegyületébe béhat.

A lélekzeti vér mennyisége a lélekzés és vérkeringés müszereinek alkatátul függ.

A vérkeringés múszerei kettösek lehetnek, midön at vérér által a részekbiil hozott minden vér kötcles átmenni a lélekzés müszerén minek elötte az iiterek által a részekbe továbl, vitetnék; - vagy szinte egyszerúck is lelietnek, ugy hogy a testbül viszszajöt rérnek csak egy része köteles átmenni a lélekzés múszerén, a többi vér pedig viszszatér a testbe, lélekzést nem látva.

Ezen utolsó eset van a mciszóknál. Ezeknek lélekzési mennyiségök és mind az attul függő minöség különbözó a vér aránya szerint, melly minden ütéskor a tiidóbe meģy. 
A halaknak kettös vérkeringésök van, de lélekzö müszerök ugy alkatott, hogy a viz közbejövetele által kell lélekzeniek; és vérök nem tapasztal egyéb behatíst mint a vizben lévö, a vízzel öszvekeveredett savító egy része által, ugy hogy lélekzetök menyisége talám a mászókénál is kevesebb.

Az emiooseknél a vérkeringés kettős, a levegó lélekzése egyszerü, a mi annyit tesz, hogy az csupán a tïdöben történik; lélekzetök menyisége azonban meghaladja a mászókét vérkeringési müszereik idoma miatt, és a halakét a körülfolyó elem természete szerint.

De a madarak lélekzetének mennyisége az emlösekét is fölüllhaladja minthogy azok nem csak kettös vérkeringést és levegôi lélekzést birnak, hanem a tüdőn kivül több üregek által is lélekzenek, a levegö egész testökhe béhatván és a függér ágait (a test ütereil) ugy fürösztvén, mint a tüdö ütereiéit.

Innét származik azon négy mozgás nem, mellyre a csontvázas állatok négy osztálya különösen szánva van: a ıégylábuak, hol a lélekzés mennyisége mérséklett, tartós erejü menésre és futásra látszanak teremve; a madarak, mellyeknél az (a lélekzés) igen nagy, izom eróvel és könyüséggel birnak a röpülésre; a mászók, hol az igen gyenge, mászásra vannak kárhoztatva s ezek közül sokan dermedésben töltik életök egy részét; a halak végre mozgások végett majdnem olly aránysúlyu nedvre szorultak, mint magok. 
Ezen négy oszály mindenike alkatásínak minden körülménye s neveretesen arok, mellyek a mozgást és külsö érezéseket illetik, sziikséges fïggésben van ezen valódi jelekkel.

Azonban az emlösek osztálya tulajdon jegyet hord elevent szülésé-ben, olly módon hogy magzatjaik a méhben a lepény seggedelmével tápláliatnak utóbb pedig az cmlók által, mellyekbül szoptalják apróikat (kölkeiket).

Ellenben a többi osztílyok tojís tojók, és, ha általíban az elöbbinek ellenébe tétetnek, szímos hatsonlatossigot talíhni rajtok, hirdetöt hogy a csontvázasok általámos tervében az ö számokra egy 11 lajdon terv létezett.

\section{A CSOTYKAZAS IIIAATOK EISO OSZTALYA.}

\section{AZ EMIÖSEK.}

Az emlöseket az állat-ország elejére kell tenui nem csak azért, mivel ez azon osztály, mellyhez mimagunk is tartozunk, hanem még azért is, mivel a többiek között ez bir a legtöbb tehetséggel, legfinomabb érezéssel, legkülönbözöbb mozgásokkal s a hol egyszersmind minden tulajdonság öszve szövöttnek tetszik, hogy egy tökéletesebb, a magán segítésben gazdagabb, az ösztön iránt kevesebbé rab s a kifejlódésre ügyesebb lény teremtessék elö. 
Minthogy lélekzésök mennyisége mérsékelt, îltalában a földön menésce vannak szánva, hanem ha-* talmas és tartós menésre. Következöleg csont-vázuknak minden izesülete igen pontos idomot bir, mozgásukat szigoruan meghatározót.

Némellyek azonban föl tudnak a levegóbe emelkedni kinyujtott tagjaik s kiterjesztett hártyáik segítségével; másoknak véğagjai annyira rövidek, hogy élénken csak a vizben tudnak mozogni, hanem mind e mellett az osztály általános jegyeit nem vesztik el.

A fölső álkapocs mindnyájánál a kaponyához feszült, az alsó csak két darabbul téteték öszve, egy fölemelkedö bütyök által a feszült halántcsonttal izesülve; a nyak hét csigolábul áll, csak egyetlen egy fajnál kilenczbül; a melső bordák porcos részek által a mel- vagy szegycsouthoz ragadnak, bizonyos számu csontdarabbul hosszasan képezetthez; fölsö végtagjaik az izesületlen hónlạ) által kezdödnek, melly az izmok között van csak fölfüggesztve és néha a melcsonthoz támaszkodik egy közbevetett kulcscsont vagyis válperec nevezetü csont által. Ezen végtag magában foglalja a kart, alkart és a kezet, mellyhez viszont e részek tartoznak : két csontocskasor kéztó-nek nevezve, egy sor-csont középkéz neve alatt, és az ujak, mellyeknek mindenike két vagy hírom, perc-nek nevezett csontbul áll.

A ceteket kivévén, az alsó végtagok eleje mindnyájanál a hát gerinchez feszült és egy övet vagy 
medencét képez, az ifjukorban három csnntpárra van oszolva, a csipsont-ra melly a hílgerinchez feszül, fancsontra melly a melsö övet, s az ülcsontra, melly a hátulsót képeri. Ezen három esont egyesüléscenek helrén ran azon gödör, hol a combkonc ízesiil, melly az alszárt emeli, a sipkonc--bul és szcirkupocs-buil allits; ezen véglag a láblual régzödik, melly a kércihez hasonlitó részekbiil áll t. i. lablöbiil, középlaibbul és ujakbul.

Az emlïsök feje mindig̨ két brïyök által izesuil a fejgyámmal vagy elsó csigolával.

Agrok mindigr kít féltekébiil tétetik öszre, egy velös lemoz, az ngy nevezett kérges test által egyesülöbiil, krèt gyomrot magúban záróbul és négy grumót (domborodást) beforöbül t. i. a csikolt testeket, a lilidegek telepeil, és a negg iker testet. (nates et testes). 1 latidegek telepei közölt egr harmadik ryomor van, közösïli a negyedikkel, az agracsok szárai a nyultagy alatt mindig egy keresztbe vígott kiallast (dudorodást) képzenek, Tarol hidjainak neverettet.

Szemok mindig a szemgödör-ben helyezödik, két szemhej s egy harmadiknak nyoma által védetik; jéglencséjök a sugár-nyujtványok által megfeszül; tiilkhätycijok egyszerüen sejtes.

Fülökben mindig találtatik egy üreg, dobüreg név alatt, melly a kürt által a száj hátulával közösül, kifelé a dobhártyával elrekesztetik s négy csontocska-láncot bir, a pö:öly, üllö. lencse, s kengyel 
csontokét; egy torncic, mellynek nyilásához feszuil a kengyel s melly három félkörös csatornával közösiil; végre egı kagyló, melly egyik lépcsójével (lád)rójával) a dobüregbe, másikkal a tornácba nyilik.

Kaponycijok mintegy három övre osztatik föl: az elsöre, melly a két homlok és a rostacsont által; a középsöre, melly a falcsontok és az íkcsont által; a hátulsóra, melly a nyakszirtesont által képeztetik. A nyakszirt-, fal-és ík-csontok közöit helyezödnek a homlokcsontok, mellyekuck egy része valódilag az archoz tartozik.

A magzatban a nyakszirtcsont négy részre van oszolva: az íkcsont teste két középrészre, tovább föloszlandóra, s azon fölül három pár oldalszárnyra; a halántékcsont háromra, mellyeknek egyike a katponyát segíti teljessé temni; másik a fül tömkelegét bezárni, a harmadik a dobüreg falát képzeni. Ezen csont-részek, a magzat elsö idejében még számosabbak, többé vagy kevesebbé gyorsan egyesïlnek a fajok szerint, és a fölnölteknél magok a csontok is összenölnek egymással.

Arcokat valódilag a két álkapocs képezi, mellyek közölt áll az orr ürege, köztök elöl a két állközti csont, hátulrul a két inycsont; köztök a rostacsont píratlan lemeze hat alá, közfulcsont név alatt; az orrcsatorna bemenetele fölöıt vannak az orr tulajdon csontai ; külsö falaihoz az alcsó csigák ragadnak, a fölső csigák, mellyek fölső és hátulsó részét foglalják el, a rostacsonthoz tartoznak. A járom- 
csont mindenik oldalon az álesont t köti a halíntcsonthoz és néha a homlokesonthuz; végre a könycsont a szemüreg belsö szegletét foglalja el, és néha az are egy részét. Ezen csontok az ébrényben vagy is méhdedben szinte igen szamos eloszlísokat mutatnak.

Dyeluoik mindig husos vagy izmos s egy szakcsont nevii csonthoz ragad, melly több darabhul tétetik ösze s a kaponyához több szalag által fïggesztetik.

Két tiedejör kavélyohra osztra, szímtalan sejtekbuil tére össze, mindig egr a bordák és rekes\% által képzett üregbe van önsze ragatás nélkïl rárva és a melhárlya ílial födre; szi-müuszerök mindig a gögsip fölsé végén van: egy hísos hosszabbodat, inyvitorla név alall, egıenes közösülést szerez gögjök s orrok hátulja közt.

Föld szinén levö tartózkodások kevesebbé tévén ki öket a hideg és meleg vátozátsainak, testök csak félfölözcttel 1. i. scör-rel bir, melly maga is ritha a hév égalattiaknál.

A csupán csak vizhen éló cetek magok szükölködnek nélküle egészen.

Husïregök hártyával takart, hashártya nevüvel; ételesöjük ezen hashártya redöjében van fölfüggesztve, bélfodor nevüben, melly számos gombolyitott mírigyeket bir, mellyekben a tej-edényck ágoznak el : a hashírtyának egy másik hosszabbodata: cseplez név atatt, a belek elött és mögö̈t csüng̣. 
A hugy, egy ideig hólyagban tartra, mindenik nemnél, igen lievés kivétellel, a nemzö részek nyilásain megy el.

Minden emlösnél lényegesen élószälöttes a nemzés, azaz a magzat tïstént a fogamzás ulán leeres\% ledik a méhbe, burkaiba takartan, mellyeknek leghülsöbbike irha vagy érburok, belseje pedig bairimyburok nevet hordoz; a méhiureg falaihoz egy vigy töbh, méhlepény uevï edényfouat által ragat, melly közösködést szerez ö s az anya közölt, honnan Liplalást és hihetöleg vérsavitást is kap; s mind e mellett is az emlösek magzatjai a terhesség elsö idejében egy a tojósak szíkhólyagához hasonló hólyagot birnak, melly még edényeket is nyer a bélfudortul. Még egy másik külsö hólyagjok is van hudduzma nevezetü s a hugyhólyaggal közösülö a hudindának hivott csó által.

A fog̣amzás mindig valódi nöszést kiván, hol a him magr belöveltessék a nöstény méhébe.

A fiak sziiletésök után egy ideig az ezen oszLálynál találtató tulajdon nedv (tej) által tápláltatnak, melly az emlókben választatik el a szülés után s olly hosszú ideig, a mint az apróknak szükséges. Ezen emlök adák ezen osztálynak az ,emlösek"6 elnevezését, minthogy, kirekesztóleg ennek tulajdonai lévén, jobban megkülönböztetik azt minden más külső jegynél. (')

(') Meglátandjuk azonban a hétsézehel, mellyeknek c tehiutclhen az egyiliziek csalitha helyet arl. 


\section{AZ EMLÖSEK}

liENDEKRE OSZ'LÁSA.

Azon változékony jegyek, mellyek az, enlöiseknek magok közötti valódi különbségét teszik, a fogás müszereituil retctek, mellyektül függ az “o nagrobb ragy kisebb ügyességök és készségök, és a ráagís müszcreitul, mellỵek eledeleik természetét hattározzak megr, s maggok után vonják nem csik mind azl, a mi az emészlés müreletével össze ran kötre, hamem sok más kïlönbfúlességer, magára az elmére nézve is.

A fogás müszereinek lökélye a ujak szama is mozgékonysága szerint becsiltetik s azon nagyobb) vagy kiscbb kiterjedésü mód szeriut, a mint véglagjok körömbe vagy mancsba takart.

A manes, melly az ujak földet éró részét egészen fö̀özi, a tappintíst kizirja s a lábat alkalmatlanná teszi a foģásra.

Egész cllentétel az, ha csak egy lemezbül képzett köröm föli az ujak végének egyik szinét, mig a másik szinnek meghagyja a maga legnagyobb finomságát.

Az életrend a zápfogakhoz van alkalmaztatva, mellyek idomának az álkapocs izcsïlése megfelel.

A hus elszeléséhez fïrészként metszö záplogats 
kellenek s ollókint záródó álkapcsok, mellyeket csak fölnyitni s bezárni lehessen.

A szemek és gyökerek megörléséhez lapos koronáju zápfogak szükségesek, és vizszínüleg vizirányulag mozogható álkapcsok; szükséges még hogy ezen fogak koronája mindig egyenetlen legyen mint a malomkö, hog̣y anyaga különbféle keménységüi részekbül álljon, mellyeknek némellyike elóbb vássék másikánál.

A mancsos állatok szükségképen mind növényevök, vagy is lapos koronáju zápfoguk van, mivel lábaik nem engednék, hogy éló (állati) zsákmányt ragadhassanak.

A körmös uju állatok többféle különbözésre alkalmasak, köztök minden életrend föltaláltató; és álkapesuk idomán kivuil, még iggen különböznck egymás között ujaik mozgékonysága s finomérzése által. Ezen tekintetbül egy jegyet fogtak föl, melly az ügyességre csudás befolyással van és a szorgalom módját szaporílja, ez a hüvelyknek a többi ujak ellenébe tehetése a legkisebb dolgok megfogása végett, a mi a kezet teszi tulajdon értelemben; melly tehetség ã embernél tökélye fö fokát érte el, kinél a fölsö végtag egészen szabad $s$ a fogásra alkalmazható.

Ezen különbféle öszvehasonlítások; - a kïlönböző emlósek természetét szigoruan meghatározók, a következö rendek fölállításának adtak helyet:

A körmösek között az elsö, ki egyszersmind 
minden más tehintetben is föl van kegyezve, az emher, csak folsö végtagaiban bir kezehet; alsú vérgtagai egyenes (liiggớs) hel yezctben tarlják öt.

Az emberhez legközelebls álló rend, a négykezïek', mind a négy végtagján liezes.

Egy misih, a husevök rendének nincs melsö réglagjain a robbi ujaknah ellenébe tehetö liivelyke.

Különben exen három rend mindenike három fugnemmel bir, t. i. zit)-, szem-, és melszö fogakkal.

Egg! neşyedih rend, a\% örlöké, mellyben a\% mjak keveset hiilönloöznek a husevöhéitiil, a szemfogak hijáral van, elöl perlign kiilönös rágásnemere alkalmaztatott metszófogakkal biı.

hörękemek azon állatoh, mellycknek wjai már igen korlátoztak, erösen betakarva naģ körmekbe, tobbunyire görbékbe s hiket még azon tökélellenség ért, hog̣ metszö fogaih hibaznak. Mások a szem-fograk hijáral is ramnak, és másohnak épen semmi fogok nincs. Mi mind ezeket a foghijusok neve alall foglaljuk öszve.

A körmös állatok ezen fölosztása tökélyes volua s igen rendes láncot képzene, ha Újholland legujjabban nem nyujtott volna egy kis mellékláncot. az erszényes (zsebes, zacskós) állatokét, mellycknek minden nemei hasonlílanak egymáshoz egész alkotásokban, s közülök mégris némellyek a húsevöknck, mások a rágóknak, harmadikak a foghlíjanoh- 
nak felelnek meg fogaik és életrendök természete által.

A mancsos állatok kevésbbé számosak, s kevesebb rendetlenséggel is birók.

$\Lambda$ kérödzők igen megkülönböztetett rendet képzenek, ketté hasadt lábaik, igazi metszö-foghijas fölsó állkapcsok és négy gyomrok által.

Minden többi mancsos állat egy magán rendbe egyesíthetö a tömbörük vagyis a marhcik rendébe, kivévén az elefántot, melly mellékesen cgy rendet tehet, távol hasonlatosságok által az örlőkhöz közelítôt.

Végre jönek az egészen hátulsó végtag-hijányu emlösek, mellyek halidomok és vizi életök által új osztály alkotására adhatnának alkalmat, ha alkatások különben egészen nem volna ollyan, mint azon osztályé, mellyben óket hagyjuk. Ezck a régiek meleg vérü halai, vagy a cetek, mellyek a többi emlösök erejével birók, a viz által föntartás szerencséjében részesülve, a legnagyobb állatokat mutatják magok között.

AZ EMLÖSEK ELSÖ RENDE.

\section{A KÉTKEZÜEK vagyis AZ EMBER.}

Az ember csak egy nemet képez és ezen nom egyetlen a maga rendében. Ennek története legCUVIER I, $\mathrm{K}$. 
'gyenescbben érdekelvén bennünket, s az öszvehirsonlitás túrgyát 8 neki kellvén tenni, mellyhez a más állatokét mérendjuik, körülményesebben szólunk róla.

Gyorsan leirandjuk azt, a mi különöset mutat müszereinek rendszerében az ember s küztök azt, a mit közösen bir a többi emlösekkel; megvizsgálandjuk azon hasznokat, mellyek ezen különösségek által adatnak neki a többi fajok fölött; megismertetendjük fö faijláit, és azoknak különböztetó jeleit, végre egyéni és társasági tehetségrei kifejlésének természeti rendét mutatandjuk meg.

\section{Az ember külünös alkotcisa}

Az cmber lába igren különbüzö a majmokétul : szćlcs, „ szart függöleg hordja maga fölött: sarka alulrul földuzzatl; ujai röridek s majd ncm gürbíthetök; a hüvelyk husszabb, nagyobb a többinćl, ugyan azon vonalban helyhë̈̈dik s velïk ellentétclbe nem jöhct; imnét a láb a test hordására színt, hanem scm a fogásra, sem a mászásra nem alkalmatos, és valamint a kezek a rijtok menésre nem valuk, - az ember maga az igazán létkezü és kétlcibu śllat.

Az ember cgész teste az egyenes (fügronalos) állásra van alkotva. Lábai, mint fülebb látuk, solikal szélesebb) ulapot adnak neki, mint aksármelly más cmlösnek líbai ; a líb és a szár kingujtó izmai igen crösck, honan a lábikráls és az alfel domborodása származik; a lábszir hajtó izmai igen magasan ragaszkodnak (tapadnak), s igy a térd egészen képes kinyulni, az ikrák pedig szembetünöbbek; a modence igen széles, s a líbszárokat és lábakal cltítroz- 
latja egymístul és a törzsöknek gúlya (pyramis) idomot id, a súlyegyennek kedvezót; a lábszárcsont (comblkonc) nyaka a csont középdarabjával szegletet képez, a melly még inkább megnagyobbítja a lábak távolságát egymástul s a test alapját szélesbíti; végre a fó sulyegyenben van az egyenes állás mellett a törzsökön, minthogy ízesülése tömegének közepe alatt létez.

$\mathrm{Az}$ cmber, ha akarna sem tudna cgész könnyüséggel négy-kézláb menni; rövid és majdnem hajthatatlan hátulsó lába, s igen hosszú combkonca a füldhöz szorítanák térdeit; kiszéledt válai s a középvonaltul messze kihclyheztetett karjaı roszul tartanúls testének clejét. A nagy fürészizom, melly a négylábuaknál mint valamelly emelö szij függeszti föl a törzsöket a hónlapok között, az embernél sokkal kisebb mint amazok akármellyikénél; feje legnehezebb agyának nagysága s az öblök vagy csontjai üregeinck kiesinsége miatt, és mind e mellett is a föntartás cszközei iggen gyöngék, mivel az cmber nem bir tarkószílaggal, sem esigolái nincsenek ugy alkotva, hogy az elöre hajlást korlálozník, és ha még képes volna is a hátgerinc vonalíban fejet megtartani, - szemei és szája a földfelé irányzódnának; nem látna maga clöttre; ellenben ezen müszcrek helyczcle tökéletes, mihelyt az egyenes (függvonnalos) állást teszszük föl.

Az agyíba ható üterek nem oszolván meg mint sok négy lábuaknál, s az olly nagy tömegü mủszerhez nagy böségben folyván a vér, gyakori gutaütés lenne a vizegyenes helyezctnek következése.

Tehát az embernek csupán lábain kell fơntartani magait. Kezeinck egész szabadságával bír a mivek számára, s érzékmúszcrei a vizsgáláshoz lcgkedvezöbb helyezetet nyertek.

Kezci, mellyck már szabadságukból olly nagy hasznot nyertek, ncm nyernck kiscbbet azoknak alkotásábul. Hüvelyliö, aránylag hosszabb a miajmokénál, igen nagy 
lïonnyüséget szerez az apró dolgok megfogására; mindenik ujnak, a grürïset kivere, magín mozgísa is ran, a mi más ảllatokníl s mig a majmoknál sincs ugr. A körmök csak az ujak heggénck egrik szinét födïzre, tímaszt admak a tapintísnak, finomsigít legkeresebbé sem kisebbitre. Kezeit tarti karjai erös támaszszal birnak nagy hónlapjokban, erös kulcs-csontukban, stb.

Az cmber, a menurivel nagy kedresést tapasztalt

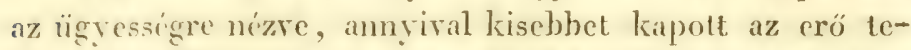
kintetiben. Futísi gyorsasíga sokkal kisebb mint az egykora termetü állatolse; nem lóvén sem clöduzzadt állkapoesai, sem kialli szemfogai, sem görbiilt kärmei, - meglámado fegrver nellizil ran; és leste nem bírvin szört sem fölsö részín. sem oldalain, egészen rédö fegrrertelen is; régre o mindon állatok kizzïll az, li logtováb) kinytelen a magản segítésre szülsséges cröt kölesönözni.

Hancm ezen grengesign nagy nyeresig lett öreá nóz-

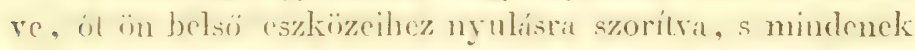
fiilibl azon êtelem hasznílísíra, melly olly magas fokon juttaték nełi.

Egr entös sem liözelit lozzá az agy liblekéinck is tekerrengeinck naggsíga állal, azaz ezen müszer azon részéce nize, melly az rlme mumkílatamak fó eszköze;

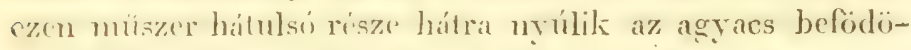
zése régetl, maga a Japonya idoma mulatja már ezen nagysifgit az agynak, valamint $a z$ are kicsinysége bizonyitja azt: melly keris tilsulylyal bir az idegrendszernek a külsö érzékekhez tartozó része.

Azonban mind ezen kiilsö érzések, noha az emberben liözípszenü 'rövel birók, szinte egészen finomak és jól súlyegyenítettek.

Kél szeme clöre irínyzódoll; nem lít egyszerre két oldalrul mint sok emlös, hanem ez látása sükerének nagyobb cgysíget ád, ís figyelmét ezen érźsnemre jobban ráfezziti. Szeménck golyoja és szivárvinybárlyaija kevessé 
változható, és ez látásának munkálatát egy meghatározott lárolsígra és rilágossági fokra szorítja. Kevessé mozogható és kris kiterjedésü fül-kagylöja nem neveli a hangok tömöllségét, s mégis ö különbözteli meg minden állatok között legjobłan a hangnemekct. Orra bonyoltabb mint a majmoké, kevescbbé bonyolt mint akármelly másik nemé, s még is egyedül ö látszik ollyanak, kit a rosz szag háborit. A szagolás finomságánal befolyással kiell az izlésére lenni; és ezen tckintetbül az ember a többick, vagy legalább a pikkellel födölt nyclvück fölött is van; tapintásának finomsága egész börének finomságátul és minden èrzéketlen rész hijányátul származik, valamint kezénck idomátul is, melly a fölúletek mmden kis egyenetlenségélıez való alkalmaztatásra minden mísokénál jo ban van képezve.

Az ember különós elsöséget bir szava müszcreiben; az cmlösök között egyedül ó tudja a hangokat izesíteni, mellynek hihetóleg szájidoma és ajakai nagy mozgélionyságának oka, és innét a közlekedésnek igen becses eszköze jutott birtokíba, mert a különbözö hangok mind azon jegyek közül, mellyeket könnyen használhatni a képzeletek torább adására, legtávolabb és ogy szerre legtöbb irányban észre vehetók.

Ugy látszik, hogy még a sziv és nagy edények helyezele is az egyenes állásra vamak nála allialmazva; a sziv a rekeszre van helyeztetre, hegye balfelé néz, a mi függerének a legtübb emlösökéétöl különbözö clágozását okiozza.

Az ember gyümölesesel, gyökerekkel és más leves nö vény-részekkel való élésre látszik teremtve lemui. Kczei könyüséget szereznek neki azoknak szedésére; mig egy oldalrul rövid és középszerüen erös állksapesai, egyenlö szemfogai pedig és gomos zápfogai a más oldalrul, nem liönnyen engednél meg nelsi sem a füevést sem a húsrágást, ha fözés által ezen eledeleket elörc nem liészítené; de mióta a tüzet birja, és mírei által az állatokat megfogni vagy távolrul megölni képes, - minden élö lény szol- 
gillhat táplálatíul, - s ez ót lsépessé tevé fajúnak a vígetlenségig szaporítására.

Emésztési mủszerci a rígáséinak megfelelök; gyomra egyszerii, bélesöve középszerï hosszaságu, vasłag belei jól kijelelıek; valkbele rörid és vastag, egy vak toldalékkal nevelve; mája csupán két karélyra és egy karćlycsára vau fölosztra; escpleze a belek elejúrül cgész a medencéig lefügg.

A\% cmber bonctudományos alkatának ezen rövid és a bevezclésre szukséges lképét teljessé teendök, hozzá adjuk, hogy harminckét csigolíja ran, két nyaki, tizenkét háti, ït ágréki, öt kerestz-csonti és három farkesonti. Bordái küzuil hél pál a melesonthoz feszül, porcos hosszabodatok által és igaz bordúknak mondatik; az öt következö pár hamis bordálinak neveztetik. A fölnöltség idején kaponyája nyole csontbul áll, u. m. egy nyakszirt-csontbul, két halintik-, liet fal-, egy homlok-, cgy ik-és egy rostacsontbul. Are-csontja tizennégy van: két állesont, két járomcsont, mellyck mindenike önoldalán a halántékcsontot az álkapocsesal kïti öszre, egy nyujtrány segedelmével, melly járom-ivuck mondatik; két orrcsont, két iny-csont a szájpadlás vagyı kemény iny hálulán, egy lïzfalesont az orr közcpén, kél könyesont a szemgüdör belszegleténél, és egy alsi állkapocs. Mindenik állkapoes tizenhat fogat bir, négy éles metszöt liözépen, két hegyes szemfogat a szegletben, és tiz, gumós, dúdoros koronáju zápfogat, ötöt mindenik oldalon; - ezek együtt harminckét fog. Hónlapja a tövisének vígén egy válesucs nevezetü nyujtványba régzödik, mellyhez a liulcscsont költetik, és ennck izesülése fölött cgy kinyult pont ran, hollor nyujtvány nevü, - némelly izmok oda feszülésére, orsó-csonija tökéletesen forog a singcsonton, azon mód miatl, mint az a fölkarral izesül. A kéztö nyolc csontot bir, mindenik sorban nćgyet; a lábtönck hét csontja van; a kéz és láb többi csontjai az, ujak száma szerint könnyen össze számlílhatók. 
Az ember szorgalma által egyidomu eledellel birrán, mindenkor ügyes a szerelem örömeire, a nélkül hogy dühvel hajtatnék reá; himtagja nem támasztatik meg csonttengel által; az clóbör által nem ragasztatik a hashoz; hanem elöre csüng a szemérem (fan)-csontok elött; vágyainak mérsékeléséhez járulni látszanak a nagy és számos vérerek, mellyek a tökök vérét gyorsan visszavezetik a keringés tömegébe.

A nö méhe egyszerü, tojásdad üreg; cmlöi , csak kettó, a melen helyeződnek és azon könnyüségnek felelnek meg, mellyel az gyermekét karjain tartja.

\section{Az ember természeti és erkölcsi kifejlödése.}

Az cmberi nemnél csak egy magzatos a rendes szúlés; ötszáz szülésre csak egy kettös (iker) esik; a még számosabb pedig igen nagy ritkaság. A terhesség kilenc hónapig tart. Az egyhónapos magzat (ébrény) rendesen egy hürelknyi hosszú ; a liét hónapos két és egy negyed hüvelknyi; a három havas öt hüvelknyi; az öt havas hat vagy hét hüvelyknyi; a hét havas tizenegy hüvelknyi, a nyolc havas, tizennégy hürcikynyi, a kilenc hónapos tizennyole hüvelknyi magas. A kik a hetedik hó feléig születnek, többnyire nem élnck meg. A tej-fogak néhúny hóra kezdenek elójóni a születés utín, a kezdetet a közcpsöik tévén. Két év alatl husz jelenik meg, mellyek a hetedik év felé egymás után kihullanak. A tizenkét hátulsó, és ki nem hullandó zápfogak közül négy ötödfél esztendökor jelemk meg, négy a kilencedikkor, a hátulsó négy néha csak a huszadik esztendő felé.

A magzat aunál inkább nól minél jobban közclít a szüleléshez. A gyermek ellenben mindig kevesebbet és kevesebbet nól. Születésekor többet felüt nagysága negyed részénél, felét két és fél érkor üti meg, három negyedét kilenc vagy tiz esztendókor. Tizennyolcadik éve elött nehezen szî́n meg a nóléstül. Az ember ritkán halad meg 
hat lábot s nem könnyen marad ötön alul. A nỏ rendesen néhány hüvellnnyivel kisebb.

A fanosodís kiilsö jecryck altal mutatja magát, tiztül tizenkettödik érikben a lényolnál, lizenkeltöluil tizenhatig a futsual. A heres ig alatt elöbb beáll. Egyik ragy másil: nöm ritkán nem\% ezen jelensíg idöszaka clötl.

Alig ére el a test magasan nölése ponljit, midön rastagodni kezd: a zsir äszrehahnozodik a sejtszöretben. A kï̈lönbfile edények fokonkint beduguntuak; a merö részek száradnak: is egr, tïbbe ragy keresebbé hosszú, lübbé vagy kereschbe meghinyt, többé ragy keresebbé fájdalmas élet utiu clirliezils az öregség, romlandiság, vénség és a halál. A s\%izon túl ćlök ritka kivételck; a nagyobb rész sokkal elöbb meghal ezen céhnál, ragy betegségeliben, vagy történet által vagy esupán az öregség miatt.

$A$ csecsemö sokkal torabb szorul meg az anya segedelmére mint annak tejére, honan annak számára elmebeli s egrszersmind természcti nevelés is szírmazik, ralamint a kettö kïzölt állandós hajlandriság. A lkél nembelick majduem egrenlö száma, az egy nönél tübbet lartásnak nehizsige, ha a gazdagsaign nem segít ki, azl mulalják, hogy nemünken az cgynösség a természeli kapoes, és valammt mindazoknál kik ezen egyesülesi nemet ismerik, ill is részt vesz az apa a nerelésben. Ezen nevelés hosszasíga mís gyermeliek nemzését is megengedi azon közben, honan a házassági egyesület természetes folytonossíga származik, valamint a gycrmekek hosszí gyöngeségébuil a házi fenyiték reszi eredetél, s köretliezóleg minden társasági rend, föltere, hogy az új családokat liépzö fiatalok föntartják szulöikkel azon egybeliöttetést, melly olly hoszszú idón által édes szokásukká vált. Ezen egymáson segítendó hajlandóság végetlenül szaporílja azon hasznokat, mellyeket már a magános embernck megszerez iigyessége és clméje; az rezeté öt a más állatok megszelidítésére vagy elrettentésére, az éghajlat kedvetlenségeinek 
megorvoslására, - és czek által lön képes a föld egész színét ellepni.

Különben az ember nem látszik semmit birni, a mi az ösztönhöz hasonlítana, semmi állandó szorgalmat, és a vele született liépzelctekbül szármozottat; minden ismerete az érzések, ön vagy clödei figychmezésének sükere. A Jeszéd által átadva, a gondolkozás által gazdagítva, szükségeihez és éldeleteihez alkalmazlatra, adúk czek néki minden mesterségét. A nyelv és az irás, megszerzett ismereteket föntartva, végetlen tökéletesedés forrását teszik a faj számára. Igy teremte ö képzeletet magínak, igy vön hasznot az egész természetbül.

Azonban mégis igen különbözö fokai rannak az emberi kifejlödésnek.

A legelsö csapatok a vadászatbul, halászatbul vagy rad gyümölcsökbül lévén kénytelenck élni, egész életüket élelmök keresésére kellvén fordítamok, nem szaporodhatván nagyon, mert hamar fólemésztették volna a vadakat, kevés clömenetelt tönck; mesterségök a kunyhók és sajkák készitésére, magoknak börrel való födözésére, nyilak és hálók csinálására volt szorítva; alig vizsgáltak egyebet, az öket utaikon vezetö csillagoknál, némelly nékik használható tárgyaknál; csak az ebet szelidíték meg, mivel annak természeli hajlandósága volt hasonló életnemre. De mihelyt a füevö állatok megszelidítésćrc julottak, a számos csorda birtokában egyre biztos életet találtak, és üres idöt, az ösmeretek bövitésére használhatandót; némelly szorgalmat fordítottak a lakhelyek és öltözelek készítésére; a birtokot és lkövelkezöleg a cserélést, a gazdagságot és az állapotok egyenetlenségét megismerlék, mint a nemes vetélkedés és alacsony szenvedelmek forrását; hanem az új legelök keresése s az évszakok követése mialli bujdosó életmód mindegyre szoros korlátok között tartotta ólket.

$\mathrm{Az}$ ember tulajdonképen nem vala lépes faját nagy fokon clterjeszteni, és ösmereteil s miveit igen messze 
vimni elöhb, mint csak a fïldmírelés fiiltalílísa ís a foildnek örökös tulajdonokira vali fölosztása úta. A földmivelés segitségérel a túrsaság tagjai egy részének kízi munkija képes mind a többit típlálni, és azokat kevesebbé szükséges munkílikal hagyja foglalatoskodni, midön egyszersmind azon remény, hogy a szorgalom által magának ég jörendöségének kellemetes lételt szerczhetni, ủj rugút adott a versenygésnck. A képzeleli becsek föltalálísa igen magasra emelé ezen versenygést, könnyítre a cserét, a javakat egyszerre függetlenebb)kké és nagy növekedésre alkalmatosakká tére; hanem clmaradhatatlan köretkezésnél fogva szinte magas folixa emelé a puhaság vétkét és a nagyravágyási dühöt.

Azon természeti hajlandóság, mellynél fogva mindent ailtalános képzeletekre ronni és minden tüneménynek okát föllelni törekszü̈k, a társasági kifejlödés mindenik fokán állított gondolkozó embereket clö, kik új képzeleteket szötek a már voltak tömegéhez; és mivel a világosság soha sem volt kïzönséges, majd mindenkor arra törekedtek, hogy fölsöbbségöket (nagyobb belításokal) uralkodisi ešliöz gyanint használjaik, érdemeiket mások szeme clött túlmagasztalra, ismeretcik gyöngeségét pedig balvéleményes képzeletelkel takarva be.

Ml'g gyoggithalallanabb rosz az erövel való visszaélés ma, midön csak az ember árthat az embernck, ö maga azon egy faj, melly örök hadban van magával. A vadak erdeikért vitáznak, a csordázól (nomadok) a legelökért; valahúnyszor pedig képesck reá, beütést tesznek a földmivelökhöz, munka nélkuil clrablandók azok hosszú munkájának gyümölcsét. Magok a mívelt népek is, tárol lévén az éldeletökkel ráló megelégedéstül, csatákat úznek a gög elsöségeiért és a kereskedés egyedül hirásaćrt. Innét van az igazgatús szüliséges volta, melly a nemzeli hadakat kormányozza, egyesels panaszait pedıg clnyomja vagy szabályzott idomokba vezesse. 
A töbhé vagy lievescbbé kedvezú körühmények bizonyos fokokon tartóztaták a társígi létet, vagy anak kifejlödését clómozdíták.

A két száraznak éjszaki jeges éghajlatát, Amerikának athathatallan erdeit még most is csak vad halúszok és vadászok lakják.

Ásia és Afrika közepének végetlen homok silkjai és sús pusztái csordázó népektül és számtalan csordálktul vannak ellepre; ezen félig mívelt csapatok mindannyiszor öszvegyülnek, valahányszor egy neki hevült vezér fölszólítja óket, és becsapnak a körülfekvö mívelt tartományolsba, ottan széket verendók és elpuhulandók, mignem más esordázók jönek és öket meghúdoltalják: cz azon önkénykedésnek igazi oka, melly minden idóbền elnyomá Persia, India és China szép éghajlatában a szorgalmat.

A' szelid éghajlatok, a természettül vizeklkel ellátott és növényelkkel bövelkedö földek a földmivelés és polgáriasodás természeti bölcsöi: és ha helyezetök bátorságba teszi óket a barbarok becsapásaitul, ott a rilágosság nemei közösen ébresztgetik egymást : illyenck voltak, curopában az elsök, Görög-és Olaszország, illyen most is majd ezen cgész szerencsés földrész.

Azonban vannak még belsö okok, mellyek a legkedvezöbb körülményck liözütt is elgátolni lálszanak némelly fajták fejlödését.

\section{Az emberfaj fajtái.}

Noha az emberi faj egynek látszik, noha minden egyének nöszhetnck egyült és termékeny egyéncket nemzhelnck, azonban némelly örölkös alkotásmódot venni nólok észre, a mi az ugy nevezetl fajtcít teszi.

Ezek kïzöll kivállképen három látszik nagyon kitünni: a fehér vagy kaukazi, a sárga vagy mongol, a felsctc vagy szerecsen (éthiopi) fajta. 
A kaukazi, mellyhez mi is tartozunk, megikülönböztetik feje idomának szép tojásdadsága által; s ez ada lételt a legmiveltebb, a (öbbicken legtöbbször uralkodott népeknek: különbözö arc és hajszinzetet mutat.

A mongol fajla megismerhetö dúzzadt are-csontairul, lapos arcárul, lieskeny és ferde szemeirül, egyenes (rideg) és fekete hajánl, rilka szakíllárul, olajszinérül. Ez alkotá a chinai és japáni nagy birodalmat, is gyözedelmeit néha a nagy pusztaságon innenre is elhozla; de mirelódése mindig szakaszos rolt.

A felete fajta az Atlas hegy déli részével határos; szine fekete, haja göndör, kaponyaja öszenyomott, orra belapult; duzzadt arcora (szaja) és rastag ajakai látszólag kö. zel hozzíls a majmókhoz; az öt kiépzö népels mindig barbarok maradtak.

Kaukazinak azért nerezték azon fajtát, mellylül mi származunk, mirel az álhirlisect és a népeli elígzísa azt a Kaspi- is Feketetenger közötti heggek láncolataig látszik emelni, homnan az minlegy sugarazra terjedelt el. A Kauliaz népei, a cirkassaiak is georgiaiak, ma is legszebbeknek tartatnak a földün. Ezen fajla fö́ágait megkiuiönbüztethetni a nyelvek hasonlialossiga szerint. Az araméni vagy syriai ág délfelt irányzódolt; elotermé az assyriaiakat, a mindig hóditallan arabokal, kik Mahomet ulín azt vélék, hogy a vilíg urai lehelnek, a föniciaiakat, zsidókat, abyssiniaiakat az arabok grarmatail: igen hilietö hogy az egriptombelick is hozzájok tartozlak. Ezen, a mysticismusra (litliozatra) mindig hajlandó ágnál szuilettek a legkiterjedtebb vallások. A tudományok és literatura néha virágzottali nála, de mindig furcsa, tarkalékos (bizarr) idomokban és éliesitett irúval (irásidommal).

Az indus, germín és pelasgi úg sokkal kiterjedtebb és jóval elóbb closzlott; azonban a legsokszorozoltabb rokonságot ismerni ki négy fönyelve közt, millyen a sancsrit, ma is szent nyelve az indusoknak, s a hindostáni nvelvek na- 
gyobb részének anyja; a pelasgok régi nyelve, melly a görög, latin is több kiholt nyelxek s a déli europai minden nyclvuck közös anyja; a góth ragy tüdesk (german) nyelv, mellylül származtak az éjszaki és éjszaknyugoti nyelvek, mint a német, holland, angol, dán, svéd s ezeknek tájbeszédei (dialectusai); végre az ugynevezett slav nyelv, mellytül származnak az éjszakkeleliek, orosz, lengyel, cseh és rend.

Ezen nagy és tiszteletes ága a kaukázi fajtának terjeszté legtávolabb a philosophiát, tudományokat és miveket, ez azolnak raktúra (órzöje) harminc század óta.

Ezt a celták elózék meg Europában, mellynek éjszalsrul jött s hajdanában igen elterjedt népségei, most a legnyugotibb pontokra rannak szorítra, - és a kantabrok, kik Afrikúbul Spanyolhonba hatottak, és ma majd egészen "̈szreolvadtak azon számos nemzetségekliel, mellyeknek maradéka öszsze van ezen félszigetben keverve.

A régi persák eredete egy az indusokéral, s azok maradékai az curopai népelskel raló hasonlatosság legnagyobb jeleit ma is hordozzík.

A scytha és tatár íg, eleinte éjszakra és ejszak keletre iráyzódva, ezen vidékség régellen puszáaiban kóborolva, onnan nem jött egyébért ki, mint testyéreinek szerenesésebb alkotmányait clrontani; a scytlsúk, kik a régi idökben becsapásokat tettek Ásia magasára; a pártosok kik ott a görög és romai uralkodảst megdönték, törökök, lkik az arab birodalmat fölfordíták, s Europában a szerencsétlen görög nemzet maradékát meghódítík, ezen ágnak rajai voltak; a finlandiak, a magyarok hozzá tartozó népek, a germán és slar népek közé mintegy cltévedve. A Kaspi-tenger éjszaki és keleli oldala, hajdani hazájok, ma is bir azon eredetü és hasonlító nyelvï népeket; de öszve elegyedve mís szímtalan különbözö eredetü és nyelvü népekkiel. A tatár nemzetek érintellenebbek maradtak azon egész kéren, honnan sok ideig fenyegetćk Oroszországot s hol 
végre az által meghidiltattak, a Duna liömlésétül egészen az Irlisen túlig. Azonban a mogolok, gyözedelmeik idején, bele lieverék véröket; és kivált lis 'Tatárhonban sok vonataikat látni.

A kaukazi fajta talír ágátul kelctre kezdödik a mogolfijta, melly egrisz a keleti Nagytengerig uralkodik. A még csordazo ígai, a kalmukok és kalkasok, a nagy puszlában küborolnak. Eldödeik háromszor vitték messze nevök rettenclessiget, Atila, Gengis (Dsingisz-lihán) és Tamerlán alall. A chinaiak ennek legrégebben mivelt ágál teszik, söt nem csak ezen fajlának, hancm minden ismert népeknek. F.g harmadik ág (a mandsúk) az új idóben foglalta cl Chinit s azt ma is kormányozza. A japániak, khoreaiak s majd mind azon esapalok, mellyek Siberia éjszakkeletín terjednck el, az oros\% uralkodís alatt, nagy részint ehe\% tarloznak; söt ide szómlílják ma még a marian, karolin $s$ lïbb (zen szigetsokhoz kïzel folkrö szigetek ösi lakosait is. Ha nemelly chinai tudisukat kiveszünk, a mogol fajla népei íllalíban a buddismus kïlïubféle felekezteihez és lio vallásához ragaszkodnak.

Ezen naģy fajtának credete az altai hegyeken látszik Ienni, a mienlié a Kaukazon; de nem lehet olly híven kïretni külinbfide ágozalinak szírmazísál. Mind ezen csordázi nipek lorténetci olly áltünök, mint tanyázatuk, a chinaiakéi pedig az ökę körülverö népekrül rövid és kevéssé folytatolt tudositísokat adnak. Nyelveik rokonsigga is igen keressé ösmeretesek s nem tudnak ezen tévelyben (labyrinthban) vezérelni.

A félsziget éjszaki nyclvei a gangesen túl, szinte mint a thibeti, némileg hasonlítanak a chinai nyclvhez, legalább természetökre nézre, melly némelly tekintetben egy szótagos, s a rajtok beszéló népek nincsenek vonúsaikban hasonlatosság nélkïl a täbbi mogolokisal; hanem déli részét ezen félszigetuk a makajok lakjâk, az indusokhoz, idomára nézxc, igen hüzclitó nćp, mellynek fajtája 's nyclve 
az cgész indus szigetsok parljain eltcrjedt. A Déli-tenger számtalan apró szigeteit szinte egy szép fajta népesiti, melly igen közclít az indushoz, s mellynek nyelve sokban hasonlít a malajokéhoz; hanem a nagy szigetek belsejében, kivált pedig a nagyon vadonos helyeken, más fekete színü emberek laknak, neger arc-idommal, mind rendkivül barbarok, s kiket alfurus-oknak neveztek; Új-gvineának és a határos szigeteknek partjain pedig más felketék laknak majdnem hasonlók az Afrika nyugoti partjain lakókhoz, s papus-oknak mondatnak. Új-holland lakosai az alfurusokhoz számlíltatnak, de Diemen földejéirül azt bizonyítják, hogy nagyobb részint papus-ok. (1)

Sem a malajokat sem a papusokat nem lehet egy könynyen a három nagy fajtának egyikéhez számlálni, hanem meg lehet-e az elsöket szorosan különböztetetni az ö két oldali szomszédaiktul, a kaukazi indusoktul és a mogol chinaiaktul? Mi megvalljuk, hogy e végre nem találunk nálok elegendö bélyegeket. A papusok pedig nem régente az Indus-tengeren clszort fekcték-c? Még nincsenek eléggé pontos leirásaink vagy rajzolataink ezen kérdés megfejtéséhez.

A két száraz éjszalki részének lakóı, a samojedok, laponok, eskimók némellyek szerint a mogol fajtátul erednek, mások szerint pedig nem egyebek a kaukazi fajta scytha és tatár ágának elfajzott hajtúsa és sarjadékanál.

Magokat az amerikaiakat sem lehet még ó szárazaink egyik fajtájához is kötni, azouban még sem birnak cgyszersmind szoros és állandó jelekkel, mellyeknél fogva tulajdon fajtát tenuének. Rézreres színók erre nem elegendö; rendesen fekete hajok és rilka szakállok a mogolokhoz

(') Lásd azon különféle fajtákrul, mellyek az Indus- és Cscndes-tenger szigcteit lakják, Lesson és Garnot UII. értekezését a : Zoologie d Voyage du la Coquille-ban 1. 1 - 113. Az isiai nemzetek nyelvériil is azoknak hulesönos rohonsigárul kerelezl me Klaproth.

1sia polyolotra-ját 
szímoltatnák óket, ha szinte ugy lifejlett vonataik, szinte ugy elölünö orrok, minl a mienk, ha nagy és nyilt szemeik, annak ellene nem tennék magokat s curopai idomunknak nem felelnénck meg; nyelveils olly számolhatatlanok, mint népregeik; s nem lehelett nálok mindeddigg semmi bebizony ito hasonlatosságot lehni, sem egymás lï̈zött, sem a régi világéival. ${ }^{1}$ )

AZ EMLÖSEK MASODIK RENDE.

\section{A NÉGYKEZÜEK.}

(LES QUADRUMANE.)

A boncolati különösségeken kivül, mellyek ezk az embertül elválasztják s mellyeket mi megmagyaráztunk, ezen csalíd igen szembetiunö jelek álıal különbözik a mi fajumktul, minthogy hátulsó lábain szabad 's a többi ujaknak ellenćbe tehetö hüvelyke van, lábúnak ujai hosszúk és hajlékonyak, mint kezeéi; azon kivül minden faja könnyúséggel mász a fikra, mig azonban csak bajosan tud egyenesen állani és járni, lábok csak a külsö szélre támaszkodva, és keskeny medencök a súlyegyennek nem kedvezve. Minduyája a miénkhez hasonlító belekke? bir, szemeik elöre irányzottak, emlöik melükön vannak, vesszöjök csüngö, agyok mindenik oldal-

(') Lásd, az amerikaiakrul, Humboldt fontos tanúságuhhal olly grazdag utazísán bivül, Vater és Mitchill értckezéscit. 
rul három karélyu, mellyeknek hátulsaja az agyacsot födi; a halántéki völgy a szemgödörtül csontfal által el van választva; különben pedig fokonkint eltávoznak fajtánktul, arcoruk (le museau, die Schnauze) jobban és jobban kihosszabbodva, farkot és inkább kizárólag négylábuas járást kapva; mindazonáltal elókarjaik szabadsága és kezeik bonyolódottsága, sok az emberéihez hasonló tettet és mozgást engednek nekik.

Már régóta két nemre osztják őket, a majmok-és mákik-éra, mellyek ma már az alárendelt idomok szaporodása által két kis családdá váltak, és mellyek̉ közé egy harmadik nemet kell helyheztetni, az ingadrikat.

\section{А МАJMOK.}

\section{(Les Singes Simia L.)}

Mind azon négykezúek, mellyeknek mindenik állkapcsában négy egyenes metszöfogok van, s minden ujokon lapos körmök, - két olly jegy, melly öket közelebbre hozza a köretkezó nemeknél az emberhez; zápfogaik, szinte mint a mieink, csak tompa böcökösek, s ók csupán gyümölcs eledellel élnek; hanem szemfogail meghaladván a többieket, fegyvert adnak nekils, mellynek mi hijáral vagyunk, és az átellenes álkapocsban ürt kivánnak, mellybe a száj becsukásakor helyeződjenek.

Zápfogail száma szerint két fở alnemre oszthatni öket, mellyek szinte számos csapatokra szakadnak el. ( $\left.{ }^{1}\right)$

(') Buffon öt nemzetségre osztá a majmokat: a tuiajdon majmok, fark nélkül, paricinok (les papions) rüvid farkuak; macskamaj-

CUVIER 1. K. 


\section{A tulajdonképen ugy nevezett, vagy az ó vilígbeli majmok.}

Zápfoguknak száma ugyan annyi mint az embernél, hanem külünben magok kïzött némelly jelekre nézve kï̈lönböznck, mellyek e kïrctkezö fölosztísokat képzék:

\section{AZ EMILóRöK.}

Les Orangs; Simia Erxl. Pithecus Geoffr. vad emberek, orangok.

Az ó világ majmai lïzolt esak nekik nines rïgmmójok, - májok pedig és valibelök az cmberéhez hasonlít. ()rok nem duzadt, nincs pofizsebök; sem a farknak legkevesebb nyoma.

Némellyeknek clegenclö hosszú liarok van, hogy fönálltokban a frildre érhelnek, lábszátraik ellenben igen rüviduk. Ezek a lulajdonkipen mondutt cmlörök.

A homlokmagas emlior; Orángutaing. Földi. (Simia Satyrus Lin.) Aud. 2. 1. Fr. Cuv. 2. 1. ( $\left.{ }^{2}\right)$

Cigy tartatik logy minden állatok között ö hasonlít leginkíbb az cmberhez, fejünck idoma, homlokínak nagy-

mok (cerkóf, les guenons), hosszú farkuak, üigumósak; göndörï̌ (les sapajous) hosszú és kúcsoló farkuak, ülgumó nélkül ; Erxleben pedig, folvéve ezen osztíst, ezen neveket, simia, papio, cercopithecus, cebus és callithrix-re forditá. A cebus és callitrix nevek, mellyek a régicknél afrikai és indiai majmokat jelentének, joy vitettek ilt Amerika majmaira. A papiók neme, csupán csak a fark rövidstígén alapodva, nem tartathaték meg, mivel a természeti rendet igen megtörte volua, $s$ a töblit is mind alosztályokba kellett tenni; végre az insaduk (les ouistitis) nemét is ki kellett vetni, melly, a sagouinokéban foglaltaték, de mellyek a többi majom nemek jeleivel nem egyeznek egészen meg.

(') Orang malảji szó, s okos valóság-ot jelent, melly az emberre, homlokmagas emlörre, és elefántra alkalmaztatik. Utang radaz vagy erdeit tesz. Innét az Orang-utang, erdei cmber-nek is fordittaték az utasoktul.

( $\left.{ }^{2}\right)$ A homlokmagas cmlór egyetlen jó rajzolata sok ideig a Voszacr-birtokabeli volt, cgy llaggan élt cyyén szcrint készitve. A 
sảga és agyának tömcge által; hanem némelly szerzök fönhéjázó állításai ezen hasonlatosságrul részint onnét erednek, hogy csupán fiatal példányokat láttak, mert igen hihető hogy vénüliésével arczora is sokkal kiduzadtabb lesz. Teste durva verhenyeges szőrrel födött, arca kékded, hátulsó hürclkei az ujakhoz képest igen rövidek. Ajakai különös módon kinyújthatók és nagyon mozgékonyak. Története igen meghamisittaték, ốt más nagy majmokkal, kiváltképen pedig a homloklapos emlörrel összekevervén. Szoros birálat alá vetrén, azt leljük, hogy a homlokmagas emlör csak a legkeletiebb tartományokłban lakik, mint Malakában, Kochinchinában, leginikább pedig Borneo nagy szigetén, honnan Javán által hozzánk hozaték, hanem igen ritkán. Fiatal korában s ugy mint Europában láttatott, igen szelíd állat, melly künnyen megszelidül és megszolik $\mathrm{s}$ alkotása szerint cselekedeteink nagy számát utánozni tanulja; hanem értelmessége nem emeli ốt olly magasra mint mondaték, sốt még az ebét sem haladja sokkal meg. Camper lkét hártyás zsebet talált föl és irt jól le, mellyek ezen állat gőgsipjának gyomrairal közösülnek, és szavát eltompítják; hanem igen bajos elhinni, hogy hátulsó hüvelkein mindig hibáznak a körmök.

Egy borneói majom, melly mind eddig csals vázábul ismeretes s Pongó (1) nevezetü, annyira hasonlít a homlokmagas emlörhöz részeinek jóviszonya s feje lyukainak és rarrányainak helyezete által, hogy, arcorának

Buffoné (Suppl. VII. 1.1.) minden tekintetben hijányos; Allamand-é (Buff.d'Holl. XV. 1. xL.) egy kevéssel jobb, mellyet Schreber lemásolt (II. I. B.) Camperé, ugyanott 11 1. C. Jemásolva, nincs pontosság hijával, banem igen megösmerni, hogy halott szerint van készitve. Bontius, Med. ind. 81, csupa képzelet szüleményt ad róla, noha Limné cblü̈l készité a Troglodytest (Amoen. ac. 1, 1. I1.) Néhány jó van még ezen munkának angol forditásában és Krusenstern utazásában, 91 és $95 \mathrm{I}$. hanem mindig csak fiatal példanyok szerint.

(') Audeb. Singes, pl. anat. I1. Ezen pongó nerezet, bogró- 
nagy elöduzadása, kaponyájúnak kicsinsége s alsó állkapcsa ágainak magassága mellett is, öt felnólt egyémek tarthatni, hanem a homlokmagas emlörök fajábul is, legalább egy igen határos fajbul. Karjainak s nyakesigolái nyujtrá. nyainak hosszasága, sarkesontjának gumóssága, meglïnynyebbítheték nelí a két lábon valú állást és menetelt. Ez legnagrobb minden majmok liözütt, és igen irtóztató állat; liözelít az ember nagyságához. ( ${ }^{1}$ )

A tübbi emlörelinél a karok csak a térdig érnek lc. Homlokuk nines, és kaponyájols a szemholdak boltja mögött mindjárt hátra lapul; nevök homloklapos emlör.

\section{A homloklapos emlör. ( $\left.{ }^{2}\right)$}

(Le Chimpanse, Simia troglodytes Lin. Vadember Földi). Felicte ragy barna, clöl rilka szórrel födölt. Ha az ntazil elbeszcilésenels hihetni, az ember nagyságát meg-

bul rontva el, mellyet Afrikában a homloklapos emlornek vagy a duzajkoknak adnah, Buflon által cgy vélt nagy orangutang fajra alkalmaztateh, melly nem volt eryéh hépzelete szüleményenél. Wurmb, egy hataviai természettudis, ezon állatnak ajándékozá el, mellyet ó irt le elöször, s mellyrül Buffonnak képzelete sem volt. Lásd a bataviai társaság emlćkiratait. II. k. 245 1. Azon gondolat, hogy folnott homlohmagas emlör leliet; cģ kozönstiges emlör kaponyájánah látísánál szállott engem meg, mellyen az areor sokkal duzadtabb-volt, mint az ceddig leirt fiatal egyéneknél; czt én megösmertetém ęy cmlćklciráslian mellyet a tudományok akademiaja clütt fölolvasik 1818-han. Ugy látszik, hogy Tilesius és Rudolphi is vizsgálták azt. L. a Berlini Ak. Emlékiratait 1824. 151-re 1.

('). M. I. Harwood (Trans. linn. XV, 471 1.) egy emlór lábait irja le, 15 anğol hüvelknyi hoszúkat, a mi egy ig̣en szcmbetünỏ nagyságot jelent s ot arra vezelte, hogy a pongút fülnött homlokmagas emlölnek tekintette volna, ha a Iondoni sebészek collegiumaheli pongónak egygyel több ágyékcsigolája nem volna, mint a homlokmagas eml.r vázálan. We ez semmi ellenvetés; mert ezen külonbözés nem cryszer láttaték az ember fajában is.

$\left({ }^{2}\right)$ Ez Tulpiusnál: quojas morou vagy angolai satyr, $\mathrm{ki}$ annak $10 s z$ hépét is adta (Obs. med. 271 1.), Tyson-nál pygmée nevü, és 
közelíti vagy fölül is haladja; de Europában egy részét sem láttuk még, melly ezen nagyságot mutatá. Guineában és Kougóban lakik, seregesen él, a bokrokbul kunyhókat készít magának, föl tud köveklicl és botokkal fegyverkezni s azokat használni képes az emberek és elefántok távol üzésére tanyájátul; azt mondják, hogy a néger aszszonyokat kergetı és néha ellopja az erdökbe, stb. Majd minden természettudós öszvezavarta öt a homlokmagas emlórrel. A fogságban igen jófejü s megtanul emberi módon járini, ülni, enni.

Az emlöröktúl mostanában clválasztatnak:

\section{A IIARNYÚK.}

\section{(Les Gibbons, Hilobates Mig.)}

Mcllyelznek karok hosszú, mint a homlokmagas eın löröké, homlokuk lelapult, mint a homloklapos cmlóröké, farok ülgumós mint a pofürüké, hanem ezeu utolsóktúl különböznek, mivel nincs farkok és pofzsebök. Mindnyája Indiának legtárolabb részén és szigetsolzán lakik.

A fekete karnyú (Le Gibbon noire. Simia Lar. Linn. Buff. XIV, I. Onkó Fréd. Cuv. 5 és 6 rl.

Durva feliete szörrel van födve, arca pedig fehérlö körrel keritetett be.

solkkal jobban van rajzolva Anat. of, a Pygmi, 1.1.), Schreber-lül lemásolva I 1. B. Scotin egy másik incglehetös rajzolatít adta, lemásolva az Amoen. acad. VI. r1. I. fig. 3. és Schreb. I. C. Egy egyén, melly Buffonnál élt s melly a muzeumban tartatik, rajzolva van, noha clég rosszul, a Hist. nat. XIV. I., lıol Jockínak neveztetik. Azon egyént sokkal jobban adá Lecat (Traité dı mourement musc: I I. 1. k.) Quimpesć név alatt; szinte ezt adja Audebert is, hanem csak a kitömött szerint. $\mathbf{O}$ pongó-nak nevezi. 
$A$ vivú (barna) karnyú, (Le. Gibbon brun. Milobates agilis. Fr. Cur. 3 és 4 rl. - Petit Gibbon, Buffon XIV. III).

Barna, arcaköre és hát-alja halaríny sárga. A fiatalok egyidomulag súrgásfehérek. Élénlisége rendkivül nagy; párosan el; malaj neve: vuvu (rourou), melly kiáltásátul réteték.

A hamvas karnyú (Le Gibbon cendré. Sun. leucisca Schreb. $r l .3, B$.)

Szcolid hamvas grypjuval födött, felicte arcu, a nádasokban tartizkodik s a legmagasabb bambus-szálolira fölmász hosszú liarjaival ott súlyegyengetre magál. Szinte vuvúnak mondatik.

A többi liarnyúlitúl megküü̈nböztethetö

A raguj (raguju karnyui, Le Siamang. Simia Syndactyla Rafl. - Fréd. Cuv. 2 rl.)

Ennck hátulsú kezein a második és harmadik uj egy keskeny hártya áltill egyesuilve van az clsö pöre egész hoszszaságában. Felicte; álla és szcmholdai rerhenyesek; számos csapatoliban él, mellyeliet bátor is rigyázéliony vezérek rezetnek; az erdülict iszonyatos lírmáral töltik el nap lielte s nyughtakor. Gegé(je härly azsebet bir.

A most kiorethezendii of vilígmkbeli majmok mindnyájinak mája több karclyra ran osztra, rakbelök vastag, rörid, toldalélıtalan; szalicsontok vértidomu.

\section{A POFÚRÜK.}

(Les Guenons. Farkos majmok. Cercopithecus Exl. részint) ( $\left.{ }^{1}\right)$.

Arcorok középszerüen duzad elö $\left(60^{\circ}\right)$, pofzsebesek, farkosak, ülgumósak; utolso alsó zípfogukon négy púp

(') Cercopithecus: farkmajom, a régi görögöknél szokásbars rolt név. 
van mint a tübbicken. Igen szímos, igen különbféle nagyságu és szinü fajaik, betöltik Afrikát, seregesen élnek és nagy pusztilíst risznek a kerlekben és mivelt mezókön végbe. Szinte könnyen megszelédíthetók.

$A$ veres pofïrü (Le Patas. Simia rubra Gm.) Buff. XIV, xxv, xxvr. Fréd. Cuv. 23.

Fölül eléggé élénk súrgaveres, alul fehéres; fekete fodél a szemei fülött, néha fehórrel szegve fülül. A Senegalnál.

Az örvös pofïrï (Le Mangabey ì collier. Simia aethiops. Lin.) Buff. XIV, xxxur. Fréd. Cuv. 24.

Fölül (a hátán) csokolád-barna, alul (hasán) és tarkóján fehéres, fejtetője élénk veres, szemhejai fehérek.

Buffon Madagaskárt, Hasselquist Abyssiniát mondja hazájának. S valóbau Sonnerat azt állítja, hogy Madagaskárban épen nincsenek majmok.

Az örvetlen pofürü (Le Mangabey sans collier. Simia fuliginosa. Geoff.) Buff. XIV, xxxı. Fréd. Cuv. 25.

Fölül egyidomulag csolisolídbarna, halaványsárga alul, szcmhejai fehérek. Buffon madagaskárbelinek mondja, és az elóbbi fajtájának tartja.

$A$ zöldeshaitu pofürï (Le Callitriche, Simia sabaea. Lin.) Buff. XIV. xxxvir. Fréd. Cuv. 19.

Fölül zöldes, alul fehéres, képe fekete, pofszakálla sárgás, farka vége sárga. A Senegálnál. ( $\left.{ }^{\circledR}\right)$

A karhamvas pofürü (Le Malbrouc. Buff. Simia faunus. Gm.) Buff. XIV, xxrx. Simia Cynosuros scopol. Schr.

(') A callithrix nevet Pliniusnál, VIII. k. 54. szak. cgy ethiopiai majom birja, hojtos szakíllı és farku, hihetsleg a sörényes tömkar. Buffon önkénybül adá ezen fajnak. 
rl. XIV. C. Fréd. Cur. 22. rl. - Audeb-nèl a\% elöbbinck fajtája. (4. fam. 2 sect. 5 rl.). ( ${ }^{1}$ )

Fölül zöldes, lagjain hamuszürlie, képe hússzínü, farkén semi sárga nincs, szemholdai fölötl egy fehér és fekete sujtás; borcksa szép lazurliél (ultramarin) szinú.

Farverhenyes pofïrï (Le Vervet. S. erythropyga Fréd. Cuv. 21 r].

A karhamrastul abban különbözils, hogy boréka fehér, segge pedig rerhenyes szörrel van körulvéve:

A szürke pofïru podig (S. grisea) Fréd. Cur. 21, hogy boréka zöld; körülvéve sárga szórrel.

Orrfekete pofürü (Le T'alapoin. S. melarhina. Fréd. Cuv. 18. rl.) Buff. XIV. 10 rl.

Füluil zöldes, po〔szakála súrgás, orra felicte a lnússzinü arc közepén.

Szerzetes pofürü (La Mone. Simia mona, is S. monacha. Schr.) Bull. XIV, xxxyr. Fréd. Gur. 13.

Teste barna, tagjai feketék, hasa, karjai belseje és feje köre fehérebbek: homlokín fekete sujtás, farka tövének mindenik oldalán egy fehér folt.

Szakillas pofürü (Le Rolowai. Simia diana. Lin. Exquima Margr. $\left({ }^{2}\right)$. Audeb. If. Fam. II. sect vi. rl. Buff. Suppl. VII, xx.

Fölül feketés fehér pontokkal, alul fehér, kereszte bi-

(') Clusius Cercopithecus barbatus-a, mellyct Linné mint Faunus-a példaját hoz föl, inkább sörinyes tömkar mint karhamıas pofürü.

(2) Azon kép, melly Margrave exquimájához adaték, a veresbßgönczé; a veresbögönz (ouarine vagy guariba) leirása mellett pedig az exquima (szakállas pofärü) ábrázolata van. Ezcn áltcserélés utóbb sok zavart okoza a névazonságban. 
bor veres, képe fekete fehér körrel, allán egy kis fehér szakáll.

Ajkcimes pofürü. (Le Moustac. Simia cephus Lin.) Buff. XIV, xxxiv. Fr. C. 17.

Hamvas barnás, sárga bojt (szörcsomó) mindenik fülc clöıt, fölsó ajakán egy vilígos kék csik, fordított vértidomban.

Bajúszos pofürü (L' Ascagne. Simia petaurista Gm.) Audeb. IV Fam. II. sect. xIII. rl. F. C. 16. rl.

Fölül olajbarna, alul szürke, képe kéls, orra fehér, mindenik füle elótt fehér bojt, fekete bajúszos.

\section{Orrfehér poflïrü (Le Hocheur. Sim. nictitans Gm.)} Aud. uo XIV. Fréd. Cuv. 13.

Feliete vagy barna fehér pontozattal csupán orra fehér a fekcte kép közepén; ajakai és szemei köre verhenyes.

Ezen utolsó öt fajta mind kicsin, kellemesen tarkázott szinü, igen szelid természetü, Guineában lközönséges. (')

\section{A FARKANYÚK.}

\section{(Les Semnopithèques Fréd. Cuv.)}

Különböznek a pofürüektül egy kis pup által, melly legtöbbször az utolsó és alsó zápfogokon van. A keleti vidékek majmai, mellyeknek kinyujtott karaik, kiváltképen pedig hosszan nyúlt farkok különös tekintetel ad. Arcorok alig duzadtabb a pofürüekénél; szinte mint azok, birnak

(') Pennant némelly hủvelyktelen pofärüt irt le, sim. polycomos és sim. ferruginea, mellybül lliger a colobus nemet csinálta, hanem én mindedelig nem láthattam öket s ezért nem szólék rólok. Temmins azt lizonyitja hogy fejok és fogaik hasonlitanak a farkanjúkéhoz. 
ülgumóval. Ugy látszik, hogy pofzsebök is hibázilk. Gögjök erszénynyel crösített.

Legrégebben ismeretes:

$A$ vezér farkanyú. (Le Douc. Sim. nemaeus. Lin.) Buff. XIV, xur. Fr。 C. 12。 rl.

Bundájának élénk és változó színei által szembetünö; tesle és karai szürkék, lkezei, szárai és lábai feketék, al líbszárai éléuk verhenyesck; farkia és egy nagy háromszegletes folt a kcresztoldalán fehćrek; képe naranesszinü: és veres és felicte nyakiköre ragyis örve van, feje oldalán pedig sárga szörcsomók. Cochinchinában lakık. ( $\left.{ }^{1}\right)$

Egy másik faj az orrának igen különös idoma által nevezetes. Ez az:

Orrkülüncz farkanyú (Kühau, Te Nasique. Simia nasica Schr.) Buff. Suppl. VII, xI és XI.

Sárga, verhenyesbe jálszí; orra rendlkivül hosszú, clöre álló, s lapoczka idomulag lkihomorított. Ezen majom nagy scregeliben él Borneóban, mellyels reggel és este a nagy fák ágain öszvegyülekeznek a folyamok szélén. $K a$ hau-t kiáltoz.

Azt mondják, Cochinchinában is lakik.

Ezen alnemhez számláltatik még, az:

Imcidott farkanyú ( $L$ ' Entelle. Sim. entellus. Dufr.) Fr. Cuv. 8 és 9 rl.

Halarány sárgás szürke; szemholdain és feje oldalán fekete ször van, elöre irányozra. Bengala magasán lakik. Ez a brama hitüektül imádott fajok egyike.

( $\left.{ }^{1}\right)$ Diard több "ezér farkanyút küldvén Cochinchinából a természettudomány muzcumáuak, meggyỏzodtünk hogy van ülgumójok, mellyet Buffon megtagadott tỏö̈, mivel nem látott egy a tömés által elrontott ifju példánynál egyebet. Innét Iliger lasiopyga nemét is ki kell törölni, mivel az csak ezen hibán alapul. 
Tarajas farkanyú (Le Cimepaye. Sim. melalophos. Rafl.) Fr. Cuv. 7 rl.

Szép s igen élénls verhenyes, alul fehér, arca kék, fején fekete szörbuil taraj, egyilk fültól a másikig.

Búbos farkanyú (Le Croo. Sim. comata Desm. S. cristata Rafl.) Fr. Cuv. 11. rl. - Presbytis mitrata Kolzeb.

Szép hamras; alul fehér, farka hegyén fehér bojt. Szemholdjain a fekete búb, és fejtetejéuek szöre hoszú és fölemelt.

Fekete farkanyü (Le Tchincou. S. maura L. Fréd.

C. $10 \mathrm{rl}$.

Egészen fekete, a fiatalok sárga barnálc. - Ezen három utolsó a Sunda szigetekrül való. $\left({ }^{1}\right)$

\section{A. TÖMKAROK.}

\section{(Les Macaques, Macaco.)}

Utolsó zápfogailson egy ötödilk púp van mint a farkanyúknál, úlgomósak és pofzsebüek mint a pofürüek. Tagjaik vastagabbak és rövidebbck az elöbbiekéinél, arcorok duzadtabb, szemöld-boltjok kiállóbb mint ezelsnél vagy azoknál. Fiatalságolsban nagyon tanulékonyak, vénségökbeu szelidíthetlenek. Paizsporcok alatt mindnyájának egy erszénye van, a göggel közösülö, s kiáltozások idején levegövcl megtelö. Farkok csüngö s mozgásaikban épen nem vesz részt; jó korán szülnek, hanem négy öt év elótt

( $\left.{ }^{3}\right)$ Malaji nevökben némelly változtatás van. Rafles. (trans. Lin. XIII.) a $S$. comata-t chinkau-nak a $S$. maura-t lotong-nak nevezi. T. h. S. fascicularis r. Kra. Rafl. uo.

$\left({ }^{2}\right)$ Macaco a majmok általános neve Guinea partjain s a gyarmatokbeli négereknél. Margrave cğy fajt jelel vele, mellyrül azt mondja: habet nares elatas bifidas, és ezen bizonytalan kifejezés, csupán 8 tóle véve, megmaradt a Buffon macaque-jának adott bélyegzetben is, noha az semmi illyessel nem bir. 
nem fanosodnak. Terhességök hét hónyi; a nöstényelnek hátulsó részcin a visclés idején gyaliran iszonyú földagadás látszik. ( $\left.{ }^{1}\right)$

Nagyobb részint. Indiábul jönck.

A sürényes tümkar (Le Macaque à crinière. Sim. silenus

et leonia Lin. et Gm. Ouanderu Buff.) Aud. II. Fam.

I. sect. III. rl.

Fekete; fejét hamvas sürény és fehéres szakáll veszik körül. Ceylon-bul.

A kalapos tömkar (Le Bonnet chinois. Simia sinica. Gm.) Buff. XIV, xxx. Fr. C. 30.

Fölül clég vilågos sárgás-barna, alul fehér; képe hússzínü, fejtelöjén a ször sugáridomban terjed ki s mintegy kalapot liépez. Bengalíbul, Ceylonbul.

A súgaras tümkar. (Le T'oque. Sim. radiata Geoff.) Fr. C. 29 .

Attúl csak zöldes színe által különbözik.

A makogó tömkar (Le Macaque de Buff. Simia cynomolgos et cynocephalus L. Földinél ebfejü és makogú majom Buff. XIV, xx. Fr. C. 26 és 27.

Fölül zöldes, alul sárgás vagy fehéres, fülei és kezei feketék; képe és borékia fúkó. ( $\left.{ }^{2}\right)$ A cscikcis tümkar ( $L$ ' Aigrette. Simia aygula. L.) Buff. XIV, xxı, csak fajlájának látszik lenni, megkülönböztetve feje tetejének hoszszabb szörcsomója által.

Némelly tömkarfajok rövid farkok által különböztetnels meg.

A farkarövid tömkar. (Le Rhésus. Aulcb. Fam. II. rl.

(') Ez mondatá, Aelianus-sal, hogy Indiában gyakran láthatni méh-előeséses majmokat.

$\left(^{2}\right)$ Told hozzá: Le Macaque à face noire (az arcfekete tömkur.) Fr. Cuv. mammif. 28, és a többi, ezen munkábau leirt fajokat. 
Patas à quaeue courte, u. o. Iv. rl. Buff. XIV, Xvı; az elsö ,maimon-t $\mathrm{t}^{66}$ Buffon ábrázolá XIV, XIX rl. $\left({ }^{1}\right)$

Szïrkés; fején és háta alján, néha pedig egész hálán sárga; képe hússzíü, farka a térdhajláson alulra ér. Bengalábul. ( $\left.{ }^{2}\right)$

A kukordu tömkar (Le Maimon. Simia nemestrina Lin.

Sim. platypigos Schreb.) Audeb. II. Fam. 1. sect. Ir.

rl. Fr. Cuiv-nél: Singe à queue de cochon.

Fölül sötét barna; fején egy fekete sujtás kezdödik s háta hosszában vékonyul, feje és végtagjai körül sárgás; farka vékony és kukorodott. $\left({ }^{3}\right)$

A FARKAGOM-ok.

\section{(Les Magots, Inuus Cuv.)}

Nem egyebek tömkaroknúl, mellyek fark helyett egy kis gomot birnak.

A közönséges farkagom (Le Magot commun. S. silvanus, pithecus et inuus. Lin. Földinél: közönséges majom)

Buff. XIV. 7, 8 Fr. Cuv. mammif.

Egészen fölve ran világos szürke-barna szőrrel ; minden majmok közölt legjobban állja ki a mi éghajlatunkat. Barbariábul eredett, hanem azt mondják, hogy a gibraltari szilikák megjárhatatlan meredékein meghonosodotl. (s)

(') Az Audebert-tül használt két egyén a muzcumnál van; megvizsgáltam óket; csak egy fajt képzenek.

$\left({ }^{2}\right)$ Buffon: MTacaque à queue courte-ja (Suppl. VII. pl. XIII. (Sime erytrhea Schr.) nekem valódi, de elvágott farku makogó tömkarnak (S. cynomolgos) tetszik.

$\left({ }^{3}\right)$ T. h. , Le macaque de l' Inde" és: "le macaque à face rouge." Fred. Cuv. mammif.

$\left(^{4}\right)$ Le pithèque Buff. Suppl. VI1, 4, 5. nem egyćb fiatal farkagomnál. Szinte ezen fajbul valók a petit cynocéphale. u. o. 6. és Prosper Alpinus: les grands et petits cynocéphales-ci. 


\section{AZ EBEEJÖMEK.}

(Tres Cynocephales.) Cynocéphalus. C. ( $\left.{ }^{1}\right)$

$\mathrm{Az}$ clóbbicknek fogai, pofzsebei s ülgumór mellett nyult és minlegy elvígott régü arczorok van, hol cgyszersmind orrlyukaik nyilnak ki, a melly öket a többi majmoknál hasonlóbbalkiá teszi az ebekhez; farkok hoszszasíga különbïzö. Ezek általában nagy, rad, és veszedelmes majmok; nagy részint Afrikát lakják.

A küzönsẹges ebfejöm (Le Papion Buff. Simia sphyynx. Linn.)

Sárga, täbbé ragy lievesebbé barnába hajló; pofszakílla sárga, képe fècete, farka hosszú. () Különbfẻle nagy sáçban látni. Fülnölve, ijesztö rad és baromi buja. Guineábul. Van egy közel faj is, rövidebb farku, zöldesebb bundiju, fehires pofszakállu, hús-szin arcu. $A$ zöldes ebfej. S. Cynocephalus. Le Babouin. Fr. C. Mém. du Mn. IV, xix.

A fekete elifejüm (Le Papion noire. Simia porcaria Bodd. S. ursina Penn. S. sphlyngiola IIcrm. La guenon ia face

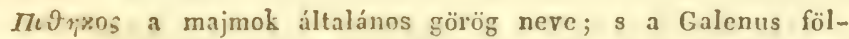
bonczolta majom nem egyéb farkagomnál, noha Camper homlokmagas cmlornek vélte. De Blainville észrevette czen hibát, én pedig megállapitám, czen két fajjal mind azt összchasonlitva, a ınit Galenus az o̊ pithekos-árul mondott.

(') Cynocéphalus, ebfej, igen esmeretes név a régieknél, annál inkább, mivel czen állat az ó egyiptomiak képjelezetében nagy szerepet játszott, a hol Tot-ot vagyis Mercurius-t ábrázolá.

$\left({ }^{2}\right)$ Azok kik ơt csutának rajzolák, mint Buffon papionja XIV, - Xrr és XrV, - elcsutították. Elöször Brogniard ábrázolá le valamelly pontossiggal, hanem az ơt nem illetö $S$. cynocephalus név alalt. Rajzképe másolva van Schreberuél XI11. H. B. Lásd a ,papion" fajokrul Fréd. Cuv. emlo̊scit. 
alongée Penn. et Buff. Supp. VII, xv. Singe noir. de Vaillant. ( $\left.{ }^{1}\right)$ Chacma Fréd. Guv. Mammif.)

Fckete, sárgúsba vagy zöldesbe átfénylö, leginkább pedig a homlokín; pofszakálla szürke, lsépe és kezei feketék. Farka egész a sarkáig leér és bojtba végzödik. A fölnóltnek nagy sörénye van; küJönben idomára és erkölcseire nézve hasonlit az elóbbiekhez. A Foknál (Cap-nál).

Az örvhosszu ebfejöm (Le Tartarin de Belon. Papion à perruque. Sim. hamadryas L. Papion à face de chen.

Penn. Singe de Moco. Buff. Supp. VII, x. $\left({ }^{2}\right)$

Hamvas, kevessé kékded; örvénck s lkivált feje oldalának szóre igen hosszú; képe testszínü. Ezen nagy ma . jom szinte egy a legbujább és legirtóztatúbban vadak közül. Arabhonban s Ethiopiában lakik.

A többi ebfejüektül meg kell különböztetni egy a Fülöp-szigeteken lakó, egészen fekete és minden fark nélkül való fajt (A farktalan ebfejöm; S. nigra. Cuv.) de a mellynek feje' a többiekéhez hasonló.

\section{A DÚZAJKAK.}

\section{(Les Mandrills).}

Minden majmok közült legdúzadtabb arcorruak $\left(30^{\circ}\right)$; farkok 1gen rövid; szinte igen baromiak és vadak. Orrok ollyan mint az elöbbieknél.

A barnás dúzajk (Földinél: Mormon paiviän és Majmon paivian.' Le Mandrill, Boggo, Choras Buff. XI, xvı, xyıl és Supp. VII, Ix. S. maimon et mormon Limn.

Szürke-barna, fölül olajszínües, állán egy lkis czitrom sárga szakáll; pofäja kẻk és barázdás. A vén hímeknél ve-

(') Ezeu koholt fajok csupán csak az egyének nagyobb vagy kisebb jó állapotja vagy különhözo̊ életkora által eredtek.

$\left({ }^{2}\right)$ Schrebernél másolva, hanem roszul színezve. Azonban van egy jớ rajzképe Fr. Cuv. emlóscinél. 
res lesz az orr, leginkább pedig a hegyén, hol bibor szinü lesz; és ez szolgált hamis olsul, hogy tulajdon fajt csináltak belóle. $\left(^{1}\right)$ A nemzö részek és a segg liöre szinte ezen szinnel birnak. Szárai szép viola-kékek. Nem lehet különöscbb és rutabb állatot képzehi. Majdnem az emberi nagyságot éri föl. A guineai feketék nagyon félnck tóle. Leirásúnak sols ronatút keverćk az cmlörökéi közí.

A sárgris duizajk (Le Drill. Simia leucophaea), Fréd. Cur. Anu. du Mus. d' hist. nat. Ix, 37, - egy fiatal és Hist. de mammif. egy fölnólt szerint.

Sárgás szürke, képe fekete, farka igen rövid és vékony; a vín egyénelsnél homályosabb lesz a szin, az áll fénylö veres.

\section{AZ Ú VILÁG MAJMAI.}

Negygyel több zápfogok ran a többicknél, üszwesen tchát harminczhat, farkok hoszu, pofzsebök nincs, ülcp̈̈k födött, gumótalan, orrok lyukai oldalvást, nem alul. Amerilia mindeu nagy négyliezuije ezen oszlílyhoz tartozik; vastag beleik nem olly foildagadtak, rak belök hosszabb) és rélsonyabb mint az ò világ majmaié.

Nimellychnek fogódzo farkok van: azaz amnak vége olly crisen loherödzhetik a testeken hörül, hogy ké gyaniml szolgílhat. Ezeknek linlimösen Görndïrï (Les Sapajous, Cebus Erxl. ( $\left.{ }^{2}\right)$ a nevök.

(1) Mi magunk, szinte mint Geofrroy, láttuk, hogy két vagy hảrom Mandril (Földi Majmon paviánja) Chorássá våry is Mormonná változott, a muzeum állat-kertében. Azon szörbojt, melly a mormon jegyciil hozatik föl, gyakran talaltatik a majmonnál is.

$\left({ }^{2}\right)$ Cebus, cepurus, Kiños, nevei egy ethiopiai majomnak; melly Aclianus leirása szerint (XVII. k, 8. sz.) nem egyćb a mi veres pofürü̈nksúl. 


\section{A BöGöNcöK.}

\section{(Les Aloueltes. : Hycetes Ilig.)}

Megkïlönböztethetók gúlyaképủ fejök álıal, mellynck Łölsö állkapesa solkkal alább száll mint a kaponya, mig a\% alsónak ágai igen magasra cmelkednek egy csontdobot fölvecndök, a szakcsont hólyagos fölfuvoltsága által tímadottat, gégéjökkel közösülöt és szavoknak nagy kiterjedést s irtíztatú hangot adót. Innét e ncrök: bögó majmok. Farkok fogódzó része alul kopasz.

'Гöbb fajok vau, de a mellyeknek megkülönhöztetó jeleik ninesenek még jól meghatározva, mivel bundájok színe, mellyckre azok építtetuck, ráltoznak az életkor és nöm szerint.

A veres bögönc ( $L$ ' Alouatte rousse. Simia seniculus. Hurleur roux. Buff. Supp. VII, XXV.

Gyakran Guiana erdcibül jö hozzánk, hol seregesen ćl. Erös rólxa nagysúgu, élénk gesztenye-verhenyes, fején és farkán homályosabb. A medvéjii bögönce ( $L$ ' Alouatte ourson, Stentor ursinus Geoff.) kevese különbözik tóle. Hanem ugy látszik, hogy több nuások vannak, mellyeknek egy része fekelés vagy barma, a másik pedig halavány színü. Bizonyos fajohnil a halvínyabb szín a nöstényeké. ( $\left.{ }^{1}\right)$

(') Margrave bras. 226, egy fekete guaribá-rul szól, harna kezekkel, mellyet Spix az ö seniculus niger-jében vile fültalálni (Müncheni Emlékiratok 1813. 533 1.) Mycetes rufimanus Kuhl.

Margr. 227, egy másik egészen fekete és szakállas fajrul szól, mellynek rajzképe 228-on van, ,exquima“" hamis név alatt, melly ugy látszik spix (32. r..) mycetes barbatus-a. Nösténje, и. о. 35. rl. halavány sirrás szürke. A him hihetöleg huhl és Neuwied Max. hercz. myycetes ursinus-a. De d'Azzara caraici-ja, melly fekete, melén és hasán sötét verhtuyes, no̊stérje pedig̣ baruá, srinte eren fajhoz számlálható.

CUVIER r. K. 


\section{A K ÖZÖNSÉGES G ÖND ̈ RÜK.}

\section{(Les Sapajous ordinaires.)}

Fejök lapos, arcoruk keressé dinad elö (areszegl. 60").

Némellycknek elsö hürelkäk egészen vagy nagyobb részint el rin a bör alí rejtre, díg-va; farliok fogódzó része alul csupasz. M. Geoll. egy nemet csinál belölök

\section{Dúguj (Atèles (hüvelktelen) név alatt. (')}

Az elsö fiaj, az ötös druguj (le chamek, aleles pentadactylus, (ieofl:), küünbözik a többicktiil, mivel cgy keressi clöállo hürellse ran, noha csali egy pörebül álló és körömtelen, egész bundája fekete.

Eurg másili faj, a hüvelkcisés duguj (Te Mikiri. Aleles hypoxanthus pr. Max. brachyteles macrolarsus Spix., rl.) szinte bir egy igen licsin hürelliet, sót azon niha körme is van. Bundaja sárgás, farka fili rozsdaszinü lesz.

Ezen két fajt Spix elválaszti s Brachytèles (rövid hüvelykü) nevet adott nekik.

A lïbbi dugujak-nál mellỵelire csak magolira ruházza spix az Ateles nevet (Coaila Bull.) egészen hibázili a kitetszö hürell.

Max. heiczegnél elojjỏ még: mycetes ursinus, melly sokkal barsábbrak látszik mint az: ursinus Geofl. és jobban a M. fuscus vagy 3. discolor Spixii-liez hözclit, 50 is 34. rl. Ezen utolsó látszik inkíbb a: Hycetes fuscus Geoft. Jenni.

L' aloutte couleur de 'paille, Stentor stramineus Geoff. et Myc. stramineus Spix. 51. rl. Inelly sárgás barna, kaponyája szerint más fajnak látszik, hanem alị lesz egyéb, mint nóstény az elobbbiekbül. Különben pedig ternészetes, hogy lı bélyegeik kevessé bizonyosak, névazonossázuk még kevesebbé ollyan.

T. L. A farksárga bỏgönc (St. flavicaudatus Gcoff.) melly' leketés barna, farka mindenih oldalán egy sárga cisihhal.

(') Anu. du musćum, VII. 260 és köv. 
Illyenck:

A valúde dieguj (Le Coaïla. Sim. paniscus Lin. Földinél:

kis Paín Macskamajom) Buff. XV, I.

Egéš fekete szörrel födve, mint az ötös dúguj, hanem teljesen minden látható hüvelk nélkül. Képe testszínü. A felele dugini (Le Cayou, Ateles ater) Fréd. Cuv. Mamm.

Képe is fekete, valamint egész teste.

Az arckeritett dúguj (Le Chuva Humb. Coaita à face bordée. Ateles marginatus Gcoff.) Anu. nus. XIII, x. rl.

Felsete, képe körül fehér ször-szélezettel.

A fehérhasu duguj (Le Marimonda Ilumb. Coaïta à ventre blanc. Sim. Beelzebuth Briss.) Gcoff. Ann. mus. VII., xvi. rl.

Fölül fekete, alul fehér; szemköre hússzínü. A sairga diguj (Le Coaita fauve. Ateles arachnoides Geoff.) Anu. mus. X[II, IX. rl.

Szürliés-sárga ragy verhenyes, szemholdai feketék.

Mind czen állatok Guianabul és Briziliábul valók, elsö kezeik igen hosszúk, igen vékonyak; mindnyája igen lassan jár. (1)

\section{A. GӧмBCSUPOK.}

\section{(Les Lagothrix Gcoff. Gastrimargus Spix)}

Fejök gömbölü mint a dúgujakć, hüvelkök kifejlett, mint a bögöncöké, farkok részint csupasz, mint mindeniknél. Illyenek:

Hurnbold gömbcsupa (Le Caparo Hum. Lagothrix Humboldii Gcolf. Gastrim. olivaceus Spix 28 rl. és le Grison. Lagothr. Canus Geoff. Gastrim. infumatus Spix 29.)

Déli-amerika belsejének majmai, a mint mondják, különösen torkosak.

(') Az emberrel némelly igen nevezetes basonlatosságuk rau az izmokban. Az állatok közütt csak ơ nálok van a kétfejü czombizom ugy k.épzỏdve, mint minálunk. 


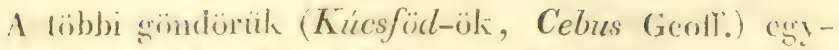
szcrsmind gömblejüek, fejlett hüvelkück, egészcn fïdötl, mola knesoli ragy is fogridzo farkuak. Fajaik móg számosabbak is szinte olly nehéz bélyegractïek, mint a bögöncökéi.

Némellycknck homlokszörc cģyculö nagyságu.

\section{1 feketés krúcsföd (Le Sajou. Simia appella Linn.)}

I felueres kiuesfïd (Le Sä̈, Sim. capnecina L.) Buff. XV, W, V. és VIII, $\mathrm{x}$.

Escrik mint a másik kïlïnbözö barna, az elsönck hrphuire fekctés, a mísiké lehéres, hancm a többi testök imroilatai változnak a barna, fekete sírga söt nóha a fehéres kïzoilt is. I vill is mel tijéla azonban rendesen halavímyabbak. fejhötejök pedig és kezeik sötótebbek. (1)

( ${ }^{2}$ A kniesfielek ammira ráltoznak a nagyon barnátul a súrgísra is felícesre, logy kisértetbe hozatva több fajt esinálnánk belölök, ha hozip-lajtiik nem létemenek, illyenek a: sim. trepida, syrichza, lusubris, fluzia L. et Schreb., valamint némeilyek, mellyeket Gofoli: hübónboztet meg, Ann. du mus. XIX, 111, 112. Spix mér szaporítja öket, véleményem szerint, könnyclmüleg.

Mi a feketés kúcsfödhöz teszszük Max. h. cebus robust-át, molly nem látszik vén cryénnél exjébnek. Spix cebus macroceplıalus-a, 1. 1. szinte nem kïlönbözỏ faj. - A fehéres kúcsfödhöz teszsziik Buft. Sai ì gorge blanclu-jit (S. hypolcucos), Spix cebus libidinosus-át, 2 ; Max. h. cebus xanthosternas-át, vagy Spix cebus xantocephalus-at, 3 , s u.a. cebus cucullatus-át, 6.

IIajlandóbbak volnánk ezeket tartani lï̈lönbriző fajoknak: Ta sajou à pieds dorés, Fréd C. le sajou brun. u. a. vagy cebus unicolor Spix 4. r. Sim. flava Schreb. 51. B. mellytül spix cebus gracilis-c (5. rl.) csupán a tömés által tetszik különbözõnck. Hanem még számos vizsgálódás kell azon nelyeken, hol ezen állatok élnek, mig azzal ilieseledhetünk, hogy a fajokat nem önkényüleg alkottuk. 
Másolnna homlokszóre különbféle fürtökbe van elrendelve.

I szarvas kiucsfïd. (Le Sajou cornu. Sim. fatuellus Gm.) Buff. Sup. VII , 29.

Homloka mindenik oldalín egy kis búb van fekete szörbül. $\left.{ }^{1}\right)$

Ezen majmok természete szelid. mozgások élénk és könnyü; könnyen szclidíthetók. Lassú fúvolahang idomu szavok miatt síró majmoknak (singes pleureurs) is mondatnak.

\section{A MaJMók-ok (Les Saïmiris.)}

firka lipos és majdnem nıgszün fogódzó lenni; fejök igen lapos. Vázoliban a két szenngödör hözfala hírtya-térel bir. Csak egy fajok ösmeretes.

d mókusu majmók (Le Sä̈miri. Simia sciurea) Bufl: $\mathrm{XV} ; \mathbf{x}$.

Mókus nagyságł, sárgás szürke; elökarai, szárai és négy keze aranysárgáls; arezora hegye egészen fekete.

\section{kúcslan (Les Sakis.)}

nevel azon amerikai majmok viselnck, mellyeknck épen nincs kúcsolí farkok. Sokaknak farka igen hosszú és bojtos, a miért roka farku majmoknak is neveztetnck: logaik inkáb\}) elönyulnak mint a többi majmoknál. Ezck Desmaret és Iliger Pithecia-i. $\left({ }^{2}\right)$

(') Ide tartoznak: Cebus cyrrhifer Gcoff. s az ettỏl különböz\&. cebus cyrrhifer pr. Max. - Cebus cristatus Fr. Cuv.

$\left({ }^{2}\right)$ Amerika minden nem kúcsoló farku majmai s az ingaduk, közünséges névvel, Sagouin-oknak (Callitrix Erxl.) neveztetnek Bulfontul. És ezen név valóban, minden apró nem fogódzú farku négykeziieknek adatik Braziliában.

1. Gcoffr. Ann. mus. XIX., 112-113, a callithrix, melly Erxlebenéuek csak eg̣y osztílya, nocthores és pithécia nemeket illalí uosan séopitheque nérvel ajándékozza meg. 
A feletés kiúcslan (Le Yarkí. Sim. pithecia. Jim.) Butl. XV. xн. Pithecia inusla Spix. $10 \mathrm{rl}$.

Feketés; képkörnyéke fehéres.

A szürte kúcslan. (Le Saki gris. Pith. hirsula Spix. s. rl.)

Szürke; kezei sárgásak.

A fekete kucslan (Joe Saki noir. Simia salunas Hoffmansegg) Humb. Obs. zool. xxvir.

Egészen fekete.

A vereshasu kiucslan (Te Saliz ì ventre rous. Singe de muit. Pithecia rufiventris (icolf.) Bull. Supp. VII. xxxi. Pithecia capillamentosa Spix. rl. 11.

Barna; hasa rerhenyes.

Spx czektül megkïlönbözteli azon fijokat, mellycknek farka bojtos ngyan, hanem testöknél röridebb. Nevök: Brachiurıs (kurtafark) kurtász.

A scirga testü kurtaisz (Brachiurnes Ouaraka Spix. \& rl.) teste súrga; feje, nyaka, lkarja s lábai feketék.

Ide kell még temi, hat kïlönbözö faj, a fejfekete kurtrisat (Sim. melanocephala IHunb. ()bs. zonol. 29 rl.), melly sárga, f’ekete fejjel.

Szinte megkïlönböztelnek töle

\section{A FOGAREJTEK.}

\section{(Les Callithrix Geoff. Les Sugouins Fr. Cuv.)}

mellyck farka vékony s fogaik épen nem nyílnak clö. Egy ideig hozzájok számlálák a majmókokat, hanem ezekneks magasabb a fejök, - szemfogaik röridebbek.

Illyenek :

Az álarcos fogarejt (Le Sagouin à masque. Call. personata Geoff. Spix. 12. rl. Call. nigrifrons u. a., 15.) Barna-sárga, - feje s kezei feketék. 
Az özvegy fograrejt (Le Sagouin en deuil, ou la veuve. Simia lugens Humb.)

Feketés: nagy fehér nyakgallérral, mellytül a Call. amicta Geoll. Sp. 13. rl. s a Call. torquata Hoffms. keveset különböznck. ( $\left.{ }^{1}\right)$

\section{AZ ÉJSZËMÖMEK.}

(Ies Nocthores, Fréd. Cuv. Nyctipithecus Spix. - Iligernél roszul : Aotus.)

A fogarejtcktül csak két nagy éji szemök és a bör alá részint elrejtett füleik által különböznek. Csak egy fajok ismeretes.

A sujtcisos éjszemöm (Le Douroucouli Humb. Obs.zool. 28. Nocthora trivirgata Fr. Cuv. Mammif. Nyctipithecus vociferans. Spix. 18. rl.

Fölül hamvas, alul sárga, egy fekete csüngö vonal a homloka küzepén, s egyegy mindenik halántékán. Ez ėjelezỏ állat déli Amerikában. ( $\left.{ }^{2}\right)$

\section{A7. INGADÚK.}

(Les Ouistitis. Hapale Iliger. Arctopithecus Geoffr.

Egy kis nemet képzenek, a kúcslanokhoz hasoulitot, s mellyekkel sok ideig összezavartattak a majmok nagy nomében; s valóban, mint az amerikai majmoknál, fejök gömbölyü, képök lapos, orrlyukaik oldaliak, ülepök födiott, nincs pofzsebök; és, mint a kúcslanolnnál, farkok

(') T. h. Call. melanochir pr. Max. - Call cinerascens Spix. 14. r. csak fiatalkoru ama fajbul, Temmink szerint. C. cuprea Spix, 17. C. Gigo u. a. 16. I. Ezen Gigo vagy Guigo név Max. W. által a Mélanochir-nak adaték, ugy hogy azt nemi elnevéśsnek veilhetni.

(2) T. h. Nyctinithecus felinus Spix. $18 \mathrm{rl}$ 
nem knesolo; minden kirrmirik lapult is hegyes, a hátulsé hürelkekét kivérén: (lsö hüvelkeik pedig olly kevessé tíroznak el a többi ujalitól, hogy mintegy lictelliedve adjuk nekik a negyliezii ncrezetel. Mint apró kellemes idomú állatok, könnyen megszelidülök.

Gcoffroy megkiilimbäzteli ì tulajdon ingactukat Jacr.hus nér alatt, s bélyeguil adja nekik, hogy alsó metszó fogaik hegyesek, iv iflomm vonalban állanak, és a szemfugakkal ergenlö nagrsiguak. Farkok nagyon szörös is gyürüzött; füleilsen rendesen egy szóresomó.

A kïzönséges ingadú (I) Ouistiti commun. Sim. jacchus

L. Paraguayban Tiki. Fäldinél: Pésma macskamajom). Buff. XV, xiv.

Farka nagyon szörös, barna és fehéres gyürükkel festve; teste szürlie-barna: liilei clöt lét nagy fehér szóresomó. Majd az egész déli Amerikíban., (1)

Geoffroy Midas-nak nevezi azon ingadú fajokal, melylycknek alsi metszö fograik vésü idomuak, majdnem egyenes romalban állanak, is a szemfogaknál kisebbek. Farkok rékonyabb és nem gyürüs.

A szürke ingadii (I.e Pinche. Simia oedipus L.) Buff. XV, XVII.

Szürke. barnával hullímzott, fején hosszú fehér ször,

(1) Nchéz a külömbféle szinü ingaduk között a jú fajhatárokat megállitani. A Jacchus.s penicillatus Geoff. Spix. 26. rl. fehér foltot bir a homlokảı, füle szörcsomói barnák vagy feketék. A $J$. leucocephalus (Max, h. 2. k.) hasonló csomókat bir, hanem a fehér szin egész fejét 's nyaka elejét elfoglalja. J. humeralifer Geoffo vállai, mele s karai fehérek. A J. albicollis Spix. 25. rl. homlokfoltja fülszőrcsomói és nagy gallérja fehérek. Ellenben vannak, mellyeknél minclen fehérsér eltünt. L. Annal. du mus., XIX, $119-1221$. 
melly fülei mögé lecsüng; farka vékony, verhenyes. Az Amazon folyam széleiról. ${ }^{(1)}$

1. kezescirga's ingadu (Le Tamarin. Sim. midas Lin. Midas rufimanius Geoff.) Buff. XV. xII.

Fekete; mind a négy keze sárgás. Guianabul.

A fekete ingadiu (Le Tamarin nègre. Midas ursulus Gcoff.) Buff. Sup. VII, xxxu. Midas fuscicollis. Spix. 20. rl.

Egészen fekete; hátán verḩenyes hullámok. Az ajakfehér ingadú (Le Tamarin à lèvres blanches. Midas labiatus Gcoff. M. nigricollıs $\mathrm{S}_{\mathrm{p}} .21$.

Fekete, keresztje verhenyes, arcora köre fehér. $\left({ }^{2}\right)$ Az aranysörényï ingadú (Le Marikina; Singe lion. Simia rosalia L.) Buff. XIV, xıv.

Sárgás; feje aranysárga sörénynyel körülvéve; arka vége barna. Surinambul.

Az aranytarka ingadu (Le Marikina noir. Hapale chrysomelas pr. Max. 2. k.)

Feliete; clökarjai, farka föle és sörénye a feje körül élénk arany-verhenyes.

A: ezüstïs ingadu (Le Mico. Sim. argentata L.) Buff. XV, xviII.

Ezüst-szürliés fehér, nćha egészen fehér; farka barna. Az Amazon folyamnál.

(') Azt vélem, hogy midas bicolor Sp. 24 rl. nem egyéb a szürke ingadu fajtájánál, a $M$. mystax pedig az ajakfehér ingadu-é.

$\left({ }^{2}\right)$ A S. leonina (oroszlány-ingadu) Humb. Obs. 1. 5. rl. barna, képe pedig fekete, ajakai fehérek, mint ezen fajé, hanem ugy látszik hogy nyaka szőre tömöttebb és sörényt képez, mint az aranysörényes ingadunál.

T. h. MTidas chrysopygus Natterer. 


\section{A MÁKIK. Földi.}

\section{(Les Makis. Lemur Limn.)}

Magoliban foglalják, Iinné szerint, mind azon négykezüeket, mellycknek egrik ragy másik állkapesában négy különbözö számu melszö foguk van, ragy legalább máskép helyezödre mint a majmoknit. Ezen tagadó bélyeg kénytrlen volt igen külïnbözö lényeket ïszrekötni, öszvetartozrikat pedig nem rala képes egybegyiijteni. Geoffroy täbb jobban bélyegezell osztísokat tïn ezen nemben. Ezen állatoli négy hürelke joil kifejlett s ellenbetehetö, a hítulso kiez elsö uja pedig foilíllo hegyes körömmel van fölfegyrerliczre; a többi körmük mind laposak. Bundájok gyapjus; fogaik el kezdenck hegyes és egymásba bevágo púpokait mutatni, mint a bogárevókéi.

\section{A TULAJDONKÉPI MÁKIK.}

\section{(Les Makis proprement dits. Lemur).}

Alul hat isszenyomott is clöre fekrö metszö foguk van; fïlül négy, egyenes, a kizzépsök egymistul tírol állok; szenfogaik metszók; mindenik oldalrul fölül és alul hat hat zápfog; füleik nem igen nagyok. Igen vidor élénk állatok, mellyeket róka arcoru majmoknak is neveztek hegyes fejök miatt. Gyümölcsökkel élnek. Számosak fajai, és csak Madagaskárban élnek, hol a majmok helyét látszanak elfoglalni, mellyek, mint mondatik, ottan nem léteznek. Egymás között a szmmél egyébben alig különböznek.

A hamvas maiki (Le Wococo. Temur catta L.) Buff. XIII, Xxir.

Szürkc-hamvas; farka fehér és feketével gyürüzött. A tarka maki (Tie Vari. Lemur macaco I.) Buff. XIIJ. IXVIY. 
Nagy fekete és fehér foltokkal tarkízva.

$A$ veres máki. (Le maki rouge. Lemur ruber Pcron.) Fréd. Cuv. Mammif.

Tidúm veresbarna; feje, négy keze, farka és hasa feketék; tarkiján egy fehér folt, mindenik fülén egy rerhenyes bojt.

A mongóc máki. Földi. (Le Mongous, Lemur mongos L.) Buff. XIII. xxvı.

Egészen barna, képe és kezei feketék. Közel fajok ragy fajták ezek még:

A homlokfehér máki (Te Mongous à front blanc. Lemur albifrons Geoff.) Audeb. Makis. II. rl.

Barna, homIoka fehér, stb. ( $\left.{ }^{1}\right)$

\section{AZ INDRIK.}

(Les indris. Lichanotus Ilig.)

Fogaik mint az clóbbieknél, kivévén hogy alul csak négy (metszö) van.

Csak cgy faja ösmeretes, farkatlan, három lábnyi magas, fckete, arca szürke, fara fehér. (A közönséges indri; Lemur indri), Sonncrat, $\mathrm{II}^{\mathrm{e}}$ Voy. LXXXVI. rl. Madagaskár lakosai megszelidítik és mint az ebet megtanitják a vadászatra. ( $\left.{ }^{2}\right)$

(1) T. h, a fekete máki. L. niger E. 218. - A homlokfekete máki (L. nigrifrons Geoff.) A fekete fejü máki (L. melanocephalus) Fr. C. A nyakbodru máki (Le maki it fraise). Le maki roux (verhenyes máki). Audeb. 2 rl. stb. Azonban nem bizonyos hogy nem megy-e töhb ezen fajokbul egyik a másikba át. L. Geoffr. Ann. nus. XIX. 160. 1. st.

(2) A hoszufarku indri ( $L$ 'indri à longue queus; mak̉i à bourre. Lemur laniger Gm.), Sonnerat $1^{\mathrm{c}}$ Voy. LxxxyI. rl., - öszvehasonlitást kiván. 


\section{A LóRIK vagy LAJHÁRMAJMOK.}

(Les Loris. Singes paresseux. Stenops Ilig.)

Fogaik mint a mákikéi, esak logg zápfogaik pupjai hegy esebbek ; arcorok rövid mint a mopszé; testök karesu; farkok nincs, szemeik nagyok, közelálluk, nyelvök durva.

Bogarakkal élnck, néha apró madarakkal sö́ cmlöselkkel, menetelïken rendkirül lajhík, életnemök éjeli. Véglagaik ütercinek alapján szinte azon apró ágakra oszlíst találta Carlisle, melly a valcidi lajhároknál van.

Két faja ösmercles, mindenik keleti Indiábul.

A lassu liri; Földincl: lassí maiki (Le Toris paresseux; le Paresseux de Bengale. Lemur tardigradus L.) Buff. Supp. VII, xxxvi.

Szürkés-sárgat; hita hosszában egy barna sujtás. Néha hibázik nála két fölső metszó fog. (1)

A karcsu lóri (Le Loris grêle. Lemur gracilis) Bulf. XIII, $\mathbf{x x x}$, és jobban Seb. I, xLvir.

Szürkés súrga, hátsujtás nélkiil, az cóbbind valamirel lisebby orra cmeltebb az állküzti csont clöduzadísi miatt $\left({ }^{2}\right)$

\section{A TALPANYUK.}

\section{(Les Galago Geoff. Otolicnus Ilig.)}

Az clöbbick fogait és bogsir-élclmét birjálk; lalpaik hosszabbultak, s hátulsú liezcilsnck rosz viszonyú mértélict

(2) Lomha járása, melly lajhárnak nézette, némelly szerzöket Buffon és az igazság ellenére azon állitásra vezete, lıogy a lajlátnem Asiában is létezik.

$\left(^{2}\right)$ Ezen különbségén az orrnak alkotú Gcofr. - az elsõ fajbul Nycticebus, a másodikbul Lóris faját. 
adnak; farkok hosszú födött, nagy füleik hártyábul valók, nagy szemeik éjjeli életet árulnak el.

Több faja ismertetik; mind Afrikábul. ( $\left.{ }^{1}\right)$

Ugy látszik hogy ide kell még számlálni ugyan azon tartományok egyik állatát (Lemur potto Gm.), mellyrül az mondatik hogy lomha mint a lírik és lajhárok.

\section{A SARKANYÚK.}

\section{(Lies Tarsiers, Tarsius).}

Az elöbbick nyult talpát és minden más idomjegyét birják; hanem a zíp és metszó fogaik között való tér több apróbb fogakkal van litöltve; a fölsö közép metszö fogak hosszúk ćs szemfogakhoz hasonkik. Arcorok igen rövid, szemök még nagyobbak mint valamennyi clöbbinél. Szinte ¿jjeli allatok, bogarakkal élnek. A molnkki szigeleken. (Lemur spectrum. Pall.) Buffon XIII, 1x. $\left({ }^{2}\right)$

(') A nagy talpanyí, (Le grand G.) tengerinyul nagyságu (Galago crassicaudatus Geoff.) a középsö t. egy patkány alkatu, (G. senegalensis). Schreber XXXVIII. Bb. Audeb. Gal. 1. rl. A kis t., még valamivel kisebl. Brown, ill. 44. V. ö. ,Le galago de Dcmidof" Fischer: Mém. des nat. de Moscou I. rl. 1.

$\left({ }^{2}\right)$ H. ö. Tarsius fuscomanus Fischer, Anat. des Makis 111, rl. és: Tarsius bancanus Horsfield. Jav.

$J e g y z$. Az utazóknak ismét föl kellene némelly állatokat keresni, mellyeket Commerson lerajzolt, is Geofroy lemetszetett. Ann. mus. XIX, X, cheirogaleus név alatt. Ezen képlapok egy új nemet vagy alnemet látszanak a négykezïck között igérni. 
AZ EMLOSEK HARMADIK RENDE。

\section{A RAG $\perp$ DOZÓK.}

\section{(LES CARNASSIERS).}

Számos és különbözö egyesületet képzenek a karmos négylábuak között; mint az ember és a négykezüek, három fajı fogakat biruak, hanem elsö líbaikon nem tetethetik a hüvelk a többi ujak ellenébe. Mind állati anyaggal élnek, és annyival kirekesztöbbleğ, minél metszöbb zápfogaik vammak. A mellyeknél ezek részint vagy egészen dúdorosak, egyszersmind töbl vagy kevesebb növényi eledelt is vesznek, azok pedig, mellyeknél hegyes knpokkal vamnak födve, leginkább bogarakkal élnek. Alsó állhapcsok izesülete kereszthe irányozott és sarkként tapadó lévén, nem enged nekik, vizirányu mozgást; - csak kinyilni tud és bezáródni.

Agyok még eléggé barázdás, de harmadik karélytalan és az agyacsot nem födözö, — mint az a következó családokban is történik; a vázban gudújok (szemgödrök) nincs clválasztva a halánték gödörtül ; kaponyájok szúkült, járomívök szélt- és fölálló, hogy állkajesaik izmainak nagyobb tömeget és erót adjon. Legkifejletlebb érzékök a szagolás, takonyhártyájok általában igen sokszoros csontlemezeken terjedvén ki. Fölkarok még majd min- 
den felé forgatható, noha kevesebb könnyüséggel mint a négykezüeknél, és első lábaikon soha sem birnak a többi ujak ellenébe tehetó hüvelket. Beleik kevesebbé kiterjedtek, eledelök erős tápláló természete miatt, és hogy a rothadás elkerültessék, mellybe a hús eledel átmenne, ha hoszú bélcsöben kellene soká tartózkodnia.

Különben idomuk és alkotásuk módja igen különböző, a mi megfelelö erkölcsi (szokási) különbözést is von maga után, annyira hogy nemeiket lehetetlen egy sorba rakni, hanem kénytelenek vagoyunk több családot képzeni, mellyek különbféle viszonynál fogva határosak egymással.

A ragadozók elsö családa.

A KÉZSZÁRNYUAK.

(Lies chéiroptères).

Még van a négykezüekkel némelly atyafisígok, csüngó vesszejek és mellökön helyezett enılöik által. Megkülönböztető jelök egy bör-redö, melly a nyak oldalain kezdódik, kiterjed négy lábok és ujaik között, öket a levegöben föntartja, sőt azoknak röpülést is enged, mellyek e végre eléggé kifejlett kezüek. Ezen alkotás erös kulcs-csontokat és nagy hónlapokat kiván, hogy a váll kivánt tömöttséggel birjon. hanem az nem volt a fölkar körforgathatá- 
sával megegyeztethetö, melly a röpülésre megkivántató erússégel meggyengílette volna. Mind ezen állatoknak négy nagy szemfoguk van, hanem metszö fogaik száma különbözö. Már régóta csak két törzsökre volt öket szokás felosztani, röpülési müszerek kifejlése szerint, hanem az elsö tölsb alosztásokat kiván.

\section{A DENEVÉREK. (Fölcli)}

(Les Chauve-Souris. Vespertitio. Lin).

Karok, chikarok és ajaik rendkiriil himyulak és a

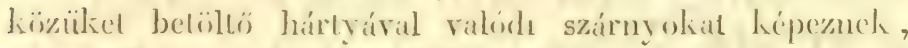
szinte olly vagy mig hitcrjedtebb firlibletiiclict, mint a madaraliei. Igy a denerirek isen magasan is igen sebescon röprilnck. Mellizmaik a syaliorlandi mozgásho\% meghivánt rastagsággal birnak, a mollesontuak pedig häzripen laraja van mint a markaraknal, hogy az izmok hozzí feszullses-

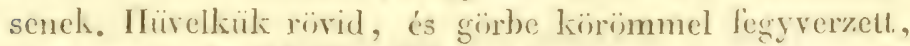

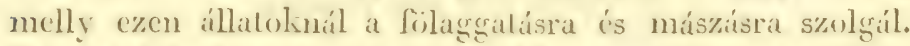
Hátulso lábaili gyöngik, öt majdnem mindig egyenlö és des és görbe karmoklial fegyverzent ujjal. Bélesalornijokban hibizili a valbel. Szemeik rendkivil aprok, hanem fiileik niha igen naggok, es a szárnyokkal együu cgy iszonyú foilületet liepzenck, majdnem egészen esupaszt s ammyira érzélienyet, hogy a denevérels barlangak munden szegletében tudják magokat irányzani, még akkor is ha szemeik kiszurattak, hihetöleg esupán a levegö benyomásínak külünbrizete által. - Fjjeli állatok, a mi éghajlatumk alatt zsibbadásban töltik a telet. Nappal homályos helyeken fölaggatják magokat. Rendesen ketoót köly kedzenek, mellyeked emloiilihez feszílve tartanak, s mellycknck uagysága az anyáchoz aránylag szembetínó.

Ezen nöm igen számos és sok fölosztúst mutat.

Elöbb elválasztandók tóle: 


\section{A SZÁRNYONCZAK.}

\section{(Les. Roussettes. Pteropus. Briss.)}

Mindenils állliapoesban éles melszö, és lapos koronảju ziipfogaik ramnak $\left({ }^{1}\right)$; nagy részint gyümölcsesel élnck s ebbül sokat clrontanak; igen jól tudják azonban a madarakat 's apró cmlósöket üldözni. Ezck a legnagyobb denevérek, húsok megehetö. Kelel-indiában laknak.

Száraik kïzött ig̨en ki ran a hártyájok metszve, épen nincs vagy alig ran farkok; mutató ujok felényivel rövidebb a kiözépsónél, és harmadik pörcöt s egy kis karmot (körmöl) bir, a többi denevércknćl hibázól; hanem a kövelkezö ujak csak két pörëssek; arcorrok egyszerí, orrly ukaik szétállók, fülök középszerï, belsö fülpore nélkül; nyelvök hátra hajló tövisekkel takart; gyomrok igen hosszú s egyenellen kilágnlásu. Csaks déli Ásiában s az indiai sziget-sokon találtattak.

\section{Farkillan SzÁxwoncaK (Roussettes sans queue).} mindenik álllsapocsban négy metszö foggal. $\left(^{2}\right)$

A fekete szarnyonc (La Roussette noire. Pterop. edulis. Geoff.)

Felictés barna, sötétebb; majdnem négy lábnyi szárnyhiterjedéssel. A Sunda és moluklkai szigetekrül, hol nappal a fílira számosan függeszliedve tartózkodik. A gyümölesöt be kell hálóval födni, hogy pusztitásátul megvédessél. Kiíltása erös és a ludéhoz hasonlit. Megfogja magát a zsílsban, melly pózna végén elébe tartatik; a honiak

(') Zápfogaik tulajdonképen két hosszas és közegyenes emelkedést birnak, egy völgyclet által elválasztva, mellyek a dörzsölés altal eltünnek.

(') Linné összezavarta öket vespertilio vampyrus faj alatt.

CUVIER I. K. 
jó izünck találják husál, hanem az emropaiaknak, pézsma szaga miatt, nem tetszils. (1)

A kïzönséges szcirnyonc (La Roussette. Pter. vulgaris. Gcoff.) Butf. X, xiv.

Barna; képe s háta oldlalai sárgáls. De France és Bourbon szigetekriil, hol fútion lakik az erdókben. Ilusát a nyul és fogolhussal hasonlíták öszre.

dz örü̈s szárnyone (La Rousselle à collier; Rougelle de Buffon. Pter. rubricollis Buff. X, xvir.

Szüre-barna, nyaka veres. L'gyan azon szigetekbuil hol az odvas fákban 's a sziklák üregeikben lakik. $\left({ }^{2}\right)$

2. Kisfarku Szánvorcik. Roussetles avec une petite quene, mindenik állkapoesban négy metszö loggal.

Geoflroy rolt az clsó, ki ezen elosztás fajait megismerteti. Fog ikök, gyapjas is saülic, (dz egyiptomi szcirnyone. Pler. aegypliarus) E.gyptomban a foild alalt lakik.

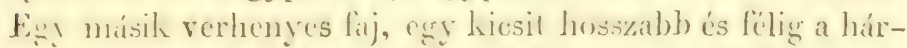
1yaba beburkolt farku, (A farkölelö szárnyonc. Pter. amplexicandus), Amm. mus. XV. k. IV.r., o\% indiai sziget-sokion honol, stb. $\left({ }^{3}\right)$

(icolfory jelelclei szerint elvílasztjuk a szírnyoneaktul migr a Haitrug-okat (Les Céphalotes), mellỵeknek hasonito zápfogaik rannak, hanem mutatio ujokon, melly rö-

(') Temmink szerint a: Roussette d' Edwards Geoff. Edw.108, melly sárga, a hátán sötét barna, ezen faj fiatal kora.

$\left({ }^{2}\right)$ T. h. Pteropus medius. Pt. phaeops. - Pter. poliocephalus. - Pt. dasymallus, Temm. Mamm. x. rl. - Pter. pallidus. - Pt. Keraudrenius, Quoy et Gaym., Voy. de Freycinet. Pter. griseus Geoff. Ann. Mus. 3. rl. XV, vi, Cop. Temm. XI. rl. Pter. personatus. - Pt. melanocephalus. Temm. XII. rl.

${ }^{(5)}$ T. h. Pter. stramineus. - Pt. marginatus Geoff. a jel. hely. v. rl. - Pt. minimus u. a. vagy kiodote Fr. C. vagy Pt, rostratus Horsf. 
rid és három pöreös mint az elöbbicknel, hibázik a kow röm. Szárnyol hártyái a helyett, hogy az olclalakhoz tapadnának, a hát közepén egyesülnek egymással, mellyhez egy látköries és hosszában nyúló rekeszfal által ragadnak. Gyakran csak két metszö fogok van.

Peron hitraga (La céphalote de Péron. Cephalotes Peronii. Geoff. Ann. du Mus., XV.rv.

Barna, vagy verhenyes. Timorbul.

A szárnyoncak elválaszlása ulím, a valósli denevérck vannak még hátra, mellyek mind bogárerök s mind három zápfoggal birnak mindenik oldalon mindenik állkapocsban, hegyes kúpu púpokkal, 's mellyekel különbözó számu álzápfogak elöznck meg. Mutatú ujokon soha sinc.s köröm, és csupán egy aluemel véve ki, hártyajok mindig elterjed a két szárok közölt.

Két fö törzsökre kell óket elosztani. Az elsö szírnyínak küzép uján három megesontosodott pörcöt bir; hanem a többi ujak s még a mutaló uj is esak két pereesek.

Ezen törzsökhöz, melly majdnem egészen idegen, a következendö alnemek tartoznak.

\section{A FÜLGÉK.}

(Les Mulosses. Molossus. Gcuff. Dysopes Higer.)

Ajkonyok egyszerï, füleik szélesck röridek, liözel az ajakak szegletehez erednek, az arcorr fölöt egymással rgyesühek, fïlök belsöje rövid a csigrítul liörül nem litkarra. Farkok a szárközötti hártya egész hosszaságát elfoglalja, és löbbuyire tovább is ny ul. Majdnen mindig csak Lét metszö fogoh van mindenik állkapoesban, hanem Temmink szeriut, többen hatol birnak verinte dul, de azuk közül ıdövel négyet elveszlcuek.

A Szürkülészek (Les Dinops de M. Savi) hat alsó

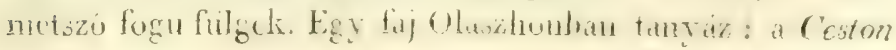


szürkülészo (Dinops Cestonï. Sari) Giorn. de lefler 21 sz. 2301.

Geoffroy Tixtinomes-elnnek (ísJELÉsz) nevezle azokat, mellyeknid nigy alsó melszä logat számlált meg. (1)

Hajdan esak Amerikíban rollak fuilgék falailva $\left(^{2}\right)$; hanem ma mint a kit viliegbeliek ösmerelesek $\left({ }^{3}\right)$. Számosak hátulsó lábinak huirelke jubban el van rálasslva a tübbi ujahnals külinösen is mozgathato, melly bélyegre epité Horsfield a Cheiromeles (Lábakéz) nemet. $\left.{ }^{(}\right)$

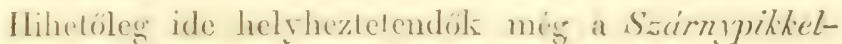
incek. Thiroptera Sp.. mollyek a lügék löbb jegret látszanak birni, s mellyckuck hürelkin egy apro homorú pikkel van, melly killönös tulajdonok s jobb liapaszliodúsıa szolgál nálok. ( ${ }^{\text {s }}$ )

(') Le nyctinome d' Egypte, Geofli., Eg. Mammif, II. rl. 2 k. és T'enm. Mlonog. des Mamm. xix. rl. - Le Nyctinome du Brésil, Isid. Geoffr., Ann. des Sc. nat. I, xxII. rl. vagy Mol. nasutus Spix, xxxv. rl. 7. k. - Le N. grêle (N. tenuis, Horsf., Jav. 5 sz.) és 'Temm. Monogr. xix. rl. kétszer.

$\left({ }^{2}\right)$ Buffon hámat tudott, mellycket Gmel. Vespertilio molossus név alatt osszczavart, t. 1. Mol. longicaudatus Buff. X, xrx, 2. - Mol. fusciventer. u. 0. 1. Mol. guyanensis u. o. Supp. VIl, dxxv. Azóta szaporodtak. MIol. rufus Geoff. Ann., Mus. VI. 155. M. alecto, 'Temm. Monogr., xx. rl. - MI. abrasus, Temm. u. o. xx1. H. MI. velox Natterer, Temm. xxı. r1. 1 k. - M. ohscurus Gcoff: Temm. u. o. xxır. rl. 2. - Hanem ezen fajok nincsenck eléggé oszvehasonlítva, sem Buffonéival, sem a $M$. ursinus Spix, xxxv. r. 4. k. - sem a $M T$. fumarius-sal, 110. 5 és $6 \mathrm{k}$.

$\left({ }^{3}\right)$ Mol. plicatus (Vesp. plicatus Buchan), Trans. linn. V, xur. r]: - Mol. de Ruplel (Dysopes ruppelii Temm). Monogr. xvir. rl.

(4) Cheiromeles torquatus Horsfield, Jav,, vagy Dysopes cheiropus. Temm. Monogr. xvil. rl.

$\left(^{5}\right)$ Thiropteron tricolor Spix., 36, $9 \mathrm{k}$. Mi ezen alnemet igeu lételkedre, helycztetjük ide, mivel leirása tökéletlen. 


\section{A. NYÚLAJKóCOK.}

\section{(Les Noctilions. Noctilio. Linn. Ed. XII).}

Arcorruk rövid, duzadt, nyulszájként ketté hasadt ajakkal, ıszonyos szömölcsökliel és redekkel födött; füleik külön ráltak; fölül négy, alul két metszö foguk van; farkok rövid és szabad szárközti hárlyájok fölött.

Legösmerelesebb faj az amerikai, egyidomulag súrga szimnel. ( $A$ sairga nyulajkóc. Vespertilio leporinus $\mathrm{Gm}$.) Schreb. Lx. ( $\left.{ }^{1}\right)$

\section{A HÁRTYORROK.}

\section{(Les Phyllostomes. Phyllostoma. Cuv. és Gcoff.)}

Meızö fogaik rendes száma mindenik állkapocsban négy: hanem az alsóbbak közül néhány gyakran kiesik, kiszorílatra a szemfogak növekedése által. Meglïiönböztetnek még az orrok hegyén keresztben emelliedö levélidomu hárlyájok álıl. Külsö fülök porca egy apró, s többé kevesebbé fogazott levelet áhrázol. Nyelvök hosszan kinýújtható s szömölcsökbe végzödik, mellyek szíró müszer liépzésére látszanak alkalmaztatra lemni; ajakaik szinte öszméresen helyeztetelt szömölcsüket birnak. Ezck Amerika állatai, a földön a többi denevércknél jobban futók, s az állatok vérél szopni szokók.

\section{Farkatlan HÁrtyoRroK.}

(Phyllostomes sans queue. Vampirus. Spix.)

A' lidérc hártyorr. Földinél: Lidérc v. tültsérorru denevér. (Le V́ ampire. Vesp. spectrum L. Brasiliában : An-

(') A Noct. dorsatus Geoff, vagy $N$. vittatus Pr. Max., fehéıes sujtást bi háta hosszában, - A $N$. albiventer Spix, 35, 2 és 4, fölül sárga, alul fehér, s valamivel kiscbb. - T. h. Noctilio rufus Spix, 35, 1. 
dira-guaçe) Scb. uvir. Geoft. Ann. Mus. XV. XII. 4.

Orhireryaja lojisdad, tölsciridomba hajlott: rerhem nỵes-barua, harkily nagyságu. Dili Amerikábul. Azzal vádollateli hogy szopása ailtal megïl az cmbereket is állatokat, hanem coupan igen lis sebnyilíst csinál, melly a\% éghajlat által néha reszedelmessé lehet. ( $\left.{ }^{1}\right)$

2. A sankinsti hirlyciba beburkolt frerku Hintronnok. -1 dirdis livirlyorr (Le Fer de lance $r$. hastatus L.) Buff. XIII, xxxiII.

Orra levele láncza-idomu, ép széllel. (²)

3. Iи́туонвок szabad furktal a hartya fülöth. A fogazoll hirlyorr. (Le Fer. (rinele. Pluil. cremulatum Geoff. Amal du Mis. XV, x rl.

Orra levele dárdaidomu, széle fogazott.

Geofleov. Mém. du Mus. IV, 418, megkiilönbrizteli a hírlyorroktul azon lajakil. mollyckneh szük, kiöllhetó

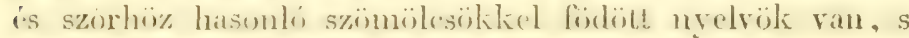

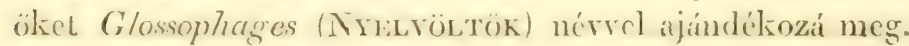

Ezen fajok szinte mind Amerikábul vilók. ( $\left.{ }^{3}\right)$

A deneverek második nagy törzökénel csak egy pörc ran a mulati ujon megesontosodva, a tribbi ujakon pedig keltö kettö.

Ezen törzsökït is több alnemre osztják.

(') T. 1. La lunette (Vesp. perspicillatus L.) Buff. Supp. VII, Ixxrv. - És a Geoff. Azzara szerini adta három fajat, Ann. du Mus. VI, $181-182$.

$\left({ }^{2}\right)$ T. L. Phillostoma elongatum Geof., Ann. Mus. XV, 1 .

$\left({ }^{3}\right)$ Vespertilio soricinus, Pall. Spicil., Fascic. III, III és IV. r. Lemásolva Buff. Suppl. 111, $53 \mathrm{rl}$. Glossoph. amplexicaudatus Geoff. Mem. Mus. IV, 18 I. F. C. - Gl. caudifer, wa. uo. 17. rl. $A$ is $B k$. 


\section{^. TöмвóRöK.}

(Les Mégadermes. Geoff. Ann. du Mus. XV).

Orrokon bonyoltabb levél van mint a hártyorrokén; fülporcok nagy, legtöb]nyire hasadt, fülcsigáik igen szélesck és a fej tetején egymíshoz ragadók; nyelvöls és ajakaik simák, a szárközötti hártya egész és farktalan. Négy melszö foguk van alul, hanem fölül azolinak hijával vannak; állközti csontuk porcos marad.

Mind az ó világbul valók, részint Afrikábul, mint a levél tümbör (La Feuille. Mlegad. frons Geoff.) melly a Senegálnál lakik, orrlevele tojásdad és majdnem akkora mint a feje; részint az indiai sziget-sokrul, mint a görcsüs tömbör (Le spasme de Ternate. Vesp. spasma L. Seb., I, Lvi.) - a lanlos tümbör (La lyre. Geoff. Ann. du Mus. XV, xir. rl. - A lúherés tömbör (Le tréfle de Java, ua. uo. stb. Egvnástul ezeket is orrlevelök idománál fogva különböztetik meg, mint a hártyorrokat.

\section{A PATKócok.}

(Les Rhinolophes. Rhinolophus. Geoff. Fers-à-cheval).

Ezeknek orra igen bonyolı hártyákkal és tarajokkal füdült, mellyek az orr hátúra dülnek s nagyban patkót ábrázolnak; farkok hosszú s a szárközölti hírtyában ran helyhezletve. Alul négy, fölül (igen kicsin) metszö fogok van, ezek a porcidomu állközti csontban.

Két fajoli igen liözönséges Frankhonban s Daubenton által találtaték föl.

A nagy patkó (Le grand Fer-ì-cheval. Buff. Vesp. ferrum equinum L.) ; Rhinolophe bifer. Geoff. Anı. muXX, r. rl. és :

$A$ kis patkóc (Le petit Fer-ia-cheval. T'esp. hipposiderus Bechst.) Buff. VIII, xvir, 2 és xx. Gcoff. a m. h. 
A köbinyáliban liknak, hol maginosan tartúzkodnak. lábaiknál fogra foinaliadva is szírnyaikba ngy beburliolúdra hogy testök egyèb risze egészen láthatatlan. (1)

\section{A GöDöRoRRAK.}

\section{(Les Nyctères. Nycteris Cuv. és Geoff.)}

Orrok hátán egy hosszúlsás árole van kirájva, melly megr a kaponyajokon is jelelkezile s be ran szegre egy börredivel, melly azt részinl födizi 1s. Orrlyukaik egyszerikl. liuluil negg lioztirtelen, alul hal metszö foguls van: fülcik nagrok. nem egyesuiltek, farkok a szárkizziolli hárlyában. Tizck abilsai fajok. Daubenton leir egy fajt campagnol vo-

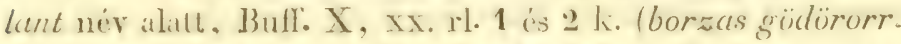
vesp. hispidus L., Schreb. LVI.); Geoffroy másokat ta- . lált Egyiptamban. $\left({ }^{2}\right)$

\section{A tálorirak.}

\section{(Les Rhinopomes. Geofl').}

Orrok hítán esckélycbb árok, orrlyukaik az arcorr rigén, fölüttiik pedig egs apro lemez, tal-nemct ábrizolva; fülcik egresültck, firtiok a hirlyát sokkal meghaladja. Egy faja ösmereles Egyiplumbul, hol leginkíbb) a gúlyákban (pyramisokban) tartózkodik. $\left({ }^{3}\right)$

(') T. h. azon más négy fajat, melly ábrázolva van: Geofi: Ann. Mus. XX, v. mellyek egyike a resp. speoris Schr., LXIX, B., és Péron. Voy. Aux Terres austral. 35 rl.

(') A thebai gödörorr. Nyctère de la Thébaide, 29. Mamm. 1, 2 , 2 ; és Ann. Mus. XX, 1 rl. - A jávai g. $N$. de Java. Geoff. Ann. Mus. XX, $1 \mathrm{rl}$.

(') Rhinopome Microphylle, Geoff; Vesp. microphillus Schr. 


\section{A. KFZÉNZSEBEK.}

\section{(Les Taphiens. Taphozous. Geoff).}

Orrok hátán gömbölyüs árok; hancm orrlyukaikon nincsenck follemelt lemezck; fejök gúlyaképü, fölül csak liét metszö foguk számláltatik, sót néha ezek is hibáznak; alsó metszó fogok négy s azok háromkarélyosak, füleik szétállók, farkok szabad a hárlya fölötl. A himeknél egy koreszt üresség van a torok alatl. Szárnyaik hártyájának egy lis nyujtránya ralami zsebnemet képez a kéztö közeletén. (') Geoffroy egy faját az egyiptomi katakombákban találta. ( $\left.{ }^{2}\right)$

\section{A MEREDFóK.}

\section{(Les Mormoops. Leach).}

Mindenik állkapocsban négy metszö fogok van, a folsök clég nagyok, az alsók háromkarélyosak; kaponyájok különösen emelliedett, mint egy gúlya az arcorr fölött; az orr mindenik oldalán egy háromszeges lemez, melly a füllel összefügg. $\left(^{3}\right)$

\section{A Közönséges Denevérek, SzÁrnyas-egerek.} (Les Chauves-Souris Communes ou Vespertilions. Vespertilio. Guv. et Geoffr.)

Arcorrok levél és minden más kitetszö jegy nélkül, füleik elválasztaltak, fölül négy metszö fogok, mellyek-

(1) Ez okbul nevezte lliger, saccopterix-nek, azon nemeket, mellyek a kezénzseb-eket foglalják magokban.

$\left({ }^{2}\right)$ Le Taphien filet, Eg. Mammif I, 1, 3.-Le taphien perforé uo. III, L., melly nem igen látszik a lerot volant, Daub. T'. senegalensis G.-tul kilönbözni. - T. h. Vesp. lepturus Gm. Schreb. LVII. Le T. des Indes. $V$. brachmanus G. - Le T, de I' Isle-de-France, T. mauritianus, G. - Le T.roux; T.rufus Wils. Amer. Ornith. VI. köt. L. rl. 4 sz. - T. longimanus, Haredw. Trans. Linn, xvir, rl.?

$\left({ }^{3}\right)$ A faja (Mlormoops Blainvillii, Leach. Trans. Lin. XII), Javábul való. 
nek két kïzépsöje tárol álli, alul hat valamennyire fogazott élkel; farkok a luirtyában ran foglalva. Ezen alnem mindnyájánál számosabb; fajai a föld minden részében találtatnak. Küzüliik hatot ragy hetel számlálni Francziatorszagban.

Nimellyclinck fülporea íridomu, és ezen osztáshoz tartozik a legösmeretescbb faj.

A szcirnyasegér denever Földi. (The Chauve-souris ordinaire. Tesp. murinus Lin. F. Myotis, Kuhl. Buff. IIII, XrI.

Fülei lossziudak, a fej nagysaģit fölütök, szöre barna, fiilül gesztenyeszinü, alul világos szürge; a fiatalok hamvas szürkék.

Nem régiben némelly kisebb) de határos fajols találtattak föl Europában. ( $\left.{ }^{1}\right)$

A tïbbi denerérels fülfödele szegletes. Illyen: A késö denevér (La Sérotine. Vesp serotinus L.) Bufl. VIII, XvilI, 2.

Sülél gesztenyeszin; szírnyai és fülei feketések, ezeknek esicrija háromszegii, a fejuel riovidebb. A nösteny halivínyabb. 'Taliéltatik a templomok és más megr ritkín lieresett épületek födelei alatt. $\left({ }^{2}\right)$

Másolnnak füllödele még félholdidomu.

Az éjelezö denevér. (La Noctule. Vesp. noctula. L.) Buff.

VIII, xrin, 1. $V$. proterus. Kuhl. V. lasiopterus. Schreb. 58. B.

Sárga, fülei háromszegück; a fejnél rövidebbek, fül-

(') $l^{5}$. beschsteinii (Leisler) Kuhl. Chauv. d'Allem. xxir. rl. V. mystacinus (bajuszos d.) ua. uo. 18. $-V$. Daubentoni Leisl. Kuhl xxv. rl. stb.

T. h. ezen idegen fajokat: $\boldsymbol{V}$. emarginatus Geoff. Ann. Mus. VIII, Xlvi. - $V$. pictus L. vagy kirivoula de Java. Seb. I, LVI. rl. 25. k. - V. polythrix Isid. Geoff. Ann. des Sc. nat. III. 440. I. - r. levis ua. uo. stb.

$\left({ }^{2}\right)$ T. h. V. carolinensis Geof. Ann. Mus. VIII, XLvII. 
födele gümbialyá; a késö-nél cgy kevéssel nagyobb. A vén fák odvaiban található; stb.

A törpe denevér. (La Pipistrelle. $\boldsymbol{V}$. pipistrellus Gm.) Buff. IIII, XIx, 1.

Legkisebb a mi vidékeinken; feketés barna, fülei háromszegletüek. $\left({ }^{1}\right)$

Geoffroy szeriut elválasztatnak még a denevérelktül.

\section{AZ ÖSZFÜLEK.}

\section{(Les Oreillards. Plecotus. Gcoff.)}

Füleik nagyobbak a fejöknél és a kaponya fölött egymáshoz ragadnak, mint a tömböröknél, tálorraknál stb. Fülfödelök nagy és lándsa idomu, a halljáraton is födelök van.

A liözönséges fajta, a nagy üszfül. - Földinél: nagyfülü denevér (Vespert auritus. L.) bövebb itt mint a denevér: fülei majdnem akkorák mint a teste. A házalsban, konyhákban stb. lakik. Yan egy másik faj is, mellyet Daubenton találl föl: a barna öszfül (la barbastelle. Vesp. barbastellus ( $\mathrm{xm}$.) Buff. VIII, xIx, 2. Barna; jóval kisebbek a fülei. $\left({ }^{2}\right)$

( $\left.{ }^{1}\right)$ T. H. Kuhl denevere ( $T$. Kuhlii Natterer) Kuhl Chaures. d' Allem. 55.

$\left.{ }^{(}\right)$T. h. A timori öszfül (l' oreillard de Timor. Plec. timoriensis Geoff.) - A füdött öszfïl (Pl. velatus Isid. Geoff). - Maugé öszfüle. Pl. Maugei Desmr.) A szarıas öszfül (Plec. cornutus, Fabre). - Vesp. megalotis Rafin.

Jegyz. Tervünk nem engedvén meg egyéb állatok osztályozását, mint a mellyeknek jegyeit tulajdon figyeletïnk vagy jól tökéletesített leirísok és képek szerint megállapítottuk, kötelesek valánk Leacb, Raflinesque st. tobb nemét kihagyni, s itt meg kell általában jegyeznünk, hogy nincs olly család, mellynek annyira volna szüksége, mint a denevérekének, arra hogy a természet szerint újra vizsgáltatnék, nem pedig a lopdozás utján. 


\section{az frröpök. (Les Nycticées. Rafinesque.)}

régre középszerii fullcik mellett a denerérek egyszerü arcorát birják, frilsö állkapcsokban pedig esak két metszö fogrok ram. Az ismeretes fajok Éjszals-ameriksíbul valók. ( $\left.{ }^{(}\right)$

\section{A MAJMUGRÁSZOK.}

\section{Les Galépilhéques. Galeopithecus. Pall. Chats volants.}

Nömileg külïnböznek a denevérektül, mert kezeik ujai, mind melszö körmökliel birók, nem hosszabbak a líbokénit; olly módon, hogy a téreket elloglaló s egész a fark oldalaiig kilerjedö hártya, nem eğ lïmnyen lesz más szolgálatot, mint hogy crnyoülil szolgál az csesben. Szemfogaik fogazoltak és röridels mint a zápfogak. Fölül két szinte fogazolt melszö fogok ran, hírom pedig egymástul

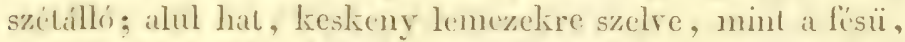
melly alkat egészen csak czen nüm tulajdona. Ezen állatok a fúlion élnck az indiat sziget-sokon is olt bogarakat s talim a madirakat is üldözils; azon chísisisul itrilve, melylyet fogaik idövel tapaszlalnak, gyümölcsiokisel is kell élnick. Nagy rakbelök vau.

Pontosan esali egy faja ismereles, mellyuck bundája foilul rölszïrkc, alul verhenves, fratalsigában kïlönbféle szürke foltolkal és csikokkal. Fz a: máki majmugrász. Lemur volans L. Audeb., Galacop., r és II rl. A molukkai és szunda szigeteken lakik stb.

Minden löbbi ragadozónál a hason vamak az emlók.

(') Vesp. lasiurus, Schreb. LXIl, B. - V. noveboracensis, Penn. Quadr. $\operatorname{xxxi}$ rl. 2. k, $-V$. borbonicus Geoff. Ann. Mus. VIII, XLVI. 


\section{A BOGÁREVÕK.}

Mint azoknak második családa.

Zápfogaik, mint a kézszárnyuaknál, kúpos pupokkal hegyezettek; legtöbbnyire éjjelező vagy földalatti életuiek: fớképen bogarakkal táplálják magokat, és, a hideg tartományokban, közülök sokan zsibadva töltik a telet. Nincs oldalhártyájok mint a' denevéreknek, azonban kulcs-csontok még sem hibázik; lábaik rövidek, mozgásik gyöngék, emlőik a hason, vesszejök hüvelyben, egyiköknek sincs vakbele, a menés alatt mind az egész talpra lépnek.

Kölönböznek metszö és szemfogaik helyezete és viszonya szerint.

Némellyeknek elül hosszú metszö fogaik vannak, mellyekre a zápfogaknál is alacsonyabb más metsző és szemfogak következnek, melly fogrende let nemét a négykezüek között a sarkanyúknál láttuk, - s a mi ezen állatokat az öılókhöz valámicsliét közelebb hozza. Másoknak szét-álló nagy szemfogaik vannak, mellyek között aprók a metszök, melly helyezet legközönségesebb a négykezüeknél és ragadozóknál. Ezen két fogrendelet pedig az olly nemeknél is találtatik, mellyek különben a födözetre, tagjaik idomára s életmódjokra nézve igen hasonlók.

\section{A SÜNEK.}

(Les Hérissons. Erinaceus. L.)

Testök ször helyett tövissel födütt. Hátok böre olly izmokikal bir hogy az állat, hasa felé hajtván fejét és 
Lacsoit, abba mint valamelly erszenybe butholhatja be magát s mindenfelïlrül töriseit fordithatjat cllensigge folé. Farkok igen rörid, mindenik líbokon öt uj; nimdenik állkiaposhan hat melszi foge, a krizapsök hosszabbali; mindenik uldatun harom hamis, harom heggezell és egy his gumós zápfog.

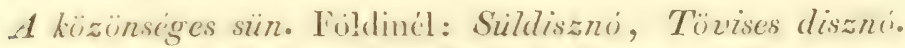
(le Hérisson ordinaire. Lirinaceus europaeus. L. Bull. IIII, vi.

Tulei rövidek. Fleqgé hëzönséges a fösakban és gyepukben; a telel tanyalyuhibum töli, s omman kikeletkor

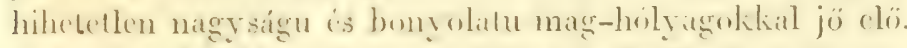
A rendes eledelet tevö bugaratihoz gyoumoilesït is kerer, melly idovel elvisiljal logai hegreil. Hajdaniban liendergerebenezésre haszuálták boúrét.

A füles sün. (I.c Ilérisson ì longues orcilles. Lrinaceus auritus Pall.) Schreb. CLXIII.

A kïzönségesnel kiscbb) fulci nagyoli mint feje licitharmada: kiblönben a mindihez idomra és orkiolesere hat-

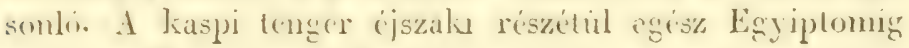
talélható $\left.{ }^{1}\right)$.

\section{A SÜNCSÚTOK}

\section{(Les Tenrecs Cur. Centenes. Iliger.)}

Testök tövisekles fïditl, munt a sünöknèt; hanem olly tökélctes gömbbe nem ludnak gömbölyödni; farkatlanok: arcorrok igen hegyes, fogaik igen különbözö. Mindenik. allkapesokban negy ragy hat metszö is ket nagy szemfog van. Szemlogaik mögöll egy ragy liél apro fog ran és négy

(') Pálas megjegyzé, mint fontos esetet, hogy a sinök száz ŕs száz hórisbogarat esznek meg minden hár nélkul; wig az ebchuck és macskáknak csak egy is intóztató kinokat okoz. 
háromszegui hegyezett zápfog. Madagaskảrban három faja találtatik, mellyeknek egyike a frankok szigetén (l' ile de France) meghonosodott. Eijeli illatok, az év három havát zsibbadásban töltók, noha a heves ég alatt élnek. Bruguiere azt is bizonyitja, hogy a legheresebb) évszak alalt alusznak.

A törises süncsut (Le Tenrec. Erinaceus ecaudatus. Linn.) Buff. XII, LVI.

Durva törisekkel födötl, s alul csak négy szemfogaklial. A három kïzölt cz legnagyobb; a mi sününlset fölülmulja.

$A$ sürtés süncsut (Le Tendrac. Erinaceus setosus. Lin.) Buff. XII, LvII.

Hajlékonyabb és a sörtćlıez hasonlóbb tövisekliel; mindenik állkapcsában hal kikanyaritolt melszöfog. A. sörtetüskés süncsut (Le 'T'enrec ray'é. Erinaceus semispinosus).

Sörtével és tövisekkel kcverve födölt; sárga és feketc sugárzattal; hat metszö s a szemfogai vékonyak és hajlottak; alig vakondok-nagyságu. $\left.{ }^{1}\right)$

\section{A szőrsüNöK.}

(Les Cladobates. Cladobates. Fr. Cuv. Tupaia Rafles.

Egy újolag bélyegezelt nem az mdiai sziget-solsrul, mellynck fogai a sünckéihez sokban hasonlitanak, kivévén hogy fölül liözépsó nietszöfogaik aránylag rövidebbek, alsó állkapcsokban négy hosszú van, hátul pedig a gumó hibázik. Ezen állatok szörrel födöttek, mezes farkuak, a többi bogárevook cllenére mókusi könnyüséggel másznak

(') Buff., Supp. III, xxxvı. H. hibásan, fiatal tövises sünnek tartotta. Sonnerat, Voy. à la Chine, 11, 146. J. roszul irja le fogait. 
a fálira; hanem hegyes arcorrolirul megkïlönböztethetui öket távolrul is (1)

\section{A cICkÁNyok. Földi.}

\section{(Les Musaraignes. Sorex. Lin.)}

Általíban apró és szörrel foidritt állatok. Mindenik olditulion a rendes szór alatl egy his esomó durra sürï sirrte tilkiltatik, mellyck kïziill a terhesség idején szagus anyag izzad li rgy tulajdon mirigy allal választalvat (1. $\left.1^{2}\right)$ Töhü a kit hizzipsö metszö logak meghajlottak s alipolson fogasuls: az alsik folierok is nyulak; az rlschere mindenik oldalom ä apró fog liörolkezik, a másodikilkra esak kello. 'Täbbnyire mindenik allkapossban

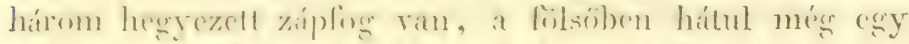
gumnis. Fyon allialok a földben ástik lyukakban tarkizkodnak, nem erglamnsen monncli li, mint coak este felé, s férgekkel és bogarakkal élnek.

frankhomban sok idoun altal csak coy faj rolt ismeretes :

A kïzünseges rickinu. Fïldi. (Ta Musaraigne commune, ou Muselte. Sorex araneus. Lin.) Bulf. VIII, x, 1.

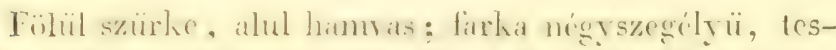

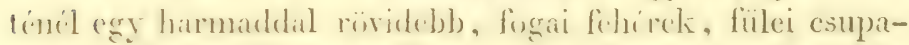
Ezok, nrillak; (ligege bij a mezüliön és réleken stb. Azzal

(') Le banxring (Cladobates javanica Fr. Cuv.); Tupaia jaranica Horsf., Jav. - Cl. tana, Fr. C. Tupai tana Horsf., - Cl. ferruginea Fr. Cuv.; Tupaja ferruginea Rafl.

Vigors és Horsfield Uu. (Zool. journ. III, viri.) grmnura neme közeliteni látszik a szórsünökhöz fogainál, a cickányokhoz pedig hegyes arcoranal és pikkelyes farhánál fogra. Mindenik lábán öt körmös uja van, és gyapjas szo̊rén fölül eléggé durva sörték sllanak cló. - Nem lchet clöbb jül osztályozni, mint mikor boucolata megösmertetik.

(2) L. Geoff, , mém. du Mus, 1 k. 229 1. 
vádoltaték hogy harapása által betegséget okoz a lovaknak, hanem ezen véleméuy hamis és hilictöleg onnan ered, mivel a macskák megölik ugyan a cickányt, hanem szaga miatt nem eszik meg a husát.

Daubentontul ismerteték meg.

A visi cickiny. Föld. (La Musaraigne d' eau. Sorex fo-

diens. Gm. S. Daubentonii. Blumb.) Buff. VIII, XI.

Valamivel nagyobb a közönségesnél. Fölül fekete, alul fehér, farka a végén összenyomott, egy negyeddel rövidebb a testuél; vágfogai veresck hegyükön, füle fehérrel beszegre s nagy részint a bör alá elrejtre, lebukísa idején majdnem hathallanul bezárható; a lábait födözö durva ször könnyíli úszását; honnan kölöuösen a folyók széleit keresi.

Europában még különbféle cickányok vetettek észre, az clöbbiektül némelly tekintetben különbözók; hanem minthogy a lkor és évszak a szinre befolyással van ezen nemnél, nem bizonyos, ha azok vajjon állandó fajak-e. ( $\left.{ }^{1}\right)$.

A külföldnek is szinte vannak cickányai, mellyck köziil legnevezetesebb :

A patkinyfarku cickíny (MI. ì queue de rat. Sorex myo-

surus Pall.) Act. petrop. 1781. 2. 1. 4. rl. Mus musquée

de $l$ Inde, Buff. Supp. VII, 71,

mellynek idoma és szine a miénkéhez hasonli, nagy fülei csupaszok, farka gömbölyú és csak ritka szörrel födött, s

(') A S. leucodon Schr., 159. D. nem látszik különbözni a közönséges cickánytul. Igen vélem logy a $S$. tetragonurus et constrictus Herm. Schreb, 159, B és C. v. Geoff. Ann. Mus. XVII, II r]. 3 k. és III rl. 1 k. sỏt még a: S. remifer, Geoff. Ann. Mus. XVII, II l. 1 k. a vizi cickány életkorai. A remifer, különösen, melly majd fehéres, majl fekete hasu - a: S. lineatus, Geoff, uo. 181, történetbeli kor-fajtája, véleményem szerint a tetragonurusnak. A s. minutus Laxmaun. Schreb. 161. B. 11cm cgyéb mint a S. py grmaeus csutitott egyéne.

CUVIER I. K. 
nagysága majd mint a rándor patkínyé. Erös pézsmatszagot terjeszt rl, mellyel mind azh megfertoztet, a mihe\% é. Egész Indiában és Afrika cgy részén talíltalili; is azon állatok számábul való, mellychet a régi egriptomiak bebalzsamoztak. (')

\section{A CICÚsZoK.}

\section{(Les Desmans. Mygale. Cuv.)}

A cickinyoktul kiét igen apri, az alsó állkapoes két nagy metszo fog̣a közé helyeztetetl fogban különböznck, s mivel migr hét lölsö víglingok háromszeges és lapos. Ezen met-

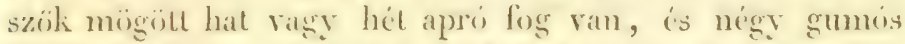
zipplog. Arezoruk rördel igen hajlélony orba nyúl ki, mellyed szünellenisl mozgatnak. Farkok hosszú, pikkelyes, lapult oldalu; hábolion öt uj, mindns aja hártya allal

Nem ugy van a dolog a sorex etruscus-(etruriai cickainy)-nál, Savi, melly a mi közönséges fajunknál féllel hisebb, feketés, csupasz fülii, fehéres arcurú és kacsoju, gümbölvü farku stb. Ez tulajdon faj.

(') Én a S. myosurus Pall. és Geof: Ann. Mus. XVII, M1. rl. 2. k., a S. capensis ua. uo. II, 1 . 2. k. a S. indicus ua. Mém. du Mus. I, Xv 1. 1 k. fajokat, egy faj korainak vagy fajtáinak tekintem, a hova més a $S$. giguntus, 1sid. Geoff. Mém. du Mus. XV, IV. rl. 3 k. számlálbató, sôt talán még a sor. flarescens is, Isid. Geof. uo. Seba le ábrázolá Mus. I, xxxı. rl. 7 és 11 k. xuin rl. 5. k., - és fehér fajtát 1 , XLviI, 4 k. -

T. H. Egér cickány (S. murinus Lin.), Jávárul, egér nagyságu, szürke, csupasz tülü, görbe s majd olly hosszu farku, mint a teste.

d rüzidfarku cz. (S. brevicaudus, Say.) Éjszak-amerikábul, feketés, rejtett fülü, farka testének egy negyedét méri.

Az upró cz. (S. parvus. ua.) csupasz fülü.

Illatos cz. (S. svaveolens Pall.) és a többi fajok, mellyeket at. orosz állatleirásában jelel bi. - Ezen nem nemhevesebbé kiván áltnézést, miut a denevérek. 
'gyesiilve, - mellyek által egész úszó állatok lesznek. Szemök igen kicsin; külsö fülök nines.

Lz oroszhoni cicúsz. (Le Desman de Russie. Rat musqué de Russie. Sorex moschatus Lin.) Buff. X, r. Pall. Acl. petrop. 1781. II. rész, $5 \mathrm{rl}$.

Majd akkora mintegy suin, fölül feketés, alul fehéres, farka egy negyeddel rövidebb a testénél; igen kiözönséges déli orosz honban a folyók és tavak mellékén. Ottan férgekkel, bogíl-bábokkal s kiváltképen nadályolkkal él, mellyeket mozgékony orrával könnyen kiszed az iszapbul, barlangját a partokba ássa, a viz alatt kezdre s ugy emelkedve föl, hogy annak fenclie a legnagyobbs viz tülirén is fölül essék. Önkényt soha scm jö a szírizra; hanem halász-hálóban számosan fogalik. Pézsmaszaga egy a farka alatt lévö kis zsebecskékben elválasztott kenöcstül jö; és még a csukák husával is közösiul, mcllyek a ciczúszokat megeszik.

A pyrenei hegyek csermelyeiben egy apro fajta talíltatik ezen nembïl, testénél sokkal hosszabb farku, mellyet Geoffroy ismertetett meg. Ann. Mus., XVII. k. IV. rl. 1 k. (A pirenei cicúsz. Myg. pyrenaica H.)

\section{AZ IRANYDOKOK.}

(Les Chrysochlores. Chrysochloris. Lacép).

Mint az elóbbi nemnek, fö̀ül két, alul négy metszö foga ran; hanem zípfogaik magasak elválasztottak, háromszögüleg kaziak (háromszögü kaz-idommal); arcoruk rïvid, szćles, fölirányzott, elsö lábaikon csak három köröm, a külsö igen nagy, fölötte görbe, hegyes, és nekik hatalmas eszközül szolgál a föld lyuggatảsára, turására; a többi kisebb. Hálulsú lábaikon öl van, közönséges nagyságu. Földalalli állatok; életnemök a vakondokokéhoz hasonlit. Elókarjok (alkarok) a jobbanáshatás végelt, egy harmadik a könyök alatt helyezoido connt altal timasztatik. 
A remény foki aranydok. (La Chrysochlore du Cap. 'Taupe dorée. Talpa asiatica. Lin. - Földinél: Aranyos vakondok.) Schreb. CLVII, jobban Brown. ill. XLV'.

Talamivel kiscbb a mi rakondoknnknál, kitetszö fark nélkul; ï azon egy emlós, melly némelly árnyalatát mutalja azon szép érefénycknek, mellyeklifl olly sok marlár, hal és bogár pompásliodik. Szöre zöld, réz is brone-szinbe átjuttszo; füleinck nines esigája, szeneit nem lehet kiösmerni. ( $\left.{ }^{1}\right)$

Afrikában lakik, nem pedig Siberiában, mint hibásan mondaték.

\section{A VAKONDOKOK.}

\section{(Les Taupes. Talpa. Linn.)}

Földalatli életiikröl ís ezen detuemre egészen alkalmatos idomokrul mindenki chiot ismeretesek. Karok ıgen rörid, hosszi homlaphoz fézzïle, erós vállperctiil támasztva, igen szides kezet hordra, mollynels tenyere mindig liragy hitra fele fordult; ezen kiz az alsó szélén metszö; ujahit alig osmerni ki rajta; hanem az azh bevégzö körmök lowszúk, erösek, liposak, metszok. Illyen az az eszkïz, mellyet a raliondok a föld felturására és hátra hányásíta hiliznál. Szegy csontján mint a madaralinál és denevérelinél, cgy laraj ran, a melly melizmoknak a munkálathoz szökséges niag̨ sígol ád. A föld állurásíra és hátra hínyására, hoszszí fejét haszuilja a rakondok, mellynek arcora egy tulaj-

(') Seba amerikai veres vakondoka, J, xxxı. rl. 1 k. (talpa rubra L) hihetoleg nem egyéh mint reményfoki aranydok, száritott egyén szerint adva, mert illy esetben ez bibor szinünek tetszik. Hanem Fermande's tucan--ja, XXIV, mellyet vele azonncvünek tartanak, mindenik állkapcsáhan két hosszí foga, s növényi élelıe végett inkúbh spalax-n.tk ragy más illy foldalatti rágcsá-nak vagy örlónek, millyen a diplostoma, tetszik. 
don csontocsesal van végén fölfegyverkezve s mellynck tarköizmai fölötte crösek. A tarkószálagban szinte egy tulajdon csont képzödils. Hátulsó része gyönge és a földön szinte olly ügyellenül mozog, a milly ïgyesen a földben. Hallása igen funom, dobja igen széles, noha kïlfüle hibázik, szeme olly kicsin s annyira el van a bör által rejtve, logy lételét sok ideig tagadtúk. Nemzö részeiben azon különösség van, logy fancsontai nem egyesülnek, a mi clég nagy kölkek szülésére segíti medencéje szúk volta mellett is. A nöstény hugycsöje a csilklón megy lieresztül. Ennek hat csecse van. Állkapesai gyöngék, élelme bogarakbul, férgekbül s némelly gyönge gyökerekbül áll. Fölül hat, alul nyolez metszó foga számláltatik. Szemfogainak két gyökerök van, a mi miatt azok a hamis zápfogak természetében részesülnck: ezek mögött fölül négy, alul három hamis zápfog van, azután pedig három gumós zápfog.

A közönséges vakondok. Földi. (Taupe commune. Talpa europaea, Linn.) Buff. VIII, xII.

Arcora hegyes; szöre finom és fekete: találtatnak fehér, sárga és tarka egyének. Igen alkalmatlan egy állat azon pusztítás miatt, mellyel a mivelt vidékeken tesz.

Harlan szerint Ejjzzak-amerikúban is létezik ez a faj.

Savi az Apenninokon egy egészen vak rakondokot talált, különben a közönségeshez egészen hasoulúl, ö ezt talpa caeca- névrel nevezı.

\section{A SUGÁRDOKOK.}

\section{(Lies Condylures. Condylura. Mliger.)}

A bogárevök két fogrendelet - nemét összekötni látszanak; folsö állkapcsoliban liét nagy és háromszegletü metszö fogok van, kettö rendkivül kicsin és vékony, és mindenik oldalrul egy erös szemfog; az alsó állkapocsban négy elöre hajló metszöfog, és egy hegyes hanem kicsin szemfog. 
Fölsö hamis zaipfagaik hírous\%eguek, szittillik: az alsuk élesek és fogozottak.

Luibaiknál is egész liülsejehnel fogra a rahombliho\% hasonlitanak, hancm firtkok hosszabb, és a mi öket attul leginkább megkilïnbözteti az, long orrlyukaik apró nozgó porcpontokkal vetettek körï, mellyek, mikor kitcrjeszkednek, sugaras csillagidomot mulatnak.

Leginkibb egy faja ömeretes fi.jszahamerihábul, a tarajos sugardok. (Sorex aristatus Limn.) (') Ez a valiondokhoz hiasonlí, orrát kiverin, hanem liélakliorintil is hosszabb farkkal.

\section{A CICTÚROK.}

\section{(Les Scalopes. Scalops. Cuv.)}

Fogaik igen hasonlitnak a cicúszolíihoz, csalkhogy apró vagy hamis zápfogaik kerescbb saimuals; arcoruk esyzzerüen hegyes, mint a cickinyoké, kezeik szélesek, erös liommïliel ligyrerezre, egyszival a turásra alkalmaztals és cócizen hasonluks a rakondulíihoz: szinte hasonló delenemök is van. Szemeili szinte liciesinyek, füleik szinte elrejtetick mint a vakondokoknál.

Csak egy faja ismeretes.

A kanadai cictur. (Le Scalope du Canada. Sorex aquaticus. Linn.) Schreb. CLVIII.

Ejszak-amerilia nagy reszén látszik lakozni a folyók

(') Ez a condylura Ilig., hanem az általa adott jegyek, La Faille rajzolatírul véve, mellyet bufion lemásolt: Supp. V1, xxxvr, 1., s mellyekre neme nevét épité, hamisak. Desmarets volt az elso , ki ezen állat fogait jól megösmerteté.

Harlan egy fajt ir le, Cond. macroura, mellynek orrlyukai körül csak igen rüvid pontok vaunak: farka öszvenyomott s pikkelyes; elhbez csatolja még, mint harmadik fajt, Pennant talpa longicaudata-ját, Hist., 445 s7. mellyet azonban, ugy látszik, önmaga nem vizsgált meg. 
mellékén. Külscjében egész az elcserélésig hasontit a mi közönséges vakondokunkhoz.

\section{A HÚSEVÖK.}

A ragadozók hamadik csaladát képezik.

Noha a húsevó melléknév minden nemnégykezü karmos és három fognemmel biró állatokat illet, minthogy többé kevesebbé mindnyája állati anyagokkal él, azonban sokan vannak köztök s nevezetesen az elöbbi két család, mellyek gyöngeségüknél s zápfogaik kupos gumóinál fogva majd csupa bogarakkal kénytelenek élni. Ezen családnál van a vérszomj annak kielegítéséhez megkivántató eróvel összekötve. Ez mindig négy nagy hosszú és szétálló szemfogakkal bir, mellyek között mindenik állkapocsban hat metszö van, az alsó másodikak gyökere pedig valamivel beállóbb a többiekénél. Zápfogaik vagy egészen élesek, vagy csak részint kevertek tompa gumókkal, gumós hegyeket nem birva.

Ezen állatok annál kizáróbblag húsevók, minél teljesebben metszö foguak s mintegy kiszámolhatni életrendök viszonyát ha fogaik gumós színe a metszövel összehasonlíttatik. A csupán növényekkel is elélhetó medvék fogai majd mind gumósak.

Az elsóbb zápfogak legélesebbek; azután egy a többinél nagyobb zápfog jö, mellynek rendesen egy szélesebb vagy keskenyebb sarka van, mögötle pedig egy vagy két egészen lapos apró fog találta- 
tik. Ezen, a száj fenekén lévö apró fogakkal rígjáik meg az ebek a fïvet, mellyet néha esznek. Mi ezen nagy fölső zápfogat, Cuvier Fridrikkel az alul neki megfelelövel együtt répö-nek, az elsö hegyeseket hamis zápfugak-nak (álzáp), és a hátulsó tompákat gumósaknak nevezendjük.

- Könnyen megfogható, hogy a kevesebb álzápu s a rövidebb állkapocsu nemek legtöbb crövel birnak az öldöklésre.

Ezen különbözetek szerint legbiztosabban állíthatni föl a nemeket.

Azonban a látulsó lábak tekintetbe vételét öszsze kell még vele kötni.

Több nem az egész talpra hág, mint az elöbbi két család, midön megy vagy áll, és ezl kömnyen megösmerheıni a szörhiányrul ezen egész részen.

Mások és pedig a naģobb szám csak az ujak hegyein jár, a sarkat fólemelve. Futások rohanób, és ezen elsö külünbözéshez más sokat kötnek szokásaikban söt még belsö alkotásokban is. Ezek és amazok a válperec helyett csak egy csontdurványt birnak az izmokba fölfüggeszlve.

\section{A. TALPONJÁRÓK.}

Azon elsö csapatot képezik, melly egész talpán jár, a mi a hátulsó lábakra való állást nekik megkönnyebbíti. Részt vesznek a bogárevők lassuságában és éjjeli életében; a vakbél nálok is hibázik, mint 
azoknál. A hideg égalattiak nagyobb része zsibbadásban tölti a telet. Mindnyájának öt öt uja van mindenik lábán.

\section{A. MEDVÉK. (Földi).}

\section{(Les Ours. Ursus. Lin).}

IIárom nagy zápfoguk van mindenik oldalon ( $\left.{ }^{1}\right)$ mindenik állkapocsban, egészen gumós, mellyek között az utolsó és eìső fölül leghosszabbak. Ezeket egy valamicskét metszö fog elözi meg, (ezen nömnek tépö foga), és az igen apró álzápfogak változó száma, mellyek néha jó korán kihullanak. E majdnem egészen nörény-eledeles fogrendelet teszi, hogy szörnyü erejök mellett is csak szükségbül esznek húst.

Ezek otromba testü, vastag tagu, igen rövid farku állatok; orrok porca nyúlt és mozgatható. Barlangokat ásnak, vagy tanyákat készítenck, hol a telet többé vagy kevesebbé mély alvásban töltik cl, eledelvétel nélkül. A nóstény ezen rejtekben kölkedzilk meg.

A fajok nem könnyen különböztethetölk meg szembetünö jegyek által. Ide számláltatik:

Az erdei medve. Földi. ( $L$ ' Ours brun d' Europe. Ursus arctos Linn.) Buff. VIII, XxxI.

Homloka domboru, bundája barna, fiatalságában többé kevesebbé gyapjas, idövel simább levő. Látni szürkéseket, majdnem sárgálkat, ezüst csillogásu barnákat, lábaik viszonyias magassága is változó, és mind ez állandó egybelsöttetés nélkül az életkorral vagy nemmel. Fiatalsága öl-

(1) Ezután nem ismételendjük e szavakat: ,mindenik oldalon", magában értỏdvén hogy mindig csak az egyik oldal zápfogairul szólunk, mellyekhez a tulsó oldaliak hasonlók. 
tizeten igen gyahran egy fehires ör van, némelly fijlák-

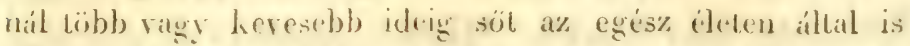

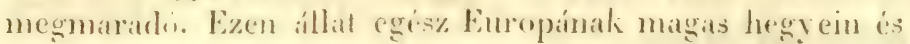

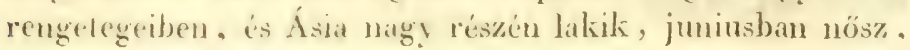
jannariusban kïlkedzik, néha iggen magas fákon lanyáz: fiatal korában jo izü a husa, kacsoit pedig minden koríbul kedrelik.

Azon hitel voll hogy a fekete erdei medte küloubüzik tole. Az illyenek gyaniul nekïnk mutatott példányoknak homloka lapos, bundija gyapjas és fekelís rolt; hanem credetiok nem látszils elötlem jó hilelesuck. (1)

Az ejszakamerikai (felete) medve. I' Ours noir de $l$ ' Amérique seplentrionale. Urs. americanus. Gm.) Fríd. C. Mammif. Schreb. 111. r. B.

Joil megkülönbïztetelt faju: homloka lapos, bundaja felecte és sima, arcora sálga. Mi níla a szemfog mögötl mindig szimosabbuak talíluk az apró fogaliat, mint az europai, erdei medrenci. Fészon sárga egyének is látlattak. Rendesen rad sgimö̈lesökkel él, néha a mezöel elpusztilja: a folyanszilekre is megy, haliszandi ha bösig van a halikban. Az cmleiseket cledel szuikebul is alig timadja meg. Husa becsültetık.

A cordillerákon egy másik frkete medve al mellynek lorka és arcora fehér, szemholdja nagyok sárgák, az orrtön egyesülök. (Az ékes medve. Urs. ornalus Fríd. Cuv. Mammif.)

Keleti indiában szinte täbb fekete szinü medve van, illyenek:

\section{1 maliji medve. (L' Ours malais. Urs. malaianus Horsf. Jav.)}

A Gangesen túli félszigeten és a Sunda szigeteken: si-

(') Előttem eşyre nincs eléggé bebizonyítva, hogy az ćjszakamerikai rettenetes hamuas medu'e a mi erdei medvénktül különbözó faj-c. 
ma, fekete, sírga arcoru, melén hasonló szinü szividomu folt. Nagy kairt okoz, a kúkospálmák tetejére fölmászra. azuknak sudarít leevendö s gyiünölesök tejét megiandó. A thibeti medve. (I' Ours du Thibet. U. thibetanus. Fr. Cuv. Mammif.)

Fekete; alsó ajaka és cgy nagy Y idomu melfoltja fehérek; oldalkèpe egyenesebb, körmei gyöngébbck. ÉjszaIxi India hegyeirül.

Hanem legnerezetesebb az indiai medvék közölt: Az ajakas medve. (L' Ours jongleur. Fréd. Cuv. Mammif. Urs. labiatus Blainv. U. longirostris 'Tiedem.)

Orrporea széles, alsó ajakínak rége kinyújtott, s mindenik mozgatható, idóvel pedig feje körül nagy szörbujtot kap. Metszöfogait igen lïnnyen elvesztvén különben lajhárnak tekinteték. ${ }^{1}$ ) Fekete; ajkonya s lába végei sárgák ragy fehéresek; félörve ragy egy $\mathrm{Y}$ idomu foltja van a nyak és mel alatt. Ez azon faj, mellyet az indiai búbájosak magokkal szerelnck idomtalansága miati hordozni.

A tengeri ragy fehér medve. Föld. (L' Ours blanc de la mer glaciale. Urs. maritimus. Linn.) Cuv. Ménag. du Mus., in $8^{\circ}$ - 68. 1. Másolva Schreb., $141 \mathrm{rl}$.

Még egy jól megkülöuböztelett faj hosszú és lapos feje , fehér és sima bundája által. A fơkákat és más tengeri állatokat ulldözi. Torkosságának túlüzött mondái igen hiressé tétetik.

\section{A TALPÁLYOK.}

(Les Ratons. Procyon. Storr.)

Három hátulsó zápfogok gumós, mellyck közül a fölsöli majdnem négyszegüek; három hamis zápfogok elül

(') Ez a : Bradypus ursinus, Schaw, és a: Prochilus nem Iliger-nél. L. Journ. de Phys. 1792 , xu. köt. 1361. 
hegyes, és folyvisti sort liépez egész a szemfogakig, melylyek egyenesek és üsszenyomottak. Farkok hosszú, hanem egész külsejek a medrét ábrázolja kiesiuben. Egész talpokra csak az állás alatt ereszkednek, menés alatt sarkokrat fölemelik.

A mosó talpaily. Földinél: Mosó borz. (Le Raton, - az amerikaiknál Raccoon, Mexicóban: Mapach. Ursus lotor. Linn.) Buff. VIII, XLIII.

Barnás szürke, arcora fehér, szemci fülölt egy barna keresztronás, farka barna és fekete gyürüzetes; borznagyságu, lïmnyen szelídithetö, azon kïlönössiggiert nevezetes, hogy semmit meg nem eszik elöbb, mint azt a vizbe mártá. Ejszak-amerikában, tojással él, madarakat vadász stb. A rákíszó talpuily. (Le Raton crabier. Ursus cancrivo rus) Buff. Supp. VI, XxxII.

Egy idomulag vilígos hamvas barna; farka gyúrüi kevesebbé tetszenek föl. Déli amerikúbul.

\section{A TALPAJÁROK.}

\section{(Les Panda. Ailurus. Fréd. Cuv.)}

A talpályokhoz látszanak közelíteni szcmfogaiknál fogva. s a mennyire többi fogai osmeretesek, ha csali ugy nincs, hogy csupán egy álzápfogoli van. Fejök rövid, farkok hosszú, menetelök a talpon tórténö, ujok száma öt, félig hátra huzható körmekliel.

Csak egy faja ösmeretes:

A fénylö talpajár (Le Panda éclatant. Ailurus refulgens. Fréd. Cuv. Mammif.) Hardivick. Trans. Linn. $\mathrm{xV}, 161.1$.

Akkora mint egy nagy macska; bundája puha sürü; fölül a legfénylöbb fahéjbarna szinnel, hátra felé sárgább, alul sötét fekete. Feje fehéres, farka barna gyürüs. Ezen 
cmlös allat, India éjszaki erdeibül eredve s az ösmeretesek küzött legszebb, du Vaucel Alfred által küldetéls be.

\section{A TALPACSOK.}

\section{(Les Benturongs. Ictides. Valenciennes.)}

Szinte hasonlítanak a talpályokhoz fogaik által; hanem fölül hátulsó három álzápfoguk sokkal kisebb és kevesebbé gumós, és ez különösen igaz a legutolsónál mindenk állkapocshan, melly igen kicsin s majdnem egyszerï. Hosszú szörrel vannak födve, s mindenik fülökön egy csomó szór. Hosszú meszes farkok a göndörüdö farkhoz közelítésre hajlandóságot mutat.

Szinte indiai állatok, mellyelznek ismeretét du Vaucel-nek köszönhetjük. Egyik faj :

A homlok fehér talpacs (Ict. albifrons Fr. Cuv.) Ann. des Sc. nat. IV. I rl. - szürke, farka és arcor oldalai feketék; nagy macska nagyságu. Butánban. A fekete talpacs (Ict. ater. Fr. Cuv. Mammif.) fekete, ajkonya fejéres, jokiora ebnagyságu. A malakkai félszigeten. $\left({ }^{1}\right)$

\section{AZ ORRAMOZGók.}

\section{(Les Coatis. Nasua. Storr.)}

A talpályok fogailıoz, farkához, éjjeli életéhez és baktató járásához egy különösen nyult, mozgékony orrat kötnck. Lábaik félhártyásak, s mégis fölmásznak a fákra; hosszú körmeik ásásra szolgálnak. Amerika heves részeiben laknak s majdnem ugy táplálják magokat, mint a mi nyusztjaink.

$A$ veres orramozg. (Le Coati roux. Viverra nasua. L.) Buff. VIII, xLviI.

Vereses sárga, arcora és farka némelly gyürüi barnák.

(') T. h. l' Iccide doré. Fićd. Cuv. 
A barna orramosy. (le (oali brun. I iverra narica Lin.) Buff. VIII, xLvir.

Barna; szemén és arcorán fehér foltok.

A Fogódzík (Kinkajous; Potto Cuv. Cercoleples Ilig.) különös nemét nem egy lïmmyen lehet máshová helyhezletui, mint ide; nálok a talpon járús mellett looszzú fogridzi fark van, mmt a gïndiorï majmoknil, arcorok rövid, nyelrök rékony kinyujthato; chit lict hegyezett, hátrább három gumós fogok.

Csak egy faja ösmeretes:

A mezezö fogódza (Tiverra caudivolvula Gm.) BulT. Supp. III, L, és jobban Fréd. Cur., Mammif.

Amerika heres részeibial s a nagy Intillats nómellyiliériil, hol ,potto" nerel, visel; aklorat mint egy nyest, szöre gyapjas, szürke ragy sírgís barna; éjjelezö, szelid természetii, gyïmölesesel, mizzel, tejjel, vérel stb. ilni tudó.

\section{A BORZOK.}

(Les Blaireaux. Meles. Stori.)

Iimme által szinte mint a talpályok a medvils közó helyeztetuck; a szemfog mögöth egy igen licsin foguk van, azutin két hegyes ziplog, mellyelse lölül egy ullyan kïrethezik, melly tépö log gyanánt liezd mulatiozni, a kiilsö oldalín lévö élnyom által; e mögüll egy négyszegri gumós ran, mindnyijíníl nagyobb; alul az utolsi clibti szinte hasonlatossigot kezd mutatni az alsi tépófogakkal, hanem miuthogg belsii oldalán két szint olly magas gumot mutat, minö az éle, a gumósak szerepét játsza: alul az ulolsó igen apró.

Ezek baktató járásu és éjjelezö állatok, mint minden clöbbick, farkok rövid, ujaik a börbe igen bekurkoltak. s mellyek torábbá még igen megkülünbözlctik magokat. egy a farliok alatt léro zseb által, mellvbiil zsiros bui- 
düs nedv szuvírog ki. Igen hosszú elsö körmeik a föld ásásra ügyesekké teszik öket.

A küzönséges borz. Földi. (Le Blaireau d' Europe. Ursus meles. Lin.) Buff. VII, viI.

Fölül szürkés, alul fekele, fije mindenik oldaláu cgy feketés sujtás. Az amerikai borz, Meles hudsonius, nem sokat különbözils tóle.

\section{A FALÓKOK.}

\section{(Les Gloutons. Gulo: Storr.)}

Linné által szinte a medvék nemébe tétettek, hanem inkább a menyétekhez hasolitanak fogaik és egész természetök íltal, a medrékkel pedig csak a talpon járísuál fogva határosak. Fölül három, alul négy álzápfoguk van a tépö elóth, melly jól ki van bélyegezve, s melly mögött egy kicsin gumós van, a fölső állkapocsban szélescbb mint hosszú. Fölsö tépöjöliön csak egy belsö kis púp van. Ez majdnem egészen a menyétek fogrendelete. Ezen állatok középszerï farkuak, melly alatt a zseb helyett egy redö van, különben pedig az idomra nézve hasonlitanak a borzhoz.

Leghiresebb faj.

A torkos falók. Földinél : rozsomuik vagy torkos borz. (Lic

Gluton du Nord; oroszul rossomak. Ursus Gulo. Linn. Buff: Supp. III, XLviI.

Akkora mint a mi horzunk: rendesen szép sötét geštenye színü, hátán egy barnább tállal, néha homályosabb szinnel is. Az éjszak legjegesebb vidékeit lakja, igen kegyetlennek tartatik: éjjel vadúsz, tél alatt nem alszik, a a legnagyobb illatokat is meggyözi, a fárul reájok ugorva. Némelly szerzók által egész a nevetségesig emeltetél. lorkossága.

Az éjszakamerikai falok (he Volverenne du nord de r Amerique. Vrsus luscus. Lin.); Edw. 103. . nem látszik 
állandó bélyegekkel töle különbözni. Ennek általában hala. ványabb színe van.

A hér tartományok szinte mutatnak némelly fajokat, mellyeket nem lehet máshová helyeztetni, mint a falókok után, azoktul másban nem különbözve, minthogy mindenik állkapesokban egy álzápfoggal kevezebb van s hogy farkok hosszú. Illyenek azok, mellyeket az amerikai spanyolok huron-oknak (füró menyéleknek) neveznek, s melyek valúban a menyétek fogail birják, a hasonló életnemmel együtt, hanem azokitul talponjárásols által különböznek.

A fekete faluk. (Le Grison. Tiverra viltata Lin.) Bufl. Supp, VIII, xxin és xxy.

Fekete: feje s nyaka föle szürke, homlokítul egy fehér sujtás nyúl vállaiig.

A barna falók. (Le Taïra. Mustela barbara. Linn.) Bufr. Supp. VII, Lx.

Barna, feje teteje szürke, torkín egy nagy fehér folt.

Ezen liél állat Amerika minden heves részén által el van terjedre, és p'zsmaszagot terjesze el. Lábaik egy kevessé úszóhártyásoli s ugy látszik, hogy néha vidra gyauánt tekintettek. ( $\left.{ }^{1}\right)$

A Bonzoxgok (Les Ratels) még egygyel lieveseb], zápfogat birnak mindenik állkapesokban, mint a heres ig alatli falokok, fölül pedig gumós fogok kevessé van kifejlödve, ugy hogy fogaiknál fogva a macskákhoz liözelítenek, hanem egész kïlsejök a fekete falókéhoz hasomlít ragy a borzéhoz: lábszíraik alacsonyak, lábaik talponjárók, ujok mindössze öt, körmeik igen erösek stb.

(1) Azon leirásbul, mellyet Margrave ad az ö cariqucibciu-jálul, s melly szerint Buffon az o̊ saricovienne-jét elneveztc XIII. höt, 319 1. azt itélhetui, hogy a barna falokiul hallott valamit. 
Csak egy faj ismeretes,

A méhész borzonc. Földinél méhész borz. (I'iverra mellivora, Sparm.; Viverra capensis, Schreb., $125 \mathrm{rl}$.), közönséges borz nagyságu, fölül szürke, alul fckete, ezen két szín között egy fehér vonal, fölül néha egészen fehér; a Jóremény - foknál lakik, és elsó lábainak hosszú körmeirel a földet fölássa a rad méhek mézlépét kutatva.

\section{AZ UJONJÁRÓK.}

A húsevők második hadát, az ujak hegyein jảrót, képezik.

Ennek elsó alosztása a tépö fog mögött csak egy gumósat bir fölül. Ezek a féregidomuaknak nevezett állatok, és pedig testük hosszasága, lábaik rövidsége miatt, mellynek segedelme által az még olly kicsin nyilásokon is átbujnak. Vakbelök hibázik mint minden elöbbinél, hanem télen nem zsibbadnak el. Noha aprók és gyöngék, mégis igen kegyetlenek, s mindenek fölött vérbül élnek. Linné csak egy nemet csinált belölök, s ezek

\section{A MENYÉTEK. (Földi). \\ (Martes. Mustela. Linn).}

Mellyeket mi négy alnemre osztunk.

\section{A MENYÉTEK különösen.}

(Les Putois. Putorius. Cuv).

Mindnyájok közölt legvérengzóbbck: alsó tépö fogukon nincs belsö gumójok; fölsö gumós foguk szélesebb mint hosszú; fólül csak két, alıl hílom hamıs záp.

cuvier J. $k$. 
foguk van. Kü̈lsohepen megösmerni már óket, a nyusztokénál ralamivel röridebb és vastagabb arcorulíól. Mindnyája búzt széleszt.

A gürény menyét. Füldi. (Le putois commun. Mustela putorius. L.) Buff. VII, xxiI.

Barna, oldalai sárgásak, fején fehér foltokkal; ez a baromfiak s tengeri nyulak rettentöje.

A furó menyét. Föläi. (Le Furet. Mustela furo. Lin.)

Buff: VII, xxy, xxy.

Sírgís, reres szemekliel, alig ha nem esmpa fajtája a grörenynek. Frankhonban csak mint hizi állat talíltatik, és a rad tongeri nyulak lyukail boili kihajtására fordíttatik. Spanyolországbul s Berberiábul jö hozzánl.

-1 longyel menyèt. (Le Pulois de Pologne; Perauasca. Mustela sarmatica. Pall. Spic. Zool. XIV, iv, 1; Sohreb. CXXXII.

Barna; mindenfelé sárga és fehér foltokkal. Böre igen kerestetik ezen szép tarkaság miatt. Egész dél Oroszhonban, Kis-ístiban és a Kaspitenger mellékén lakik.

A sibiriai menyét. (Te Putois de Sibérie. Mustela sibirica Pall.) Spic. Zool. XIV, IV, 2.

Esvidomu viligos sárga, orra és szeme liöre barna, arcora hegye, s alsó íllkapesa alja fehérek.

szinte ezen alosztíly hoz szímláltatik a mi éghajlatunk alatti liét apró faj.

A kiözünséges menyét. (La Belette. Mustela vulgaris. Limn.) Buff. VII, xxIx, I.

Egészen egyidomu verhenyes.

A hïlgy meny'ét. F. (L' Hermine. Mustela erminea. L.)

Bull. VII, xxix, 2; xxxi, I.

Nyiron verhenyes, télen fehér, farka rége pedig mindenkor fekete. 'Téli böre legszokottabb prém.

Még ide közelít: 
A vidra-menyét. (Le Mink, norek, noerz, putois des rivières du nord. Mustela lutreola. Pall.) Spic. Zool. XI. 1. Leche, Mém. de Stockh. 1739, xr. rl. Schreb. GXXVII.

A vizek mellékeit lakja Europa éjszakán és keletén a Jegestengertuil a feketéig, békákkal és rákokkal él, ujai alapja között egy kevessé úszhártyás a lába, hanem fogai és gömbölyú farka által inkáb liözclít a menyétekhez mint a vidrálkhoz. Verhenyes barna, ajkai köre, s állkapcsának alja fehérek; szaga csupán pézsmás, böre szép prémzet.

Némcllyck megkülönböztetik töle az éjszakamerikai vidra menyétet (Mustela vison Gm.), s mellyre a mink nevezetet áltvivék, melly szinte fél úszonyos lábu, hanem csak állcsúcsán fehér, néha még egy vékony sujtással a torkán. - Én némelly egyéneket megszerezvén magamnak, kitanultam, hogy az állkapocs fehér köre nem állandó, s hogy az elsö is gyakran csak álla csucsán hord fehér foltot, mint az amerikai, — s innét egy fajnak vélem öket.

A heves tartományok szinte birnak menyételiet.

A jávai menyét. (Le Putois de Java. Putor. nudipes.) E. Cuv. Mammif.

Aranysárga; feje s farka hegye fehérek.

Afrikai menyét. (Le Putois d' Afrique. Put. africanus, Desmar.)

Fölül verhenyes sárga, alul sárgás fehćr; hasa közepén az elsö lábaktul a hátulsókig egy verhenyes sujtás.

$A$ csikolt menyét. (La Beletle rayée de Malagascar. Put. striatus Cuv.)

Közönséges menyét nagyságu, verhenyes barna, ot fehéres, hosszában nyúló sujtással; alul s majdnem egész farkán fehéres. 
A remény foli menyet. (T.e Putois du Cap. Zorille, Bull. Viverra zorilla. Gm.) Buff. XIII, XLI.

Rendetlen feher is fekete vonatokkal. Fzen állat a gïrényekkel ammira össczarartatek, hogy a zorillo (rókícska) név is tulajdonává lön, mellyen a spanyolok az anerikin görénycket neverik. Fzekhez közclit is ugyan ásó körmei által, hanem különben menyét-alkotásu. Körmei földalatti ćletre mutatnak, s szerintök ezen fajt a tibbi menyétektül el lehetne szakasztani.

\section{A NYUSZTOK.}

(Les Martes proprement dites. Mustela. Cuv.)

I menyétektoil kiilönböznck, föluil alul egy hams ziipfogrgal többet birrat, s alsi tépöjök belsején egy kis gumi által, molly kíl bélyeg valamivel természetök kegyetlenségét is szeliditi.

Furopában kél egymáshoz igsen közelílö faj van:

A kïzonséges nyusat. Földinal nyusat menyét. (La Marte commune. Mustela Martes. Lin.) Buff. VII, xxil.

Barna, lorka alalt egy sárga folttal; az erdökben lakik.

A nyest nyusz/. Fialdi. nyest menvét. (La Fouine. Mustela foina. L.) Buff. VII, Xvir.

Barna, egész torka s myaka alja fehéres, a házakat megkeresi. Mindenik sok kárt tesz.

Siberiában élnek:

4 coboly nyuszt. Fäldinél coboly menyét. (La Marle: zibeline. Mustela zibellina.) Pall., Spic. Zool. XIV, II, 2: Schreb. CXXXVI.

Gazdage, prémbörérül hires. Barnat, némelly szürke foltokkal a fején, s az clöbbicktül abban különbözik, hogy réész az ujai aláig szorös; a legjegesebb hegységekben lit- 
hik. Ladíszata: tél liözepén, a legiszonyubb hóban egy a: ismert legreszedelmesbbek közül. Siberia keleti vidékeil a czoboly keresés utján találták föl.

Ejszak-amerika szinte több nyuszlfajat tart, mellycket az utazók és természetvizsgálúk ezen meg roszul hatírozott nevel alatt említenek: pekan, vison, mink, foutereau, stb.

Egyike azokuak a fehér nyuszt, a szücsök fehér visony-a (Mustela lutrocephala. Harl.) szinte mezes lábu, s majdnem olly puha szörï miut a coboly, hanem viligos sárga szinü s majdnem fehéres fejü.

A kanadai nyuszt (Pekan; Mustela canadensis Gm.) melly Kanadában s az Egyesületek földén lakik, barnával vegyült szürke fejü, nyaku, vállu és hátfölü; orra, keresztje, farka s tagjai feketések. (1)

\section{A GÖRÉNYEK.}

(Les Mouffetes. Mephilis. Cuv.)

Mint a menyéteknél, fölül két, alul három hamis zípfoguk van; hanem fölsö gumós foguk igen nagy és ally hosszú mint szćles; alsó tépöjök a belsö oldalon két gumót bir, a mi ókel a borzokhoz vezeti közel, mint a menyétek a falókokhoz közchítenek. A görényeknek különben, mint a menyéteknek, hosszú ású kürmeik rannak clsö lábokon, sôt ók még félig talponjárók is; a hasonlatosság egész a szinoszlásig halad. Ezen buize által nerezetes családban a görények a többiekénél nagyobb biiz által jelesek.

A görényck általában fehér sugárosak fekete alapon,

(1) Ez Daubenton pekan-ja; hanem torka alatt nem mindig fehér. Vannak még töl, menyét is nyusztfajak is, mellyeket Molina, Humboldt is Haldu kijeieltch; hanem azok uij atvizsgálast hivinuah. 
hancm a sugarak szima ugyan azon fajhan is különbözm látszik. Fjszahamerikíban legismeretesebb faj a szagos görény. Fïldima szagos petymeg. (Fiverra putorius, Gin.; Catesb., Carol., II , 62; Screb. 122.), melly fekete, többé keveschbe sáles fehér sugaralikal, fekete fehér hegrö̈ farkkil. Büre mint a menyeiteké, igen erös foghagyma szaggal kererve. Ennél undokabb nincs.

Ugy lílszil logg déli Amerikában sokszor clöjöu cgy feher farku faj. Hálsugarai neha az cgész hát hosszát. elfoglaljak: büzös görény (Le Chinche. Tiverra mephitzs, Gm.) Imull. XIII, xxxix. (1).

A Bïzi:rvik (Les Midaus. Cuv.) aluem gryanánt allhatnak fiil, mellych a sörónyck fogait, lábait söt még szincit is birjak, hamen vágult areorok dismo orjának idomát veszi magára, farkok pedig csak egy kis bojt.

Csals egy fija ösmeretes:

A jüvai büzeny. (Le Télagon de Java. Midans meliceps.

Fréd. Cur. és Horsf. Jar.)

Fekele: larkioja, ery hit hoszsujlisa es farka fehereli, hátsugara neha középen közheszakadrit. Szinle olly rosz. szagu mint a görény.

\section{A. VIDRÁk.}

\section{(Les Loutres. Lutra. Storr.)}

Fölul s alul hírom ályápfogruk; folsö tépöjükin erios sark, az alscinak belsö oldalín egy gumo, fölül egy gumós foguk, nagy és majd olly magas mint széles: fejöik esszenyomolt, nrelviik féldurra. Különben ninden elöbbi alnemtül küirinbriznck kiozhártyás lábok é:

(') Jobban ábrázolva Fréd. Cuv. Hist, de Mammif. A chilii góréry (Buff. Supp. VII, I.vir, csak roszul tartott fajtájánah látszik. I.isd iolem: Recherches sur les ossem. foss. IV, 469, 
súlyegyenesen összelapult farkok által, melly kél bélỵeg óket vizi állatoklsá teszi; halakkal élnck.

A közönséges vidra. Földi. (Loutre commune. Mustela lutra. L.) Buff. VIII, XI.

Fölül barna, ajka liörén, arczán s egész leste alatt fehéres. Látni néha tarkákat és fehéreket. Europa vizeiben.

'Több külföldi vidra alig különbözik a mienktül. A carolinai (Lutra lataxina, Fréd. Cur.) valamivel nagyobb) lesz s néha sötétebb színü, s teste alja barnás, hanem gyakran még az árnyolatokban sem különbözik. Brasiliában a caroliniaiakhoz egészen hasonlók ramnak. Az indiai (Lutra nair. Id.) csak ralamivel simább, és szemholdai körül észre alig vehetóleg halaványabb. Az indusok halászatra meg tudjálk tanítani, mint mi radászatra az ebeket. A jávai (Simung. Lutra leptonyx Horsf.?) fehérebb torku : ezen fehérség a fej oldalíra fölhalad a szemeket körülveendö. A reményfokinál (Lutra capensis Fr. Cur.) a torok, a fej és nyakoldal fehérsége tisztább, kiterjedtebb; az orr hegyén is létezik; de leginkább megkülönbözteli az, hogy (legalúbb. bizonyos korig) nines semmi körme, melly bélyegre Lesson az Aonix nemet alkotá. Azonban a Reményfoktul hozaltak némelly körmös fiatal egyének; mellyekrül ki kell tudui, vajjon azon fajbeliek-e.

Az amerikai vidra. (La Loutre d'Amérique. Mustela lutra brasiliensis, Gm.)

Egészen barna vagy sárga, torka fehér vagy sárgás, a mienknél valamivel nagyobb, teste kinyultabb, szóre rövidebb. Különbözik azonban, mivel orra hegye sem esupasz, mint az állatok nagyobb részénél, hanem szörös. mint a többi arca. A két Amerika vizeiben.

A tengeri vidra. F. (La Loutre de mer. Mustela lutris. L.) Schreb. CXXVIII. ( $\left.{ }^{1}\right)$

(') Ezen kép, a mint látszik, roszul készitctt. egyén szerint 
Két akkora mint a mienk: teste igen nyult, farka háromszor röridebb a testénil, hálulso lábat igen alaesonyak. Bundaja tekelés, igen vidam biborlényii, a legbeesescbb prémbör. Neha fehéres lejiliek is vimnak. Az angoJok és oroszok az egész Csendeslenger éjszalsi részén hajJászszáli ezen állatol, börél Chinaban és Japanban cladandúk. Alul esak negy metszö loga ran; de raípfogai, mint a többi vidríknál.

Az ujonjárók második aloszlálya két lapos gumósat bir a fölsö́ tépö mögöll: mellynek magáuak is elég széles sarka van. Ilúsevök, hanem erejökhö\% hépest nem mutatuak elég bitorsígot, és gyakran döggel élnek. Miudnyajának van eģ kis vakbele.

\section{AZ EBEK.}

\section{(Les Chiens. Canis. Jinn.)}

Föhul három, alul negy alraploguk vam, is liet gumbi

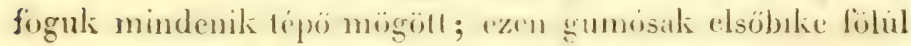

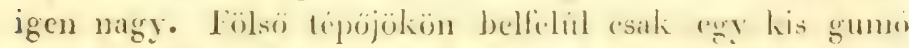
van; hanem az alsonak hátulso resze regresen gumos. Dyelrök puha; clsö líbaikon öl, a Jrilubsikon nigg uj van. A szelid eb (kutya). Füld. kutya eb. (lee chien domestique. Canis familiaris. Lin.)

Megkülönböztetik fölkutyorodott firkáa által, s kïilönben régetlenül ráltozil nagysága, idoma, szórénck szine s minösćge szermt. Ö a legteljesebb, különöscbb és Jasznosabb hódítís, mellyet az ember valaha tett; az egész

csinálıa, rendkivüles hasonlatosságut mutat a fókákkal, a mi némelly természetrizsálót azon véleményre birt, hogy ezen newet sobhor közel kell tenni; - de egész alkotása a vidráké. L. Everard Hom., Trans. phil. 1796. 
faj tulajdonunkká lön; minden egyén egészen a gazdajacé. annak szokásait fölveszi ; tulajdonát ösmeri s védi, hozzá hív marad haláläig; s mind ez sem kénytelenségbül, sem félelembül nem tórténik; hanem csupán háladatosságbul s valódi barátságból. Az eb gyorsasága, ereje és szaglása hatalmas szövetségresévé tették öt az embernek más állatok ellen, s meglehet, hogy a társaság alapítására szükségesek voltak. Egyedül ö azon állat, melly az cmberl az egész földön kísérte.

Némelly természetvizsgálók azt vélik, hogy az eb) megszcliditetl farkas ragy sakúl; de a puszta szigeteken elvadult ebek egyilkhez sem hasonlítanak. A rad ebek, és a kevessé mivelt népek, mint az új hollandiaials, ebeinek füle egyenesen fülálló, a mi azon véleményt szülé, hogy az elöpéldányhoz legközelebb járnak a mi komondorunk vagyis juhászebünk, a kuvasz vagy farkaskutya; hanem a kaponyák öszvehasonlítása közelebb hozza a mészóroseb-et is dineb-et, mellyek után jönek a kopó, a madarcisz is a tacskó vagyis borzeb, mellyek egymás közöll csak nagyságokra s tagjaik viszonyára nézve különböznek. Az agár karesúbb, homloköblei kisebbek, szagolísa gyöngébb. A komondor és kuvasz a radebek fölíllo füleit birják, hanem agyok kifejlödtebb, melly kifejlés az értelmességgel együtt még nagyobb a bolonyai ebnél és az uszkár-nál vagyis pudlinál. Más oldalrul a szelindek állkapesai rövidsége és creje által nevezeles. Az apró ölebek, a inopsz, selyem, angorai kutyák stb. legkifajzoltabb szülemények s legerösebb tanúi azon hatalomnak, mellyet az ember a természeten gyakorol. ( $\left.{ }^{1}\right)$

$\mathrm{Az}$ eb vakon (zárt szemekkel) születik, s tizedik vagy tizenkettedik napon nyitja föl szemeit; negyedik hónapban fogakat kezd váltani; második érvel megszünt nőni.

(') L. Frid. Cus. Ann. Sus. XVIIl, $333 \mathrm{~s}$ höv. lą. 
A nóstény hatranhárom napig hasas s hatot egész tizenkettöig kölkedzık. Az eb tizenötüdik érében vén s husznál toyáb nem igen d. Kilii ösmeri az ö vigyázását, ugatását, különös nostését s azon különbözö nevelést, mellyre alkalmatos.

A küzönséges farkas. Földi farkas eb. (Le Loup. Canis lupus. Lin.) Buff. VII, I.

Nagy faj, cgyeues farliu, sírgís szürke bundaju, súrga szíru, a vénelinél az elsó száralion egry fekete vonal ('), a mi videkcinken a legírtalmasabb ragadozó. Egyiptomtul egész Laplandig találtatik, s uģ látszok hogy Amerikíba is átjulott. Ejjzzakon megfehérül télen a bundája. Minden állatmokat megtámadja, hanem erejével arányos bátorságot nem mutal. Gyakran döggel él. Erkölesében s természeti kifejlüdésében sok hasonlatosságot mutat az ebhe\%.

A fekete farkas. Földinél Likion eb; fekete róka. Le Loup noir. Canis lycaon L.) Buff. IX, XLI.

Szinte Europíban lakik, sö́l Frankhonban is találtatik, haneu ingen ritkán (²). Bundája egyidomulag sötét fekete, fehérrel arcora hegyin, s egy apró hasonlí szinü follal a melin. I kïzönségesuél radabbnak mondatik.

$A$ mexituoi farkas. (Le Loup) de Mexique. Canis mexicanus. Linn.)

Verhenyes szürke, kevés felietéssel regyitve; arcora küre, hasa és lábai fehéresek. Mintegy a közünségges farkas nagyságu $\left({ }^{3}\right)$.

(') Ezen vonal töbhé keresebbé kifejlödve a sakálon, mexikór farkason, stb. is talaitatik.

( $\left.{ }^{2}\right)$ Mi négy egyént láttunk, mellyek Francziaországban fogattak és òlettek meg. Nem kell öket a fekete rókával összezavarni, mint Gmelin a kettõ hasonnevezetét egybe vegyíté.

(3) Ezen bélyeg egy magábul Mexicobulküldött példány után vaw 
Az ainerikai veres farkas. (Le Loup rouge d' Amérique. Canis jubatus, Cur. Agoura Gouazou, d' Azz.)

Szép fahcj-veres, gerince egész hosszíban rövid fckete sörény. Déli Amerika mocsáraibul.

A sakál farkas. Földinćl Sakial vagy török róka. (Le chacal, Loup doré. Canis aureus. L.) Schreb. XCIV.

Az elöbbieknél kisebb; hegyesebb arcorú, barnás szürke, lábszárai világos sárgák, fülén verhenyes; farka a sarkát alig éri. Ez nagyon torkos állat, az ebek módjaként. radászó, mellyekhez minden fajok läöt leginkábbl látszik hasonlítani alkotása s kümnyen szelidíthelése által. A sakálok Indiátul s a Kaspitenger mellélétül kezdve egész Guineáig találtatnak; hancm bizonytalan, ha mind azon fajbeliek-e. A senegaliak p. o. (Can. anthus Fréd. Cuv. Mammif.) magasabb, száruak s a mint látszik, hegyescbb arcoruak; s valamivel hosszabb farkuak.

A Rókák a farkasolitul és szelid ebektiil megkülönböztcthetök hosszabb és bojtosabb farkok, hegyesebb arcorok, nappal csüggö (hosszában fekvö) hasadásos szemfényök, s fölül kevesbbé kivájt metsző fogail által. Büdös szagot terjesztenek; barlangokat ásnak s esak gyönge állatokat üldöznek. Ezen alnem szímosabb az elöbbinél.

A közönséges róka. Föld. róka eb. (Le Renard ordinaire. Canis vulpes. Lin.) Buff. VII, vi.

Többé kevesebbé rcrhenyes, farka hegye fehér; Svédhontul egész Egyiptomig cllerjedt; a két vilíg éjszaki ré-

véve; azon egyént Humboldt ajándekozá a királyi gyüjteménynek. Azokat cl kell vetni, mellyeket a sze:zỏk Recchi hamis ábrázolatàrul vettek s melly Hernandèsnél, 479. I. fölvéve van. Hanem Say és Harlan uu. "Faun. am.", mís két farkas fajrul szólanak (Can. iatrans és C. nubilus), mellyeknck öszrehasonlitó vizsgálatra van szükségök. 
szein lévök (C'an. fulvus Desm.) esupán fényesebb szinüek. Állaudo kiilönbséget sem vehetni az ó vilígbeli s az éjszak-amerikaiak kïzött. A tüzes róka, Föld. (Le Renard charbonnier. ('unis alopex. Schreb. XCI), mellynek farka hegye fekete sugyanazon tartominy okban találtatik, melylyeliben a küzönséges; a keresztes róka (Le Renard croisé, na. XCI. A.), melly éjszakrul jö, és csupán csak felietésség által különbözik gerince hosszában és a vállain; a szücseinlitil ugy nevezell türük róka, melly sárgás szürke, fehér farkhegygyel, neglehet nem egyebek a közönséges róka fajtáinál; - hanem a következö fajok jól különböznek.

A braziliai rúka. (Le Renard du Brésil. Canis Azarae. Pr. Max. Bras. Aguarachai d' Azzara.)

Szürke; nyaka oldalai rerhenyesek; tarkoján fekete ronal kezdödik s farka egész hátán elterjed.

1 saiga rokk. (Le Corsac; le petit Renard jaune. Canis corsac, Gm. Bufl. Supp. III, xvi. Adive név alatt.

Halaviny sírgás stürke, farka tövén némelly feketés hullímok, farka hegye felete, illkapesa feher. Asia közpének tér vadonaiban liözönséges, a Volgátul az Indusig. A mi rokink természetét birja, soha sem iszik. Azt vélem, nem liell töle a nubiai abouhosseint (Can. pallidus. Ruppel, xr, ) megkülönböztetui.

Van még Éjszak-amerika belsejében egy kicsin róka a gyors róka (Can velox Say és Harlan, f., Ann. am., 91), - melly a földben lakili, - a sárgílul más szine által külüubüzni lítszik, mint lékietés farkit stb. által.

A három ssinii rokia. (Le Renard tricolor d' Amerique. Canis cinereo-argenteus). Schreb. XCII. A.

Föliil hamvas, alul fehér, oldala hosszában egy fako-reres sujtás. A liét Ameritia minden heves és mérsékelt részében. 
A fekete róka (') (Le Renard argenté; Renard noir. Can. argenteus.) Schreb. XCII. A.

Fekete, szöre hegye fehér, kivévén a fülein, vállain és farkín. hol az tiszla fekete. Farka hegye egészen fehér. Éjszak-amerikábul. Böre a legszebbek és drágábbak közé tartozik.

Az éjszaki róka, F. (Te Renard bleu, on Isatis. Can. lagopus. L.) Schreb, XGIII.

Sötét hamvas; ujai alja szörös $\left(^{2}\right)$, néha télen fehér. A két világ éjszakán, kivált Norvegiában és Sibiriában. Böre a szủcsöknél igen becses. A reményfoki róka. (Renard du Cap. Can. mesomelas.) $\left.{ }^{3}\right)$, Schreb. XCV.

Oldalain sárga, háta közepe fekete, fehérrel vegyitve, hátrafelé hegybe végzódóvel; fülei rerhenyesek szinte mint a lábai; farka hátulsó kétharmada fekete stb.

Afrika belseje némelly, fülök nagyságárul s bajuszszörök erösségérül nevezetes rókafajokat táplál; - ezeket Iliger: Megilotis-oknals nevezı. Kettö ismeretes.

A füles róka. (Canis megalotis, Lalande.)

A reményfoktul; a közönséges rókánál ralamirel nagyobb, magasab) szárı; fölül sárgás szürke, alul felı́res; lábai, farka s egy hátsujtása feketék.

A nagyfülü róka. (Can. Zerda Gm. Fennec. Bruce.) Buff. Supp. III. xIx.

Még nagyobb fülei vamnak; egy kis fajta, majdnem fehére változó súrga, - Nubia homokpuszlain barlan-

(') Gm. ïszezavarla cat a fokcte rókáral canis-lycaon, né alaft.

(2) Ejszation sok róka szört kap a talpán, még a közönséges is.

(3) Gmelin ôsszezavarta Bufton adize-jérel, melly koholt faj, és a sakíltul miben sem külónbözik. 
gokat ás magánals ( $\left.{ }^{1}\right)$; szöre gyapjas, és egész az ujui alá terjed.

Végre mint negyedik alnemet elválaszthatjuk s az ebek után kiovetkeztethetjük

A seregeb-ct. (Le Chien samvage du Cap. Hyaena venatica. Burschell, Hyaena piota, 'Temm.) Au. gén. des Sc. phys. III.

Cjanak száma által kï̈lönbözik, melly mindenik lábain négy. Fogrendelete mint az ebelsucl, nem a hiénáknil, termete karesu, bundaja fehérel, sárgíral, szürkével és feketíssel mirrányozva; nagysága mint a farkasé, fülei nagyok, fekcte hegyück stb. Nagy seregekben él, és nagyon meghözeliti a fuhvárost, mellynek környékét pusztílja.

A PETYMEGEK.

(Les Civettes. Viverra.)

Fölül hírom, alul négy hamis zápfoguk ran, $s$ az elsöbbek néha hihullanak, föluil két elig nagy gumós, alul csak rgy: tepö logguk belsö felén elóre liét elóálló gumó, migg ezen fog többi része többé lievesebbé gumus. Nyelvök durva es hegres szömöilesikkel fïdütt; körmeik a menetel közben többe kevesebbé fölirányzúdnak; seggökhöz liozel egy többé lievescbbé mély zseb van, hol tulajdou mirigyek cgy kcnöcsös és gyalixan szagos anyagot válaszitanak el.

Négy alnemre szakadnak:

A tulajilontiépi Petymegek. (Viverra. Cur.)

$\mathrm{Hol}$ a mély zseb, a seg és nemzö müszer kiözötl

(1) Bruce ábrázolatán, mellyet Buffon és szerinte sok misok lemásoltak, a fül nagysága túlizzött. Végre jó képrajza s pontos Icirása van ezen állatnak a. Voy de Ruppel, Zool. III. yl. 
helyezLetve, és két részre oszolva, kenöesesel böven telik meg, melly pézsmaszagu s a zseblörúli mirígyek által válaszlaték el. Ezen anyag kereskedési cikkely a füstölés száınára. Hajdan milior a pézsma s az ambra kevesebbé roltak ismeretesek, gyakrabban használtaték. - Szemfényök nappal kerekes marad; körmeik csak félig vonulnak vissza.

A közönséges petymeg. (La Civelte. Viverra civetla. Lii.) Buff. IX, Xxxiv.

Hamras; fcketével rendetlenül foltozott és sujtásozott; fackia teste felényi, vége felé fekete, töre felé négy vagy öt gyürüvel; torka két fekete sujtással körülvéve, arca egygyel bekeritelt; háta és farka egész hosszában egy fölmereszthetö sörény. Afrilsa leghevesebb részeibül.

$A$ cibét petymeg. Földi. (Le Zibeth. Viverra zibetha,

L.) Buffon IX, XxxI.

Hamvas; feketén pontozva, egész farkán fekele félgvürük, nyaka oldalain fekete sujtások, nincs sörényc. Kelet-indiábul.

\section{A JANÓTOK. \\ (Les Genettes. Genetta. Cuv.)}

Hol a zseb egy esckély homorodásbul áll, melly a mirígyck emelkedése által képeztetik, majd minden észrevehetö elválasztás nélkül, noha szaga igen érezhetö. Világossal egy csúgô hasadélkot mutat szemfényök, körmeik mint a macskáknál egészen hátra vonulhatól.

A közönséges janót. Földinél janót petymeg. (La Genette commune. Viverra genetta, Lin.)

Szürke; barna ragy fekete foltozatu, arcora feketés, szemholdjain, arcán s orra hegye mindenik felén fehér foltok; farka olly hosszu, mint a teste, fekete és fehér gyürükkel; a fekete gyürik száma kilencztül tizen- 
egyig. Deli Frankhontul kezdve egész a Júremeny-folig talíltatik: változo azonban foltjai nagysága és száma, a rálai és maka hosszában lérö sujtások s tarköjanak vonatai állal, stb. (') A folyók hosszában . a források körül stb. tartizkodili; böre nerezetes cikliely a prém kereskedésben.

A javai jancit. (Ia Genelte de Java. Tiverra linsang. Hardw. Trans. lin. XIII, xxiv. rl. Felis gracilis. Hosrf. Jav.)

Testen libb licreszt-, rendetlen, barna sujtisok; farkán hét gyủrï.

A madagaskiri janót. (Ia Fossane de Madagascar. Y'iverra fossa). Buff. XIII, xx.

Tölseje, oldalai és farka súrgák: alsaja és szárai sárgris fehérek; verhenyes barna follokkal, mellyek közül a hátin lerok nég hosszas esikot kipzenek: farkín verhenyes fellgyúrük, melly a test filhosszaságát birja. (²)

(') A janótaak jobb ábrázolata az, mellyet Pennant ada, Synops. 172 s7., Hist. 280 s7. a fossane hamis név alatt. Ez azon fajta, melly a foktul gyakran hozatik. - Van egy más ábrázolat egy fiatal eqyén szcrint, Brown, ill. xurt. r. szinte fossane hamis név alatt. Fz megkülönböztetik feliéres, nem pedig barna szárai által, ćs mi hozzá hasonlót láftunk Senegalbul. Bufon-én (IX, XxxVı.) a nyak is rállak sujtásai nincsenek eléggé kijesyezve. Farka fekete gyiriïe kilenc, egész tizenegyig.

A civete de Malaca Sonnerat, deuxieme Voy. Lxxxrx. 1. melly ugyan az Buff. genette du Cap-jával (Supp. VI, LVmr.); a chat bisaam Tosmaer., mellyekbül Gmelin fajokat csinált, neın lítszanak közönséges janótnál egyebeknck.

(2) Fzen leirás a Poivre által Buffonnak kiildött s a Hist. nat. xill, xx. r. ábrázolt példány szerint ran. Dauhenton leirása pontos, a foltok closztására nézve; hanem ỏ azokat feketék-nek mondja, pedig zerhenyesek. Végre ezen állat nem egy könuyen lehet a fossa Flac., mellyet ezen szerzơ olly nagynak mond, mint egy 
Az endiar janót. (La Genelle des Indes. Viverra rasse, Horsf. Jav.)

Szárai barnák, teste barna szürke, apró barna foltolkal, mellyek a kereszten öt hoszvonalba egyesülnek. Farka rövidebb a testénćl, fekete és fehér gyürüzetü, hat vagy hét fekete gyürüvel ${ }^{1}$ ). Szöre az elöbbiekénél kevesebbé puha.

\section{A KরUKKOROK.}

\section{(Le Paractoxure. Paradoxurus. Fréd. Cuv.)}

A janótok fogait s bélyegeik nagy részét birják s azokkal sokáig összekevertettek, - hanem idomuk otrombább; ujak félig úszóhártyásak, járások majdnem talpi; és a mi öket leginbább megkiilönbözteti, farkok kúksokorodó, noha nem fogódzó.

Csak egy faja ösmeretes.

dz indiai kútor. (Le Pougouné. Parad. typus. liréd. Cuv.)

Indiábul; sárgás barma, némelly barnább foltozattal; lábai, arcora s farka egy része fekctésck; fehér szcmholdas és szeme alatt fehér foltu.

A pondichéryi francziák Marte des Palmiers-nels hivják. $\left({ }^{2}\right)$

borz. Poivre állitàsa cllenćre is hasonló szemfényhasadást bir czen faj a töbi janótokkal

(') Hihetóleg ez az animal du Musc (La Peyronie, Acad. des Sc. 1728, xxrv. 1 464. 1.) inelly a czibét mennyéttel összezavartaték; hanem a czibét nagyobb és más színii. Ezen alosztáshoz számlilható még az indiai : putois rayé, Buff. Supp.' Vill, Lvil. (V'iverra fasciata, Gm.)

(2) Ez a hirtelt Genette de France, Buff. Suppl. III, Xivil. \%. és a Civette à bandeau, Geofr.

CUYIEK I. K. 


\section{P'E'T'YZSEBEK.}

\section{(Les Mangoustes. Cuv. Herpestes. Iliger.)}

Hoi a zseb lág, cgyszcrü, s mellynek mélyén a vég-

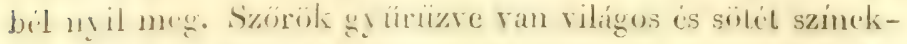

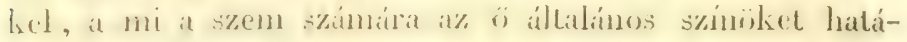
rozza meg.

As esyiptomi petyzseb. (La Mangouste de ligyple. Vizerra irhneumon.) Dishlinil egyiplomi petymeg. Butl. Supp. III, xxvI.

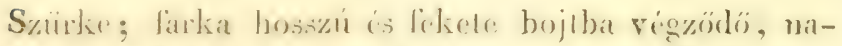
gyob) a macshinhual, karesi minl a ny us\%. Kübnësen

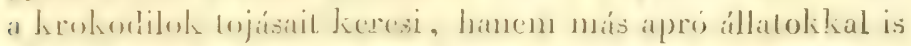

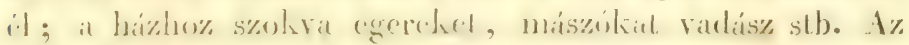

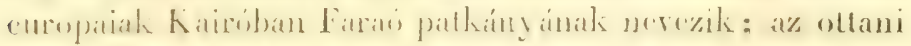
nép nems-nck. Az a mit a régiek beszéltek, hogy a krokodilok testébe negy, ókel megölendö, csupa mese.

Az indiai pelyzseb. (Lällongonste des Indes. I iverra mungos. Lin.) Buff. XIII. xxx. - és

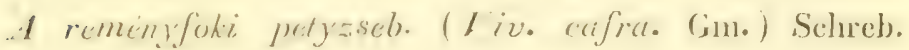
CXVI, B.

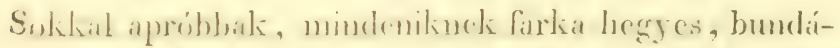
ja surke rayy barna, hamem ememel hamvasahb, az clsönćl sárgább, melly liülönben inég verhenyes is arcán és álllsapesain.

1\% indiai petyaseb hires a legreszedehuesebb laggoik-

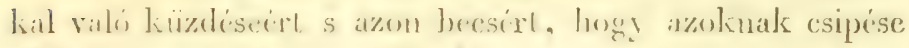

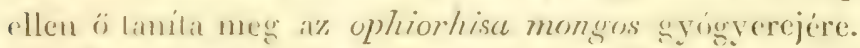

O)moreles mign ege jovai pelyaseb (Mangouste de Javit. H(rps. javanicus), uchly verhenyes barnal, area geszlenye verhonyes, torka súrgúbb; - - egy nagyobb a remenyloki menesirohbul (morsari petyesseb; I/. paludinosus), melly majducm engidomu verhenyes barna, fekr- 
lesbe hajló, az állán egy kissé halaványabb; egy harmadik a Reményfoktul: az ecsetes petyzseb (H. penicillatus), melly súrgís szürke, farka hegye fehér; egy a Senegaltul: a fehérfarku petyzseb ( $H$. albicaudus), melly szürke, egészen fehér farku; - de ezen állatok liözölt igen nehéz a faj-határokat megállítani.

\section{AZ ÖSZNYILAK.}

(Les Suricates. Ryzaena. Iliger.)

Hasonlítanak a petyzsebekhez, szinte a ször szinéig és kereszt sujtásozatáig, hanem tölök s minden eddig emlitett husevötül kiïönböznek, minthogy minden lúbokon esak négynégy uj van. Magasabb száruak is, s a szemfog mögötti zápfog hibázik nálok. Zscbüls a segbe nyilik.

Egy fajok ösmeretes.

Az afrikai ösznyż. (Viverra telradactyla. Gm.) Buft. XIII, VIII.

Afrikából credö, valamivel kisebb az indiai petyzsebnél. ( $\left.{ }^{1}\right)$.

\section{A MANGOK.}

(Les Mangues. Crossarchus. Fréd. Cuv.)

Az ösznyilak arcorát, fogait, zsebét és járását birják, és a petyzsebek nemzó részcit.

Csak egy faj ösmeretes.

$A$ sülét Mang. (Crossarchus obscurus. Fréd. Cuv). Sicrra leonátul, petyzseb nagyságu, barnás szürke, halavínyabb arcu, mezes farku.

It egy különös állatot kell említenünk déli Áfrikából,

(1) Sonnerat, ,zénik"-e (deuxième Voy., xcu. rl.) nem lálszik ą üszuyiltól különbözni, csak hogy durvább festésü. 
melly esak fiatalságábul ismeretes még 8 melly a petymegek öt elsö és hitulsó ujához és egy lissé kinyujtott fejéhez a hiénák magas lábail, a hátulso lábak röridebbségét és sörényét kütik. melly bundaja szinc're nézxe is nagyom hasonlit a csikus hiénához. Elsö hüvelyke rörid ís magasabb; $\mathrm{ez}$

Lalande petyüre. (Proteles Lalandii. Isid. Geofr.) Mém. du Mus. XI, 354, xx. rl. Üregekben lakik.

A megrizsgillt és még fiatal cgyénck, csak három apro hamis rippogat mulattak, is egy kis gumos zápfogat hátul. Loy tetszik, hogy fogaik elidéllenedtek, mint az a petymegeknél gyakorta megtörténik. (')

Az ujonjárók utolsó alosztálya épen nem bir apró fogakkal alul a nagy zápfog mögöıt. Ez a legkegyetlenebb állatokat foglalja magában, az osztály leghúsevóbbeit. Hét nöm van benne.

\section{A HIÉNÁK.}

\section{(Les Hyènes. Hyaena. Storr.)}

Föluil három, alul négy hamis zípfogok ran, mind kúpos, tompa és különösen vastag; fölsö tépöjuikön belül és cliil $\mathrm{egy}$ kis gumó, hanem az alsón nines, s ez csak két erös metszö hegyet mutat. Nyelrök durva, mindenik lábokon csak négy uj van mint az ösznyilaknál, és seggök alatt egy mély s mirigyes zseb, melly némelly régiekkel azt hiteté el, hogy ezck nöshimek. Nyakok és állkapesaik izmai olly erösek, hogy majdnem lehetetlen azt tölök clvenni a mit egyszer megfoglak. Nevök arabul a nỹakasság jelképe. Megtörlénik néha, hogy ezen

(') L. Cur. „Recherches sur les ossem. fossiles, IV. köt. 588. Iap. 
erölï̈dés által üsszeformak nyakcsigolíik s igy mondaték, hogy nyakokban csak egy csontuk ran. Éjjeli íllatok, barlangokban laknak, fökípen dïggel élök és azokat egész a sirokban is keresök, - rólok pedig számtalan elöitéletes mesék mondatnak.

Három fajok ismeretes :

A csikos hiéna. Föld. Tiéna eb. (L' Hyène rayée Canis hyaena. Lin.) Buff. Supp. III, xLvi.

Szürke, rendetlen kereszt barna vagy feketés csikokkal; tarkója s háta egész hosszában sörénye ran, mellyet haragja idején fölmereszt. Indiátul fogva egész Abyssináig és Senegalig lakik.

A barna hiéna. (L' Hyène brune. Hyaena brunea Thunberg.) Acad. de Stockh. 1820. I r. 2 rl. H. villosa. Smith. Trans. linn. XV, 19 rl.

Sötét barna-szürke, feketés csikokat csak a szárain birra. Afrika délérull, hol a foki gyarmatosok parti farkas (loup de rivage) név alatt ösmerik.

A foltos hiéna. ( $L$ ' Hyène tachetée. Canis crocuta Lin.)

\section{Schreb. XCVI. B.}

Szürke vagy verhenyes, fekete foltokkal. Szinte déli Afrikábul. Ez a fok tigris-farkasa.

Ezen utolsú idöliben számos barlangjaiban Frank- Német-és Angol-országuak, sok hićua csont találtaték, egy clveszett fajtul (H. spelcea) mellynek itt kellett laknia, s melly sok fogai által megsértett más állatok csontait hagyá ott hátra, söt még tulajdon ganaját is. (')

\section{A MACSKÁK.}

\section{(Les. Chats. Felis. Lin.)}

Minden húsevök közölt legerösebben fegyverkeztek. Rövid és gömbölyü arcorok, rüvid állkapesaik s minde-

(') L. Buchlandtul: Reliquîae diluvianae; és Cuv. Ossement. „fossiles" második kiadásának IV. kötetét. 
nek fülött az ö vissza hwhaté karmaik, mellrok a nyugralom idejón fölfele visszahajolnak s az ujak közi elbujnak rugékony szalagols munkílliodísa által, és igy liegyöket ragy élöket soha el nem resztik, igen rettenetes állatokkí reszik öket, kiváltképen a nagy fajokit. Fölül, alul kitliét álzápjok rau: fölsö tépöjök három karélyt és behül egy compa sarkot bir. az also kit hegyes es metszö karétyt minden sark nélliul; vegre csak egy igen apró gunnós fogok van föliil, mellynek alıl semmi sem felel meg. Ezen uem fijai nagyon szinusak, s nagyságra és szinre nézoe igen kiilënbiöök, noha idomra mind hasonlatosak. Csak nagysiggoli is szörök hosszasigúnak igen kevessé fonlos bélyegei szcrint oszthatók föl.

Ezen nem elején mutatkozils:

Az Orozlin. (Oroszlin F.) (T.e lion. Felis leo. Linn.) Bufl: VIII, I, Ir.

Megkiilimbözlethetö egy idomulag sírozi szine, farka hegyének bujlja s azon söreny által, melly a him Cejal, nyakál és molét fëdözi. Ez a legerösebb d's legabitrabb a ragadozik hrizölt. Hajdan a régi rilág mind a három részciben ellerjedt, ma pedig esals Afrikáras Ásia ezzel határos részcire vau szoritva. Az orozlimmak négyszegleliiebl) feje van, mint a köretkezendö fajolnnak.

A ligrisck nagy fajok rövid störrel; tobburire vidor jegyezellel.

A rohanoic tigris. Füldincl tigris. (Le Tigre royal. Felis tigris; Lin.) Bufl. VIII, IX.

Szinte olly nagy mint az orozlán, nyullabb, gömbölÿ̈ъb fejü, fülül vidám súrga, alul tiszta fehér, rendellen fekete kereszt csikolatokkal: legliegyellenebb az emlösck közölt, s Keletindia legiszonyubb csapása; ereje s futásbeli gyorsasága ollyanok, hogy a menó hadscregnél néha a nyereghäl lisemelte a lovagot s az erdö nurlyébe hurenlí a néllkül hogy el lchetett rolna ót érni. 
Az onka. Tüldi. (Le Jaguar; 'Tigre d' Amérique. A szücsök nagypárduca. Felis Onea, Limn.) D' dzzara, Ix. rl. Fred Cur. Mammil.

Majduem akliora, mint a lictchi rohamo tigris, smajd ncm szinte olly reszedelmes; fölül vidím sárga, oldala hosszában nigy sor szemidomu fekcte foltokkal, azaz (übbr kevescbbé teljes gyürükliel, közípen egy feliete ponttal; alul fehér, fekete keresztesikokkal. Vannak fekete egrénck is, mellyeknck sülctebb foltai csak bizonyos helyezetben láthatól.

A parduc. T. (La Panthère. Felis pardus. Lim.) A régiek pardalis-a. Cuv. Ménag. du Mus. $8^{0} \mathrm{I}, 2121$.

Fölul sárga, alul fehér, hat vagy hét fekete foltsorral, rózsaidomban, azaz üt ragy hat apró egyszcrii folt összerakisíbul képzödve, mindenih oldalon. Farka testhosszaságu, a fejét oda nem számolra.

Ezen laj egész Afrikában clterjedt s Asia meleg rószciben, szinte mint az indiai sziget-sokon.

Vamnak egyénck, mellyclinél a szór alapja ickete, sütétcbb fekete foltokkal (Felis melas Pér.); hancm ezck lajt nem képzenek. Többször látlatek mair, logg ugran azon anya sárgákat és feketéket szoptatott. $\left.{ }^{1}\right)$.

A leopard. Füldi. (Le Léopard. Felis leopardus. Lin.)

Afrikábul; a párduchoz hasonlit, hanem liz apróbb foltsorral. $\left({ }^{2}\right)$.

Ezen kél faj kiscbb az onkíníl. Az utasok és börkereskedök meghatározatlanul nevezik öliet majd lcoparduak majd pirducnak, majd afrikai tigrisnck stb. $\left({ }^{3}\right)$.

(') Temminknél ezen faj neve: felis leopardus.

$\left({ }^{2}\right)$ Ugyan azon természetvizsgáló a mi leopardunkat párlucunk fajtájának nézi s az 8 felis leopardusa alatt egybe zavarja.

$\left(^{3}\right)$ Buffon az orkát elismeré s az ó világ párluca gyanánt tekinintle; a pirducol is leopardot sem kulonhörtelé jol meg; s ezen ok- 
Van egy hamadik faj is, Kelet-india tírolín laliszo, cyy kevessé alacsonyabb száru, testél és fejét fölütö farku, számosabb is apróbb foltu (Felis chalybata, Herm. Screb, 101, Foltjasok.) $\left.{ }^{1}{ }^{1}\right)$.

A puma, (Le Conguar, Puma. Felis discolor. Lin.) az állitott afritai orozlain. Buff. VIII, xix.

Verhenyes, valamivel sötétebb apró verhenyes foltokkal, mellyek künmyen megkülönböztethetök. Egész Anerikíban, hol a tyúkudrarokat pusztílja, stb.

Az alsubb fajak kïzölt meg kell különbüzteแni

\section{^ HIÚZOKAT,}

mellyek füleiken lévö szörecset által szcmbetünök.

A kereskedésben (szarvas-farkas, loups cerviers név alati), négy vagy ö eléggé különbözö laj ismeretes, du mellycknck fijhatírai nincsenck még eléggé kijelelve. Mindnyaja igen rövid farku, bundajols többé kevesebbé foltos.

A legszebbils, akkora mint egy farkas (a szarvas hiúz. F'elis cervaria. 'Temm.) Asiábul jö Oroszhonon által, s ogy licvessé veres szürke szörü, szép fekete foltokkal.

bul nem hivatkozni bizonyosan a VIIl, hötete $\mathrm{xt}, \mathrm{xII}, \mathrm{xIII}$, és xiv. rajzlapjaira.

(') Ezen fajnak tulajclonítja Temmink a párduc nevet, azt vélvén hogy Linné elött ez volt, midỏn felis pardus-árul azt mondá: caudà elongatâ. Az azonban bizonyos, hogy a régieknél olly osmeretes és a romaiak játékában olly gyakran clöfordult párduc, nem lehetett Eclet-india belsejébül való.

Buffon, „Once"-ja (IX, xir. r.l.) (Felis uncia, Gm.) a párductól és leopardtól eqyenetlenebb, rendetlenebbül rakott s részint kicsorbitott vagy györïzött stb. foltokkal különbözik. Ugy látszik. Persiában találtató. Mi ŏt csak Buffon ábrázolata szerint ösmerjük s abbil mellyet Shnith Hamilton ezen munka angol forditásához adott egy Londonban élt egyén szerint. 
A másik Kanadábul és Svédhon éjszakárul jö (éjszaki hiü. Felis borealis. Temm.) Egész a líbai aljáig igeu bojtos bundáju, hamvas szürke, aligfoltos.

A közönséges hiúz, (Felis lynx. Temm.) mellynek a mérsékelt Europa szolgált honul, hanem a népes tartományokbul cltünt, s csak a pyrenéi s nápoli hegyelien találtatik még, s a mint mondatik, Afrikúban is, - verhe. nyes bundáju, verhenyes barna foltokkal.

Ezen hírom fajnak vagy fajtának fekete farka hegye van. Meg lehet talán tólük különböztetni a déleurópar hiüzt, (Felis pardina. Oken.) melly kisebb, keresebbé födött, verhenyes, feketével foltozott, s mellynek farka szinte mint a teste bir foltozattal.

Találtatnak még Éjszak-amerikában :

A verhenyes hiúz. (Le Chat cervier des fourreurs). (Felis rufa. Güldenst.) Schreb. CIX, B.

Verhenyes sárga, vagy szürkés, barnás foltokkal; barna hullámok a combjain; farka barna vagy fekete gyürükkel, valamivel lisebb a mi hiúzunknál. (1)

A mocsári hiüz. (Le lynx de marais. Felis chaus. Güldenst.) Schreb. CX.

Sírgás-barna-szürke, négy lábának hátulja feketés; farka egész a térdhajlásig nyúló, hegyén fekete gyürüs; Kaukazia, Persia és Egyiptom mocsáraiban lakik, vizi madarakat vadász stb.

Az a vélemény hogy töle megkülönbözlethetö:

A saru's h, (Le lynx botté, Felis caligata. 'Tem. Bruce, 30 rl. melly valamivel kisebb, hanem egy kevéssé hoszszabb farku; füleinek külső szine verhenyes. Ez legalább igen határos faj, ugyan azon erkölcscsel is biró.

(') Rafinesque által emlittetnek még: I'nx fasciatus, lynx aureus, floridanus, 2. montanus; és Temmink iltal: felis auratr, mellyek mind e his törzsöhhöz tartoznának. 
Az o hiuz; Rarakill. (T.e Caracal. Felis caracal. Lin.) Buff. IX, $\mathbf{x x}_{1 \mathrm{y}}$. Supp. III, XLV.

Najdnem egvidomu borreres. Persa s Törökhonbul stb. Ez a régiek ralódi hiúza.

Azon alsi fajok, mellychnek fülein nines szórecset (ïb) be licresebbé hasonlitimak a nni házi macskánkhoz, illyenek:

A szemge. ( $L$ ocelot. Felis pardalis. L.) Buff. XIII, xixy , xxxif.

Valamivel alacsonyabb szárn, mint a tibbbiek, nagyobb rész szürke, nagy sírga foltokkal, fekete körïeklect, az nldalun gïrbe sujlásokat kípzöhkel. Egész Amerikábul.

A jimbor macska. (Ta Chati. Felis mitis. Fr. Cur.)

Máromszegï nem eģ yesült sirga foltokkal, mellyeket rekcle körkeríl be.

A kafferi macska. (Le ('hat de Caprérie. Felis ("afra.)

Magas száru, szürke, kereszi fekete sugárzatu.

A zümökc:ze: zümük macskia. (Tie Serval. Fel. Serval.

Limn.) Bufl: XIII, $\operatorname{xxxy.~}$

Sárgás; szabílyalan frkete foltokkal. Afrikábul.

A kures; karcsu macska. (Le Jaguarondi. Felis jaguarondi. Azzara.) voy. x. rl.

Nyúlt, s egészen feketés barna. Dél-amerika erdeibül. A haizi vagy egerész macska, v. cica. Tüldi. (Te Chat ordinaire, Felis catus. Lin. Buff VI. I. stb.

E⿺edetét a mi europai crdenilsból veszi. Vad állapoljában barnás szürke, homályosabb kereszthullámokkal; alul halaványabb, czombjai és négg lába belscjén sárgás; farkín három sujtás, s alsó hamada feketés. Szelidültében, mint kiki tudja, víltozo szin̈̈, szörnagyságu és finomsagu, haucm régetlenül kerescbbé mint az eb; ugy szinte: sokkal keresebbé hódol ö és simúl az emberhez. 
Iu mellékesen egy alnemet lehetue csinálni az egyik rajbul, mellynek feje gömbölyübb és röridebb, s mellynek karmaı (körmei) vissza nenı húzhatik. Fz a lepfolt (T.e Guépard; le tigre chasseur. Felis jubata, Schreb. . 105; is jobban: felis guttata, na. 10.5, b.) leopaird nagyságu, hanem karcsubb és magasabb száru: furka hosszú, régén gyürüs, bundája sárga lepre egyidomu apró fekete foltokkal ; szemétól egy fekete ronás megy száj szegletíig. Természete a nöm többijétül igen nagy szelidsége s liönnyá megszelidithetése által különbözik.

\section{A KÉTLAKUAK.$$
\text { ( } L \text { es } A m p h i b i \text { es.) }
$$

A harmadik és utolsó kis törzsököt képezik azok közül, mellyekre a húsevóket osztottuk; lábaik olly rövidek s a börbe ugy bebonyoltak hogy a földön csak mászásra szolgálhatnak nekik; hanem ujaik közei hártyákkal lévén kitöltve, jó cvezók; ezen állatok életök legnagyobb részét a tengerben töltik el, és szárazra csak a napon nyugvás és szoptatás végett jönek. Nyúlt testök, igen mozgékony gerincök, hatalmasan hajtó izmokkal birva, keskeny medencök, ritka s a bórhöz lapuló szörök, egyesülnek hogy jó úszokká teremtsék öket, - s boncolatok minden tulajdonsága megerósíti ezen elsó nézetet.

Méğ csak két nemök kölönbözteték meg: a fókcik és rozmcirok.

A FóKÁK. F.

(Les Phoques. Phoca. Lin.)

Fülül hat vagy négy, alul négy vagy liét metszö for 
gok ran, szemfogail hegyesek, zápfogaik száma husz, huszonkettö vagy huszonnégy, mind éles ragy lípos, minden gumós rész nélkül; mindenik lábolion üt uj ran, az elsökön azok a hürelyktül a kis ujig egrre röridülnek, a hátulsokon pedig a hüvelyk és kis uj leghosszabbak, a közepsök legrövidebbek. Az elsö líbak egész a líbtöig beburkoltals a börbe, a hátulsók majdnem a sarkig. Ezen utolsók liözült egy rövid fark ran. A fólsáls feje az ebéhez hatsonlit, s ók szinte olly értelmesek, és édes kifejezö pillantatuak. Könnyen megszelidithetök, s ekkor nagy hajlandoságot mutatnik tiplílojokhoz. Nychök sima, hegyén ki kanyaritult; gyomrok egyšcru, vakbelök rövid, bélesatornájok hosszú s eléggé egyenlö. Halakkal élnck; mindig a vizben esznck s lehukásolikor orrlyukaikat egy lebbentyii által be tudják zárui. Mlinthogy soká liépesel bukni, az rolt a rélemény, hogy Botal rezetéke nyitva marad nálok, mint a magzatnál ran, de a dolog nincs ugy; azonban mégis egy nagy vireres öbïl találtatik májokban, üliet a bukísban segitö, a l'́lekzést a vérkeringésre nem ollyan szülsségessé tére. Vérök igen bö s igen fekete.

\section{A tulajdonképi vagy külfültelen FókAk.}

Vígfogaik hegyesek; minden ujok bir bizonyos mozgrissal (és hegyes karomba) régzödik, melly az ujakat egyesítö hártya szélen van.

Alosztásokat vágó (metszö) fogaik számátul kapnak.

A VÁgatöвиек-nek (Les Calocéphales Fr. Cur.) fölül hat, alul négy vígfogok ran; illyen:

A borju foka. F. (Le Phoque commun. Phoca vitulina. L.) Buff. XII, xLv. Supp. VI, xLvI. Phoca littorea. Thienem. VI. rl.

Háromtul öl lábnyi hosszú, sárgás szürke, barnással lübbé kevesebbé úrnyozva vagy foltositva, kora szerint; néha barnás, apró sirrgás foltokkal. Ténségében fehéres lesz. 
Közünséges a mi partjainkon, hova nyugodni nagy csapatokban jö. Éjszak felé is elég távolra találtatil. Azt is bizonyitík hogy czen faj lakik a Kaspitengerben és Oroszhon s Sibera édes vizü tavaiban, hanem ezen állítás nem Játszik eléggé pontos äszvehasonlításon nyugodni. Valóban tulajdon tengereink is több fóka fajt birnak, mellyck soká összezavartattak, s mellyek közül némellyek, meglehet, csak fajtái a másikaknak.

Igy ran egy, mellynek cgész háta fölhös, összefutó barnás apró foltoklsal födött, - sárgás talajon. (Phoca hispida. Schreb.) ( $\left.{ }^{1}\right)$ Ezek legközönségesebbek az Éjszakitengeren. Másoknál homályos talajon hullámzatok vannak, néha gyürüket képezók. $P / h$. annellata, Nils. Thienem. IX. - XII. rl; Ph. foetida, Fabr. $\left(^{2}\right)$, stb.

Könnyebben megösmerhetó faj:

A félholdas fóka. (Le Phoque à croissant. Phoca grönlandica el ph. oceanica). Egede. Groënl. fig. A. 62 l. Lepechin. Act. Petrop. I. I, rész, VI-VII. rl. 'Thieneman. XIV-XXI. rl.

Sárgás szürlie, fiatalságában barna foltozatu, utóbb egy görbe, barna ragy fekete sujlással mindenik oldalán; a vén him feje fekete; hosszasíga öt láb. Az cgész föld ejszakán.

A szakillas fóka. (Le Phoque barbu. Ph. barbata. Fabr.) 'Thien. I-IV, rl.

Szinte egćsz éjszakon, s az elóbbieket nagyságra fólül haladja, melly hét nyole lábnyi. Szürke, fölül barnásabb, fekete hoszvonallal, melly a homlokán keresztet idomoz. Bujúsza erösebbs s tömöttebb mint a täbbicknél.

(') Azt vélem, hogy ide számlálható: Ph. scopulicola, Thien. V. I'.

(i) Ez cry azok bözül, mellyehct Cuv. Fr. a "l'hoquc commun." név alatt úbrizolt le. 
A fehérkürmï föka. (Le Phoque à ungles blancs. Phoca leucopla). 'Thieneman. XIII. rl.

Sárgás szürke.

A nyulfarku fóka. (Le Ploque à queue de lièvre. $1 \%$. lagura. Cuv.)

Fehér és gyapjas farku. $\left({ }^{1}\right)$

A VÁG.INÉGYEK.

(Les Stenorthinques. Fréd. Cuv.)

rïliil s alul négy vágófoggal, zíplogank mélyen vannak három hegyre elosztva.

Csak egy faj ismeretes a Dilitengerekbül. ( I délszaki fokia. Phoca leptonyx. Blainr.) Nagy sága mmit a szakállasé, föliil szürkés, alul sárgás, körmei aprók.

А ТОMKÚPOK.

(Les P'elages. Fréd. Cuv.)

Szinle löliil alul negregey rígofoggal, hanem záplogaili tompa kupoli, chïl és hatul egy alig ismerhetö sarkkal.

Egy laja vau a Középtengerben:

A feherhasu fokta. (Le Phorque is ventre blanc; Moine.

Plinea monachus. Gm.) Bull. Supp. VI, xin. rl. $\left(^{2}\right)$

'Tiz lizenkét láhnyi hosszú, feketés barna, fehérhasu. Leglöképen az Adria s Güröglenger szigetei liözötl talózkodils. Hihetöleg ezcn faj volt a régiek clött ismeretes.

(') Nem akartam egyćb fajokat megemlíteni, mint a mellyek eléggé megállapítottaknak látszanak. A fókák újlag közzé tett hoszú jegyzche túl látszik ỏhet szaporitani.

() Ez épen azon egyéu, mellyet Hermann leirt a Berlini tcrm. vizsor. ilatiaban, ,monachus" név alatl. 


\section{A ZÁPANYOMAK.}

(Les Stemmatopes. Fr. Cuv.)

Föluil négy, alul két metszörel, összenyomott könnyúden híromkarélyozott s vastag gyökerü zípfogakkal. Illyen:

A tarajos fika. (Le Phoque à capuchon. Ph. crislala; Gur. Phoca leonina. Fabr.) Egede. Groënl. vi. rl. Dekay lyc. de Newyork, I, viI. rl.

Hét nyole lábnyi hosszú lesz, fején sima börrel, melly Cölduzasztható s mintegy csuklyát képezhetó, mellyel a veszély idején szemeit befödheti; s akkor orrlyukai is két hólyag gyanánt fölfuródnak. A Jegestengerbül. (')

\section{Az ORMÁNYóK.}

\section{(Les Macrorhines. Fréd. Cuv.)}

Végre az clöbbick metszö fogaival együt, lompa kupos zápokat mutatnak, s arcorrok rövid mozgékony ormányidomú. Ezen számbul vali az ismert fókálk legnagyobbika.

Az oroszlcin föka. Földi. (Le Phoque ì trompe. Ph. leonina, Linn. Lion marin., d' Anson. Loup marin, Pernetty; az angoloknál: tengeri elefint, stb.) Peron. Voy. xxxII. 1.

Husz, huszonöt lábnyi hosszí, barna ; a him arcora rendes ormányba régzödö, melly a harag alatı folfuvodik. Közönséges a Csendestenger magínyos partjain, a Túzföldnél, Újzclandnál, Chilinál s(b). Nagy halászat téletik reája, bö zsirja végett.

(') Azon késziilet, melly által a tarajos fóka magát folfúja, mindcddig nincs cléggé fölvilígositva. L. Dekay et Ludlow, Mém. du Jycée du New-York, 1. köt, 94, és 99. lap. 


\section{A külfiules fókik. (Otaries. Peron.)}

Megérdemlenék hogy tulajdon nemet tegyenek, mirei elöálló Jällfülciken kivül, fölül közép rágfogaili kettios élïek, (molly idom még semmi más állatnál nem láttaték), a külsök egyszerück és kiscbbek, a négy alsó villa-idomu. Minden zipjok cgyszerüen liúpos; clsö evezöik ujai majd mozdithatlanok, hátulsú lábának hártyája mindenik ujon tul nyúlik; minden karmok lapos és véliony. A sürényes fúka. (Le Phoque à crinière. Plı. jubata., Gm.

Lion marin de Steller, de Pernetty stb.) Buff. Supp. VII, xLVTH.

Hosszasága tizenöt, húsz s täbb lábnyi, sárga, a him nvaka sürübb és bodrosabb szörrel mint a többi teste. Az egresz Csendestengerben találtatnck, ha a Magrellan szorosi (a mint látszili), nem különbözne az aleuti-sziget körülicktül.

A medve fóka. Földi. (I' Ours marin. Phoca ursina. Gm.) Buff. Supp. VII, xuvII.

Nyolc lábnyi hosszu; särciny nilhül, barnátul fehéresigr víltozó. A Cisendestenger éjszakárnl.

Talaillatuak migr ezou tengerben a medre fókálul csaks nagysigra is szime kilinbözük: illyen Buffon kis fekete fokcija (le petit phoque noir. phoca pusilla). ButI. XIII, uni, a scirga folice (le phoque jaunc de Schaw,) sth.

\section{A rozMárok. Földi.}

\section{(Les Morses. Trichechus. Linn.)}

Tagjakra s testök általútuos idomára nézye a fölsálkhoz hasonlitanak, hanem igen külünböznek tölök fogaik és fejïk tekintetében. Also állkapesok metszö is szemfogak hijáral ran s melöl összenyomolt idomot nyer, hogy a fölsis illkapoes iszonyu két agyara küzé nyomuljon, mellyek alí iranyoztak s neha ket libnyi hoszuak arínyos vastagsagga! 
birva. Az illy agyarak fölvételére szülséges iszony li lơgsejtek a fölsö állkapocs egész elejét földuzadt arcorképen emelik föl, az orrlyukak pedig az ég felé néznek, mintha nem az orr régét temuék. A zápfogak mind rövid és hárántosan melszett henger-idomuak. Minden oldalon fölül s alul négy van; hanem bizonyos életkorban a fölsök közül keltö ki szok hullni. A két szemfog közt többnyire két melszö van, zápfoghoz hasonlitó, s mellyeket a szerzók nagyobb része szemfogaknak nem akart elösmerni, noha az állliözli esontba íkeltettek; még ezck közölt van a fiatal egyéneknél két apró s hegyes fog.

A rozmírok gyomra s belei majdnem rgészen ollyanok, mint a fókíké. Ugy lítszik, hogy fucus-sal szintugy élnek, mint állati anyagokkal.

Még csak egy faja különböztetelik meg ( $\left.{ }^{1}\right)$

A közönséges rozmair. Földi. (Vache marine, Cheval marin, Béte à la grande dent. stb., - Trichechus rosmarus. Limn.) Buff. XIII, LW. s jobban Cook, III. Út.

A Jegestenger minden részén lakik, nagyságra a legeröscbb bikákatịfölümulja, egész husz líbnyi hosszú lesz, sárgás rörid szörrel födölt. Zsira és agyarai végett vadísztatik; agyarai szemesek ugyan, hanem azért a mivekiben használhatók. Börébül jó kocsiszíjakat is csinálnak. ( $\left.{ }^{2}\right)$

(') Schaw azonban azt véli hogy két faj állittathałnék föl, cgymástul töbhé vagy keveseỏbé nagy, többé vagy kevesebbé összeta:tó agyaraik által különbözendó.

( $\left.{ }^{2}\right)$ Elóttünk a Rozmárokkal helytelenül voltak a Manatok-és Halicorék, mint a cetekhez küzelébbi állatok, cgyesitve. 
AZ EMLÖSEK NEGYEDIK RENDE.

\section{$\triangle Z$ ERSZÉNYESEK.}

(KÉTMÉHÜ EK. LES MARSUPIAUX)。

Ezeket különben a ragadozók végére tettem, mint ezen nagy rend negyedik családát, ugy látszik, hogy egy különös rendet képzenek inkább, mivel sok hülönösséget mutatnak alkotásokban s mindenek fölöı, minthogy bennök némileg három különböző rend képe mutatkozik.

Minden kiilönösségök között elsö, kölkeik idöclötti szülése, mellyek a kifejlödés olly korában születnek már, melly aligg hasonlítható ahoz, melylyet a magzat néhíny napra a fogamodís utín mutat. A mozgússa alkalmatlanok, végtagoknak s más külsó müszereknek csiráit aliģ mulatják, anyjaik cmlöihöz ragaszkodnak s oda szegezve maradnak, mígnem azon fokra fejlödtek ki, mellyen az állatok rendesen születni szoktak. Majdnem mindig zsebképben van a hasböre ezen csecsek körül helyhezödve, s a kölkek mintegy második méhben tartatnak ott, sőt még midön júrni liezdtek is, soká visszatérnek oda, ha veszedelemtül félnek. Két tulajdon csont, a fancsontokhoz feszúlö s a hasizmai között fekvö, ad az erszénynck támaszl; s ezen csontok a hímeknél 
s azon lajoknál is találtatuak, hol az erszényt képzó redó észre alig vehetó.

Az ezen csalídbeli állatok méhén nem egy egyetlen nyilás van a hüvely fenekébe, hanem két nyélidomu csö által közösül ezen csatornával. Ugy látszik hogy a kölkek idétlen születése ezen alkotás miatt történik. A hímeknél a đöbbi állatokkal ellenkezőleg a borćk csüng a vesszö elött le, a vesszö pedig a nyugalom idején hátra irányozott.

Az erszényesek másik különössége az, hogy fájaik egymásközti olly nagy hasonlatossága mellett is, hogy belölök soká csupán csak egy nenict csináltak, amnyira különböznek fogaikra, emészlési múiszereikre s lábaikra nézve, hogy ha szigoruan csak ezen bélyegekre néznénk, óket különbözó rendekbe kellene elosztanunk; ök bennünket észrevehetetlen árnyolatokon ált a ragadozókıul az örlókhöz vezetnek, söt még vannak köztök olly fajok is, melylyeknek medence hasonló csontokat bir, de metszö söt néha minden nemü fogaik hiánya öket a foghijasokhoz vezeti közel. Mi ezeket ottan is hagyjuk, Egyvékuak neve alatt.

Egy szóval, azt mondhatni, hogy az erszényesek egy tulajdon osztályt képzenek a rendes emlösekéivel egyközüleg futót s hasonlító rendekre oszthatót; olly múdon hogy ha ezen két osztályt két sorba helyheztetnök, a fijahordók, mezfarkok és körömkülök a hosszú szemfogu bogárevőkkel lennének átellenesen, ugymint a süncsutakhal és vakondokokkal; a perc- 
külök és fönfarok a borzokkal és cickányokkal; a tulajdoképi vetfarkok nem egy könnyen hagyják magokat akármellyikkel összehasonlitani, hanem az ereszek az örlökkel jönének szemközt. Végre ha csak az erszény tulajdon csontjára tekintenénk, és az azt birókat mind erszényeseknek mondanók, akkor a kacsaszájok és gömbölyök is itt a foghíjasokkal egyenközú csoportot tennének.

Limué minden ismerte fajat a didelphis nem alí helyeztet. melly szó két méhet jelent; az exszény képezvén némelly tekintetben a másodikat.

17. erszényesek elsö alosztálya hosszú szem-, 'ś apró metszó fogakat bir mindenik állkapocsban, hátulsó zápfogai hegyekkel födtek s általában a bográrevö ragadozók bélyegeit mutatják; az életrendben is közelitenek azokhoz.

\section{A FтАHORDóк. (Földi).}

\section{(Les Sarigues ( $\left.{ }^{1}\right)$. Didelphis. Limm.)}

Az crszenyesels kizzitt legrégebben ismcretesek, s egy tulajdon nemet kípezunck Amerikában. Tölül hat zápfogok van, mellyek küzült a kïzépsök valamivel hosszal)bak, alul hat; három elsö zápfoguk összenyomott, négy hílulsó pedig fogas, - kïzülök a fölsók háromszegüek:

(') Carigueia braziliai nevök Margrave szerint, mellybül sariguoi, cerigon, sarigue lett. Paraguaiban micouré-nak hívják sket, manicuu-nak a szigetehen, opossum-nak az egyesïletekben, thlaquatzin-nali Mexikóban. 
az alsók hosszúdadok. Igy a négy szemfoggal egyült ötven logat birnak, melly szám leguagyobb az emlöseknél eddig leltek között. Nyelvök tövses, farkok fogódzó ès részint csupasz; hátulsó hüvelykök hosszú s a többi ujaknak könnyen ellenébe tehetö, melly okbul lábkezüek-nek (pedimanes) is neveztettek el ezen állatok; karom, (karm) hijával van ez. Igen kimetszett szájok és nagy csupasz fülök különös tekintetet ad nekik. Vesszejük makkja kétágu. - Büdös éjjeli állatok, kevessé gyors járásuak; fákon fészkelnck, s olt a madarakat, bogarakat stb. üldözik a nélkül hogy a gyümölcsöt megretnék. Gyomrok egyszerü s kicsin, vakbelök középszerï pufladúsok nélkül.

Bizonyos fajoknál a nöstényeknek mély zsebeik vannak, mellyekben esecseik léteznek s hova kölkeiket elrejthetik.

A fülekétszinü fijahordó. (Le Sarigue à oreilles bicolores. Az angol-amerikaiaknál: Opossum. Didelphis virginiana. Penn. Hist. quadr. 302. (')

Majdnem akkora mint egy macska; bundája fehérrel és feketéssel kevert, fehér bajúszozaltal, fülei félig feketék félig fehérek, feje majd egészen fehér, egész Amerikában lakik, éjjel a lakott vidékekre jö a tyúkokat üldözendö s a tojásoliat eendö stb. Kölkei, mellyek száma néha tizenhat, születésükkor esak egy szemert ha nyomnak. Noha vakok s majdnem idomtalanok, mégis ösztönbül föllelik a csecseket s oda ragaszkoduak, mignem egérnagyságuak lettek, a mi csak az ölvenedik napon történik, midön szemeik megnyiluak. Nem szünnck meg a zsebbe visszaléréstül, mig patkín nagyságuak nem lettek. A méhben való viselés csak huszonhat napig tart. ( $\left.{ }^{3}\right)$

(') Ez a sarigue des Illinois, $\mathbf{s}$ a sarigue à longs poils, Buff. Supp. YII, xxxur. s xxxiv; did. marsupialis Schreb. cxLv. I.

$\left({ }^{2}\right)$ L. Burton levelét Ronne-hoz a fijahordók terhességériil. 
A ekete farcaru fijahordó. (Le Gamba, ou grand Sarigue du Paraguaty et du Brésil. Did. Azzarae. Temm.)

$\mathrm{Az}$ elóbhitül azon fcketében különbrizik, melly areorát s majd esész füleil födi. Szinte igen hosszú farka vall.

A rsersiszcikos fijahordu. Földi. (Le Crabier, ou grand. Sarigue de C'ayenne, du Brésil cic. Did. marsupialis et did. cancrivora. Linn.) Buff. Supp. III, LIV.

Akkora minl az elöbbick, sárgás, keverve barnással, barna sörteklicl, barna romal az orrlöre fölöl. A tengerpart moesíraban tartrzkodili, hol föképen rákokkal el. (') A foltszemes fijaturiti. (Le Puatre-oeil ou moyen Sarigue de ('ayenne. Did. opossum. Lim.) Bufl. X, XIV, XLVI.

Föliil gesztenyebarna, alul fehér, mindenils szeme fóläl egy lehór vagy halavíny sárga folt; farka végsö harmada fehér; a nagy patkánnál is nagyobb. -

Mís fijolinal nincs crszény hanem esak egy redö a a has mindenik oldalín, melly ammak csak nyoma. Ezck a hátokon szokjálk hordani külkciket, mellyeknek farkai, az anyáé köré göndörödnck. -

A ('supaszfarkitu fijahordó. (The Sarigue à quatue mue. D). nudicauda. Geoff. D. myosuros. 'Temm.

Sárga: igen hosszú s még a törén is meztelen farku lsét fehéres foll mindenik szem fölöl is egy, alitl.

(') Ez az állitolt: grand philandre oriental, Séba., mellybül Linné a did. marsupialis-t csinálta. Buffon, ki a hímet leirá, Supp. III, LIII, rl., azt vélé, de csalódva, hogy a nostény zseb hijával van, a melly okbul, hibásan, egy másik faj, did. cancrivora Gm. Carcinophaga Bodd., alkottaték. Cayenne-ben a csecsiszákost pian, v́agy puant néven nevezik. 
A hátas fijałordo. Földi. (Le Cayopollin ( $\left.{ }^{1}\right)$. Did. cayopollin; did. philander et did. dorsigera. L.) Bult. $X, \mathrm{LV}$.

Súrga-szürke, szemköre s egy hoszsujtís az orrtövén barnák; farka feketével foltos; höresök-nagyságnyi. Farka fölsö negyede szörrel födött.

A szürke fijatıordó. (Le D. cendré, ou. Grison. D. cinerea. 'Temm.)

Világos hamvas, feketés fénynyel, melén vereses, farka hátulsó fele fehér; akkora mint az elóbbi. Brasiliábul.

Az egerü fijahordó. (La Marmose $\left({ }^{2}\right)$. D. murina. L.) Buff. $X$, LII, LIII.

Sárgás szürke; egy barna vonallal, mellynek közepén a szem; farka nem foltos. A patkánynál kisebb. $A$ rövidfarku fijahordó.

Háta feketés, oldalai vidám rerhenyesek, hasa fehér, farka rövidebb a testénél. Kisebb a patkánynál.

Ezen három faj déli Amerikíbul való.

Végre ismeretes még egy faj, melly uszóhártyás talpu s vizben élönek kell lenni; nem tudni van-e erszénye; ez:

Az Úsztalp. (uszótalpu fijahordó). Chironectes ( ${ }^{3}$ ) Ilig.

(') Cayopollin ezen nem cgyik fajának neve, melly Mexikó hegyein él. Ezen fajra önkény szerint alkalmaztaték.

$\left.{ }^{2}{ }^{2}\right)$ Marmose nevet Buffon fogadá el Séba francia forditásának nyomtatísi hibája szerint, ki az iratban azt bizonyítja, hogy ez Brasiliában marmotte nevï. Csak annyi igaz, hogy Margrave idejében a hollandusok rat de bois (erdei patkany)-nak, a brasiliaiak taibinak hivták. A cayennei franciáknál szinte: erdei paskány. Séba hihetoleg mormoga-nak tevé a boschrattet.

J. A páris védéki gypsfejtỏkben egy az egerï fijahordólız közelíto̊ fijahordó csontvảát találták.

$\left(^{3}\right)$ Chironectes, azaz kézzel úszó. 
Didelph. palmata, Geoff. La petite Loutre de la Guiane Buff. Sitpp. IfI, xsir. Lutra memina, Boldd.

Fölül barna, három szürke s hözipen megszakadó liereszt-sujtással, alul lehér: nagyobb a vándor patkánynál.

Minden többi ersénscsek a keleti tartományokban homolnak s fökepen L jhollandiában, melly ridékek leginliább czen esaládbeli állatokkal látszanak népesítve lenni.

\section{A KÉTMÉIIÜEK.}

\section{(Les Thylacines. Thylacinus. (1) 'Tem.)}

Legnagrobbak ezen clsö osztílıban; a fijahordiktul megkïlönböztetnck hürelyktełen hátulsó lábaik, lepledt (mezes), nem fogodzo farkok, mindenik állkapocsban kettivel kevesebb metszö fogok által; záplogaik hasonló szaimuak. Ekképen negyren hat liggok ran, hanem a hirom nagyobbak külsö srále clönyult és cles majd mint az ebek típö foga ; fülcik lepledtck (mezesek), középszcrïck.

Csak egy faja ismereles, Tan Diémen földérül, melly farkas nagysigu, alacsonyabb száru, szürhe szinï, kereszlén fekete ítronatlal. Ebfejü kélmèhü, Didelph. cynocephala, Harris. 'Trans. linn. IX, xix, I. s Encycl. meth. Mammif. Supl. viI. rl. 3 k. Igen húsevö, minden apró emlösre vadászatot tesz.

\section{AZ ISZÁкок.}

\section{(Les Phascogales. Phascogale. 'Temm).}

Fogaik száma az, melly a liélmébüeknél; hanem liözépsö metszöfogaik a többiekud hosszabbak, hátulso zípfogails pedig göröngyesebbek, a mi öket a fijahordokhoz ve-

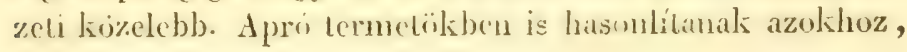

(') Thylacinus, a $\vartheta v i \alpha \% 0_{-}-\lfloor u \mid$, melly erszényt jelent. - A mi (parisi) gypsbányáinkban is talailattak ency kétméhii faj csontai. 
hanem farkok nem fogúdzú; hátulsú hüvelykök igen rürid ugyan, hanem jól kiösmerhetó.

Az ecsetes izsák. Le Phasc. à pinceau. Did. penicillala. Sh. (Gem. zool. I, II. xl. 113. Schreb. CLII, B. L.

Hamvas; farka hosszú fekete szörrel födött, vándorpatkíny nagyságu, a fákon lakik Újhollandban és olt a bogarakat kergeti.

Az apró iszcik. (Le Phasc. nain. Dasyurus minimus, Geofl.) Schr. 152, rl. B. C.

Alig nagyobb az egérnél, bundája vereses, gyapjas. Van Diémen fồldénék délérül.

\section{A MEZFARKOK.}

\section{(Les Dasyures. Dasyurus. Geoff.) (')}

Minden állkitpesoliban két metszö s négy zápfoggal keresebbök van mint a fijahordóknak, ugy hogy csak negyvenkét fogok marad, s farkok egészen födve hosszú szörrel, épen nem fogódzó. Hátulsó hüvelykök gumo idommá csuporodott vagy egészen is eltünt. Újhollandban élnek bogarakkal, dögökkel, hízakba is behatuak, hol igen alkalmatlan torkosságuak, stb. Szajjok kevesebbé hasitott, arcorrok kevesbé hegyes, fülcik füdültek s rövidebbek mint a lijahordóknál. Fákra épen nem másznak.

A borzu mezfark. (Le Dasyure hérissé. Did. ursina. Harr.) 'Irans. lin. IX, xIx, 2. k. és Encycl. Supp. 7, 6. k.

Szöre durva hosszú feliete, néhány rendetlenül rakott fehér folttal; farka testénél fóllel rövidcbb, alul majdnem csupasz. Tan Diémen földének éjszakín lakik s nagysága a borzéhoz közelíl.

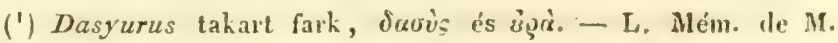
Geoff., Ann. du Mus. 111, 353. 1. is XV, 301.1. 
A hossufarku mezfark. (Le Dasyure a longue queue. Das. macrourus. Geofl.) Peron. Voy. 33. rl. Schreb. CLII, B. a.

Macslia nagy ságnyi, farliat olly hosszú mint a teste, bundija barnat, testen s litrkin fehir fultokisal. A hürelyk-gumó még ezen fajban igen láthati, hanem a liöreckezölnél nem.

Maugé mezfarka. (Le Dasyure de Mauge. Das. Maugei. Geoll. Toy. de Freycin. Zool. 4. rl. Schreb. CLII, B. b.

Ulajziold, fehér foltukkal, farka folttalan, valamivel kisebb az elöbbinél.

Thite mezfarka. (Le Dasyure de Ifthile. Did. viver-

rina. Schaw. Gen. Zoul. CXI.) Whute. Bot. b. App. 285. - Schreb. CLII, B. c.

Feliete, fehér foltokkal, farka folttalan, az elsönél egy harmaddal kisebb.

\section{A KöחöNKŨLYöK.}

(Les P'eraméles. ( $\left.{ }^{1}\right)$ Perameles. Geolf. Thylacis. Ilig.)

Hílulsó hürelykök rïrid mmt a mezfarkok elsöjénél, az czelire küretlezö kít uj a bör által egész a körömig egyesitett. Elsö lábaili hürely lie s lis uja egyszerï gumóidomuak, ugy hogy esak három ujat látszanak ott birni; fölül tiz metszö fogok ram, mellyek liözölt a szélsök hegyesck, szétíltik; alul csak hal; hanem zápfogaik mint a fijahordiknál: mégis negyvennyole fogok számláltatik. Farkok fơdült, nem fogódzó. Szinte Australiában élnek. Elsö, majdnem egyenes nagy körmeik azt mulatják, hogy földásók, hútulsí hosszú lábaik pedig, hogy futísok sebes lehet.

(') Pera-meles=erszćnylion (meles boiz, pera erszény). L. Mém. de M. Geoff, Anu. du Mus. IV, h. 
A hegyes arcoru kürümküly. (Le Péramèle de museau pointu. Perameles nasutus. G.) Ann. du Mus., IV.

Igen kingull arcorral; liegyes fülekkel, szürkésbarna bundíral. Elsó látísra a türises sünesuthuz hasonlít. (')

Az erszényesek második alosztálya az alsó állkapocsban két hosszú, széles, hegyes és éles, elöre hajló metszőfogat hord, mellyeknek a fölső állkapocsban hat felel meg. Fölső szemfogaik még hoszszúk és hegyesek; hanem az íny által elrejtetnek; az utolsó alnem néha épen nem bir egyet is.

Életrendök nagyobb részint növevényi; innét beleik, s kivált vakbelök sokkal hosszabbak, mint a fijahordóknál, mindnyájának nagy húvelyke van, a többi ujaktul annyira elválasztott, hogy majdnem mint a madaraknál hátra irányzottnak látszik. Körömtelen, - s az ő reá következő két uj egész az utolsó pörcig egyesített a bör által. Ezen alkotásnál fogva hivatnak

PERCKÜLYöK-nek.

(Phalangers. Phalangista. Cuv.)

A tulajdonképi perckïlyök.

(Les Phalangers ${ }^{2}$ ) proprement dits. - Balantia. Ilig.)

Oldalaikon a bör nem lerult ki; mindenik állkapocsban négy, két sorban álló nígy hegyü hátulsó zápfogok

(') A Bougainville körömkülye. (Le Péramèle Bougainillle, de M. M. Quoy et Gaymard) a hegyes arcorutul faj:lag nem különhözik. A péram. obesula, Geoff. nem eléggé hiteles.

( $\left.{ }^{2}\right)$ A phalanger novezctef Bufton hét megvizsgalta egyénnek adi, 
van, elül pedig egy nagy, kúpos összenyomot, és ezek s a fölsö szemfog liözött liét apró s hegyes, - mellyel_nek alul igen kiesinyek felchek meg, mint rólok szólánk; - farkok mindig fogódzó.

Ez némellyelnuél nagy részint pikkelyes. Ezck a fákon laknak, a molukkaiakon, hol bogarakat s gyümölcsöt keresnek. Ila embert látnak, farkoknál fogva fölakasztják magoliat s leszesen nézrén reájol, annyira mehetui, hogy a bádjadtság miatt leesnek. Rosz szagot terjesztenek el, húsokat azonban még is megeszik.

Külünbfële nagı siguakat és szörüehet ismeni, melylyeket Limé mind egrbe foglalt a Didelphis orientalis név alatt.

Temmink atzokat lajokrit gondoli oszthatóknak a mint következik.

A medve-perckiely'. (Phalanger oursin. Ph. ursina. 'I'.)

Majdnem alikora mint a kïzänseges pety meg; bundája tömött, lekelés barna; a liatalok sárga-barnál. Celebes sziget erdeibül.

Az aranytereszlï perckïly. (Le Phalanger à croupe dorée. Ph. crysorrhous. 'Т.)

Akkora mint egy nagg macska; bundaija hamvas barna; alul fehere, a keresztén aranysitrga. A molukkai szigeteliriil.

általa a lib kèt ujünak egyesitését jelentendō. A philander név nem szármozott a görögtiil mint hinni lehetne, hasem a pelandor-tul, melly malaji nyelven tengeri nyulat jelent s mellyet az Amboina lahosai egy z'etfark-fajnak adtak. Séha és Brisson kiilonbség nélkül adák minden erszényesnek. A perckülök a molukkai szigeteken kuszkusz vagy kusszu nevüek. Az elsõ utazók nem küionböztetvén öket a fijahordóktul eléggé még, azon hilre adtak alkalmat, hogy ezen utolsú fij mindenik foldrészen honias. Bulatia. Porhayrov-lul (zsch), zsák) jô. 
A foltos perckïly. (Le Phalanger tacheté. Ph. maculata. T.) Buff. XIII, I. rl. Voy. de Freycinet. 7. rl. Voy. de Duperr, 4. rl.

Macska nagyságnyi, fehéres, barnával rendetlenül foltozva vagy márványozva.

$A$ homorhomloku perckilly. (Le Phalanger à front concave. Ph. cavifrons. 'Г.) Buff. 10. rl. (a nöstény). Voy. de Duperrey, (a him).

A him fehér, a uö sárga, háta hosszában egy barna sugárral.

Ide rethetö még

A hátcsitos percküly. (Le Phalanger Quoy. Ph. Quoy.) Voy. de Freycinet. vi. rl.

Barnaszürke, keresztén feketés barna hosszas sujtis; feje föle fahaj-verhenyes, pofa, lorka, mele fehérek. (')

Másoknál, mellyek mind eddig csak Újhollandiában találtattak, a fark egész a hegyéig lepledt (mezes). A rókís perckilly. (Le Phalanger renard. Did. lemurino et vulpina). Schaw. Bruno de Viq. d' Az. White. Voy. 278.

Erös nacska nagyságnyi, barnaszürlie, alul halaványabb, farka nagy része fekete.

Cook perckillye. (Le Phalanger de Cook.) (Cook utolsó utj. 8. rl).

Kiscbb a macskánál, fölül barna, alul fehér, fején s oldalain verhenyes; farka hátulsó harmada fehér.

Bougainville perckülye. (Le Phalanger de Bougainville).

Akkora mint egy mókus, fülül hamras, alul fehér, farka hálulso fele fekete, füle hátulsó fele pedig fohér. $\left({ }^{2}\right)$

(') $\mathrm{Ez}$ jól megkülöuböztetctt faj.

() Egy ij faj, mcllyct Bougainville báró hozolt baza ulolsn útjåról. 


\section{A REPÜLó PERCKÚLYÖK.}

(Les Phalangers volants. Petaurus. Schaw. Phalangista, Iliger.)

Oldalbörök täbbé levesebbé literjedve száraik kïzött, mint a röpereleknél az örlöh (rígesák) rendében, “ mi obet nomelly ideig a levegüben fön hagy ja tartózlodni a nagy ugrásokra segriti. Szinte esupin Újhollandban takáltatnak.

Nímclly fajaiknil ramulk migg alsó szemfogak, hanem iscn kicsinyck. Fölsö szemfogank s clsö három zápfogok mind foilul mind alul igen hegyesck; hátulsi zápaik mindenilién négy hegy. (1)

1 kis repülö perckilily. (Le Phalanger volant nain. Did. P.gemaea. Shaw. Gen. zool. 114 rl.) Schr. CXLIV. A.

Egérszinii s majdnem regenagysigu; farka szöre igen szabályosan rendelve el, híl oldahul mint a loll szakíllit.

Másolnuil hibiznak az alsi szemfogak s a lölsök igen aproik. Negg hilulsi zaplogek szinte negy hegyet mulat, hancm egy heresse libholdulag görbiilve, melly idom

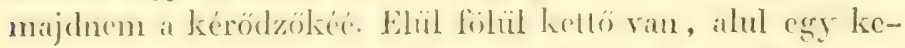
vesbé bonyoll: a melly alkat a többickncl inkáb növeny evőkké teszi öket.

A nagy repuliö perckilly. (T,e grand Phalanger volant. Did. petaurus. Schaw. Gen. zool. cxir. rl. White. Voy. 288.

Nag̨ sígára nézve a sziget-soki röpevethez és a csakugrászhoz hasonlíl; szöre pulha, sírï, litlia hosszú s lapult. Fülül barna-felece, alul feher. Külöblële barna áruyalatuak, de tarkák, és csupa fehérek is rannak.

(') Ezcn clsõ alosatálybul csindila Desinarets az acrobate nemet. 
A tarka repuili perckilly. (Le Phalanger volunt borde. Did. sciurea. Shaw. cxmI. rl. 3.)

Vándor-patkány nagyságnyi, fölul hamvas, alul fechér ; cgy barna vonal az orrtüvétül leczdődve lenyúl az egész hátín; az oldalhairlya szélci barnák, farka bojtos ès olly hosszú mint a teste, hátulsó részén fekcte. Újguinea szomszéd szigeteirül.

A leples repülö perckiilly. (Le Phalanger volant à pieds velus. Pet. Peronii. Desmar.)

Verhenyes-barna-sziüke, fülci elcje s teste alja fehéres; lábujai igen mezesek, barnák; farka fekete, testénél hoszszabb, végén fehér.

A hosszufarku röpülö perckilly'. (Le Phalanger volant à longue queue. Did. macroura. Schaw. cxin. rl. 2. k.

Fölül sölét barna, alul fehér, akkora mintegy vándor patkány, farka vékony, másfélszer olly hosszú mint teste.

Harmadik alosztályunknál a metszők, fölsö szemfogak s a hátulsó láb cgyesült ujai ollyanok, mint a másodiknál ; hanem hibáznak nála a hátulsó hüvelykek és az alsó szemfogak. Csak egy nemet foglal mazában.

\section{A FÖNFAROK.}

(Les Potoroos. Hypizprymnus. Ilig. (')

Utolsó állatok ezen családbul, mellyck a ragadozok általános sajátságaibul valamit birnak. Fogaik majdnem épen azok, mellyck a perckúlöknél s föliil még egy hegyes szcmfogok is van. Fölül a két középsö metszö fogak

(") "ryoเrovuvòs =fölemell hátulsó fel. 
hosszabbak a löbbicknél és hegyesek; az alsík szima liettö s ezck elöre irányzottak. Flül egy hosszú éles és fogazout zípjok ran. mellyre negy másik következik, nigy négy tompa gumovial födött. Ezen állatoliat leginkább megkülönbözletili hátulsó száraik, aránylag sokkal nagyobbak az elsöknél, mellyelsen a lábak hürelyk nélkiil szüiölküdnek s elsï liét ujok cgész a körömig egyesült, olly mridon, hogy clöszörre csak három ujat vélünk látni , mellyek közül a belsö két körmöi hord. Néha két lábon jímak, s aklior a föntarlizkodás vígett hosszú s crös farkokhoz támaszliodnak. 'Tehát a retfarkok idomát és erkölesét birják, mellyektül csak fólsö állkapcsokbeli szemfogok állal különböznck. F́letrendïk növényi, gyomruk nagy, két zsebre oszlott, s löbb puffaclís által crösített; hanem rakbelök középszerï s gömbölyú.

Csak egy-fajok ïsmeretes, egy kis tengeri nyul nagyságnyi, s egérszürce, a : rendes fünfar. (Kanguroo-Rat. Macropus minor. Schaw.) Újhollandbúl jö, hol a lakosolnat Potoroo a neve. White, Bot. B. 286. Voy. de Freycinct, $10 \mathrm{rl}$.

A negyedik alosztély a harmadiktul csak abban különbözik, hogy épen nincs szemfoga. Ezek:

A VeTFArкoK. (Farkagyámok. Ugrányok.) (Les Kanguroos. Macropus, Schaw. Halmaturus. Ilig. ( $\left.{ }^{1}\right)$.

Ezek mind azon jegyeket mulatják, mellyeket az clöbbi nemnél elmondtunk, kivévén hogy fölsö szemfogok hibizik, és hogy középsö metszöik a többieket nem haladjak meg. Szairaik eggenclensige még nagyobb, ugy

(1) Halmaturus, ugrani alkalmas fask. 
hogy négy lábon csak nehezen és lassan mennek, hanem nagy élénken ugrálnak a hátulsólkon, mellyuek kzözépső nagy körme, majdnem mancsidomu, védelmül is szolgál nekik, mert egyik szárokon és iszonyú farkokon támaszkodva, a szabad lábakkal elég eröszakos ütéseket lsépesek osztani. Különben pedig igen szelid állatok, füvel élök. Zápfogaik nem is mutatnak egyebet kereszt-emelkedeteknél. Öt számoltatik nálok, az elsők többé kevesebbé élesek s idövel kihullók, a honnan a vének néha csak hármat birnak. Gyomrokat két hosszú erszény képezi, puffadatokra oszlú mint a hurkabél. Vakbelök szinte nagy és puffadt; orsú csontok elökarjoknak teljes kürmozgást enged.

Ezen két nem resszeje nem kétágu; hanem nömüszereik ollyanok mint a többi erszényeseknél.

Az ugrainy vetfark. Földinél Kenguru ugriny. (Le Kanguroo géant. Macropus major. Schaw. Didelphis gigantea. Gm. Schr. CLIII.

Néha hat lábnyi magas; legnagyobb állat Újhollandban; Cook által találtaték föl 1779ben s ma Europában is tenyész. Azt mondják, hogy husa a szarvaséhoz hasonlit. Kölkei, mellyek születésükkor csak egy hürelyknyiek, mind addig vissza mennek anyjok zsebébe mignem legelészni képesek, mit arcorrokat a zsebbül kidhgva tesznek, mig maga az anyjok is legel. Ezen állatok scregekben élnek, mellyeket az öreg hímek vezérelnek. Szörnyủ ugrásokat tesznek. Ugy látszik, hogy ezen név alatt mind. eddig több újhollandiai és szomszéd szigetekbeli fajok zavartattak egybe, mellyeknck bundája, többé kevesebbé szürkke, csak igen csekély árnyolatokban különbözilk. (')

Sokkal clöbb ismeretes volt egyil faj:

( $\left.{ }^{1}\right)$ Gcolroy megkülönbözteti a kormos z'etfarkot (Le kanguruo enfumé melly sötétebb szürke, bajuszos v. (le k. à mơistaikes), melly fölso̊ ajakín fehcies; a veresnyaku 2 . (le k. a cou roux), A többiekuél egy kissé apróbbat, verhenyes tartiojut. Lcsson is Gar-

CUVIER I. K. 
As arui vetfark. (Le kanguroo d'Aroé. Didelphis Brunii, Gm.) Schrcb. CLIII, máskép: Pelandor Aroé; Lapin d' Aroé (arui tengeri nyul) a malajoknál Amboina szigetén.

Hanem az europai természetvizsgálók nem voltak clegendö figyelemmel a Valentin és Bruyn rólok adták leirásra. Nagyobb a nyulnál, fölïl barma, alul sárga, s az arui szigetcken találtatik Bandi-hoz kïzel, s a szoloriakon is. A tetswelmes vetfark. (Le Kanguroo élégrant. Halm. eleganis. Per. Voy. xxvir. köt.

Akkora mint egy nagy nyúl: s keresztben barna sugárzatos, fehér szürke alapon. Sz. Péter szigetén találtatik.

Az ötödik alosztály alsó állkapcsában két hoszszu metszö fog van szemfogak nélkül; a fölsóben közepen két hosszu metszö, oldalvást néhány apró, s két kis szemfog; csak egy nemet bir.

\section{A CsúT-ok.}

(Les Koala Cur. Lipurus, Goldfuss. Phascolarclos. Blaint.)

Zämök tesucl, rövid szárokkal, fark nélkül; elsó njaik, szímra öten a fogús végett két csomóra oszlanak, a hüvelyk és mutató uj cryik, a más hírom másik félrül.

not még egy barna velfarkot áhrázolnah le oualabate név alatt. $\mathbf{L}$. Duperrey. Voy vir. rl. Szinte helye lesz hihet8leg, hogy a fahejzerhenyes retfarkbul ( $k$. laniger, Quoy et Gaym.), Voy de Freyrinct. $I X, r l$. és a kékes hamvas retfarkbul külön fajak csináltassanak; hanem mind czen emlóseket meg kell különbözỏ életkoraikban vizsgálni, s megósmerni, melly befolyással van a nem és kol a színekre, minekelotte rajaik meghatározra fölállittatnának. 
Hátulsó lábokon hibázil a hüvelyk, mellycken az elsó ujak egyesülve vannak, mint a perckülyöknél és vetfarkolknál.

A hamvas csút (Lipurus cinereus Goldf. Schreb. CLV, A, a.) - egy ösmeretes faj, hamvas szörü, melly élete egy részét a fákon tölti, a másikat pedig az azoknak tövén ásott barlangokban. Az anya solká hátán hordozza kölkeit.

\section{Végre erszényeseink hatodik alosztályat vagy}

\section{AZ ERSZÉK}

\section{(Les Phascolomes, Phascolomys. Geoflr. (')}

Fogaikra s belcikre nézve valósígos örlök. s a ragadozók osztályáral semmi bélyegegyezést nem tartanak megr: mint alsó állkapcsok ízesülésél; és a szigorú rendszerben öket az örlókhöz kellene helyheztetni; s mi oda is tcttük volna, ha szakadatlan sorban nem rezeltetünk volna a fijahordóktul a perckülyekhı̈z, ezektiil a vetfarkokhoz, a retfarkoktul pedig az erszékhez, s végre ha nemzö müszercik teljesen nem hasonlítanának az egész erszényesek családjáéihoz.

Otromba állatok, vastag lapos fejjel, rövid szárakkal, mintegy elvágott, farkatlan testtel, elsö lábaikon öt lörmöt hordozók, a hátulsókon négyet, a hïvelyk helyett cgy kis gumóval, mellyek mind hosszúk s ásni valók. Járások rend fölött lomha. Mindenik állkapcsokban két hosszí metszó fogok van majdnem az örlókéihez hasonlók, zápfogaikon pedig két kereszt-eresz ran.

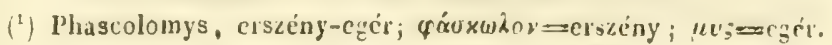


Fúvekkel élnck; gyomrok körteidomu, vakbekik nagy és rövid, féregtoldaléku mint az embernél s a homlokmagas emlörnél. Vesszejök kélígu mint a fijahnrđóknál.

Csak egy faja ismeretes, borz nagy ságu, tömöttszoru, többé kevesebbé sárgás barna. King szigetén él, Újholland délénì, barlangokban, s nálunk kiönnyen szaporodik; azt mondják hogy húsa igen jeles. Ez

A barna ersze (Didelphis ursina. Schaw.; a lakosoktul If ombat-nak neveztetik. (') Peron. Voy. xxxvin. rl.

AZ EULÖSEK ÖTÖDIK RENDE.

\section{AZ ÖRLÖK.}

(RÁGICSÁK, LES RONGEURS.)

A perckülycknél olly apró szemfogakat látunk, hogy azokat semmi gyanánt vehetnök; szinte eledelök ezen állatoknak nagy részint a növényországbul vett, beleik hosszúk, vakbelök bö; és i vetfurkok, mellyeknél éppen nincsenek szemfogak, csupán növénynyel élnek.

A most ábrázolandó állatok sorát az erszékkel

(1) Bass leirt egy állatot, melly külsơképen az erszchez hasonlit, s mellyet $\delta$ srinte Wombat-nak nevez, de a melly hat metsı̉, hét szem-és tizeuhat záp-fogat bir mindenik allkapcsálıan. Ha 11 két kulönbözỏ leirás hamis összekeverése nem rejterkedik, egy alnem lesz, a hörombillyek közeletere helyheztelendo. Iliger neg is alhota már ezt amblotis ( $\mu \rho i \lambda \omega r \iota s$, abortus, velélkedés) név alatl. L. Mém. de Pétersb. 1805. 1806, 414. 1. és Bulletin des 8e. 72 s\%. X1. ér. 
lehetne kezdeni, mellyeknek rágása még tökélytelenebb.

Két nagy metszőfog mindenik állkapocsban, a zápoktul üres tér által elválasztva, nem könnyen foghat élö zsákmányt, sem a hust nem tépheti el ; sôt azok az eledeleket el sem metszhetik, hanem azoknak reszelésére s hosszú munka által lisztté valo őrlésére szolgálnak, egy szóval az órlésre; innét adaték az örlők nevezete az ezen rendbeli állatoknak; innét van hogy sikerrel támadják meg a legkeményebb anyagokat is, s gyakran fával és kéreggel élnek. Ezen cél jobb elérhetése végett metsző fogaikon csak melül van nagyon kemény erös máz, s innét hátulsó felök az elsőnél mindig jobban elvásván azok mindig vésü idomot birnak; hengerképök miatt pedig gyökerökrül annyival nölnek fölebb, menynyire fönt elvástak az örlésben; és ezen nölési hajlandóságok olly nagy, hogy ha valamellyik fog elvész vagy kitörik, átellenese egész az iszonyatosságig nól, nem lévén a mi kisebbítse. Az alsó állkapocs hoszszúdad bütyök által ízesül ugy, hogy látköries mozgása csak elörül hátra $s$ megfordítva van; a mint az örlés munkálathoz megkivántatik; a zápfogaknak szinte lapos koronáik vannak, mellyeknek máz-emelkedései mindig keresztben állók, hogy az állkapocs súlyegyenes mozgásával ellenzésben legyen s jobban szolgálhasson az örlésre.

Azon nemek, hol ezen emelkedéseket egyszerü vonalok teszik s hol a korona jó lapos, egészen 
kizárólag növényevök; azok, mellyeknek fogai tompa gumókra osz.tott emelkedésïek, mindenevók; végre azoknak esekély száma, mellyek hegyes kúpokat birnak, más állatokat önkényesen támadnak meg, s valamennyire a ragadozókhoz közelítenek.

Az örlök testének idoma általában ollyan, hogy hátulok magasabb az elejöknél, ugy hogy inkább ugranak mint mennek; ezen hạ̣lam némellyeknél szinte olly mértékföli mint az ugráuyoknál.

Az örlök' belei igen hosszúk; gyomrok egyszerü vagy, kevessé osztott, vakbelök gyakran igen nagy, a gyomornál is nagyobb. A pelék alneménél azonban mégis hibázik ezen bél.

Ezen egész osztályban majd egészen sima és ujnyomattalan az agy; a szemgödrök nincsenek a halanték-árkoktul elválasztva, a kevessé mélyektül; a szemek egészen oldalvást irányzottak; a gyönge és alá hajlott járomivek az állkapcsok gyöngeségét hirdetik; az elökar alig forgatható s annak két csontja gyakran egyesült; egyszóval: ezen állatok alsóbbsága alkotások bélyegeinck nagyoblo részében mutatikozik. Azonban azon nemek, mellyeknek erösebb vállperceik vannak, bizonyos ïgyességet birúk s elsö lábaikat az eledelek szájokhoz vitelére használják.

Még a fákra könnyüséggel mászók is vannak köztök; illyenek :

A Mókusok.

(Les Écureuils. Sciurus. L.)

Megismerhetók igen öszenyomolt alsi metszö fogails 
és hosszú s bojtos farkaik által. Elül négy, hátul üt ujok van. Néha a melsó hüvelykök egy gomó által mutattatik. Mindnyájánál négy, különbféle púpozatos zápfogok van, s többnyire elül fölül még egy apró is, melly jókor kiesik. Fejök széles, szemeik kidúzadtak, élénkek. Igen könynyú állatok ezek, a fákon fészliclök s gyümölcscsel élök.

\section{A tulajdonképi мóкusok.}

(Les Ecureuils proprement dits. Sciurus. Cuv.)

Farkok bojtja oldalvást irányzott és mintegy nagy tollat ábrázol. Sok fajok van a két szárazon.

Az evet mókus. Földi. (L. Écureuil commun. Sciurus vulgaris. Lin.) Buff. VII, 32. Schreb. 212. rl.

Háta vidám verhenyes, hasa fehér, fülei szörbojtba végzödök. Az éjszakiak télen szép hamvaskékes hátuak lesznek, s a szürke evetprémet (le petit-gris) adják, ha csak a hátárul vetetik, a fehérszürkét (vair) ha a hasa fehér része is rajta hagyatik.

$\mathrm{Az}$ amerikai fajok nem birnak szörecsetet füleiken; illyenek:

A karolinai szürke mókus. (L' Écureuil gris de Caroline.

Sciurus cinereus. Lin.) Petit-Gris. Buff. X, xxv.

A mienknél nagyobb, hamvas, fehér hasu.

Az cilarcos mókus. ( $L$ ' Écureuil à masque, ugyan azon vidékrül. Sc. capistratus.) Bosc. Sc. cinereus Schreb. GCXIII, B.

Hamvas; fekele fejü, fehér arcorru, fülü, hasu. Egyik s a másik is barnára vagy feketére változó, s néha egészen feketék leszuek. ( $\left.{ }^{(}\right)$

(') Ugy látszik hogy a Sc. vulpinus, carolinensis és niger csak fajtäi enuck. 
$\mathrm{Az}$ of vilígheli fajtík nagyobb része is ecsettelen fuilii. Egy a legszebbek közuil :

Az indiai nagy mikus. (Le grand ficureuil des Indes. S'c. maximus et macrourus. (1) Gm.) Buff. Supp. VII, I.XXII.

Majd alskora mint egy macska, fölül fekete, oldalain és feje telején szép ridám geszlenyeszinü; feje, testc egés\% alja s tagjai belseje halavány sárgáls; pofája mögöll esgy rerhenyes barna sujlás. A pálmafákon lakik, s kivált a kókosdiók tejnedvét szomjuzza.

A heves éghajlat alatt ramuk még hosz-csikolatok által nevezetes mokiusok, mellyek bundájokat tarkásítjåk. Illyenek :

A berber mokizs. (Le barbaresque. Sc. getulus. L.) Buff. $\mathrm{X}$, xxvi.

Mellynek csikolatai egész a farkig nyulnak.

A pálmaizó mókus. (Le Palmiste. Sc. palmarum, L.) Buff. X, xxvi.

Csak a hátán sujtásos.

Igen hihetö, hogy a mókusoktul némelly fajok alaposan megkülönböztetendök, pof\%sebeket birók mint a hörcsölsök, s füldalatti üregekben dök. Ezek:

\section{A HÖRCSEVETEK.}

Illyen: (Tamia. Ilig.)

A csikolt hörcsevet. (Le Suisse. Sc. striatus. L.) Buft. $\mathrm{X}$, xxviı.

Melly egész Asia és Amerika éjszakán találtatik fóképen a fenyres erdöliben. Farka kevesbbé bojtos, mint

(') Elegendỏ Pennant is Somucrat ábrázolásait ösezehasonlitani annak megitélésćre, hogy ugyan azon állatot mutatják. 
az europai evetnél, fülei simák, bundája barna, üt fekete és két fehéres csikolattal.

Hihetóleg még megkülönböztethetók:

$$
A \text { farkevetek (Les guerlinguets), }
$$

mellyeknek hosszú, majdnem gömbölyü farkok, s iszonyú fïggö borékok van. Fajai mind a két szárazon találtatnak ('). Már elválasztattak:

\section{A RÖPEVETEK.}

(Les Polatouches. Pteromys. Cuv.)

Mellyeknél az oldalak bóre a melsö és hátulsó lábak között kiterjedve lévén, ügyesekké teszi öket, hogy egy ideig a levegöben tarlózkodjanak és igen nagy ugrásokat tegyenek. Lábaikon hosszú csonttoldalékok vannak. mellyek ezen oldalhírtya egy részét tartjáli.

Egy faja Lengyel-s Oroszhonban és Sibériában talíltatik:

A lengyel röpevet. Földinél repiilö mókus. Sciur. volans. Linn.) Schreb. GaxxiII.

Fölül hamvas szürke, alul fehér, patkány nagyságu, farka hossza teste felét üti föl; magányosan lakils az erdókben. Egy faj Amerika éjszakárul:

Az amerikai röpevet. $S c$. voluccella. Linn. Buff. X. xxI.

Föliil verhenyes szürke, alul fehér, félakkora mint az elöbbi, farka csak egy negyeddel kisebb a testénél. Seregesen lakik a mérsékelt Éjszak-amerika rétein.

$\mathrm{Az}$ indiai sziget-sokon egy majdnem macska nagysígu faj van; a hím fölül szép vídám gesztenyebarna, alul verhenyes; nösténye fölöl barna, alul fehéres. Ez:

(') Azonbau $\mathrm{mi}$ a hörcseveteknél is firkercteknél, nem kiilönben mint a röpeveteknél uzyan azon zápfogat találtuk, mellyeket a mókusoknál. 
A sziget-soki rüpevet. (Le 'Taguan. Buff. Supp. III. xxı. és VII, Lxvil. Sc. petaurista. Lin.)

Hanem ugyan azon sziget-sokon egy másik kis fij is van:

\section{A nyilas röpevet. (Sciurus sagitta.)}

Fölül sötét barna, alul fehér, a tübbi apró fajoktul föképen abban különbozö, hogy mint az elöbbi fajuál is, egy igen hegyes kiálló szegletet képez keze mögütt a lártyảja.

Végre Geoflioy oliosan clválasztá czen nemtül

\section{AZ ÁJÁJAK-at.}

(Les Aye-Aye. Geoffr. Cheiromys. Cuv.) (')

Mellyeknek alsó metszö fógaik még összenyomtabbak s föképen jobban kinyultak elörül hátra mint a mókusoknál, s a keréksarthoz hasonlítanak; mindenik lábakon öt uj van, s ezek közül elül négy igen hosszú, s czen számban a középuj a többinél sokkal vékonyabb; hátulsó líbokon a hüvelyk a többi ujak ellenébe tehetö, ugy hogy illy módon ök azok az örlók közt, a mik a lijahordúk a ragadozik közöll. Fejök alkotísa különben igen eltározik a többi örlókétül s némelly tekintetben megegyez a négykezüekével.

Az ajjájnak esak egy faja üsmeretes, mellyet Sommerat talált föl Madagasłạban.

A madagaskari äjaj. (Sc. madagascarinensis. Gm.) Buff. Supp. VII. LxviI.

Nyul nagyágu, sairgíral lievert barna, hosszú, vastag farku, durva fekete szörrel födve, meztelen nagy fülü. Ëjjeli állat, lomhán mozgi, barlangban lakó. Vékony ujait eledelének szájába hordására használja.

Linné és Pallas egy esapatba egyesítették,

(1) Pceromys, szácuyas patkiny; cheiromys, kezes patkány. 


\section{PATKÁNYOK}

(Rats. Mus.)

nevezete alatt, minden vállpereces örlöt, mellyeket nem lehcle valami igen szembe ötlö külsó jegy által megkülönböztetni, mint a mókust és hódot farka által, hounan az eredt, hogy általános bélyeget nem lehete nekik adni; nagyobb részénél csak az alsú metsző fogak voltak hegyesek, hanem még ezen jegy is kivételeket szenvedett.

Gmelin már elválasztá tólök a mormogáksat, peléket és nigregerckel; hanem mi sokkal torább vittük alosztásokat, zápfogaik idomát véve tekintetbe.

\section{A MoRMogáK.}

\section{(Les Marmottes. Arctomys. (') Gm.)}

Alsó melszö fogaik hegyesek mint a patkányok ncméhez tartozó állatok nagyobb részénél, hanem zápjaik, mint a mókusoknál, fölül mindenik oldalon öten vannak, alul négyen, mind hegyekkel födve. Ezek szerint némelly fajak könnyen húsevésre határozzák magokat és bogarakat szinte ugy esznek, mint növényt. Elsö lábokon négy ujok van, és egy gumó a hüvelyk helyett, a hátulsón öt uj. Más tekintetben ezek majd egészen ellenkezó állatok a mókusokkal, otrombák, rövid száruak, középszerü vagy rövid mezes farkuak, széles lapos fejüek, a telet mély barlangokban zsibbadva töltök, mellyeknek bemenetelét szénacsutakkal dugják bc. Társaságosan élnek és könnyen megszelidülnek. A régi vilúgban két faj ösnieretes :

A havasi mormoga. Földinél havasi murmulér. (La Marmolte des Alpes. Mus alpinus. Lin.) Buff. VIII, xxviII.

Akkora mint egy tengeri nyul, rövid farku, sárgás

(') Arecounys=medrepathány. 
szairke bundiju. feje felé hamvas. A magas bérecken lakik mindjárt az örök havak alatt.

A lengyel mormoga. (La Marmotte de Pologne, ou Bobac. Mus bobac. Lin.) Pall. Glir. V. Schreb. CCIX.

Akliora mint az elöbbi, sárgás szürke, feje felé rereses; a kevessé magas hegyeket és halmokat lakja Lengyel-hontul egész Kamcsatkíig; néha a legkeményebb földben ás ( $\left.{ }^{2}\right)$.

Amerikában is van néhány faja; az egyik nagyobb, szürke, hosszab feketés farku s fej-fölü; ez

A szürke mormoga. (Arct. monax. Buff. Supp. III, 28.)

És egy kisebb, szürke, alsó részei veresek. Ez

A verhenyes alu mormoga. (Arctomys empetra, Schreb. GX.)

Ürgék, Mormogzsebücük (Spermophiles.) Fréd. C'uv., neve alatt megkiüönbözleljük a pofzsebbel biró mormogákat. Könnyebb idomok mialt földi mókusoknak neveztetnek. Keleti Europa bir egyet közülök.

Az ürge. Földinćl ürge murmutér. (Le Souslik ou Zizel. Marmota Citillus. Linn.) Bufr. Supp. III, xxxi.

Csinos barna szürke állat, fehér esöppekkel hullámozva avvagy foltozva, melly Csehországtul egész Siberaiaig találtató. Különös hajlandósága van à hushoz, s tulajdon faját sem kíméli.

Éjszakamerikában több faj van, mellyek közül az egyik tizenhárom sárga csikja által nevezetes, melly háta feketés talajú (alapu) szinén uralkodik. Ez

(') Az orosz utazók Buchariában némelly más mormogákrul is szólanak: arct. fulvus, arct. leptodactylus, arct. mugosariius, mellyek azonban talám uem eléggé különböznek a lengyelmormogítul vagy az ürgétial. 
A 13-csikos morgzseböc. (Le Souslik à treize raues, Arctomys 13-lineatus, Harl. Sciurus 13-lineatus, Mitchil; arct. Hoodii, Sabine. 'Trans. limn. XIII, 29. rl. (').

Ugy látszik hogy a mormogákhoz közelít egy örlö, melly földalatti végetlen barlangokban seregesen tanyázásaért nevezeles. Az angol-ameriliaiak réti ebnek mondják ót, vagy ugató inókus-nak, szava miatt, melly az apró eb ugalásához hasonlít. Ez az Arctomys ludovicianus, Say., Voy, aux mont roch. I, 451. Rafinesque öt ujat tulajdonít neki mindenik lábáu s C'ynomys (ebegér) nemét alkotá belöle.

\section{A PELÉK. F. \\ (Les Loirs. Myoxus. Gm.)}

Alsó metszófogaik hegyesek, zápfogok mindenuitt négy, mellyeknek koszorúja beható mázvonalokłsal fölosztatolt.

Virgonc állatocskák, sima szörrel, mezes söt bojtos farkkal, élénk tekintettel, a fákon tartózkodók mint a mókusok, és gyümölescsel élök. Az örlök illyen nagy számában ez azon egyetlen nem, melly vakbél hijával van. A hideg érszakol mint a mormogák, igen mély zsibbadt álomban töltik. $\left({ }^{3}\right)$

(') T. h. arct. Parrii. Richards., App. du Voy. de Parry. 'Tobb marmota faj, mellyek Lewis és Clarke, Pary, Franklin, stb. utazásában emlittetnek, arct. Franklinii, Richardsonii, pruinosa ugy látszik, ezen alnembe helyhezletendỏk. L. Sabinc, Trans. Linu. XIII. xxvir, xxvil, stb. rl.

$\left({ }^{2}\right)$ Myoxus $=$ hegyes arcoru egér.

$\left.{ }^{3}\right)$ Ez annyira természetökben van, hogy egy senegali pele (M. Conpeii), melly természcti honiban hihetölcg soha scu zsibadt álumba, Europában a hideguch bitétetve, mindjart bele csett. 
Az ennivaló pele. Földi. (Le Loir. Mus glis Lin.) Buff. VIII, 24.

Patkány nagysigu, fölül hamvas-barnás szürke, alul fehéres, szeme körül sötétebb barna; farka cgész hosszíban jól lepledt (mezes) s majdnem ugy alkotott mint egy mókusé, gyakran a végén elágozott; Europa délszakán lakik, hol a fák odvaiban s a sziklák hasadékiban fészkel. Néha az apró madarakat üldözi. Hihetóleg ez azon patkíny, mellyet a régiek meghizlaltak s csemege gyanánt ettek. ( $\left.{ }^{1}\right)$

A cser pele. F. (Le Lérot. M. nitela. Gm.) Buff. VIII, 25.

Az clóbbi pelénél valamivel kisebb, fólül harna szürke, alul fehér, szeme kiörül feketésség, melly kitcrjeszlicdre egész a vállig uralkodik; farka esak a végén bojtos, - fekele, csak vége fehér; küzönsönséges a mi (francí́li) lierteinkben, hol a falak lyukaiban tartózko. dik, s a lécezetekben sok kárt tesz.

A mogyoró pele. $\mathrm{F}$. (Te Muscardin. M. avellanarius. Linn.) Buff. VIII, 26.

Egér nagyságu; föliil fahej-rerhenyes, alul fehér; farka szöre valamennyire tollidomba helyhezletelt. Egész Europa crdeiben. Fübiol csintil az alacsony ágakra lészket magának, kïlkcit ottan ncvelendö. Egyéb idejét s kivíltképen a telet fa-odvakban tölti $\left({ }^{2}\right)$.

A pelékhez közelítenek

\section{A TÖVISEGEREK.}

(Las Echimys. Geofl. Lonchères, Ilig.)

Szinte négy zápfogok van, hanem a fölsök egy $\mathrm{l}$. idomba hajlott két lemezböl, az alsok, cgy hajlott és cgy

(') A Mius dryas-a némelly szerzỏknek (Schicb. 220 B.) nem látszik kuilönbözni a cser pelótỏl.

(") Myoxus Coupci, Cur, Fridr, Manmil. 
cgyszeru lemezbül képezettek. 'Több fajnál a bunda durva és lapult törisckkel (mint a kardras) kevert. Amerikai állatok.

\section{Egyikök :}

Az aranyfarlu tövisegér. (L' Echimys à queue dorée; Lérot à queue dorée. Buff. Sup. VII, 72. Hystrix chrysuros. Schreb. GLXx, B.

Két akkora mint a vándorpatkány, szép állat, gesztcnye barna, fehér hasu, fején hosszú szörbül egy taraj és egy fehér hossz-csík; farka hosszú, fekete, hátulsó felén sárga. Guyanebul jö.

$A$ verhenyes tövisegér. ( $L$ ' Echimy's roux. Rat épineux d'Azzara. Voy. xiIr. rl.)

Akkora mint egy patkány, vereses szürke; farka rövidebb a testénél. Gvianában találtatik, s Brasiliában, Paraguaiban. Hosszú földalatti meneteket ás.

Másoknak csak közönséges, de többé kevesebbé durva szórök van.

\section{A pikkelyes tövisegér (Echimys dactylin. Geoff.),} legnevezctescbb köztök, melly az aranyfarkunál is nagyobb, s elsó lábain két középsö uja két akkora mint a szélsök; pikkelyes farka hosszabb a testénél; bundája sírgás szürkez orra szörci elöre irányzott tarajt képzenek. (')

\section{A VIZEGEREK.}

\section{(Les Hydromys. Geoff.)}

Külsejökre nézve sokban hasonlítanak a tïvisegerekhez, hanem minden egyéb patkányoktul különböznck hi-

(1) T. 1. a cajenni tözisegér; a sörtès tözisegér. Ugy vélcm, hogy a: mus paradoxus. Thoms. Tians. linn,, xi. (neteromis, Lesson.) a tövisegerchiül núsban nem különbozih, minthnzy profacebe van. Azonban fogait én nem látván, nem osztilyozhután ot. 
tulsó lábaik által, mellyek két harmadnyira úszóhártyásak; zápfogok mindenütt kettö s különös sajátsággal biro; minthogy koronája ferdén négyszegletes karélyokra osztott, mellyeknek teteje kanálidomra kiríjott. Viziek.

Van Diémen földérül fehérhasu és sárga hasu egyének hozattak, fölök pedig sötét barna, farkok hosszú, töben fèkete, hátulsó fèlén pedig fehér. Néha kèt akkorák mint a vándor palkíny. Hydromys leucogaster és 11. chrysugaster, Geoff. Ann. Mus. VI. 36. rl. (Fehérhasu, sairgahasu vizegér.

\section{A NYÚLEGEREK.}

\section{(Les Houtias. Capromys. Desmar).}

Mindenült negg záplogok vau, lapos koszorúju, mellynek máza befelé redösuil, ugy hogy a fölsö zápfogakon hírom bemenö szegletet képez a kïllsö szélen, egy cgyeset a belsön, - az alsó zípfogalion megfordítva. Farliok gömbölyü, gyöngén lödölt; hátulsó lábaikon, mint a patkányoknál, öt ujok van, az elsökön négy és a hüvelyknek csiraja; idomok iszonyu palkányhoz hisonlit, melly tengeri ragy mezei nyúl nagyságu volna.

Két faj ismeretes, egyik barna, arcora s nyalia alja feheres, farka rövid s testénel felével rövidebb, neve: Fourniere nyulegere. (C'apromys Fournieri. Houlia congo.) (Desm., Mém. de la Soc. d' Hist. nat. de Par., I., 1823.); - és egy kiscbb, barna, fehéres torku, veres is olly hosszu farku mint a teste; régén valamennyire csupasz, neve fogódzó nyúlegér. (C'apromy's prehensilis, Pocssig. Houtia caravalli.) Mindenik Kuba szigetén lakik; hol az agroutival együtt a laliosok fó radít teré a föltalálás elólt.

A tulajdonképi PATKÁNyoK.

(Les Rats. propement dits. Mus. Cur.)

Mindenüt három zápfog, ezels liözött az elsö legnitrrobb, mcllyucli liuszorija tompa púpolira osztotl, s 
mellyek elvásvín annak kï̈lönbféleképen kiesipkézett tállap idomot adnak; farkok hosszú, pikkelyes. Ezen állatok igen ártalmasak az ö termélienységök és torkosságok miatt, mellyuél fogra mindeuféle anyagokat megörlenck s fölfalnak. A házaliál hírom fajok szaporodolt igen $\mathrm{el}, \mathrm{u} . \mathrm{m}$.

Az egér. Földinćl házi egér. (La Souris. Mus musculus. Linn.) Buff. VII, xxxIx.

Minden idóbül s mindenki elótt ismeretes.

A patkiny. Földi. Le Rat. Mus rattus. Lin.) Bufi. VII. xxxy.

Erröl a régiek nem szóltak, s ugy látszik hogy a lözciplintban hatott be Europiba. Kétszer aklioráníl is nagyobb minden átméröben, mint a hízi cgér. Bundija fékictés. Néha löbb egyénekel találtak összenólve farliaili rgybe bonyolítása által; s ezekel nevezéli patkány kirílyaknak. $\left.{ }^{1}\right)$

A vindorpatkiny. (Le Surmulot. Mus decumanus Pall.) Buff. VIII, XxviI.

Europába csak a 18 században jött be, s ma a patliánynál kïzönségesebb Párisban s némelly más nagy vírosokban. Egy negyeddel nagyobb a patkányníl, attul még verhenyes barna szöre által is különbözik. $\left({ }^{2}\right)$.

Ezen kél faj keletrül látszik credteni; hajöinh mindenfelé ugy elterjeszték mint az egereket.

Keleti Tatárhouban és Chinában van rgy patkíny a mićnkhez hasonló, valamivel rövidebb farku, erósebb állkapesu, szókc szinü; = a tatár patkinzy. M. caraco Pall. Glir. XXIII. Schreb. CLXXVII.

(1) L. Bellerman: a patkány-királyrul. Berl. 1820.

( $\left.{ }^{2}\right)$ Persiábul látszik credni, hol barlangolaban Jakik. ('sah 1\%!; jö̋t Astrakánba, egy földindulás után, a Volgát áltuszva.

CUVIER I. K. 
Indiában még egy másik faj van, a váudor patdánynil megegy negyednyivel nagyobb, verhenyes baruil; $=$ az indus pathingy. Ral. perchal. de Bull. S.ıpp. VII, IXIX.

Az indiai sziget-sukon szinte ran egy, nigy, feketi's bitma; $=$ a sziget-soki patliny. Hus setifer. Horsf. Jav. - Ezen két faj durva sörtékjel bir, szörét meghaladókkal.

A szörnyü pritkiny. (Le Rat musqué, on pilori des Antilles. M. pilorides, Pall. et Gm.)

minden ismertek kiazl lenagrobb s legkirtikonyab), far-

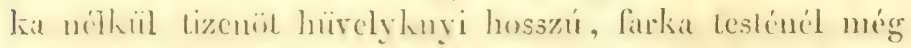

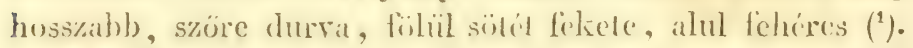

hereschbe vizsgallattak meg az apro, egernagysign fajok.

A kahirii egerr. (La Souris du C'aire. Mr. cahirinus. Geofl. Desc. de l' Eg. Mammif.)

Ilítiun a ször helyett törises. Alár Arishoteles megjegyzó.

Franczianorágighan egy fajuál tibb alig ismeretes, melly a házaktól tárul laknék; ez a mezei egér (le mulot. M. sylvaticus). Bulf. WII, xr.t, melly alig nagyobb a hízi egérnél s attul vörhenyes szöre által kïlönbözils. Sok

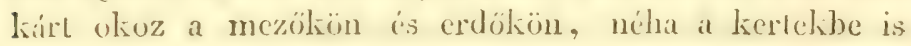
behat.

Ugy tetszik azonban, hogy némelly lartományokban $\mathrm{cgy}$ kiscbb szürke faj is talliltatik, melly Angliaiban is vetelés észre (M. messorius), Shaw, 'Tom. IJ. I. Part. Frontisp.); és egy harmadik, még is sokikal kiselb, apró egér, le mulot nain. M. pumilus, Fréd. Cuv. Mammil.)

(1) Egészen hilhásan irják Pallas és Gmelin egészen fehérnek le. Az elsỏ tcrmészetvizsgálók ezén gyarmatokban, azon szinekct tulajdonitjúk uekik mellyeket mi láttunk raj̣tok. 
Vigre, még sok föltalálísohat kell ezen apró emlösek kïruil tenni, még a mi hazánkban is. ( $\left.{ }^{1}\right)$.

A hév tartományok a leirt patkínyokhoz minden bélyegben hasonló fajokial láplálnak, de mezescbb farkuakat. $\left({ }^{2}\right)$.

$\left.{ }^{1}\right)$ Hibetóleg ezen osztáshoz tartoznak: $M$. agrarius, $M$. minutus, $M$. soricinus, $M$. zagus, $M T$. betulinus, $M$. striatus, $M$. barbarus, Schreb.

Ide kell még jönie az iszonyú fajnak is: mus giganteus IIardwick, Linn. Trans. VII, xxvıı.

Ide helyeztendök még: a reményfoki egér (le rat rayé du Cap. II. pumilio Sparm.); a délamerikai kék szürke egér (le rat grisbleu. M. cyanus Molina) s még több más faj, mellyck riszint nem jeleltettek föl a szerzök által, részint igen kevéssé összehasonlitólag irattak le. Igy ván Azzara patkányaival is a dolog, mellyck nagyobb részét csak az újra vizsgálás után lchet haszomual oszályozni. Rafinesifue 8rlöinek nagy száına is hasonló sor'su. Jelesuzeteik sokkal rövideblek, mint hogy használhatók volnának.

$\left.{ }^{2}\right)$ Hypudaeus variegatus, Lichtenst., Tar, flava. - Meriones syenensis, Ua.; mellyekhez adható: Arvicola messor, Lecomte, ar\%. hortensis, Harl. vagy Sygmodon, Say., födölt fülek által különbözve, mint a szíttanyászokéi.

Egy másik csoportban, mellynek farka szinte Jepledt (mezes), de fogai elöbb elvásnak, lesz: Ilypudaeus obesus, Licht. mus ruficaudus. Ua.; az 8 meriones sericeus-a pedig egy harmadikat képezhet, zápfogai eaymásba viszonosan bevágo emelkedetei s volgyei által bélyegezettet.

Egy csapatot képezhetni mér ezckbül: Neotoma floridanum Say, vagy arvicola floridanus, Harlan; és arvicola gossypina, Lecomte, mellyek majd a nagyságra s még a szinekre nézve is rģymáshoz igen hasonlók, mellyeknek gyökérrel biró fogaikon a koroua azonhan, ha valamennyire elvásott, a mezötanyászokéhoz hasonlit.

De minel ezen állatok, a meghatározott osztályozís végett, isszrehasonlitó s teljes vizsgút hivánnínak, azaz belscjökön és kül. sejokön épüllet. 


\section{AZ ÖRÖLKÉK.}

\section{(Tes Gerbilles. Gerbillus. Desm. Meriones llig.)}

Zippogaik a palkingokitul kerésben kïlïnbözok, csak valamirel gyorsabban rásnak el s ugy hogy liereszl lalmolitulsal mulatnak; frilsi melszirilson barízda van, hatulsi lithaik a liozinsiges patsámyohidhoz lépest valamivel hosszabbak, a hürelyle s kisuj prodic hátra áll rajtok; farkolk hosszú, mezes (lepledt).

A regi vilag lomolios he videkei tïb) faje típlátnali köziilök.

Az indus ïrülice. (La Gerbille des Indes. Dipus indicus, Hardwick. 'Trans. linn. VIII, vII. xl. Hérine, Fréd. Cuv. Manmil.

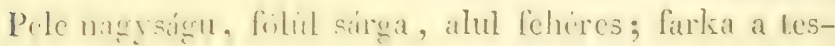
ténél hosszalob s vége félé fekelés.

Ehhor krzaclil a homoki örölke (La Gerbille des sables. D). meridiunus, S(dirch. 231.). melly majdncm ugyanazon szinü, hanem valamivel kisebb.

E.s a : grüüs furku örülke (Te Gerbille des tamarix. D. tamaricinus. Sh.hr. 232., melly uck birnás syürük vannak a farksán.

A grilicis örölke. (Ia Gerbille des pyramides. Dipnss py'ramidum, Oliv. Voy.)

Ifálulsi lábai hosszabbak: cser-pele naçysagu; burıdảja fölïl vörhenyes, alul fehéres.

Egyikiik a Sencgálnál ridámabb verhenyes és tisztább fechér.

Egy mísik a Reményfoknil, valamivel nagyobb, vereses, farlsa rége kevescbbé mezes (lepledt).

Egy Nubiában majenem lélényi kicsm, tölül vilị́̂: verheryes, alul szép fehér. 
A RESZELKÉK.

(Les Mérions. Meriones. Fréd. Cur.)

Mellyeket mi a tübbi örölkéktül elválasztunk; háıulsó lábaik még hosszabbak, farkok majdnem csupasz. fölsö rápfogail elölt egy kis fogok van; melly bélyegek az úgregerckhez rezetik öket kïzel: fölsö metszöiken azon barázda ran, melly az örölkéknél; ujaik hasonlók.

Egy kis fajok ismeretes, Éjszak-amerikábul a a kanadai reszelke. Mus canadensis, Penn. Dipus canadensis Sh. II, I, 161 rl. Dipus americanus, Barton. Eggí nagyságu, sárgás szürke szörü, testénél hosszabb farku. Fürgenesége rendlsivüli; a foild ala rejtezkedik s a telet zsibadva tölti $\left.{ }^{1}\right)$.

\section{$\Lambda$ HÖRCSÖKEK.}

\section{(Les Hamsters. Cricelus. Cuv.)}

Fogaik majdnem ugyan azok, mint a patkányokuál, hancm farkok rörid és mezes, és szájok két oldala, mint ncinclly majmoknil, crszényckbe vagy polizsebekbe van kilígulva, mellyek gabonamag hordásra szolgailnak füldalatti tanyájolira.

A küzünséges hürcsük. Füldinél hürcsök murmolér. (Jae

Hamster commun; Marmotte d' Allemagne, cte. M. cricelus. Linn.) BufT. XIII, XIV.

Nagyobb a patkínynál, fülül vereses szürke, oldalain s alul fekele, mindenik oldaliun három feheres foltal: nég lába fehér, valamint. mége egr folt a lorka alall és cgy a melén; ramuak egészen fckete egyének is. Ezen olly sripen tartsizoll szinü allat, egy a legkirtékonyab-

(') T. H. Gerbillus labradorius. Hart. vagy. Mr. labrad., Sahine, Voyage de Frankliu, 661.1. 
bak kïzïl, mirel igcn sok gabonat hord issze, azzal barlangjál betölcudio, moly néha bét dábnyi mély. Minden homolins ridéken kïzönséges, Némethon éjszakálul egćsz Sberiáig.

Ezen ululsi tarlomány lübb apró hörcsölsfajt táplál. mollyeket Pallas ismertetett meg. (')

\section{A MEZŐTANYÁSZOK.}

(Les Campagnols. Arvicola. Lacép.)

Mint a palkányolinail, mindenülı három zípfogok vam, hanem grähirle]en. s mindenik háromszeges hongerbül

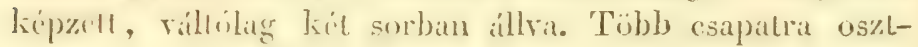
Jatok:

\section{A HABTANYÁSZOK.}

\section{(Les Ondatrcts. Fiber. Cur.)}

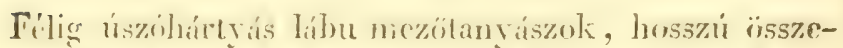

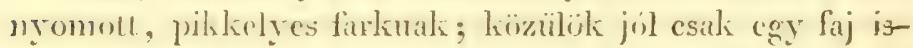
mereles:

A kanadai habtanyaisz. I' Ondalra, ou Rat. musqué du C'anada. C'astor zibeticus, Liu. Mus zibeticus, Gm.) Bufl: X, I.

Akkora mint egy tengeri nyul, rereses szürke; ezek

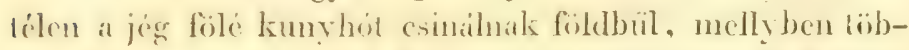
ben lakoznak egrill s homman egy lyukom ailt kílmos

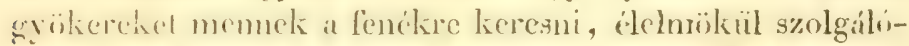

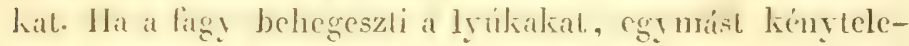

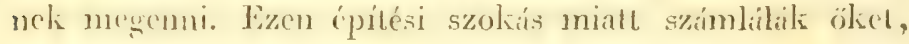
némelly természet-rizsgálók a hód nemhez.

Músodil aloszlúsba jönck:

(') M. accedula. - MI. arcnarius. - M. phoeus. - M. songarus. - is. furunculus. L. Pall. Glir. és Schreb. 
A közönséges MEzöTaNYászoK.

(Arvicola, Cuv. Hypudaeus, Ilig.)

liarkok mezes s majdnem olly hosszu, mint a tesŁök; lábaik uszóhártya nélkül.

A poc, pocik, Földi. (Le Rat. d' eau. Mus amphibius,

L.) Bufr. VII, xLII.

Valamivel nagyobb a közönséges patkánynál, sötét barna-szürke, farkia teste hosszaságu; a rizek szélcin lakik, a mocsíros földben ás, gyökereket keresve; hanem rosszul úsz és bukik.

A füldi mezötanycisz. (Le Schermaus. Rat. fouisseur, Alsaciúban. Mus terrestris. Lin.)

A poc-tul csupán lievésscl kisebbsége által kïlönbüzik; farka rövidebb. A föld alatt lakik, mint a vakondok, hanem leginkább a magas fekvésü rćteken, meneteket csinál, s az üregébül kilúrt füldet a nyilástul valamivel torább clhordja. 'Tárai, mellyeket leginkább rad sárga répagyökérrel tölt meg, azokat két hürelyknyi darabokra vígva, néha két lábnyi átmérövel birnak.

A mezei mezötanyász; Földinćl mezei egér. (Le Campagnol, ou petit Rat. des champs. Mus arvatis. Lin.) Buff. VII, xLvi. Némelly francia tarlományokban mulot-nak neveztetik, hanem rosszul.

Egér nagyságu, rcreses hamvus, farka a testéuél ralamivel rövidebb. Barlangokban lakik, mellyeliet a mezöliön is, és gabonával megtölt a lélre; néha rendkivül clszaporodik és nagy károkat okoz.

A gyökerész mezötanycisz; Földinél gyölerész egér. (Le campagnol de prés. Mus oecconomus. Pall.) Glires. XIV, A. Schreb. cxa.

Valamivel sötétcbb s egy kevéssel rövidebb farku; egy kicsin, katlanidomu, a pázsit alatt ásott üregben lakik: 
honnan täbb egrenes is ágas esatorua rezet különbfële irányban; más csalornáli egy második üreggel liüzlekednek, hol eledelit halmozza föl. Egész Siberiiban lakik. Azt gondoljálk, hogy Sreicbans déli Frankhonban is találtatik, kïlönösen, a mint bizonyitjáls, a burgonya fïldeken. ( $\left.{ }^{1}\right)$.

\section{A LEMMINGEK. F.}

\section{(Les Lemmings. Cuv. Georychus. Ilig.)}

Mellychuek farkit s fïlcik igen rövidek, s melsö ujaik különösen az ásásra szántak.

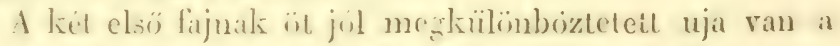
melsö lábalion, mint a rahsilinál és szöliegereliuél.

\section{1 küzünséges lemminğ; Füldinćl lemming murmulér.}

(Le Lemmings. Mus lemmus. Limn.) Pall. (Blir. XII, A. B. Schreb. Gxav.

Éjszalii faj, egír nagrsigugu, sárgáral és felictével tarlia szörü: az idoorul idore, hatírozoll idos\%ak nélkül és szamutitan esapiloliban temi szoliult vándorlásairul igen hires. Azt mondjaili, hogy aklior egyenes ronaban nyomuluak clö, a ncilinil hogy lolyamak, hegyek vagy más akadílyok föllartizlatuiti oket, s hogy úljokban mindent clpusztítanali. Rendes lakísok a Jegestenger partján látszik lenni.

A siberiai lemming. (Le 'Zocor. Mus aspalax. Gm. Pall. Glir. X, Schreb. GaV.

Vereses szuirlic, mulsö három kïzép lïrmei hoszszúl, Görbék, cosszenyomlak és mclszök a foild és gyökerek melszise végeu: liglasai rividek, farkia alig van.

(') Hihet8leg ide tartoznak még: $M$. saxatilis, aliarius, rutilus, gregalis, socialis. (Pall. Glir.). Hanem az MI. lagurus és torquatus inkább lemmingek. Ejszakiamerika szinte tohb nezótangászl bir; illyenek: Arvicola xanthognatha, Leach., Miscell. I, Xxvi. 
szemei rendkiviil aprók. Siberiában, hol mindig a foild alatt lakik, mint a valiondoliok és raksik: a liliomosak hagymáival táplálja magát leginkább.

A harmadik fajnál, mint minden a nagy patkány nemhez tartozókuál, a melsó lábakon csak durványa vau a hüvelyknek. Ez :

A hudsoni lemming. (Le Lemming de la baie d' Hudson. Mus hudsonius. Gm.) Schreb. cxavi.

Világos gyöngyhamvas, fark és külsö fülck nélkül; a hím melsố lábainak liét kiözépsö uján kettös köröm látszik lenui, minthogy az ujhegyének böre havadílyos (cscrepes) s a köröm hegye alatt dúdort képez; melly allsotís csupún ezen állatnál találtatik. Akkora mint egy patkány, s a föld alatt lakik Amerika éjszakán.

\section{A sZÍTTANYÁsZoK. \\ (Les Otomys. Fréd. Cuv.)}

A mezótanyászokhoz közelítenck (szittanak); szinte három zípfogok van, hanem csekélyen hajlott lemezekbuil képezve, egymás után sorba állitra. (1). Metszö fogaik hosszán egy barízda ran. Farkok mezes (lepledı), minl füleik, az igen nagyok.

$\mathrm{Az}$ ismeretes faj, a reményfoki szít-Lanycisz; (Otomys capensis, Fréd. Cur.) Afrikáb)an lakik, pathány nagysáğu, bundája feketérel és súrgával gyüriuzve. Farka egyharmaddal rövidebb a testénél.

r. - Arvicola pensylvanica, Wilson., Amér. ornith., vi, 50. rl. 3. k. - Ar2. palustris, Harjan. stb. Kivánatos, hogy hamarjában jobb képekei és leirásokat kaphassunk az eddig létezőknél.

(') Kicsinyben az elefánt zápfogait pontosan mutatják. 


\section{AZ UGREGEJEK. \\ (Les Gerboises. Dipus. Gmel.)}

Majdnem azou fogaik ramak mint a tulijdonképi patkinyolinak, s csak ncha ran egy igen kicsin fogok a fölsö zíplog melïl. Farkok hosszú s bojtos régü, fejök széles, szemeik magroli, kiallok; hanem fö bélyegöliet mód nélliil hosszú hítulsci lábaik teszili, a meliilsókhez képest, s mellycknél a hírom középsö uj kéztöje esak cgy csontbul kiprödïll, mint a madarak szírnytöje. Tagjaik ezen helyezełe mialt nevezik öket a régick: kéllibu putkinyoknatk. Valoban nom egy kömnyen mennek máskép, mint hosszú hátulsi lábaikon ugrálva. Melsö lábaikon öt ujok van; ís bizonyos fajoknál hálulsó lábok nagy három uján hiviil megr lis oldal-njak is rammak. Ezen örlok barlangokban élnek, s tél alitl mély zsibbadisba esnck.

A nyilas ugregere. (Le Gerboa. M. sagrila. Lin.) Buff. Supp. VI, xxxix, és Xl.

Csmpán három uja ran, patkíny nagyágigu, liblül vilígos súrga, alul feher, farlibojlja feliete, vigén fehér. Barbaricitul a Kaspitengerig.

A bozontos libu ugreger. (Le Gerboa is pieds velus. Dipus hirtipes. Lichtenst.)

Feje ässzenymmollabb a lïbbiekéncl; Isátulsó lábain csak három uja ran mint az elöbbinck, hanem szöröiscbb. Afrikíbul. ( $\left.{ }^{1}\right)$.

Al lïellö ugregèr. (I) Alactagra. M. jaculus.) Pall. Cilir. XX. Schr. CCXX VIII.

Két apri oldalujjal, hosszab fülekkel mint a uyilaséi, hanem majdnem azon szinückkel. Pallas három különbözö nagg ságuakat lítoth, a tengeri nyúlćtul a patkínyéig;

(') T. h. Dipus telum, D. platurus, D. Irgopus Eversman. Maycidorf utazása Bucharában. (a francz. ford. 390. 1.) 
czek talán különbözö fajok. (') Mindeniket Barbariátul egész a Keletitengerig s Indıa éjszakáig találni.

A többi ugregerektuil és az egész patkány nemtül elválasztjuk:

\section{A SZÖKEGEREK-et.}

(Les Helamys, Fréd. Cuv. közönsg. lièvres sauteurs.

Pectetes. Ilig.)

Mellyeknck feje széles mint az úgregereké, szemök nagy, farkok hosszú s kirílt elsó végtagaik nagyou kicsinyek, a hílulsókhoz képest, noha az aránytalanság jóral kisebb mint a valódi úgregereknél. Tulajdon bélyegeik a szökegereknek: mindenült négy zápfog, két két lemezbiil tére össze, elsö lábaikon öt uj hosszú hegyes liörmekkel, nagy hátulsó lábokon négy, mind megkülönbüztctve, még a lábtó csontjai által is, és széles, majdnem mancshoz ragy is lókörömhöz hasonló kürmükbe végzödve. Ezen uj-szám megfordítottja annak, melly a patkínyok között legközönségesebb. Alsó metszö fogaik csonkák s nem hegyesek mint az úgregercknél s a patkány nemhez tartozott állatok nagyobb számánál.

Csak egy faja ismeretes, a kaffer szükegér. (MLus Caffer, Pall. Dipus Caffer, Gmel.) Buff. Supp. VI, 41. és jobban, Fréd. Cuv. Mammif, melly tengeri nyul nagysígu, vilígos sárga, hosszú, bojtos és fékete végü farklial. Mćly barlangokban lakik a Jóremény fokínát.

\section{A VAKsıк. (Vakondegerek). (Les Rats-T'aupes. Spalax Guld.)}

Szinte okosan vílaszlattak el a patkányoktul, noha zápfogok hírom és gumris mint a tulajdonképi patkí-

(') Sokkal njabban (Zoographic russe, 1, 182. I.) Pallas a hisebl) lörellöhet Dip. acontion, név alatt megkülönbözteti. 
nroknail is hïresökeknel, is esak kevéssel egyenlibbek (ogmás livïill: de az metsziili sokkal nagyobb, minlsem Jogg ajalsaik által befiolethetnének; az alsok riggzéle visüsen szelö és nem hesyesen: száraih igen rövidek; mindenik lábokon ö rörid uj és öt lapos rekony köröm; farhok ragg igen rörid ragg semmi, munt külsö fülök. I riild alatt inck, mint a rakondokok, a fiildet turják mint amazok, noha az closzlísara lieresebbe hatalmas eszközökkel; csupán gyökerekkel élnek.

1 vak vaksi; Füldind vak murmutér; küzünsésesen. füldi kul ra. (Te. Zemmi, Slepetz on Rat-taupe aveugle. Mus typhlus. Pall.) Glir. 8. rl. Screb. 206.

Kuibuös állat, cegeszen ielombalan nagy s oldalrást

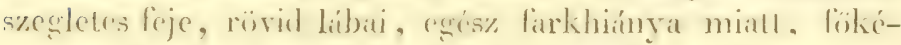

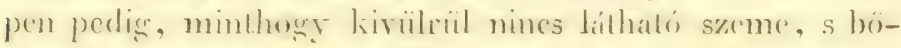
re alatl cale rgy hiesin fekete magszom talítlatik, melly

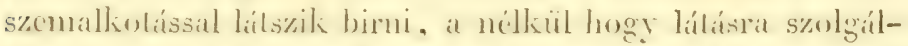
hatua, mext a boor my ilás és rékonyodís nélkül megy el

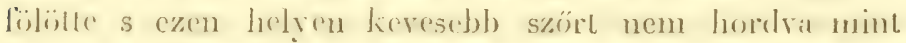

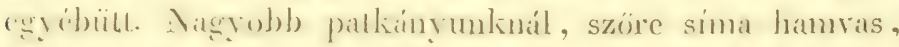

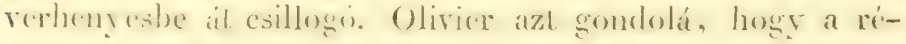
Gich czen illatrul ahartak szislani, midön azt mondík, lıogy a rakondok egészen rak.

A Sunda szigetek is típlálnak egy valssit, tengeri "1yul nagysigul, sütit szürkit, egy fehér hoss\% runatlal lején. (sundai vaksi; Spalax javanus).

A vaksiktul is megkülönböztetendók :

\section{A PISLOĠ́K.}

(Les Oryctères. Fred. Cuv. Bathiergus. Iliger.)

Mellyeknek, ezen nem általános idoma, lábai s melszífogai mellett, mindeniutl negy záplogok van: szemöik kicsiny ugyan, hanem nyilı, farkok is rövid. 
A zritonyi pisloga. (L' Oryctère des dunes. Mus marilimus, Gm.) zálony i patkíny: 'Taupe des dunes. Bufl. Supp. VI, 38.

Majdnem akjkora mint a tengeri nyul, fölsó metszöi egy barázdások, szórök fehéres szürke.

A fehérfoltos pisloga. (L' Oryctère à tache blanche. Mus capensis. Gm.) Taupe du Cap. Supp. VI, 36.

Alig akliora mint a tengeri diszno, barna, egy fehér folual a füle körul, egygyel szeme kïrül, egrgyel fötetején és ajkonya hegyén. Metszöi egyenes simák.

Van még egy kisebb faj, szürke, sima metszókkel, $s$ alig akkora minl egy patkány. A hottentoti pisloga. (Balhyergies hottentotus. Less. és Garn.) Toy. de la Coquille, $2 \mathrm{rl}$.

A vaksikhoz és pislogákhoz közel teendök:

\section{A ZSEBEGEREK.}

(Les Geomys. Rafinesque ou Pseudostoma. Say. Ascomys. Lichtenst.)

Nindenütt négy zápfogok van összenyomott hengerLinu; az clsö kettös, a más három egyszerii; a fölsö metszök melül liettös barázdások; mindenils lábokon öl nj; melül a kïzépsö három liarom, kivált pedig a kïzépujé, igen hosszú, görbe, metszö. - Száraik alacsonyak, pofzscbeik igen mélyek, külsö nyilásuak, fejök és nyakok oldalait különcösen vastagítók.

Csak egy faj ismereles: Az amerikai zsebegér. (Mus bursarius, Shaw. ( $\left.{ }^{1}\right)$.

(') Azon ábrázalatok, mellyeket hajdan adtak czen állatrúl, Trans. linn. soc. V. k. vII. rl. és Schaw, II. k. I. r. 138, rl. 8t pofzscbének els felé hiforditott borével mutatjik, mintha két függö zsebe volna feje oldalán. Hllyesmit nem találni a természetben. Jiil van ábrázolva a berlini acad. irataiban 1822 , ćs 25. 2. rl. 


\section{A CSÚTEGEREK. \\ (Les Diplostoma. Ral.)}

Majduem egéšcu hasonlok a zsebegerekhe\%, livévén, hogy teljességgel fark hijáral vannak. $\left({ }^{2}\right)$.

Ezek is Ejjzali-amerikai állatok. Az clöttünk lévö faj verhenyes és tiz hüvelknyi hosszú.

Most az erösebb örlökhöz megyünk át, mint a mellyekröl eddig szóltunk; de a mcllyek között töhbeknél igen ki vanuak a válperecek fejlödve.

Ezen szímhoz lartoznak:

\section{A HóDOK.}

\section{(Les Castors. Castor. Lin.)}

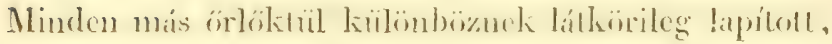
majduem tojástad idemu is pilkelyes firtiok által. Labaitkon üt öt uj, a hátulsók hártya által cgyestïtek, a hü-

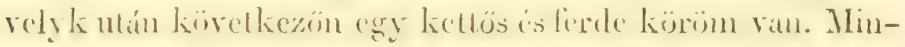
dentül négy, lapos hoszoríju záplogek van, mellyck ugy latszik, mintha magrira hajloll csontszalagbul rolnthak készítre, s ennél fogva follül a belsö szélen cgy, a külsön három likianyarodús lítszik, - alul az ellenkezö escel ran.

A hódok elég nagy állatok egészen vizi életüek; lábaik is fartiok jol segitik öket az viszísban. Nlinthogy fökipen lieregbul is más kemíny anyagokikal élnek, metszoik igen hatalmasak s crösen nibnek a grökirruil a mint eliil risistak: czelset használjíls mindenfele fák lerígására.

(') Rafinesque csak négy négy ujat ád nekik minden lábokra. A sni fajunknak öt vau mint a zsebegereknch. 
Azon nagy mirígyidomu zsebek, mellyck elöbörökön nyilnak meg, egy igen erös szagu kenöcsöt választanak el, a gyógyszereselinél hídony, (castoreum) név alatt ismereteset. Mindenik nemnél a végbél végébe nyilnak a nemzés múszerei, ugy hogy esak egy külsö nyilísok van.

\section{A kanadai hơd, Földinél kaszlor húd. (Le Castor du Canada. Carstor fiber.) Buff. VIII, xxxvi.}

Nagysígra fölülmulja a borzot; minden négy lábuak között ö fordíl lakhelyépítésre leguagyobb szorgahmat. lakhelyeket társaságosan épít Éjszali-amcriki legmagúnyosabb helyein.

A hódok a jó mély vizcket rálasztják ki, hogv az fenckig solua be ne fagyjon és ha lehetséges a folyóvizeket, mert igg fölebb lerígvín a fíkat, a viz iltal oda vitelik a hová akarják. A vize egyenlö magassígon tarljâk egy ágalibul kövel és agyaggal regyitve csinált töltés álıal, mellyet évenként kijavílanak, s melly kihajtva valósúgos gyepủré vál. Egyes laksok liét három család szímári vannak, s liét emeletïek; a felsö szíraz, az állatoknak, az alsó a viz alatt van a kéreglakarmány tartása végett. Csak enuck van nyilása, s az ajtó a viz alatt van minden közlekedés nẹlkuil a szírazzal. Ezen lakok egymísba fout is agyaggal crösitett ágalkbul készittetuek. A hódok különben több barlangokat is birnak a folyo hoszszában, a hová lakhelycik megtámadtatásalior menekedni futnak. Épülctciket csak télen haszuálják, nyúrou clszélednek s mindenik magának él.

A hiolot könnyen megszelidíthetui s állati eledel cvésre szoktalhatni.

A kanadai hód egyenlö rerhenyes barna; börét, mint undva van, igen keresik a kalaposok; vanuak szólkck, feketék és néha fehérek is.

Mind eddig nem állapithattuk meg szigoru összehasonlítgatásunk mellett is hogy a Rajna. Duna, Wesers 


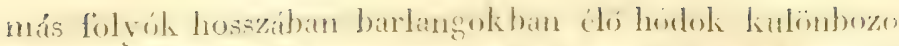
fajuali-e az amerikitul: vagy esak az emherek küzclete akadályoztatja ólket az építésben.

\section{A szítródoK.}

\section{(Les Coüa. Mypotamus. Commerson.)}

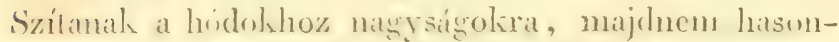

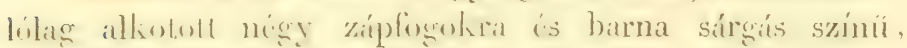

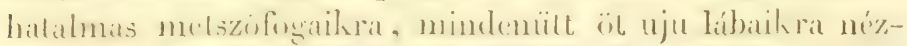

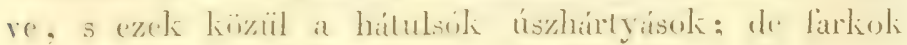
hosszú s gömbölyü. Ezck is vizi állatok.

Gsak egy faj ismeretes:

A delamerikai szilhid. (Le Coü. Mus Copmus. Mlılin.) Geoffr. Aun. Mus VI, 35. rl.

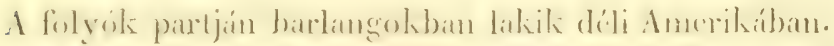
Sirrós barna szöre. alapján gyapjazallal löme, a kit-

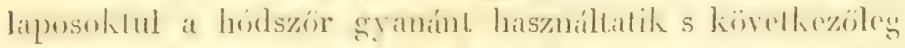

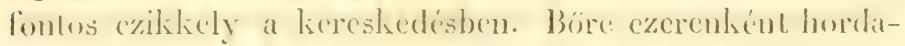
lik be Europába.

\section{A SƯLÖK.}

\section{(Les Porc-Epics. Hystrix. Linn.)}

Elsö pillantísra mecrisnerhetoli azon durva s liegyes

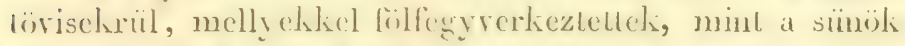

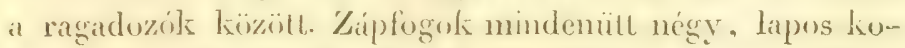
ronáju. mázlemezek allal külünbfeképen módositva, mellych árkos kïzöket hagynak rajtok: nyelvök tövises pikkelyekkel takart: villkulesaik igen röridek a melesont-

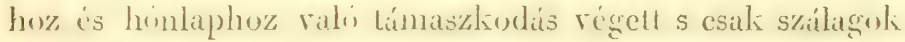
által figgeszletels föl. Exen állitols üregeliben lakinah.

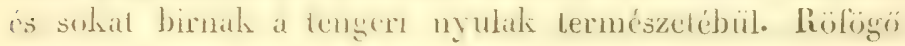
szavoli, nagy és csonhitout arcorruk miate a diszurikhoz hasonlíttatnak és, tüsliés disznó "' nevet kaplak. 


\section{A tulajdonképi súLök. \\ (Les Porc-Épics.)}

Fejök többé kevesebbé boltos az orresont kifejlödése által. Melül négy, hátul öt ujok számláltatik, nagy körmökkel födve.

Az europai faj: A tarajos sül. F. Hystrix cristata Lin.) Buff. XII, 51 és 52 rl. - Olasz- és Spanyolország délén, Siciliában lakik; Barbariában is találtató. Tövisei igen hosszúk, fekete és fehér gyúrüzettel; fejét és tarkóját hosszú serte taraj foglalja el. Farka rövid és csonka üres tollakkal födött, mellyek vékony kocsánokon ülnek, és összeverödve zörögnek, valahányszor óket az állat fölmereszti. Csontos fején az orr kïlöncösen boltozik.

Indiában s Afrikában vannak kevésben különbözó fajok, hanem kevesebbé boltos fejüek.

A tulajdonképi súlöktül megkülönböztetnek

\section{A SzíTsúK.}

\section{(Les Atherures. Cuv.)}

Mellyeknél sem a fcj, sem az arcor nincs földuzadva, s mellyeknek farkia hosszú, nem fogódzó; lábaikon az ujak ollyanok, mınt a tulajdonképi súlölnnél.

A csomós szitsï. (Le Porc-épic à queue en pinceau.

Hyst. fasciculata. Lin.) Buff. Supp. VII, 77. Schreb.

170. $\left({ }^{1}\right)$.

Teste tövisei elül barázdások, farka lapos szárnyidomu lemez-csomóba végzódils, közönként összeszorítva.

(') Ezen kép Seba után másolva (I, 52, 1.) igen xövid. Buffoné jolb, hanem farka végének szijai nincsenck eléggé vilígosan mutatva. Épen nem láthatni át miért számlálik Blanville és Desmaret ezen fajt a patkány-nemhez; midơn a sülök fogait és tolbli külsơ s belsó bélyegeit birja.

CUVIEL I. K. 


\section{A TÚREJTSỨK.}

\section{(Les Ursons. Erétisons. Fr. Cuv.)}

Kaponyáijok lapos, arcorols rövid, nem duzadt; farhols közipszerü, töviscik röridek s filig a börbe rejtettek.

Csals egy faj ismeretes Éjszak-amerilia éjszalsárul. (Hystrix dorsata. Lim.) Buff. XII, LV. ${ }^{1}$ ).

\section{A GÖNDESÜLöK.}

\section{(Les Coendous. Synetheres. Fr. Cuv.)}

Arcorok nagy, rövid; fejük a homloknál boltos, tiirisei rövidek, füliépen pedig farliok hosszú, csupasz végii ès fogcodzo mint a fijahordié vagy göndöriié; lábailion esak négy uj van körömmel fegyrerkezell; a fálira másznak.

Amerika heres videlicin van egy fiij, fekcte s fehér töviselikel, fekctés barna störrel, a fogridzó gündesül. Mystrix prehensilis. Lin. Cuendu, Margr. Hoitzllapuatzin, Hern. $\left({ }^{2}\right)$.

Amcrilában ran ç̧y másik kiscbb faj is, részint verhenyes, részint súrea töriselikel, mellyck az esztendó cgy résziben barnís szürle ször alí rejletlek. (Azzara gündesüle. Le Gouîy d’ Azzara. Hyst. insidliosa Lichtenst.) Pr. Max. Brésil.

\section{A NYUT,A].}

\section{(Les Lièures. Lepus. Linn.)}

Abban igen megkülönböztetö jegyök van, hogy foilsi metszioik licltözöltck, azaz mindenik mögött coy másik

(') Buffon ráfogott Coendou-ja (XII, 54.) szinte türejtsí, Janem elromlult és szórevesztelt.

() Ezen mexikói szó tövises fijahordót jelent. Ez a hosszú fárhu coendou, Buff. Supp. VII, 78; hanem ilt arcora nem clég hoszszii. Hermandez ábıázoliata jobb képét adja. 
kisebb van $\left({ }^{1}\right)$. Zápfogaik, mindenütt öten, két függö́s egymásba forr lemezbül liépzetlek, s fölül még egy halodik is találtalik, melly egyszerú s igen kicsin. Melül öt, hátul négy ujok van, valibelök irtóztató, hatszor akkora mint a gyomor, pörge (csigahajlongásu) lemezzel belül, melly az egész hosszán végig fut. Szájok belscje s talpok ollyan szórös mint többi testök.

\section{A tulajdonképi NYULAK. (Lepus. Cuv.)}

Füleik hosszúk, farkok rörid, hátulsú lábaik solkkal hosszabbak a melülsöknél, vállkulesaik lölsélyetlenck; a vázban a szem gödöralatti tér hályogidomulag átlyuggatott.

Igen számosak a fajták s egymáshoz annyira hasonlök, hogy nchéz bélyegezni óket.

A mezei nyul. Földi. (Le lièvre commun. Lepus timidus.

Lin.) Buff. VII, xxxvin.

Sárgás szïrke; fülei cgy tizeddel hosszabbak a fejénél, hátul hamrasak, hegyötön feketék, farka combja hosszaságu, fehér, fölül egy fekete vonallal.

$\mathrm{Az}$ egész világ ismeri ezen állatot, mellynek fekete húsa izes s böre hasznos. Magányosan lakik, nem épit soha, a sik földre fekszilk, radászLatva a tért nagy kürökben kerengi át; nem szelidítheték még meg.

A változó nyul. (Le Liève variable. Lepus variabilis Pall.) Schr. Gaxxxy. B.

Valamivel nagyobb a liözönségesnél (mezcinél), fülei s farka valamivel rövidebbek; ez mindenkor egészen fohér, többi szöre pedig nyáron szürke, télen fehér. Ezen

(') So̊t van idö, kivált fogváltoztatásokkor, midön három metszö fogat lítæzanak egymás mögött birni, tehát mind össze hatot. 
illat, melly éjszakon s déli Europa magas hegycin találtatik, a mezci nyul természctét birja, hanem húsa iztelen.

A tengeri nyul. T. (Le Lapin. Lepus cuniculus. Lin.) Bull. VI, L.

Kiscbb a mezei nyulnál, fülci fejénél valamivel rövidcbbek, farlia a combjánál kisebb; szöre sárgás szürke, tarkrijin verhenyes; torka s hasa fehéresels; fülei szürkék, feketeség nélkül, farkín barnaság van.

Ezen állat, mellyet Spanyolhonbul credtnek mondanak, ma egész Europában clterjedt. Seregesen lakik barlangokban, hova mihelyt üldöztetik, monekedni fut. Fchị és joirzü husa solsat kïlönbözils a mezci nyulétul Megsszelidítre régetlenül szaporodik s igen külünbözö színeket és szört kap.

Az idegen tartományokban több faj van, mellyelict, csak igen nagy vigyázal mellett különböztethetni meg a mi tengeri nyulunktól. Illyenek:

A siberiai nyul. (Lapin de Sibérie. Lepus tolaï. Gm.)

Schreb. cexxxiv.

Mintegy liözépet tart a mezci s tengeri nyul között arányaira nézve s az elsöt nagyságíra nézve néha fölül mulja. Barlangokat nem ásva, a sziklálk hasadékiba s más üregekbe vonul.

A: amerikai nyul. (Le lapin d'Amérique. Lepus americanus et brasiliensis. Gm.) Lep. nanus. Schr. Gaxxxiv. B.

Majd akkora s majd olly szinü mint a miénk; lábai verhenyesek, feketeség nélkül a fülein vagy farkán; a fatörzsökökben fészkel, s azoknak odváhan gyakran egész az ágakig fólmegy. Húsa izetlen és lágy ( $\left.{ }^{1}\right)$,

(1) T. 1. az indiai nyul (le lapin des Indes), fekete tarkóval. 
Másol a mi mezei nyulunkkal igen kitünö hasonlatosságot birnak. Illyen

Az afrikai nyul. (Le Liève d' Afrique. Lepus capensis. Gm.) Geoff. quadr. d'Égypte.

Fülei cgy ötöddel nagyobbak fejénél, nagysága és színe majd mint a mi nyulunké, lábai verhenyesek valamivel hosszabbak.

Ugy látszik, hogy Afrika egyik végétuil a másikig talíltatik, legalább az egyiplomi nem különbörik a jij reményfokitul.

\section{A SÍPőrLÉK. \\ ( Les Lagomy's. Cuv. ( $\left.{ }^{1}\right)$.)}

Füleik középszerïck, szátaik egymás közt alig különbözök, szemgödöralatti lyukok egyszerí, majd tökélyetes vállperecück, farkatlanok; néha igen sipító hangot adnak. Mindedig csak Siberiában talíltattak s Pallas ismérteté meg ökel. (Glir. 1. l. s köv.)

Az apró sipörle (Le Lagomys nain. Lepus pusillus.) Pall.

Glir. I. Schreb Gcxxxrir.

Barnás szürke, alkoril mint egy poc; kis üregekben lakik, termékeny tájakon, gyümölcsökkel és bimbókkal él. $\left({ }^{2}\right)$.

A szürle sipörle. (Le Lagomys gris. Lepus ogotonna.)

Pall. Glir. III. Schreb. ccxxxix.

Igen halaviny szürke, súrgús lábakkal, valamivel nagyobb az elóbbinél, kóhalmazatokban fészkel, és sziklahasadékokban, stb. hol szénát gyújt a télre.

(') Lagomys=nyulpaikiny.

$\left({ }^{2}\right)$ Pallas egy még kisebb fajt emlit, Ásia éjszak-keletériil; lejus hyperboreus, Zoogr., Ross. 1, 152. 
1 havasi sipörle. (Le Lagomy's pica. Lepus alpinus.) Pall. Glir. II. Schr. coxxxvin.

Alkora mint egy tengeri disznó, súrgás rerhenyes. A hegyek legmagasab) tetejin lakik, hol a nyarat fürek keresésíben s szárilásában tölti a télre. Ezcn, néha hat hét lábnyi magas széna petrencéi becses találmányok a coboly vadíszok lovainak.

Korsilia csont-fejlöiben egy ismeretlen sípörle faj csontai talíltattak. L. Cur. Ossem. foss. IV. 199. l.

A súlek és nyulak két neme utín azon örlök jönck, mellyelict Limé és Pallas a Cavid név alatt egryesítet, de a mellyeknch lohchetlen mís läizünséges s teröleges bélyegel találni. mint löhédyellen víllkulesokal, noha a hozyajok tartozi lajol nincscnek rgymás kïzt hasonlatossíg

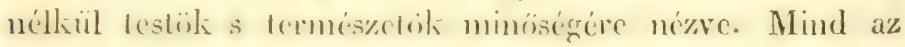
iij világbul valok.

\section{A HÁRTYöRlék.}

(Les Cabiais. Hydrochoerus. Erxleben.)

Il(liil négy, hátul hírom ujok van, mind három széles hiormmel fegyrerliczres búrtya által egyesítre; mindenüll negy zípfogok, mellyek kïzül a hátulsiłs hosszabbals, számos eggazerï s liozegyenes lemezckbül téve öszs\%c: a meliilsök kilágu lemezckbül, az ágak a fölsökbeu a kiúl, az alsókban a bel-szél felé irányzódván.

Csak egy faj ismeretes.

1 gujanai hairlyörle. (Cavia capybara. Linn.) Cabybara de Marg. Capijgoua. d' Azz. C'abiai. Buft. XII, NurX.

Aklina mint egy siami disznó, igen vastag arcoru kurta sziru, szöre durra, súrgás barna, fark nélkül seregeson lakik Guina vizeiben s a Maranhonban. Jó vad, s 


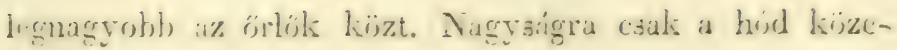
lít hozzá.

\section{$A Z$ öRLECSEK. (tengeri disznók.)}

\section{(Les Cobayes. Cochons d' Inde. Anoema. Fr. Cur.}

\section{Cavia. Ilig.)}

Kicsinben a hártyörlètet mutaljál; hanem ujaik elrúltak, zápfogaikun csak egy egy lemez van, és egy másik, melly a fölsöknél ki, az alsislinál be-felé úgzott.

A legismerctesb faj, a tengeri örlecs. Füldnél tengeri malacz kivia. Cavia cobaia Pall. Mus porcellus Lin.) Buff. VIII, 1. igen elszaporodott Europában, hol a házakban tartatik azon rélemény létezvén hogy szaga a patkányakat elüzi; szinében rálızij mint minden házi állat. Alaposan rélhetni, hogy egy aperea nerü amerikai úllattul szúrmazik, melly hasonli nagraigu s idomu, hanem egiszen verhenyes szürke szinu Brazilia s Paraguay erdeiben taluiltatik.

\section{A MóKoK.}

\section{(Les Mocos. Kerodon. Fréd. Cuv.)}

Zúpfogaik ralamirel cgszzerübbek az ürlecselínel, s mindenik csupán liél húromszegletes heugcerbül kipzett.

Az ismeretes faj szinte braziliai: ralamirel naggobb a tengeri örlecsnél, színe olajzöldes szürǩe.

\section{AZ AGUTחK.}

(Les Agoutis. Cuz. Chloromys. Fr. Cur. Dasyprocta. Ilig.)

Melül négy, hítul híronn ujok ran, mindenütt négy zápfogok, majd ceyenlik: lapos rendetleniil barázdás, kerekes kïrazilii koronitral, a fijlsijk kikanyaritra a belszílen, az alsik a kïlszélen. Termézzetijhre s húzokra nézre a mi nyulaimkhoz s tengringulhoz hosonlitanak, mely- 
lyeket mitegy íbrázoljáls az Antillákon s Amerika heves részeiben.

A küzönséges aguti; Földinél aguti krivia. (L' Agouli ordinaire. Cavia acuti. Lin.) Buff. VIII, L.

Firka nem esgéb egy egyszerü gumónil ; szörc barna a him licreszljén súrga; akliora mint egy mezei nyul. A farkis aguti. (L. Acouchi. C'avia acuchi. Gm.) Buff. Supp. III, xrxvi.

Farkat hat ragg hél esigolís; fölül barna szórü, alul sárga, lengeri nagyságu.

1 pampasz aguti. (Lae Lièvre pampas des créoles de Buenos-Aires. Cavia patagonica. Penn. és Schr.)

Aguti fiajnak lítszik, losszabb) lüilekkel, ignen rövid

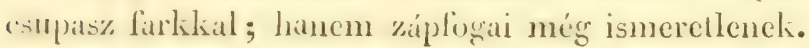

\section{\ PAKÁK.}

(Les Pacas. Coelogeny's Fred. Cuv. (')

Fogaile clegge hasonlitanti az aguliheihoz, s cgy kis

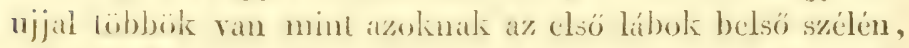
a hátulsik mindenik oldalín pedig szinte egy igen his ujok létezik wy hogy mindenüt ät ujok ran. Azon kivül egy ürege látni poláijohban, molly az igcon szóles és kivillo járomii szile alatt lickszik $\left({ }^{2}\right)$, melly a csontos tejnck különös tehintelet ád. Azt mondjaik húsárul, hogy iggen jó.

Van cgy sárga és egy barna faja vagy fajtája, mindenik fichir follos. ('avia paca. Linn. Páka kavia. Földi.) Buff. $X$, xhIIf. Supp. III. xxxy.

(') Anoema, erõtlcn; chloronıys, súrgapatkány; dasyprocta, tahart alfel, coelogenys, vájt pofa; hydrochoerus, vizidisznó.

(") Harlan (Fauna amcric. 126. 1.) egy a philadelphiai tárban tartolt fej szerint egy új nemet alkotott osteopera név alatt, hanem rzen leirása szerint azt mi ncm másnak véljük mint a pakának. Deg marets ur is ésricvette már ezt. 
Végre még cgy állat van hátra, talám a kaviákhoz, talám a sipürlékhez ragy a patkányokhoz közelítö; de a mellyet igazín nem tudunk hova helyhezteini, nem ismervén fogait; - cz a Csrкkörre (chinchilla), mellynek böre a liereskedés számára bören hordatik be, de egész testél még ncm lehete megszerezni. Akkora mint egy tengeri örlecs ragy kis tengeri nyul; hosszú sürü s a prémeknél ismertek lözött legfinomabb szórï; fülei nagyok, félig csupaszok; farka testének harmadát üti föl, durvíbb s olly módon helylieztelett szórü, hogy az oldalvást összenyomottnak lálszilk. Elsó lábain négy uja van s a hüvelyknek nyoma; a hátulsúlion csak húrom. Ezen emlös déli Amirika hegyein lakik.

A Tiscache mellyet d' Azzara irt le (Quadr. du Parag., a fr. ford. II, 41. l.) s mellyet mi ábrízolra látánk alig egyéb, mint a csinkörle nagy faja, rövidebb és durrább szórrel. $\left({ }^{1}\right)$.

AZ FILÜSEK HATODIK RENDE.

\section{A FOGHIJASOK.}

Vagy állkapcsok elején fogak nélkül szükölkö-dö emlösek; - nálunk a karmos állatok utolsó ren-

(') Az ábrizolatokat Hamilton Snith és Brookes közlötték veliink. Ez azon allat, mellyet Blainville gerboise géance név alatt ir le, Desm. Mamm., 315 , és Nouv. Dict d' hist. nat. XIH, 117. s melly ezen munka angol forditásában Marmot-diana aćv alatt restve van. 
dét képezik. Noha esupán tagadó bélyeg últal egyesültek, azouban mégis némelly tevöleges jeleket is birnak együtt, nevezetesen nagy körmöket, melylyek az ujak végeit körülölelik s többé kevesebbé a mancs természetéhez közelítenek; továbbá bizonyos lassuságot, fürgeség-hijányt, mellyek tagjaik helyezctétül származnak s abbul könnyen ismerhetök; hanem ezen jelek is eléggé kitünö csorbákat hagynak, ugy hogy a rendet három törzsökre kell osztanunk.

\section{i I.ASSANJÁROK.}

Elsö osztályokat képzik. Rövid arcok van. Nevök rendkiväli lassuśnguktul jö, melly valóban szokatlan alkotások következése, hol a természet abban létszott mulatni akarni, hogy valami tökélyellent s grotesket teremtsen. Csak egy neme létezik még.

\section{A. IAJHÁROK.}

\section{(Les Paresseux. Bradipus. Linn.)}

Ziipfogalk hengeresek, szemfogaik hegyesek ég ezen zápoknál hosszabbals; mellükön két csecs, ujaik bör által egyesíttettek, s kirülrül csak iszonyú, összenyomott, fö̈rbe liörmök által jeleltettek, mellyek nyugalom idején a tenyèr vagy talp felé hajlollak. A hátulsó lábok ferdén izcsültek a szíralkhoz s csak a külsö szélre nchezkednck; az ujak percei feszes csuklí-izesülésüek, s az clsök bizonyos életszalkban a kéz és lábtö csontaihoz forruak, s czek is egybe forrással végzödnek a gyakorlís hijinnya miatl. 
Végtagjaiknak ezen alliolísbeli alkalmatlanságához, egy nem kisehb szövetkezik arányaik miatt. Karjaik és elökarjaik sokkal hosszabbak combjaik-és száraiknál, ugy hogy mentökben könyökökre kell támaszkodniok; medencök olly széles, combjaik annyira oldalfelé irányzottak, hogy térdeiket nem tudják egymázhoz közel vezetni. Menetelök természeti kơvelkezćse ezen aránytalan alkotísnak. ('). Fálion tartúzkodnak, mellyeket elöbb el nem hagynak, mint mikor leveleiktül megfoszták, anynyi fúradságokba kerül egy másik fa elfoglalása; még az is mondatik, hogy azoknak ágairul készakarva lecsnek, a lemenetel munkáját kikerülendók. Csak egyet kölkeznek s azt hátukon hordozzák.

Ezen állatok belsörészei nem kevesebbé különcösek többi alksolásuknál. Gyomrok négy zsebre oszolt, a kérödzök négy gyomrához igen hasonlókra, hanem belül lcmezek ragy más apró emelkedésck nélkül, mig azonban bélcsőjök rövid és véghéltelen.

AZ ÁJ-ok.

(Acheus. Fr. Cur.)

Cuvier Fridrik Acheus nevet ád azon fajoknak; mellyek melülsö lábaikon három ujat birnak; ezcknek farkok igen rövid.

A közünséges cij. ( $L$ 'Ä. - Töldinél háromuju lajhár. Bradypus tridactylus. Lim. Buff. XIII, v és vI.

Azon faj, mellynél a lajhaság és azt okozó alkotás legmagasabb fokon mutatkoznak. Hüvelyke és kisuja, apró

(') Carlisle észrevelte, hogy a végtagok üterci számtalan ágacsokba oszlással kezdódnek, mellyck tovább egy törzsökbe egyesülnek, honnan a rendes ágak származnak. Ezen alkotás a lórikban is mutatkozván, mellyeknck júrísa szinte lajhár, lehelséges hogy mozgásol 
durvinyolsra szoritra, a bór alá rejtvék és a láblohözs kézlühö forrtak : a vaillkules szinte esak durvíny s üsszeforte a villteturel. Karjai liétszer olly hosszúk mint szárai; feje, hála, lagja szöre hosszú, durva, nem rugékony, majd mint a sziritott szina, a mi rút tekintetet ad neki. Színe szürke; gyakran birna s fehcir foltoklial a hátín. Nagysága mint a macsláe. Mindeddig ö az az egyellen emlös, mellynek kilene nyakesigolája van.

Ismereles migg egy aj, az ugy nerezett pörkïlt haitu.

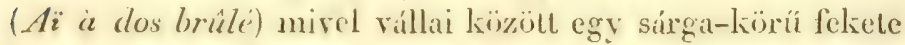
fultja van; cz, 'l'cmmink szerint, csak lijla, ugy lámadva, logy rállai közötl a szoúr levásott. Hanem

-1z ürzüs cij ( $I$; ai à collier noir. Brad. lorguatus. Geoll., Aun. Mus.) - Schr. IXXIV, A.) megkiülünbüzteleut faj, még leje csontalkotisa által is.

\section{\ I.AJHÁROK tulajdonképen. (Bradypus Fréd. Cuv. Cholaepus. Ilig.)}

Curier Fridr. megtarlja a BRADYrus nevet azon fijolinit, mellycknch melsó lábaikon kél ujok van. Szemfogaik losszabbak es hegresebbok; farkok egészen hibázik. Csak egy ismeretes.

A küzönsegres lajhar. (r) Tinau. Bradypus didactylus. L.) Bufl'. XIII, 1.

Az ájuál valamivel szcrencsisebb alkotísu. Karjai kerescbbé hosszúk, víllkulesai trljesek; lábain s kezcin nem forr annyi csont ösze; arcola hrosszabb); stb. Felenyivel nagyobb az ájuál s egyidomulag barnás szürke, melly néha verhenyes ányolatot kap.

lassuságára némelly befolyást gyakorol. Végre a lürik, a homlokmapas emlór, a valódi dúguj, megg annyi igen lasú állatok, karjaik hosszasigárul ismeretesel. 
Ezen két állat Amerika heves részeibiil való. Hihetölegr kiirtaltak volna már régen, ezen tartományol számos ragadozcii által, ha körmeikben nem birnúnak valamelly védó szert ( $\left.{ }^{1}\right)$.

Amcrikában két állatnak ásvány-csontváza találtaték ezen rendbril, igen nagy termetüeké, mellyeknek egyike, a Hal-aj. Megatheriun (Guv. Ossem. fossiles, V-köt. 1. r. 174. 1.) a lajhárokéhoz igen hasonló fejet birt, haucm szemfogak nélkül, s vázának egyebe részint a lajhárokéhoz, részint a hangyészokéhoz hasonlított. 'Tizenkél. lábnyi hosszú, hat hét lábnyi magas. A másik, a Fogy-aij. Megalonix no. 160. 1.) ralamivel kisebb. Ennek jól csak az ujai ismeretesck, mellyek az elöbbiéivel sok jelben meg egyeznek.

A második törzsökben vannak:

A rendes FogHIJAsoK.

Arcorok hegyes. Némellyeknek még van zápfogok. Két nemök van.

A тAтúk. Földinél Pánczélos cillat, latu, armadill. (Les Tatous. Dasypus. L.) ( ${ }^{2}$ )

Minden cmlösck között jelesck azon pikkclyes, ke-

(') Az különös hogy a közönséges lajhár Séla ideje elôtt nem volt ismeretes, s ezen tuclatlan gyüjto̊ szerint, sokáig nyakason ceylaninak mondaték. Exxleben afrikabelinek mondá, mivel helyette Bosmannn poto-jait nézé, melly talpanyú. (1. ezt.) Az bizonyos, logy a közönséges lajhár csak déli Amerikábul jỏ.

Shaw (Gen. zool.) egy állatot it le bradypus ursinus név alatt, mellybuil lliger a prochylus nemet csinálta. Buchanan azonban (Voy. dans le Mysore, 1. kött. 198. 1.) megismerteté, hogy ez valóságos medve; és valóban Shaw egyéne kaponyájámak meguézése által meggyŏzödtem, hogy ez medve és pedig az ajakos fajbal, mclly metszó fogait elveszté. Lísd clöl a 159 lapon.

(") Tatu braziliai nevök. A spanyolok armadillo-nak hivják, 
mény, apri padlazatkörckhez hasonlitó részckbül üsszctett pincel által, melly fejölsct e's néha farkokat is takarja. Ezen anyag paizst képez a homlokion, egy másikat igen nagyot és domborút a víllakon, egy harmadikat, az elöbbihez hasonlót a kereszten, s ezen két utolsó liözölț lübb mozgékony és küzegyenes öret, mellyck a testet hajthatóvá teszik. Farkok majd soros gyürüklicl födött, majd csupaín különłféle gumókikal, mint a szárok. Ezen állatoknak nagy fülök van, nagy liürmeik és pedigg clül majd négy majả ül, hálul mindig öt; arcorok eléggé hegyes; zápfogaik hengeresek, egrmástul elvílasztoltak, mindenütt hét ragy nyole, belül máz nellï̈l; nyclvok sima, kevessé ny ujthato: a pikkelyck között ragy a bör födözctlen páncóltalan részcin rilka szö̀ van. Barlangokat ásnals, s részint nörényekkel részint bograrakkal és dögöklicl élnck, gyomrok egrszerii, valsbelïl hibizil. Mind Amerika hév vagy legalább mérsélett részébül ralók.

Alnemekre oszthatiok meliilsö lábaik alliolisa és fogaik szima szcrint. A legnaggobbszimmál a melsij lábalion czak neg uj van, mellyck kïzül a liét lïzépsü leghosszahb).

\section{A TA'TUHETEK.}

\section{(Les Cachicames. Cuv.)}

Csak hét fogat birnak mindenik oldalon, mindenik allkapocsban: arcorols hegyes, farlioli hosizú, csonlgyilrükkel körülvéve; illyen

A kilencövü tahuhét. Földinćl kilenczüves pánczélos allat. (Le tatou noir d' Azz. - Dasypus noverncinclus. Lin.) (achicame Buff. X, 37. 'T'aton ì longue quene.

fegyverzetöt mialt; a porlugallok encuberto-nak uyan azon ohluul. Még más nevöh: quirquincho. Dasypus (fölölt lib) is uyul és tenseri nyul nevei höé lastozoll a görögökaćl. 
Ua. Supp. 1II, 58. 'I'atuete Schr. 73. 'Tatupeba. Margr).

Kilene öve van közćpen, ncha nyole; rendesen feketés; tizcnül hürclyknyi husszú, farka szinte akkora. A hétövü tatuhét. Le tatu mulet d'Azz. Das. 7-cinctus.) Schreb. 72.

Csak hétövï s kisebb marad; aránylag rövidebb farku.

\section{A TATUTÍzEK.}

(Les Apars. Cuv.)

Ujaik mint a tatuhétckéi, fogok mindenütt kilenc vagy tiz.

A háromövï tatutiz. (Le tatou apara. Marg. Apar. Buff. Mataco d' Azz. Dasypus tricinctus. L.) Schr. LXXI. A.

Középen három örvel; igen rövid farku, rendesen gumós vérlckkel. Össze tud gömbölyödni, fcjét és lábail pánréla közé behuzva s teljes lapdát képezve mint némelly bogarak a százlábu nembül. Braziliában s Paraguayban likik. Ez egy azok közül, mellyck délen legtávolabb találtatuak. Közép-nagyságu marad.

\section{A TATUPIKKEK.}

\section{(Encouberts. Cuv.)}

Elsó lábaikon öt ujok van, a három középsö lcghoszszabb; nagyrészint ötöncö]t pikkelylyel födve; fogok szíma mindenütt kilene vagy tiz.

(') A tatou is tête de belette de Grow, Cirquinson de Buff.; a das. octodecimcinctus. L.; közonsénes vagy hatövü tatupiki; hanen Grew. a hereszt-púncél sorait mozgékonyuak tartí. De megszámlalva, isy is mind össze csak tizeshatol tesznch, - s úbrázulata sem mulat cnućl többel. 
A közünséges (hatövii) tatupikt. (Le tatou encoubert Encoubert et Cirquinson. Bulf. ('). Tatou poyou d' Azz. Das. sexcinctus et octodecim cinctus. L.) Buff. X. XLI. Supp. III , xLII.

Minden tübbiektül abban külünbözik, hogy az állküzti csont mindenik oldalín egy foga ran; páncéla hat vagy hét öret bir, lockíi simák, nagyol, szegletesck; farka liözépszerï s csak a tiovén grúrüs; minden lábán öt uj.

A füreszes tatupilk; The Pichiv d’ Azz. hasonlít az clïbbihez, hiverén hogy álliözti csontjaban nincseneli fosai, s hílulso púncila lúrészes, a pikkelytclen részek pedig hosszabb es toimöltcbbs szorrick mint a täbbicknel.

A füclüt talupikl. Le talou velu d' Azz, haláros faj.

A tatuk egy hamadik alosztísámil a melülsö líbakon ö иј ran, hanem lerdén fekrö, ugy hogy a hüvelyk és a mutati uj rókonyak, cz loghosszabb, a középsön cgy iszonyú metszij häröm ran, az utúna jörön szinte egy egg nagy de rïridebb liöröm, az ulolsó uj pedig mindnyíja hïzölt legrö̈rideb\}. Ezen kézidom alkilmatossí teszi ölet a fïldiscisa es a grons bele burisra, vagy logalibb az crös belchapaszliodísra, ugy hogy nagy bajjal vonhatni el óket.

\section{A TATUVÁJAK.}

\section{(Les Cabassous.)}

Erzen alosztisba tartoznak s mindenik oldalon mindenik illkapocsokbam csak nyole ragy kilene fogok van.

A tulajilon tatuvij (Le Cabassou propre. Bufr. Tatouay

d' Azz. Das. unicinctus. L). Buff. X, $\mathbf{x L}_{\mathbf{L}}$.

Tizonkit liözépörrel: larka hosszú ; öremek és páncilinak liochai negyszegüek, szilesbek mint hosszak: mindentitt it uj, meliil negyen iszonyú körmök külsï szćlökön metszök. Nagvra nöl. 


\section{A. TATUKARMOK.}

(Les Priodontes. Fréd. Cuv.)

Ujaik még egyenellenebbek, karmaik még iszonyubbak, mint a latuvájolinál, mindenütt husz, huszonnégy apró fogok ran, mindössze tehát kilencven négy vagy kilencven hat. Illyen

A szörnyï tatukarm. (Le Tatou géant. Geofl. Grand Tatou d' Azz. Dasypus gigas. Cur.) Deuxième C'abassou de Buff. X, XIV.

'Tizenkél vagy tizenlárom középörrel; farka hosszú és házfödelesen pikkclyczett, a kockák négyszeletüek, szélesebbek mint hosszak; cz legnagyobb a tatuk között; uéha fark nélkül nagyobb három lábnyinál.

Végre a tatuk mögé helyhezletendók még, mint rgy alnem

\section{A HÁTAVÉRTESEK.}

\section{(Les Chlamyphores. Chlamyphorus. Harlan.)}

Mindenül tiz fogok, minden lábokon öt uj; a melülsökön igen nagy görbe összenyomott s mint a taluvájoknál, igen hatalmas ísí eszközt adó karmok vamuak; hátok pikkely-kockás keresztsorokkal füdött, minden merö páncél nélkül elül ragy hálul, hanem esak egy vértet képezve, melly testökhöz csak gerincök hosszában tapad; testök hátulja minlegy elrágolt, s göndörödôtt farkok részint testök aljủhoz feszült. (')

Csak cgy faj ismeretes, (a csonka hátavértes, Chlamyphorus truncatus. Harl.) öt, hat hüvelyknyi hosszu, Chili belsejébül credö, hol élete nagyobb részét a föld alatt tölti.

(1) Mi ezen áliatol csak Harlan leirásábul ismerjuk. Annales Au Lycée de Newyork, 3, 235. I is xx1, rl.

CUVỊER I. K. 
Jegyz. Vázlcirisa, Yarrel által adra, (Kool. journ. XII.) igen soliban megegyez a tatuvájéval Mindenik szemholdi fólött egy különős gumósság látszil..

J. Ugy látszik, hogy Amerikíban, asványállapotban találták egy szörnyü nagysígu tatu csontjait, melly farka nélkïl talím tiz lábnyi hosszú volt. (L. Cuvier Ossements fossiles, V. I. r. 191. lap. jegyz).

\section{A. VÁJLÁBAK.}

(Les Orycteropes. Orycteropus. Gcoff.) ( $\left.{ }^{8}\right)$.

Sokáig öszezarartattak a hangyászokkal, minthogy ngyan azon eledellel élnek, fejök idoma hasonló, nyelrök cgy kissé szinte kinyujhato: hanem különböznek mégis, minthogy rápfogakat birnak, s minthogy körmeik laposak, ásók, nem metszök. Fogaik alkotása minden más emlöscitül kiulönbäzö; rzek tömött hengerek, egész hosszasigoliban régetlen sok apró csatornálkal birik; mint a spanyol naid: gyomrok egyszerú, a csuk felé jzmos vakbelök kicsin, tompa.

Csak egy fijok ismeretes.

A reményfoki vajjláb. (I. Oryctérope du Cap. Myrmecophaga capensis. Pall.) Buff. Supp. V. xxx.

$\mathrm{Az}$ ezen gyarmatbeli hollandusok födi disznónak nevezik. Ezen allat alikora mint a borz és nagyobb, alacsony száru, csuta szörï, barnás szürke, farka a lesténél röridebb s hasonlóképen csutaszörü; melül négy, hátul ï ujat van. Uregekben lakik, mellyeket rendkivüli könnyüséggel ás. Húsát megeszik.

\section{A többi rendes foghijasoknál hibáznak a záp-}

(') Orycteropus, vảjó, ásó lábu. 
logak s következöleg semmi-némü fogok sincs. Iı is két nem van.

\section{A HANGYÁszoK. F.}

\section{(Les Fourmilliers. Myrmecophaga. L.}

Szörrel födtek; arcorok hosszú, kicsin szájba rígzodo minden fog nélkül, mellyböl fonálidomu nyelv jö ki, nagyon elönyújihatú, s mellyet ók beduguak a hangyabolyokba és termeszfészkekbe, hol a rajtok Iévó cnyves nyál által ezen bogarakat megfogdossák. Elsó karmak crösek, metszók, a fajak szcrint különbözö számuak, a tcrmesz-fészkek clrontására és eléggé jó védö fegyverül szolgálók. Nyugalomkor mindig félıg hehajlottak ezen karmok, az ököl egy havadályának megfelelve, e szerint az állat csak líba oldalára nehezkedils. Gyomrok egyszerü, a csuk felé izmos, bélcsatornájoli középszerü s vakbéltclen. (1)

Mindnyája az ujjvilág heves és mérsékelt részeiben él; egy kölket szülnck, s azt hátakon szokják hordani.

A sörényes hangyás. (Le Tamanoir. Myrmecophaga jubata. (Buff. X, xxxix. Supp. III, Lv.

Négy lábnỵinál hosszab, melül négy, hátul öt nijal, farka alul s fölull föggösen irányzott hosszú szórrel födölt, bundája barnás szürke, mindenik válán egy fexde fekcte, fehérrel szegett sujlás; legnagyobb a hangyászok között. Azt bizonyitják hogy még az onka ellen is védi magát. Az alacsony (lapos) vidékeken lakik, fákra nem mász, lasan jár.

A fogódzó hangycisz. (Le Tamandua. Myrmecophaga

(') Daubenton a kétıju hangyászban két igen apró toldalékot ssmertetett meg mellyeket szigoruan lelset vakbél zyanant venu. Arrul bizonyos vagyol hogy a fogódzó hangyászban nem leteznek 
Iamandua Cur. Myrm. Letradact!la s. M. Iridarlyla. I.) Silueb. LIII.

Idoma s lábai mint az elóbbié, hanem felényinél is

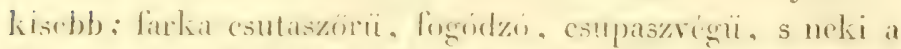

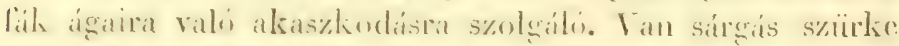
is, válán egy leerde csikolattal, melly csak a fény vissza

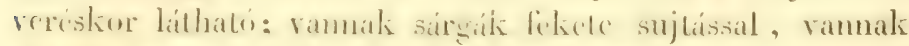

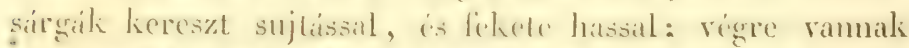

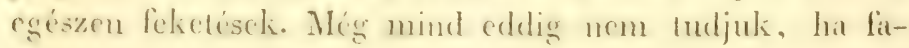
jokat bélyegeznek-e ezen különbségek.

A ketuju hangycisz. Firldi. (Le Fourmillier is deux doigh, Myrmecophaga didactyla. Lin.) Buff. X, xxx.

Akhora mint rog pathiny, syapjas sárgal szorii, hila hossziban egy receses ronal, larka fogrdzi, csupasz végü, elül csupán liét uja van, egyik nagy, - hátul négy ( $\left.{ }^{1}\right)$.

A Tomzoskák. (Pikkelyes cillalok) Földi. (Les Pangolins $\left({ }^{2}\right)$. vulg. Fourmillicrs écailleux. Manis. Linu).

Fogok nines, nyelvik igen lingujthati, hangyakkal is termeszeklich dnek, mint a hangyedsok: hancm teslök tagjaik es farkok nagy melszö pikkelyckkel födöttok, wobozidomban fekrokliel s mollyelict frilmeresztenek, ̈̈sszegömbölörlve, ha valamelly ellensigg ellen akarják magokat rédni. Minden líbolion öt uj van. Gyomrok

(1) A myrmecophaga tridactyla. L. Séba, F. rl. ncm egyéb cgy rosszul íbrázolt fogúdzú hangyisznál. A myrm. striata Schaw., Buff. Supp. III, LVI. Il. egy a kitömötûl elrontott orramozg.

(') Pangoeling, Séba szerint, a jávai nyelven annyit tesz, mint: összegömbölölö. Bengalában badjarkita vagy sziklák mászója, nevet visel; foldi pontynak is neveztetit. A hollandi hajósok formózai ördögnek hivják, stb. 
középen esekélyen elosztoll; vakbelök hibázik. Csak az ú világban találtatnak.

A rövidfartiu tobzoska. (Le Pangolin à queue courle. M. pentadactyla. L. M. brachyura, Erxl.) Buff. X, xxxiv.

Három négy lábnyi hosszú; farka felényi mint a teste. Kelet-indiábul. Ez az Aclianus Phattagen-je (Lib. XVI. Cap. VI.

A hosszu farku tobzoska. Föld. (Le Pangolin à longue queue. Phatagin de Buff. M. tetradactyla. Linn. M. macroura. Erxl.) Buff. X. xxxrv.

Két három lábuyi hosszú; farlía kétszer hosszabb a testénél; pikkelyei liegyelikel fegyrerkezre. A Senegaltul, Gvineábul, stb. (').

A Pfalz-ban a föld alalt egy liörömpörczöl találtak, melly húsz és lübb lábnyi hosszú tolozoskát mutat. Cur., Ossem. foss. V. I. r: 193. 1 .

AZ EGYVÉKUAK (EGYÜRÜEK).

(Monolremes Geoffr.)

A foghijasok harmadik törzsökét teszik. Nevöket azért kapták, minthogy a mag, a hugy és más ürületek számára csak egy külsö nyilások van. Nemzö müszereik különös rendellenségeket mutatnak; noha hasok alatt nincs erszényök: még is at. erszényesek számfölötti csontjait hordozzák a faıcsontok fölött; magcsatornáik a hugycsóbe nyilnak ez pedig a ganalóba; lankadtság idején a vesszói

(') Mi a hosszufarku tobzoska hazáją Adanson (̇s más ulasoh fudósitisaibul hatíroztuk meg. 
hüvelybe vonul vissza, melly egy lyuk által a ganaló fenekébe nyílik. Méhül csak két csatorna vagy kürt szolgál nekik, mindenik különösen nyilva és két torkolattal a hugycsöbe, melly igen bó s a ganalóba tátong. A mint végre nem egyeztek még meg emlöik lételérül $\left(^{1}\right)$, nem tudhatni, ha élötszülök-e ezen állatok, vagy tojók (²). Vázokban nem kevesebb különösséget mutatnak, föképen egy vállkules által, melly mindenik vállal közös, a rendes vállperec elébe helyeztetett s a madarak villacsontjához hasonlit. Végre, az öt karmon kivül mindenik lábokon, a límek a hátulsókon egy tulajdon sarkantyut is hordanak, csatornával birót, melly egy a comb belsó oldalához ragadó mirígy által elválasztott nedvet bocsát ált. Azt bizonyitják, hogy sértései mérgesek. Ezen állatoknak nincs külsö fïlesigájok, szemeik igen aprók.

(') Meckel emlö gyanánt tekinti azon két mirigyhalmozatot, mellyet igen kifejlödve talalt egy nöstény kacsaszájnál. Geoftroy azt véli, hosy ezek inkábh mergegyezök azon mírigyekkel, mellyeh a cickányok oldalain találtatnak.

(2) Rövid jdo óta bebizonyodottnak mondják az utasok, hogy ezen illatok tojásokat tojnak. Azon esetben, ha ez ugy van, az egyurüeket (eryvékuakat) tulajdon osztúlyu állatoknak kell némiképen tehinteni; hanem ohajtandó, hogy egy értelmes boncoló pontosan leiruá ezen tojásokat, belül törtéuỏ eredetöket, és a kitojảsut.ui kifej!odésöket. Ezt azon sok orvostul várbatui, kik Jackson kikötőjének gyarmatját naponként meglátogatják. L. különben a kacsaszáju boncolatárul azon pontos kïlönirist, mellyet Meckel tett kozzé; vedd segédül, nemzö múszereikrïl, sir Everard Home jegyzéseit; tỏlem a: Leçons $d^{\prime}$ anatomie comparée, tome V. és M. Geofroy-Saint-Hilaire jegyzékeit.Mém, du Muse, XV. k. 
Az egyúrüek csak Ujhollandban találtatnak, hol csak az angolok letelepedése óta födöztettek föl. Két fajok ismeretes.

\section{A GöмвӧLYӧк.}

(Les Echidnés. Echidna. Cuv. Tachyglossus. Ilig. Fourmilliers épineux.)

Arcorok hosszú, vélony, kicsin szájba végzódö, kinyujtható uyelvet biró mint a hangyászok és tobzoskák. Szinte hangyáklkal élnek, mint azon két nem. Fogaik nincsenck, hanem padlatuk több sorı, apró, hátra irányzott tövisekkkel födött. Rövid lábaikon öt öt igen hoszszú, igen erős ásó köröm van, s testök egész föle tövisekkel födött, mint a borzé. Ugy látszilk, hogy a veszedelem idején szinte laptaként összegömbölyödhetik. Farkok igen rövid; gyomrok lág s majdnem golyókerek, vakbelök küzépszerü; vesszejök négy gumóba végzôdik.

Két fajok számláltatik.

A tövises gömbüly. ( $L$ 'Echidné épineux. Echidna hystrix. Ornithorhynchus hystryx. Home. Myrmecophaga aculeata. Schaw.)

Vastag törisekkel egészen födve.

A sertés gömbüly. ( $L$ 'Echidné soyeux. Echidna setosa. Ornith. setosus. Home.)

Szörrel födött, melly között a tövisek félig elrcjtettek. Némellyek ezt csak kor-fajtának vélik.

a Kacsaszájuak. Földi.

(T.es Ornithorinques. Ornithorlynchus. Blumenbach. Platypus. Schaw.)

Kinyult s egyszersmind különösen széles és lapos arcorol leguagyobb hasonlatossagol mutat a kacsa lem- 
zéjérel (szaijáral), annyival inkább, minthogy szélei apró kereszt lemezcsékikel födrék. Fogok csak a szájok fenekén ran, liettö mindenütt, gyökértelen, lapos koronáju, s mint a rájlábé apró függelmes csóvekbül álló. Melüsö líbaikon hárlya ran, nem esak az ujakat egybekötö. hanem a körmeket is jiral meghaladó; hátulsókon a köröntörelsncl végzodili a hárlya; melly két bélyeg a lapos farkkal egyuit a kacsaszájuakat vizi állasokká teszi. Nrelvök némikiepen keltös, egyik a lemzében, bojtokkal foidre a, másik amannak alapján, vastagabb es liet apro izom legyel hordozo. Gyomrok kicsin. hosszudad, nyitja kïzel ran a esuklsoz. Vakbelök kicsin; ezen bélben több) kiálló küzegyenes lemezcket látni. Veszszcjen esak kit grumo. A kizesaszájuak Ujholland vizeiben is mocsáraiban laknak Jackson kikïtoje kïzeletén.

Csak liét fajok ismeretes, egyik vereses ritka sima szörii. (A kéjtelen kaciassiju. F. Ornithorhyneluus paradoxus. Blumenb.)

A másik fclictés barna, lapos, göndör szörü. Meglehet hogy csals lior-fajtíli. loy. de Péron, 1. xxxiv. rl.

AZ EUI USEK HETEDIK RENDE.

\section{A VASTAGBÖRÜEK.}

(LES PACHYDERMES.)

A foghijasok végzik a körmös állatok sorát 5 látók, hogy köztök némellyeknek olly nagy és az ujak végét annyira betakaró körmeik vannak, hogy bizonyos fokig a mancsnsakhnz közclítenek. Azon- 
ban még egyre képesck, t. i. ujaikkal különbözö tárgyakat körülfogni s azokat nagyobb kisebb eróvel megtartani. Ezen tchetség teljes hijánya bélyegezi a mancsosakat. Lábaik csupán támasz gyanánt szolgálván, soha sincs vállkulcsok; alszárok mindig a borintás állapotjában marad; s ők növény életre szorítvák; idomok, életek módja sokkal kevesebb változást mutat mint a karmosaké s nem egy könynyen lehet köztök két rendnél többet fölállitani, a kérődzőkét és nem kérödzőkét; hanem ezen utolsók, mellyeket rendesen vastagbörü̈k-nek mondunk, némelly családokira eloszthatók.

Az első az ormányos és agyaras vastagbörüeké, rövidebben mondva

AZ ORMÁNYOSAK.

(Proboscidiens). ( ${ }^{1}$ )

Mindenik lábokon öt uj, a vázban jó teljes, hanem a lábot bebonyoló, a kérges bórtül annyira födött, hogy csak a mancsfaj széléhez ragadt körmök által tetszenek ki. Szem és tulajdonképi metszö fogaik hibáznak, hanem metszö-csontjaikba két agyar van alkotva, a szájbul linyuló s néha iszonyú nagyságra nölö. Ezen agyarak sejtjéuek megkivántató nagysága olly magassá teszi a fölső állkapcsot, és

(') Az ormányosak különbféle jelckben megegyeznek némclly 6riỏkkel: 1) nagy metszo fugaikban; 2) gyakran kozegyenes lemerekbül képzett rípfogaikhan; 3) töbh csontok idomában, sth. 
az orresontokat annyira megrövidíti, hogy a vázban egészen az arc fölén találtatnak az orrlyukak; hanem ezek az élö állatnál egy henger idomu s több ezer apró s különbféleképen egylue font izmokbul összetett miuden felé mozogható ormányba nyulnak, melly kiválogatott érzéssel bir, s egy ujidomu coldalékkal végzödik. Ezen ormány majdnem olly ïgyességet ád az elcfántuak, mint kezei tökéletessége a majomnak. Ezzel fogja ö mind azt meg, a mit szájába akar vimni, ezzel szívja az italt föl, mellyet azután torkába fecskendez, meggörbítve ezen csudálatos müszerét; és igy kipótolja a hosszú nyakat, melly nem hordozhatandá ezen nagy fejet és azon nagy agyarakat. Végre a kaponya csontfalai között nagy üregek ramnak, fejét könnyebbítók; alsó allkapcs egészen metszö fogak hijával van, belei igen tömegesck, gyomra egyszerü, vakbele iszonуu; csecse kettö csupán, a melén. A kölök szájával szop, nem ormányával. Az élö természetben c'sak egy neme ismeretes az ormányosoknak, - ez.

AZ ELEFÁnToK-é. F.

(Les Éléphants. Elephas. Lin.)

A leçnagyobb szárazi emlöseket foglalja magában. Az ormányoktul kapott bámulandó szolgálat, melly egyszersmind mozgékony és hatalmas eszliöz, a tapiutás és szaglis müszere, iggen ellenütk̈̈zö az $\ddot{j}$ otromba tekintetökkel $\mathrm{s}$ idomtalan viszonyaikkal; és mivel egyszersmind meglepö tckintetii, ๔\% is hozzí járult, hogy ezen állatok értelmessége fouhéjizra adasseck elö. Mi ökel sok ideig vizs- 
gálván, nem láttuk logy az ebét vagy tübb más emlósét fólülmulta volna. Különben az elefántok szelid természetüek, s a vén hímck vezérlése alatt seregesen élnek. Cisak növényekkel táplálják magokat.

Megkiilönböztető bélyegök a zápfogak, mellyeknek leste bizonyos függö lemezekbül áll, mindenik csonlállománybul képzödve, mázzal takarra s egy harmadik, kérgesnek neveztelett állomány által köttetve össze; egy szival azokhoz hasoulítra, mellyeket a hártyourléknél és több más örlönél látlunk. Ezen zápfogak nem függösen következnek egymásra, mint a mi maradú zípfogaink a tejzápfogakia, hanem hátulrul clöre, olly módon, hogy a mennyire egyik fog kivásik, annyira azon idóben az utám na jövötül elöre nyomatik; s igy az elefánt majd egy majd két zápfogat bir mindenik oldalrul, összesen pedig az idöszakok szerint négyet vagy nyolcat. Az elsöknek ezen fogak közül kevés lemezeik' vannak, a következendöknek pedig mindig több. Azt mondják hogy némelly elefántok eképen nyolcszor cserélnek zápfogakat. Agyaraikat egyszer cserélik el.

A mai elefántok, durva börrel födvék s majdnem szöretlenek, csak az ó világ hér ege alatt éluck. s mind eddig csak két fajok ismeretes.

Az indiai elefánt. ( $L$ Éléphant des Indes. Elephas indicus. Cav.) Buff. XI, I. Supp. III, Lזx.

Feje hosszúdad, homloka homorú, zípfogainak koronája kereszl vesszóket mutató, hullámzókat, mellyek az. azokat képzó lemezck szélci, a dörzsölés által elvásva. Ezen faj fülei kisebbek; hátulsó lábokon négy körỏm ran. Az induson tul a Keleti-tengerig lakik s a nagy szigeteken India délszalsán. Ott végetlen idö óta megfogatnak némelly egycuck tanítás végett s húzo és terhordó állatokká tétetnek; hanem hízi állatképen mindegyre nem vala tenyészthetö, noha alaptalan az, a mil szemérmetességük- 
rï mondanak, hogy t. i. tanúk chöt nem nösznek. A nöstenyeknck igen rövid agyaraik ramnak s ezen tekintetben sok him hasonlít hozzájok.

As afrikai elefänt. (T) EGlephant d' Afrique. Elephas "Ifricanus). Cur. Perraull. Mém. pour l' IIist. des An., és Fréd. Cur. Mammif.

Feje gïmbilyü, homlokia domboru, fülei nagyok,

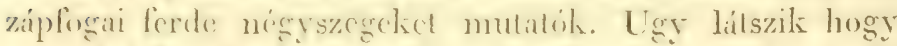

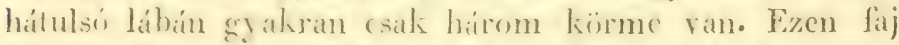

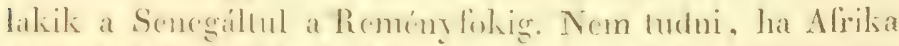

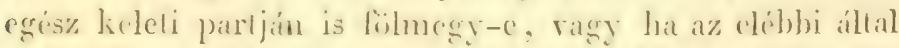
pritoltatik-e oll h. A no-ling ek agrarai olly nags ok, mint

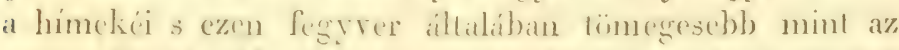
indiai lajnát. Ma már nem szelideltik meg at afrikai

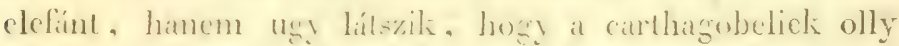
hasznát vették, mint az indusok a magokénak.

A föld alatt a két világ majd minden részében talál-

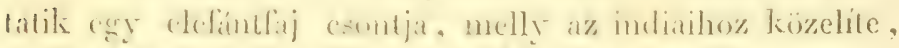

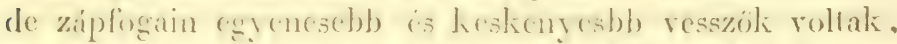

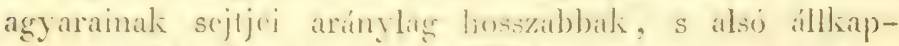

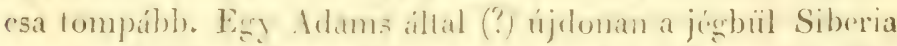

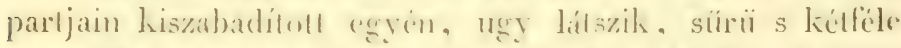
természetii szörrel firdetell: wgy hog lehetsiges, hogy ezen faj a hideg eghajlalokban di. Ez régrila rllint már foildgolyonkril. (I. Cur. Recherches sur les ussem. foss. tom. I.)

Az ormányosak második neme, ragy

\section{A KÚPFOGÚK.}

\section{(Les Mastodontes. Mastodon. Cur.)}

Egészen elveszetl, és egy élöfajat sem hagyoll. Liabai, agyara, ormánya és sok más alkotási bélyege kïzös rolt az elefántokkal; hanem azoktul kïlöubözöl zápfogai által, mellyeknek az inycu túli koronaja nagy kupos 
hegyelikel födetet s elvásása után többé kevesebbé széles körtílokat mutatott, ezen kupok lemetszését ábrázohikat. ('). Ezen fogak, mellyek hátulrul elöfelé cserélkeztek mint az clefántuál, annál több kíp-párokat mulattak, minél idősebb volt az állat.

A nagy kúp fog. (Le grand Mastodonte. Masdoton giganteum. Cuv. a f. h. h.)

A legjelesebb laj, mellyuck kup-vágásai ferde négyszegüek. Az elefántol fölüti, hanem még otrombább arányú. Maradélai csudálatos jôl menekclve és nagy böséggel találtatnak északi Amerika majd minden részében. $\mathrm{Az}$ ó világban végetlenül rilkábbak.

1 keskenyzcipu kúp) $\int \mathrm{og}$. (Le Mastodonte à dents étroites.

Mastodon angustidens. Cuv. a h. hely.)

Zápfogai kicskenyebbek az elóbbiéinćl, s clvásván lóheridomu tillapokat mutatók, melly okbul némelly szerzök ezeket a viziló fogairal összezavarták. Ez az elóbbinél egy hamaddal lsisebb rolt és jóval alacsonyabb szírn. Maradrínyait majdnem egész Europában találhatni s déli Amerika legnagyob) részében. Némelylior rassal athatra lévén fogai, fölhevilés által szép liék színt öltenek föl s az ugy nerezett nyugoti türkiszt adják ( $\left.{ }^{2}\right)$.

\section{Második családunk magában foglalja}

\section{A szorosb értelmi vastaGBöRÜEK-et,} mellyeknek lábain négy három, vagy két uj van.

( $\left.{ }^{1}\right)$ Ezen alkotás, melly a kúpfogúkkal, vizilovakkal, disznókkil, stb. közös, azon hamis véleményt szülé, hogy az elsók húsevök voltak.

$\left(^{2}\right)$ Még némelly kcvesebbé elterjedt fajokat is találtak föl. I. Cúv. a hiv. helyen; és egészen újdonan igen nevezetes fajok hozattak a birmanoh tartományábul, mellyeknek leirását Bucklandtul rárjuk: Mast. latidens; Mast. elephantoides, etc. 
Azok mellyeknek páros számu ujai vannak, némiképen villáslábuak, és némelly tekintetben, vázokra söt még gyomrok bonyolatára nézve is közelítenek a kérödzökhöz. Rendesen csak két nembe tétetnek.

\section{A VIZILOVAK.}

\section{(Les Hippopotames. Irippopolamus. Lin.)}

Mindenik lábolkon négy ujok van, majdnem egyenfok, apro manesbar regzö́dök; mindenuitt hat zípfogok s czek hïzuil a hírom melülsö lkúpos, a három hátulsó két pár hegy gyel födïtt, mellyck olvisván, loheridomot nyernek: mindenik allkaposbon negg melszö, a fölsök rövidek, kilposak, visszahajlotlak, az alsok hosszík, hengeresek, hegyesek, rlöre fekrök: mindenik oldalon föhül alul egy szemfog, a foilsii egyenes, az alsí igen vastag, $\checkmark$ isszallajlotl, a kettio pedig eģili a másilkat vásílja.

Ezen állatok teite igen tömeges, szörtelen, száraik rïridek, hasok majdncm a földet kússza, fejök iszonyú, szćles duzalde orjba régzö́lio, melly vastag melsó fogai kiszuiletel rejti cl: farkok rövid, szcmeik és fülcik aprik. Crommoli wabb zsebre ran eloszlva. A folyanoliban gÿ̈kereklicl is egyib) nierenyi anyagokkal ilnek, is nagy viddságol s ostobaságot mutatnak.

Csak egy fajoli ismeretes, melly ma Afrika közép

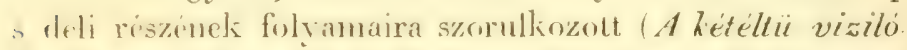
F. H. amphibius. L.) Buff. Supp. III, $4 \mathrm{~s}$ 5. Különben a Niluson rgész Egyiptomig lejöt; azonban már jöideje, hogy ezen vidélirill eltünt.

Europa rizmosatai ehez az afrikaihoz igen hasonlitó vizilofaj ('soutjait rejtik, és liet ragy három kiscbbo is kisebb fajéit. (L. Cuv. Recherch. Sur les ossem. foss. tom. 1). 


\section{A DISZNóK.}

\section{(Les Cochons, Sus. Lin.)}

Minden lúbokon két nagy középujok van, crös mancscsal fegyrerkezve, és két oldalujok, sokkal rövidebb, a földet meg alig érö; metsző fogaik száma változó, de az alsók mindig clöre feküvook, szemfogaik a szájbul kimeredök s egyik a másik felé fölhajolva; arcorok csonka ormányba (orjba) végzödik, melly földturásra alkalmatos; gyomrok kevessé osztott.

A tulajdonképi disznóknak huszonnégy ragy huszonnyolc zápfoguk van, ezek közül a hátulsók hosszúdadok, gumós koszorúval, az elsók többé kevesebbé összenyomtak; zápfogok mindenils állkapocsban hat.

A sertés disznó. F. (Le Sanglier. Sus scropha. L.) Buff.

V. XIV, XYiI.

Ez a hízi disznónk s az ö fajainak törzsökapja; agyarai hengeresck, ki-s egy kevéssé fölfelé görbültck; testök zömök, füleik egyenesek, szöre sertés, fekete; kölkei, a malacoknak neveztettek, fehér s fekete csikolatuak. Nagy kárt okoz az erdók közcletén feküró mezókïn, otl gyökérkeresés régett turkílva.

A házi diszno (szelíd sertés) nagysíga, szírai magassága. fülei iránya és színe különbözök; ez majd verhenyes, majd tarka. Kiki tudja, melly hasznos ö táplálatı liönnyüsége, husának jó ize, és sóban soká cltarthatása s végre szaporasága által, melly a nagyságabeli állatokét sokkal fölülmulja, az emse tizennégyet is malacozwán. Négy hónapig hasas, és érenként kétszer. A sertés öt vagy hat érig nöl, egy esztendös korában nemzhet, s husz ćrig éthel. Noha elég durra természetü, a rad és szelid scrtések még is társaságosak, a farkasok ellen védni tudják magokăt, körhegyuüle s mindenfelé túrójoliat mutatva. Torkosak, rofógôh, önün malacailiat is fölfatrik. 
Ezen faj az egész földön elterjedt, és csak a zsidúk s Mahomet hivei nem típlálják vele magokat.

Az cilarcos disznc. (Le Sanglier à masque. Sus larvatus. Fr. C. Sus afrecanus. Schr. CCCXXVII. Sanglier de Madagascar. Daub. MDCCCLXXXV.) SamueJ Daniels Afric. Scenery xxr. rl.

Agyarai mint a sertéséi, hanem arcorinak mindenik sdalán. az aggarhoz krizel, nagy gumó ran, majdnem nöemlöhöz hasonliti, egy esont-kiaillís által tartatolt, s a melly igen kiilinniis idomot ád az állatnak. Madagaskárban s Afrika délszakán lakik.

1 babirussza disznó F. szarvasdisnó. (Le Babiroussa ou

Cochon-Cerf. S. babirussa.) Bulï. Supp. III, xrr.

A tobbielnat magasabb is karesubb száru; agyarai hosszuk rékonyak függösen tekeredök, a fölesök csigásan hajolnak hátra. Az indiai sziget-sok némelly szigesein lakik.

A disznólatul clválaszhatók.

\section{SZÖMÖCSPOFOK.}

(Les Phacochoeres. Fréd. Cuv.) ( $\left.{ }^{1}\right)$.

Zuipforgaik hengerelibuil títettek össze, kéreg által kötictre ey máshoz, majdnem ugy mini az elefántéinak kerešt-lemezci szinte ugy hitulrul clóre váltják föl azolsat.

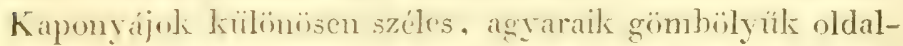
visi is fillelé irim zoltak, irtuzlalis nagyok; es mindenik pofájokon egy nagy izom-karély csüng, a mi idomok ocsmáng sigut teljessé teszi. Lölul csak két zápfogok ran; alul hat.

A ziold foktul hozolt eggéneli (afrikai szömöcspof. Sus africanzes. Com.) általiłhan içon teljesen birják ezen

(1) Phaco-chocrus, szömölcsös diszno. 
metszófogaliat; a Remény foktul jövök (a szerecsen szömöcspof; Földinćl szerecsen disznó. S. aethiopicus. Gm. , Bulf. Supp. III, xx, ezeliet soha sem mutatják; csupán csak nyomaikat lehi néha az iny alatt; meglehet hogy ezen különbség a kortul függ, melly a fogakat az utolsóknál elvásatá, de az is meglehet, hogy faji különözést jelent, annál inkább, ininthogy a reményfokinak feje is szćlesebb és rövidebb valamivel.

Anníl keresebbé hagyhatók a disznók nemében

A HÁTANYíL-ak.

(Les Pécaris. Dicotyles. Cuv. $\left({ }^{1}\right)$.

Majd egészen a tulujdonképen ngy mondolt disznók záp és metszö fogait birjáli, hanem szemfogaik a többi állatok rendes helyezét birva, nem állanak kı a szájbul; hátulsó lábaikon a külsö uj hibázik. Farkok nincs, ágyékaikon mirígyes nyilás van, mellybül büdös nedv szivírog. Két nagy ujok kéz és lábtö́csontja egy darabba forrt össze mint a kérödzóknél, mellyekhez még hasonlóbbakká teszi öket több erszényre oszlott gyomrok. Az különös dolog nálok, hogy függerök néha igen földuzadt, hanem a uélkül, hogy a földuzadás helye meg volua határozra, - mintha lükevéuy (ancvrisma) alá voluámak vetve.

Csak kél fajok ismeretes, mindenik déli Amerikábul, mellyelict esak d' Azzara kïlönbözlelett meg egymástul; Linné a Sus tajassu név alatt egybe zavarta óket. Az ürvös hátanyil. Földinćl pésmadissnó. (I.e Pécari à collier ou Patira. Dic. torquatus. Cuv.) Bufl. X, III, IV.

Szóre szürkérel és baruával gyürüs; örve fehéres, az alsó alkapoes szegletétul ferdén menó a vállhoz; felével kisebb a sertésnél.

(') Dicotyle, kellös külidưk, a hátál való nyilás miatt.

CUVIER I. K. 
Az ajakos hatanyil. (Le 'I'agnicati, T'ailetou, Tajussou, ctc. Dic. labiatus. Cuv.)

Nagyobb, barna, ajakai fehérek.

Ide helyluezlethetö egy az éló terníszclben ma ismeretlen nem, mellyet mi talíltunk föl s ezen nevet adoil. neki:

\section{anoplotherium. Cuv. \\ (Fegylenösd).}

A rastagöbrïck kïlönbféle törzsökeivel a legkiilönösebb) hasonlitossácrokat mutatja s némelly tekintetben a liérödzok rendéhez ksizclít. Mindenik állkapocsban hat metszö fog, - a metszölihioz hasonlito négy szembiog, eggmásba be uem vígra, is mindenült hét zípfog, egy folýásti sort képez minden hézagosság nelkïl, a mi csak az cmberben láltalik. A negy hátulsó záplog mindenik oldalon hasonlit a szarvorru, szililabí is a hatjlano-(palocolheriumi) ćihoz. azaz fölül négyszegü, alul két ragy hairmas félholdu. Lábaik két nags ujba régzödök, mint a kírödzóhnel, azoktul abban különböznck, hogy a kiz és líbto csonljai, soha sem forral egy darabba össze, mindig elválra maradnali. Lábtojök alkolísa, mint a teréknél.

Ezen ncm esontjai nem labiltatlak maig egrébüt mint a gypszloányálsban Páris köruit. Mi ilt ät fajat ismextük ki, cgy nagyot mint a szamár, a vidra alacson idomáral és hosszú farkával. An. commune Cur.) elsö lábainak belsö szélén egy lis mellékes uj ran; egy másilial, gazella nagyságnyit és künnyüségül: An. medium.); egyet a nyul nagyságáral és majdnem arányaival, két apró mellékes ujjal a hátulsú lábak oldalain, stb. (L. Cuv., Recherch. sur les ossem. foss. tom. III.

A nemvillás lábu rendes vastagrbórüek három nemet foglalnak clóször magokban, egymáshoz 
iggen hasonlót zápfogaikra nézve, mellyek fölül mindenik oldalon heten vannak, négyszegü koronával, különféle emelkedett vonalokkal, alul is heten, kettös félholdu koronával, az utolsó mindenütt három félholdu, - hanem metszö fogaik különbözök.

\section{AZ ORRszaRVUAK. (szarvorruak F.) '}

(Les Rhinocéros. Rhinoceros. L.)

Még ezek is különböznek egymásközt e tekintetben. Nagy állatok; mindenik lábok három ujra osztoll s orrcsontjaik igen vastagok s boltidomban egyesültek, cgy tömött szarvat hordanak, a börhöz tapadút, rostos és szarrállományút, mintha üssze enyvezell szörbül állana. 'Természetök ostoba s rad; a nedves helyeket szeretik, füvel s faígakkal élnek, egyszerï gyomruak, belcik igen hosszak, rakbelök igen nagy.

Az indiai orrszarvu. (Le Rhinocéros des Indes. Rh. indicus. Cuv. Buff. XI, viI.

Huszonnyolc zápfogán kivül, mindenik állkapcsíban két crös metszöfog, lét más apró az alsók közölt és kiet még lisebb a fölsokön kivül. Csak egy szarva van; böre azon mély redók által nevezeles, mellyet az a vállak mogölt s keresztül, s a combok clött s rajtok kereszlül kípez. Kelet-indiában lakik s föképen a Gangesen tul.

A jávai orrszarvú. (Le Rhinocéros de Java. Rh. jav'anus. Fréd. (Cuv. Mammif.

Az elöbbi nagy metszóivel s egy szarvával; böre ṛedöi keresebbek, cgy, tarkóján, szćlesebb, és, a mi ucrezelesebb, egész böre födve van apro sürü szcglcies fumókkal. Még misull nem találiaték mint Járában. 
A szumatrai orrszarlu. (Le Rhinocieros de Sumulre. Rh. sumatrensis. Cur.) Bell. 'Trans. phil. 1793. Crid. Cur. Nammif.

Azon négy nagy metszö loggal mint az elöbbiek, beiren allig rammak redok, melly libbuyire elígré mezes. (lepledl) s a kirzinsteges stare mögäl egy misilial is hordoz.

As afrikcie orrszarvu. (Le Rhinoceros d' Afrique. Rh. africanus. Cur. Földind kitszarue szarvorru.) Buft. Supp. VI, VI.

Kél szarvu mint az clöbbi, börén semmi redö, egy melszij loga sincs; zaiplogai majdnem az egész allhapoes

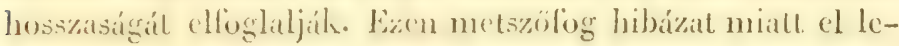
hetne ö́t vílasztani czen nemtiil.

I föld alatl, Siberiában s Vómelhon különbözö vidé-

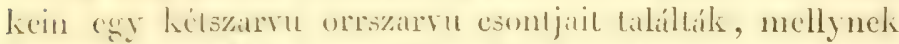

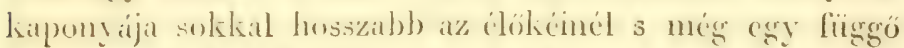

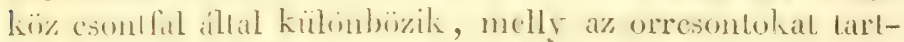
ja. Ez elreszett faj; és egy majduem egész dö

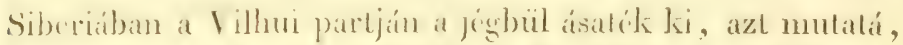

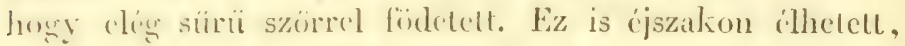
mint az ásványos elefänt.

Ujabban Toscana s Lombardiciban más orrszarvu laj csontai isattak ki, mellyck az alrikaichoz sokkal jobbau látszanak közelíteni.

Nincthonban ollyanok takáltatlak, mellycknck metszilogiaik roltak mint az ásianak; végre Franciaországban wly csontok találtallak, mellyck a disznóentíl alig mulatnak naggob) termetet. (L. Cur., Recherch. sur les ossem. fossiles. tom. II.)

\section{A SZIKLABÚK.}

(Les Damans. Hyrax. Hermann.)

Suk idcrig a rágesák (örouk) közé tétettek igen kiesin 
lermelók miatit; de jól megrizsgálrín, azı találjuk, hogy a szarvat kivévén, szarrorruak kicsinben, legalább pontosan ugyain azou zápfogaik vaunak; hanem fülsö állkapcsokbau liét erös metszöfog ran, alá görbülve f fatalságokban liét igen kicsin szemfog; az alsú állkapocsban négy metszö van, szenrıfogak néllkül. Melsö lábaikon négy uj számláltatik, a lrátulsókon három, mindannyi igen apró vékony gömbölyü :manes-nemmel, a hátulsó láb középuját kivévén, melly görłe ferde körömmel fegyverkezetl. Ezen állatok arcora s füici rövidek, szórrel takartak, a fark lielyett esak egy gunıót riselnek. Gyomrok két erszényre oszlott; a nagy rakbıelen s a hurkabél tübb kilágulísán kivül, emenuek kiözepre felé két toldalék láttatik, a madarak vakbeléhez hasonlító.

Egy faj isméretes, melly lengerinyul nagyságu , szürliés szinü, egész Afrika szikláin igen liözönségges, hol néha a ragadozó madarak zsákmánya lesz, - s melly Asia némelly részćben is lakni lálszik: - legalább mi bizonyos külïnbséget nem találunk a foki és syriai sziklabui (hyrax capensis el syriacus.) kïzölt Buff. Supp. VI, XLII, XLIII. VII, LXXIX. ( $\left.{ }^{1}\right)$

\section{HАJ®ANÓC.}

\section{(Les Palaeotherium. Ciur.)}

Szinte egy elreszell nem. Zápfogai ollyanok mmt a liét clóbbinél, melszöje hat, szemfoga keltoó mindenik állkapoesban mint a tapiroknál, mindenik líbokon három lítható uj: azonkiviil egy rövid izmos orjat is hordanak mint a tapirok, mellynck izmai végelt az orresonlok rövidek vollak s alantok nagy kıkanyarilist hagynak. Mi czen

(') A luyrax hudsonius, Bewick, 407. és Schreb. CCXL, c. valódiságámul iģen kélelkelem. Csupán csak gyüjteménylárban líltatott. 
nem csontjail keverten találtuk a fegylenösd-(anoplo-therium)cival Paris videkinck gipsz-bányáiban, Franciahon egyéb több helyén is léleznek.

Már lizenesgr vagy lizenkèt faj ismereles. Párisnál csupán, találtatnak ló tapir 'is kicsin juh nagyságuak; Orleanshoz kizzcl egg olly faj esontja találtatik, melly majdnem az orrszarmut itte foil. Exen állatok a tavak és mocsárok szélén líts\%anak lanyizzani; minthogy a csontjaikat takaro kösziklikban ides vizbeli csigáls is vamnak. (I. Cuv., Re(. Jerch. sur les oss. foss., tom. III.)

tarijfog. (Pólya).

(Les Lophiodons).

Egy másik rleszett nem, melly az clébbihez kiozel allhatotl; de also zápjai licreszl emelkedetüek roltak. Maig tiz vagy tizenkid faj isalék ki hajolani édes viz-telekeinken, a hol a hajdanócok ialillatnak. (L. Rechrch. sur les oss. foss. tom. III.)

Ezen nemek után követkczendök a

TAPIROK. F.

(Les Tapirs. Tapir. L.)

ITnszonhét záplogga lizzoil az cldözsolódés efott mindcyyik két egyenes is hárint hahmol malat: molül mindenik allkapocsban hat metszö és két szemfog ran, a zípfogaktul üres ter illtal válasziva el. Orra kicsin izmos orjidomu: melsö lábaikon négy uj ran, a hátulsokon három.

Sok idön által csak egy fuja volt ismeretes

A damasz tapir. F. Az amerikai tapir. (Le Tapir d'Amerique. Tapir americanus. L.) Buff. Supp. V. I.

Nagysága minl egy kis szamáré, böre bama, majdแ'n csupasz, fartia középzzcrï, nyaka husos, a tarkrijún

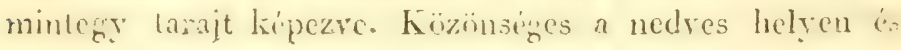


a folyók hosszában déli Amerika heves vidékein. Husát megeszik. Külkei fehérfoltosak mint a szarvasbornyúk.

Néhány év óta egy másik tapir-faj találtaték föl az ó világban; $\mathrm{ez}$

Az indiai tapir. (Le Tapir de $l$ Inde. Tapir indicus.)

Nagyobb az amerikainál, fekete barna, háta fehér, szürke. Malacca félsziget erdeiben, Sumatra szigetén, stb. lakik.

Vamnak még ásvínyos tapircsontok is egész Europában clterjedre, s a többek közölt, egy szörnyü fajé, mellynek nagysága az elefántél megliözclíté. (Szörnyi̋̈ tapir. Tapir giganteus. Cuv. Ossem. foss. tom. II.)

Roulin tanár a Cordillerákon egy új tapirfajt talála fül, feketél, siúrü szörrel födöttel; - hosszas orresontúl, - s ennél fogva a hajdanóchoz közelítót.

Schleyermacher egy nagy ásráuyos állat alsó állkapcsálıoz julott, mellyrül azt vélik, hogy valami óriási tapiré. Szörnyü szemfogai voltak ennek s szájábul kimereclök; - 'gy mellékes nemet kelle hihetöleg képeznick. Nagysága még féllel nagyobb lehetett a vizilóénál.

A vastagbörüek harmadik családa, vagy a nem kérödzö mancsos állatoké magában foglalja

\section{A MERőKÖRMÜEK-et. F.}

\section{(Les Solipèdes.)}

Látszólag csak egy ujat birmak s egy mancsot mindenik lábokon, noha a bôr alatt kéz és lábtövök oldalain két csövekcsét (karcol) hordanak, két mellékujat ábrázolót.

Cisak egy nemök ismeretes, 


\section{A LOVAK. F.}

\section{(Les Chevaux. Equus. L.)}

Mindenik állkapoesban hal metszó fog, mellyeknek koronifia a fialalságban gaïlrös: mindenütt hat záplog, nẹgrszęil koszorúral, s a beléjels ható máz által négy folhuddul jegyezre megr, s azon lïluil a foilsök még egy lis liptillat a belsö szílen. A himeknek többuyire lict kis stomfogoli van a fiblsö alllsapocsban, s néha mind a kethiben, az pedig majd mindig hibazik a kancétsnál.

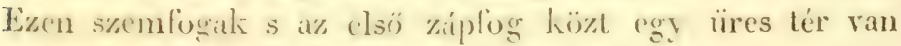
a szajjszeglelnek megfelelio, a hova a zabola tétetik s mellynel segrelelmivel esupán lin az ember képes ezen hatalmas cmlösek messzeliditésere. Gyomrok egyszerü s kijzípszerii, luanem belcik igen husgriks s rakbelök iszonyú. 'Tögyök combjaik közölt.

A kï̈zünségés ló. I. I mén. (Tie Cheval. Equus caballus.) Lin. Bufi. IV. I.

Nemes társa az embernek a vadúszalon, hadban, a fïldnirrés, mirck és hereskedes munkíibatt, a megszeliditelt állatok kïzött legfonlosib)b és legjobb gondriselést nyerï. Ugy hitszik hogy rad alliapolban nem laláltuk többe. kiverén az olly lielyeket hova az elöbb szelid rolt lovak szabadon boesillallak, mint Tatárhonban s Amerikíbin; ezek ill seregesen duck, egy idös méntül (him(iil) rezeltetre ís vedetre. A fietal mének (ménesikók) azonnal elhajtatnak, milelyt firlserdieltek (fanosodtak) s tárolrul kiscrik a cosordát, mindaddig miğ liatal kancákat csalhaltak magokhoz.

A rabszolgasígban hat hét hónapig szopik a csikó, a két nöm a második érben elválasztatik; zabola és tartás alí harmadik évben kezdenek tétetni; esak a negyedik ivben nyergeltetnek meg, s cask ekkor nöszhetnck ártalom nélkül. A kanca lizenegy havig hord.

A ló cletkorál lecrinkább metszö ligai mulalják meg 
T'éjfogai tizcnöt nappal kezdenck mutatkozni a születés után; két és fól érre, a küzépsök fülcscréltetnek három és félkorra, a két következö, négy és félkor a két szélsö. Eleinte mind ezen fogak koronája mély, hanem ezen árkot az elvásís miatt lassanlént elvesztik. Két és fél ragy nyolc éves korokban minden árok eltünt, a ló életkorát torábbá nem jelelhető.

Az alsó szemfogak három és fél érkor jönek ki, a fölsök négylkor; amazok hatig hegyesek maradnak, tizkor vásni kezdenek.

A ló életiora nem eggy könnyen haladja meg a harminc évet.

Mindenki tudja, mennyire különbözik ezen állat szinére s nagyságára nézve. Fö fajtái is szembetünö különbséget birnak fejök idomára, arínyaikra nézre, s mindenik különbféle munkára való elsöbsége által bélyegeztelik.

Legkarcsubbak és legsebescbbek az arabok, mellyek a spanyol fajta tökélyesitésére használtattak, s ezzel együtt az angol fajtál segiték képzeni; a legnagyobbak s legerösbbek az Éjszaki-tenger partjairul jönek; a legkisebbek pedig Srédhon éjszakírul és Korszilkíbul. A radlovak feje vastag, szörö̀k kondor, arányuls kevessé liellemes.

A dsagatiij. (Le Dzigguetai. Equus hemionus. Pall.) Schreb.

Ezen faj, arányaira nézve küzép helyen van a mén és szamár közötl, s közép Ásia homok puszlaiin seregesen él. Szine isabella sárga, sörćnye s hálcsilkja fekete; farka fekete bojtba régzödilk. Hihctóleg cz a régiek rad üszvére.

A' szamair. F. (L'Ane. Equus asinus. Lim.) Buff. IV, x.

Ismerhetö nagy fülcirül, farka végének bojtjárul, a vállain lévö fekete keresztrül, a mi elsö jelenkezése a liövelkezö fajokat megkrïlönböztetö csikoknak. Közép Ásiának nagy pusztíibul eredt, hol rad állapotban most is 
találtatik, számatlan esapatokban, mellyek az érszak szerint éjszakrul délléé kölẗ̈znek. Igy az igen éjszalki vidélicken rosszul is tenyész. Türödelmét, jözanságát, crös mérsékletét s a szegényebb mezcieknek adandó szolgálatát kilsi ösmeri.

Hangja (ordílisa) a göggje fenckén lérö kél külünös apró ürességtül rekedt.

$A$ zébra. Czebra. F. (Te Zèbre Equus zebra. L.) Buff. XII, I.

Majdnem szamáridomn, tökéletes rendességgel ran regiszen megesikolva fekete s fihcr kereszo sujtísolkal. Afrika egész déli rriszében honol. Mi lílluk, hogy egy

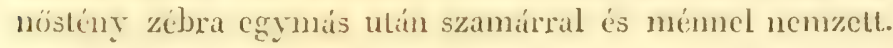

A kuaga. (Le Couagga. E. quaccha. Gnı.) Butl. Supp. VII, VII.

A lihoz hasonlibb mint a zibríhoz, hanem rele egylomu. Nyakin es vílain barna szörï, fehér sujtásokkal kereszlben; kereszlje rerhenyes szürtie, farka s szárai feheresch. Neve szavát lijezi lii, az ugaháshoz hasontot.

A berclo. (L' Onagga ou Dauw. Fr. Cuv. Mammil.) Equus montanus. Burchell.)

Afrikai faj, kisebb a szamárnál, hanem a kuaga szép idomáral, izabellasárga, fekete esikokkal fején nyakíns lörzsökén, váltra szílesbekkel s keskenyebbekliel. A há. tulsoik ferdén menuek clöre; szárai s farka fehérck. 
AZ EMLÖSEK NYOLCADIK RF.NDE.

\section{A KÉRÖDZÖK.}

(LES RUMINANTS. PECORA. L.)

Ez talán az egész osztályban legtermészetibb s legmeghatározattal rend, mert ugy látszik, mintha ezen állatok majd mind ugyan azon minta szerint alkottattak volna s csupán a tevék mutatnak némelly kis kivételt a közös bélyegtül.

Ezen bélyegek közt első az, hogy csak az alsó állkapocsban van metszőfog és pedig majd mindig nyolc. Azokat fölül kérges duzadat pótolja ki. A metszők és zápok közt üres tér van, a hol, de csak némelly nemeknél, egy vagy két szemfog találtatik. Zápfogaik, majd mindig mindenült hat, két kettős félholddal jegyzett koronát birnak, melly félholdnak domborodása a fölsőknél be, az alsóknál kifelé irányzott.

Négy lábok két ujba s lét csülökbe végzödik, mellyek lapos fölülettel (színnel) néznek egymásra, ugy hogy egy csülöknek tetszenek, de ketté hasadtnak; a honnan jött ezen állatok, ,hasadtkörmüek" nevezete; (magyarul jobban csülkösöknek mondhatók).

A csülök mögöit néha két apró sarkantyzu(csülök) van, a mellékujak nyomai. A csick (láb̉ó) 
és elöcsïk $(k e ́ z t \delta)$ két csontja egybe olvadt, mellynek neve tócsont (canon), hanem bizonyos fajokban mellékes töcsontok is találtatuak.

A kérödzök neve már kijelenti ezen állatok különös tehetségét, az eledelek másodszori megrághatását, mellyeket az elsö lenyelés után visszakérnek a szájba, gyomraik különös alkotása segedelnével. Gyomrok mindig négy van, mellyek közül az elsö három ugy alkottatott, hogy önkény szerint akármellyikbe mehetnek az eledelek, minthogy bárzsingjok a közlekedés pontján ömlik ki.

A legelsönek és legnagyobbuak neve böndö, ę bören fogadja el a durván elharapdált s elöször megrígott füreket. Innét ezek a másodikba menwek, mellynek neve recés gyomor ( recör), mellynek oldalai a méhek lépéhez hasonló lemezeket birnak. Ezen igen kicsin és gömbölyü gyomor elfogadja a füvet, beáztatja s apró lajodákba nyomja, a szájba lasanként viszont fölmenökbe, hogy ott megrágassanak. Ezen munkálatnál csendesen tartózkodik az állat, melly addig tart mig az clsö gyomorba elöször jött fü mind átesett rajta. $\Lambda z$ igy ismét rágott eledelek egyenest a harmadik gyomorba jutnak, sscizrétii (leveles) nevübe, minthogy oldalainak hosszas lemezei a könyv leveleihez hasonlíanak, - ebbül pedig az utolsúba vagy az olló gyomorba, mellynek filain csak redök vamnak, s melly az emésztés valódi müszere, a rendes állatok egyszerú gyomrához hasonlító. Mig a kérödzök szopnak 
s csuprín téjbül élnek, utolsó gyomrok legnagyobb. Az elsö nem fejlik ki és iszonyú kiterjedését csak a szerint kapja, a mint füvel terheltetik. A kérödzök bélcsatornája igen hosszú, hanem vastagbeleik kevessé duzadtak. Még vakbelök is hosszú s elég vékony. A kérődzők zsirja meghülvén, jobban megkeményedik mint a más emlösöké sőt még töretes is lesz. Faggyú név adatik neki. Tögyeik a combók között vannak.

Az emlösekbül minden állatok között legtöbb hasznot arat az ember; majd mindnyájábul ehetik, hús eledelét majdnem egészen ebbül veszi. Vágó marhául több szolgál neki; mások tejök, faggyújok, börök, szarvok és más szüleményök által használnak.

A két elsó nemnek nincs szarva.

\section{A TEVÉK.}

\section{(Les Chameaux. Camelus. L.)}

Az elöbbi rendhez a többiekuél jobban közclítenck. Nenıcsak szemfogaik rannak mindig a két állkapocsban, hanem még két apró hegyes fogok is van a metszöesontba bealkotva; alsó metszö fogok hat, zápfogok husz ragy csak tizennyole, melly tulajdonsígot egyedül birják a kérö́dzök közzött, valamint hogy csíljjök esúnak-és köbcsontja elválasztott. A nagy mancs helyctt, melly a belsö oldalon lapos, mindenik uj alsó szinćt betakarja s a láb rendes létúgu idomát meghatározza, nekik esak egy kicsin vau, csak az ulolsí perchez ragadí s öszméres idomu, miut a vastagbörrieké. Duzadt s rágolt ajakok, hosszú nyalsok, kíilló szemgödreik, kcresztök cyöngesége, szá- 
raik is lábaik liellemetlen aránya, óliet némiképen rut valúkliá teszili, de fö juzanságols s azon tehetségek, hogy ivís nélkül több napig ellehetuek, elsö hasznuakki teszi öket.

Ezen tchetsigg hilıctöleg azon nagy mirigy halmozatolitul származik, melly elsö gyomrok oldalail takarja, s mellyekben egyre larlatik ragy nemzödik viz. A többi kérödzóknél nines semmi ehez hasonló.

A tevék hátra felé hugyoznak; hanem resszcjök megvállozlatja irinyál a nószendéskor, melly nagy bajosan lörtinik, s melly alatl a nöstény feküszik. A nöszliödéskor buidös nedv foly lii fejökbül.

\section{A tulajdonképi TEvÉK.}

Kel ujok alol egyesulve ratn majdnem egesz a hegyokig, egy kïzös lalp állal, hitakon zsircsomal. Ezen nagy allatoknak a\% o vilighml, két fajok ismeretes, melly teljesen meg van szelidítve. $\left.{ }^{1}\right)$

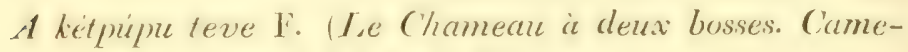
lus bactrianus. L.) Buff. XI, XxiI.

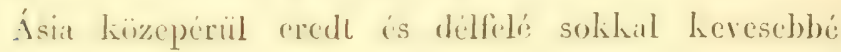
megy le, mint

A kï̈önseges teve. T. Egypupue leve. (Le Chameau a une seule bosse. Camel. dromedarius. L.) Buff. XI, 1X.

Mclly Arabiábul rerisz cjoszaki Arikún, Syria nagy részén, Persiában, stb. elterjedt.

Turkestanban, Thibetben stb. az elsö használtatik, mellyce escisz a liajlial liözeletére fïlrezemek. I máso-

(') Pallas a buchariak s tatárok hitére azt beszéli, hogy-közép Ásia pusztáihan rad tevek találtatnak; hanem azt meg kell jezyezni, hogy a kalınukok vallúsi ohföbül mincienféle állatoknak szabadságot aduak. 
dik ige'n ismeretes a puszláli átulazásához valú szükséges voltiért, s ö az egybeköttetés egy eszliöze a velök határos tartományok számára.

A kétpúpu teve kevesebls bajjal júr a nedves tájakon mint a másik; nagyobb is és erösebb. A vedlés idején cgészen clreszti szörét. Az egypúpu teve pedig a maga meglarlóztatást tírolabb viszi. A közönséges teve a kélpripunak tulajdonképen csak fajtája, könnyebb és a futásra rigyesebb.

A tevék husa és teje cledelül szolgál, szörök pedig ruhául azon népeknek, mellyek tevét birnak. Mind a két faj haszna-vehetetlen a sziklás vidékeken.

\section{A L̇ÁMÁK.}

(Les Lamas. Auchenia. Ilig.)

Két ujok clvílt; príptalanok. Mindeddig csak kít jol megkülöıböztetett fajok ismeretes, mindenik az tij világbul, és az elóbbicknél sokkal kisebb.

A szörös líma. Földinél lakma teve. Vad állapoljában.

Guanaco. (Le Lama. C'amelus llacma. L.) Buff. Supp. VI, xxvir.

Akkora mint egy szarvas; szöre durva, gesztenyeszin, a szeliditetnél külöuböző. Peru meghódílásakor az cgy tehcrhordó rolt oltan; száz ölven fontot clhord, de rövid napi utakat tesz. Az alpaka neki fajtaja, hosszú gyapjas szórrel.

A gyapjas lima. Földinél gyapjas teve. (Le Vigogne.

Camelus vicunna. L.) Buff. Supp. VI, xxvir.

Birka nagyságnyi, sárga gyapjas, mellynek finomsíga és simasága csudálatos, s melly drága anyagolsal ád.

\section{A PÉSMÁK. F.}

(Les Chevrotains. Moschus. L.)

I tevinel solikal kisebbek: a reudes liérodzóktul csik 
szarvhiányuk állal különböznek s az által, hogy fölsö allkapesok mindenik oldalán eş hosszú szemfog ran, melly a himelneil a szajbul hiall; azon fölül rázolban egy kis vékony szárlitpesok van, i mi mig a teréknél sem lítezik. Ezck totszclmes állatok kïmnyüségöjs s kellemetességök miatt.

A tatcir pésma. F. (Le Musc. Moschus moschiferus. L.) Buff. Supp. VI. xxix.

Legnevezelesb faj. Akliora mint egy öz, majdnem farktalin, egészen lödre olly durva is szuros szörrel, hogy az majdnem sertinek nevezheto; de leglöképen azon zseb tesri hiressé, melly a him elöböre elöt ran, s azon illitos anraggal tehk meg, melly at orrosolnál s illatïzésnél pésma név alatt annyira ismeretes.

Ezen laj azon zordon is szillís tájon lítszik lakni, homman Asia folyanainak nagyobb šima foly le, s melly Siberia, China is Thibet kizzl terjod ki. Flede éjoli s magányos, fétenlisege mirlékluli. I Thibet is Tunkin-beli adja a leçołb) pésmát, ijszakon majel illittalan ezen annyag.

A löbbi pésmík pésma-crszeny hijával vammak. Nind az óvilág heves videheil lakják ( $\left.{ }^{1}\right)$; a kérödzök között ök a legkisebbek és legkellemesbek. $\left({ }^{2}\right)$.

Minden többi kéródzóknek, legalább a hímeknek, két szarvok van, azaz két többé keveschbé

(1) A moschus americanus, melly Seba szcrint állittaték föl, ne̊n egyéb mint a guianai szarvas bornya vagy nôsténye. Szinte ugy van a dolog Schaw moschus delicatulus-ával, melly az amerikai szarvas borjúja.

${ }^{2}$ Moschus pigmaeus. Buff. XII, XLII. (Pogonya pésma. Földi. 98.)

Moschus memina, Schreb. CcXlIII.

Moschus javanicus, Buff. Supp. V1, xxx. 
hosszú fölemelkedése a homlokcsontnak, melly semmi egyéb állatcsaládban nem találtatik.

Némellyekuél ezen emelkedetek rugékony anyagu tokkal födettek, minteģy enyrezett szörbül tétetve össze, melly rétenként nöl s az egész élet ideje alatt; különösen szarvnak mondatik a tokállomány, maga a tok oduszarv nevet hord (hordhat). Azon emelkedet, mellyet ez födöz, az egrész élet alatı nöl mint a tok maga, és soha sem hull le. Illyenek az ökrök, juhok, kecskék és zergék szarvai.

Másoknál csak mezes (lepledt) börrel födettek ezen emelkedetek, melly a fejbörébe folytattatik és soha le nem nyivödik; ezen emelkedetek soha sem hullanak le. A hegyelü (Giraffa) egyedül bir ilylyeket.

Végre a szarvas nemben egy ideig lepledı (mezes) börrel vannak ezen emelkedetek födve, mint a fej többi része, tövökön egy gyürü van csontgumúkbul, mellyek továl)b növekedve, ezen bör táp láló edényeit összenyomják és elrekesztik. A bör elszárad, lchull; a csontemelkedés meztelenül maradva egg idö mulva elvál a kaponyátul, mellyen létezett, leesik s az állat egy időre fegyvertelen marad. De hamar újak jönek elö, rendesen nagyol,bak az elöbbieknél s ugyan azon változások alá vetettek.

Ezen esupán csontos, és idöszaki változásol. CUVIER I. K. 


\section{alá vetett szarvakat tömszarvaknak (szilárszarvak) mondják (mondhatni).}

\section{A SZARVASOK. F. (Les Cerfs. Cervus. L.)}

Mind azon állatok, mellyeknek feje tomszarakkal fegyrerzell; hanem, a nyargalicol liréve, a möstenyeli. (teheneli) mindig hijoklial vamak. Ezen iomszarrak anyagit, mikor azok rgiszen kifejlödlek, igen timött, gözlruk is öböltelen csont; idloma a fajak szerint nagyon víltezi, sôt az illetlor szerint meng wgymazon fajnál is. A szaryasol ien sebes futásu állatok, rendesen az cerdöliben Gok fiivekiktl, lombokkal, fabimbikkal, sth.

Meghluilimboztctuck az egészon ragy részint lapos tönszarvu fajok; illyenck:

A javor szurvas. I. (Li Lilan. Cerv. alces. L. Europa

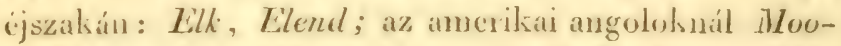
se-Deer, Canadaban Orignal). Buff. Supp. VII, IXXX.

Alikora mint reg mon és niha nagyobb, magas száru, porcos duzadt ajkonyu, torka alatt egy különbféle silonu golyra ragy lepenyegr; szóre mindig durvat, s többe kereschbe sïtel hanrats. A gim (him) tömszarva (cinte nyársidemu, utobb) repedisckre osztotl, öl esztcndök or haromszegü lenczidomoi vesz magára, kiülszélén fugas és kocsányon ül. A korral cygült ötven ragy hatvan fontuyi sulyra nöl s mindegyik agat is kap. A járorszarvas a kíc világ éjszalsi részónek nocsáros erdeiben lakik: bőre becses a timármunkálì közt.

Az irámszarvas, nyargalic. F. (Le Rhenne. (' tarandus. Lin.) Buff. Supp. III, xviI. kétszer.

Akkora mint egy szarvas, hanem szárai röridebbek. vastagahbak: mindenik nömnek vannak tömszarvai, töbs 
ágakia oszlók, eleinte véliony s hegyesekre, de utóbb a rénkorban tenyerekké szélesedök és fogasodók; szöre nyáron barna, télen majdnem fehérre változilk. ${ }^{1}$ ) Az irámszarvas esak a jeges részein lakik a liél rilágnak. Ezen állat igen hires azon szolgálatért, mellyet a lapponok kapnak töle, kik számos csapatait birják, azokat nyáron tartományok hegyeire hajtják, télen pedig a sikokra eresztik, belólük teher liordó s húzó barmokat csinálnak, husokat tejöket eszik, börükkel ruházkodnak, stb.

A daim vad. F. (Le Daim. C. Dama. Limn.) Buff. VI, xxvIr és xxviII.

A mi szarvasunknál kisebb, tẻlen felictés barna, uyáron sárga, fchér foltozattal; tomporái mindig fehérek, mindenik oldalrul fekele, alul fehér. A gím tömszarva gömbölyï törü egy hegyes szemboggal, különben cgész hosszában lapos és kifelé fogazolt; bizonyos életkor után kisebb lesz és rendellenül oszlik több ágacsra. Ezen faj, melly a régiek platiceros-a, Europa minden tartományában közönséges lön, de Barbariábul látszik eredni $\left({ }^{2}\right)$; néha egy fekete, folttalan fajtảja találtatik.

A gömbölÿ̈ tömszarru fajak számosabbak; a mérsikelı éghajlatuak télen löbbé kevesebbé megváltoztatjaik szinöket.

A közönséges szarvas. F. (Le C'erf' commun. Cerv. elaphus L.) Buff: VI, Ix, x, XII.

Szörc nyáron barnás-sárga, gerince hosszában feketés ronal, és mindenili oldalon egy sor halavíny sárga folt: kereszte s farka mindenkor halavány súrga. A mérsékelı

(') Ezen változás mondatá a régickkel hihetóleg, hogy a nyargalóc kedve szerint veszi a színeket magára.

$\left({ }^{2}\right)$ A Recherches sur les ossements fossiles második kiadása utin egy vad dínszarvast kaptunk, melly tunistul délfelé !nvetek az erdökben. 
Europa s Ásia minden creleiben tanyaz. A gím tömszarra gömbölyí s a második érben bújik elö, eleinte nyársidomu, ntobb belszinin amál löbb ágat kap, minél rénebb lesz. és mintegy tïh) apro hegyii tenyéred (áscival) koszoruztatik. Az igen vén szarras folietésul; nyaka szóre hoszszahbul s szurós les\%. 'Tümszarra tavaszszal esila le, a véneknel liezdre: a nýáron által újra nöl s ezen egész idö alitt elrálva élnek a szarrasok. Midión rijra nólt, ellsezdödik a nösa's, három heligr tartandio, s molly alatt a gímek mintegy dühösek. 'Telelendés végetl nagy esapatokban egyesulncli a gimek is tehenck. A szarvastehén nyole bavigh hord s majusban bornyadzik: a bornyú sárga, fehér foltokkal.

A szarvas radászat, melly a mind tudva van, a legnemeschb mulalsignak s gyakorlísnak larlalik, miv-ciklelylye lön, melly tulajdon chmeletel is mivszritudományt bir, hol a legismerclesebb dolgok bizar vagy legalább rendes értelmöktül cltorlott kilejezést kaptak.

1 kanadai szarvas. (T.e C'erf du Canada. Cerv. Canadensis. (im. C. strongyluceros. Schrob. 246. A 217. F. G. Az angol-amerikaiaknál: Elk ragy Eilan. IV apiti.) elc.

Egy nesyeddel nagyobb a mienknél, majdnem azon szinii, hanem keresztfölülete szílesebb is halaványah), lömszarvat egyenlön gömbölyüek, ha nem jobban kifejlettek es soha tenyereschlie ncm levök. Ejozakamerika minden mérsélrelt tíjín.

A Inuisianai ragy virginiai szarvas. (The Cerf de la Lomisiane ou de Virginie. C. virginianus. Gm. A\% angol-amcrikaiaknal: Daim.) Screb. caxtvin. H.

hisebb a mienknél. Karesubb, arcora hegyesehb, "yáron vikégos sárga, télen verhenyes szürke, torka s larka alatt mindig feher, farka harmada fekete, hegye fehér. A sim tomszarvai rovidebbek mint az curopai fajuál. 
gömbölyük, simák, fehćresck, kifelé lágulók, hogy ivboltbau jöhessenek be s clö felé; ágaikat hátulsó szinükiön hordozzúk, livérén a szcmbogot vagyis a tövágot. Ollyanok öten vagy hatan vannak. $\left({ }^{1}\right)$.

A hév tartománybeli fajok nem változtalják meg szinöket.

Déli Amerilsában több faj van még, de ezelnnels leirása még nem teljes s bélyegeik nem eléggé összehasonlítoltak.

A nagy pej szarvas. (Le Gauzou-Poancou ou grand Cerf rouge d'Azz. C. Paludosus. Desm.)

Mellynek szarvai egyenesebbeknek tetszenek mint az clöbbiéi. Szöre világos barnaveres, egy fekete sujtással az orrtö lıosszán s fekete gyürükkel a lábak végén. Különösen a mocsáros helycket lakja.

Az alacsony szarvas. Le Guazouti d' Azz. C. Campestris. Fr. Cur.

Szarvai röridek, egyenesek, elö-s hátra ágoliat bocsátók, cléggé számosakat (Ossem. foss. IV. III. rl. 46-48. lir.); bundája sárga, hasa, comb belseje, ülepe s farka vége fehérelk. $\left({ }^{2}\right)$.

Még több faj van keleti Indiában.

Az indiai follos szarvas. (Le Cerf tacheté de l'Inde, ou Axis. Cerv. axis L.) Buff. XI, xxxym. xxxix.

Mindig sárga, tiszta fehér foltokkal; torka s farka alja fehérek; farka sárga, fölül fehérrel szegve; szarvai gömbölyük, idóvel igen nagyra nölók, hanem töveik felé csak szembogat hordóls, végöliön villásak. Bengalábul

(1) L. Cuv. Ossem. foss. IV. v., rl, 1-17 kr. cervus mexicanus, Penn. s Oss. foss. V. 1. 23. k. nem lehet más mint egy igen vén louisianai szarvas.

$\left({ }^{2}\right)$ T. h, Cerv, nemoralis. Hamilt. Smith. 
eredt, hanem ribikenken is igen jul tenyesz. Mar a rumaiak ösmerék.

Indiában meg löbb nás het szembugu szarvas ran mint a foltos. mellyek csak rond ido uta külomböztettek meg.

Szamok kizt van egy, melly nyakin is torkin hoszszú szört hordoz s melly Indra ijszakin flvén, Aristoteles Mippelaphos-inak lelel meg. Lristuleles szarzasa ('ervus Aristotelis. Cuv.) (1).

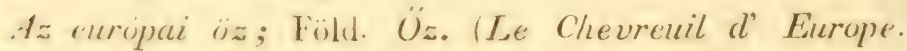

Cerv. c(ipreolus. Lin.) Buff. VI, xxxı, xxxII.

Szante esak lsét lobog van tönszatrain. Sírgás szïrke, fehér farral, kinggödrök nélkül, majdnem farktalan. Vimnak ridam verhenves szinü, nem külöuben leketés egyenck. Ezen taj kellesérel èl a mersékelt Europa magas erdein, tömszarrait az ösz régérel hányja el, a tél alatl vissza kapja, noremberben nösz, s ot és fél hónapig riselös. IIusa a szarvasínál sokkal becsesebb. Oroszhouban nem találtatik.

1 tatir öz. (Le Chevreuil de 'Tarturie. Cervus pygargus. Pall.) Schr. CCLIII'

Hasonlit a mienkhez, hanem szarrai a tönel ágasab)bak, szöre hosszabb, nagysága majd mint a dámradé: a Volgán tul a magas síǩkon lakik.

Ugy lálszik hogy Amerikában olly özek találtatnak. mellyeknck szarvai uyársidomuak, bogok nélkiil.

(') Add h. hippelaph-szarrast, Wallich szaryascit, mariani szarvast, Lechenault szarvasát, Peron szarvasat, a ló-szarvast s ezekrül 1. a Recherches sur les ossem. foss. IV. köt. s azon ábrázolatokat, mellyeket Smith Hamilton adoft exen munka angol fordításához. 
A verlienyes üz. (Le Gouazoupita d'Azz. Cervus rufus. Fr. Cuv.)

Bundaja verhenyes, ajakai, hasa hátulja s farka alja fehérek. Kél álkapesában szemfogak. Erdökben lakik. ( $\left.{ }^{2}\right)$.

A többi özektül el lehetne rálasztani, némelly india apró fajokat, mellyeknek hegyes szem-fogaik és rövid tömszarvaik vannak szörrel födölt kocsánokon, homlokukból emelkedve. Illyen

Az indiai öz. (Le Chevreuil des Indes. Cerv. munijac. Gm.) Buff. Supp. VII, xxvI.

A mienknél kisebb; apró csapatokban lakik Ceylanban és Jáván. ( $\left.{ }^{2}\right)$.

\section{a hegyelü. (Fönmelü. Földi girafFa).}

La Girafe. Camelopardalis. L.) Buff. VII, LxxxI.

Bélyegül mindenik nömben kél kúpidomu, mindig mezes (lepledt) börrrel födött és soha el nem hulló szarv van. Csontesirajok a fiataloknál egy varrány által izesült, a homloktö közepén egy púp van, vagy is egy harmadik szarv, szélesbb és sokikal rovidebb, hanem szinte varrány állal izesült. Ezen állat kilüuben legnevezelesebb mindany"yi küzölt nyaka hosszasága és melülsö lábainak aránytalan magassága által.

Csak egy faj ismeretes (Tevepcirduc Giraffa. F. Camelopardalis girafa. L.) Fréd. Cuv. Mammif., - Afrika pusztáinak körén, szöre csuta, szürke, egészen behintve szegletes sárga foltokkal, - lis szürke és sárga sörénye van. Minden állatok közt cz legmagasabb, mert feje tizen-

(') 'T. h. Cerus nemorivagus Fr. Cuv. (Evdöbolygó sz. Le Gouazou-Bira); C. simplicicornis Ham. Smith. (Le Gouazon Apara.

(2) T. H. C. philippinus. Ham. Sin. Cern' moschatus, ua. 
nyole lábnyi magas. Kulönben szelid természelii, is falevelekkkel ćlö. A rómaiaknál ćlö hegyelïk roltak a játékokon; Heliodorus ji leirásolsat adja; ragy kettii a lközépkorban is hozatick Olaszhonba. Az egriptomi újabb viszonyok rövid idö ota néhány európai fejdelmet lettek birtokosává.

Geoffroy St. Ililaire azt véli néhány Europában létezö egyének follozati s koponya görbülési kïlönbsége mialt, hogy a nubiai s abyssiniai faj, különbözilk a reményfokitul.

ODUSZARVAS KÉRőDZöK.

Számosabbak a többieknél, igy nemekre kellett óket osztani igen kevéssé sulyos jegyck szcrint, szarvok idomát s különbözö részei viszonyát véve tekintetbe. Geoffroy még azon bélyegeket adá sikeresen hozzájok, mellyeket a homlokemelkedés anyaga vagy a szarv csontmagva mutat.

\section{A ZERGÉK.}

(Les Antilopes. Antilope. Lin. (').

Csontmagrails anyaga tömölt és gözür-s öbültelen, mint a szarvasols tömszarvianal. Külïnben nagy részint hasonlitanak a szarvasolihoz künygüdreik, termetiik karcsusága és fulások gyorsasága által. Ez igen számos nö̀n, mellyet föképen szarvaik ıdoma szerint kelle fölosztani.

(') Ezen név nem ó; az antholops-bul van elrontva, melly Eustathiusban találtatik Constantin idejébül, s melly az állat szép szemeit látszik kifejezni. A közönséges gazıllát jül leirta Aelianus, dorcas név alatt, melly tulajdonképen özt jelent. Ö ezt dorcas lybius-nak nevezi. Gazel az arab neve. 
a. Gyürüs, keltös tekervényü, elö be vagy fölfelé irányzolt hegyü szarvakkal.

A gazilla. Gazella. F. (La Gazelle. Ant. dorcas. Lin.) Buff. XII, xxin.

Szarvai gömbölyülk, vastagok, feketék; termetök és idomok kellemes mint az özé; bundájok fölül világos sálga, alul fehér, mindenik oldal hosszában egy sujtús, mindenik lérdökön egy bojt, mindenik lágyékon egy mély zseb.

Afrika egész éjszakín él számtalan seregben, mellyek megtámadtalva kerekbe gyülnek s mindenfelé szarvaikat mutatják. Az orozlạnok és párducok rendes eledelét teszik. Szclid tekintete számos liépet szolgáltat az arabok szerelmes versezetébe.

A korinna. (La Corinne. Ant. corinna. Gm.) Buff. XII, XXVII.

Amattul csak sokkal vékonyabb szarvai által különbözik; talím csak különbözó nüme.

A kevel. (Le kevel. Antil. kevella. Gm.) Buff. XII, CCLXXV.

Még ez is majdnem egészen hasonló; hanem szarvai töben összenyomotlak, és sokkal számosabb gyürüsek. Nem akarják még Kämpfer Ahujálul, vagy a persák és törökök dseirainátul (Ant. subgutturosa. Gm.) megkülönböztetni, kivévén hogy torka alatt csekély emelkedést venni ćszre.

$A$ dseren. (A mogoloknál). (Le Dseren. - Hoang yang (vagy sárga kecske) a chinaialnál. - Ant. gutturosa. Pall.) Schr. ccLxxv́.

Ez is még majdnem azon szinoszlatást és szarvakat mutatja, mellyelset az arab gazel; hanem nagysága a dúmvadéhoz közelít, - s a hímnek erós emelkedése van a nyak alján, a gögtül okozva, s hasa alatt egy eléggé nagy zseb. A nösténynél hibáznak a szarvals. Ezen faj Középásia szá- 
raz sikain él seregesen. nzel vags erdot li nem allhatva.

A szölücz; szülï zerge. ILe Springbock ou Gaselle it bourse. Ant. euchore. Forst.) Buff. Supp. VI, xxI. rl. Seregeivel ellepi Afrika délšakit. A gazclnél nagyobb, hanem hasoulo idomu és szinii, - s altul egy bör redö állal különbözili a licresztén, felı́e szörrel szegre s mindeu szökésnél meg megnyilva.

A szajja. Le Sä̈ga. Ant. Säga. Pall.) Strabo Colus-ia. Schreb. CCLXXVI.

Délszaki Lengyel-és Oroszhon pusztait lakja; szarrai szinte mint a gazelláti, hanem sárgásak, itmetszök. Akkora mint egy dámrad. Nyáron súrga bundaja télen fehéres szürke lesz: porcos vastag puliudt arcorán az orrlyukak igen nyiltak, s e miatt hátrálra kénylelen lenyelni. Néha kél ezernél nagyobb csoportokban egyesïl.

Az addra (az araboknál). Le Nanguer. Ant. dama. Pall.

A berl. acad. 1824. III, IV. rl.

Dímvad nagyságu, fehir; homloka nyaka s hálának "ry reze verhenyesck; szarvai aprok vékmyak. Nubiában s a Sencgálnál lakik (1).

b. Gyúrüs, híromtekervényü szarvakkal.

. A indiai zerge ( $I$ ' Antilope des Indes. Ant. cervicapra. Pall.) Buff. Supp. VI, xvur. XIX.

Mégr igen hasonló a gazellához; hanem szarvai háromstor tekeredtek; belölök Indiában fegyvereket esinálnak keltöt keltöt üsszeállitva egymás ellenébe tett hegyekkel; a nösténynél hibáznak.

(') Buffon (XII, bòt. xxxiv. rl.) nem ismert egyebet, mint egy fiatal equént elöre egyszerüen sürbülő szarrakkal, - s ezen okbul hivé logy az. Plinius dama-ja. 
A nubiai zerge. ( $L$ ' Antilope de Nubie. Ant. addax. Licht. ( ${ }^{1}$ ). A berl. acad. 1824. xI. rl. Ruppel. vil rl..

Szarvai szinte háromszor tekeredtek, vékonyabbak és hosszabbak mint az elöbbiéi; teste otromba, szöre feliéres, a látán szürkés, a homlokán egy széles barna folttal.

‘. Gyürüs, két tekervényü, hanem az elöbbivel ellenkezöleg, s hátra irányzolt hegyü szarvakkal. (Részint Smith Damalis-ai.)

A bival zerge. (Te Bubale. Ant. bubalis. Lin.) Vache de Barbarie Buff. Supp. VI, xıv.

A többi fajoknál rútabb arányokkal, feje hossziu. vastag; szarvas nagyságu, szöre sárga, farka végét kivévén, melly fekete bojtba végzödik. Barbariában közönséges.

A Joki zerge. (Le Caama. Ant. Caama Cuv.), a hollandusoknál közsg. foki szarvas. Buff. Supp. VI. xv. rl.

Az elóbbihez hasoulító, hanem szarva görbúletei szegletesbek; ezeknek tövkörce, a homloktö alján egy sujtás, egy ronal a nyakon, egy hosz-csik mindenik száron, és farkok vége feketék. Közönséges a Remény-loknál.

d. Apró egyenes vagy kevessé görbült s a fejuél kisebb

(') Lichtenstein azért adá neki czen nevet, mivel Plinius $A d$ dax-ával vagy Strepsiceros-ával egynek gondolá. Egyiptom több ó emlékén láttatik.

Ezen alosztáshoz tartoznak még: le kevel gris (szürke kevel) Fréd. Cuv. Mammif. - L'Ant. pourpre, Bonte-Bock a hollandoknál, Ant. pygarga. Schr. CCLXXIII. (bibor zerge). - $L$ 'Ant. à pieds noirs vagy Pallah. Sam. Daniels, Afric Scener., rx. rl. (Ant. melampus Lichtenst. fekete lábu zerge), Schr. 274. - Le coba (Ant. senegalensis), mellynek csak a szarvait ismerik. Buff. X11, xxxri, 2, ha nem a fekete lábuhoz tartozik. - Ant. suturosa Otto. - Ant. mytilopes Ham. Sm. s talún a Kob., Bufr. melly hihetóleg az Ant. adenota Ham. Sm. 
szarvakkal; mellyck a fajok nagyobb risziben esah a hímeknél találtatnak.

A gyapjas zerge. ( $L$ ' Anlilope laineuse. Recbock vagy b́z a hollandoknál. Ant. lanata. Desmar.)

A dámradnál valamivel kiscbb, szóre grapjus, fílïl szürke, alul fehér; a tagok külsö szinén s az alsó illkapocs csucsán fekete.

A buvair zerge. (L' Antilope plongeante. Duiker-Bock a hollandiaknál. Ant. mergens. Blainv.)

Világos sairga barna, alsó álliapesa alatt fehér, tagjai külsö szinén egy fekete vonal. Neve azon szokísátul vétetók, mellyel a bokrokba rohan, ha vadisztatik.

A sziklangró zerge. (I.e Sauteur des rochers. Klip-ispringer a hollandusokníl. Ant. oreotragus. Forst.) Bufl. Supp. VI, xxII. rl. Schr. 259.

Megismerhetö durva s szúró szórérül és zöjldes sárga színérül. ${ }^{1}$ ).

Ezen osztisba helycztetnck a legapróbb zergéls.

A tetöbojtos z. (Le Grimme. Ant. grimmic. L.) Fréd. Cuv. Mammif.

Sárgaszürke, homlokiöre felietés; feje telején egy kis szórbojt.

A törpe zerge. (Le Guevei. Ant. pygmea. Pall.) Fréd. Cuv. Mammif. $\left({ }^{2}\right)$.

Hamras, egy halarány vonal feketés homloka mindenik oldalán.

e. Gyúrüs, cgyszerün görbült, clöálló hegyü szarvakkal. Smithnél : REDUNCAE.

(') T. h. Ant. quadriscopa. Haun. Sm.

(') Schreber képe, 260. B. igen verhenyesie festett; Scliawé, Gen. zool. vol. Il, 2. r. cLxxxvıi. rl, igen nagy szarvu. 
A horgelöc. (Le Nagor. Ant. redunca.) Buff. XII, xuvi. Schreb. 265.

Verhenyes barna. Senegaltul. ( $\left.{ }^{1}\right)$.

f. Gyürus, egyenes vagy kevessé görbült, a fönél hoszszabb szarrakkal. Smithmél: OrYx-ok részint.

A szarvahosszu zerge. ( $L$ Antilope à longues cornes, droites. A. oryx. Pall. Buffon rosszul nevezte Pasannak, Supp. VI, xvir. A hollandusoknál foki köszálzerge. $\left({ }^{2}\right)$.

Akkora mint egy szarvas, szarvai vékonyak két vagy három lábnyi hosszúk, egyenesek, hegyesek, gömbölyüek, alsó harmadokon ferdén gyürüsek, a nösténynél kisebbek; szöre hamvas, feje fehér, feketével rostélyozra: egy fekete sujtás a gerincén s egy egy az oldalain, sölét barua folt a vállán s egy a combjain; farka hosszú s feketés, gerince szóre a tarkó felé irányzolt. A Reményfoktul éjszakra s Afrika belsejében találtatik. A többi fajokéinál hosszabb csiilkci a sziklákon könnyú mászóvá teszik, és valósággal leginkább a hegyes tájokon is tarlozkodik. $\left({ }^{3}\right)$.

Az algazel. (I' Algazel. Ant. gazella. L.) Ant. leucoryx. Licht. berl. acad. 1824. rl.

Szarvai hosszúk vékonyak, gyürüsek, egy kör ivébe

(') T. h. Ritbock. (Ant. eleotragus.) Ourebi. (Ant. scoparia). Ilt szukségesképen meg liell jeggyezni, hogy sok zergénél igy elóre görbült a szarv a fiatal korban.

$\left({ }^{2}\right)$ Lichtenstein jegyzé azt meg, hogy ezen szarvahosszu z., csupán Afrika délszakán élvén, semmi hihetỏséłgel nem lehet az oryx. Inkálbb a következỏ faj az.

$\left({ }^{3}\right)$ Ant. leucoryx. Schr. C(LVI, B. vagy az Ant. blanche, Penut., melly cœ̃y Persiában 1717-ben készuilt kéfrul másoltatott, nem listszii egyél, lenui, mint az oryx fajtảjs, vagy lalán clósul nézetl algazcl. 
hönny idden hajlollak: bundaja feheres, súreával és veresessel kïlönblëlekipen áruyolra. Afrika ajszakírul, Nitbiátul cogesz Sénćgalig. Gyaliran ábrázoltatik az egyiptomi is unbiai emlékeken, s Lichtenstein hihetöleg oliosan véli, hogy ez a régiek valódi oryx-a. ( $\left.{ }^{1}\right)$.

g. Gyürüs, egrszerüen tekeredett, hítra álló hegyü szarrakkal. Smilhnél: Aigogeros.

1 kék zerge. (I' Antilope bleue. Ant. leucophaea. (im. kék bak. Rosszul dseiran.) Bufl. Supp. VI. xx. rl.

Valamivel nagyobb a szarrasnil, kekes-hamvas, a szarvak mindenik nömben nagyok. egyenletesen gürbültek, husznál több gyürüsek.

A lizerge. (I; Antilope chevaline. Ant. equina. (icofl.)

Akkora mint egy li, vereses szürke, feje barna, mindonik szeme clött egy fohér folt, nyalián sürény, szarvar nagyok, stb.

Jegyz. Arrul bizonyosakká lellïnk, hogy Kobu-nak a lizerge nevezlctili ma a Sencgahníl. A horgelö-cöl ( $\mathrm{Na}$ gor Buff.) ottan Mbillnek hívják.

A sumatrai zerge. ( $I$; Antilope de Sumatra. A malajok erdei bakja (Cambing-oulang). Anl. sumatrensis. Shaw.) Fred. Cur. Mammil. Marsden. Sumitr. II. kiad. X., rl.

Akliora mint eģ nagy keeske, szöre fekete, sörénve fehcir, nyalain s tarkelején likrö; szarvai aprók hegyesek. $\left({ }^{2}\right)$.

(') Az angolok egy majdnem egyenes szarvu, durva s tövén gyapjas szorü, Thibet begyeirül való zergérül szólnak, melly néha az egyik szarvát elveszti, s nekik azon egyszarvu gyanánt jegyeztetik ki, melly országcímökben látszó. Neve: Chira. Ham. Smith azl véli, hogy ez lehet Aelianus Kemas-a. 1, xiv. 14. sz.

( $\left.{ }^{2}\right)$ T. h. Ant. goral. Hardw. Trans, linn. XIV, XIV. rI. s Cuv. Frid., emlósei között: bouquetiu du Nepaul név alatt. - Ant 
h. Szarvaik pörge szegélylyel.

A lepenyétes zerge. (Le Canna ou Impooko. Ant. oreas.

Pall. A hollandusokuál: foki jávor. Buff. rosszul Coudous-nak nevezi. Supp. IV, XII.

Akkora mint a legerósebb lú, szarvai vastag-kuposegyenesek, pörge szegélylyel kírülvéve; szöre szürkés, gerince hosszában egy kis sörény, nyaka alatt lepenyék, farka bojtba vígzódö. Scregesen lakils a hegyelien éjszakra a Remény foktul. ( $\left.{ }^{1}\right)$.

A szakillas zerge (Le Coudous. Ant. strepsiceros. Pall.) Buffonnál, de rosszul, Condoma, Supp. IV, xim. rl. Sehr. 267.

Akkora mintegy szarvas, barna szürke, fehér kereszlsugárzatokkal, csak a hímnek van szarva s ezek nagyok, simák, háromgörbületüek, csak egy hosz-szegélylyel, melly csekćlyen pörge; — álla alatt egy kis szakáll, gerince hosszában sörény ; magányosan él a Reményfoktul éjszaknak.

i. Villás szarvakkal. (Antilogarpae. Ord. Digranogeros. Ham. Smith.)

Ezé legkülönösebh minden oduszarvak között, egy összenyomott horog cred a tövétïl vagy törzökébül, majd

sylzicultrix. Hihetőleg ide adható még egy gyapjas, hosszú szỏru s igen apró szarvu faj Amerikábul (Ant. lanigera. Sm.) Trans. liı. XIII, IV. rl. $\mathrm{s}$ talám az is, mellyet Séba ábrázol I, XLII, X, III. rl. r mellyet Smith igy nevez: Ant. mazame. Azonban semmi sem bizonyitja mer, hogy Heruandès IIazames-ai nem volnárak amerikai szarvasok és özek, a mint ezen szerzö mondja, öket a spanyolhoni szarvasokkal s ozekkel hasonlitva össze.

(') A lepenyékeshez közel helyeztetendök: A Guib. (Ant. scripta) Buff. XII. XL. - A Bosch-Buck. (Ant. syliatica) Buff. Supp. V1, xxv. 
mint a tömszarv töboga: hegyes vége hitra görbuil. Legismeretebb faj

$A$ villis zerge. Antilope furcifera. H. Sm. Trans. limn. XIII. II. r. A kanadaiaknál: Cabril.

Nagy seregesen lakik Éjszak-aimerika temérdek kïzép és keleti sikjain; nagysága majdnem minl az özé; szöre tömött, hullámzott, vereses; szarvainals töboga magossígok közepén van. $\left({ }^{1}\right)$.

k. Négy szarvakkal. ('Tetrracíres. Lcach).

Facn Indiúban ujdonan fültalált alosztás, nem volt a régielncl ismeretlen. Aclianus a XV. l. XIV. sz.-ban szol rola: négyszarru Oryx nér alatt; az elsö pír a szemek clötl van, a hítulsó cgészen hátul a homlukesonton.

A szarvanégy. (Te Tchicarra. Ant. Chicarra.) Hard.

'Trans. Lin. XIV. xv, rl. Fréd. Cuv. Mammif. (2).

Öz nag̣yságu, majelnem egyenlön sírga. A nöstéuy szarvtalan. Indostan erdeiben találtatik. $\left({ }^{3}\right)$.

l. Kél sima szaruval.

(') Az Ant. palmata. Smith, u, o. III. rl, csak szarvainil fogsa ismeretes, nellyeknck tôhona egészen körel van a sarr tovéIur. Fzen zergéket is ugy akarák tekinteni, mint Ilernandés mazames-eit.

(') A Trans. linn. XIV. köt. 523. lapján lévó jegyzésehre nézve meg kell azt itt jegyeznem, hogy nem a boldogult Vaucel hibaja, howy a IIist. des Mammif.-ben neki tulajdonittaték a szarvanégy aluázoląta s leirása. Küldeményei nem voltak mindign teljesek; néha rajzolata jött meg magyarázat nélkïl, $s$ kora halála megakadáJyoztatá jegyzékei hijányainak kitöltését.

(') Az Ant. fcornis. Blainv. nem ismertetik hülönhen, csak egy hap̧o:ıya szcrint, mellynck melsö szarvai arányilag nagyobbak. Journ. de Phys. Aug. 1318. Meglehet, hogy ez csak életkori küIönhözés. 
A nyaksakillas zerge. (Nyakinszakaill. (Le Nylgau. Ant. picta et trago-camelus. Gm.) Buff. Supp. VI, x, xr. rl.

Akkora mint cgy szarvas és nagyobb; szarvai kurták, clögörbültek; nyaka lsözepén szakíll, szöre szürliés; mind a négy lábán épen a csülök fölölt keltös fekete s fehér gyürük, erösen metszve. A nöstény szarvtalan. Indiai faj. A köszaili zerge. Földi. (Hátrahorg) (Le Chamois. Ant. rupicapra. Lin.) Buff. XII, xvI. rl. A pyrenei hegyeken: Ysard.

Egyetlen cmlös Europa nyugot-szakán, melly a zergékhez hasonlíthati, azonban tulajdon bélyegeket is bir: egyenes szarvainak hegye hirtelen görbül hátra mint valamelly horog; mindenik füle mögölt, a bör alatt, erszény van, kifelé csak egy kis lyuk által nyiló. ( $\left.{ }^{1}\right)$. A köszáli zerge termete akkora mint egy nagy kecskéé; szóre sötét barna, cgy a szemétül az arcor felć futó felrete sujtással.

Legnagyobb ïgyességgel fut meredek sziklákon, és kis csapatokban tartózkodik az igen magas hegyek közép-táján.

Smilh elválaszlja a zergélitül CAtToblepas nöm neve alatt.

A Gnu zergét. F. (Le Gnou ou Niou. Ant. Gnu. Gm.) Buff. Supp. VI, viII, Ix. rl.

Igen küiönïs állat, melly clsö tckintetre különbfẻle állatok részcibül öszretctl csudának látszható. Teste s kereszte mint egy kis lóé, barna szörrcl füdve, farka hoszszú fchér szörrel takart mint a lófark, nyakán szép meredt sörény, tön fehéx, régén fekete szörrel. Szarvai töben közclállók és szélesek miut a reményfoki bivalé, elül legör-

(') Meglehet hogy ezen nyilás rosszul értett jelentése mondatí Einpedokles szerint a régickkel, hogy a kecskck füleik íltal kilekzenck.

CUVIER 1. K. 
builnek, hegyoik föl visszahajol; arcora széles, lapos és fölálli szörkörrel keritve be; torka és lepenyéke alatt egy másik fekete sörény fut; lábai a szarvasémak könnyüségét birják. Mindenik nömnek van szarva.

Ezen állat a hegyeken él éjszakra a Reményfoktul, hol clég ritkának látszik; ugy tetszik azonban, hogy a régieknek mégis volt rúla valami ismeretök. (1).

A három hátra lévó nem oduszarvainak csontmagvát nagy részint a homloköblökkel közösülö sejtek foglalják el. Szarvaik irányzása adá fölosztások alapját.

\section{KECSKÉK.}

\section{(Les Chèvres. Gapra. L.)}

Szarraik fïl és hátra irányzottak; állok általábau hoszs\%uszakíllu, homlokok majd mindig domború.

A türzsük kecske. (L' Aegagre on C'lèvre sauvage. Capra aeggagrus. Gm.) Cur. Ménag. du Mus. in $8^{-v o .}$ II, 177.

Ez minden házi liecskéink fajlájínak törzsölapául látszils szolgálni; megkiülönbriztetik elöl metszö szarvai által, mellyck a himuel igen nagyok, a nösténynél rövidek $\mathrm{s}$ néha hibázisk a mi a vad és kaukazi kecskénél is történik. Ez seregesen lakik Persia hegyein, hol paseng név alatt ismeretes, stalám sok más vidéken, s még a havasokon is. A keleli bezoár a belében találtató iszrenölés.

(1) Iliheto̊leg ez adott az \& cazablepás-okra okot. Lásd Plinius VIII. könyv, xxxı1. szak. és Aelianús vIr. k. v. sz.

Jegyz. Legtohéletesebl munka a zergéhıü az, mellyet Hamillon Smith ezen munka angol fordításáboz toldott, és én nagyon sajnálom, hogy elegendỏ vizsgálati tárģah hijúnya miatt azt egészen nem hoźhatám löl. 
A bak. F. és a házi kecske (capra hivcus L.) végetIcnül különböznek nagyságra színre, szőrök hosszaságára s finomságára, szarvaik nagyságára, sốt számaára néże is. $\mathrm{Az}$ angorai kecskéknek, Kapadokiában legpuhább és selymescbb szörölk van. A thibetick hiresek lettek a szörök kïzzt nölö csudálatos finomságu gyapju miatt, mellybül a kasmirkendöliket gyártjáls. Fgyiplom magasản egy tömöl szörü, cmelt homloku, dúdor alsó állkapocsu fajta van, melly meglehet, kores szïlemény. A gvineai kecskéls, mellyeket mambrin s júda-kecskéknek is mondanak, igen aprók, szarvaik hátrafekürók. Mind ezen állatok erösek, szeszélyesek, bolygók, hegyi eredetöket elárulók, v. szíraz és vad helyeket szeretök, durva füvet vagy fahajtást esznek. Az erdólknek igen ártalmasak. Jobban esak a gidákat eszilk meg; hanem a kiecsketéj sok nyavalában hasznos. A kecske már hét hónapos korában meghasasulhat; öt havig hord; rendesen kettôt ellik. A bak már egy éves korában bakzik; cgy baks több száz liecskéhez elegendö: öt vagy hat évig él.

$A$ vad kecske. F. (Le Bouquetin. Capra ibex. L.) Bull. XII, XIII. rl. Schr. CCLXXXI.

Nagy szarvai clöl négyszegesek, keresztesomólikal bélyegeztek. A hegyláncok legmagasabb tctején lakik az egész ó világban.

A kaukazi kecske. (Le Bouquelin de C'aucase Capra caucasica.) Guldenst. Acl. petrop. 1779. II. XVI, Xviı. rl. Schreb. CCLXXXI. B.

Megkülönböztetik nagy, háromszegletü, clül tompa , de nem négyszegletes, $-\mathrm{s}$ mint az elöbbinél, csomús szarvai által. Ezen két faj termékeny nöszést üz a házi kecskével. $\left({ }^{1}\right)$.

(i) T. h. Bouquetin d' Éthiopie, (szerecsen Kecske) Fréd. Cuv. Mammit. - Bouquetin à crinière d'Afrique, Tackhaitse, Sam, (sörényes kecske.) 
A JUHOK. F.

\section{(Les Moutons. Ovis. L.)}

Szarvaik hátra irányzotlak s többé lievesbé clöre lierúlök; homlokok általában domború, - szakílltakanok. Annál inkáb) nem volnának némileg a kecskéliül elvílaszlandók, mivel azokikal termélicny koresokal nemzenek.

IIt is, mint a bak nemben több eléggé közel álló vad fajta ragy faj ran.

Az argali juh; Földinćl argali kecske. (I; Argali de Sibiric. Ov. ammon. L.) Pall. Spic. XI, I. Schreb. CCLXXXVIII.

Kosinat igen nagyok a szarvai, töben háromszegletïck, hegy cu sömbölÿïk; clil laposak; keresztben vonalosak; az anya szarvai összenyomlak, sarlé-idomnak; nyairi gyapja csula, sárgís szorrlie, a léli súrü, lemény, rechenges szirrke, arcorán lorkán s hasa alitt fehér vagy feheres. Igen rövid farku, s minden idöben egy sárgás tér van a litra kürén mint a szarrasnak. Ezen állat egész Ásia hryein latilis is alikorára nól mint a dimvad.

A sardiniai juh. (Te Mouflon. Mufione sardiniában, Muffoli Korzikában. Ovis musimon. Pall.) Bull. XI, xxix. rl. Schreb. CCXXXVIII. A.

Atul csupoin abban látszik különbäzni, hogy olly nagy nem lesz, s hogy nösténye nen, ragy ritkin szarvas, s szarrai igen aprok. Mondjails, hogy Kritában is titláltatili. Tammak egészen vagy részint felicte fajtaii, s mások löbbé kevesebbé fehérek.

Hilictséges, hogy

Az amerikai juh, (Le Mouflon d'Amérique. Ov. mon(ana.) Geoff. Ann. Mus. II , Lx. rl. Schreb. CCXCIV. D. Az arçali fajhoz tartozik, melly a jés fölött álthat- 
hatolt a tengeren. Szarrai igen nagyok, s pergébbek mint a rendes argaliénál.

Az afrikai juh. (Le Mouflon d'Afrique. Ov. tragelaphus. Cuv.) Penn. XII. sz. Shaw. Gair, rl. 2. Schreb. CCLXXXVIII. B.

Szöre verhenyes, lágy, nyaka alatt hosszú csüngö sörény és egy másik mindenik lábizesülésén; farka rövid; tulajdon fajnak látszó. Egész Barbaria sziklás vidékein lakik, Geoffroy Egyiptomban is észre vette.

Az a vélemény, hogy az argali vagy a szardiniai juhtól származnak a mi gyapjas barmaink számtalan fajtái, mellyck az cb mellett legtöbb különbözésnek tétettek ki.

Europában vannak közönséges ís finom gyapjuak, nagy és kicsin termetüek, nagy, apró, az anyánál vagy mindenik nemnél hibázó szarvuak, stb. Legérdekletesebb fajták a spanyol juh, finom kondor gyapjural, a himnél nagy perge szarvakkal, melly egész Europában el kezd terjedni, - és az angol juh, finom hosszú gyapjuval.

Az Oroszhon délszakán legeltcrjedtebb fajtának igen hosszú farka van. A szinie hosszú farku indiai s gvineai fajta abban különbözik, hogy szárai magasak, homloka igen domború, fülei függók s szarra nincsen s kurta szörrel födetett.

Europa s Ásia éjszaka majd mindenütt apró s nagyon rövid farku juhokat tart.

A persiai, tatárhoni és chiniai fajtánál a fark majd egészen át ran kettös zsirgolyórá képezve, a syriai s berberi fajtáé hosszú ugyan, hanem szinte vastag zsirtömegü. Mindeniknél csüggók a fülek, a kos szarvai vastagak, az anyánál és báránynál középszerück; gyapja szórrel kevert.

A julı becses lusa, faggyúja, teje, böre, gyapja s ganaja miatt; a jól intézett nyájok mindenfelé termélsenységel terjesztenek. 
A bárány két hónapos lioríban elvílasztatik, hatodik hóban kiheréltetik, töjfogait elsö s harmadik ére közt elcseréli. Az egy éres anyajuh hordhat, tiz tizenkét évig tenyészt; terhessége öt hóig tart, liét bárányt ellik. A kos tizennyolc hóval serdült, harminc juhoz elegendö; nyolcadik éve felé meghizlaltatik.

\section{A MARHák. F. \\ (Les Boeufs. Bos. L.)}

Szarraik oldalvást irányzottak s föl- vagy elófelé félhold idomban visszakanyarúlik; ezek kïlönben nagy, széles száju, otromba testü, erós száru állatok.

A közünséges marha (barom). Földinél bika, ökör, tehén. (Le Boeuf ordinaire. Bos laurus. L.) Bulf: IV. XVI.

Saját bélyege granánt homloka lapos, hosszabb mint szóles: gömbölyü szarrai a homlokat a lejháttul elválas\%(i) szélnek hèt régére helyezletlek. Az ásvínyos kapo"ýáhban, mellyek e fiijhoz lítszanak tartoztani rad állitpotban, (a rescick urus-a), a starrak elö s alá görbüluck; de a házi számbalan lajtukban ignen kïilönbözö irányzások vill, weha cegren is hibiznals. A heves ég rendes fajtijinali mindegyile zsirpúpol hordo\% vílla fülüL, s ezen számban a disznónil alig nagyobbak is vannak. Mndenki ismeri ezen állatok hasznos voltit a dolgozáshoz, és húsoliét, faggyújoliét, böribiét s tejölict; szarrok is haszuáltatik a mívelknél.

A tehén kilenc hóig hord, s tizennyolcadikban folyathat (foghat), a bika két éves korábain bikhat (üzhet) A kiherélés tiz̄ennyolcadik harában türlénik, tizedik évében meghizlaltatik.

$A$ bïlén). F. (Aurochs a németeknd, Zubr a lengyeleknél. Bos uruso) Gm. Bison a régicknél. Gesm. cuvir. Rendesen de hibísan a házi marha vad lïrzö̈lénels 
tartatik. Különbözilk attul emelt és szélesb mint magas homloka, szarvainak a fejbúbi taraj aljához való tapadása, szárai magassága, egy párral több bordája, a bika fejét s nyakát fơdó s torka alatt rövid szakállt képezó bodor gyapja, s röfögö szara által. Ez dülı̈s állat, ma csak Lithvania, a Karpatok és Kaukaz mocsáros nagy erdeibe szurulkozva, de melly különben az egész mérsékelt Europában élt. Ez leg nagyobb az Europában honos emlösek között.

Az amerikai bülény. (Le Bison d'Amerique. Buffalo az angol-amerikaiaknál. Bos Bison. L. Bos americanus. Gm.) Buff. Supp. III, v. Fréd. Cuv. Mammif.

Feje csontos, bölényünkéhöz igen hasonló, és szinte valamint nyaka s rállai, bodor gyapjuval födött, téleu igen meghosszabbulóval; hanem szárai s kivált a farka sokkal rövidebbek. Éjszak-amerika minden mérsékelt részén lakik s a házi tehénnel tenyészt.

A bival F. (Le Buffle. Bos bubalus. L.) Buff. XT, xrv.

Boeuf sauvage. Aristotelesnél: Arachosiai vad ün̈̈r.

Indiábul credt, a középkorban Egyiptomba, Görögs Olaszhonba hozaték, - homloka emelt, hosszabb mint széles, szarvai oldalvást irányzottak s melöl hosszú emelt szegélylyel. Ezen állat nehezen szelidíthetö, hanem hatalmas erejii, a mocsáros helyeket szerelö s azon durva növényeket, mellyekkel az ökrök nem típlálhatók. Teje jó, böre igen erös, hanem husa kevessé becsült.

Indiában egy olly fajta van, mellynek szarvai cgész Liz lábnyira kilerebülnck; nevök Hindostanban arni. E\% Schaw. bos arni-ja.

A gival. (Le Gyall; Bueuf des Jongles. Bos frontalis. Lamb.) 'Trans. lin. VII, Iv. s Fréd. Cuv. mammif.

Bélyegei nagyobb részében megegyez a házi marhá‘il, hanem szarvai elörül hátulra lapultak, és szegletes 
szegélytelenck, oldalríst irányzoltak s ¿ïbbé kerescbbé föl felé, hátra soha. Bundäja csula, fikete, liverín hogy a homlokin s háta hosszinak eggik vonala szürhe vagy sárga, szárain pedig fehér.

Ez egy hazi lajta India ejszak-keleli hegyes videkein s a melly hiluetoleg a bivalnak a közönséges fajjal történö regyülésébül származk.

A röjügö ölür. (Le Yack. Bos grunniens. Pall. Bulfle à queue de cheval. Tache grognante de Tartarie, stb.) Schreb. caxcrx. A. B.

Kis termetü faj, mellynck farka cgészen befödetelt hosszú sziorrel mint a lơe. hálín hosszú sörénye van, feje a bivaléhoz látszik hasonlitani; szarrat nem iratlak le cléggé. Ezen állat mellỵrï már Aclianus cmlékezetl, a thibeti hesychbül cred. Emnek farkábul csinailják a törökäk azon zászlcikat, mellyck a fübb tiszteliet liülünböztetik meg.

A remény foli bival. (Le Buffle du C'ap. Bos caffer. Spar.) Schr. GcGI.

Szarvai igen naggok, oldalrúst és alá irínyzottak, hegyök vissza cmelkedö, laposak, lóben olly szélesek, hogy majdnem az egciz homlukat belakarják, csak egy háromszegletet haggra egryméts kïzirll. Ez igen nagry állat, rendkivïl rad természelï, Kalferhon erdeiben lakó.

A pésma ölür. Füldi. (Le Boef musqué de Amerique. Bos moschatus. Gm.) Schreb. cccir. A feje Buff. Supp. VI, III.

Szarrai lïzzelítóls s ugy irányzollak mint az elöbbinél, hanem a homlokion egrenes ronalban összeérök, (a tehenéé apróbbak és szétállóls); homlokia emelt, arcorának hegye szörös. Alacsony száru; cgész a földig csüngö bojtos szórrel takart. Farka rendliviil rövid. Az egész nemben létezö pésmaszagot erösebben terjeszli; csak Éj- 
szak-amerika leghidegebb részein láttatik; hanem ugy látszik, hogy kaponyáját és csontail a jég egésż Sibériáig clhordá. Az eskimók saplákat csinálnak farkábul, mellynek ábrázatukra csüngó szöre oolket a szúnyogoktul védelmezi.

AZ EMLÖSEK KILENCEDIK RENDE.

\section{A CETEK.}

(LES C ÉTACÉS. CETACEA)。

Hátulsó-lábtalan emlösek; törzsökök vastag farkba folytattatik és vízegyenes porcos uszonyba végzódik; fejök olly rövid és vastag nyak által köttetik törzsökökhöz, hogy semmi bevágást észre nem vehetni, - $\mathrm{s}$ az igen keskeny és részint összenölt csigolákbul tétetik össze. Végre a melsö végtagokon az elsö csontok rövidek, a következök pedig laposak és inas hártyába burkolvák, melly belölök igazi úszonyt csinál. Ezen állatok külső idoma majdnem egészen ollyan mint a halaké, csak hogy ezeknek farkúszonya függelmes. $A$ cetek szinte mindig a vizben tartózkodnak, hanem tüdó által lélekzvén, gyakorta föl kénytelenek a viz színére jóni, ottan levegöt szivandók. Meleg vérök, kifelé noha igen apró lyukak által nyiló füleik, élöt szülésök, emlöik, melljek által fijaikat szoptatják, s minden 
boncolati sajátsígok különben eléggé megkülönböztetik őket a halaktul.

Agyok nagy, félıekéi jól kifejlettek; a sziklacsont, vagy a kaponyának azon része, melly a belfület foglalja magában, el van a fej többijétól választva, s ahoz csak szalagok által köttetik. Testökön nincs külfül vagy szőr.

Farkokat idoma miatt a tovább mozdulás végett fölïlruil alá kell hajtaniok, melly a vizben való fölemelkedésre nagyon segíti ökel.

Az eddig a cetekhez számlítl nemekhez adjuk mi a különben a rozmárok nemébe zavartakat. Ezek nálunk az első családbeliek, vagy

\section{A FÜEVÓ CETTEK, FǗCETEK.}

(Les Célacés herbivores. Cetacea herbivora.)

Fogaik koronája lapos; mi életnemöket hatirozza meg, melly öket néhat a vizbül kijövésre kényszeríti, hogy a parton mászszanak és legeljenek; mellükön emlö van és bajúszul szörök, két olly körülmény ; melly távolrul, ha egyenesen emelék melsö részöket a vizbül ki, némelly hasonlatosságot nyujthata nekik az asszonyokhoz vagy az emberekhez s hihetőleg alkalmul szolgála némelly utazók regéinek, kik tritonokat és sireneket akartak láttani. Noha a kaponyában magasan nyiltak az orrlyukak, a börön csak az arcor hegyén vannak Gyomrok négy erszényre osztot, mellyeknek ketteje oldali; vakbelök nagy. 


\section{A KÉZCETEK.}

\section{(Les Lamantins. Manates. Manatus. Cuv.).}

Testök hosszudad, - tojásdad nyult úszonyba végzödö; zápfogok mindenült nyole, négyszegü koszorúju, két háránt emelkedetii; a véneknél sem metszók sem szemfogak ninesenek, hanem az igen fiataloknál az állközli csontban liét igen apró hegyes fog van, hamar eltünendö. Úszonyok szćlén láthatók a kiörömnyomok, mellyet clíg ïgyesen forditanak a mászásra s fijaik hordozására; a melly olkbul ezen müszerek a kezckhez hasonlítlattak s az állatoknak a manat (kézcet) nevet szerzék meg; belöle elrontás által lön a francia lamantin.

Még életnemökéri tengeri tehénnck s ökornck is mondatnak, cmlöik miatl pedig tengeri asszonynak stb. (Trichechus manatus. L. Mancil rozmár. Füldi.) Buff. XIII, LVIr.

A folyamak torkolatai körül talúltatnak, az Atlás tenger legheresebb részein s ugy lítszik az Amerika folyamabeliek különbüzuck az afrikaiakıul. (') 'Tizenöt lábnyi hosszúk lesznek. Husok ehetó.

\section{A HABILÁNOK.}

(Les Dugongs. Lacep. Halicore. Ilig. ${ }^{2}$ ).

Zípfogaik kít oldalvást egyesült tekébül tétetlek mintegy össze; fogaik, melszö csontukba alliotva be, anynyira tartrisak és nevekedök, hogy valódi agyarakká válnak, hanem többnyire födve maradnak nagy részint az izmos küvér és bajuszos ajakak íltal. Testök nyult, farkok félhold idomu úszonyba végzódik.

(1) L. Recherch. sur les oss, foss. 1. k. 1. r.

$\left({ }^{2}\right)$ Halicore, tengeri szǔz. 
Csak egy fajok ismeretes (Hal. dugong.), melly az Indiai-tengerben likik, s mellyet tïb) b utasok föleserittek a kiezcelcklicl. Ezt is nerezik sirén-nck tengeri tehénnek, stb. (Renard, Poiss. des Indes, xxxiv. rl. 180. k.; Home, 'Trans. phil.; Fr. Cuv. Mammif.)

\section{A IEGELCETEK.}

(Les Stellères. Cuv. Rytina. Ilig.) ${ }^{1}$ ).

Ugy litszik hogy mindenik oldalrul csak cgy zápfoguk ran, lapos koszorúju és mízlemezekkel födöut. Úszónyaikon még azon apró körmök sincsenck, mellyek a kézcetelinél látszanak. Steller szerint, ki elsö s maig egyedül irta le öket, gyomrok is sokkal esyszreiubb. $\left({ }^{2}\right)$.

Csak egy fajok ismeretes, a Csendes-tenger éjszakín tartózliodó.

A második család, vagy

A RENDES CETEK.

(Les Cetacés ordinaires.)

Az clóbbiektül egy különös készület által külonböztetnek meg, melly a fúvók (souffleurs) általános nevezetét szerzé nekik meg. Ugyan is a zsákmáuynyal együtt az igen szíthasadt torokba nagy tömegü vizet nyelvén le, útra volna szükségök annak kibocsátásához; ez az orrlyukakon megy által az ínyvitorla tulajdon készülete segedelmével, s egg-az orrlyukak oldalán lévö zsebbe gyül össze, honnan hatalmas izmok szorítása által erószakosan kilöketik egy kes-

(') Rycina, barázdás, redelt.

() Nova comm. petrop., II, 291. stb. Még nincs ábrázolata. 
keny nyiláson keresźtül, melly a fó tetején létez. Igy hozzák elö azon vizoszlopokat, mellyeknél fogva már távolrul észre veszik óket a hajósak. Orrüregök szünetlen sós haboktul mosatván, nem takarható a szaglísra eléggé finom hártya által; szinte a többi állatok csigalemezei nélkül is szükölködnek; a szagló ideg többeknél hibázik, s ha vannak is szaglási érezéssel birók, az iggen csekély lehet. Gögjök gúlya idomu, az orr hátuljába béható, a levegö fölvétele s a tüdóbe vezetése végett, a nélkül hogy az állat kénytelen lenne fejét s torkát a vizbül kiemelni; gögsipjokban nincsenek emelt lemezeik s szavok egyszerü bődülésre szoríttatott. A szörnek semmi nyoma rajtok, hanem egész testök sima börrel födött, melly alatt kövér és zsirral bövelkedó szalonna van, melly kerestetésök fó oka.

Emlöik a segghez közel; úszonyaikkal semmit sem képesek megfogni.

Gyomroknak öt és néha egészen hét megkülönböztetett erszénye van, egy lép helyett több aprót, golyósakat birnak; mellyeknek fogaik vannak, azok mind kuposak és egymáshoz hasonlítanak; eledelöket nem rágják meg, hanem sebesen befalják.

Két apró csont az izmok közé a segghez közel fölfügģesztve, ieszik hátulsó végtagjaik egyedúli nyomát.

Többeknek hátukon függgelmes úszonyok van inas anyagbul, hanem csonthoz nem tímaszkodú. 
Melöl lapított szemeiken a tülkhártya hövér és tömött; nyelvök födözete sima s lágy.

Még két apró törzsökre oszthatók föl: melylyeknek feje rendes arányban van a többi testtel, - és mellyeké mértéktelenül nagy; az elsóbe a delfinek és kétfoguak tartoznak.

\section{A DELFINEK. F. SUHANÚSZÓK.}

Mindenik állkapocsban rammak fogaik, mind eg̣szcrüek s majd mindig liniposals. Erek legragadozib)bak, s termetök arányára nézre a rendben legleggetlendbbek. Vakbelök nincs. (').

\section{A tulajdonképi DELFINEK. (Delphinus. Cuv.)}

Homlokok domború, arcorok a fö clején exy a fej többi részénél keskenyebb kávort képez.

A küzünséges delfin. F. (Le dauphin ordinaire. Delphinus delphis. L.) Lacep. Cet. XII. rl. 1. k.

Károrok (szájok) összenyomott s az allkapocs mindenik felérïl negyrenkét sót negyvenhét vékony, ivelt, és hegyes foggal fegyverkezve; failuil fekete, alut féhér, nyole s tiz lábnyi hosszú. Ezen állat nagy seregekben elszéledt minden tengereu, mozgásai sebessége által híres, mellynél fogva néha a hajök födelére fölszökik, - s valóban ugy látszik hogy ez a régiek delfine. Agyánals egész müszer-

(') Alig van az emlóseknek valamelly családa, mellyet nehezebb volna vizsgálóra venni, mellynek leirása olly kevessé volna teljes, névazonossága ingadozóbb, mint a ceteké. Én csak a megvalósult fajokat iparkodám ailni. 
zete azt bizonyitja, hogy nines a neki tulajdonitott laníhatóság hijáral.

A nagy delfin. (Le grand Dauphin. Delphinus tursio. Bonnaterre.) Le Souffleur. Lacep. xy, 2. k.

Kávora rövid széles lenyomott; mindenütt huszonegy s cgész huszonnégy kúpos és gyakran elvásolt foga. Vannak tizenöt lábnyinál hosszabb egyének s ugy látszik hogy a Középtengerben szinte ugy találtatik mint a Nagytengerben. $\left({ }^{1}\right)$.

A két Nagy-tenger számos delfin fajtákat típlál, mellyek soká összezavartattak.

$A$ kétes delfin. (Delph. dubius. Cuv.) néha a mi partjainkra jö, állkapesa mindenütt csak harminchat vagy harminchét foggal feggyverzett, hanem ezek olly finomak és hegyesck mint a közönséges delfimél, mellyhez szinére nézve is hasonlit.

A homloki delfin. (D. frontalıs. Duss.) Dussumier által találtaték föl a Zöldfok szigetcinél; az clöbbihez igen hasonlít, hanem valamivel más szinü s mindenütt larminenégy foga van.

A homlokas delfin. (D. frontatus.) mindenült csak huszonegy foggal, hanem nagyobbakkal mint az elóbbiéi, arcora is hosszabb s összenyomtabb; eredete nem ismereles.

As ólmas delfin. (D. plumbeus. (Dussum.) Malabar

(') Belon cethala ( la baleine) vagy capidolio-ja és orca-ja, melly utolsó a régiekével azonos lehet, szinte a kávoros delfinckhez tartoznak, s a fölhozott fajokat nąyságra fölülmulják, hanem bélyegeil: nincsenek eléggé meghatározva. Boumaterre dauphin fères-c hilictóleg ez cgyikhez tartozik. 
szigeténél; arcora szinte ësszenyomotl, hanem mindcniilt harminchét foggal fegyverzett. ( $\left.{ }^{1}\right)$.

A gyors delfint (D). velox) Ceylantul hozá Dussumicr; arcora ralamirel hosszabb, foga mindenuït negyvenegy.

A hosszi kcivoru delfint (D. longirostris Duss.) ngyan ö Malabirtul hozí, melly a kïzönsciges delfint is föliilmulja logai számával, melly mindenült, ötrenöt egész hatvan. $\left({ }^{2}\right)$.

\section{KÁVORÚSZOK.}

\section{(Delphinorynques).}

Blainville elválaszija az elöbbi delfmeklól ,Der.pHsomurvotes" név alatt azon fajokat, mellycknck nyilt es véliony líirora nines föltünü barizda álial a homlultul clválasztva.

A kis szirnyze kivorisz. (D. micropterus. Cuv.) a mi partjainkra rert faj, kicsin és igen hátra levö hátuszonya illal nerezcles. 'Tizenöt lábnyi hosszú lesz, és korán elveszti minden fogút. $\left({ }^{3}\right)$.

(') Én azt vélem, hogy ezen ólmas delfin ugyanaz a melly a D. malaianus. Less. és Garn. Voy de la Cog. 1.x. rl. 5. k.

(2) Ezen munkába nem vehetjik foil a csak távol látott fajokat, s mellyeknek semi része nem hozaték el; azonban mutatásul folhozzuk ezeket: $D$. albigena. Quny et Gaym. Voy. de Freycinet, XI. t. vagy $D$. superciliosus. Less. et Garn. Voy. de la Coq., IX. r. 2. k. - D. cruciger. Quoy et Gaym. uo. 3. és 4. k., melly legalább igen közel van a $D$. biriccacus-hoz, Less. et Garn. 3. k. - D. lunates Less. et Garn. 4. k. Annál kevesebbé hozhatjuk föl a még le sem rajzolt fajokat.

$\left({ }^{3}\right)$ Blainville; Nouv. Bullet. des Sc. IV, 139, és Fréd. Cuv. Mammif. a $D$. de Dale illetlen s a pallatfoguakhoz tartozó név alatt.

Jegyz: A d. rostratus Schaw, nem más mint a gangesi. 
1 csorros kicivorísz. (D. rostralus. Cuv.) szinte látInati ncha; kírsua rékony s kivälröl egészen egymeneIclú a fejjel; foga mindenïl huszonegy. Látuszonya rendes nagyságu. ( $\left.{ }^{1}\right)$.

A gangesi kávorisz. (Le Dauphin du Gange. D. gangeticus. Roxburgy! czen elsö csoportul megkïlïnbzztelendö, mellynek lecskendezöje hoszastonalu. Ez isen lávolra fothalad a Gangesben. Inilecóleg cz Plinius platanista-ja.

\section{AZ AJKABOLTOK.}

\section{(Les Marsouins. Phocaena. Guv.)}

Kívorok nincs; arcorok rövid; cgyenlön domboru. A barna ajkabolt; Füldincl barna delfin. (Le Marsouin commun. Porpess az angolohuál. Delph. phacoenc L.) (1) Lacep. xtir , 2. l..

Fogai öszenyomtak, vígík, gömbölyúi ielomuak, mindenik állkaposban mindenik oldalon huszonkettölül egész. luszonölig; föliil feketés, alul fehés. Mlinden tengerünlben igen läzönséges, hol nagy csapatokban tarbzkodik. A celek lirizl leghisebb, esak négy ragy ä lábnyi hoszszaságol érve el.

A Reményfok tengereiben egy a mienkhez igen hasonliti fij ran, de a mellynck mindcuüit huszonnyolc foga van, hengeridomu, egy keressé hegyes, és a micnhíi ellenére soha issze nem nyomoll. Ez a foki ajkabolt. D. capensis. Dussum.

1 kardos ajkrabolt (L' Épaulard. Bulskop' 'is Scluwerifisch a hollandiaknál és némoteknél. Grampis az

(1) A. D. couronné, Freminville Nouv. Bull. des. Sc. III. num. 56, I. T. 11. k.

$\left({ }^{2}\right)$ Marsouin a német Mecreshwein-ból van clrontva, melly tengeri disznót jelent: Porpess. a latin porcus piscis-lyiil.

CUVIER I. $\mathrm{K}$. 
angoloknál. ( $\left.{ }^{1}\right)$ D. orca is D. gladiator.) Lacep. xv, 1. és keresbé jól, v, 3.

Fogai vastagok, kíposak, egy kevessé görbültek, mindenïlt tizenkellen, a hílulsrik háránt (keresztben) lipul1ak; testiok foilit fikete, alul fehér: szemök fölött egy fehires lolt fúl hold idomban, hálszarrnyok fölemelt is hegyes.

Ez legnagyobb a delfinck kïzölt, néha husz süt huszonöl lábnyi hosszí, a cetuck leghegyellenebl) ellensége. soregesen tamalja azt meg, addig ingerli, migg szájät faitálja, és ekkor mindjárt kieszi nyelvét.

I kos ajkabolt. (Delfin. aries Risso), Anu. Mus. XIX, 1. 1. 1. k. - néha néha a francia partolira jövó kicsin faj, melly fölsö állkapesábul liorín clveszli fogail, at alsoban is csalk licreset tart meg. Initszíruya alacsonyabb) és haitráb) fekvó, mint a kardosé. $\left({ }^{2}\right)$.

A gulyejë ajkabolt. (L' Épaulard à lète ronde. Delph. globiceps. Cur.) Amm. Mus. XIX., I. 1. 2, 3. k. J). deductor. Scoresby.

Feje füle bollos mint egy golyi, melszírnyai hosszúk, heggyesck; hosszasíga husz lúbnyinál naggobb; fekele, de torkitul egész a seggéig egy lehór sujlás vau. 'Iöbb szizankint él csapatokban, a vén himektuil vezéreltetre, s ncha a francia partolira rettelik. Mindenütt lilenctiul

(') Grampus a francia grand poisson-bul rontatott el. Butskopf vasy iukabb boots-kojf annyit tesz mint: sajkafejü. Schwerdtfisch, kardoshal, hátuszonya miatt.

(1) Az Épaulard ventru Bonnaterce, Lacep. XV, 3. Hunter. Trans. Phil. - ébuil másolva le, azon idomot mutatja; hanem Iunter egyéne tizennyole lábnyi hosszú volt, a mieink tiznél nagyobbak soha sem lesznek.

A D. griseus Ann. Mus. XIX. I. M. I. k. csak a kos ajkabólt rosz ábrázolatja, (uo. 4. k.) A régiek valúdi aries-e a kardos ajsabolt. 
rgész lizcnhírom loga van, hanem idövel mindnyáfit clveszli. ( ${ }^{1}$ ).

\section{\ HÁTASIKAK.}

\section{(Jes Delphinaptères. Lacepéd.)}

Az ajkaboltoktul csak abban különböznck, hogy hátuszonyok nines.

A fehéres haitasik. (Le Beluga on Iipaulard blanc, a dínoknail Huidfisk. Delph. Leucas. Gm. D. albicans. Fabr.) Scoresby artc. reg. II, XIV. rl.

Mindenült kilenc, vastag, rásolt régï foga; böre sárgás fehér, feje kirülrül bollos mint az ajkaboltoké; akkora mint a kardos ajkaboll. Az egész Jeges-tengerben lakik, homnan a folyamokba nagyon messze elólhat. $\left({ }^{2}\right)$.

$A$ Seliérszaju haíasil. (Le D. à museau blanc. D. leucoramphus. Péron.) Voy. de la Coquille. 9. rl. $\left({ }^{3}\right)$.

A Déli-tengerekhen lakik; feje kevessé boltos s cléggé hegyes; arcora, melszárnyainak egy része g teste egész

(1) A golyófejiu ajkabolt fogaitu lmegfosztott feje az, melly le van rajzolva Bonnaterre Cetol. VI. rl. 2. k. és Lacep, Ix, rl. 2. k. cachalot swinewal név alatt; Campernél, Cet. xxxi, xxxir, xxxıv. r. narwal édenté alatt.

$\left({ }^{2}\right)$ Rondelet, peis-mular és senedette név alatt, egy a fehéres hátasikhoz igen hasonlitó cetet ábrázol, azonban nem mondja, logy fehér. Az olasz capidolio nevet is rá alkalmaztatja. Ez hátasik lehetne, ha képe a képzelödés szüleménye nem volna; hanem én attul annál inkábl, tartok, mintbogy a mular és capidolio név tulajdonképen a fizétert illetik. Végre a fehéres hátasik ada rá okot, hogy egyy his fehér fizétcr faj állitassék föl, mivel fölsö fogait korán elveszti. Lúsd a fejét, Voyage de Pall. atl. Lxxix. rl.

$\left({ }^{3}\right)$ Ezen kép arcora igen hegyes. Commerson fekete végtagu fehér delfin-e (Lc diuphin blanc ì extrémités noirs) ehez igen közclíl. 


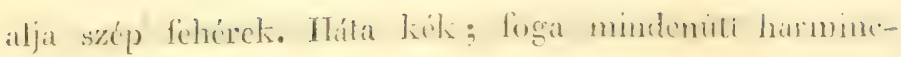
nyolctul egész negyvenkettö.

Dussumicr egy fajt talílt föl ezen alnembül, molly-

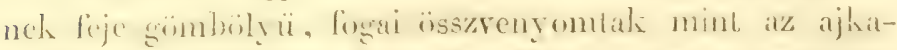
bollolinil djkaboltos hatasit. Delphinapterus plocatnoicies. ( $\left.{ }^{1}\right)$.

\section{A PADLATFOGUAK.}

\section{(Les Hyperoodons. Lacep.) $\left({ }^{2}\right)$.}

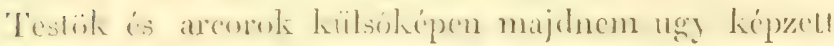

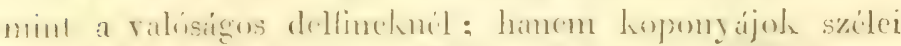

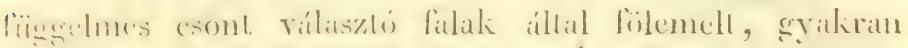

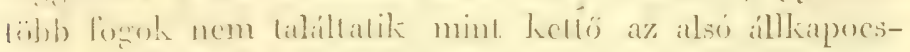
han, mollych hi mom mindig látszanah: szaijparllatok apri gumókkal födött.

Csak egy ismeretes, melly lutz, huszonöt láb-

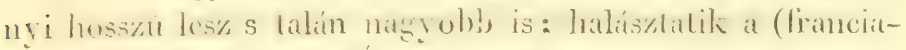

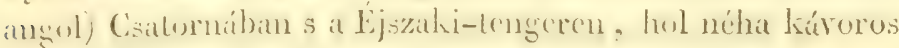
harkos) cetnek is (baleine is bec) mondalik. $\left({ }^{3}\right)$.

\section{A KÉTFOGUAK. F.}

\section{(Les Narvals. Monodon Liu.)}

'Tulajdomkipen ugy nerezcll fogers egr sines, esupain esilh hil egyenes és hegyes agyarok, az állkazti esontba

(1) Rafinesque eggy két hátszárnyu delfinäl szól, Quoy és Gaymard egyet líttak, mellyet D. 'rhinocéros-nak neveztek, Voy de Freycinet, II, I. k, ; lanem csak távolıul s félig vizbe buktan látván azt, szemcsalódástul nálok nagyon tarthatui.

(3) Hyperoodon, fogak a szájpadlatban.

( $\left.{ }^{3}\right)$ Ezen állat, leirva Baussardtul, Journ. de Phys., mars. 1789. (Delph. edentulus, Schreb.) mellyre Bonnaterre a butskopf ncvet áttevé, a kardos ajkabojt-ét, ugyanaz Hunter kétfosu délfinć-vel; Boussard is különüsen szúl kiét fogálul. Ez szinte a balacna rostra- 
ikelve, s a test tengöle iringát tarto: kïlïnben testök is amnak idoma sokat hasonlít az ajkaboltokéhoz.

Jól csak egy faj ismeretes.

A narvail kiétfogzu. F. Monodon monoceros. Lin. (Scorcsby, arcl. reg. XV.rl.) (1).

Enuck agyara pürge barizdás, néha liz lábnyi hosszú, sok ideig az egyszarvu szarvának neveztetek. Az állatban jol meg ran a két agyar csirája, hanem igen rilkáu nól mind a kettö egyenlön. Rendesen csak a baloldali fejliti lii, a mísik pedig az egész delcu által rejtre marad a jobb scjtben. $\left({ }^{2}\right)$. A roblok adout lcirisok szerint a kétfogu alig hosszabb) liélszer ragy háromszor az agyarínál, böre fehéres és barna márúnyzatu, arcora domboru, szíja liesin, fecskendöje a fö telején, hátuszonya nines, hanem gerince egész hosszában egy emelt taraj. Némelly, egíszen sima kéllogu àgyarakat is látni. $\left({ }^{3}\right)$.

ta, Klein, Chemnitz, (Beschr. der herl. ges. IV, 185. 1.); Pennant; Brit. zooI. V. sz. ; Pontoppidan Norv. II, 120; Dale bottlehead-je, stb. Chemnitz lítta az egyik fogát. L. Cuv. Recherches sur les ossem. foss. V. k. 1. r. 324. 1.

(1) A narual microcéphale; Lacep. v. rl. 2. k. nem egyéb mint a rendes kétfogu, valamivel rosszabbul ábrázolva, mint 15 . ․l. 5. k. melly egy rosz rajzolata után, készïlt Klcinnek, Tisc. per pulm. respir. Ir. rl. c. k. melly egy az Elbében 1736. fogott s dresdáhan kifömve látható egyér után csináltatott. Anderson ugyanazon egyeunek valamivel johb képét adja.

$\left(^{2}\right)$ Mi aöbb kaponyában föltalíltuk ezen apró agyaíat meállapitva; a mit Auderson mondott. Ez épen nem fejlodik ki, mivel belso ürege gyorsan belelik a csontanyaggal s igy kecsonyás anyaga clieked.

$\left({ }^{3}\right)$ A monodon spurius, Fabricii, vagy a grönlandi anarkak (ancylodon Iliger), mellyuck csak fölsö állkacsában van liét görbe foga, hátán pelig úszonya, - alig távozik el messze a a padlatfogutul. $\mathrm{ral}$, wale, minden tentonitul szármozott nyelven cetet, ceihalat jelent, s syabran dilabiban a cetek je- 
$\Lambda$ többi czeteknél olly nagy a fej, hogy az maga foglalja a testhosszaság harmadát vagy felét; hanem sem a kaponya sem az agy nem részesïl ezen ellenviszonyban, melly egészen az arccsontok iszonyu kifejlödésétül származik.

\section{A FIZÉTEREK. Földi. (sZöKETöK.)}

(Les Cachalots. Pliyseter. L.) (').

Fzcn cetck feje igen nagy területii, rendkiviul fülduzadt, kivált elül. fülsö állkapesa cgéśçı bajusztalan s fogalk nélkiul szïlö̈lï̈dö, ragy fogai aprok, lieressé kiállik, hancm az alsó állkapocs cgyences, hosszú, a fölsönek cģ barázdájába illö s mindenik oldalrul egy sor hengeres ragy liúpos fogaklial, mellyck szajjcsulás idején a fölsö állliapocs megfclelö üregeibe hatnak, van fölfegyrerkezre. Iszonyú fejök fölsö része majdnem esak egy nagy üregbül áll, molly porcok által van fuidre s clrálasztva, s azon föluil olajzsirral betöltre, melly a hidegben folyourá lesz s a kereskedésben a furcsa (bizarr) spermaceli nér alatt (halzsir, fagyány) ismeretes, és halászaLokban a fö nyereséget. teszi, testïk szalomnáral nem igen leven takarva; de ezen üregels a valódi kaponyüregtül igen liülïnbizoile, az igson licsintül, hátulsí részen helyezódö́tül s aggrat rendesen birótul. Ugy látszils hogy a halzsir(fagyány.)-csatornák, molly franciául máskép blanc de baleine és adipocire neret is hord, a test tübb reiszciben clágoznals, liüzüsülve a fej anyagát kitöltó üregelikel,

lentetuek vele; nar az ¿landi nyclven dögöt tesz; - s azt fogjảk ezen nemre, $\log y$ döggel él.

(') Physeter, valamint physalus füro't (fecshendezort) jelent. Cachalot nevoliet a baskok adák, cachau-tul, melly baski nyelven fogat jelent. 
sît még a kïzönséges szalonnába is bebonyolódnak, a\% egész bör alatt lćtezöbe.

Az ambra grisea (szürke ambra) név alatt igen ismert illatos inyag egy a fizéterek belciben, fökípen némelly beteg állapotban képzett összenövésuck lenni látszik, s a mint mondják, leginkább valibelökjon talíltatik.

A fizéterek fajai épen ninesenek jól meghalározra. A leghözönségesebbuek látszó (a hosszîfejü fizéter. Töldi. Le cachalot macrocephale de Schaw et de Bonnetcre. Lacep. X) ( ${ }^{1}$ ), hátuszonya helyett csak eserepes domborodást bir. Alsó állkapesában mindenik oldalt husz, egész huszonhárom foga vau, fölső állksapesában az íny alatt elrejlve két apró szemfoga; fecskendöje egy és nem kettös mint a celek nagyobb részénél; és az azon fölül roszidomzatu, a bal oldal felé irányzúdvín s ezen oldalon végzödvén az arcor elején, melly mintegy elrágott idomu $\left({ }^{2}\right)$; elhez pedig még azt is adjáls, hogy balszeme sokkal kiscbb a jobbnál, és a halászok ezen oldalrul szeretik az állatot megtámadni. Ezen faj sok tengerrc elterjedt, ha, a mint mondják, ö ád minden halzsirt és ambrát, - mert czen anyag éjszalsrul és délrül is hozatik. Ezen hátuszonytalan fizétereket egész az Adria tengerben is fogták. $\left.{ }^{3}\right)$.

(') Ez neni Linné macrocephalus-a.

$\left(^{2}\right)$ Mi két kaponyábun látttuk megvalósodottnak ezen Dudley, Anderson és Swedianer íltal hirdetett roszidomzatát a fecskendỏnek, s e miatt hajlandók vagyunk a szemek egyentelenségét is hiuni, mellyrül Egéde szól.

( $\left.{ }^{3}\right)$ Mi semmi valódi különbséget nem látunk ezen fizéternél, mellyuek jó áhrázolatai s vázának tobb része kéznél van, és Robessoné között ('Trans. phil. LX. köt.) mellybül Bonnaterre egy fa csinált trumpo név alatt, melly a bermudi szigeteken egy továbbá pontosabban meg nem határozott fizéternck adatik ki.

A mi a kicsin fizétert illeti ( $P h$. catodon L.) ennél a nagyságon hivül más különbözis nem hozatik föl, mint a hegyesebb fogak, a 


\section{A SZÖKETELYTK. \\ (Les Physélères Lacepède.)}

Ezeh a háluszonyos fizéterek. Közliik esah hét liij

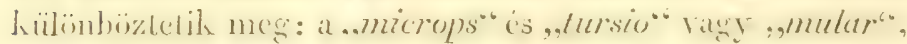
is ezek is az ircli vagy egyenes, hegyes vagy tompa fogak ingadozó bélyege szerint. $\left({ }^{1}\right)$.

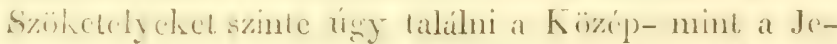
ses-lengerben; czen ulolsokat a lukik leghegyelleneb) ellenségénels tartják.

\section{A CетHALAK. (Földinél: baléma). (Les Baleines. Balaena. Lim.)}

'Termotre s fejök arányas nagyságára nézxe fülérnek

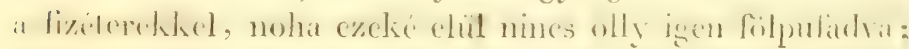

mi az életkortul származhatik. Az scm bizonyos azouban, hogy a neve alatt mutaltak, nem jonlnek-e a kardos ajkabolttul vagy más nagy delfintül.

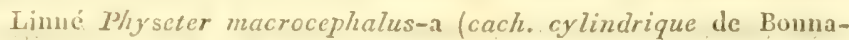
lere, Plıysale mem Lacep.) igen jó isélyeget birua föcskendöje hílrább lérõségében; hanem ezen faj csak Anderson egy rosz ábrázolatán alapul, és hozzá hasonlót senki sem látott.

Az albicans Brisson, huïd-fisk Eged és Anderson, mellybül Gmelin a liosszúfejünck fajtiját csinálá, nem egyéb mint a felıéres hátasik, mellynck fơlsỏ fogai jókor kihullanak, a mint róla meggyözödtem.

(1) Valamennyire bizonyosan csak egy faj ismeretes, Bayernek egy rosz képe szcrint (Act, nzat. Cur., IlI, 1. rl.) melly egy Nizzánál partra rectett eģénrül készitteték. A mular nevezet igen határozatlanul adaték neki; Nierenber mular-ja fizéter ugyan, hanem semmi scm bizonyítja megr, hogy más faj volna.

Lásd különben a szökelök különbféle jelcletérül a szcrzonknél Cuv. Recherches sur les Oss. fossiles, V. kät. 328. sth. lap. és Foyage de Freycinet. x11. 1. A mi a Lacépede által (Mém du Mus. 
lugok épen nines. Sajisa vagy forditott háfudel idomu fülsö állkapesuk vékony, súrün álló keresztlemezckkel takiarlatik, mellyck halesontnak neveztemek, rostos szarvanyaghul képzctick; szćlökön rojtoltak, s azon apró állatok megfogísára szolgálik, mellyekkel ezen szörnyá teremlérek élnek. Alsó állkapesok, két ki-s fölfclé ívelt csoulág által támasztra minden fegyrer nalkül, cgy igen körér izmos nyelret rejt el s a száj becsukísakor a fölsö liapoes egész belscjêt, ralamint az azt szegélyezö szarvlemezeliet is betakarja. Ezen müszerek nem hagyjaik a cetet olly nagy állatokkal élni, mint termetök szerint himi lehetne. Iralakisal éhek s még inkább férgekekel, puhángokkal, állatnörényeklicl s azt mondják. logy czek kïzül is az igen aprókit, a szíjlemezcik rojtaiban fönakadtakat uyclik leginkébb. Szaglásolira nézre a delfinclinél jobbau allotrúk; orrüregüliben némelly esiggalcnez ran, s ugy látszik apró szagló ígocshíliat is kapnak. Vakbelök rüvid. A közünséges cethal (küz. cethal. F.) Ia Baleine franche. Bal. mysticetus. ( ${ }^{1}$ ). Lin. Lacep Cét. 2 s 3 rl. Nordcaper név alall; Scoresby. arct. reg. II., 12.rl. $\left({ }^{2}\right)$.

IV. köt.) japáni rajzolatok szerint leirt fizétereket illeti, azon bizonyságok természete, mellycken ők nyugosznak, azt sem engedi meg', hogy öket e munkába fölyegyen.

(1) Aristoteles és Aclianus $q \alpha \lambda \alpha \omega \alpha-j a, a$ delfinck cllensége, ugy látszik hogy egy fogakkal fegyverzett cet vala. Aristoteles a valódi cetek közül csak az ugy nevezte mysticetus-t ismeré, melly hihetóleg a középtengeri árka-cet roit. Azonban ugy vélhetö hogy Juvenalis a közönséges cetet érté ezen versében :

\section{Quanto delphinis balaena britanica major.}

De a latínok altatían balacna nevet adtah meghatározatlanul minden nagy cetnck; mint az éjszaki népck $\mathrm{ma}$ is tesznek a whale, $\mathrm{s}$ wall-al és azok származataival ; fontos jesyzék az azok irásait olvasóknak.

$\left({ }^{2}\right)$ Martens régi ábrázolata (Lacep. I, I. I. és több más szerzőnél), a fejet.igen vastagnak mutatja. 
Soki legnagyob!nak tartaték az ismert állatok között, hanem Scoresby hajisnagy utolsú figyelutei szerint ugy látszik, hogy hetren lábnyinál aligg hosszabb, melly mérteket a barázdís hası celck gyakran fölül haladják. Hátokon soha sines szírnyok. Ezen fajt rïdözik évenként egész hajoseregekliol, szalonajjaćrt, melly néha löbb lábnyi rastag s végedlen sok halzsirt ád. Különben elég valimerö s a mi tengereinkben is logható rolt, de lassanként a magas éj:zakra ronulı rissza, hol száma naprul napra fogy. Zsirán kivil a kereskedésbe adja még azon feketés, hajlekony, nyole liz lábnyi hosszú szarvlemezeket, melylyek halesont név alatt ismeretesck: minden egrén nyole, kilene szizat bir illyent, mindenik oldalán szaíjpadlatának. Egy magányos egyén sziz luusz tomma zsirt ad; a csigák börére ragadnak s azon miut valamelly köszálon szaporodnak, vamnak a ,balanus" esaládbul belsejébe béhatók is. Azt mondjáli, hogy ezen szörnyü eet csak igen apró puhángokkal al, mellycklicl tengeri tanyája pezsg is. Úrületei szép reresek és a vásznat jól festik. $\left.{ }^{1}\right)$.

\section{A SZÁRNYUCETEK.}

\section{(Les Balénoptères Lacép.)}

Azon cclfajak mellynck háluszonyuk van; czck még tovíb) osztalnal fiil, a mint sima ragy árlos (medres) hasuak.

\section{A simahasu SZÁRNYUCETEK.}

Igen közcl íllanak a tulajdon cetckhez. Csak egy fajok neveztetik.

A szikicir szarnyucet. (Le Gibbar a baskoknál. Balaena physalus L. Finnfisch a hollandialnál, is hambur-

( $\left.{ }^{2}\right)$ Martens és Zorgdrager lizonyos helyeinek rosszul értésébül származott az, hogy a Nord-Caper-bül tulajulon fajt csináltak, melly éjszaki cet volna, a rendesnél vékonyabb; de a déli sarki tengerek egy a közönségeshez igen hasonló fajt birnak, mellyet a hol- 
giaknál. Martens után másolva van Anderson és Bonnaterre s többeknél. Lac. I. fig. II. k.

Olly hosszú, de jóval vékonyabb a közönséges cetnél, igen közönséges ugyau azon tájakon mint amaz, hanem a halászoktul kicrültetik, mirel kevés szalonnát ad, s mellette igen vad, fogni nehéz, söt a lis hajỏnak veszedelmes is eröszakos mozgásai által midöu megtámadtatik. Nincs egészen megbizonyítva, hogy nem ez-ce a baski árkacet, rosszul vizsgálva s neve elrontva.

Az cílios hasu száRnYucetek vagy ÁnKACETEK (RoRQUALS). (1).

A bör torkokon és melökön hosszában redelt, igen mély árkokkal, mellyek következóleg igen kiterjeszthetók, de ezen tulajdonság haszna még nem igen ösmeretes.

Ugy látszik, hogy az europai tengerek két fajt birnak.

A baski árkacet. (La Jubarte des Basques. Balaena boops. Lin.) Lacép. I. 3. k. IV. 1 s 2 k. - V, I. k. VIII, 1, 2. k.

Hosszabb a közönséges cetnél, hanem a szilsár szárnyucelnél följegyzett alkalmatlanságot mind birja.

A küzéptengeri cirkacet. (Le Rorqual de la Médilerranée. Bal. musculus. L.) Lacép. VI, VII.

Melly az elöbbitül csak néhány részlet viszonyaiban különbözik. $\left({ }^{2}\right)$.

landiak szinte nord-caper-nck neveznek. L. Cuv. Recherches sur les ossements fossiles. $361-3631$.

(') Rorqual barázdás cet, ezen redok miatt.

$\left({ }^{2}\right)$ A balaena rostrata Hunter, Fabric. Bonnaterre, vagy a boops igen különbözỏ Pennant és Pontoppidanétul, melly padlatfogu.

A bal. gibbosa és gibbosa B. vagy nodosa Bonnaterre jobban volnának meghatározva; hanem csak Dudlcy (Trans. phil. 387.) szerint ismeretesek, és az nem hizonyos, hogy ezek meg nem vállozott egyének c. L. Cuv. Recherches sur les Oss. fost u. o. 


\section{A 'TOJÓ CSONTTIZAS ÁLLITOKRL ÁLTALÁ- $\mathrm{BAN}$.}

Noha a tojó csontrázasok három osztílya sokat hülönbözik eģmástul a lúlekzés mennyisége s minden ide tartozó dolog, u. m. a mozgútsheli erók s az érzćlhek hatalma által, még gis sok közös bélyeget mulatnak az emlösclinek vagy elevenszülö csontvázasoknak ellenében.

Agyok csak igen vékony féltekéket bir, kérges test által nem egyesitetteket; a kisagy s zálaai nem képzik az ugy nevezett Farol hidje elöduzadísét: a gumók, nates (legalább két osztálỵani), igen kifejlödnek, egy gyomor-ïr van bennök, a fóltekéktiil nem takartatnak, hanem az agy alatt ragy oldalain láthatók; belsö orrhészületök kevessebló bonyol!; fülokben nines annyi esontocska, söt némellyeknél egészen hibáznak; a csiga, mikor létez-scz cask a madaraknál történil, sokkal egyszerüb), stb. Mindig elég szímos dauabohluul öszszetetl alsí állkapesok homorú fölülettel a halánték csontnak egyik emclt részéhez ragad, de a sziklacsonttul el ran választva; kajonya-csontaik jobban elosztvák, noha arányilag azon helyet foglalják el s azon munkálatol végezik; igy a homlokesont öt vagy hat darabbul van; stl). A szemfog gödrök csak egy csont- 
lemez vagy hártya által választvák el az íkesonttul. Mikor elsö véglagaik vannak ezen állatoknak, a kulcs-csonton kivïl, melly gyakran a túl oldalival összeköttetvén villacsont nevet kap, a váll-lapocka is a mellesonthoz támaszkodik egy igen hosszú és széles hollónyujtvíny által. A gége (gơog) eggyszerúbb s göggledúdlen; a tüdö nincs a hastul teljes rekesz által clválasztva. De ha mind ezen viszonyokat eló akarnánk adni, olly bonctudományos leirásokba kellene merülnünk, mellyek munkánk ezen elsö részét nem illetik. Legjen itt elég a tojóknak hasonlatossígát megjegyzeni, melly alkotások tervének tekintetében nagyobb, mint akármellyiké az emlösökhöz képest.

A tojási nemzés lényegesen albban áll, hogy a nemzedék nem kapesoltatik méhlepény által a méh vagy petevezetó falaihoz, hanem altul legküỉsö takarója által elválasztatik. Tápláléka elöre elkészítteték s egy zseblue csukaték, melly bélcsőjével van kapcsolva; ez a tojás szike vagy sárgája, mellynek a nemzedék némüleğ függeléke, eleinte észrevehetlen, a szik nedvét fölszíva táplálódó s nevelkedö. A tüdö által lélekző tojástojók még a tojásban egy, edényekkel iggen gazdag hártyát is birnak, a lélekzésre szolgálni látszót; ez a hudhólyaggal köttetik egybe s az emlősek hudduzmáját (allantois) ábrázolja. A halaknál nem találtatik, sem a békafélieknél (batrachia), mellyek, elsö életszakokban, mint a halak, kopótyuval lélekzenek. 
Sok hidegvérü tojús állat csak akkor szúli megr nemzedékét, mikor már kifejlödött s megszaladult tojáshajaitul vagy egyéb öt az anyátul elválasztó takaróitul; ezeket mondjuk - ál elevent szïŁók-nek.

A CSONTYAZASAK MÁSODIK OSZTÁLYA.

\section{A MADARAK.}

Tojíst tojó, kettös vérkerengésü s lélekzésü csontvázas állatok, repülésre alkotvák.

Nem osztott, a bordákhoz szorított tüdejök nagy lyukakkal bövelkedö hártyába takart, melly a levegót a mell, alhas, hónal sok üregébe sôt a csontok belsejébe is ereszti, olly módon hogy a külsö folyam nem csak a tüdö-edények fölületét érinti, hanem, a többi test végetlen sok edényét is. Ennél fogva a madarak némileg ugy lélekzenek a függütér ágai, mint a tüdö-ütéréi által, s ingerlékenységi hatalmok jó viszonyban áll lélekzésök meny-nyiségével (1). Egész testök ugy rendeltetett, hogy ezen hatalomnak hasznát vegye.

(') Két szabad veréb annyi tiszta levegot megemészt, miul eE. tengeri disznó. Lavoisier. Mémoires de Chimie 1. 119. 
Melülsó végtagaik repülés eszközeivé színatván, nem használhatók sem állásra, sem fogásra; tehát kétlábuak, s a földrül szájokkal veszik föl a tárgyakat; szinte testöknek elöre kell lábaiktul sulyongani, mig ujaik jól megnyujtrák, hogy elegendö alapot szerezzenek neki/ A medence igen ki van hosszában nyulva, rag-helyet engedendő azon izmoknak, mellyek a törzsököt emelik a szárakon; söt van még egy sor-izom, a medencétül az ujakhoz menö, s a térd és sark fölöıt olly módon elmenö, hogy a madár egyszerü terhe már meghajtja az ujakat; illy módon képesek egy lábon állva aludni. - $\mathrm{Az}$ ülcsontok $\mathrm{s}$ föképen a fancsontok hátra nyulnak s eltágulva elég helyet adnak a tojások kifejlésére.

A nyak és csorr hosszudtak, hogy a földre érhessenek; de az első szükséges fogékonyságot bir, hogy csöndes álláskor hátra hajtathassék. Tehát sok csigolyája van. Ellenben a szárnyaknak támaszt adó törzsök kissé lehete mozgékony; a mellcsont fóképen, mellyhez a szárnyat a levegö-verés kedveért aláhuzó izmok ragadvák, nagy kiterjedésü, s fölszinét még a közepén emelkedő lemez is nagyobbítja. Eredetileg öt darabbul alkottaték; egy közép darabbul, mellynek az emelt lemez része; két mellsö háromszegletü darabbul a bordák összeragadására, s hátulsó oldalvásti villás darabbul fölúletének kiterjedése végett. Ezen utolsók kivágásainak nagyobb kisebb megcsontosodása $s$ azon tér, mellyet köztök 
s a födarab közölt hagynah, jeģyzi hi a madaral. töhb ragy kevesebb repuïlési crejét. A nappanali ragarlozó madiurak, a föllongük, a pompályok idövel mind elvesztik ezen nem-csontosodott helyek nyomait.

A villacsont, a két liulcs-csont egyesülése által képzett, és azon hé hatalınas írtúmasz, mellyehet a hollónyujúnyok szïlnek, szílteszítve lartják a vállakat, azon cróködés diacára, mellyet a repülés ellenirányban kiván; s föképen a villacsont amnál eróschb és nyilabh, minćl jobban repül a matiur. I váll, alkar és a kihosszult, s egy ájat s más liettönek nyomdolít mutató kér által tartott száruy, egész hosszában rugéknny tollak sorozatít mulalja, melly a levegüt verö fölületet nagyon bíviti, literjeszti. A hézhez tapadú tollak elsürangucek s illyen mindigg tiz van, az alkaron lévök misodranguak; a keveselbué erös, s a vállhoz tartozók villlollak, a hürelyket ábrázoló csonton szinte vatn mehíny kores (bitardes) nevü toll (fuik secirny); - az evezí tollak alajjáin apróbb tollak sorzata van, ezeknek neve: takarók, feclezók.

Csontos farkok igen rövid, de szinte crós tollsorozatot bir, melly kiterpesztve a madár föntartátását elösegíti (kormánylollak).

A lábak részei esy comb-csont, és a sipcsont és szárkapocs, melly utolsúk a comb-csonthoz rugéliony izesülés álıal kötletvék, s igy kiterjesztve maradnak az izmok munkílkodása nélkül is. 
A lábtö s középláb csupán egy csont által ábrázoltatnak, melly húrom tekercsbe végzödik.

Legiöbbnyire három uj van elül, s a hüvelyk hátul, melly néha hibázó. Elöre vàn a föllengüknćl irányozva. Ellenben a kúszóknál a külsö uj s a hüivelyk hátra irányozvák. Az ízek száma minden ujnál nevekszik, a hüvelyknél kezdve, melly kettöt bir, s az ötöt biró szélsőn végezve.

Általában a madár tollal födött, melly takaró leginkább védheti oót a légmérséklet gyors változásai ellen, mellynek mozgásai által kitétetik. A teste beljét elfoglaló lég-üregek s a csontokban is velö helyét kitöltők, aránylagos könnyüségét elömozdítják. A bordák mellesonti része, valamint a gerinci is csontosodott, melle kiterjedésének nagyobb eröt adandó. Mindenik borda egy kis csontot emel, véle hamar összeforradót s a jövő borda felé ferdén irányzottat, - melly szinte nagyobb szilárdságot segít a mellkasnak adni.

A madarak szeme olly módon alkotott, lingy mind távolrul, mind közelrül egyenlön jól láthassák a tárgyakat; a mit hiletóleg egy edényes és redós hártya, a szemgolyó fenckérül a jéglencse széléhez menö, mozdít elö, azon jéglencsét elhelyezve. A golyó melsó része különben csontdarabokbul álló kör által erösítteik; s a két rendes szemhéjon kivül egy harmadikat is bir', melly egy nevezetes izomkészület segedelmével a szem elejét lepelként takar-

CUVIER I. K. 
hatja. $\Lambda$ szarvhártya igen domború, de a jéglencse lapos s az üvegtest kicsin.

A madarak füle csak egy csontocskát bir, eggy a dobhártyához ragadó ágtul s egy másikıl, melly a petés ablakra támaszkodó lapba végzö́dik, képzettet; csigájok kevessé ívelt (hajolt) kúp; de félkörú csatornáik nagyoks a kaponya egy részében helyezö́dnck, hol minden oldalrul légüregekkel vetettek körïl, a dobüregg nyilílikal. Csak az éji madaraknak van nagy kïlsö csigrijok, de melly mindazáltal nem áll clö, mint az emlöseknél. A fühnyilás rendesen wllakkal takart, a többicknél foszlottabb szakálluakkal.

A szagolás müszere a csorr alapjába elrejtve rendesen csak porcos orresigúkat bir, szímra hármat, bonyolódásra nézve változókat; igen érzékeny , noha a kaponya mélyébe nincsenek öblei. Az orxlyukak csontos nyilásainak szélessége hatírozza meg a csont ercjét, s a porcok, hártyák tollak és egyél takarók, az ezen nyilásokat keskenyitök, befolyást gyakorolnak a szaglís finomságáia s a táplálit módjára.

A nyelven kevés az izomanyag, és egy a szikcsontlal izesïlt csonttul tartatik; a nagyobble résznél igen kevessé kényes.

A tolicsák, valamint a tollak (evezök), a tölök csak nagysśgra nézve különbözók, alul üres csökbül, s továbbá szakállbul vagy vitorlábul állanak, melly egyes szakáll ismét kisebbekbül áll; szövetök , 
fényök, erejök s általános idomok végetlenül változó. A véle takart részekben gyöngének kell a tapintásnak lenni, - s a csorr majd mindig szarvas és kevessé érzékeny s az ujak is fölül pikkelyekkel, alul havadályos börrel lévén takarva, ezen érzék hihetőleg kevessé hathatós a madaraknál.

A tollak évenként kétszer hullanak ki. Bizonyos fajoknál a téli tollazat szinte különbözik a nyári ruházattul; a sokkal nagyobb számnál a jérce különbözik a himtül, kevesbé élénk szinezete által, s illyenkor mind a két nömü aprók az anyíhoz hasonlítanak. Mikor az idölt him s nó ugyan azon színüek, az apróknak tulajdon szinzetök van.

A madarak agya azon általános bélyegeket mutatja, mint a többi tojó csontvázasoké; de különbözik arányilag igen jeles nagyság által, melly gyakran az emlösöknélit is fölül mulja. Ezen tömc's föképen a csikolt testeknek megfelelö gumóktul függ, nem pedig az igen vékony és tekervénytelen féltekéktül. Az agyacs elég nagy, majd oldalkarélyok nélküli s fơképen a gilisztaképü nyujtvány által képzett.

A madarak gőgsipja egész gyürüs; ketté ágzásanál van a hang-szor, legtöbbuyire tulajdon izmokat biró, s algög (larynx inferior) nevet hordó; itt képzödik a madarak hangja, mellynek erösségét elömozdílja a lég-zsebekben tartott temérdek levegô, múdosítúsail pedig a gögsíp eszközli ki, külön- 
bözö idomai s mozgásai által. Az igen egyszerï fölgögo, igen kereset foly ide bé.

A madarak area vagy föl-csöre, föhépen a kapocsközti csontokbul képzett, hátul két ívbe nyúlik el, mellyek köräl a belsö az inyesontokbul és röpesontulibul, a hïlsö pedig az áll-és járomesontokbul hépzödik, s mellyck egrüıt a mozgékony dob-(fül-)('sontra, hözönségesen h'gy sägesont nevíure, a sziklacsontnak megfelelöre, tímaszkodnak; fölül ezen arc izesítve vagy egyesítve van a kaponyához rugékony lemezck által, melly egyesülési mód mindig hagy némi mozgást.

A két csörlemezt takaró szarvanyag a fogak helyét pótolja s nébar fürészesen s fogakat íbrázatlólag $\mathrm{ki}$ is van csiphedve; idoma, valamint az ö képzö két lemezé (kapocsé), végetlenül váhtozik a mindenik fajt illetö eledel szerint.

A madarak emésztése megfelelï viszonyban vin életmunkásságokkal és lélekzési erejöklel. A gyomor hároun részbiil áll: a bescy-biil, melly a biursing kilágulása, a zseilér-vagyis hurlycis gyot mor, falainak anyagában szimos mirigycket biró, mellycknek nedve az étkeket megáztatja, s végre a zíz, vagy ziza, két hatalmas izommal fegyverkezve, mellyek kél sugáros in által egyesülvék s belül porcos-bársonyos börrel van bélelve. Az étkek amnál kömurebben megzizatnak benue, mivel a madarak apró löveket is nyeldesnek le, hogy az örlést clösegítsék. 
A huis ragy halevô fajak legnagyobb részénél a zúz izmai s biborhártyája igen gyöngék, s ugy látszik, mint lia a zúz egy zsebet képezne a zsellérgyomorral.

A begy kitágulása szinte hibázik néha.

A máj a belekbe két csatornán által üríti lii az epét, mellyek váltogatva állanak azon két vagy három csövel, mellyeken a hasuyálmirigy nedve ürül ki. A madarak hasnyálmirígye jókora, de lépök kicsin; cseplezök hibázik, mellynek munkálata részint kipótoltatik a légüregek válfalai által; két rak toldalék létez a végbél kezdeténél, közel a segnyiláshoz; többé kevesebbé hosszúk, a madár életrende szerint. A gémeké csak rövid; s több nemeknél, mint a harkályoknál, egészen hibáznak.

Az ürgyü (cloaca) olly zseb, hol az úrülendöségek összegyülnek, hova összenyilnak a véģbél, a hudvezetök, a magcsatornák, vagy jércéknél a petevezetők; kivülre a végbélen által nyilnak. Rendesen nem hugyoznak a madarak, hanem húdok a többi keményebb ürületekkel vegyül. Csak a strucok (szaladárok) ürgyüje tág annyira hogy a hugy öszvegyülhet benne.

A nemek nagyobb részénél a közösülés a seg összetétcle által történik; a strucoknak s több úsztalpuaknak van azonban barázdás vesszejök, melylyen a mag átvezettetik. A herék belül vammak a vesék fölött, közel a tüdőkhöz; csak egyik petevezetó fejlett ki, a másik nem eggyéb egy kis zacskónál. 
A petefészektül eloldott pete (tojás), hol csak a székét lehete észrevenni, a tojásrezetö magasán fölszirja az ugy nevezett fehérnyét, héjjal pedig ugyanazon csatorna aljän retetik körül. Az ülés kifejti ehben a fiatalt (magzatot), ha az éghajlat melege a cellra nem elegendü, példa ran rá a szaladároknál. A magzat csörhegyén szarvhegy ran, mellyel a tojást fölvágja, a születés után kevés nap mulva leesendő.

Kihi ösmeri azon különbféle szorgalmat, mellyel a mudarak fészkeiket készitik, s azon gyöngéd gondot, mellyel tojásaik s apraik iránt viseltetnek: e fü része östönüknek. Különben gyors átrohanásol a lég sok rétezetein, s ezen elemnek hatalmas folyrásti rájokhatása, alkalmasokká teszik öket a légkör változásainak elö́rzésére, mellyeket mi képzelni sem tudunk, s mi okbul már legrégibb idök úta, balvélekedés körethezésében, jósolási erö tulajdonittaték nekik. Kétségkivül ezen tehetségtül származik a vándorlú madarak azon ösztöne, melly öket délfelé menni kényteti tél közeletérel s visszatérésre birja taraszszal. Nem hibázik nálok torábbá az emlékezü erö, nem a képzelüdés, mert álmodnak: s az egész rilug tudja, milly könnyen megszelidülnek, különbféle mesterséget tanulnak, dalokat és szavakat elmondanak. 


\section{A MADÁROSZTÁLY RENDEI.}

Minden állatosztályok közöı a madaraké legjobban bélyegezett, cunek fajai leginkább hasonlitanak egymáshoz, s ez legnagyobl) térrel van minden töbhitül elválasztva; egyszersmind ez az, mellynek alsóbb fölosztása bajosabb.

Fölosztísok, mint az emlöseknél, az evés müszercire vagy csorr-ra, s a megfogási múszerekre, azaz szinte a csorr-ra s fókép a lábakra alapíttatik.

Legelöször is az riszhcirtyás lábok tünnek szembe, azaz, hol az ujak hártyával kötvék össze, s ezek az ziszó madarcik. Hátra helyeztetett lábaik, hosszú mellcsontuk, néha száraiknál is hosszabb nyakok, hogy mélyre érjen, tömött, sima, viz-átjárhatlan tollazatok lábaikhoz illók, hogy jó úszókká tegyék őket.

Más madaraknál, mellyeknck leggyakrabban szinte némi uszhártyás a lábok, legalább a külsü ujak köze, emeltek a lábak; a szárak aláfelé tollatlanok; termetek karcsu; szóval, minden rendeltetésök megvan a vizek gázolásához, ott élelmeket kcresendök. S valóban illyen a nagyobb szám életrende; s noha némelíyek száa'azon is élnek, nevök gázlók marad.

A valóban szárazi madarak között a tyukféliek, p. u. a házi tyuk, idoma esetlen, röpte rövid, csorra középszerü, boltos felsỏ csorr-lemezzel, orrlyu- 
kai részint fedvéh liggy, duzadt pikke lylyel, njaik maju mindig fogas széliek, rövid hírtýaral, legalibly az elsöh alapja hözött. Föhịen szemmel élnek.

A ruguluzi malurak csorra horgas: hegyes és alíhajlott vigü, az orrlyukak a csorr egész alapjit befedü hártyihan nyilnak meg; lábaik hatalmas karmokkal fegrrerezvék. Hussal élnek, a többi madarakat ïldözik, s még nagy részint erös reptüek is. A naggublo szám hülsö ujai közt még egy kis hártya is van.

A verélfiliek sokhal több fajt számlialnak, mint minden többi csalidtok; de alkotásohban olly hasonlatossíg van, hogy el nem vílaszthatók, noha termetre s eröre nézve igen különböznek. Két külsö ujok alapja s néha hosszának egy része is egjesítve van.

Tégre kriszók nevét kapták azon madarak, mellyek külsó uja hátra van irányozra, mint a hüvelyk, mert ralóban a legnaģobb szám kedvezöleg van a függöleges helyzethez alhotra, hogy a fák törzsökein kedvére kuszhasson. ( $\left.{ }^{1}\right)$

Mindenik rend családokra s nemekre osztatik, föképen csorra alkotása szerint. De ezen különbféle csoportok gyakran majd észreveheılen fokozattal

(') Elsô elemi lajstromumbul, 1798-rul, kihagyandónak taJíltam most Linné, „Picus" rendét, mint meghatirozott bélyeggel aem birit. Illiger s az uj madártudósok nagyobb része elfogadták e kihagyást. 
mennek egymásha át, olly módon hogy nincs osztály, mellyben a nemek és alnemek határait nehezebb volna kijelelni.

A MADARAK ELSÖ RENDE.

RAGADOZÓ MADARAK, (ölvök F.)

(Accipitres Lin. Les Oiseaux de Proie. Raubvögel.)

Ismerhetők görbe csorrok és körmeiknél fogva, melly hatalmas fegyverekkel a többi madarakat, sôt még a gyönge emlöseket és mászókat is üldözik. Ök azok a madarak között, mik a szinte ugy nevezett ragadozók az emlöseknél. Combjaik és alszáraik izmai markóik erejét mutatják; talpaik ritkán hosszúk; mindnyája négy uju; a hüvelyk és közepsö uj körme leghosszabb.

Két családra oszlanak, nappali-s éjire.

A nappaliak szemei oldalvást irányzoltak; csörök (csorrok, csó-orrok) alapját egy ugy hítt vicaszhcirtya (cire) födözi, mellybe az orrlyukak metszvék be; három uj elül, egy hátul tollak nélkül, a két külső majd mindig egyesülve van alapján rövid hártya által; a tollazat sürü, a tollak erösek, a repülés hatalmas. Gyomruk majd egészen hártyaféle, beleik kevessé terjedtek, vakbelök igen rö- 
vid, mellcsontuk széles és majd egészen csontosult, a szárny izmainak téresebb tapadást engedendő, villacsontuk félkörded, s igen elterült, hogy jobban ellenálljon a kar eröszakos aláhajtásának, mellyet a gyors repülés megkiván.

Limné csak két nömet alkota bennök, - mclylyek inkább két természeti családnak mondhatók, a keselyükèt és sólymokét.

\section{A KESELYÜK.}

(Vultur. L. Les Vautours. Geier.)

Szcmeik fejök magasán vammak, talpaik hálísak, azaz apró pikkelycklkel takarváls; csorrok hosszult, csak a végén görbült (horgas), s fejénck sö́t még nyakának i többé kevesbé kiterjedt része, csupasz. Markoiik creje nem felcl nagyságoknak meg, s inkább csorroknak lálszanak hasznát venni, mint kïrmciknck. Szárnyaik olly hosszúk, hogy júrtokban félig kitcrjesztre tarlják azokat. Gyára madarak, inkább döggel mint elö zsákmánynyal tartók; mikor ettck, begyök nagy buckot képez a villa alatt, orrlyuliaillbul büdös nedv foly, s majdnem nómileg eltompultsági állapotba esnck.

\section{A tulajdonképi KESELYÚK.

$$
\text { (Vultur Cuv.) }
$$

Vastag erös csorral, az orrlyukalk ennek alapján keresztben állók, a fej és nyak toll és husrigya nélkül, a nyak alján hosszú toll vagy pehely-körv (gallér). Csak az ó vilúghbon láttattak még.

A sárga keselyü. (Le vautour fauve). Vultur trencalos. Bechstein. Le Percnoptère Buff. le grand Vautour 
u. o. Hist. des Ois. I, v. rl. (1). Le Vautour Albin. III. r. Nauman. p. 2. rl. Der weissküpfige Geier.

Sárgába menö szürke ragy barna, fejének s nyakának pelyhe hamvas, nyakörve fehér, néha barnával vegyes; szárnyai s fark tollai barnák, csorra s lábai ólomszinüek; a felnölt hasa fehér. A legkiterjedtebb faj: az egész ó világ hegyein találtatil. Teste fölüti söt meghaladja a hattyuét. $\left({ }^{2}\right)$.

A barna keselyü. Le Vautour brun. $V$. cinereus Gm. enl. 425. Nauman. 1. rl. Vieillot. gal. 1. t. Arrian. la Peyrouse-nál. Der graue Geier. Brehm II. 1. 1. kép.

Feketés barna; nyaklkörve ferdén (hárántosan) egész a hátfö felé emelkedik, mellyen még egy tollpamat is van; lábai s csorra aljának hártyája viola-kékes, az elóbbinél nem kevesebbé terjedt el, s nagyobb. Gyakran az élő állatokat is megtámadja. $\left({ }^{3}\right)$.

$A$ füles keselyü. (L' Oricou. $V$. auricularis. Dand. Vail. Afr. Ix. t. Der Ohrgeier.

Feketés, nyaka mindenik oldalán hosszanti hús-taraj a fül alatt. Afrikábul. $\left({ }^{4}\right)$.

(') I. Buffonnál a grand vautour leirása a következö fajt illeti, de az ábrázolat ezé.

$\left(^{2}\right)$ Az indus keselyü. Le vautour des indes Lath. és Sonnerat. Tem. 26. sz. t. legalább igen közeli faj, szinte mint a Chassefiente. Vaill. Afr. 10, t. Add hozzá még: a fekete keselyŭ $V$. (aegypius) Temm. col. 407. és császár keselyä, sinka ( $V$. imperialis) u. o. 426.

$\left({ }^{3}\right)$ V. monachus Edw., 290. Vaill. 12 és Col. 13. a barna keselynitől csak rövidebb csorra által különbözik. $A$ tarajos $k$. ( V. Cristatus Gmel.) csak Gesner rosz ábrázolata után isméretes, melly hihetỏleg valamelly sasfajrul véteték le. A vuleur barbarus nem egyéb mint Földinél a szakállas grif.

(') A pondicheryi $k$., the de Pondichéry, $\boldsymbol{V}$. poneiceranus, 2. 
Amerika keselyiihet treme jeleselet azom taraj (husrigga) miatl, melly viazhirlyajohon iil. Csorrok alihora mint az elibbieknet, de orrlyulsails lojástadols is hoszanliak. Ezcknek nere:

\section{TAIR AJKESEL YEK.}

(Sarcoramplus de Dumiril: Gypagus, Zopilole Vicillot. K(tmmgeier).

Ameriha lakioi jelesek azon húsesombikirul, mellỵd:

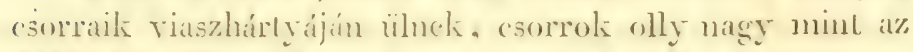
clobbicke, de orrlyukatik peleidomuak s hosszantiak.

1. A pripa tarajkesely. (Pip)a keselyï. F. Le Roi des Vautours. Irubi Cha. de Azz. Fultur papa. Lin. Der Geierkönig). Enl. 428. Vicill. Gal. 3.

Ludnagyságu, elsö liorában f(ketés; (Spix. 1. rlo), ulibb felieterel és súrgíval licrert (Vaill. Afr. 13.), vigre negyedik érben, köpönyege súrga, Lollai (evezöi s nyalilati) feketck. Feje s nyakia esupasz részei dénk sziniek, csombrikja pedigr fogas mint a kakastaraj. Déli Amerika sikjain s más heres tájain lakik. (Honi) neve onnét jö,

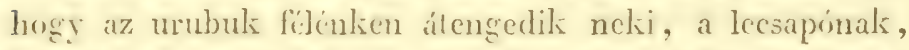
helyöket azon dïgnel, mellynck créschez ök már hozzá foglak.

2. A kondor, srif tarajkesely. (Grif keselyü F. Le Condor ou Grand T'autour des Andes. Vultur sryphus L. Der Condor oder Cuntur. Cathartes Gryphus. Temm. rl. 133 és 408. Humb. Obs. zool. rl. virr.

Feketis, számya nagg része hamras, nyalslata selyem kípü s fehér; a himmeli, felsö nagg de fogazallan huscsombólján kivil ran csorra alatt is, mint a kakasnál.

8z. t. igen közelit az Orikuhoz. Oldal-taraji nem hatnak olly magasra, csorra gyöngébb. 
Elsö koríban hamras barna és nyaklótlan. A nöstény taraj hijával ran s egészen szürkebarna. Ez azon nevezeles faj, mellyck termetét olly nagyuak költötték, azonban rsak kevéssel nagyobb a mi liesely-sasmuknál (Földi szakállas grifjénél), mellyhez természete is hasonlít. Az Andesek legmagasabb bérccin tanyáz, s a leginagasbra emelkedő madár.

\section{A TYUKKESELYEK.}

(Les Cathartes. Cathartes. Gur. Gallinazes, ou Catharistes. Vieill. Hühnergeier).

Csorrok mint a tarajkeselyelsé, azaz vastag, és tojásidomu hosszanti orrlyukakkal; de nines tarajok; fejök nyakok csupasz.

1. A barna tyukkesely. (Le C. Tautourin, Tult. californïanus. Sh. Tem. Col. 31 .

Új Californiábul; nagyságra kondorhoz közclíl; szálnyai aránylag hosszabbak; egész tollzala barna.

2. A fekele ty. ( $L$ ' Aoura. $V$. aura. L. Der A-Ura. Acabiray Az. Enl. 187. Vicllot. Am. sept. 2. et Galer. 4.

Fekete; farka vágott; kakas nagyságú.

\section{A DÖGKESELYEK.}

(Les Percnoplères ${ }^{1}{ }^{1}$. Percnopterus. Cuv. Gypatos Bechst. Neophron Savigny. Aasgeier.)

Cisorrok véliony, hosszú, görbülete fölöll kissé dızadt, orrlyukaik tojás-idomuak, hosszantiak, s csak fejök esupasz, nyakok nem. Küzép nagyságu madarak, s cröre nézve a tulajdonképi kesclyúlkhơz nen liözclitüli;

(1) Percuopterus=fekete szárnyu. Igy hivták e fajt a ségich. 
azon fülül még torkosabban kapják a dögöt s minlenfilc szennyet, mellyekre távolrul eljönek; még az úrületeket sem velik meg. Iliger az elóbbieklkel együtt, Cathartes ${ }^{66}$ nemébe foglalta óket.

1. Az aegyptusi dïgkesely (egyiptomi keselyii $\mathrm{F}$. Ie Percnoptere d' Égypte. Tult. percnopterus. Tult. leucocephalus. Vult. fuscus. Gm.) Enl. 407. s 129. Vicillot. Galer. 2. Naum. 3. rl. Vultur de Gingi Sommer. Daud. Origourap. Vail. Afr. 14. Rachamah de Bruce. Farao tyukja Aegyptusban. Akbaba törökül. Brehmnél I. lap. 1. kép.

Holló nagyságu, pofja s torka csupaszok; lkinölt hime fehér, száruytollai feketék, a fiatal s a nöstény barnaik. Ezen madir az egész ó vilígban elterjedt s kïlönïsen a heves tarlományoliban igen küzönséges, mellyeket a dögüktül megtisztit. Nagy csapatokban liséri a pusztálsbeli liaravánolsat, megeendü minden elveszettet. A régi aegyptusiak igen tisztelék tett szolgálatiért s gyakran leúbrázolík cmlckeiken. Ma sem búntják iöt, süt vammak buzgó mozleminok, kik örökrisiolést hagynak, mellybul bizonyos számmal tartassanak illy keselyek.

2. Az amerikai dëglesely. Irubu. (I) Crubu. Tult. jola. Ch. Bonap. Der Urubu.) Viell. Am. sept. I. rl.

Nagysága, idoma az clób\})ié; csorra eröscbb, eģisz teste fémyes feliste; egész feje csipasz. Amerilia minden meleg és mérsélielt részében kïzünséges, hol azon szolgálatot teszi, mellyet az aegyptusi dïgkesely az ó rilágban, csoportosan rohanra a dügölire s minden mocskot megemésztve. $\left({ }^{1}\right)$.

(') Ezen madarat igen soká összezavarik a fekete tyukkeselylyel; de csorra jóval vékonyabb.

Add lozzá még. "Le Chatarte moine" (barát tyukkescly) pl. cul. 222 . 


\section{$\Lambda$ KESEI ISASOK.}

(Les Griffons. Gypaetos. Stor. Pliène Savign. Der Bartgeier).

Ginclintül a sólymok közé tetettek, de inkúbb a keselyúlkhöz küzelítenek életmódjokra s alkotásokra nézve; szemeik fejtetejök közclén vaunak, karmaik aránylag gyöngék, szárnyaik nyugtokban félig kitcrjedtck, begyök, mikor telt, kiduzad nyakok alján; de fejök egészen tolltakart; különböztetö jelök: erös, egyenes, végén horgas s a görbületen dagadı csorr; orrlyukaik durva, clöre irányzott selymekkel takarvák, hasonló selyempamat van csorrokon is; lábaik rövidek s egész az ujakig tollasols, szárnyaik hosszúk; harmadik evezöjöls leghosszabb.

A szakillas keselysas. (Szakillas grif. F. Le Vaulour des agneux ou Lämmer Geier. V, barbatus et Falco barbatus. Gm. Gypaetos barbatus. Cuv.) pl. col. 431. Edw. 106. Vieillot. Galer. 8. rl. Nauman 4 és 5. rl. Nisser. Bruce Abyss. 31. rl. Brehmnél: Bartgeier-adler I. lap. 2 kép.

Lcgnagyobb az ó világ ragadozó madarai közölt s itt kevés kivétellel mindeu hegyláncot lakja; meredek szilklíkon fészkel; meglámadja a bárányakat, kecskéket, zergéket, söt a mint mondják, az alvó embereket is. Azt vitatjáls, logy gyermekeket is rabolt el. (Voigt szerint ez 1813-ban is történt Lauterbrunnthalban). Az állatokat meredek sziklákrul kéuyszeriti leugrani, s fölfalja öket, mikor az az esés által összctörtek. Azonban nem veti meg a döghust. Majdnem 4 lábnyi s 9-10 lábnyira terpeszkedik. Köpünyege fekelés, minden tolla kïzzepén egy fehér vonallal; nyaka s egész test-alja világos fényló sárga; fejét fekete szalag keríli. A fiatalolinak, egész a beleszámlált 1-dik évig, töbló kevesbbé sötét barna nyakok és melök 
ran. Ezcu madár volt a görögök phénje g a rumalials ossifraga-ja. $\left({ }^{1}\right)$.

\section{A SÓLXMIOK.}

\section{(Les Faucons. Falco. Lin. Der Falke.)}

A nappali ragadozi madarak második és jóral szímosabb oszályál teszik. Fejök és nyakok tollal fedcll: szemboldjok cmelkedelet kípez, mellynél fogra szemök mélyen dítszik fekïdni s arcronalok a keselyiüiétiil egészen liülinbrizö kinyomíst kip) : nagyobb részint dö zsálimánybul táplailkodnak, de az ennck elnyerésére haszníl, bádorsig tekintetéden igen külömböznek eggmástul. Elsö tollok gyakran mís szinii mint az iclültcké, s illyent esak hammadik negyedik erokben kiapnak, s cz az oka, hogy fiajakat rendkiviil szalporilík a tormészetirók. A nö rendesen egy hamaddal nisgobls a himnel, s ennek neve a franciáknál ez olbul tiercelet (harmadea).

Ezen alrend két nagy fónemre osztatik.

\section{A tulajdonképi sótтмок.}

(Les Faucons proprement dils. Falco, Bechst. Edelfalten.)

Az elsô föncmet teszik. Termelökhöz képest ök a bitrabbak, melly minósigniket karmaik is szimyails crejénck kïszönik; s ratriban csorrok alaptul kezdre görbül s hegye mindenik oldalán éles foga ván; szárnyok másulik erezoje leghosszab, noha az cloö is majelnem olly hosin, a mi mialt számyok hosszabb. Innit kiilönös szolsís és tetmrid szírmazik: szimtollaik Joszszasága a viziránybeli repüles erejel gyöngiti s repüléseket elö fele igen ferdére leszi, ez olsbul pedigg, eggenest

(1) Sazizny határozí clöször szigoruan móg ezen névazonságot Aegyptusról irt e nagy muıkajában: Ois. d' $E_{g}$. et de syric. 181. 
akarván emelkedni, szél ellen kénytelenck repülni. Ezck leglanulékonyabb madarak, s a madárvadászatnál ö́cel szokís leginkább használni, megtaniltatrín a rad kergetésére s visszajöretelre, mikor hivatuak. Szárnyaik vamali olly hosszúk mint farkok vagy hosszabbak is annál.

1. A közönséges sólyom. (Le Faucon ordinaire. Falco Communis. Gm. (1) Der gemeine Falke.)

'Tyukuagyságu, mindig megismerhetö fekete háromszegü bajuszárul a poffín, melly nála szélesebb mint ezcu nem akírmelly fajánál; különben tollazata, korára nézye mintegy igy ráltozik: a fiatal föluil barua, s tollai rozsdís szegílyüek, alul fehéres, barna foltokkal keresztben. Idösülrén, hasa s szárainak foltai feketés kereszl-vonásokká lemni iparkodnak, torkán s nyak-alán nól a fehèr-; egyszersmind háta tollzata egyidomuabb lesz s barna, fekelés-hamras kereszt csikokkal; farka fölül barna, verhenyes foltpárokkal, alul halvány szalagokkal, mellycknck széle egyre fogy; torkuk mindig fehér, lábaik s viaszhártyájok majd kékes, majd súrga.

Ezen különbözést kövelhetui, Enl. 470 a fiatal; 421 vín nöstíny; 450 vén him. $\left({ }^{2}\right)$. Nammanm 24 és 25 . rl. Wils. am. Ix. Lxxvi. rl.

Az ury nevezcht vindor sólyom, (Faucons pélerins. Enl. 469 et Wils. Amér. IX. 76. rl. Falco stellaris

(') Mindazáltal örizkedni kell, azon ráfogott fajtảit a közönséges sólyomnak ide rakni, mellyeket Gmelin összehalmoza; igy p. o. az Frisch $\alpha$ fajtíja 74, ölyz; a $\delta$ ugyan o nála 75, a durualábu ölyv.; az $\varepsilon$ õ níla 80 , a töıpe s., $\delta$ I. 0. 76. ölyvं, valamivel halaványabb mint rendesen; $\varkappa$ Aldrov. 494., igen megkülönböztetett faj stb.

Ellenben a falco islandus, barbarus és peregrinus könnyen meglehet hogy nem másak mint a këzönséges sólyom, a vedlés különbözö szakábau.

$\left({ }^{2}\right)$ Frisch fiatal sólymol ad LxxxiI. rl. Edwards vén nöstényt mulat 1Ii. I. a fiatalt iv-en.

CUVIER I. K. 
ct peregrinus. Gmo) a lübbicknél kissé fcketébb fiatal lä̈zönséges sólyomnak látszik.

Ez azon hires faj, melly nevét kölcsönzé a ragadozó madarak által törtćnö vadászatnak (solymozásnak, fituconnerie, Falknerei). Földünk cgész éjszaki részén lakik és olt a legmeredeliebb sziliálion lészkel. Repülése olly gyors, hogy alig ran hely a füldön, hova el nem jutna. A silyom függólegesen esap le zsúlsmányára, mintha az égbiul esnćk alá, s ez okbul csak röptükben foghalja meg a madarakat, különben összezúznék. A himet szarkáls és más kiseb) madarak vadíszatára haszuálják, a nöstényl fácánok és még nyulak ellen is.

Van egy másik, valamivel nagyobb faj.

A szabda súlyom, (Lanier. F'alco laniarius. Lin. $F$.

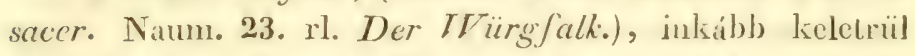
mint éjszalirul jö, smellynck tollazata mitjdnem megegyez a fialal sólyoméval, kivérén hogy bajusza keskenyebb, licvesebbé kijelelt, s torka foltos; a kerecsent lï̈zelíti megr farkára nézve, melly száryait fölülmulja; leginkább Magyarországból kapjuk.

Europánk még $\mathbf{6}$, kiseb) silymot nevel, s ezck közül három az igazi szilymot híven ábrázolja idomban és tulajdonsígban.

1. Az ülyüded sólyom. (Le Hobereau, Falco subbuleo. Lin. Der Baumfalk) Enl. 432. Naum. 26.

Föluil barna, alul fècéres, barna-hosszúkús foltokkal; combjai s alhasa verhenyes; barna vonás a poljún.

2. A türpe súlyom ( $L$ ' Émerillon. $F$. oesalon. Lin. Der Zwergfalk. Mcrlin.) Enl. 468. Naum. 27.

Barna fölül, fehéres alul, hosszában barna foltos, még combjain is; ragadozó madaraink között a legkiscbl).

A sziklai súlyom (Le Rochier. Falco lithofalco. Lin. Enl. 447. fölul hamvas, alul fehić-vereses, homályos bar- 
na hoszloltokkal, nem egyéb vén himnél. Sziklákon fészkel.

A többi három fajnak rövidebb ujai s ezeken kevesbbé elölálló gumói vannak. Nem röpülnck olly sebesen, cgereket bogarakat vadásznak s megfogják az ülö madarat.

Legszámosabb

3. A vércse. (La Cresserelle. Falco tinnunculus. Lin. Der Thurmfalk.) Enl. 401. s 471. Naum. 30.

Fölül verhenyes, fekete follokkal, alul fehér, hoszszíban halvány barna foltokkal; a hím feje s farka hamvas. Francia s ugy látszik magyar nevét is esilkorgó (vercsegö) kiáltásátul kapta. Ó tornyakban és falakban fészkel.

4. Az apró vércse. (La petile Cresserelle. Falco cenchris: Frisch. et Naum. $F$. tinnunculoides. Schintz et Temm. Cerchneis Cenchris. Br. der kleine Thurmfalke.) Naum. 29. Frisch. 89. Brchm. V, 3.

A hím fơlül folttalan, különben hasonlít a vércséhez; szárnyai kissé hosszabbak, körmei fehérek. Ezen faj, soká összezavarra az elöbbivel, leginkább délszaki Europúban lakik.

5. A szürke (veres lábu) vércse. (La Cresserelle grise. Falco rufipes. Beseke. F. vespertinus. Gm. Erythropus vespertinus. Br. V: 4. Der rothfüssige Falke).

A hím sötéthamvas, combjai s hasala verhenyös; a nönek háta hamvas, fekete foltokkal, feje s egész alrésze többé kevesebbé verhenyö. Az elöbbinél is kisebb; Europa keletén kiterjedtebb, Siberiában közönséges, Német-és Franciaországban ritka. $\left(^{1}\right)$.

(') Add hozzájok cz idegen fajokat: 1-ször a vércséhez szomszédok: a montagnard, $F$. capensis Sh. (foki sólyom); $F$. sparverius. Enl. 465. Wils. II, xvi. 1. és IV, $\operatorname{xxxII,~2.~-~és~két~vagy~}$ 


\section{A KERECSENEK.}

\section{Les Gerfaults. Hierofalco Cur. ('). Lidelfalke).}

Szírnytollaik mint a töhbi nemes madaraké, melylycknek hajlandiságait is mulatják; de csorrokon esak kis fogfćle dudor van mint a nemlelenelín $\left(^{2}\right)$. larkok, hoszszú s vágelt, számyaikat joval meşhaladja, noha ezek is igen hosszúk; lábaik rövidek is hálizollak, s foiluilröl cay harmadinyira tollasak. Jól csak egy laj isméretes.

Iz ejsaki kerecsen. (l.e Gerfaull. Fibleo candicans et. IV islandicus (im. Mierofako grimlandicus. Br. Der

Lárom faj még, mellynek szirnyai, hiblinben tollaik kölesonos viszonyai allal hasonlitok a nenes madarahilioz, rovideblock a farkníl, illyenck a $F$. punctatus. Cuv. Col. $45^{\circ} F$. columbarius. Wils. $11, \mathrm{xv} .5$.

2. Az. ölyüded sólyomhoz közclick: $\boldsymbol{F}$. coerulescens. Edw. 108. Vieill. gal. 18. e Col. 97, alig nagyohb eggy verébnél; - f. aurantius. Lath. F. rufogularis, Lath. - Et thoracicus, 1lig. Col. 348; $\boldsymbol{I}$. bidentatus. Lath. vagy Bidens rufwenter. Spix. VI. mellynek csorrán két fog van. Col. 58. s a fiatal, col.288. vagy Bial.albizenter Spix. VII, de igen kurta szárnyokkal. $F$. diodon. Col. 198; - F. femoralis. Temm. Col. 121. és 545. Spix. VIlI; F. Aldrovandii Heinw. Col. 128.

Jegyz. A $F$. coerulescen's. Vigorsnál a Hirkax nem; a kétfogu fajok pelig, vagy is Spix. BIDENSEr Vigosnál = HARpagus.

3. A valódi sólyomlız közeliek: $\Lambda F$. chiquera. Vail. Afr. 50. F. biarmicus. F. col. 521. F. huppé. (F. frontilis, Daud. bóbitrés. F. galiriculatus. Sh.) Vaill. Af. 29. $F$. huppard. (F. lophotes. Cuv.) Enl. 10. $F$. à culotte noire Vail. 29. ( $F$. tibialis Sh.)

(') Hiero-falco = szent sólyom, melly név azon tiszteletet fejezi ki, mellyel a régi aegyptusiak a ragadozó madarak iránt viscltettek.

( ${ }^{2}$ Naumann I, 278. I. azt erósíti hogy a sólymászok veszik le a herecsenck fogát. Ezen: eselben, hosszú fukobat hivevén, a tobbi sólymok közé jutnáuk, s hozzájok kellene ınég adui a szabdu sólymot. 
grünlïndische Edelfalke.) Buff. Enl. 210. 156, 462 Naum. 21. 22. Brelim. V. 1.

Egy negyeddel nagyobb a sólyomuál, s minden vadászó madarak ḳ̈özött legbecsültebb. Leginkábḅ éjszakrul hozalik; tollazata rendesen barna fölül, minden tollon halványabl) pontozat-szegélylyel, és keresztvonalokkal a takarókon és tollakon; alul fehéres, hosszas barna foltokkal, mellyek idövel a combokon kereszt-vonalokká változnak; farka barnával és szürkével sugarolt; de annyira különbözik a barna vagy fehér, bösége vagy hiánya miatt, hogy rannak egészen fehér testüek, és a hol barna nem marad máshol fön, mint egy folt a köpönyeg mindenik tollának közepén; lábails és viaszhúrtyájok majd sárga, majd kék. $\left({ }^{1}\right)$.

A sólymok alrendének második föneme:

\section{A NEMTELEN RAGADOZÓ MADARAK-é.}

Igy nevezetnek, mirel nem egy könnyen használtathatnak, a vadászatra; e törzsök számosabb sokkal a nemesekénél, s többszöri felosztást kivínnak. Számyok leghoszszabb tolla majd mindig a negyedik, az elsö pedig igen rövid, a minek azon sükere van, mintha szárnyok végrïl ferdének volna melszive, homnan gyöngébb repülésök számazik, külöuben mindenben megegyeznek; csorrok licresebbé fegyrexell, mivel hegyéhez küzel nines oldalfoga, hanem esekély kimetszés hossza közepén.

\section{SASOK.}

(Les Aigles. Aquila. Briss. Adler.)

Az clsö törzöküt képzik; csorrok igen crös, egyenes

(') Add hozzá mint idegen fajt, a hamuas kerecsent (rerfault cendré, $H$ atricapillus Wils. VI. Lu, 3, s a hamuas öly". (la buse cendrée, F. cincreus (Gm) csak fiatal lehet fajbul. 
alapu, s hegye felé gơrbült. Ezek között talíltatnak a nem legnagyobb fajai s a leghatalmasabb ragadozó madarak.

\section{A tulaljdoképi sasok. \\ (Les Aigles proprement dits. Aquila. Cuv. Eigentliche Adler).}

Lúbok tollas, egész az ujok gyöléig; hegyekben élnek madarakat és emlöseket radászra; szárnyaik olly hosszuk, mint farkok, repülésök olly magas mint gyors, s bátorságok minden más madárét fölülmulja.

1. A parlagi sas. F. (L' Aigle commun. Falco fulvus.

F' melanaèlos, F niger. Gm. ('). Enl. 409. Naumanu 8, 9. rl. Wils. VII, Lv. 1.

Többé kevesbé barna, tarköja súrga, farkat felsó fele fehér, a többi fekete. Ez legkiterjedtebb faj minden hegyes vidékeken.

2. A sairga (havasi) sas, (F. Aigle royal. F. Chrysaètos), Enl. 410., csak abban különbözik töle, hogy farka feketés, s rendetlon hamras szalagolkkal jelelt. Azt bizonyitják, hogy ez teljesen lsinött parlagi sas $\left({ }^{2}\right)$.

3. A csciszári sas. (II' Aigle imperial. Falco imperialis. Bechst. F. Mogilnik. Gm. Aquila heliaca. Savign. Ég. ois. xir. rl. Vicillot gal, 9. Naum. 6, 7 rl. Temm. Col. 15. és 152.

Szárnyai még hosszabbak; rúlltollain cgy nagy fe-

(') A valódi faj jól mutattatik: Enl. 409, melly parlari sas. A vedlés némeliy szakaban, láthatni tollazatán a tollak alapjának fehérét. Ekkor $=F$. fulvus canadensis. Edw. I. A mi a $F$. melanaëtost illeté, csak a régiek ingékony leirásán alapult s csak az emlitett ri. Enl. 409. hivattatik. Végre a $F$. niger. Brown. nem egyéb mint életkori csekély különbség.

$\left({ }^{2}\right)$ Temm. Man. d' Ornit. 1, 39.1. 
hér folt, orrlyukai kcresztek, farka fckete, felsö részén szürkével habzoll. Termete zömökebb mint a parlagi sasé, s ö még rettentóbb a többi madarakra nézre. Déli Europa magas hegyein lakik, s öt illetik azon fönhéjázó mondák, mellyek a régiek aranysasok crejét, bátorságál s nemesszivüségét dicsérék.

Az apró sas. (Fekete sas. F. Le petit Aigle ou Aigle tacheté; Aigle criard. F. naevius ct $F$. maculatus. Gm. Naum. 10. és 11. rl. Aquila melanaetos. Savig. Eg. Ois. 1. rl. és 2. rl. 1. k. Der Schreiadler.

A másik kettönél cgy harmadnyival kiscbb, lábai vékonyabbak, tollai barnák; farka feketés, halvínyabb szalagokkal; a fiatalnál fchéres a fark hegye; halvány sárga foltok szalagot képzenek az apró fedezókön, s a nagyok végénél, melly fölhág a válltollakig, és a másod tollak végén. Szárnya fölső része sárgás csöppekkel hintett. A vének egészen barnává lesznek. Ezen faj közönséges az Appenninokban s déli Europa több hegyein, de éjszakon igen ritkán mutatkozik: csak igen gyönge állatokat vadász. Elég tanulékony s radászatra használható, de azt mondják, logy a karvaly is képes öt üzni s meggyözni.

Ugy vélem, a sasok közé kell tennem még egy kelet-curopai madarat,

A tollas sast (Falco pennatus. Gm. Col. 33. Briss. supl. 1. rl.); mert szárai tollasak s fejtetején hegyes tollak állnak, de különben nincs akkora mint az ölyv, csorra pedig majdnem annyira görbült, mint annak, tollzata sárga, barna foltokkal, lábai kékck. Francia-s Némelországban igen rilka. $\left.{ }^{1}\right)$.

( ${ }^{2}$ Paris közclén mult évben fogaték meg egy. Temm, még cgyy curopai fajt ad az Aq. Boneli-ban. Col. 28s, de ismcretes minden állapotjában.

Toldi ide még: le Griffard. (F. armiger. Sh.) Vaill. Afr. I. A malaji. Sas. ( $F$. malaiensis. Reinw.) Col. 117. A senegali kis sas 
Új Hollandia a micinkhez hasonlo relomi sasokat táplál, farkokat kivévén, melly elvágolt. ${ }^{1}$ ).

\section{A HAT,ÁsZSASOK.}

(Les Aigles pécheurs. Cur. Maliaetus. Savgny.

\section{Die Fischadler.)}

Szimpok mint a\% clöbbicklié; de líbaiknak esak folsö fele tollas, a misik fele pectig paizsolt. A folyamok is tenger partjin tartizlodnak, s nagy részint halakkal élnck.

A sonllürö h. sas (C'sonuürö sas. F. T' Orfraic, le Pygargue F'alco assifragus. $F$. albicilla, $F$. albicaudus (im.) Der weissschwanzige Seeadler. Voigh. Der deutsche Seeadler. Br. III. rl. 1. kép.

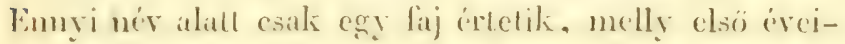

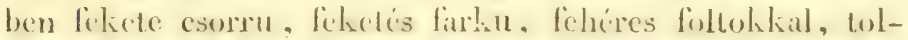

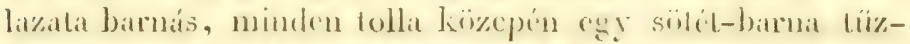
ronissal; (Enl. 112 is 115. Naum. 1, a validi ('sonllörö), idovel sohkal egaldomuab) barna szärlic les\%, liojén s nyahán halinamyab, egeszen liehce larkkal s halaviny súrga csörel. (Frich, Lxx. Namn., 12, 13. ez a lí al-

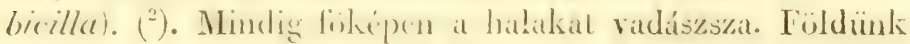
egész éjszaki részén találtatik.

A fehérfejü halaszsas. (L' diggle à tile blanche. Falco

(F. senegallus. Cuv.) az curopai apró sashoz hasonlító, de orrlyuhai hevesbé gümbölyúk, s fatal farha alatt soh apró szalag van. A reményfoki apró sas ( $F$. naevioides. Cur.) baruával, sárgíval $\mathrm{s}$ feketéssel tarka.

(') (Falco fuscosus) Col. 32.

$\left(^{\prime \prime}\right)$ Ezen áltváltozís többször bebizonyittaték a museum állattanyajánál. A hiscbb Falco alobicandus, hime a nagyobb $r$. albi cillának. 
lencephalus. Der weisshöpfige Adler). Enl. 411. Wils. IV. xxxvi, és VII, LV, 2.

Egyidomulag sötétbarna, fehér fejü s farku, csorra sárgás, majd akkora mint közönséges sasaink, ÉjszakAmerikíban s olt szüntelemül öldözi a halakat. Ugy látszik, néha eljö Europa éjszakára is. Fiatal korában teste és feje hamvas barna. Azonban nem kell föleserélni a fehéres fejü vén csonttörö sassal.

Az idegen halíszsasok között megjegyzendök:

A garuda halciszsas. (Le petit Aigle des Indes. F'alco ponticerianus. Gm. Der kleine indische Adler). Eul. 116. Vieillot. Gal. 10.

Kisebb a kányánál, szép vidám gesztenye verhenyes; feje, nyaka, mele fehérek vagy gyöngyszürkék. A Ilinduknál is saruda nevï, s Brahma vallása szerint Visuunak szent. ( $\left.{ }^{1}\right)$.

A FOLYAMSASOK.

(Les Balbusards. Pondion. Savigny. Flussadler.)

Csorrok, líbaik mint a halíszsasoknak, de liömeik alul gömbölyiuk, mig más ragadozó madaraknál csalorna árkol birnak; líbaik hálózollak, s második evezö tollok leghosszabb.

Csak egy faj ismeretes, najd az egész világ édes vizcinck partjain kiterjedt, lievés változással tollzatában, ez

(1) Ide tartuzók még: a Falco blagrus Sh. (Le Blagre. Vaill. Afr. 5. melly hihetóleg $=F$. leucogaster. Lath, vagy Aigle océanique. Col. 49. - F, vocifer. Sh. Vocifer. Vaill. Afr., 4; $-F_{\text {. vul- }}$ turinus. Sh.; le Caffre. Vaill. Afr. 6.; - F. macei. Cuv. I' Aigle de Macé du Bengal). Col. 8, és 223.; F. aguia (l'Aigle aguia.) Col. 502; - F. ichthyaetus, Horsf. jav; - Nilvago ochrocephalus. Sp. I, Chimachima. Azz. vagy $F$. deneger. Ilig. 
$A$ rendes folyamsas. (Le Balbusard. Falco hatiaetus.

L. Der I'lussfischadler.) Fnl. 11. s jobban: Calesby. II. Wils, V, xxxviI. Vieill. Gal. II. Naum. 16.

Ecy harmaddal kisebb a csontlörönél; fehér, kïpönyege barna, egy- barna csík száll le esorra szcgletétül hita fclé, barna foltok rammak lején és tarkóján, nchány a melén; viaszhírtyája majd sárga, majd kék.

\section{A KIGYós $\Lambda$ SOK.}

\section{(Tes Circaites. Circaetus Vieill. Schlangenadler.)}

Némileg közípen ramuak a halászsasok, folyamsasok ís älyrek liözöll. Szárnyaik mint a sasoké s ölyrekéi, líbok hálózott mint a folyamsasé.

1. A röviduju kigyósas. (The Jean-le-blanc. T. gallicus.

Gm. F. leucopisis. Bechst. $F$. brachidactylus. 'Tem. Der Kurzzühige Schlangenadler.) Eul. 413. Naum. 15. Brehm. III. 2.

Nagyságra fölülnuja a folyamsast; csorrának görbüilóse hevenyebb mint minden lïbbi sasuál s arányilag rïvidek az ujai. Fölitl barna, alul lecher, halvány barna foltokkal. Magariselete (módja) inkább ölyré mint sasé. Leginkább kigyókkal és békálkkal él.

2. A rövidfarlu k. s. (T.e Bateleur. Vaill. Áfr. 7 s 8 . Falco ecaudatus. Sh).

Afrikai faj, farha rendkirüli röridségériil nerezctes s lollazatának szép larkasigárul. Viaszhairly ája reres. (1).

Kulönlien megjegyzendok még, hogy a sasoktul észrevehetlen írnyalatokkal történik az ölyvehbez az átmenetel.

(') A. h. Koronás kigyósus (l' Aigle couronné. d' Azz. F. coronatus. T. Col. 234. - A szenegáli $k$. s. (Le C. du Senegal. C. cincreus) Vieill. Gal. des oiscaux. xır. rl. - A gyász kigyósas (le Caracara funèbe) (F. novae Zelundiae, Lat.) Col. 192. 224. 
Amerilsában találtatnak sasok, hosszú szárnyuak mint az elóbbiek, csupasz, pikkeles lábuak, fejek oldalínak nagyobb kisebb része, néha torkoké is tollatlan, közös nevök KARAKara (Caracara) ( ${ }^{1}$ ).

$A$ rendes karakara. (Le C. ordinaire. $F$. brasiliensis. Gm. Polyborus vulgaris. Vieill. Galer. 7. rl. A fiatal-é, Spix. 1.)

Akkora mint egy folyamsas, fehér és fekete keresztcsilkokkal, feslett s torkán fehér tollakkal, fekete tetövel, melly kissé bubbá hosszúl. Szárnytakarói, combjai s farka hegye feketések. Ez legszámosabb ragadozó madár Paraguayban s Brasiliában. ${ }^{(2}$ ).

Az apró karakara. (Le petit Aigle à gorge nue. Falco aquilinus. Gm. Enl. 417. Ibycter leucogaster. Vicillot. Gal. 6. Der Schreiadler mit nackler rother Kehle.)

Fekete, hasa s farka alfedezöji fehérek; torka csupasz, veres.

KAROMSASOK. RöVRÖPÖK.

(Les Harpies. Harpyia. Cuv. $\left({ }^{3}\right)$. Harpyen, rövidszárnyu halászsasok.)

Szinte amerikai sasok; lábaik igen vastagok, crösek,

(') Azzara Voy. IIl. 30. s köv, lap.

$\left({ }^{2}\right)$ Ez Margrave Caracarája, de leirása szerint nem ismerhetó. Jobbat lelni Azzaranál. Mi természet után irtuk le. A $\boldsymbol{F}$. cheriway, Jacq. Beyt. 15.1. 11. sz. hihetð̊ csak kor mialti különbség. A. h. fekete karakara ( $F$. aterrimus Temm. Caracara noir.) Col. 57. 542. vagy Daprius ater. Vieill. gal. v.; - gymnops fasciatus. Spix. IV. A हymnops strigilatus féle csak fiatal.

Jegyz. Ezen karakarábul csinálta Vieillot daptrius, ibycter, polyborus, nemeit, a mint fejcik csupaszsága többé vagy kevesblé terjedt ki.

( $\left.{ }^{3}\right)$ Ezcn nemeit és nevet Vieillot vette föl. 
hálizottak, s fólig tollasak, mint a rendes halíszsasok, mellyektiil esak szárnyok röridsége által kïlönböznek; csorrok és kirmaik crösebb mint akírmelly más törzsöknél.

A nagy karomsas, a nagy rüvröp. (La grande Harpie d'Amerique. Aigle destructeur de Daudin, srand Aigle de la Guiane de Manduit, hihetöleg. F. harpyia s $H$. cristatus. Lin. $F$. harpyia et imperialis. Sh. Die grosse Harpye.) Col. 14. $\left.{ }^{1}\right)$.

Egr azon madarak liaziil, mellychnek karmai s csor-

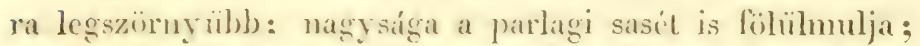
tollazala hamvis a lijen dis nyakin, barna feketis a köpönyegén s mel-oldalian, folneres alants barnín esikolt a combjan; hingult tollai lekete búbot kép\%enek feje hálulján, s mikor ezeliet fölberzeszti s poftollait kiterjeszli, igen hasonlit a liuhancistos. Gyakran külsö uja hátra irányzott, mint a hïvelyls.

Olly crösnck mondatik, hogy neha esorrival clhatsití az emberi liapenyal: a liejhirok rendes cledelet teszik, s nem rilkín szarrasbornyúkat is rabol el.

\section{A IIÉJASASOK.}

(Les Aigles-autours. Morphluns. Cur. $\left({ }^{2}\right)$. Habichlsadler).

Az clöbbiek szerint rovidebb a szárnyok farkoknál. de magas, véknny lábaik s şö̈nge njaik miall elvílas\%-

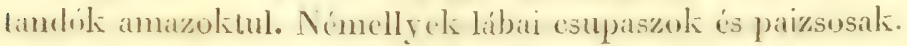

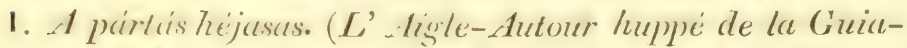
ne. Falc. grmianernsis. Daud. Petit Aggle de la Gruiane.

(') Ez kétséghiväl Fernandés yzquautzli-ja; de azon iró igen túlemeli nagysúgát, azt egy juhlıoz hasonlitva. E szerint még $=r$. cristatus. Jacq. és Falco Jacquini. Gmel.

$\left.{ }^{2}\right)$ Morphaeus görög neve volt a ragadozó madarak egy meghatározatlan fajúnak. Ezen Morpheusból csinúlta Vicillot a spizacites-t. 
Maud. Fncycl. Der weisse gehäubte Habichlsadler von Guinea.

Szinćre s bubjára nézre különösen hasonlit ugyanazon tíj nagy halíszasához: hancm termete Jkisebb, s emelt, csupasz, pilkkeles lábai cliggé megkiilönböztetik attul; köprinyege feketés, néha sötét szürkérel tarkizott; hasa lehér, néha többé keresebbé kitünö súrga hullámzattill; feje s nyakia majd fehér, s fejluáltin a hosszú búb fekelés.

1. A parlátlan héjasas. (I' Urubitinga. F. urubitinga.) Lin. Spix. I. '.

Fekete, pártállan, firkesikja s fartöve fehér. A fiatal löliil batrna, alul sárga, barnás follokkal. (Col. 55.) Ezen szép madár az eláradt helycken vadász. (').

Mísokntk lábai cmcltck s egész hosszában tollasak.

3. A tolltarajos héjasas. (L' digle-autour noir huppé d'Afrique. F' occipitalis. Daud. Huppart. Val. Afr. I, I. Bruce Abyss. xxxr. rl. Der schwarze gehäubte Habichtsadler aus Afrika.)

Varju-11agságu, felicte, fejhátán le hosszu búbbal; lábrai, szárnyszćlei s farlia alau némelly csikok fehéresek. Arrika egész széltében lakik.

4. A larka héjasas. I' Aigle-autour varié ou. C'rulaurana. $\left({ }^{2}\right)$. Falco ornatus Daud. F. superbus. Sh. Autour huppé. Vaill. Afr. I. xxvi. Spizaëtus ornatus. Vicll. Galer. 21. Aigle moyen de la Guiane Maud.

(1) A Filol longipes Ilig aquila picta. Sp. I. fiataI pártátlan héjasoknak látszanak. A. h. foltos héjasas. (L. A. ou. moucheté Aq. maculosa) Vicill. Amer. III. rl. - Panema Aq. miluoïdes, Spix. 1

(') Ez bizonyosan Margrave Urutauraná-ja; de cz akkorának mondja, mint egy sas, a mi legalíbl, egy harmaddal sok. A. harpya braccata, Spix. III, fiatala. 
Encycl. Lipervier palu. Azz. Der bunte Habuhlusadler.)

Fejtetöje s búbja feketék, nyakoldalai élénk verhenyesck, kïpönyege fekete szürtiével tarkís fehér hullámu; alant fehér, oldalain, combján, lábain szürke sugárzatu. Szép madír deli Amerikában, melly a feliete-és fehértöl sötét barnáig változik. $\left({ }^{1}\right)$.

Yamnak végre Amerikíban madarak, mellyek esorra minden coobbbiekéhez hasoulit, lábaik igen rövidek, hálósik, clölül fülig tollakartak, szárnyok farkoknál rövidcbb, (le azon legmegkiilïnböztetöbb jellel, hogy csörlyuliaik majdnem zártak, hasadélihoz hasoulúk. Ezclibül egy kis törzsölköt csinálhatni.

\section{HOROGSASOK}

(Cymindis Gur. ( $\left.{ }^{2}\right)$. Hackenadler)

név alatt. Illyen:

1. Apró horogsas. (Le petit Autour de Cayenne. Bull: $F$. cayennensis. Gm. Enl. 473. Spix. VIII.

Tulajdon bélycgül egy kis fogat bir azon helyen, hol csorra görbül. Az idült fehér, küpönyege kékes fekele, feje hanwas, négy f’ehér szalag a farkán, a fiatal hïpünyege barnával és verhenyessel kevert, feje fehér, nehány felrete folttal. $\left.{ }^{3}\right)$.

(') A. h. ezon búbos fajokat: a fehéres héjasas, lle blanchard.) Vaill. Afi. 3. F. albescens. Sh.; Autour tyran (F.tyrannus Pr. Mat.) Col. 75. - Autour cristatelle, Temm. Col. 285. s e nem búbos fajokat: Autour neigeux. Temm. Col. 127.; - Aut. incolore, ua, u. 0. 134. v. Fal lineatus Horsf. Jav.

$\left.{ }^{2}\right)$ Cymindis!, görög neve egy meghatározatlan ragadozó madáxfajnak.

(3) Nem tudom, nem Gatal horogsas e, mellyet a Buse mante- 
A HÉJÁK.

(Les Autours. Cuv. Astur. Bechst. Daedelin. Savigny.)

A nemtelenek második fölosztását kípzik; szárnyaik - mint az utolsó három törzsölnél, röridebbck mint farkuk; de csorrok tövölstül kezdre görbül, mint minden következóknél.

Tulajdonképi hejáknak mondatuak, mellycknek lábai paizsosak és egy kevessé rövidek.

A küzönséges héja (Héja Kerra. F. L' Autour ordinaire. $F$. palumbarius. Lin. Enl. 119. is fiatal: $T$. gallinarius. Gm. cal. 425, és Frisch. Lxxir. Stockfalke. Der gemeine Habicht. Taubenstösser.) Naum. 17. 18. ${ }^{1}$ ). Brehm. VI. 1.

Egyetlen faj e tájéliokon; fölül barna, szemöldei fehéresek, alul fehér, a vén barna kereszt ronalokkal; hoszszús foltakkal a fiatal; ot barnább szalag a farkín. A héja fülüli nagyságra a lierecsent, de bátorságra nem, mindiģ ferdén csap le zsálsmányára A sólymászatnál mind a mellett használtatik gyönge vadalra. Közönséges a halmos és alsó hegyes vidékeken.

$\mathrm{Az}$ idegen héják lïzött megjelelhetni az üj hollandiait (Falco novae Hollandiae), Voy. de White. 250. 1.,

lée. (F. palliatus. Temm.) Col. 204. mutat, iggen különbözo̊ altul, mellynek ez a francia neve van. Col. 437.

A. h. horgas horogsas. (F. hamatus. Ilig.) Col. 61. 231. F. leucopygus. Spix. II. F. uncinatus. ua. Col. 103. 104. 105. Ezen madarak, idejökre nézve igen különböznek.

Jegyz. A Falco glaucopsis. Merem. II. vir. rl. (Aigle de Gottinque, közönséges ölyv. Az Aigle blanc. (F. albus. Sh. John white. Voy.) héja.

(1) Hihetóleg szinte $F$. gyrfalko. $F$. gentilis. Gm. - Illy roszszul voltak mér a ragadozó madarak meghatírozva akkor, midón e munka elöszöı adaték hi. 
melly nicha egészen hofehér: de ngy látszik hogy esak lajtájal egy oltani madamak, melly fölül hamvas, alul fehér, szürke lullám-nyomokkal. (1).

A héjakhoz számbithatni még némelly amcrikai madarakat rövid szim oktsal és rövid de hálís lábakkal.

A haholas héju. (I' Aulour rieur, on. ie calolle blandhe.

f'. cachinnans. Lin. Nacagua. d'Azz. Der Lachfalke.) Vieill. Galer. 19. Spix. III.

hiáltisa szerint nerezteté el; feher, kïpönyege s rey szalag, melly at szem liaririb indul el s a larkin lísiral egvesuil, barna es fehée fultokkal. Délamerika unoesálaiban mászikkal s (hüllökkel) halahkal él. (²).

\section{A KARvaly (Karoly, F.) (Epervier. Nisus. Cuv. Sperber.)}

nerct kizänségesen arok. kitpjak, mellyeknek líba pilizsos is emeltebb. - hancm egroik oszlíshul a másihba majdnem észrevehetlen az átmenclel.

(') Mús idegen héják: a szürke hasú h. (Fv poliogaster. T.) Col. 261. 295. - A három szalagú h. (F. trivirgutus. T. Col. 505; - A fehér tarkóju h. ( $F$. leucauchen. T.) Col, 506.; a kiillös heja (F. radiatus. Lath.) col. 125. - Autour poliosome. Quoy et Gaym. Voy. de Fieycinel. xiv. rl.; a F. leucorrhous. uo. xur. Il.; - A farkkörí h. (Aut. à queue cerclée. F. unicinctus. . C Col. 313.) Ezen három utolsi igen hasonlit a pátátlan héjasashoz. \& pensilvaniai k. (F. pensyluanicus. Wils. IV. LIV. 1.) - A veresfarku h. (Aut. à queue rousse. F. borealis. L. Vieill. Am. xrv. rl. Wils. LI, 1. - Falco leverianus. Aut. levérien. Wils. LII. 2. - A vonatolt h. F. serinlatus. T. Aut. multiraie. Co1. 87. 294. vagy Asturine cendrée Vieill. gal. 20. F. monogrammicus, T. Aut. monogramme. Col. 514; - Dusummiere héjája. (F. Dussumieri. T.) Col. 308. 366. Ezek lassanként a karolyokhoz vezetnck által.

$\left({ }^{2}\right)$ Ide tartozók: F. Melanops. Lath. Col. 105. Ezcn alosztásbul csinálta Vicill. a HerPéTHTHOÉREs-cket. 
A küzönséges karvaly. (Epervier commun. F. nisus. I.11. Der Sperber, F'inckenslösser. I'inckenhabich.) Eul, 412. 467. Natm. 19. 20. Br. VI. 2.

Színe; mint a héjảé, de lábai magasbak, s termetc egy harmaddal kiscbb. Mind a mellelt szinte haszníltatik vadászalra. A fiatalnál alul nyil vagy könyidumu, hoszszas, és verhenyes foltok vannak; köpönyege tollai szinte. verhenyessel szegettel.

Vannak még apróbb idegen fajok. ${ }^{1}$ ).

De vannak sokkal nagyobbak is, mint:

A dalos karoly. (L' Epervier chanleur. Taucon chanteur. Vaill. Afr. xxvir. F. musicus. Daud: Der Singsperber.)

Ölyü nagysågu, fölül hamvas, alul és farcsikín leheir barna sugárzatlal, liatalságában barna, verhenvessel

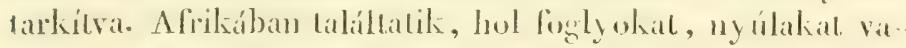

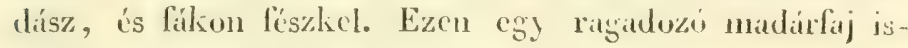
neretes, melly lsellemesen énekel. $\left({ }^{2}\right)$.

(1) Mint a Gabar. Vaill. Afr, 33. F, gabar. Sh. Col. 122, 110. a Minule, uо. 34. F. minullus. Sh.

( $\left.{ }^{2}\right)$ Más idegen karolyok: a Buse mixte couleux de plomb. AzL: 67. vagy a kurtauju karoly (F. hemidactylus T. Col. 5. 91.; a $F$. mugnirostris. Enlum. 460. Col. 86.; a F. columbarius. Calesb. 4. Vicill Am. rI. 2. Wils, 1I. xv.; 3. Ep. tachiro. Vaill. Afr. 24. F' tachiro Daud. Col. 377. s 420.; - a kukuk-karoly (F. cuculoüdes 'T.) col. 110. 129. a verhenyhasu $k$. (F. xanthothorax. T.) col. 92.; a vesszös k. (F. virgatus. T.) col. 109.; - a rözid szárnyu k. (F. brachiplerus. T. col. 14.116. vagy $I$. concentricus. Hig. - a sapkás karoly. (F. pileatus. pr. Max.) col. 205; - a csupasz torku k. (F. gymnogenys) col. 307.; a pensyluaniaik. (Ep. ardoisé. I'. pensylvanicus. Wils. VI. xLVI, 1, - Igen különbözơ a lasonlón nevezett ölyvlül u. a. LIV. II.), a fialal, col. 67.; syors $k$. ( $I_{0}$ velox.) Wils. VI. Lin. 5.; a téli k. (F. thiemalis.) Wils. IV. xxxv, 1.; a sue

CUVIEL I. I. 


\section{A KÁNYÁK.}

Les Milans. Milvus. Bechst. Milan.

Lábaik rövilek, njaik is kiormeik gyingek, csorrok szinte kevessé arinylagros a nagrságokhoz, mellyeknél fogra az egész nem leggevíráb) fiaját teszik; de kitünnck rendlsivil hosszi szármyaik is villís farkots által, melly miatt leggyorsabb és legkönnycbb reptök van.

Nimellyelinek lábai ggen röridek, recísek, s fölülröl félig tollal takartak, mint a sasok Iegntolsi apró törzsökece Savigny-nál Elanus-ok.

1. A fekelessairnyu kinya. (Le Blac. I'. melanoplerus. Daud.) Sar. Eg. ()is. 2. rl. 2. k. Taill. Afi. xxxi. xxxyIr. Ch. Bonap. Am. II. xr. I.

Karraly-nagyságu, tolla lígy, selymes, farka kevessé villis, fölul hamvas, alul lehir, a szimny apro taka-

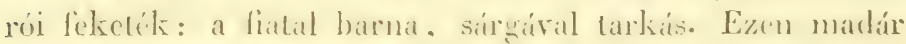

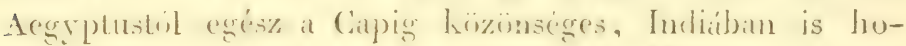

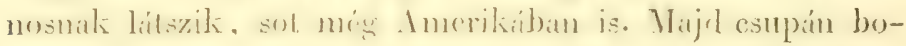
garakat (rovarokat) radász.

1 villais (karolinai) kanya. (Le Milan de Caroline. I'.

furcatus. L.) Catesb. IV. Wils. LI. 2. Vieill. Am. 10.

Fehćr, szárnyai s farka felictések, ennek két szélsö tolla igcen hosszú, nagyobb) az clóbbinct. A mászóliab is megtámadja $\left({ }^{1}\right)$.

garas $k .(H$. striatus.) Vicill. Am. 14. 1.; a fekete $k$. (F. niger.) Viell. Galer. 22.

(') A. h. F. riocourii Vieill. (Milan riocourt), col. 85 ; a szabailytalan farku k. (F. dispar Temm.) col. 319., melly Vigors-nál Nauclerus nem. 


\section{A tulajdonképi БÁNYÁK.}

Lúbaik paizskások és erősebbek. 1 közünséges kánya. (Milan commun. Falco milvus. Lin.

Die Gabelweihe. Königrsweihe. Der rothe Milan. 122. Naum. 31. 1. k.

Sárga; szárnytollai fekelék, furka verhenyes, madaraink kioziul ó leng legtovább és legesöndesebben a levegóben. Majd csupa mászókal vadísz (1).

A DARÁSöLYVEK. PIKKÁK.

(Les Bondrées. Pernis. Cuv. $\left({ }^{2}\right)$.

A kányák gyounge csorra mellett igen kïlönös bélyegük az, hogy a szem-és esorrok-közti tér, melly különben a sólymok egész neménél csupasz, s esak némelly szörrel takirt, ezeknél igen tömött s pikkekre oszlott tollakkal födetik; lúbaik félig tollasak fölülröl s recések; kül̈̈nben farkok egyenlö; szárnyok hosszú, csorrok alaptul kezdve görbülö, mint minden kïrctkezölnél. Nálunk egy fijok van.

d kïzönséges pikka (darcisalyv.) Isa Bondrée commune.

F. apivorus. L.) Enl. 420. Naum. 35. 36. Der Wespenbussaid.

Az ölyvuél valamivel kisebb, fölül barna, alul különbözöleg hullámozoll barníral és fehéressel az egyének sze-

(') A. H. Le Parasite. Vaill. Afr, 22, v. a fekete kánya. enl. 472. Naum. 31. 2. k. Sav. Eg. Ois. IIl. rl. 1. k. = F. ater F. aegyptius $F$. Forskahlii. Gm. F. parasiticus. Lath. et Shaw.; a missisippii kánya. (F.missippiensis. Wils. IlI, xxxv. 1.) vagy: Ictinie ophiophage, Vieill. galer. 17. k.

Jegyz. A $F$. Austriacus. Gm. fiatal közönsćges kánya.

( ) Pirnis vagy pernes, egy lagadozú madár neve Aristolelesnel 
rint; a him feje cgg korig hamvas. Ezcu madiu bogarakat vadász s leginkább darást és mébeket.

Az idegen földeken más fajok is vannak.

al tarajos pikka. (La Bondrée huppée de Java. Pern. cristata. Cur.)

Egészen barna, leje hamvas mint a micnké, de farka likete, s diozepin egy feheres szalarg; fejhátán barna búb. Javabul Leschenaut hozá $\left({ }^{1}\right)$.

AZ ÖLYÚK. ÖLYVEK.

(Les buses. Buteo. Bechst. Bussard.)

Száruyok hosszú, farliok cgyculö, csorrok alaptul hezdre görbül, ez és szentei kïzt a lír tollatlan, lábolk erös.

lamak, mollyechól a lábak egés\% az njakigr tollasak.

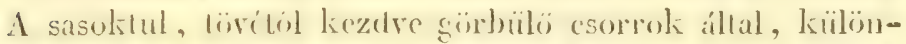
böznck, a héjaktul ragy héjasasoktul pedig tollas lábok és hosszú szárnyaik által. Nálunk egy van.

A durvalibu ïlve. (Lac buse patue. F. lasopus.) Gm. $\left({ }^{2}\right)$.

Frisch. Lxxv. Vaill. Afi, xvin. Wils. Am. IV. xxxur.

1. Naum. 34. Sc/unee-Aaar.

licudellonül viltozik läbbé kevescbbé világos barnával s löbbé licresebbo súrgás fehírel. Ez egy a legeltcrjedteb]) marlarak kïzüil; majd mindenütt talílták, s mindig ugy tekintették, mint más valamelly madír fajtáját. $\left({ }^{3}\right)$.

( $\left.{ }^{1}\right)$ Temminch e madarat buse ptilorinque név alatt adá. Col. 44.

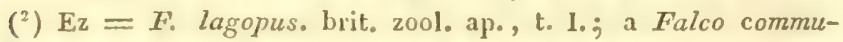
nis $\delta$. leucocephalus, Frisch. 75. a $F$. sancti Johannis, arct. zool. 1x. rl.; - a F. communis fuscus. $F$. variegatus, $F$. albidus, $F$. versicolor Gm. csak különbözó korú közönséges ölyvek.

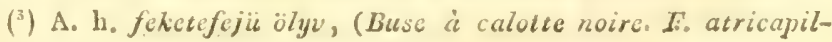


De az ölyvek nagyobb részénck líba csupasz és paizsos. Nílunk csak

a közönséges ölyü találtatik. (La Buse commune. F. buteo. L. Der Müusefalk.) Enl. 419. Naum. 33.

Barna, fehérrel többé kevesbbé hullámzott a hasán és torkín; vidékeinken ez a legbóségesb és ártalmasb ragadozó madár. Egész évben crdöinken marad; zsákmányíra a fúk vagy domb magasárul csap le, és sols vadat ront el. $\left({ }^{1}\right)$.

Némelly fajok búbosak.

A gyilhos ölyv. (Le Bacha.) Vail. Afr. xv. rl.

Akkora mint a mienk, barna, melle oldalain $s$ hasán apró gömbölyü és fehér follokisal; búbja fehér és fekete, farka közepén széles fehér szalag. Igen kegyetlen madár Afrikában, fóképen a sziklabuikat vadászsza. $\left({ }^{2}\right)$.

lus. Cuv.), col. 79. vagy a buteo melanoleucos. Vieill. galer. 14; - a fekete ölyú. (F. niger). Wils. VI. LIII. 1 és 2. mellgeket Bonap. K. egynek tart Penn. F. sancti Johannis-ével.

(') Más idegen ölyvek: Rou-noir.Vaill. Afr. 16. (F. jacal. Daud. és Sh.); - Tachard. u. a. 19. (F. tachardus, Sh.); - a Buseray, u. a. 20. (F. busarellus. Sh.) - a szïrke pöfü ö. (F. polygenis. Tem) col. 325. - A barna ölyz. (F. fuscus.) Vieill., An., 5.; - A Tachiro, Vaill. 24. ( $F$. tachiro Sh.). A Milan cresserelle, Vieill. Am., 10. s a fiatal no̊stény, col, 180.; ezen fajbul a $F$. plumbeus, Spix. VIII. hihető vén egyén, és hol az oldalvágány némelly egyéneknél foggí hegyesül, noha tollai mint a nemteleneké. - A hosszú szárnyu ö. (F. pterocles. Tem.) col. 56. 139. a foltos hátu ö. (F. paecilonotos. Cuv.) col. 9. - a köpönyeges ö. (F. lacernulatus. 'T.) col. 437. - a halvány. ö. (F. liventer. T.) col. 43S. - a rozsdás farku ö. (Buteo ferruginicaudus) Vicill. Am. , 6.

$\left.{ }^{2}\right)$ A. h. az indiai fehér búbu öly'zet. (F.albidus. T.) Col. 19.

Jegyz. A Buse roussatre, Tem. col. 25. valemennyire közelit az örvölyúkhöz cmelt lábai de nem a nyahhorv által; ezcn két osz- 


\section{$A$ önVöLYüK.}

\section{(Les Busards. Circus. Bechst. W' eihen.)}

Az ülyrektiil emeltebls líb)ak s nemi nyakür által különböznek, mellyet a füleiket takari tollak hegyei nyukok mindenik oldalán képeznek.

E videken három fajok ran, mellyeket tollazatok változísa szerint igen elszaporitottak a nevaduk.

1. A szánto örvälü (Le Soubuse. F. Pygargus. I.) Enl. 443. 450. Naum 38. 2 és 39, I. 2. fölül barna, alul sírga, hosszas barna follokkal, firr-esika fehér. Az Oisean Saint-Martin. I'. ('yancus, Ir. albicans. ('). enl. 450. Naum, 39. 1., hamvas, s számytollai feketék, nem egyeb mint kiet éves him. Еzen faj a fobldön fészkel, igen sokat tartizkodik a mezökïn, a földhöz hözel repül, estre palkínyokat, lialal foglyokat stb. vadász.

2. A hamvas ürülvï. (Le Busard cendré. F. cincraceus. Montag.) Naum. 40. Vieil. gal. 13. rl. (Die Thiesenweithe).

Karcsubb de losszabb szárnyí mint a szíutio irrölyä: a vén him hamras, wollai naggule s a felicte misod tollakon szalagya van; a kit ires him is nö liiliil barnil, alul fehér, mellén barnás vonacskákial; a fialalok egész alteste verhenyes. Szokissa igen hasonlit az elóbbi fajhoz. 1 veres örvölyü. (La IIarpa)e. F. rufis. J.) Enl. 47о. Naum. 37. 1.

Barnís es verhenyes, farkil s szimyainak clsö iollai

tá közöte is fokonkénti átmenetelek és majel észrevehetetlen ámyolatok vannak.

(') Hasonló módon vannak a Falco communis F. albus, Frisch, Lxxv. rl.; a $F$. montanus. B. F. griseus.,Gm. sôt még a $F$. bohemicus. Gm. is. 
hamvasak. A Busard du marais (F. acruginosus), enl. 424. Naum 38, barna, fején és mellén világos sárgával, ngyan az de idöscbb madár; de vannak rizsgálók, kik különbözö fajnak vitalják. Mindenik különösen a vizck közeletén tarlózkodik, oll bogarakal vadászindón. (

Végre

A titkair kigyósas. F. (Messager, Secretaire. Serpentarius. Guv. Gypogeranus), Ilig. $\left({ }^{2}\right)$.

Afrikai ragadozó madár, mellynek lábai legalább másfél olly hosszak, mint az elóbbickéi, melly okbul sok természetvizsgáló által a gázlók közé számláltalék; de egészen tollakkal födött líbai, gürbült és szelt csorra, duzadt szemholdai, s boneolatának minden adata a jelen helyre teszils. Lába paizsos, ujai arányilag rövidek, szemköre tollatlan; durva hosszu búbja van fejhátán s farka két középsö tolla sokkal hosszabb a többinél. Cap környélién a száraz nyilt helyeket lakja, hol liutva kergeti a mászókat; innét a járkálás mall vásotlak körmei. Nagy ereje lábában van. Ez Gm. Falco serpentarius-a enl. 721. Vieill., gal. 260. Martinique szigetén szaporitni probálták, hol

(') Külföldi fajok: I' acoli. Vaill. Afr. 31. ( $F$. acoli. Sh'). Le tchong, u. a. 32. és Sonerat II, 182. ( $F$. Melanoleucos. - ( $F$. palustris. Pr. Max. col. 22.) - Le grenouillard. Vaill. Afr. 25. (F. ranivorus. Sh.). - Le busard roux. Vieill. Amér. IX. $\mathrm{xl}$. mellyet c szerzó cgynek gondol a F. hudsonius-sal Edw. 107. - a téli örvölyü (Cire. hiemalis) Vieill. Anér. 71. melly ugy látszik $=$ F. hiemalis Wils. IV. Ixxv. 1. - A fehér farcsiku ö. (Circ. europygistus) Vieill. Amér 8. - Hihetőleg a $F$. uliginosus Ediv. 291. ezen alnemhez tartozik, de nindaddig nehéz lesz fijait meghatározni, mig neın vizsgálat foljtatél azon változísohon, mellyeket a kor tesz tollazatokkal. Bonap. $C h$. azt inondja, hogy a $F$. uliginosus cyaneus-nak fiatal nŏsténye.

$\left({ }^{2}\right)$ Vieillot e nevelet opyiothères-re változtatí. gat 260. M. 
jgen nagy szolgúlatot tehetne, pusztitva a líndsatviperákat, azon sziget luáborgatóit.

\section{ÉJELI RAGADOZÓ MADARAK.}

Frjök vastag, igen nagy szemeik elöre iránymblak, s clvált tollakkal vammak körúlkerítve, melylych közölt az clsök a csór viaszhórtyajját takarják, a lítulsík a fülek nyilását. Nagy szempillájok amnyi sugaral creszt bé, hogy a teljes naplény által elvahillatnak. Kinponyájok vastağ, de kömnyü anyagu, magy ïreggeket bir, a füllel összeköiöucket mellyek hihetüleg a hallás érzését crősitik, de repüilési készületiok nem erös; villacsontok kevessé ellenálló, finom szakáiyú, fnom pelyhü tollaik semmi zajt nem csiníhak repü̈lésben. Lábok külsö uja kényök szerint clöre vagy hátra irányozható. Ezen madarak leginkább esthajnalhor és holdvilágnál repkednek. Nappal meghtimaltatvín, vagy valamelly uj tárgytul megrlepetvén, el nem repülve, fölegyenesednek, furcsi helyzetet vesznek föl s nevelteló mozgásokat csinálnak.

Elögyomiruk dégggé izmos, noha csak állati eledellel élnek, melly eggerekhiil, appró madarakbul, bnganahbul all; de nagy begytiil diótclik meg; vak beleik hosszúk, de végökön kiterülık, stb. Az a frú madaraknak temészeti allenszenvök van ezek cllen s minden felïl gyyälnek ezek megtámadására, melly ulbul öhet a madarals törbe csalisára is használjâk. Csak eớy fönemet csináltak belölök. 
A BAGLYOK.

(Strix. Lin. Die Eulen.)

Föloszthatók tollpamaljaik, szcmök nagysága, szcmeiket körúlvevó tollkörök kiterjedése s más egyéb ješ gyck szerint.

Azon fajok, mellyeknek szemök kïrrén elvált tollakbul nagy s iģen teljes kögük vau, s még ez is pikkelyes tollkörrel vagy örvel vételik körúl, s a keltö között nagy föhyyilísok van, a nappali ragadozó madarakul mind idomra mind erkölcsre jobban eltúvoznak, mint a kicsin, tojásdad, s elszort s csak a szem alul credö tollakikal takart fülück. Ezen különbség nyomait még a vázban is látni.

Az elsóbbek közül nevezendök.

A FÜLES BAGLYOK. F. FỨLBEG-ek. (Hiboux. Otus. Cuv. Nachteulen.)

Homlokolion két tollpamat van, kényök szerint fölállítható; fülesigájok félkïrben a csorrtul egész a fejtctö feléig litcrjed s clölrül hárlyafedövel védetik. Lábok az ujakig tollal takart. Illyenek Europában:

1. A nagy fülesbagoly, fejes bagoly. T. a nagy fülbeg. (Le Grand Hibou it huppes courtes. Str. ascalaphus. Sav. Eg. Die kurzohrige Nachteule.) Britl. Zool. Tab. III.

Esy negyeddel nagyob) a kiozinnsegesnde mint at sítgil, hama follohkal, szárnyain s hálán gilliszlás. de hasa keskeny vonalokkal kercszthen csikoll. Tollpamaljai (bollagai) röridek. Tulajdonképen afrikai, de néha Europában is mutatkozik, $\left({ }^{1}\right)$.

(1) Tanuja ennek az, mellyet a Zool. britt. lerajzolt s mollynek ábrảja annyit háborgatá a természetvisgálókat. 
2. A küzünséges fïlbeg. (Középszerï fülesbagoly. F. Le Hibou commun ou moyen Duc. Buff. Str. Otus. Lin. Die Nitlere Ohreulel. Frisch. xax. Brit. Zool. 'Tal. B. IV. 1. K. Naum. 45. 1.

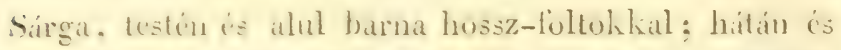
számyatu barnáral grilisztúlt: follagai hosszak, mint fëlleje, farksín nyole ragy liklene barna szalag.

3. A huhogó fuilúeg. (La Choutle ou le moven Duc it huppes courtes. Str. ulula et Sir. brachyotos. Gm.

Die kurzolurige Eule.) Enl. 438. Frisch. c. Naum 4.j.

2. Brit. Zool. L. B. Iv. 2. k. Wils. IV. xxxir. 3.

Szincire majdnem hasonli az elobbiloz; hata nem

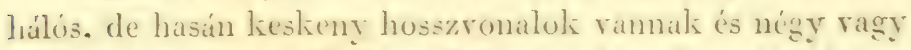
ai barna szalig a farkitu. Tollag esali a himnel talitlatik: melly olly kicsin, s olly rilkin mereszletik foil, lugg majd alig reletile eszre, s ez olibul e madál solsiig a Lollagtalanokhoz szamittatick, ragg kit faj granant veteték. Majd az egész földön elterjedt $\left({ }^{1}\right)$.

\section{HUHOT,Y}

(Chuettes. Ulula. Cur.)

nevet tarlhalni meg azoli számára: mellyek csorra s fiile a fülbegeliélez liasunlit, de nincs tollagoli. Tálumk

(') Add hozzá: amerikai fülbeg (Str. mexicana.) Gm. vagy Strix clamator, Vieill. Am., 20. v. Sch. longirostris Spix. IX. melly alig különtozik máslan a mi közönséges fullę̧inhtol, miut feketébl, kcvesbbé mosott foltok által. - Az afrikai fülbeg (Le Hibou tachèté du Cap. Sir. africana. T.) col. 56, vagy Str. maculosa Vieil. gal. 25. - A nagy csorru fülbeg (Str. macrorhyncos, T.) Col. 62. - Afehér pofu fülbeg (Str. leucotis. T.) Col. 6. - A sárga pofu fülbeg. (Str. Otus.| Wils. VI.51. 3., különböznek az europai közönséges füles bacolytul. Az amerikai foltos fïlbeg. (Str. naevia Lath.) 
ezen nembül egy faj sincs, de van a lkét száraz éjszaki részein, p.u. ( $\left.{ }^{1}\right)$

A laphoni huholy. (La grande Choutte grise de Taponie. Str. laponica.) Gm.

Majd akkora mint a mi nagy súholyunk: fölül saürkével s barnával kevert, alul fehères, szürke-barna hoszszas foltokikal. Srédhon éjszaki hegy ségén lakik.

\section{A BAGÁLYOK. (FÁTYOLBAGLYOK.) (Les Effrayes. Srix. Savigny).}

Fülök akkora, mint a fülbegeké s füdüt bir majunem nagyobbat ezen utolsókéníl; de hosszú csorok csak vége felé görbül meg, mig mindeu lübbi alnemnél hegyénél kezdve ivelt. Nincs tollagok; lábaik tollasak, de ujaikon esak ször ran. A szemöket körrilvevö, ször tollaktul képzett ál-arc, kiterjedtebb s nekik még rendlivuliebb areidomot ad, mint a többi éjeli madaraknak.

A laing-bagcily. (Strix flammea. L.) enl. 440. Frisch LxxxviI. Naum. 47, 2.

Franciahonban egyedül ismert faj, s az egész földön elterjedettnek látszik. Háta sírgával és hamvassal vagy barnával föllegezett, igen csinosan ran behintve fehér pontokkal, mellyck mindenike két fekete pont közé zárt; hasa majd fehér, majd súrga, barna foltokkal vagy nélkül. A tornyakban fészkel, s a lköznép eঈt szokta leginkább a szerencsétlenség jósának tartani. $\left(^{2}\right)$.

Wils. 1lI. xıx. 1., mellynek no̊sténye vagy fiatala a Str. asiu. u, a. IV, XLIr, 1. - Az iiregi fülbeg (Str. cunicularia. Cl. Bonap.) Aı. I, VII. 2.

(') A. h. a kanadai szürke huholy. (Str. nebulosa. Gm.) Wieill. 17. Wils. IV. Xxıı. 2 .

(2) A. 1. (Str. badia. T.) Col. 54. Jegyz. A Chouette à queue 


\section{А RESZGöॅYÖK (FАBAGLYOK).}

(Tes (Yatsom Muans. Sirnimm. Savign. Die Banmenlen.)

Kagök ran szint dollakbul s uralskïrvïk mint az clobbichnek: de fiesigajok esak tojishopui ür hejez, melly a hapony a magassistuak felet sem loglalja ol; tollagok nines; láhaik a körmökig tollasak.

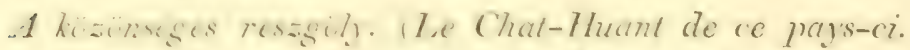

Strix aluco et stridula. Liu. Hulotte, Chuotte des

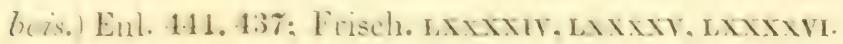

Naum. 46, 47. 1.

Vulamivel nagy ob]) a krizinsiges fülhegnel, mindenüll hakarva Jarna hossz-follohkal, mellyck az oldalakon lic-

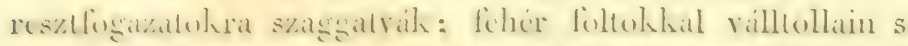
száruy a melso szithe A tollazat alipja szuthes a himned,

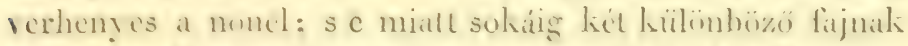
larkathah. (1). Ezen madarak az erdoben fiszhelnek, hol

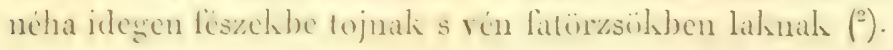

SUHOL Yok-nak

(Ducs. Bubo. Cur. Schulıú.)

merozuk azon fajokit. mellychuch esigija szint olly kirsin. hollhriguk hereshbe hitunö mint a reszerïlyöké, s

fourchuc du brésil, col. 432, a baglyátul csak a kitömés miatt látszih különbözni.

(') Ezen fajok: Strix syluestris, rufa, noctua alba, Scopoli, és a Sirix soloniensis, mellyet Gmelin rendszcrébe bédugott, sokkal kevesclibe ramak meghataroera, minthogy fajtihnal egjebehnek gondoltathatnának, hihetőleg a reszgöly-nél. Jỏ még tudni, hogy ezen uemben a nỏstények verhenyebbek a hímeknél; s innét szaporittattak meg méha a fajok.

(2) A, h. Strix pagodarum. Tem. Col. 220. 
tollagok van. Az ismerteknek vastag lábaik vammak, eggés'z a körmökig tollasak; illyen:

A nagy suholy. Nagy füles bagoly, fejes bagoly. Füldi. (Le grand Duc des naturalistes. Strix bubo. Der grosse Shuhu.) Enl. 434. Frisch. xcm. Naum. 44.

Legnagyobb éji madár, sárga, de minden tollának szárközepe s oldalpontoza barnák; fölül a barna szin uralkodik, alul a sárga , tollagai majd egészen feketék. ( $\left.{ }^{1}\right)$

A tollagos resagölyök. (Les Choutles à aigrettes.) Vaill Afr. XLIII.

Nem egyebek olly suholyoknál, mellyeknek tollagai távolabb állanak.

AZ ÉJBAGLYок. (Éjbegek). (Les Chevèches. Noctua. Sav. Kauz.)

Nines tollagok, sem kimetszett s kimélyelt csigíijok; cmnek nyilása tojáskćpü, alig nagyobb mint más madaraknál; a szórt toll-kög kisebb s kevescbbé teljes mint a suholyoknál. Hasonlalosságok a nappali ragadozó madarakhoz szinte szokásaikban is mutatkozik.

Némellyek hosszú vágott farkkal tünnek ki; ujaik igen tollasak; nevök:

\section{KAROLYBAGOK, KARVAL-BAGLYOK.}

(Choultes-eperviers. Surnia. Dumer. Sperbereulen.)

Ugy látszil hogy cgész éjszalion találtatik nehány egymáshoz igen közeli s rosszul különböztetelt faj vagy

( $\left.{ }^{2}\right)$ Str. scandiaca. Lin. nem állhat meg, mert csak egy Rudbek által hátra hagyott ábrára építteték, melly hihetỏleg a nasy suholy egyik fajtája szerint készült. A. h. Str.mugillanica. enl. 585. mellyruil a Str. virginiana. Daud. II. 13. Wils. Am., VI. L. 1. vagy a Str. pinicola. Vicll. An. 19, csak verhenyesh szinezés által külonbozik. 
liajta, illy nevek alatt: Str. funerea, hudsonia, uralensis, accipitrina, etc.

A küzünséges karolybag. (Strix nisoria If olf. Die eigentliche Sperbereule) enl. 473. Naum. 42. 2.

Legismertesebb faj, a földteke egész ejjzaki részén, karoly-nagyságu, fölïl fekclés barna, csöpképü fehér foltokkal fejen, heresztronatokkal vílltollain, alul fehér és banna locresztsugárzaltal, tiz liereszt fehér ronallal farkán ; inkább nappal radász, mint éjjel.

Az urali karvabagoly Str. uralensis. Pall.) Naum. 42. 1., majohem akliora mint a havi ej bagoly, foilul barnil. felré follokkal, alul felrér. hosszu birna follokkal, larhin äl szürke kereszlvonal. Szinte nappal radász, s néha Nemetországban is mulatiozik. Ez hiletoileg Aristoteles Iybriswe vagy Plynx-e L. Ix. c. 12.

Iz akadiai (tirpe) karolybag. (Strix acadica), Namm. 43. 1 és 2. k. Wils. Am., IV. xxxrv. 1. Der Zwergkauz.

Néha szinte látható, s a löld cgész éjszaki részén

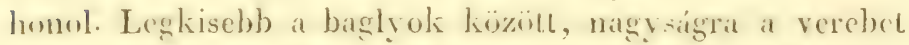
alligr haladja meg. Nem irtizile a naptul. I aillant egg afirikai karolybagol (Choucow, xxxrmi) ismertet meg, melly alul egrizen feher, tizemnegy vagy tizenöt keresztronallal a farkín, s melly, ö szerinte, migg éjjelibb minden más baglyoknál. (1).

Mís ejbaglyolnak rövid farkok és lollas ujok van. Legnagyobb, és egyszersmind minden tollaglalan iji madarak legnagyobbika a

(') Str. griseata, Sh. Vaill. Afr, 4j. Guyane-bul. Sirix strepitans. 'T. col. 174. 229, Bataviábul. 
Ilavi (havas) éjbagoly (hóbag), (Le harfang. Str. nyctea.

L.) Enl. 458. Wils IV. xxxir. 1. Naum. 41. Die Schneeule,

melly nagyságra majdnem lülüti a nagy suholyt. Hófehér tollazata barna keresztfoltokkal jegyzett, ully mértékben eltünökkel, a mint a madár vénul. A két száraz világrész éjszalii felén lakik, magas sziklákon fészkel, nyulakat, crdöszfajdokat s hófajdokat vadász. $\left.{ }^{1}\right)$.

Még sokkal kischb fajok is rannak, p. u.

A gatycis éjbagoly. (La Cheveche à pieds emplumèes. Str. tengmalmi. Gm. Str. dasypus. Bechst.) Naum. 48. k. 2. 3 .

Háta barna, behintve f'chér csöppekkel; alul halványabb, szćlesebb fehér foltoklkal, négy fehér kereszl vonal a farkán: erdókben tartózkodik.

A veres éjbagoly. chevéche rousse. Str. passerina. Mey. et Wolf. nósténye.

Azonban ezen apró fajok nagyobb számánál igen vékonyan rannak az ujak szörökkel behintve. Illyen:

A küzönséges éjbagoly. (Kanakicz. F. Chevèche commune.

Str. passerina. Gm. Str. 1ygmaea. Bchist. Der gemeine Kauz.) Enl. 439. Naum. 48. 1.

Csekélylyel kischb az clóbbinél, de majdnem azon tollazalu. Farkil kcréssel rövidebb, de öt szélesb halavíny veszszövel: grakran ó falakban költ. Tübb igen küzel faj van Amerikában, Indiában stb. $\left({ }^{2}\right)$.

(') La chonette bhanche, Vaill., Pfr. 45, nem egyéb vén haras ejbagolynal. A föllınott viszony különbségek a kitöméstiil származtak.

(3) Str. brama. T. col. 68, melly alig különbözik a közönségestiil. - Str. sonnerati, 'T. col. 1. - Str. urucurea', u. a. s eunck nös- 
Vamnak czen tollatlan úju ejhaglyok köziilt, nagysigra a mi reszgöly eiukhez közclítök. Cayenne töb) szipl laj! ad, s nevezelesen a három kiöretkezöt.

A sairga éjbargoly. (La chevèche fauve. Str. Cayennensis.

Gm. 442. Sírga alapon barníval rendetlenül s finoman kiülözve kereszlben.

A fekete éjbagoly (Huhul. La Cheve'che noire ou Huhul.

Vail. Afi. xu. Str. lineata. Sh. Str. albomarginala.

Spix. x.

Fekele alapon fehérel ronatolva lieresztben, farkín négy fohie vonal. Olly lieressé irtizik a naptul, hogy nappali bagnlynak is nereztetik. Ezen két faj nagysága a közönséges éjbagolyéral egy.

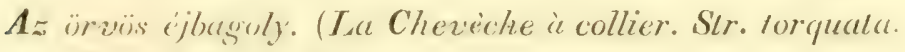

Daud.) Vaill. Afr. xurr.

Föluil barna, alul fehéres, szcmböre és cgy szalag a mellén barmik; lorka is szemholdai lichecek. A reszgiolye

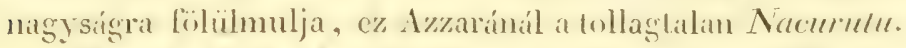

I amnak végre Amerikíban szinlolly (supasz líbuah, mint ujuali; illycn a mesillibu ejbagoly (la chevèche mudipeide, str. mutipes I and.) licil. Iméx. xv. - Végre.

\section{A PICZIBEGEK, (PARABAGLYOK.)}

(Les Scops. Scops. Savign. Zwergolıreule.)

Fïlei a fej tetejen rammak, kögrik tökitetlenck s ujaik csupaszol mint az chobbichnil, collugails hasonlik a súholyok- és füles baglyokéihoz.

ténye a: Sir. grallaria. ua. Col. 136. - Str. castanoptera. Ilofi. vagy Str. spadicea. Reinw. coI. 98. - Str. pumila Ilig. v. cabouré. Azz. col. 59. s ennek a Str. passerinoides, hilhetöleg híme col. 341. - Str. fermininea. pr. Max. col. 199. - Strix hirsute. T. cal. 289. - Sir. occipitalis. - A Str. Maurei, col. 16. már elér nagy lesz. 
A VERIBEK.

Egy fij van a mi égalumkban a Strix scops, enl. 436. Naum. 43. 3. alig akkora mint egy rigó, hamvas tollu, többé kevesebbé sárga felhös: szípen tarkítva apró hosszí fekete vonatocskákkal s szürke, gilisztís keresztvonakkal, váltollain fehéres folt-sorokkal s hat vagy nyole tollal minden pamatban; kellemes kis madár. ( $\left.{ }^{1}\right)$.

Némclly idegen s elég nagy termetï fajoknak lábai csupaszok mint ujaik. $\left({ }^{2}\right)$.

A MADARAK MASODIK REVDE.

\section{A VEREBEK.}

(Les Passeraux. Passeres. Sperlingsartige Vögel.)

Legszámosabb az egész osztályban. Bélyege eleinte csupán tagadúnak látszik, mert magában foglalja azon madarakat, mellyek sem úszók, sem gázlók, sem kúszók, sem ragadozók, sem tyukféliek. De összehasonlítva, hamar igen nagy alkotási hasonlatosságot veszünk nálok észre és föképen olly finom

(') Én nem látok különbséget Ser. zorca. Cetti. és Str. carniolica. Scopoli, Str. pulchella. Pallas és a picibeg közöt ; ezen vizsgálók különbözöknek hihették ınadaraikat, mivel Lisné csak eøy tollat ád az övének tollagúba. A. h. Ser. nudipède. (Bubo nudipes. Vieill.) Amér. 22. - Strix atricapilla. T. col. 45 v. Str. crucigera. Spix. 1x. - Strix noctula. T. col. 99.

$\left(^{2}\right)$ A Str. ketupa. Tem. col. 74, s a Sir. Leschenauldi, u. s. col. 20. mellyek legfülebb is egy fajt kepezhetnek.

CUVIER I. K. 
átmeneteleket egy nembül a másikba, hogy igen nehéz nálok alosztásokat csinálni.

Sem a ragatozok hevességét, sem a tyukféliek vagy vizi madarak szabott életmódját nem mutatjík; táplálatul szolgriknak nekik a bogarak, gyümölcsök, magrak, a magvak annál hizáróbban, minél vastagabl) esorruak, a bongarak pedig, minél rékonyal,b a csorr. Mellyeknél ez erós, még az aprú madarakat is üldözik.

Gyomrok izmos zuzát képez, s általíban két igen lis vakbelök van; lözöttük talíltatnak az éneklë madarak s a leghonyoltab) al-légripok.

Szárnyok aránylagos hosszasága s repülésök kirerjedése annyiara különböznek, mint életnemök.

Mellesontuk fehölt korukban rendesen csak egy himelszés bir alsó szélénel mindenik oldalán; azonban kellöt a szalakistáhnál, jegéreknél és gyurgyaliagoknál; egészen hibáát pedigg a föllengüknél és pompályoknál.

E.Isí fölosztimmankat a lábak szerint csináljuk, utóbb a csorrot veszszük segédül.

1 legelsös slegszamusho orztat aron nemehel fogJalja magáaban. mellıelinél a külsö uj a közepsöhöz ragadt, de csak egr vagý hét percénél fingrat.

Ezen oszlat első családa

\section{A CSORRFOGAS $\perp K-e ́$.}

Mell ̣ ehnek csorra a hegy oldalán ki van szelve. Ezen csatádban lélui a bogárevó madarak legnagyobb 
részét; azonban majd mindnyája eszik bogyót és más gyönge gyümölcsöt,

A nemeket a csorr általános idoma után határozzuk, melly erós és öszvenyomott a gebicseknél és rigóknál, lenyomott a légykapóknál, gömbölyü és vastag a verebélyeknél (tanagráknál), karcsú s hegyes a billegtctöknél; de az átmenetel ezen egyik idombul a másikba annyira fokozott, hogy nehéz a nemek határait kiszábni.

A GÉBICSEK. F.

(Les Pies-Grièches. Lanius. Lin. Würger)

Csorrok kúpos vagy üsszenyomotl, s hegyén löbbi kevesebbé horgas.

\section{A tulajdonképi GÉBICsEK.}

Csorrok az alapnál háromszegü, oldalvást összenyonıtt.

A gébic'sck csaláclusan élactón, egyenchenül s rohauva repülnek, élesen kiáltozva; IPlán fészkelnek a fákon, öt vagy hat tojást tojnak, s aproikrul igen gondoskodnak. Szokások a szonszédságokban lakó madarak szavíl utínozni. A nólsućl s fiataloknál a test alsó része rendesen finoman van kereszlben vonatolva.

Némellyeknél a felsö lemez ívelt; azok, mellycknél ammak hegye crös és jôl görbült, hol a kimetszés kis fogat képez annak oldalain, olly batorak és kegyetlenek, hogy sok természetrizsgálók által a ragadozó madarakhoz tetettek. $S$ valiban üldözik is az apró madarakat, s sükeresen védik magokat a nagyok cllen, söt ezcket megtámadják, ha fészkciktül akarják elúzni. (1)'.

( $\left.{ }^{2}\right)$ Ezen elsó alosztatbul csinálta. M. Vieillot lanius nemét gal. caxxy. Il. 
Nálunk négy vagy öt faj ran ezen nembül. Az ör gébics. F. (Bába szarka, - szarka gaibor. La Pegrieche commune. Lanius excubitor. Liu. Der grosse graue IV ïrger.) Enl. 445. Naum. 49.

Akkora mintegy huros, fiblül hamras, alul feher; szir-

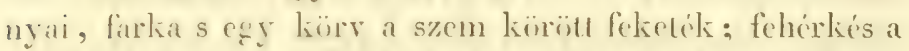

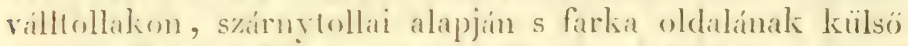
szithe Egesz irben megmarad Franciaorszigban.

Europa dilszakín van cgy fajla vagy lalín faj, sïtclcbb szinï, alul borrerhenyes, neve :

Deti sebies. (Tan. meridionalis. 'Г(mm!. Der südliche

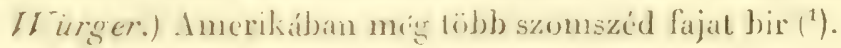
A his iorgebies. (olasz ö.). - Ia petite Pie-grieche, dite d' Inalie. Lanius excubitor minor. Der Schwarzstirnige Hürger - Enl. 32. 1. Lan. minor. Naum. 50.

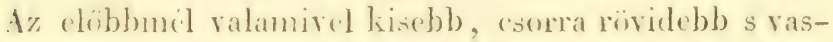

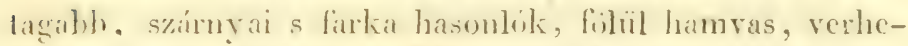
nyes a hasin, szemeinek fekcle szalaga a homlukon széles

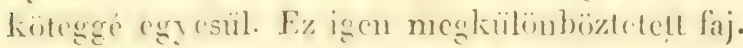

A verhenues gébics. (La Pie-grièche rousse. Lan. collurio rufus, et L. pomeranus, Gm. Enl. 9. 2. L. rutilus. Lath. L. ruficollis. Sh. L. rufies. Naum. 51.

Söblege, szimyai s farkia mint az elöbbinél: termelc kicsivel hischb): foje s nyaka fible viligos veres, hália liliete; rílla, hasa s farcsilia fehérek.

(1) Tan. carolinensis Wils. 1II, 22, 5. és t8le a Lan. excubitor, 1, V., 1. mellyet szinte azonnak tart. Bonap. K. Lét fajt csinál belo̊le s a $L$. Iudoricianushoz, és $L$. septentrionalis. Gm, vagy Lan. ardesiacus-hoz és borealis-hoz. (Vieill, Am. 50, 51.) s7ímítja. De meg kell vallani, hogy ezen különbözö ábrázolatok roszul hasonlítnak egyuáshoz. 
A tövis-szúró gébics. F. (L. Ecorcheur. Lan.collurio. Gm.) Enl. 31. Naum. 52. Der Neuntödter.

Valamivel még kisebb, feje's farcsikföle hamvas, háta s szárnyai sárgák, alul fehéres, fekete szalag szeme fölött, szárnytollai féketék, sárga széllel; a farkéi feketék, oldalvást alapoknál fehérek. Oldösi az apró madarakat, fiatal békákat, és számos bogarakat szokott a bokrok töriseire fölszurni, hogy könnyebben ehesse meg vagy annak idején megtalálja.

A három utolsó faj télen ált elhagy bennünket.

Az idegen tarlományolsban szinte ranuak illy íves csorru gébicsek. Csorrok fokonként kisebbül s hegyök is gyöngülvén, a fajok szeriut, annyira, hogy lehetetlen hatírt szabni ezen alnem és a húrosok közütl. ( $\left.{ }^{1}\right)$.

(') Ero̊sebb csorru fajok, p.u. a capi gépics ( $\boldsymbol{L}$. collaris Gm.) enl. 477. 1. Vaill. Afr. LxI. LXIr. 1. - A boubou Vaill. 68. (L. boulboul: Sh.) $\rightarrow$ Le brubru. Vaill. 71. (L. capensis. Sh.) - A.maclagascari kis gébics (L. madagascarensis, Gm.) enl. 299. - A kék apró g. (L. bicolor, Gm.) enl. 298. Aluisianai g. (L. americanus), cul. 397. - Le sourciroux, Vail. 76, 2. vagy tangara verderoux de Buff. (Tanagra guianensis, Gm). - A fekese fejü g. Sandwich szigeteirül ( $L$. melanocephalus, Gm.) Lath., Syn., I, 465. - A hegyes s arku g. (L. pyrrhonotos, Vicill. gal. 135.

Vieillotnak Lanio neme egy ivelt csorru gébieste van épitve, mellynél a felsơ cso̊rlemez szélei kevessé szegletesck. Ez $\rightleftharpoons$ tangarı mordoré Buff. enl. 809, 2. (Tan. atricapilla, Gm.)

A rigókhoz közelebb álló fajokhoz tehetok: muscicapa tamnophiloides, Spix, 26, 1. - oliva, Vaill. 7.5. s 76; 1. ( L . olivaceus, Sh.) - Le gonolec. (Lan. barbarus, Gm.) enl. 56. Vaill. 169. L. gutturalis, Daud., Ann. mus 1II, 114. rl. xv. vagy pie-griése perrin, Vaill. 286. - (Turdus zeloinus, Gm.) Enl. 272. vagy Le Bacbakiri, Vaill. 67. (L. bacbakiri, Sh.) (Hotacille dubia, Sh., La cravatte hlanche) Vaill. 115. - Turdus crassirostris, Gm., Lath., Syu., 11, 34. melly = Tanagra capensis. Sparm. carls. rl, XI.. s 
Más gébiesclincil egresz hosszíban egyenes a felsci lemez s esak vegen horgas. Mlind idegenck s idomuk észrevetlen fokon megy által a zencisckibe s mis billegtelökébe. (1).

tübb szinte olly kétesek. Ezen gyöngél)l, esorru alosztatbul esinálta Vieillot a Laniarius nemet, gal. 145.

Vireo-ji csak valamivel rövidebb s vékonyabb csorr állal különböznek $V$. flurifrens. Vicil. Am., 5t. v. Muscic. sylvicola. Wils. I. vII. 3. $-V$. musicus, Vieill. 52 vagy musicus Vieill. 52. vagy Muscio. cantatrix. Wils, II, XVII, 6. v. Musc. novo-boracensis, Gm. - olizaceus, Ch. Bonap. v. Musc. oliv. WVils, II, Xri. 3. v. samnophilus agilis, Spix, 34, 1.- $Y$. gilvus Cl. Bonap v. Muscic. melodia, Wils. V. xu. 2. A zenérekhez majunem egrenesen vezetnek.

(') Le blanchot. Vaill. Afr., 285. (Lan. icterus, Cuv.) v. tamnophilus, Vieill. gal. 139. - Le grand battara, d' Azzar, v. tamnophilus magnus. pr. Max. v. Th. albiventer, Spix, 32. - Le tehagra, Vail. 70. (L. senegalensis, Spix. L. collurio melanocephaus, Gm.) enl. '479, 1. s 297, 1. - Le fourmilier huppé, Buff. (Turdius cyrrhatus, Gm). enl.479, 2. annak nösténye. - Le tachct Vaill. 77. (L. punctatus, Sh.) - A cayenni kïllós gébics. (L. doliatus), enl. 297, 2, v. radiatus, Spix. 35, 2. - (L. virgatus Term. col. 256, 1. - Az álarcos g. (L. personatus); u. a. v. $\boldsymbol{L}$. rubicus, Licht) col. 256, 2. - A tamnophilus lineatus, Spix, 33. Th. serigilatus, ua. 56, 2. Th. melanocephalus, иa. 59, 1. - Th. leuconotos, иo. 2 .

1 madagascari veres $g .(L$. rufus, Gm.) enl. 298.

Ezen egyenes csorru gébicsekhez tartozik a $I$. galericulatus, Cuv. (le geai longup, Vaill. 42), de ez a karolygákhoz rezet.

Ide teszem még a természetrizsgálók által anyira meghányt madarat: Turdus mindanensis, Lath, és Gm. (merle de Míndanas). Buff. enl: 627). ugyan az gracula saularissal, dialbird, Albin 11I. 17, 18. Edw. 181, Vail. Afri, 109. (Sturn. solaris, Daud). Sót még közel vezethets a Turdus orientalis (le'terat boulan), enl. 273, II, de szintolly közel van a hurosokhoz

A Tamnophilus $\nabla$. battara, Vieill, nem czen egyenes csnriu', de roszul meghatározott gébicsekhiil képzetik, mellyet mások a liansyazúzokhoz, irireokhoz stb. számlállak. 
Némellyeknél ('zen gubicsek liözött igen erös az egyenes csorr s az alsó lemez igen dagadt. $\left({ }^{1}\right)$.

Mások egyenes és karesu csorruak s hátra irányzott tollbúbról nevezetesek. $\left({ }^{2}\right)$.

Ezen valódi gebiesck liörúl némelly idegen alnemek csoportosodnak äzve, többé kevesebbé kïlönbözók s melylyeket mi ezennel elszámlálunk.

\section{A KAROT,YGA.}

\section{(Les Tanga. Buff. Sperberwürger.)}

Csorrok nagy, mindenfelül igen összenyomoll, hegye igen horgas. s az also esomlemézé fölfele gürbuilt. $\left({ }^{3}\right)$.

\section{A FECSKEGEBICSEK.}

(Les Langrayen ou Pie-grièches-Hirondelles, Ocypterus $\left({ }^{4}\right)$. Cur. Schwalbenwürger.)

Csorrok liúpidomu, minden felül gömbölyített, ćltelen, hegye felé is alig ivelt egy lissé, hegye igen finom,

(1) Lan. lineatus, Leach,, Zool. misc. VI. rl. Tamnophilus guttatus. Spix, 35.

${ }^{4}$ ) A geoffroy, Vail., Afi. 80. 81, Vieil. galer. 142. (Lan. plumatus, Sh.) mellybül Vieillot Prionops v. bagadais nemet csinált, galer. 142. s a manicup., Buff. enl. 70?. (Pipra albifrons, Gm.) melly a piprákkal semmi közöset mást nem bir, mint hogy a két kủlso̊ uja egyesült s igy a rendesnél kevéssel tovább nyult. Ebbüil Vieillot a Pithys nemet csinálta, Galer. 129.

$\left({ }^{3}\right)$ A vanga. Enl. 228. (Lan. curvirostris Gm.) s ez új fojak: Y. destructeur. Cuv. 273. a búbos-zonatos kar. Toy. de Freyc. xvII, XIX. Il. v. Tamnophilus Vigorsii, Zool. journ. suppl. vir. és VIII.

(') Ocypterus, oxypterus (gyorsszárnyu, hegyes szárnyu) görọ̈ neve egy ismeretlen madárnak, igen alkalmazható itt, - Vicilluł Artamus névvel köszönti e nemet. 
mindenik oldalrul keressé kivágotl, líbai kevessé rävidek, szárnyai olly hosszak ragy meg hosszabbak mint a farka, mi okbul repülések a fecskékéhez hasonlít; de birják eggszersmind a gebiesek bátorságát s még a hollót sem félneir megtámadni. (1).

Fajai eleg számosak az indiai partokon és szigclekm, hol oroblitie s gyorsan repdesnek, bogarakat üldözve. $\left(^{2}\right)$.

\section{A VARJUGEBICSEK.}

\section{(Les Cassicans Bull. Barila. Cuv. $\left({ }^{3}\right)$. Krühenwürger.)}

Orrok nagy limpidomu, egyenes, alapjánil görgeleg, a homlok tollait egy körmetsmésbe béfoglalio hátán gönbölyai, oldalvist isszenyomott, horgas hegyü s oldalvíst kimelszre. Orrlyukai aprók, ronaluak, s viasztérrel nincsenek köritve.

Ezek nagy madarak üj Hollandban s a mellék szigeteken mellycket a természetrizsgálik kenyök szerint hánytak ol más nemek hirzé. Igen zajos szokásokat és sipito szot tulajdonitanak nckili. Apró madaraliat ïldöznck. ( $\left.{ }^{+}\right)$.

(') Sonnerat, 1ar. Voyayc. 56.1.

${ }^{2}$ Ide jönek: Lan. leucorynchos。 Gm. Enl. 9. I. = Ian. dominicanus. Sonnerat. I. Voy. xxv. rl.; - Lanius viridis, enl. 52 , I. - Ocypt. cinereus. Val. - Ocypt. fuscatus. - Ocypt rufiventer. Ezen nem felul vedd hasznat azon eayes leirúsnak, mellyet falenciennes ur közlött a muscum cmlékirataiban. VI. küt. 20. lap. 7, 8, 9. ri.

$\left({ }^{3}\right)$ Barita, görög neve egy ismcretlen madúrnak. Vieillot az én baritái-mat CRACTICUS néven nevezte.

(4) Ide számithatúk: a cassican. Buff. (Coracias varia. Gm. Gracula varia. Sh.) Enl. 628. A futeur (Coracias tibicen, Lath. második pótolék, Grac.tibicen. Sh.) Voy. de Freyc. xx. 1. - A rézeil-

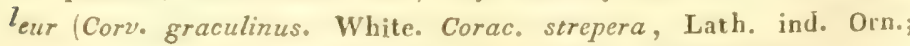
Grac. strepera, Schaw; Réveilleur de l'ile Norfolk, Daud; gr. calybé, Vail. Ois. de Par。 67; Vieill. galer. 109, - és egy vágott farhu faj (Bar. anaphoresis, Temm.) 


\section{AZ ACÉLGÉBEK.}

\section{(Les Calybés. Chalybaeus. Cuv. Stahlwürger.)}

Orrok hasonló idomu a varjugebicsekével, de alapjáníl nem olly vaslag, s az orrlyukak téres hártyán nyilnak meg. Az ismerelesek új Gvincábul hozattak és szép acélbarna szinök által jelesek.

A paradizi acélgéb. (Le Calibé de Paradis. C\%. paradisaeus Guv. Paradisaea viridis, Gm.) Enl. (634.

Fej-és nyakıllai kibodoritolt biborhoz hasonlók, s czen okbul s tollainak szép ragyogásaèrt a Paradicsommadarak (paradizárok) közé tétettek.

2. A szarvas acélgéb. (Le Calibé cornu. Ch. cornutus.

N. Barita Keraudrenii. Less. et Garn. Voy. du Duperr. 13. rl.

Tejhátán két hegyes tollpamat van; gögsipja híromszor forog körben mielött a tüdóbe hatna.

\section{A. VEREBGÉBICSEK.}

(Les Becardes. Buff. Psaris ( $\left.{ }^{1}\right)$. Cuv. Sperlingswürger.)

Csorrok kúpu, igen vastag s alapjín görgeteg, de a homlokat nem metszi be, hegye könnyüden öszrenyomott s horgas.

Fajaik déli Amerikában élnck. Legismerctesb: a kajáni ver. geb. (Lanius cayanus. Gm.) Enl. 304, 377. Vieill. Galer. 134. Spix. 44, 1.

Hamras; feje, szárnyai, farka fekcték. Erkölcse a mi gébicsünké. $\left({ }^{2}\right)$.

(3) Psaris egy ismerellen madál görög neve. Vicillot ezt TuTYRAval cserélte föl, galer. 134, 1. Spix. parchyrhyncus-ra. Av. brasil. 44 .

(3) Buffon roszul terjeszté ki e bécarde nevet egy gébicsre (Lan. 


\section{A HOLT,ÓGÉBEK.}

(Tes C'toncaris. Buff, Graucalus ('). Cur. Rabenwürger.)

Csorrok kereshbé összenyomoll mint a gebicselié, fölsö csorrlemeze hegyzell, egész hossziban egyenlöleg irell, öszbucsa (commissura) szinte keressé ivell; a\% orrlyukait néha befedó tollak matt a hollókhoz tartoznátnak, de csorrok kimelsz'se mialt riszont elrílnak azoktul.

Szinte mint a rarjgaboli az Indiai-tenger leglávolabb) részébül jönek. $\left({ }^{2}\right)$.

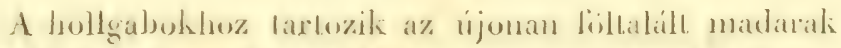
leggsebbehének eggihe a vidiken a: coracius puella, l ath., irena puella. Horst., drongo azuré. 'I'emm., a diszes hollgab; javai madir, biborfikele, hála pedig a legszeb) képzelhetố ultra-marinkéls.

sulfuratius.) s egy a rigóhhoz igen hözeli gébicsıe (L. barbarus). A. h. pachyrrhyncus semifasciatus. Spix. 44. 2, melly $=$ Psaris Cuvieri Swains. - A psaris erythrogenis. Selby, zool. journ., I, 484. I. A pachyrrhyncus niger, Cuvieri, cinerascens, rufescens, Spix 45. 46. kisebb csorrt, de azon idomut birnak.

(') Graucalus, görög neve egy hamvas madárnak; s négy hollógéb közül három illyen szinü. Vieillot e madarat összezavarja coricririr-val, mellyek = Gymnoderes és Gymnocephales, melylyekrül utóbb szólandunk.

(2) Corz papuensis. Gn. 650. Vicil. Guber. 113. Corv. nonac Gvineae. Enl. 629. Corv. melanops. - Lath. - Rollier à masque noir. Vail. Ois. de par. 61. 86. Egy másik acélfényü violás barna, (nősténye zöldes) = PrRoLı. Temm. = pTILonorynchus, Kuhl. melly nem a fejnek liboridomuabb tollaira épitteték. A sprorcotnér. nem, Vieill. galer. $147,=$ choucarivert, Voy. de Freycinet, xxı. rl. a többitül csak abban kuilönbözik, lıg sy szemhörén kevéssel töbh, cșupaszág van. 


\section{A SZARKAGÉBEK.}

(Les Béthyles ( $\left.{ }^{1}\right)$ Bethylus. Cuv. Elsterwürger.)

Csorrok nagy, rövid, minden részrül boltos, rége felé könnyüden összenyomott.

Csak egy faja ismeretes, mellynek idoma s színci kicsinben a mi téli szarkánkat ábrázolják. $\left({ }^{2}\right)$.

\section{A CINKEGÉBEK.}

(Les Falconelles ou pies-grièches mesanges. Falcunculus. Vieill. Meisenwürger.

Csorrok összenyomott, majd nem olly magas minl hosszú; felsö lemeze boltos, ivelt.

A szén-cingel (Lanzus frontatus) második púlolék; col., 77, Vicll. Galer. 137.,

verébnagyságu s majdnem a szén-cinke szineivel. A hím fején búbbí emelliednek a tollak. Uj Hollandiában él.

\section{A PARAGÉBEK.}

(Lues Pardalotes ou pies grièches-roitelets. Pardalotus. Vieill. Zaunkönigwürger.

Csorrok rövid, lissé összenyomott; a felsö lemez hegyes, íves, a hegy kimetszetı. Igen apró madarak, rövid farkkal.

(') BETHYLus egy ismeretles madár görög neve. Vieillot ezt PILLURION, vagy CISSOPis-ra változtatá.

$\left(^{2}\right)$ Ez a pie-grièche, Vaill. Afr, 60, és Vieill. galer, 140, Lan. leverianus Sh. Lan. picatus. Lath. Higer tangarát csinál belöle. lde közelítbetó a nagy gébics (Lan. corvinus, Sh.) Vail. Afr. 78, mellynek csorra azonban öszivenyomott. 
A pontos paragéb. (Pipra punctala. Sh.) Misc. zool. III., col. 78; Vieill. galer. 73. rl.

Legismeretesb faj, részint fehérel pontulva, mint a senegalli csiz. Szinte ủj Hollandbul jö. $\left({ }^{1}\right)$.

\section{A LÉGYKAPók. (Földi.)}

(Les Gobe-1Mouches. Muscicapa. Lin. Fliegenschnüpper.)

Csorrok vizszinilleg lenyomoll, alapján szörrel szegedl, hegse többe lierescbbe horgas és limetszell. Szoliások általiban mint a gebiescké : és nagrsigok szerint apró madarakkal ragy bogarakkal élnek. A leggyougabbek észrevillenül a billegtetökhüz mennek ált. Mi következólipen osztjuk öket föl :

\section{A ZSAROLYAK.}

(Les Tyrans. Tyrannus. Cuv. $\left({ }^{2}\right)$.

Csorrok egyenes, hosszú, igen erös; a felsö lemez egrenes, fompa; hegye gyorsan horgadt. Amerikai madarak, gébies nagyságntak s batrak miul azok. Fiaikat mégg a sasok ellen is védil, s f'́szkcilitil minden ragadezci madarat el tudnak hajtani. A legnagyobb fajak apró madarakiat fognals, s a dïgöt sem mindig vetik meg. $\left({ }^{3}\right)$.

(') A. h. diszes paragéb. (Pard. ornatus. Gemm. Col. 3921, 1. - Pard. percussus. u. a. 394, 2. A paragebek a széphangu verebélyekhcz vezetnek.

(') Vieillot vette föl e nevet és nemet, galex. 133.

$\left(^{3}\right)$ (Lanius pitangua. Gm. Le bentaveo) Brasiliabul, enl. 212. - Lan. sulfuraceus, sárgahasu zsaroly). Enl. 296, = Corvus flaz'us, Gn. legarlu, Cayennebul, enl. 219.; - A leples zsaroly (Husc. velata, Spix, 22). - Musc. polyglotta, id. 24. - Musc. similis ua. 25. s a Musc, rufina, U. 0. 131. aunak csak fiatala. - A hameas fejü 


\section{A LÉGYCSIPÉK.}

\section{(Les Moucheroles. Muscipeta. Cuv.)}

Csorrok hosszi, igen lenyomott, kéiszerte szélesebb mint magas, még alapján is; a lemez igen tompa s még is nélı elöngró, a szélek kissé tojúsdad görbülettel; a hegy és a kimelszések gyöngek; a csorr alapján hosszú serték ragy bajúsz.

Gyöngeségök csak bogarak vadúszatát engedi meg. Mind idegenek, s nem keresen hosszú farktollakkal s szép fejbúbbal ékesittettek vagy lcgalább élénk szinckkel tollaikon. A nagyubb szám Afrikábul s Indiálibul jö. (1).

verhenyes zsaroly. (IIatalmas gébics. Földi. Le tyran à ventre blanc. Lan.tyrannus. Gm.) Enl.537. és 676. Vieill. Gal. 133. A hamvas zsaroly (Le tyran cendré, Musc. cinerascens Sp. 22.) A veres farku zsaroly. (Musc. audax. Gm.) enl. 453, 2. Wils. Am. II, xı1. 1. Az apró zsaroly. (Musc. ferox. Gm.) enl. 571. 1. = Musc. furcata. Spix. 19. - A szürke és fekete zsaroly (Musc. vetula. Spix. 18.) - A villásfarku zsaroly, Cayennebul. (Musc. tyrannus. Gm.) enl. 171. 2. - A \%.f. zsaroly Mexicobul (Musc. forficata. Gm.) enl. 677. A \%. f. zaroly Braziliábul (Musc. longicauda. Spis. 17.) Zool. journ. II, IV. rl. A búbos zsaroly (Musc. crinita. Gm. enl. 569. Wils. Am. II, XIII. 2.

(') Megkülönböztetendö elöször a keresztbíbu (kereszttollagu) légyócipe, (roi des gobe = mouches Buff. todus regius, Gm.) enl. 289. Azutån jönek a tollizos és a hosszú farktollí fajok, p. u. a paradizi légycsipe, (Le Moucherolle de paradis. MLusc. paradisiet Togus paradisiacus. Gm.) enl. 234. - Jeryz. Ezen ábrák csak nỏstényeket mutatuak; a himek farka sokkal hosszabb. A paradizi kis l'gycsipe (Te pert much. de par. ou. schet de Madagascar. (Musc. mutrata.) Két madír, mellyeket Buffon máshol e rév. alatt ir le: vardiole ou. pie de paradis. - Továbbá a búbatlan fajok de részint hosszú farktolluak; (Musc. psalura. T. le much. yetapa.) col. 286. 296. vagy Musc risoria. Vieil. 151. - A kakasfarku légycsipe; gallita. Azz., Musc. alector. pr. IIax. col. 155. Vieill. 132. Platyrhyncos filicauda. Spix. 14. 
Némclly a légyesipékhez közel esö fajok, (Lapesorrok, Platyrhyncos, Les platyrhynques) még szélesebb és lenyomottabb csorrukk. $\left.{ }^{1}\right)$.

Misuknal a mollett hogy esurrok széles is lenyomull, hosszu lats is rörid lark mutalkozik. Csak kit ragy három imeretes; mind Amerikábul, hangyákkal

Némelly fajok hártyakört birnak szemök köriil: NTusc. melanoptera. Gm. Enl. 567. 5. - M. telescophtalma Lass. et Garn. Yoy. de Duperrey. Zool. Xviu. H.

Misohnal a csorr hosszí, lapos, tompa, majdnem at tódokéhoz hasonli; de himelszéssel, melly amazohnal hiházik: különben mảsképen idomitott. $T$. cinereus. Desmar vagy $T$. Melanocephalus. Spix. 1x. 2. A fatal $=T$. cinereus. Desm. - $T$. griseus. Desm.

Végre sok más faj, mint: Musc. borbonica, enl. 573. 1. (Le Mantelé. Vaill. 151.) - Musc. cristata, enl. 573. 2. etc. tehitrec. Vaill. Afr. III., 142. 1. - M. caerulea. enl. 666. - T. leucocephalus, Pall. Sp. VI. II. 2. = Musc. dominicana. Spix, 29, 2.; a Mlusc albiventer. Ua. nósténye.) - T. sylvia. Desm. - Platyr. chrysoceps. Spix. xı. 2. - Platyrh. ruficauda. U. o.1. - Platyrh. hirundinaceus, Spix. 15. 1. - Plath. cinereus. Uo. 2. - Husc. barbata. (melly = TYRAxxLLA nem, Swaison-nál) enl, 830. 1. és ennek nóstéuye a M. xantopygus. Spix. Ix. 1. - Mr. coronata, enl. 675. 1. 1 molenar. Vail. 160, 1 és 2. v. Muscic. pistrinaria. Vieil. - A g. m. à lunettes. uo. 152. 1. - M. fammiceps. Temm. col. 141. 3. M. mystax, Spix. 31. - M. murantia Enl. 331. 1. - Musc. querula (melly = MrackA. nem Vigor's és Horsfieldnél). Vieil. 59, mellytül a Plath. cinereus, Spix. xirı., 2. alig különbözik. M. cucullata. Lath. stb.

(') Ezen osztatra épité Vieillot a Plathyrhyncos neinet, gal. 126. llyenek: 11. aurantia, enl. 851. 1. Tod. macrorlynchos Lath. Syn. I. Xxx. rl. v. todus rostratus. Lath. Desm. s legiukább Todus platyrhynchos. Pall. Spic. VI. III. Lathatni, hogy tohb légycsipe a tódok hözé téteték. Pallas ada rá példát, a csorr kimetszete $s$ a külsö uj elválása annak ellene vamuak. A. h. platyr. olizaceus, T. cul. 12. 1. v. sulfurescens. Spix. 12. - Platyr. cancronus. ua. uo. 2. 
'luck; imcét a rıgok azon kis törzsökével egyesítettük öket, melly hangyazúz nevet bir. (').

\section{Tulajdonképí LÉGYKАРо́K.}

(Les Gobe-mouches pr. d. Muscicapa. Cuv:)

Bajuszok löridebb s csorrok keskenyebb a légyesipélínél. Azonban méğ lenyomott, fölül szembetünö eröszszel, egycnes oldalakkal s kissé görbült hegygyel.

Ezen alnembül két faj lakik nyáron vidékünkön; clég szomoruan dó a magas fák tetején. Legközönségesb a szürke légrkapú. (Le Gobe-monche gris. Muscicapa grisola. Der gefleckle Fliegenfinger.) Enl. 565. I.

Fülül szürke, alul fehéres, némelly szürkés follocskákkal mẹllén. Némelly tartományokban légyfogdosís régett a szobákban tartják. A másik

a nyakkörves légrkapó. (Le Gobe-mouche ì collier, Musc. albicollis, 'Tem.) Enl. 563. 2. 3. s jobban: Hist. des Ois. IV. kor. 4-rét, 25. rl. 2. kép. A hím meuyegzös ruhában. Naum. 65. különbözö állapotban.

Igen jeles a him tollazatának változísa által. Télen a nóhöz hasonló, azaz szürke, fehćr szalaggal a szírnyín; a szerelmeskedés szakíban feliér és tiszta fekete szinbül kap kellemes tarkasígot; fejteleje, háta, szárnyai és farka fekelék, homloka, nyakzata s teste egész alí, egy nagy folt a számyán, egy kisebb clöbbre s liukia külsö széle fehérek. Fa-lörzsökökben fészkel. $\left({ }^{2}\right)$.

(1) Ide jo̊nck: turdus auritus. Gm. enl. 822. Vicil. gal. 127. = pipra leucotis; de a melly sem rigó sem fipra. És : pipra naevia. eul. 825. 2. kíp. Ezen megkuilönboztetésre alapitá Vicillot a conopoPraGA nemet, galer. 127.

$\left({ }^{2}\right)$ A régiek jól ismerék ezen madarat a sycalis és ficedula név alatt rendes ruhazatáhan, meleneorhynchos és arricapilla alitt pedies 
Kevés idoi úla megküüuböztetik töle, egy hasonlo villozísok alí relett faj, de mellynél a him larkoja, a szerelem idejoben, fekcte mint a háta, s mellywél a szárny szélén nincs meg a kicsin fehér folt. $\mathrm{Ez}$

A gycisz legykapú. (Gobe-mouche-bec-fique. Musc. luctuosa. Tem.) Naum. 64. Edw. 30. 1. A nö enl. 668, I. Az elöbbinél továb]) megy éjszakra.

Nimuthumban egr apro vereses fiij is talíltatik fül. A kis légykapi. Musc. parva. Bechst. Naum. 65. 3.

A legrliapoik csorra mindegyre kisebbedrin (karesosodván) régıe megközelíti az ököıszemet. ${ }^{1}$ ).

Nimclly fijok, hol az crös valamirel emeltebbs s ivben gärbuil a hegrlelé, a sziklabilolihoz rezetnek. $\left({ }^{2}\right)$.

sacp tollaival; hanem mivel a beque-figue (= firedula,) déli Franciacoszighan s Olaszorszaghan kübübozơ zenérehre és pipárokra alkalmaztatik, a természetvizsgálók ezen madarak tulajdonságait a légyhapo hizonyos állapotjára alkalmaztatak, s isy Buffon és követöi utín egy beque-figui, nevezeti képzelt fijt teremtének clỏ. Bizonyosan a nyakkörves légykapó = Becca-fico, Abdrovande, Ornith. II.., 758, 759.

(') A légykapókhoz számláljuk még: Muscicap. bicolor (le gillit) enl. 675. I. - (Muse senegalensis, Gm. Le pririt.) Vail. 161. enl. 567. 1 és 2. - M. albicapilla, Vicill. Am. 37. - M. armillata. uo. 1, 2. - M. diops. Tem. 144, 1. - M. eximia, во. 2. - M. ventralss. ua. Col. 275, 2. - M. virescens. uo. 3. - M. obsoleta. uo. 1. - II. flabellifera, io. Gm. Lath. Syn. 11, p. I. rl. 49. - II. serita. Vail. Afr. 154. - M. ruticilla. Gm. enl. 566. Vieil. Am. 35 és 36. Wils. I, v. 6. - Platyrhynchos paganus, Spix. - Pl. marinus. ua. 2. - Pipra elata, na. vir, 2.

Jegyz. A M. flabellifera a RIPIDURA nemet adí Vigors és Horsfield-nek; a H. rutilla a SETOPnAGA nemet Swainsonnak. A H. ste7zura. T. col. 167, 5, szegleles farkáét, STENURA nem lön Swainsnél; és a tollnagyitotta lejück, mint a Musc. australis. White 239. 1. képzik a paCriceprala nemet. Van egy szomszéd nem is, a Seisura. Lath. T'urdus volidans-ábul.

(") Hllyenck: Oranor, Vaill. IV. 155, s több szomszéd faj, szin- 
Némelly madiir nemek vagy alnemek igen közel v'annak a légy kapók sorának bizonyos láncolatához; noha nagyságra azolsat igen fölülmulják. Illyenek:

\section{A ZSAROLYCSUPOK.}

\section{(Les Gymnocéphales. Geoffr. ou Tyrans-Chauves;}

\section{Nachtkopf.)}

Csorrok majd mint a zsarolyoké; csak az erösz ível. tebb egy kissé nálok, s arcok nagy része csupasz.

Csak egy cayennci faj ismeretes; varju nagyságu $\mathrm{s}$ spanyol-dohány színü. $\left({ }^{1}\right)$.

\section{A CSőRRöP-ek}

(Les C'ephalopteres. Cephalopterus. Gcoffi.).

Csorrok töve ellenben fülemelt tollakkal bélelt, melyIyck felsö végökön kiterjedve, széles tollcsomagot képzenck napernyő idomban.

osztásra igen hasonlitók a $I I$ ruticilla-hoz, de csorra nézve különbözo̊k, mint Mr. miniata. 'T. = turd. speciosus. Lath. col. 156. M. flammea. Forst. Zool. ind. 25. Tem. Col. 263. = Parus malabaricus. Lath. - MI. hyacinthina, Col. 30. - M. azurea. (I' Auzuroux) Vail. Afi. 158. 2. - M. nigerrima, Vieil. Dict. Spix. 18. 1. - M. galeata. Spix. 17, különbözỏ faj. - M. stellata. Vieil. Vaill. 157.2. - M. longipes. v. Miro - Miro. új Zelandban. Less és Garn. Voy. de Duper. Zool. 19. rl. 1. - M. crysomelas. uo. 18. rl. M. nivea. Sp. 29, 1. $M I$. icterophys. Vieill. Dict. $M T$. mirundinacea. 'Tem. col. 119. - $I T$. multicolor. Gm. Lath. Syn. II, L. melly annyira közćpen van a légykapók és a füstfarku billegteto̊ között, hogy habozva adhatni néki helyet.

Ezek ero̊sebb csorru fajok, mellyek, ugy teszik, = DRYMoPHYLES. Temm.

(') Ez a choucas chouve, Buff. enl. 521. (Corius calvus. Gm.) I' oiseau monpère (atyámmadir) a kajánai négercknél Vail. Qis. d' Amer. et des Indes Xxix. 1.1 .

CUVIER I. K. 
Szinte csak egy faja ismeretes az Amazon folyam partjairul, melly szajki nagysigu, fekcte, s mellynel melle aljinak tollai némi csïngö pocok idomot képzenek, ez a

diszes csörröp. (C'ephalopterus ornalus, Cicoflr.) Ann. du Mus. XIII. rl. xv. Coracina cephaloptera, Vieil. galer. 114.'Tem. col. 255; Corac. ornata; Spix, Lıx.

\section{a selyeafarauak. Földi.}

(Les ('otingas. Ampelis. Liu. Der Sh/muckvogel.)

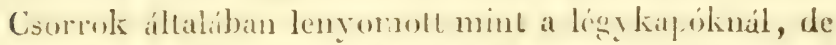
kissé rövd arangilag, dig széles s höm! ilden irelt.

PIOIIóK.

(I'iauhau, Querula, Vicillot.)

Nevid kapják kiáltások modjánt azok, mellyckuck

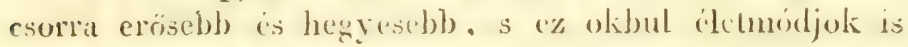
igen bugáreris. - Amerikaiak, s eseportonkinat repdeznek az erdöben bogarakat ildö̈re. (1)

\section{A RENDES SELYEMFARKUAK.}

Cosorrok valamivel gyöngebb) bogarakon kivial bogyokat és gyonge gry imölesöt keresuck. Amerikában nedves helyeken tartizkodnak s niagrobb részint jolesek aton bitoor is azur ragyogísrul, melly a himek tollazatít festi a

(') Ide josnek: a rendes piohó (d. Piquhau ordinaire, MIusc. rubricollis. Gm.) enl. 381. Vieill. gall. 115. fekete, biborszin torku, - s a nagy piohó, (Cotinga rouge. Vail.) Ois. d' Afriy et des Indes, xxr és xxr. $1_{0}=$ Coracias Militaris, Schaw, - A szürke selyemfarku. (smp. cinesea.) cnl. 699. inkább a piohóbhoz hasoulit, mint a reudes selyemfarkuaklioz.

A hajnal torhu piohó. (Le P. a gorge aurore. Corac, seutette.

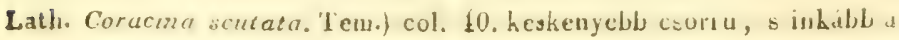
cso̊rropethé közelit. 
szerelem érsakában. Különben a kiı nömuek csak szürke vagy barna szinzete van.

A vigó selyemfarku. ( $L$ ' Ouette. Ampelis carnifex.

Lin.) Eul. 378. Spix. V.

'Teteje, farcsika-s hasa skarlátvercs, a többi fekete; negyedik számytolla hátrahuzott, rövidebb és mintegy szarvudult.

.1 pompa's selyemfarki. (Le Pompadour. Amp. Pompa-

doro. Lin. Der rothe Schunuckvogel.) Enl. 279.

Szép vilúgos biborszin, fehè szárnytollakkal; nagy takarójinak durra szakállai két lapra irányzoltak hegyes szeglettel, mint valami tetó.

A kék selyemfarku, (Le Cordon bleu. Amp). Cotinga. Lin.

Der blaue Schmuchvogel.) Eul. 186 és 188.

Lcgszebb ultramarin szinii, mele violaszin, gyakran keresztulrágra szćles kél szalaggal, s hajnalszin loblokkal jegyzetl. (').

A SZÁRNYADÍSZEK.

(T.es 'T'ersines. T'ersina. Viell.)

Sclyemlarkuak, alapon kissé szélesebb csorral. $\left({ }^{3}\right)$.

A F IRKAGOK.

(Les Echenilleurs. Ceblepyris $\left(^{3}\right)$. Cur.)

A mellett hogy csorrok mint a selyemfarkuaké egy

(1) A. H. Amp. cayana. en!. 299. - Amp. cucullata. '1'. col. 365. Swains, ill. zool. 57. - A7 Amp. cuprea. merremic. av., 1.2. a vágó fajtijának lenni látszik.

(2) Amp. tersa. Gin. = La tersine. Buft, Vieill, 119. $=$ P'rocné tersine. Trm. col. 5. = Procnias hirundinacea. Sw. zool. ill., 21.

(3) Egy ismerctlen madir görög neve. Viell. utóbb caxpepiraga nevel adott czen nerunch. 


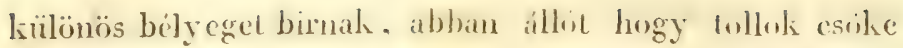
egy kissé elönyoutolt, durra és szmós a faresiktollaknál. Afrikában s Indiákban dinck, bogarakat szedve a legmagasb fúkon; azigazi sclyemfarkuak ragyogísát nem birják. Farkok egy kissci villís középen, oldalvást pedig elvágott. $\left({ }^{2}\right)$.

Elválaszthatók szinte:

\section{A LOCsKÁK.}

(T.es Juseurs. Bombyeilla Brisson. Seidenschwanz.)

Fojök a többicknól kissé hosszabb lollbubbal ékesirell, mellyck majd mindnyájánál mégr továbbá azon külimins belyes van szirnyaik másod rendii lollain, hogy csölök vége petés, sima, veres köggé szélesül ált:

Europaban egg faj ran, melly, nem tudatik mi okbul nevezteték franciául csehországinak, magyar neve:

1. Selvemfarku locska. (Locskice selyemfarku. T. Saseur de Bohême. Amp. garrulus. Lin.) Enl. 261.

Kisse nagyobb a verébué, borverhenyes szürke tollazatu, Lorka fekete, farka fekete, régén sírgával szegre; szimrna lekete. fehérrel tarká. Ezen madír seregesen jö hozzánk igsen hosszú idöszakokban s rendetlenül, mi okbul igen sokii rosz jósoknak tarlattak. Ostoba, könnyen megfoghati s szelidithetio, sokat és mindenbül eszik. Azt hiszik, hogy igen magas éjszakon fészliel. Husát iggen jónak tarlják.

2. Az amerikai locika. (Ampelis garrulus, b. Linn. Amp. americana. Wils. I, vis. I; Bombyc. caroli-

(1) Illyenck: Muscic. cuna, Gm. cnl. 541. $=L^{\prime}$ échenilleur cendré, Vail. Afr. CxLı. rl. Vicill. galer. 130 ; $-L$ ' échenilleur noir. Vail. Lxiv. Tole az Ech. jaune, Lxir. rl. = fiatal Turdus phoenicopterus. I. $_{0}$ Echenille à epaulettes rouges. col. 71. - A b. Ceblepyris fimbriatus, (Ech. frangé) Tem. col. 249. 250. 
nensis. Wiels. - Bomb. cedrorum, Vieil. Gal. 118.

Vaill. Ois. de par. I. 50. rl.

Amahoz igen hasonlit, de kissé kisebb.

3. A japáni locska. (Bomb. phoenicoptera. Tem.) col. 450.

Japáni faj, szárnyain fügelékek nélkül, farka hegyo s szárnyának apró takarói veresek.

Hoffmansegg és Iliger nem lkiseb) okozatossággal választák el a selyemfarkuaktul

\section{A SZELECSŐRÖK-et,}

\section{(Les Procnias. Hoffm.)}

mellyeknek csorra gyöngébb, lenyomottabb s egész a szemek aláig szell. Amerikában élnek, bogarakkal láplálkozva.

Ezek tovúbb föloszthatók még:

A tulajdonképi szececsörök csorra tollakkal takart. Egyik fajok:

A torongyos szelecsör (Ampelis carunculata. Gm.) enl. 293. egy hosszú, puha torongy által különös, melylyet csorra alapjáu hord. Felnólt állapotjában fehér, különben zöldes.

A топкаasupok (Les Averanos. Casmarynchos. Temm.) csupasz torku szelecsörök.

1. A tarka torkacsup) (Ampel. vartegata. Lin. col. 51. L' Averano. Buff. IV. 457. 1.)

Himjénél a torok meztelen része cgészen izmos torongyokkal takart.

2. A torongyatlan torkacsup (Procn. araponga, pr. Max.) col. 368, és 383, vagy Casmar. ecarunculalus. Spix. 4.

A him torkánals csupasz részén csak igen apró s ritka 
sziorii tollak rannak. E madarak fehérek az drelt illapotban; a fiatal hím s a nöstény zöldesek.

\section{A NYAKACSUFOK.}

(Les Gymnoderes. Gymnoderus. Geoffr.)

Mellyeknek csorra csak egy kissé crösebb, de a melylyek nyaka részint csupasz s fejök bibor tollakkal lakart. Az ismeretes faj szinte déli Amerikúbul ran, nagy részint szemevö, galambnagysígu, kékes szárnyakkal, neve:

A délamerikai nyakacsup). (Gracula nudicollis, Sh. Corvus nudus, et Gracula foetida, Gm.) Enl. 609. (').

\section{A BOGÁRKAPÓK.}

\section{(Les Drongos. Edoline. Cuv. Dierurus. Viell.)}

A légykapók nagy soríluz tartoznak mig; esorrok szinte lenyomott s kimelszett végü: fclsö erösze kitünö; de az külünbözteti meg öket, hogy két csörlemezök egész hosszíban könnyüden irelt: orrlyukaik lollal fedvék, s azon kirul még bajuszt kípzö hosszú szörök is van.

Fajaik igen számosak az Indiai-tenger szólére esö tartományokban. Általában fékcle szinök s villás farkols van; bogarakkal élnek: azt mondják, némellycknek éncke szép mint a fülemileć. $\left({ }^{2}\right)$.

(') Vaillant faja, Ois. de l'Amér. et des Indes, Xrv és XIvi. ta. lán kiilönbörik tỏle.

Jegyz. Vieillot a hollógabokat, nyakacsípokat és eso̊rröpöket. conacina nevii neméber egyesíti.

(2) Fajok: Ian. forficatus, Gm. enl, 189. Vail. Afr. IV. 166. és Vieil. galer. 111. - Lan. malabaricus. Shaw. Vail. 1v. 475. Sonnerat, Voy. aux. Ind. et à la Chine, xcvrr. r. - Cuculus paradisiacus. Briss, IV. xrv. 1. A. 1. - Lan. coerulescens. Gm. Edw, xLVr. I. Vail. Afr. IV, 171. - A drongo bromzé。 ua. 176.

És több uj faj. 


\section{A BOGFOG:ÁROK.}

\section{(Ties Phibalures. Phibalura. Vicill.)}

Csorrok erïzc ivelt mint a bogárlsapóké, de a esorr fellel röridebb mint fejök.

A sárga csorru bogfogair. (Ph. flavirostris. Viel. gal. 74. 'Tem., col. 118. Ph. rristata Goains. Zool. ill. 31. rl.) Ismeretes faj Braziliábul; farka igen rillás, tollazata feketével és sárgáral foltos, fejón pedig veressel, a mi némelly zsarolyokra s légykapókra emlékeztet.

\section{A Verebéltyek. TANAGRA. (Földi.)}

Csorrok kúpidomı, alapján háromszegletii, eröseén könyủden ívelt, vége felé kimetszett, szárnyaik s reptök rörid; szokásaikban verebeinkhez hasonlítanak, s a szemeket szintugy keresik, mint a bogyókat és bogarakat. A gyüjteményekben nagyobb részök élénk színek által tünteti ki magát. Mi igy osztjuk öket föl. (').

\section{A HANGAJók.}

\section{(Les Euphones ou Tangaras Bouvreuils.)}

Csorrok rövid s ha vizszinüleg nézetik, alapja minde nik oldalán Jiterjedést mutat: farkok arányilag röri$\operatorname{debb}\left({ }^{2}\right)$.

Jegyz. A bec-de-fer, Vail. Afr. 79. mellybül Iliger a Sparactes nemet csinálta, s melly lemásolva van Viellot galer. cxur. rl. Temmink megvizsgálása szerint. szakállárnak (szakálmadárnak, barbican) lenni találtaték, mellyuck más Jábokat és tollagot adtak. Egy keres. kedó teltc ezen tréfít s megresalta Raic de Brenkelenwaerd urat, egy gazdag hollandi madárkedvelöt.

(') Lásd ezen egész nemrüls a piprárul és tódrul Demarets w és de Courcelles Paulina kisaszony, most Knnip asszonyság munkáit.

${ }^{(2)}$ Tanagra violacea, enJ. 114. 1.2. - T. cayononsis, นે. 0. 


\section{A NAGYCSORRU VEREBÉLYEK.}

\section{(Les Tangaras gros-becs. Gross-schnäbel.)}

Csorrok kúpos raslag, boltos, olly szćles mint magas, a felsö lemez haita gömbölyödött. ( $\left.{ }^{1}\right)$.

\section{A tulajdonképi verenérrek.}

Csorrok kúpidomu, fejöknćl rövidebb, olly széles mint magas, felsö csorlemeze ivelt, egy kissé hegyes. $\left({ }^{2}\right)$.

\section{A RIÓVEREBÉLYEK. \\ (Les Tangara loriots.)}

Csorrok kúpos, ívelt, hegyes, limetszett végii $\left({ }^{3}\right)$.

3. - Pipra musica, enl. 809, 1. - Tan. diademata, Natterer, col. 243, vagy lindo bleu, Azz. E Bonzreuil azuré, Vicil. gal. 51. Lindo bleu doré, Azz. (Tan. chrysogaster, Cuv.) - Tan. viridis, Vieil, col. 36. 3.

(') Tan. magna, enl. 205. - Tan: atra. enl. 714. 2. - Coracias cayennensis, enl. 616. - Tan. flammiceps, pr. Max., col. 177. - Tan. superciliosa, Spix, 57, 1. - Tan. psittacina. uo. 2. Ezen osztatra épité Vieillot a nABIA nemet.

(2) Tan. talao, enl. 127. 2. - Tricolor enl. 33. - Mexicana, enl. 290, 2. és 155, 1. - Gyrola, enl. 133, 2. - Cayana, enl. 201.2. és 290, 1. - Episcopus, enl. 178. - Coelestis, Spix, 55, 1. - Varia, Desm. (Motacila velia, Lin.) enl. 669, 5. s a T. Schrankii, Spix. 51. amannak Gatala lehet. - Punctata et siaca, enl. 153. L. - Tan. multicolor, Vieil. galer. 76. = Fring. zena, L. Catesb. I, 42. Tan. thoracica, Tem. col. 42. 1. - Tan. citrinella, ио. 2. - Tan. vittala, uо. 48. - T. penicillata, Spix. 49. - Tan. auricapilla, ua. 52. - Tan. vittata, Tem. col. 48. - Tan. leucoptera, vagy Oriolus leucoptcrus, Lath, Syn.

(3) A tan. gularis, enl. 156. pileata, 720, 2. és speculifera, Spix, 56, 1. a billegtetokkhöz közelítenek vékonyabb csorroknál fogva. Tan. nigricollis, 720 , 1. valódi billegteto, némileg ökörszem, kissé yastag csorral. 


\section{A SARKÁLYOK (SARKÁLYVEREBÉLYEK.)}

\section{(Les Tangaras cardinals.)}

Csorruk kúpu, kevessé ivelt, oldalvíst egy kitetszö tompa fog. ( $\left.{ }^{1}\right)$.

Végre:

A KÁVADÚZ-ok, KÁvADÚZADT VEREBÉTYYK. (Les Tangara rhamphocéles. $\left({ }^{2}\right)$.

Csorrok kupidomu, az alsó lernez vagy is állkapea ágai hátra felé duzadtak. ( $\left.{ }^{3}\right)$

a rigók, hurosmadarak. Földi. (Les Merles. Turdus Lin. Drossel.)

Csorrok összenyomott és ivelt, de hegye nem horgas,

(') Tan. cristata, enl. 7, 2. és 3012 . és ennek fiatala a Tan. brunea, Spix , 49, 2. - Nigerrima, enl.179, 2. és 711.- Olivacea. - Archiepiscopus. Desm. Spix. 55, 2. - Tan. rufiventer, Spix, 501. - Rufigularis, ua. 56, 5. - Suira. ua.48,1. - Viridis, ua., 2. Ezen osztatot таснурноnus néven köszönté Vieillot, gal. 82.

De ide tartozó tỏle még a pYrANGa nem is, melly csak egy egyéni idomtalanságra van alapitva. Mi az $\delta$ faját Tan. cyanieteranak mondjuk.

Le palmiste, Buff. enl. 509, 1. (Turd. palmarum.) Gm.) Vieil. Am. 1I. 69, szinte ide tartozik; kimetszése alig észreveheto̊, s majd egészen eltün egy szomszéd fajnál, mellybül Vicillot az ICTEnIA (Ict. dumicola, Viel. Am., et gal. Ixxxy, = Pipra polyglotta, IVils. 1, Vr. 2.) nemet csinálta. Ezen faj a fonárokhoz vezet.

Tan. missisipiensis, enl. 742. = T. aestiva, Wils. Am. I, vr. - 3, 4. - Tan. rubra, 156. 1. - T. ludovicéana. Wils. ill. xx. 1.

(') Vieillot ebbïl csinálta a JACAPA vagy RHAMPนOCÉLES nemet, galer. 79.

$\left({ }^{2}\right)$ A tanagra Jacapa. (Jacapa. F.) enl. 128. - T. Grasilica. enl. 127. 1. T. nigrogularis. Spix. 47. 
s nem okoznak olly crois fogakat, mint a gebicscknél: azoubanban, mint mondtuk, lokonkénti menctel ran regrik nemtiil a másikhoz.

A riscik (letncme inkibl) szemevö, cligr általínosan bogyơral ćlnck: szokásaik magánosak.

Bı́;́kNAK nerezteluck külin̈̈scbben azon fajok, melylycknil a szin egy ragy nagyobb tömeghen ran elosztra. Legszímosabb

a fekele rigó. (Le Merle commun. Tardus mèrula. Lin.

Die Amsel. Die Schwarzdrossel.) Naum. 71.

A lím (Fn. 2.) cgészen fekete, csorra sírga; a nö (Enl. 555.) fölül barna, alul barnás-verhenyes, melén bama foltokkal. Igen rad madír, de mégis kïmuyen megszeliditheto; joil megtanul inckelni is. Egész erbon nilink marad.

Egy közel faj, de csak a'tmenö s különöscn a heggeket kövelö.

Az ïrü̈s rigó. (Le Merle it plastron blane. Turd. Iorquatus. Lin. Die Ringdrossel.) Enl. 168, 182. Naum. 70.

Felete tollai résznt tchéressel szegrék, s mele hasonlí szinü vértlel jegyezet.

Déli Europa magas hegyei kiet fajı típlálnak A sziklai rigot. (Le Merle de roche. Turd. saxatilis Lin.) Enl. 562. Naum. 73.

A tiek rigót (Le Merle bleu. 'T. Cyanus. Lin. Enl. 250.

Naum. 72. mellyektül

A mascinos rigó (T'urrl. solilarius. Lin. T,e merle solikaire) nem külünbäzil $\left({ }^{1}\right)$. Az elsö melly leglöbbször

Jegyz. A tan. atricapilla, 809, 2. 5 a guyanensis, gebicsek. A tan. cristatella, Spix, v. fringilla cristata, Gm. Tan. graminea, és a 7 : ruficollis, Sp. 53. sármányok.

(') Bonncli észrevétele. 
jö ejszakra, legismeretesebb, mererdek sziklákon, ó romokon fészkel; szépen fütyöl. A him feje s nyaka hamvas, háta barna, faresika feliér, alrészes farka naranesszín. ( $\left.{ }^{1}\right)$.

HúRosoK, IÚRIK : (Hurosmadcir F. GRIVEs) nevet (hangjoktul) kapmak a tarka tollazatı fajok, mellyck apró lekete vagy barna foltokkal boritrák. Ilyen négy van Europában, a háton mind barnák s mellökön follosak: ćnekes madarak, bogarakkal és bogyókkal dök, nagy cšoportokban utazók, húsok igen jó izii.

1. A lép húri. (A lép rigó. F. La Drenne. Turdus viscivorus. Liu. Die Misteldrossel, Der Ziemer. Schneer.) Enl. 489. Frisch. xxv. Naum. 66. 1.

Legnagyobb; szárnyai ala felıér; igen szereti a lépgyümölesöt, s ezen ćlósdi növényt elültetui segiti.

2. A fenyös húri. (Fenyörigó: F. La Litorne. Turd. pilaris. Lin.) Fnl. 490. Frisch. xxvı. Naum. 67. 2. Die IV acholder Drossel. Krammetsvogel.

Az clółsbitül leginkílbb abban különbözik, hogy feje s nyaka fóle hamvas.

3. Az éneklö Túri. (Éneklö rigó. F. La Grive propr. dite. Turd. musicus. Lin. Die Singdrossel. Zippe) Enl. 406. Frisch. xxvir. Naum: 66. 2.

Szárnyainak alja sárga; ez legjobban énckel s czt leginkább eszilk.

(') Shaw urral azt Jehctne gondolni, hogy a sziberiai szajkóval összezavarván, adá ncki Linnacus a rövröpök tulajdonságait, majd Coruus, majd lanius infaustus, néven nevezi.

A sziklai rigóhoz hözclithetök: le rocar Vaill. Aft: 101 és 102 ; - $L$ 's espionneur, แa 103.

A magános rigóhoz hözelitó idegen fajok: turd. manillensis. enl. 636, hihetóleg turd. violaceus, Sonn. deuxième Voyage, 
4. A boros hiri (csipegö rigú, boros r. F. Le Manvis. 'Turd. iliacus. Lin. Die hothdrossel. IV eindrossel.) Enl. 51. Frisch. xxvin. Naum. 67. 1.

Legkisebb, száruyai ala s oldalai verhenyök. ( $\left.{ }^{1}\right)$.

A rigó nembeli idegen madarak igen számosak. Mi fóképen megnevezzül

a sokszavu rigút. (Le Moqueur. 'I'urd. polyglotıus Lin.

Ejszak-amerikai faj, fölül hamvas, alul halaványabb. szárnyán fehér folttal. Jeles azon meglepö könny üségérül, mellyel nyomban küretni tudja más madarak énekét, söt. még minden hallott szarat. $\left({ }^{2}\right)$.

cvin. rl. - Turd. eremila, enl. 359. Turd. zarius. Horsf. Myiothera Andromedae. Tem., col. 392.

(') Még, noha igen ritkán, Némethonban két faj találtatik: a zerhenyes foleos hitú s oldalu hüri. Turd. Nuumanni. Naum. 68. 8 a fekete torkus melï hür. Turd. Bechsteinii. Naum. 69.

$\left(^{2}\right) T$. orpheus (Le petit moqueur), Edw., 78.; - T. dominicus, (le moqueur de Saint-Domingue.) enl. 553, 1. igen közelick Lozzá, szinte mint a $T$. gilıus, Viel. Am., 68.

A. h. a foltos mellii vagy testalu idegen rigókhoz: T.rafus, Gm. enl. 645, és Vieil. Am. 59. - T. fuscatus, Viel. Am., 57. bis, - T. minor. Gm. vagy T. mustelinus. Wils. (Grive tannée v. gr. solitaire.) Vicil. Am. 62 is 63 ; - T. interpres. Kuhl. col. 458.

Csupán foltos torokkal, legaláhb a vén: 'T' migratorius L. enl. 556; Catesb., 29. Vieill. Am. 60, - 61. - T. ochrocephalus, col. 156. - T. plumbeus, enl. 560. Vieil. Am., 58; T. Falclandiae, T.; - T. olivaceus, Gm.; le grivron, Vaill. Afr. 98; - $T$. campestris, pr. Max.

Csupán foltos oldalakkal, T. punctatus, Sh.zool. nov. Holl. I, ix. 1. melly $=$ crsclosoma. Vig. és Horsf. Trans. Lin. xv. 219.1.

Az alul nem foltos idegen rigók köziil : $T$. brasiliensis, Lath; - perspicillatus; - T. melanotis v. réclameur, Vaill. vagy $T$. zociferans, Zool. ill. 179 ; $-T$. naevius, Vieill. Am. $66 ;-T$. $l_{i}$ riduus v. chat-bird. Wils, 14,$2 ;-T$. citrinus, Tem. col. 445; - T. rubripes, ua 409. - T. leucogaster, enl. 648,$1 ;-$ T. ma- 
Némclyck e madarak közül a gébicsekhez látszanak szohúsaik által szitani, a nélkül hogy csorrok idoma óket mảs rigóktul megkülönböztetné. ( ${ }^{1}$ ).

Észrevehetơ bélyegeknél fogva nem különböztethetni megr némelly afrikai rigólat, mellyek számos és zajgó csapalolsban éhnek cgyiül mint a seregélyek, s bogarakat üldöznek vagy a kertekben nagy kárt okoznak. Köztök sokian jelesek tollaik ragyogása által, mellyek színe acélbarna $\left({ }^{2}\right)$, s ezek közül egyik faj elvágott s testénél egy harmaddal nagyobb farka által tünik ki. ( $\left.{ }^{3}\right)$.

dagascariensis, enl. 557, 1. - T. Australasiae, Sh. Nat. misc. 1015; - Malurus frenatus, Tem. col. 385; - T. pectoralis, enl. 614 , 10. Ezen utolsó három fajat roszul szúmlálta Buffon a hangyazízokboz.

Jegyz. A turd. aurocapillus, Lath. enl. 398, 2. és Vieill. Am., 64. (Motac. aurocap. Lin.) igazi billegtetó s a zenérekhez tartozik; $T$. calliope, Lath., Syn., suplém. czim-ábra a veresbegyüekhez való; - a turd. cayanus, enl. 515, tanagra dominica nósténye, enl. 156, 2. mellybül Vicill. a Dulus-palmarum-ot képzé. gal. 146.

(') Már a gébicsełnél szolánk némelly, rendesen a rigókhoz tett fajokrul, millyenek: Turd. zeilonus, enl. 272. Ugy látszik ide közelít még: a T. cafer, enl, 563. Vail. 107. melly igen keveset különbözik, még szinében is, a Lan. jocosus-tól, enl. 508. E két faj magával huzná a $T$. capensis-t, enl. 317. Vail. 105. és a T'urd. crysorrhaeus t Tem., Vaill. 107.

Más oldalrul nehéz a zeilosusutol elszakasztani a hausse-col noir-t, Vaill. Afr. 110, s a cravate noire-t, ua. 113.

Jegyz. A gébicsekhez közeli rigókhoz számlálandó még: Muscicapa carinata, Swains.; 1]. zool. 147. mellybül Vigors és Horsfield a MoNARCira nemet csinálták.

$\left({ }^{2}\right)$ Kiváltképen a : Turd. auratus, enl. 450. (nabirop. Vail. Afr. 89.) és T. nitens. enl. 561. (Couigniop. Vail. 90.)

Ide jönek míg: $T$. crysogaster. Gm. $L^{\prime}$ oranvert, enl. 318 ; - T. bicolor. Gm. Spreo. Vail., 88 ; - T. morio. Le jaunoir, enl. 199. Vail. Afr. $83=$ Corz. rufipennis, Sh. s hihet8Ig $L^{\prime}$ éclatant, Vail. 85, és Le Choucador, ua. 86 ; = Cor\%. splendidus. Sh.

( ${ }^{3}$ ) Turd. aeneus, enl. 220. (vert doré, Vail., 87.) 
Ugy réljuik ill van helye

Az uj guineai rigri-nak (lie Merle de la Nonvelle-Guinée. Paradisaea gularis. Lath. el Shaw, Par. nigra. Gm.) Vail. Ois. de Par. 20 és Vicll. Ois. de Par. vill. rl. et Galer. 107.

Firkil hírumszorta nagrobb teslinch, lején két Lollbub, mellybül paradiz-madaral csuk Lollai különösségecirt. s hasonlíthallan pompájaért csináltak. $\left({ }^{1}\right)$.

Más raggoga tollazah rigohual a lejhat tollai heggezettek mint a seregélyeké, ezek

A Ridgoh. (Les Stournes on famprotornis. Temm. (2).

Mís rigólinale csorra viszont olly karesu, $\log y$ a sziklabilckhez közchítenck; czek

^ nuricsok. (Les 'Iurdoides ou Ixos. Temm. ( $\left.{ }^{3}\right)$.

Másoknak esorra vékony, de egyenes és erós, s crek Läzt jo szimmal igen-iģen villís liurduak vammak, neviok:

RIógébeK. (Les Enicures. 'Tem. Oenicurus) ( ${ }^{4}$ ).

Vannali mog labaik magassiga illal kitünök, s immit a gázlók idomát hazudók, ezck:

(') Viellot e madirnak illy nemi nevet ada: IsTuspid.

(2) Turd. mauritianus, Gm. cul. 648, 2. Col. 149; T'. cantor; Soun prem. Voyage, Lxxu1. H; Lomprotornis metallicus. T'emm. Cul. 266. Megkülönbözletendó volıt: Lampr. erythrophris, szép veres samöldökeiéat, mellyetiet poreus tullak hépzenck.

(3) Illyenck: 'T'. erythropterus Gm. (Le podobé) cul. 351 ; - A ianfredic, Vail. Afr. $111 ;-1$ grivetin, ua. 118 ; - A coudor, แa. 119 ; - a turd. tricas. cul. 709, 2. - A turd. orientalis. Gu. (le terat-boulan.) eul. 275, 2. (-zen csoprortut as earyenes csorru gebicsekhez vezeti.

A. L. Ixos calcocephalus, Gem. Col. 453. I. I. squammatus, no. 2; - R. atriceps, cul. 157. s fóképen T. dispar, col. 157. melly torka alatt veres porcos tollukat bur, mint száriytoldalékain i locsha.

(") Aenie, coronatus. Tcmu, col. $11 \overline{3},=$ Turd. Lescheraultii, 
A Hurafzok (Les grallines, M. Vicill.; gal. 150, Tanypus, Oppel. Mém. de l' Acart. de Munich, 1812. vin. $\mathrm{rl}$.

A csönöxszönek (Les ('rinons. Criniger. 'Ten.) olly rigcik, meliyeknck csorrsaürei igen crösck, s tarkútulaik néha selyembe rógzödók.

Illyen :

A szakílos csürönször. (Criniger barbatus.) Col. 88.

\section{A IINGYÁROK, (IIANGYAZUZOK.)}

(Les I'ourmilliers. Myothera. Ilig. ('). Ameisenfänger.)

Buffou által méltán választattak el a rigóktul.

Ismerhetök magas lábaikrul s rövid farkokrul. Bogarakkal s fóképen hangyálkal élnek. Mind a kíl szárazon találtatuak.

Azonban a régi száraz fajai tollazaluk dlénk szine álLal jelesck, ezck Buflommál nRévess nevet kaplak, I icllotul prTra nevet, s magyarul mosgönös-eknch: mundhatók. Ide taztozó faj

A rövidfarku hansyöröly. Corvus brachyurus. Giu. cul.

257, s 258 Eáw. 221, mellyhez ulóbb több szép liaj adaték $\left(^{2}\right)$. (Europában egy sem labaltatik.)

Ide adaudó még:

A kék hangyöröly. (I; Ausurin, Turd. c)anurus, Lath.

Vieill. gal. $115,=$ Motac. speciosa, Hors.; - Aenic. velutus, $\mathbf{1}$. col. 160. Hasouló joggal közehtenck az egyenes csorru gebicscklicz.

(') Vieillot e bevet mrrotiERA-ra vílioztatí.

(") Illycuek : Pitta erythronaster, Cuv cul. 212; - P. gigas, T cu. col. 217; - P. cyanoptera, ui. no. 218.; - P. superciliosa, C. - P. strepitans. Leadheater, col. 33.5.

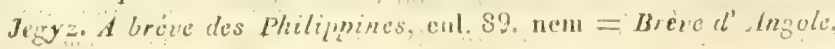


et Gm. Corv. cyenurus, Schaw.) Ful. 355. (') molly amaltul csak hegresre vígoll fark által különbäzik.

Az új szíraz sokkal szímosabb fajai, barnább szimïck, s csorrok crissigge s hoss\%a külïnbözö. Ezcn vilígrész tomerdek naģ ságu erdei s puszlai hangyaijival élnek: a nistenyeli naggobbak a hímeknil. Kereset repuilnck, szarok hangus s némelly fijoknál rendlivïili is.

A raslag hajloll (sommali lïzölt megielelendö: A kircilyi hangyörüly. (Le Roi des formilliers. 'Iurdus

rex Gm. (orv. grallarius. Shaw.) Enl. 702. Der Ameisenkönıg.

Minduyajok liöa legnagyobb, legmayasb lábu, legrövidebb farku; elsij pillanalla gazhlimali mondanád; naggsigat mint a fiirje s szïrke tollazati hellemesen larkizoll. Sokkal magánosabban él mint a többiek. $\left({ }^{2}\right)$.

Az egyenesebb de még elig crós csorruak a hasonló csorru gébicsekhez közclítenek. $\left({ }^{3}\right)$

Edw. 524, mint liall. monlta, - mellyre rigó-fejet tettek. Én a tormészetben láttam.

(') A kék hangrörïly. nem Cayennebiil valo, mint Buflon mondá, hanem Keletindiałul. Ez a pitta cyanura, Vieil. 15.5. A h. Myiothere affinis. Horsf. sỏt még a Turd. cyuneus is, melly = bréze bleuce, Tem. col. 191. melly azonban az egyenes csorru gébicsekhez vezet.

A Pitta thoracica, Tem. col. 76. melly szerint Horsfield és Vigors urak a THIMLIA nem ábráját álahiták, kevéssel távozik el a kék hangyorrilytül, kivévén homályos szinok s elore egyenlön kisebbülz csorrok által, a mi sket a verebélyekhez vezeti.

$\left({ }^{2}\right)$ E madárbul csinálta Vieillot a grallarra nemet, gal. 154. A. h. Turd. tinniens. (le grand be(Jroi) enl. 706. 1. mellybül Vicillot a MYотнеra nemet képzé: csorra kisebb, - Myrmothera guteata, Vieil. gal. 155.

$\left(^{3}\right)$ Illyenek: Turd. colma B. (le tetema) enl. 821.; - turd. formicivorus (le palicour) enl. 700. 1; - turdus lineatus (le petit beffroi) cul, 825. 2; -(thamnoph. stclluris Spix. 39 ; thamn. mro- 
Másoknak csorra vékony és hegyes, s ez okbul és mivel farkok vonatolt, a csaláncsattogatókhoz közelítenek. $\left({ }^{2}\right)$.

A zuzgárok (Les Orthonix, 'Tem.) szinte a hangyárokhoz közelitenek. Csorrok mint a rigóké de rövid és vékony, lábaik magasak, körmeik majd egyenesek, s kiváltképen farktollaik hegybe végzódók mint a kúszóknál.

A rigóktul szinte elválaszatandók:

Łherinus. ua. 42. A $M$. Leucophris, Tem. col. 448, noha Javábul, mégis e csoporthoz látszik közeliteni. A Brachypterix montana, Horsf. Jav. szinte közelit hozzá lábai nagysága által, de farka arányilag hosszabb s csorra a sziklabiléhez hasonlit.

(') Illyenek a turd. bambla, enl. 703; - turd. cantans. ( $L$ ' arada.) enl. 706, 2. Ide jö a Ramphecène nem, Vieil. 9.12S.

Azonban több fajt a rigókhoz kell visszavinni, mellyeket Buffon a hanzy-örölyökhöz telt némelly színhasonlatosság miatt; illyenek, név szerint: $T$. tintinnabulatus (le carillonneur). enl. 700,$2 ; T$. cinnamomeus (Le merle à cravate) enl. 569, 2; az Enl. 644. rajzlapján lévöket (1, és 2), mellyeket o a Palicour fajtáinak vél, minđen hihctőség ellen. Ezen sorsunak mondom még: a thamnoph. griseus-t Spix. $48,1 . \mathrm{s} 4 \mathrm{I}, 2$; - a striatus-t, ua, 40,2 ; - melanogaster-t. ua. 43, 1. - A myothera capistrata melanothorax, Tem. Col. 185.

Kicsinségök daczára is a rigókhoz számlálandók a hosszúfarku fajak, mellyeknek Buffon e nevet adá: fourmilliers rossignols. (Turd. coroya. et $T$. alapi. Gm.) enl. 701. szinte mint a myothera malura,) Natterer. col. 353. s a M. ferruginea, et rufimarginata, col. 132. közel lévok a $T$. punctatus és grammiceps-hez; - a $M$. gularis és pyrrhogenis. Tem. 442, 448 .

A M. mertalis és strictcthorax, Natt., col. 179. véleményem szerint a gébicsekhez tartozik. Semmi csoport sem terheiteték anuyira változandó fajokkal meg, mint a hangyároké. De meg is kell régre vallani, hogy nincs szigorubban kihatárjelelve mint a csorr foguak többi csoportjai. 


\section{A VIZTENGÉLYYE. (ARRIÓK.)}

(Les ('incles. Cinclus. Bcchst. $\left({ }^{2}\right)$. Merles d' eau. Y'izirigúk.

$$
\text { Wasserschwäzer.) }
$$

Csorrok összenyomott, egyenes; lemezei egyenlön magasak, majd ronaluak, hegyök felé csúcsosodnak, a felsö alig ivelt.

Nálunk csak egy van:

A seregely cirrió (viztengély). Sturnus (inclus. Lin. Turd. cinclus. Lath.) Enl. 940. Vieill. Galer. 152.

Lábai lissé cmclele, farka elég rövid, mi okbul a hansyárokhoz liozclít. Barna, torka s mele fehérck, s azon különös szokisa ran, hogy egészen lemegy a rizbe, nem uszra, hanem a fenclien júrra, ott azon apró illatokat keresö, mellyekbül él.

Afrika s az indiai tenger-melleki tarlományok líplitnak egy a rigrikhoz szomszéd madírnemet, mellynek ueve nálam:

\section{IIÚRszi. (Pliziedon.) ${ }^{2}$ ).}

Csorrok összenyomoll, egész hosszában könytiden ives, hegve kïzelén kimetszell; orrlyukaik nagyok, porcképü pikkelylyel takarrak, nyelvök ször-ecsetbe régzödö.

Fajaik, tübbnỵire némelly alkatási különösség miatt kitünók, a szerzók által mindenfúle nemek közé hányattak.

(') Vieillot ezen nevet erre változtatá: HYDROBATA.

(2) Commerson a Polochion-t (merops Moluccensis. Gm.) akará igy nevezni, melly e nemhez tartozik. L. Buffon. Hist. des Ois. VI., (4-rétb.), 4\%. lap. Tieillot ezen madarak legnagyobb részébül a Polochron nemet képzé, s azt latinul inkább szercti Philemon, mint Philedon néven nevezni, gal. 189. Lewin Mr.trmaga neme szinte majd egészen a húrszi nembe fér. 
Vannak esorraik végén hús torongyosak. ( $\left.{ }^{1}\right)$.

Némellyeknél legalább a bör egy része megr van az arcon tollaktól fosztva $\left({ }^{2}\right)$.

Még azoknál is, mellyekuél semmi rész sem csupasz, néha móg kuilönös elrendelést venni a tollazatban észre. $\left({ }^{3}\right)$.

(') Ide -jỏ egy új hollandi madár, mellyet Daudin, Ornith., II, Xvr. pie à pendeloques nevezett, $=$ corvus paradoxus, Vieill. galer. 94., = merops carunculatus, Phillip. Latham. és Schaw., de mellynek labai nem gyurgalagéi, csorra kimetszett, nyelve ecsetü, orrlyukai szóretlenek. - A sturnus carunculatus, Lath. és Gm. v. gracula carunculata, Dand. és Schw. (Lath. Syn. III, Xxxvi.) és Certhia Carunculata. Lath. és Gm. (Vieill. Ois. dor. II, rl. Lxix. szinte, mint látszik, ide tartoznak. Ezen utolsó, ugy mondják, csudálandólag énekel s az Amis srigeteken lakik. Ezen alosztatbul csinálta Vieillot a Creadion nemet, gal. 94. melly $=$ ANTHochera Swaison, ki hozzá teszi még a Mlerops phrygiust, stb.

${ }^{(2)}$ A merops phrygius, Shaw. Gen. Zool. Vlli, $\mathrm{xx}$; - le gorack, Vieill. (C. goruch, Sh.) Ois, dor., II. Lxxxvin; - le fuscalbin, ua. uo. Lxi. rl. (C. lunata); - le craculé, ua. no. rl. Lxxxvir. (C. craculina); - le polochion Buff. (merops moluccensis. Gm.); le Ph. à oreilles jaunes, Less, Voy. de Dupperrey, 21. rl. 2-szer. s némelly új fajok ez osztathoz tartoznak.

$\left({ }^{3}\right)$ Nevezetesen a merops Novae Hollandiae-nál, Gin. et Brown, 1H. IX. = merle à cravate frissèe Vail. Afio, v. merops circinatus, Lath. et Shaw. Gen. Zoul. VIII. rl. Xxir. Fültollai bodoritva majdnem mele elébe jutnak le. - Melliph. auricomis, Swains. Zool. ill. 45. 1 .

A. h. Certh, auriculata, Vieill. Ois. dor, 85. C. novae Holiansliae, uo. 7.

Ł nemnek illy különösség-nélküli fajai : Certhia xantotus, Sh. Vicil. Ois. dor. II, 84. rl.; C. australasiana, uo. 55 ; - C. mellivora, ио. $86 ;-C$. caerulea, ио. $85 ;-C$. seniculus, ио. 50. Magam is azt hiszem, hogy a cap noir, Vieil. 60. (Certh. cucullaเa, Sh.) ide tartozik, noha hosszu csorru; Merops niger. Gm. v. fasciculatus, Lath. v. Gracula nobilis, Merrem. Beyträge 1. Cs. r. r.l. melly més hihetỏbben ide való. Semmi esetben nem lehet Gíur gyalag. A hurszik közé teszem még - a cochinchinai hurszit, 


\section{A TARRIÓK.}

\section{(Jes Mainates. Eulabes. Cuv.)}

Igen közel vanuak a hurszilshoz. Csorrok majdnem mint a rigúé; orrlyukaik gömbölyük, egyesültek; megliülömböztetnek széles és esupasz börtorongyaik által fejhátok mindenik oldalán s egy liopasz hely által arcokon.

Linné lièt fajat zavarí össze a Gracula religiosa név alatt. ( $\left.{ }^{1}\right)$.

\section{Az indiai tarrió (Eul. indicus.) Enl. 268.}

Rigó nagyságu, fekete, fehér folttal szárnya nagy tollainak alaptajján. Lábai, csorra s feje csupasz részei sárgák.

\section{A joivai larrió. (E. javanus.) Vieil. gal. 95.}

Csorra szélescbb, szeltebb, végén horgas és kimetszetlen. Küretkezóleg a szalakítílihoz rolna helyezeudö, de különben egészen hasonlit az clöbbihez s leginkább fejének csupasz torongya által. $\left({ }^{2}\right)$.

(Verdin de la Cochinchine.) enl. 643, melly a második Turd. malabaricus, 125. sz. Gmel. (mert az elsỏ, 51. számu, csacskír.) és a certhia cocincinica-t, sh. Viel. 77 és 78. - A. h. Philéd. cap. nègre, Tem. (Cert. atricapilla. Lath.) col. 335, I; Philéd. moustac. (melliph. mystacalis, Tem. uo. 2. - Philéd. grivelé (tarka hürsi, Melliph. maculata, T.) col. 29,1 ; - Philéd. reticulé, (Mell. reticulata, uo. 2.; - a fehér pofu húrszi (Phil. à joues blanches (Melliph. leucotis. col. 435; - Philéd. Dumerilii, Foy. de Duperr. $\mathrm{XX}$. rl. s talán a turdoide à tète blanche is. Ruppel. av. 4.

(') A religiosa nevet ę̧y különös tulajłlonságért adák neki, melylyet Bontius elbeszél (Méd. Ind. or., 67. 1.); de természeti szokásaitul idegen. Én nemi nevét görögre forditva csináltam.

${ }^{2}$ ) A módszercsinálók elött semmi sem lchet kétségbeejtobb mint a csorr különbözése az ennyire hasonló madaraknál. 
Azt mondják, ezen madár mindenck között legjobban utánozzá az emberi nyelvet.

\section{A csАсsка́rok. (Csacskamadár. Földi.)}

(Les Martins. Gracula. (").

Még a rigókhoz rokon nem; Afrikában s az Indiaitengerre fekvö vidékeken lakik. Csorrok összenyomott, igen kissé hajlott, könnyüden kiszelt; oszbúcsa szegletet képez mint a seregélyelknél. Fejtollaik majd mindig keskenyek, s szemeik körül csupasz tér van. Szokásaik mint a seregélyeké, s mint ezek, nagy csapatokban repülnek, bogarakat úzve.

Egyik faj néha Europában is látható:

A rossasain csacskár. (Le Merle couleur de roses. Turd. roseus. Lin. Pastor roseus. Meyer. Merula rosea. Naum. 63. Enl. 251. Vail. Afr.

Fényes fekete; háta, farcsika, válla s melle halvány rózsaszín; fej-tollai keskenyek, és búbba kinyúlók. Nagy szolgálatot lesz a hév tarloınányokban, a sáskákat pusztíva. $\left(^{2}\right)$.

A sáskaevö csacskir. (Gracula gryllivora. Daud. Paradiscrea tristis. Gm. Gracula tristis. Lath. et Schaw.) Enl. 219.

Hasonló remü szolgálatáér lön nevezetes, mellyet ll-de France szigeten tön; különben mindent eszik, pálmafákion fészkel, könnyen szelidíthetö s tanítható. Rigónagyságu, szine barna, fején feketés; egy folt a szárnya eleje felé, hasa alja s farka oldal-tollainak hegye fehérek. $\left({ }^{3}\right)$.

(') Vieillot e nevet CridoturRes-re változtatá, galer. 148.

(') Elso̊ kialásum óta megbizonyodtam a rózsaszín csacskár éz a csacskárok nembeli rokonságárul.

(') Nehezen foghatni meg, mint csinála helole Linné patadiz- 


\section{A CSACSOGÁK.}

\section{(Les Manorhines. Manorhina Vieill.)}

Csorrok igen üszenyomoll, kissé ivelt, gyöngén kimetszett, orrlyukaik nagjok, de nagy részint esak egy keskeng hasadéliot hisgo hórlyáral zárvák; nyakok rö-

madarat. E nemliez tartoznak még Gracula cristatella, enl. 507. is Edw., 19, melly alig fajtája a rendesnek; - a jorte lambeaux, Vaill. Afr. xcill és xcIv. $=$ gr. carunculata Gm. vagy gr. larrata, Sh. vagy Siurn. gallinaceus, Daud.; - Turd. pagodarum (le martin-brame) Vail. Afr. 95. Vieil. gal. 148. Az elsö $T$. malabaricus, a ' $T$ '. ginginianus, a ' $T$ '. dominicanus, enl. 627.2 ; a martin gris de fer, Vail. Afr. 95, 1. és a Seurn. sericeus, Gm. szinte ide tartozók néhany üj fajjal még. Hozzávetöleg, ide teszem még. T'urd. ochrocephalus, Lath. (Sturn. ceylanus, Gm.) Brown. III. xxı.

Jegyz. Nem foghatui meg, melly typust csináltak Linné s hovetơi a GrACula nemräl. Limné cleinte, tizedik kiadásában - hét igen elválasztott fajbul képzé össze, mint: 1. Gr religiosa, tarió;

2. faetida, mellyet én nyakarsupnak s igy tehát selyeufarkuak szomszédának tartok; 5. Barita. 4. Quiscula, mellyek csoportályok. 5 iristatella, melly csacskár, 6. Saularis vagy inkább solaris, melly egyenes csorru gebics $\mathrm{s}=T$. mindanensis, Enl. 627, 1, végre? Arthis, melly rigó.

A tizenkettedik kiadásban hozzáadja a guolin-t (gracula calv'a), s a rendes csacskirt (rózsaszinït) a paradizárokhoz teszi.

Gmelin, Pallas szerint, hozzá teszi a G. longirostra-t. (carouge.) *) Ide teszi a torongyos csacskárt (gr. carunculata, le martin porte-lambeaux) a rendes csacshárt a paradizárok közt hagyva; ide tette a gr. cayennensis-t (le picucule), melly fakúsz. Lathan ide hozla ált a sáskaeró csacskárt, a csupasz csacskárt (col. nu, grac. nuda) s egyet az én hursziim közúl (Grac. icterops). **) Utóbh Daudin olly fajokat ada a csacskirokhoz, mellyck valóban hasonlitanak hoz,ájoh, mellyek hozul Gmelin hettót a huriknál hagya (Turd.

\footnotetext{
*) Én nem ismerem Pallas Gracula sturnina-ját.

**) Sxintugy nem ismeren a Grac. melanocephala es viridis-t $L a$ tham. - de vélem, hony hurszi-imhoz tartoznak.
} 
vid. Homlokuk tollai puhák mint a fiatal madaraknál, részint az orrlyukakra jónek. (').

\section{A zAJGÁroK (huroshollók).}

(T.es Chocards. Pyrrhocorax. Cuv. ( $\left.{ }^{2}\right)$ Steinrabe. Steinkrïhe.)

Csorrok összenyomott, irelt és kimetszett mint a rigókié; de orrlyukaik tollakkal fedvék mint a hollóknál, mellyekkel sok idón ált egyesíttettek.

Nálunk van egy faj, csóka-nagyságu, A havası zajgair. (Le Chocard des Alpes. Corv. Pyrrhocorax, L. Die Shneedohle.

Egészen fekete, csorra sárga, lábai eleinte barnák, aztán sárgák, a felnóltben reresek; az igen magas hegyek szikláinak repedéseiben fészkel, honan télen nagy csoportokban jö le a völgyekbe. Bogarakkal, csigákkal él, megeszi a szemeket és gyümölcsöt, s a dögöt sem veti meg.

Indiák̇ban egy másik vau :

A pusztacsökü zajgair. (Le Sicrin. Pyrth. haxanemus. Cuv.) Vail. Afr. Lxxxr. rl.

Három szakállatlan csök által különbözik, mellyek olly hosszak mint teste s mindenik oldalon a füleit takaró tollak közt állanak ki.

pagodarum et malabaricus.) Shaw. végre teljessé tete a nem furcsasáyát, még három varjugebicset téve hozzá (Gr. Strepera, varia és tibiccn-t) és a talapiot-ot, inelly fakúsz, vagy favágály (grac. picoides.) Az való $\operatorname{logy}$ az igy összerakott ncmek menthetik vagy inkább igazságosítják a rendszerek ellenségeinek szeszélyét. L. Lich. tenstein emlékiratait, a berlini academiánál. 1817.

(') Manorhina viridis. Vicil. gal. 149; Merops albifrons, Shaw ?

(?) Virillot vette föl ezen nemet is nevet. 
Nem találok semmi clegendö bélyeget, hogy a rigóktul elválaszthatnám

A rALód Loniók-at. (cranylbegyek F. Sägarigók.) (Les vrais Loriots. Oriolus. Lin. Die wahren Pirol.)

Csorrok hasonlú a rigókéhoz, csupán egy kissé erösebb, lúbok lissé rüvidebb és szárnyaik arányilag egy kissć hosszabb. Limé és több liövelöje elég rosszúl cgyesiték oket a csoportályokkal, mellyekhez csak szinök altal hasonlítanak.

A sairga lorió (scirga arangybegy. Földi). Le Loriot d' Europe. Oriolus galbula, Lin. Gm.) Merle d'or. Arany málinkó. Pirol. Goldamsel.

Kissé nagyobb a rigónal. A him szép súrga, szárnyai. farkia is egy foll a szem s csorr közl feketék, farlsa rége súrga: de elsö liét érében, mint a nóstény egész életében, a súrga loclyét olajszin foglalja el, a folieteét barna. Eacn madir mestersiges fészliet alsaszl föl a fákra, cscresnyét és egyeb gyumölesöt eszik, tavaszszal bogarisz; fö́nkl, nálunk csak rövid ideig mulat a szép érszaliban: másod-harmad magáral utazik.

Fajtíja az arany lorio (Or. aureus Br. Der Goldpirol), melly Brehmnél. a xI. rl. a 4. képen szépen van festre.

Inciában a mienkliez igen hasonló fajok ranuak ('): de e szimban a többick fölöl megkiülüböztetendö:

Az urasigos lorio. (Or. regens, Le lorio prince regent.) Col. 230. Sericula regens. Less. Melliphaga regia. Lewin, Sericulus. Chrysocephalus, Swaison.

Legszebb selyemfekete, szép biborféle narancs-sárga

(') Oriol. chinensis. enl. 570; - or. melanocephalus, enl. 79, จ. a loriot rieur. Vail. Afr. 263 ; le loriot d' or. Vail. 260 ; Viell. 
tollakkal a fején és nyakán, s hasonló szinü nagy folttal a szárnyán. ( $\left.{ }^{1}\right)$.

\section{A LoRICSUPOK, (Csupaszfök.)} (Les Goulins. Gymnops. Cur.)

Csorrok erös mint a lorióké, orrlyukaik kerekck, pikkelyek nélkül, hárlya-szegéstelenek, s fejöl nagy része tollaktul fosztolt. $\left({ }^{2}\right)$.

Némellyeknél emelkedések vannak a csorron $\left({ }^{3}\right)$. Ezen utolsóknál a nyelv ecsetidomu mint a hursziknál.

\section{A LANTÁROK.}

\section{(Les Lyres. Maenura. Sh. Leierschwanz.)}

Nagyságok miatt némellyektól a tyukokhoz számláltattak, de világosan a verebüekhez tartoznak elvált ujju lábaik miatt (kivévén a külsö és közepső uj elsö izét), a rigókhoz közelítenek alapon háromszegletü, hoszult, kissé összenyomott s végén kimetszett csorrok által; hártyaféle orrlyukaik nagyok, s részint tollal fedvék mint a szajkúknál. Megkülönböztetnek a him nagy farkánál fog-

gal. 83 ; le coudougnan, Vail, 2, 61; - Or. xanthonotus. Horsf. Jav.

(1) Lesson. (Voy. de Duperr. xx. rl.) nơ gyanánt egy húros szinii madarat ad nek:, igen különböző arányút attól.

$\left({ }^{2}\right)$ A kopasz loricsup, (Grac. calva, Gm. Le goulin gris), enl. 200; a zöld loricsup (le Goulin vert, mino Domuntii, Less.) Voy de Duperrey, xxv. $\mathrm{H}$; - az alajszin loricsup (Le Goulin oli2e, Grac. cyanotis, Lath. merops cyanotis, Sh.)

$\left({ }^{3}\right)$ A corbicalao (melly Swainsonnál a Tropidorynchus nem) Vail. Ois. d' Am. et des Indes, pl. xxıv. (Merops corniculatus, Lath, et Sh.), és egy szomszéd faj, mellynek nagyobb torongya a homlok felé irányzott (Mer. monachus, Lath.) Ezen két új hollandi madár nem szarvály, sem gyurgyalag, me^ł külsỏ ujaik nen ragadtak jobhan öszve mint a legközönsönsésesh verebekuél. 
va, melly híromf'le tollairul nerezetes; "gyanis a közönséges tzenkét szál ıgen hosszú, szakálla elvált s igen tárol álló azon fölül középen keltö ran, esak egy oldalán biro sürii szakízllt, a két szélsö $\mathrm{S}$ görbulést mutat, mint a lantnak ága, mellyek belsö szakálla nagy lömött és széles szalagot mutat, a kïlsó ig̨en rörid s esak a rég felé szélesül. A nönél esali rendes alliatú tizenkét toll van.

Az ij hollandi lantir. (Maenura lyra.) Vieil. ois. de parad. xIV. xv. rl. Galer 192. Sh. Nat. misc. 577.

Különös faj, - Uj Hollandia sziklás vidékein lakik; nasgságra valumirel lisebb a fácámuál.

\section{A Billegtetö. Földi. (BIL-ok.)}

(Les Bees-fins. Motacilla. Lin.)

Rendkirül számos családol liépeznek, megismorhetót egyenes, réliony, áridomu csorrárul, melly midön alapján kissé lenyomott, a liggkapókélız hasonlit; midön ̈̈sszenyomoll s hegye keressé viszszagürbül, a\% egyenes csorru gebicsekhez vezet.

Következö módon kisérték föloszani óket.

\section{A SZIKLÁROK. SZIKLABILOK.}

(Tes Traquets. Saxicola Bechst. ('). Steinschmätzer.)

Csorrok kissé lenyomott s alapján lissé széles, a mi okel leginkabb) a légykapók utolso kis törzsökéhez köli. Fíénk madarak, elég magas líbakkal. Az itteni fajok a földön ragy füldalatt fészkelnek, esak bogáral duek.

Nálunk három van:

1. A feketetorku sziklir. Tranquet. Motar. rubicola. Lin.) Enl. 678. Naum. 90, 3. 1. 5.

Apró barna madár, mele veres, torka fekete, nyak-

(') Vicillol e nevel OENANTuE-re (Motteux) rállozlatá. 
sldalán, számyán és farcsikán fehérrel. Szünetlenül ugrail a cserjeken, bokrokban, s lassu kiáltása van, a malom liklak hangiálioz hasonlító, s innét ran a franczia neve.

2. A fekele-pofu sziklár. (Le Tarier. Mot. rubecra.

Enl. u. 0. 2. Naum. 89. 3. 4. Der Braunkelchen.

Igen hasonlít az elsöhöz, de a fekele szin torka helyelt arcán van. Kissé nagyobb, s többet van a földön.

3. A hont sziklir. (Hontmadar. Föld. Le Motteux, ou Oul-blanc. Mot. oenanthe.) Enl. 554. Naum. 89. 1. 2.

Farcsika s farka oldalainak fele fehér. Hime folül hamvas, alul verhenyes fehér, szárnya s szeme fölölt egy folt fekete. A nö egész fölül barnás, alul verhenyes. Ezen madár a szántás alatt léró földeken tartózkodik, hogy a barázdákbul kiszedje a föltakart férgeket (kukaczokat).

Meg kell tóle különböztetni.

4. A verheny sziklir-t (Le motteux roux. M. à gorge noire. Buff. Saxicola strapasina. T.) Naum. 90. 1. 2.

Dél europai faj, ki néha minket is meglátogat. (Az Cöbbihez némileg hasonlít. A him feje, nyakelöje, válla s szárnyai feketék; fejtetöje, farcsika s hasa fehćr; nyakháta s egész hála rozsdaveres. V.)

A sziklabilokhoz közelíl cgy dél-francziaországi madár, melly fekete, faresika s farka felsó két negyede fehér, elöbb a rigól közé tétetell. Ez a Turd. leucurus. Lath. Synops. II, 38, rl. ('). Saxicola cachinnans. 'Tem).

(') Add a fekete torku sziklárokhoz: Mot. caprata, enl. 255; mot. fulicata, enI. 185,1 ; - mot. philippensis, no. 2 ; - le patre Vail. Afi. 180. 1.

És a hont sziklárokhoz: mot. leucothoa, enl. 583. 2 ; - l' imitateur. Vaill. Afr. 181. ua.; - le familier, ua. 185.; - le montagnard, иa. 184; - leformillier, 186; - mot. leucomela, Falc. 
A DALÁROK, DAIABILOK.

(Les Rubiettes. (1). Sylvia. Wolf ct Meyer, Ficedula. Beclis. Sänger.)

Csorrok csak kevéssel keskenyebb az alapján mint az elöbbielié. Magános madarak, rendesen lyukakban fészkelök, bogarakkal, férgekkel, bogyókkal élök. Nálunk belólük négy faj ran.

1. A veresbegyü dalcir. (Veres begyü billegtetö $\mathrm{F}$. Rouge-gorge. Mot. rubecula. Lin. Das Rothkelchen.) Enl. 361. 1. Naum. 75. 1. 2.

Fölül barna szürke, torka s mele verhenyes, hasa fehér; közel a földhöz fészkel az erdökben, kivánesi és barátságos. Némellyek télre is megmaradnak, s a nagy hideg idején a lakhelyre menekednek s ott igen hamar megszelidülnek.

2. A kékbegyü dalcir. (La gorge-bleu. Mot. svecica. Lin. Das Blaukelchen. Enl. 361. 2. Naum. 75. 3.4. 5. Kékbegyiï b. F.

Fölül barna, torka liék, mele verhenyes, hasa fehér, az elöbbinél ritkább, az erdök és mocsárok szélin fészkel.

Voy. III, xxx, és col. 257, 3. A. h. saxic. aurita, to, col. 257. 1; - S. monacha. col. 359,1 ; - S. deserti, uo. 2.

A mot. cyanea, Gm., Lath., syn. 11, LII. rl. csorra ollyan mint a feketc torku sziklárć s attul maga is csak kevéssel hosszabb farkával kïlönbözik. Yieill. gal. 163. Mérion, vagy Malurus nembe tette, mellyet utóbb minden hosszú s ikidomu farku madarak gyül. házává csinált, millyeuek a Merion bridé. Tem. col. 385. melly rigó ; a MI. natté, a $M$. leucoptere, Quoy, et Gaym., Voy. de Freycinet, 25. rl.mellyek a colious-hoz közelitenek, a fluteur Vail. (Mot. africana) Afr. 112, melly igen közel van a Synallaxes.hez.

(') Rubiette nevet hord a veresbegyü dalár némelly franczia tartományokban. 
3. A füstfarku dalair. (Füstfarku B. F. Le Gorge-noire ou Rossignol de muraille. Mot. phoenicurus. Lin. Schwarzkelchen, Rothschwänzchen.) Enl. 351. Naum. 79. 1. 2.

Fölül barua, torka fekete, melle, farcsika s melle oldaltollai világos veresek; ó falakban fészkel, édes énekü, melly némüleg a fülmile változatosságát mutatja.

4. A veres-farku dalair. (La Rouge-queue. Mot. ertthacus, tytys, gibraltariensis, atrata. Gm.) Edw: 29. Naum. 79, 3. 4.

Az elöbbilül különbözik, leginkább abban, hogy mele fekete, mint torka. Sokkal ritkább. ( $\left.{ }^{1}\right)$.

\section{A ZENÉREK, ZENEBTLOK. \\ (Les Fauvettes. Curruca. Bechst.}

Csorrok egyenes mindenütl vékony, elül kissé összenyomott; a felsö erös, a hegye felé valamennyire görbül. Ezen alnem legjelesb madara.

1. A dalabaij zenér. (Fülemuile. F. Dalabáj. Le Rossignol. Mot. luscinia. Lin. Die Nachtigall.) Enl. 615. 2. Naum. 74. 2.

Fölül verhenyes harna, alul fehéres szürke, farkán valamivel verhenyesebb. Kiki ösmeri az éjnek ezen bájos dalnokát $\mathrm{s}$ annak melodiás hangjait, mellyekkel az erdöket eleveníti. Fákon fészkel (inkább bokrokban) s csak addig énekel, mig fiai kikeltek. Azután az aprók táplálása a himet ugy látszik foglalatoskodtatni, mint a nöstényt.

Europa keleti részében (ncvezetesen Magyarországban

(') A h. a kekhátu dalár (Le Gorge-rouge à dos Blen. Mot. sialis.) Enl. 590; - Mot. Calliope, Lath., 1só pótolékk. homlokkép. 
és Lengyclorszighan) ran nagyobb fijtaja a dalabajnali. könyüden szürke foltos mellel, neve

2. Magyar dalabij. (Mot. sylvia-philomela, Bectst. Mot. luscinia major. L. Die Basturd-nachtigall. Ungarische Nachtigall. Naum. 74, 1.

(Az elïbbinél crösebben csallog. ()römest a fiuzesckben tartózkodik).

A többi fajok öszres neve (francziául) FAtverTes. zexín, 's majd mindnyaijinak kellemes dila, vidám erkölese van. ̈̈rökké repkednek a bogarak wán, bokrokban fészkcluck s nagy részint riz széleken, nádasokban stb.

fin egy elég nagy lajt teszck elöl, molly majd mindig a hurik közé számlíltaték (). Ez

3. I nidi zenér. (La Roussignol de riviere, stb. 'Iurd. arundinaceus. Lin. Sylvia hurdoides. Rohrdrossel.) Enl. 515. Naum. 81, 1.

Föliil verhenyes barna, alul sárgás, lorka fehér, szeme filüt cgy halaviny ronat; kissel kisebb a boros rigónál, csorra majd szintolly hajolt.

A kákásaliban lészliel, s majd esupa vizi bogarakat eszils.

4. A vizi zener (kis nádi zenér). La pehte Rousserolle ou Effarvelte. Mot. arundinacea. Gm.) Naum. 81. 2. Der T'eichsünger.

Szokísaira s szinére nézve hasonlít az clóbbihez, do egy harmaddal kisebb.

(1) Az idegen tartományokban közép fajok is rannah a nag̣y és kis nádi zenér között, s ez és a füzike között, ugy hogy véleményem szerint a nádi zenért el nem választhatri a zenérektiil, noha átlátom, hogy iģy majinem észrevehetlen átmenetel származik a rigúk és billegtetôk kozött, valamint ollyan van már a billegtetök és crgyenes csorru gebicsek, a rigók és hajlott csorru gébicsek kiizött. Mind e nemek szorosan fïgguek egybe. 
5. A füzike zenér. (Füzike. F.) La Fauvette de roseaux. Mot. salicaria. Gm. Enl. 581. 2. Der Binsensünger.

Elöbbinćl is kisebb, csorra aránylag rövidebb, fölül olajszin-szürke, alul igen halvány sárga szeme $\mathrm{s}$ csorra közt sárgás huzat.

Van még a vizes helyeken több apró zenér, foltos tollazatu, mellyek a tarka zenér (mot. naevia) név alatt soká zavartattak egybe, s meghatározások ma sincs egész rendben. ( ${ }^{1}$ ).

Ezeknek számábul megnevezendö:

6. Az erszénylakó zenér. (F. cysticola, Gm.) Col. 6. 3.

Háta súrga, fekete foltos, alul világos sárga, farka vágott, s mindenik tolla alul egy fekete foltu. Déli Europából, fészkét ugy csinálja, hogy több több fü vagy nádszálat öszvehúz s különbféle füvekkel összevarr. ( $\left.{ }^{2}\right)$.

A jobban szárazhoz kötölt fajok között áll:

7. A barcitka zenér. (Barátka Billegt. F. La Fauvette à tète noire. Mot. atricapilla. Lin. Der Schwarz

(') L. S. phragmitis, Naum. 82,1 ; S. cariceti, ua. 2. 3, S. aquatica. ua. 4. 5; - S. fluviatilis, ua. 83. 1. - S. locustella, ua. 84,2 . 3. - Hasonlítsd hozzájok S. locustella. Roux, 229; S. Schoenobenus, ua. 230 ; -- S. paludicola, ua. 231. - S. cisticola, ua. 232. szinte mint Buffon, Brisson, Bechstein képeit. Egy madár nem sem kiván több magánleirási vizsgálást, mint ez, s öszveegyeztetését a különböző elnevezéseknek.

A h. az europai vizi zenérekhez. Siln. galactodes, T. col. 251. 1 ; - S. luscinioides, Savi Egypt. Ois. xur. A; S. cetti, Marmora on la buscarle. enl. 655. 2. Roux. 212; - S. Melanopogon. Ten. col. 245. 2 .

(2) Lásd. Notizia sul nido del beccamorchino (Sylu. cysticola, Ten.) Savi Piltul. Pisa. 1823. 
kopf. Enl. 580, 1. 2. Naum. 77, 2. 3. Roux. 205. kétszer.

Föluil barna, alul fehćres, a himućl fekete fejtetö, veres a nónél.

8. A validi zenér. (La Fauvelte proprement dite. Mot. orphea. Tem. Der Meistersanger. Enl. 579, I. Naum. 76, 3. 4. S. grisea. Roux. 43.

Egy a legnagyobbak küzül fülul hamvas barna, alul fehơres, szírnya mellén feliérség, farkia külsö tollának két harmada feher, a következönek hegyén feher folt, a többi szeget.

Néhány év óta megkülönböztettetik tóle.

9. A küllös zenér. Fanvelle rayée. Sylv. nisoria. Bechst. Sperbergrasmücke. Naum. 76, 1. 2. Rowx. 222.

Farkian a fehér sokkial lievesebb, nöstényének hasán szuirke kereszthullámok rammak. Legnagyobb europai faj.

10. A poszcita zenér. (Poszcila B. Töldi. La Fauvelte babillarde. Mot. curruca. Lin. Az Angolok F'ehérbegye. Brit. Zool. V. rl. 4. 12. Frisch. 21. Naum. 77. 1. Roux. 216.

Az elöbbickuél kisebb, csorra vékonyahb, de farlia elsö tolla szinte nagy részint fehér. Feje hamras, háta barnás.

11. A verhenyes zenér. La Fauvette roussatre. Mot. sylvia. Gm. S. cinerea.) Naum. 78. 1. 2. Riet-vink. Noseman II. 97. rl. Enl. 579. 3. Roux. 220.

Föhül verhenyes-barna-szülie, ahul feher, farka fehére mint a két elóbbinél, tollai s szárnytakaróı reressel szegrék.

12. Az apró zenér. (La petite Fauvette, passerinette ou. bretonne. Mot. salicaria. L. Sylvia hortensis, Bechtst.) Naum. 78, 3. Nosem. 72. Enl. 579. 2. Roux. 221. 
Finkin scmmi fehér niucs, fölül barna szürke vagy olajzöld, alul sírgás fehér $\left(^{1}\right)$.

Bechstein a többi zenérekitiul elválasztá

A. (havasi) csАtтogány-t (Accentor.) Havasi csculoginy. F.

Mclly $=$ Mot. Alpina, Gm. La fauvette des Alpes, Bulf. Eul. 668, Pegot, Vieill. Gal., 156, Naum., 92. 1. ( $\left(^{2}\right)$, mivel karesu de pontosabban kúpidomu csorrán mint a többi billegtetóknél, a szélek egy kissé beronottak.

Ez egy hamvas madár, fehér torku, feketével pontozolt, sziruyán két sor fehér folltal s vidám veresscl oldalain. A magas havasok legelöin tarḱzkodik, hol bogarakat vadász, shonnan télen leszáll a falulira, otl nómelly szemeket keresendö. Ugry vélem, hasonló csorrot reszek észre

a cs.logánY-nál. F. (Ta fauvelle d' hiver. Traine buissons, Mot. modularis. Lin. Enl. 615. 1. Naum. 92. 3. 4. $\left({ }^{3}\right)$.

Az egyctlen faj, molly télre nálunk marad, s cgy kis-

(') A zcnérek leirásai olly hatálozatlanok, s ábrázolataik nasyobh része (Naumannéit livéve) olly rosszak, hogy fajaikat meghatározni majduem lehetlen. Minden iró másképen rendeli ej öket. ^ mi irásunkra számolhatni, de synonymiámka nem teljességgel; azon. Jan vélem hogy Naumann-és Roux-val megegyezek.

$\mathrm{Az}$ el8bh cmlitett fajakhoz adandók: Sylv. ruscicola, Roux; S. passerina, Col. 24, 1 ; S. sarda, uo. 2 ; - S. Nattereri, uo,, 5 ; - S. supalpina, Bonnelli v. Leucopogon. Meyer, col. 6. 2. és 251, 2, 3. Roux., 218. Jegyz. Savi ur szerint a S. passerina, Tem., col. 29, 4. a S. subalpina, fiatal himje. - A Pithou (S. ferruginea.) Enl. 655, 1; Roux, 219. Az apró fajok az öhörszemekhez vezetuek.

$\left(^{2}\right)$ Ez szinte a Sturnus montanus és St. collaris, $\mathbf{G m}$.

(3) Litom, logy ezen közclitést Temmink és Naumanu utak vettćk föl.

CUVIER 1. K. 
sí fïlvidílja ezen érszakol kellemes dala által. Föliil sárgís, fekctérel foltositra, alul palasziirke. F́renkint kétszer fés\%kel; nyíron éjszakra megy s a hegyi erdokbe, télen, bogarakat nem kapvín magvakkal is beéri.

Ezcn kit madír zuzaja izmosabb a többi zcnérkéné (').

Ide mellékelhetö még:

A keleti csalloginy ( $L$ ' Accenlor is jones noires. Accent. montanellus. 'Tem.) Naum.92.

Dellielet Europa madaral, Franczianrszigig el nem julio.

Meg lchetue még nemelly idegen billegtetöket külün-

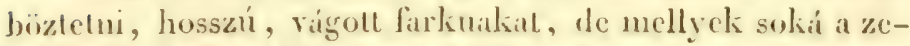
nérchél hagyallak. $\left({ }^{2}\right)$. Nimelly fijok pamalbil vagy mis rostos anyagbul igen mesterséges liszkcket csinalnali: $\left({ }^{3}\right)$.

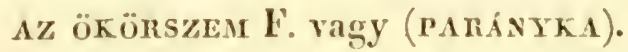 (Les Roilelets. ou Figuiers Regulus.) Cur.}

Csurrok viliony, tïlideles kripidomu, igen hegyes, s

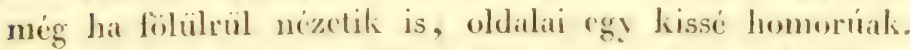
Ezek apro madarak, a líkon eloks otl samyongokat lourdusók. Nílunk találtatnak:

(') Nitsch. ap. Naum. 11, 959. I.

(2) Hot. fuscata. Gm. enl. 584. 1; - Hot. mucroura. Gin. enl. 752, 2. vagy Cajolier, Vaill. 129, 150, 1; - Malurus galactodes. T. col. 65,1 ; - Mal. marginalis, T. uo. 2 ; - Mal. clamans, Ruppel, II. Il; - Mal. squamiceps, uo. XII. - Hot. subflara, Gm. enl. 581. 2. hihet8leg = citrin. Vaill. Als. 127; - le double sourcil, ua. 128. Részint ezen osztatbul csinaltak Viellot és Temm. a mérion vagy malurus nevet; de én nem tenném ide, mint az clsö, a Mot. cyanea-t, a sziklár-csorrut.

Jegyz. A malurus galactodes, MEGalunus nöm lön Vigors tis Horsfieldnél.

( $\left.{ }^{3}\right)$ Némelly europai s idegen zenérek. p. W. S. sardu, szemöh horölt cgy apró kurt birnah. Ez Ienne a zosterops nem Vigots és Horsfieldné!. 
1. A kircilyka ökürszem. (Le roitelet. Mot. regulus. I) as Goldhïnchen.) 651. 3. Naum. 93, 1. 2. 3.

Europai madaraink käzöll legkisebb, fülül olajzöld, alul sárgás fehér, a him fején rgy szip aranysárga foll, f́ketével szegett, mellynck tollai fölcmelhetök (mereszthetók). Fúkon épít gümbidomu fészket, mellynck oldalvást a nyilása, az ágokra mint a czinegék mindenféle mó don lölfüggeszti magál, lỉlen a lakhelyekhez közelí. (1). Kevés idö óta megkülönbözteltctik töle eģv valanivel kisebb faj, naramessárgább folltal, s likete vonallal szeme elólt és megölt. Nere:

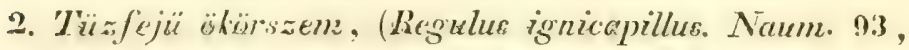
1. 5.6 .

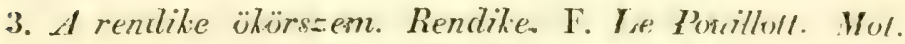
Irochilus. Lin. Der IV eidkenünger. Birkensinger.) Enl. 6.51. 1. Naun. 80. 3.

Az 1-sönél kissé nagyobb, lassonlí sziuí, de lioroniillan; cgy erkölcsï azzal, de ralamivel kellemesb énekü, télen eltározik.

4. A rendi ühürsam. (Le grand Pouillot. Mot. hytolais. Dei gelbbänchige Laubsünger.) Bechts. III. xxiv. Enl. 581. 2. Naum. 81. I.

Kerésscl migg nagyobb, hasa czüistszinubb mint a rendikeé. $\left({ }^{2}\right)$.

Az idegen parảnykitk igen számosak s gyalkran kellemes szinück. $\left(^{3}\right)$.

(1) A. H. Roitelet omnicolor, Virill. gat. 166.

$\left(^{2}\right)$ A. h. es curopai fajohat: Moto sibiatrix, Col. 245 ; 3. Naum. 30,2 ; - Met. fitis, Naum. 80, 5 ; - Mot. rufa, Naum. 80, 4.

( $\left.{ }^{3}\right)$ Illyenek: a tscheric, Vail. 114, 121; - Iot. pensilis. \{Cou-jaune.) En\}. 686, 5; - a canadai foltos parányki (110t. aesti-

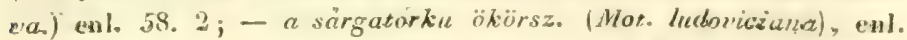




\section{А CS.LLÁNCSATTOGATÓK. F. GYEPÜKÉREK. (Troglodytes. Cuv.)}

A parabilokul csak egy kissé még karcsuabb s könynyüden hajlott csor» által különböznek.

Nálunk csak egy van:

A telclí syepükér. (Le Troglodyte d' Europe. Mot. troglodyles, Lin. A franciálsníl sok helyen Roilelet azaz ökürszem a neve Zaunkünig. Schneekünig.) En]. 651. 2. Naum. 83. 4.

Barna, feketés kereszt vonatokkal, torksin s staímya zélén feléres, fintka igen rörid s emelı. Földïn fészkel, s kellemesen dalol a tél legnagyobb hidegéig. ${ }^{3}$.

\section{A BILLEGÉRöK.}

Csorrok a zenéreliénél karcsubb, farkok hoszú, melylyet szünet nélkïl billeggtenck, lábaik emeltek, de föképen válltollaik ammyira hosszak, hogg az öszrelelt szárnyok véget is betakarjak, a mi öket a grizlok nagyobb részéhez hasonlóvá teszi.

731. 2 ; - a sárgamelii par. (Hot. mystacea) enl. 709, 2., Edw., 237,2 ; a canadai hamvas ök. (Mot. canadensis.) enl. 685, 2; ile de France-i par. (Mlot. mauritiana.) enl. 705. 1 ; - le Plastron noirc. Vaill., III, 123; - Sylvia venusta, Tem. col. 293. 1; - Syli. speciosa, uo., $2 ;$ - S. palpebrosa, uo. stb. Mellycknck csorra az alapnál valamicskét bö, az egyenes csorru gébicsekhez szítanak. Az amcrikai egyesületekheli fajok elo̊számlását 1. Bonaparte K-nál, Lycéc de de New-York, Jul. 11. 18. 26. 76 és köv. lapokon.

(1) Az idegen gyepükérek egy részrül a hangyárokhoz más részrül a fakiszohhoz kottetnek. Ide adandó més. Thriot. longirostris Vieill. Galer. 168. (Le Thrioture is long bec. Kampylorhynchus scolopaceus, Spix. 79.) 


\section{A Brta.egTeTő́, tulajdonképi BILt_EgéREK.} (Les Hochequene propr. dite. ou Lavandières. Molacilla. Cuv. Bachstelzen.

Hürclykökön a köröm mindegyre görbült mint a többi billegetöknél. Vizpartokon laknak.

A barázda billegletö. (Fehér billegetö F. Motac. alba et cinerea. L.) enl. 652.

Hazínkbeli faj; fölül hamvas, alul felıér, sapkája a fejhátán, torka s mele felseték.

Déli Europában van egy, melly idövel fekele hátat kap, de fiatalságában az elöbbilıez hasonlit; ez A goycisz billegetö (Mot.lugubris, Roux, 194.)

\section{A BILCSIRTÁK.}

(Les Bergeronnelles. Budytes. Cuv. Kuhlelzen. ( ${ }^{1}$ ).

A billegtetók többi bélyegei mellett, hüvelykök körme hoszult és kissé írelt, mi okból a pipárokhoz és paesirtákhoz közelítcuek; legelökön tartózkoduak, s a csorda közt kergetik a bogarakat.

A lavasui bilcsirta. (La bergeronneite de printems. Mot. flava. El. 674, 2.

Fölül hamvas, háta olajzöld, alul sárga, szcmöldöke s farka oldaltollainak liét harmada fehér. $\left({ }^{2}\right)$.

\section{a PIPÁrok. (PIPIBILOK).}

(Les Farlouses, Anthus. Bechst. Pieper.)

Sokáig a pacsirtákkal voltak egyesitve hüvelykiok

$\left({ }^{2}\right)$ Budytes, mivel az ökrök (marhák) között tartózkodik.

$\left(^{3}\right)$ A. h. a sárga bilcsirta (La Berg. jaune. Mot. boarula. Lin.) Edw. 259. Vieill, gal. 162. 
hosszú kiorme miall: de vikony s himetszell csorruk a többi billegtetokhäz kïli riket. Egyszersmind, mísod lakaroik es tollaik szokis szermli rövidsege nem hagyja öket a bilesirtákkal osszezavarni.

Nomellyck, még cliggé hajlott kïrmück, örömest foilühek.

A rendes pipar. (Le Pipi. Allauda trivialis et minor.

(im. Anthus arboreus Bechst.) Enl. (660). 1. (1). Naum.

84,2 . Rotux.

Föliil olajzöldes barna, alul verhenyes szïrkc, melén feketés foltokkal, szárnyán kiet halavány kereszot szalag.

Másoknak hïrelykén egés's pacsirtat-liöröm van; ezck többet tartózkoduak a fòldön.

A réti pipár. (Ia Farlouse, Alouette de pré. Alauda pratensis. Gm. Der IF iesenpiper. Inthus pratensis, Bechst.) Ent. 661. 2. $\left({ }^{2}\right)$. Naum. 8.1, 3. és 85, 1.

Fühil olajzüldes-birna, alul fihéres, melén s oldalain fehér foltok, fehéres a szemöilde; farka kül tollainak szélei fehérek.

Nedves vagy clíradt réteken tartozkodik, kákúsakban ragy sürü füben fészkel. Ószszel a szölötül igen meghizils s Franciaország nómclly tarlományaiban bec-figue vagy vinette néven igen kerestelik. ( $\left.{ }^{3}\right)$.

(') A pipár hamis neve alatt: la Pirose ortolane, Buff., enI. 612, 2. (Motac. maculata, Gm.) annak fiatala. L. Roux. 288.

(3) Roszul neveztetik Alouette pipi-nak. Naumann e képet az Anthus aquaticus-hoz számlálja, s ebbil fiatal himnek gondolja, s meå keil jesyezni, hog̣ ezen alnen synonymiája nem kevesbbé homályos, mint a zenéreké.

$\left(^{5}\right)$ Add h. Anthus aquaticus. Naum. 8.5, 2. 34; - Anth. campestris. (La Rousseline.) enl. (161, 1. Naum., 84, 1. vagy Alauda musellana, Lath., mellynek fiatala a provencei Fist, enl. 654, 1. (Mos. massiliensis, (im.) 1. Roux, 292. 1.; - Anth. Richardi, 
A VEHEBEK.

Mi a fogcsorruak ezen családát némelly olly madarakkal végzendjük be, mellyek minden elöbbiektöl különböznek, mivel két külsỏ ujjok alapjokrul kezdve majd hosszaságok két harmadáig öszszenöltek, ini okbul az összujjuakhoz közelítenek.

\author{
A PIPRÁk. F.
}

\title{
(Les Manakins. Pipra. Lin.)
}

Csorrok üsszenyomott, magasabb mint széles, kimetszett, orrgödrei nagyok. Farkok s lábaik rövidek; általános viszonyaik mialt sok ideig a ezinegéklie\% igen hasonlóknak tekintettek. Elül, külön csapatkint helyezendők :

\section{A KöTANYÁroK. (Kövi PIPRÁK. F.)}

Nagyok, fejökön kettös függöleges búbot birnak legyezö idomu tollakbul. Két amerikai faj ismereles:

1. A kisebb kötanycir. (Pipra rupicola, Gm.) cul. 39, is 747. Vieill. gal., 189.

2. A nagyobb kötanyár. (P. peruviana, Lath.,) eul. 745.

Ezeknek felnölt hímei igen szép narancssárgáls, a fiatalok homályos barnák. (Az elsónek bubján szegély van. a másikén nincs, az barna, ez feketébb szárnyu s farku.) Gyümölesökkel élnek, a földet vakarják mint a tyukok, s fészlköket száraz fábul a sziklík mély üregeibe rakják. A nő lkét tojást tojik.

\section{A KÖTENGEK.}

(Les Calyptomènes. Horsfield. Calyptomenes.)

A kőtanyároktul csak abban különböznek, hogy búb-

Vieill. uo. 110. Roux. 189, 190. Az idegen pipárok között áll : Alauda capensis, enl. 504,2 ; Al. rufa. uo. 238 , 1. ki hihetöleg Rupra. Edw., 297. Anth. rufulus, Vieill. gal. 161. 
tollaik ninesenck lesgezii idlomba szedre. Ezen bélyeget egr

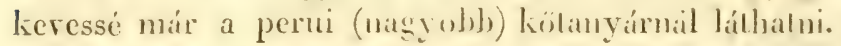
$A$ zöld kröleng. (Calıplomenes viridis. Horsl. jar.)

Az indiai szigelsolvbul, a legszocbb smanagdszinii, $11 \cdots m$ nagyobb egy rigónál.

$\Lambda$ VALÓDI. PIPRÁK.

\section{(Les Vrais Manakins. Pipra Cur.)}

Aprok s majdnom minduyajat dink sxincirul dicsorhetni ('). A nedres crebókion apró cesoportokban laknak.

\section{A CSÖRBôK CSORATÁG-ok.}

\section{(Les Eurylaimes. Eurylaimus. Hors[.)}

Tiaik mint a pipráknál és kötanyároknál de esormk crös mint a zsarolyoké, szörnyen lenyomott és sziles, mert alipja mog a homiokot is follülmulja szélességre nizve. Ilegye kissé horgas, s mindenik oldalán könnyüden kimetszelt; erösze tompa.

Az indiai szigcelsoli madarai, alap tollazatuk fekele,

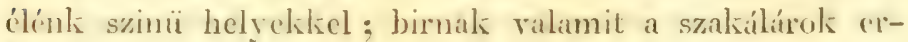
kïlescibïl, melly egészen liülïnbözö rendbeli nem.

Vizek közclén laknak, bogarakkal éluck. $\left({ }^{2}\right)$.

(') Mipra militaris. Sh. Nat. Musc. 849: - P. caudata, Sh. Nat. mus. 153. Spix. 6 ; - P. pareola. enl. 637,2 ; és 300,2 ; $P$. filicauda. Spix. 8 ; - $P$. superba. Pall. sp. 1. 111. 1. 1. k; Erytrocephala, enl. 51, 1; - Aureola, 34, 3. és 302; - Rubrocapilla, col. 54, 3. vagy cornuta, Spix. 7, 2; - Serena, enl. 324, 2. Vieill. gal. 72; - gutturalis, 324, 1: Leucocapilla, 34, 2 ; Manacus. 302,1 , s 303, 1; - Strigilata, p. pr. Max. col. $54,1.2$.

$\left(^{2}\right)$ Todus macrorhynchos. Gm. Lath., Syn. II. xxx. rl. és col. 151. Euryl. nasutus, név alatt; Eur. jazanus, Horsf. és Col. $130 \mathrm{~s}$ 151. Eur. Horsfieldii, név alatt; Eur. cucullatus, Tdm. col. 26!; 
A szeltcsörüek. (Fissirostres).

Nem számos családot képeznek, de minden másoktul igen különbözöt, rövid, széles, vizszínüleg lapított, könnyúden horgas, kimetszéstelen, s igen mélyen szelt csorrok által; csorrnyilásuk igen tág lévén, könnyen lenyelik a reptökben kapdosott bogarakat.

A légykapók törzsökéhez leginkább közelítenek, s nevezetesen a szelecsórökhöz is, mellyeknek csorra ezekétül csak kimetszése által különbözik.

A teljességgel bogárevó életmód kitünőleg vándormadarakká teszi óket, mellyck télre' ellagynak bennünket.

E madarak nappali-s éjjeliekre oszlanak, mint a ragadazók.

\section{A FECSKÉK.}

\section{(Les Hirondelles. Hirundo. Lin. Schwalbe.}

A nappali fajokat foglalják magokłsan; mind kitünö tolla tömöltsége, szárnyai rendkivüli hosszasága s repte sebessége által.

Köztök megkülönböztetnek :

A FöLLENGÜK.

(Les Martinets. Cypselus. Ilig. Segler.)

Minden madarak kïzölt arányilag leghosszabbs szíl-

Eur. Blainuilli, Less. et Garn. Voy. de la Coquille xrx. rl. 2. k. A csorr bélyege rendkivül kifejlett az Euryl. Corydon, Tem. col. 297. 
nyakat biruak s leznagyobb crörel repünek; farknk villís: líbok igen rövid s ezen igen igen kïlünös bélyẹgel, hogy hiivelyke elöre irányzolt majd mint a többi ujjak, s hogy a közép és kïlsö ujjon csak hisom hírom iz van mit a belsön.

Víllesonlok rövidsege, nvulványainak s\%élessége, petés villatsontuk, alja felé kimetszéstelen mellesontuk mutaljali még a vizban is, menuyire szánatlak e madarak cros repulise: de lábaik rövidsége, szárnyaik hosszasigátho\% kïlve, teszi hogy ha a fibldre szálltak nem egy kömynyen ludnak ismét szirnyra kapni; ez okbul, ugy mondhatra, leregoben töltk éllöket, csapatonkiut s nagy lármával ïldizve a bogarakat a legmagasb tájakon. Fal és sziklaly̧ukakban fészkclnek, s gyorsan másznak fölfelé a legsimább falakon (fölúleteken) is.

Nálunk két faj ismeretes:

1. A siki föllengü (lcibatlan, kiöfali fecske. F. Hirundo apus, L. Mauersegler.) Enl. 541. 1.

Fekete, torka fehér. Igen közönséges faj.

2. A haz'asi fïllengü. (Hirundo melba, L. Der Alpensegler.) Edw. 27; Vaull., Afr. 243; Vicill. gal. 121. Brehm. X. 2.

Amanual nagyobb, fülïl barna, alul feher, nyaka alatt barna körvrel. $\left({ }^{1}\right)$.

\section{A tulajdonképi FECSKÉK.}

(Les Hirundelles propr. dits. Hirundo. Cuv. Eigentl. Schwalben.)

Ujjaik, lábaik, mellesontuk ugy ramuak elrendelve, mint a verebüek nagy számánál.

(') A. h. Hir. sinensis; - Martinet à croupe blanche, Vaill. Afr. 244, 1? - Martinet velocifère, ua, uo. 244, 2? - Martinè 
Némellyek líbai egész a kïrmökig tollal fedvék; hïvelykök még hajlamot mulat az elöre fordulisra; farkok villás, közép nagyságu.

1. A feliér hasu fecsíe. F. (1' Hierondelle de fenêtre. Hirundo urbica. L) Eul. 542. 2. Hausschwalbe.

Fölül fekele, alul s farcsikán fehér. Az egés\% vilíg ismeri azon erös fészkeket, mellỵekel sírbul csinál az ablakszegletekhez, födélereszckre stb. ( $\left.{ }^{1}\right)$.

2. A füstös fecske. F. Kémény fecske. F. (I' Mrondelle de Cheminée. Hir. rustica. Lin. Rauchschwalbe. Enl. 543. 1. Br. x. 3.

Másoknál csupaszok az ujjak, villás a fark, gyakran igen hosszú villával:

Fölïl fekete, homloka, szemöldöke s torka verhenyes, különben alul fehér. Nevét rendes lakásátul vette.

3. A parti fecske. F. (I' Hirondelle de rivage. Hir. riparia. L. Die Uferschwalbe.) Enl. 543. 2. Cotyle fluviatilis. $\mathrm{Br} . \mathrm{x}, 5$.

Fölül s melćn barna, torka s ala fehérek. Parti lyukakban fészkel. Bebizonynltuak litszik, hogy télre elzsibbad, soút hogy ezen évszakot a mocsárok vizének fenekén lölti el.

Az idegen fecskék kózött megjegyzendö:

Az ennivaló fecske. F. (F'észekmester. La Salangane. Hir. esculenta.)

Igen kicsin faj az indiai szigetsokrul, villás farku, fölül barna, alul s farka végén fehéres; híres azon réle-

à moustaches. (Cyps. mystaceus, Less. et Garn.) Voy. de la Coq. 122. s.; - M. coîfëe. (C. comatus, T.) col. 268; - le Martinet longipenne; hoszútollu föllengü. Hir. longipennis. Col. 83. 1.

(1) A. h. Hir. cayennensis. enl. 723, 2;-Hir. ludoviciana, Nob. enl. 725 , 1. et Catesb. 1, $51 ;-$ Hir. montana $=$ rupestris. 
genként rakott kocsonya anyagu fészkekriil, mellyet egy küï̈nös fucus lajbul, vélions fehér száluból, liészit, molylyet megrág és forraszt clöbb. Az ezen fészkeknck tulajdonított erösitö tulajdonságért, azokbul nagy kereskedési cikkely csináltatéli Chinában. Mint a szegfügomba készáttetik el. ( $\left.{ }^{1}\right)$.

A külsö tartomínyoliban rannak majdnem négyszegfarku fecskék $\left({ }^{2}\right)$, s mísok, mellyeknél a kurta s négyszegü fark tollai hegybe végzödnek. $\left({ }^{3}\right)$.

\section{А LАрPАNтYúk. (Kecskefejök F.)}

(Les Engoulevents. Caprimulgus. Lin. 'Viegenmelker. (').

Ugyan azon könnyiu, puha, szürkérel és barníval arnyazott (tarkított) tollazatuk van, melly az ciji madarakat.

(1) Ide jönek: IIir americana. Wils. V. xxxvin. 1, 2. vagy rufa, Vieil. Am., 3; - egy másik rufa, enl. 724. à : - II. fulva. Vieill. Am., 32 ; - Hir. fasciata, enl. 726, 2; - Hir. violacea; cnl. 722. vagy Hir. purpurea, Wils. V. Xxxıx, 1, 2; - Hir. cha-. lybaea, enl. 515, 2 ; Hir. senegalensis, enl. 310 ; - Hir. capensis. enl. 223, 2; - Hir. indica, Lath. Syn. II. LVI; Hir. panayana. Sonn. premis Voy. Lxxxvi. rl; - IIir. subis, Edw. 120; IHir. ambrosiaca, Briss. II , Xlv. 4. k., - Iir. tapera, uo. 3. k.; - IFir. nigra, ua. Xr.vı. 3. k.; - Hir. daurica; $-\Lambda$ verhenyes homloku f. Vaill. Afr. 245, 2 ; a mocsári fecske, wa. ио. 246. 2; - a bubos fecske, ua. uо. 247 ; Cyps. senex. T. 397 ; - IIir. fucata, T. col. 161. 1. - Hir. jugularis, pr. Max. col. uo. 2 ; - Hir. javanica, Lath. col. 83, 2; - Hir. melanoleuca, pr. Mat. col. uo. 1; - Hir. bicolor, Vicill. Am. 31. = Hir. viridis, Wils. V. xxxvı1. 3.

$\left({ }^{2}\right)$ Hir. dominicensis, enl. 545, 1. - torquata, enl 723. 1; - Hir. leucoptera, enl. 546, 1; - Hir.francica, enl. 544, 2; Hir. borbonica; - Hir. americana; - l' Hir. fauve. Vail. Afr 246. 1.

$\left({ }^{3}\right)$ Hir. acuta, enl. 514.1; Hir. pelasgia, enl. 726.1,2.s Wils. V. xxxux, 1; - Cypselus giganteus, Tem. col. 364; - IIr. albicollis, Vicill. galer. 120. = Cypsel. collaris, pr. Max. col. 195.

(1) Caprimulgus, tète-chìre, oegothelas, kecskefejö, Gcismel- 
bélyegzi; szemcik nagyok, csorruk még szeltebb mint a fecskéknél, erós bajuszszal biró s a legnagyobb bogarakat clnyelni hagyó, mellyeket ragadós nyállal tartanak vissza; alapján az orrlyukak vannak, apró csőidomban; szárnyaik lısszak; lábaik rövidek, tollas szárokkal, ujaik, alapjoknál rövid hártya által egyesülvék, még a hüvelyk is illy módon egyesülve van a belsö ujjal s elöre irányozható; közepső körme gyakran fogas a belső oldalon, s a külsö ujj - a mi ritka alkotás a madaraknál - négy percet bir. A lappantyúk magánosan élnck, csak esthajnalkor vagy szép éjeken repdesnek, éjilepkéket, éjipilléket és mús éjibogarakat vadásznak, a földre mesterség nélkül kevés számu tojást tojnak, a repülés küzben tág csorrokba béható levegő különös morgást okoz.

Europában csak egy faj van:

1. Az europai lappantyu. (Europai kecskefejö. F. Caprimulgus europaeus, Lin. Der Nachtschatten.) Enl. 193. Brehm. x, 1 .

Húri-nagyságu, barna szürke, feketés barna hullámzattal és foltokkal, csorrátul fehéres szalag megy tarkójához. Harasztokban fészkel, csak két tojást tojik.

Amerika több illy madarat tart, kerek vagy négyszegü farkut, s ezck közül egy akkora mint a füles bagoly. 2. A nagy lappantyu. (Capr. grandis.) cnl. 325 . És. egy másik:

3. A. lármás lappantyu. (Capr. vociferus). Wils. V. XLI.

Hires azon crös kiállozásairul, mellyeket tavaszszal hallat. $\left({ }^{1}\right)$.

her, mind azon furcsa képzclettöl credt nevek, hogy a kecskéket, so̊t még a tehencket is megfejik.

(') A. 1. Capr. virginianus. Edw. 63. vagy americanus, Wils. ‥ xL. 1. 2. melly, véleményem szerint, igen kö̌cl lenni lúlscik a 
1. Az uj hollandi lappantyu (C'apr. novae Hollandiae). Phillip. bot. 6. 270. 1.

Ebbuil Vigors és llorsfield az AEgotneses nemet csinálták.

Afrikában is ran nchány ( $\left.{ }^{1}\right)$, s czek szimaiban van herges firku $\left(^{2}\right)$, s vammak villás farkuak, a lecskékkeli rokonsígot amnál mkább bizonyitók ( ${ }^{3}$. Söt még Ameri-

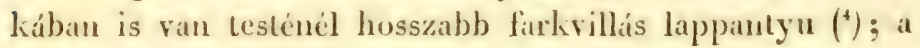
villís lardau tajoknál nem fogars a kïzipuj körme.

5. A hosszutollu lappan!yu. ('apr. longipennis.) Shaw., Nat. Miscell. 265.

Srinte afrikai faj, de kerek farhu, s iscon neveretes rgy a testinél kétszerte huszabb tolla által, melly mindenik szirny hürelyk-izenck közelin ered s csak a vége felé szakíllas.

\section{TAPFOG}

\section{(I.es Podarges. Podargus.) Cirs.}

Idommk, szinok, szokisaik mint a lappantyuke; de esorok (erisebb, njaik kizzill scm hirlya mucs, sem fog a közеријј lï̆mén. $\left(^{5}\right)$.

gruyanensis he\%, cul. 25j; összezavartaték a vociferus-sal; - Capr. carolinensis, Catesh. 8. Wils. V1. LIv. 2. a mienklez igen körel faj; - C. jamaicensis, Lath. Syn. II. Lvil. - C. rufus, cnl. 735; - Capr. semitorquatus ; enl. 754; - C. cayennensis, cul. 760 ; C. acutus, 752; - C. Natuereri, col. 107; - C. diurnus, pr. Max. col. 482 ; - Capr. mystacalis, T.

(1) Capr. infuscalus, Ruppel. VI. Il; - C. isabellinus, T. col. $579 ;$ C. eximius, Rupp. col. 598.

$\left({ }^{2}\right)$ Capr. climacurus, Vieill. gal. 122.

(i) Capr. furcatus, Cuv., Vaill., Afr. 47;-C. pectoralis, ua. uo. 91.

(') C. piselurus, Trus. (i) 117, 151.

(') Vigors usy tekinti a lappogakat, mint hik a lappantyukat a pacsirtatitial kotik ossze. 
1. A hamzas lappoga. (Le P. cendré. P. Cuvieri. Vicil. gal. 123.

Hamvas, fehéres is feketies tarkázaltal; varju nagysigu.

2. A verhenyes lappoga. (Le I. roux. I. javanensis). Ilorsl. Jav.

Verhenyes, barníval larka, fehér szilag a villtollik hosszaibaru.

3. A szarvas lappoga. (Le Pod. cornu. P. cornulus. 'Т.) col. 159.

Verhenyes, fehérel Larka, nagy tollbúbok a fiilcin.

A verebüek harmadik családa.

\section{A KúpCsotruth.}

Az. crös, többé kevesebbé kupidomu s ki nem melszelt csorru nemeket foglalja magában; - ezek ammál kizárobban szemekkel élnek, minél erösebb és vastagabb a csorrok.

Közlök legelöször is megjelelendü nem:

\section{A PAcsirták.}

(Aloueltes. Alauda. Lin. Die Lerche).

Hüvelykkörmök egrenes, erös s a többinél jóval husszabb (1); czek magszencrö, polozo madarak, a löldön Lamyázók és fészkelök.

I.egnagyobb számokinál egyenes, lïzćpuagysigu s hegyes a csorr.

(') Ezen bélyeg töblué kevesebbé ki van fejlödve a bilcsirtíknál, pacsirtáknál, pipúluknál, mellyekriil már szólottunk, s a havas sármánynál, mellyrül szólandunk. 
1. A szántóka pacsirta. F. (Aloutle des champs. All. arvensis.) Eul. 368. 1. Naum. 100. 1. Die lieldlerche.

Mindenki üsmeri egyenes (függï) repülésériil melly kïzben erösen és víltozatusan dalol (liì äl); 一 böven fogatik meg aszlaliaink számára. Tollazata fölül barna, alul fehéres, mindenült homályosb barna foltokkal; farka liét szélsö tolla kifelé fehér.

2. A bubos pacsirta. F. Pisinek. F. (Le Cochevis, Alouelle hoppée. Alauda cristata. Die Haubenlerche. Enl. 503. 2. Naum. 100. 2. Br. xix.7.

Majd azon nagyságu s tollazatu; fejtollait bubbá cmelhcti; rilkább az elöbbinćl, a falukhoz és pagonyolihoz kïzclít.

3. Az erclei pacsirla. F. Alouetle des bois. Cujelier. Lulu. Al. arborea. A. nemorosa. Baumlerche). Enl. 503. 2. Naum. 100. 2.

Szinte van egg his bubja, de kevesblec foiltioü: kisebb, megkülünbizzcllecio egy fehéres vonat által a feje lïrül, és egy fehór vonallal a lis takarrikon; legörömestebb az ('rdök mólycbeli tisztísolial szercti. (').

Néha Europában is látható:

4. Az éjszaki pacsirla. (Aloutte à hausse-col noir. Al. alpestris. Al. flava. Al. sibirica. Gm. Berglerche.) Enl. 652. 2. Naum. 99, 2. 3. Wils. An. I, 4.

Sibcriai s éjszakamerikai madár, homloka, arca s torka sárgaili, fekete ronatokkal; szćles fekete foll mole magasin keresztill. A himnek kis hegyes bubja van mindenik füle mögött.

(') A h. le tracal, Vail. Afr. Cxc1. 1.1. - a nagy csorru pacs. 11a. CXCHI. xI. 
A VEREBEK.

Másoknak olly nagy csorrok van, hogy e tekintetbül a verebekhez kïzzelíthetök.

5. A déli pacsirta. (La Calandre. Al. calandra.) Enl. 363. 2. Natm. 98. 1 .

Legnagyobb curopai faj, fölül barna, alul fehéres, nagy feketés folt a him melén. Europa délérül s Asia pusztáirul.

De kiváltképen:

6. A tatar pacsirla. (L' Alouetle de Tartarie. Al. tatarica et mutabilis. Tanagr. sibirica. Gm.) Sparm. Mus. Carls. xıx. rl. Vieill gal, 160.

A felnóltek tollazata fekete, fölü] szürke hullámzattal. Néha Europába is eltéved.

Másoknak csorra hosszalt, kissé összenyomott, s ivelt, melly okbul a babutákhoz és gyurgyákhoz közelítenek :

7. Az afrikai pacsirla. (Le Sirli. Al. africana, Gm.) Enl. 712. Vieill. Gal. 159.

Közönséges madár a homokos téreken Afrika egyik végétül a másikig; ruhája kevessé külömbözik a mi rendes pacsirtánkétul. ( $\left.{ }^{1}\right)$.

\section{A CINEGÉK. CINKÉK. F.}

(Les Mésanges. Parus. L. Meise.)

Csorrok vékony, rövid, kúpos, alapján apró szörrel szcgett, csorrlyukai tollak liözé rejtvék; igen vidor madárkák, szünetlenül repkedök és kiúszók az ágakon, ott mindenféle módon függeszkedök, a táplálati magvakat el-

(') Addh. Alauda bifasciata, Rupp. 5. rl. col. 393.

Jegyz. Swainson elválasztja a pacsirtáktul Vaill. baceleurjét, 194. rl. BRACHONYX név alatt, a SENTINELLE-t, MACRONYX név alatt, s az én hosszú csorrúimbul a Certhilauida-t csinálta.

CUVIER I. K. 
harapók, sok bogarat is evók s még az apró madarakat sem vetök meg, ha öket betegen s meggyözhetve találják. Szokások szemeket gyüjteni halomra, vén fa odvakbau fészkelnek s többet tojnak a többi verebüek akármellyikénél.

Franciaországban tiz tulajdonképi cinege faj van :

1. A szén cinege. F. (La Charbonnière. Parus major. L.

Kollmeise.) Enl. 3. 1. Naum. 94. 1. Br. xxrv. 2.

Fölül olajzöld, alul sárga; feje valamint egy hoszas szalag is melén fekete; mindenil arcán fekete háromszög; legközönségesb a cserjesekben és kertekben.

2. A fenyves cinege. (La petit Charbonnière. Parus ater L. Die Tannenmeise. Frisch. I. xur. rl. 2. Naum. 94, 2.

Az elóbbinél kisebb, hamrast bir az olajzöld helyett, fehérest a sárga helyett. Különösen a nagy fenyvesekben tanyáz.

3. A mocsári cinege. (Le Nonnette. Par. palustris. L. Sumpfmeise.) Enl. 3, 3. Naum. 94, 4.

Fölül hamwas, alul fehéres, sapkája felsete.

4. A kék cinege. F. (La Mésange à téte bleue. Par. coeruleus. Die Blaumeise.) Enl. 3. 2. Naum. 95, 1. 2.

Föluil olajzöld, alul sárgás, fejteteje szép kék; fehér arca feketével kerítelt, homloka fehér; vidor madaracska, elég számos a pagonyokban.

5. A búbos cinege. F. (La Mésange huppée. Par. cristatus. L. Die Haubenmeise, Kappmeise.) Enl. 502. 2.

Fölül barnás, alul fehéres, torka s arcköre feketék, apró búbja fekctével s fehérrel tarkított.

6. A hosszu-farku cinege. F. (La Més. à longue queue. Par. caudatus, Lin. Die Schwanzmeise.) Enl. 502. 3. Naum. 95 , 4. 5. 6. Br. xxrv. 3.

Föluil felsete, szárnytakarói barnák, fej-foile s egész 
alja fehér, farkia hosszabb a testénél. Fészkét a cserjek ágára csinálja, s lölülról betakarja. (').

\section{A SZAKÁLLCINOK.}

(Les Mouslaches. Mystacinus. Br. Bartmeise.)

A tulajdonképi cinegéktól abban különböznek, hogy csorrok felsö lemezc egy kissé az alsóra görbül. A rendes szakillcin. (szakillas cinege. F. La Moustache.

Parus. biarmicus. L. Die Bartmeise). Enl. 618. 1. 2. Vieill. 69. Naum, 96. Br. XXIV. 5.

Sárga; a hím feje hamvas, egy feketc szalaggal, melly szemét körülreszi s hátul hegybe végzödik. Ezen madár a legsuirübb kákásban fészkel. Az egész régi világban találtatik, noha ritkán.

\section{A CSÜGECINOK. (Les Remiz).}

Csorrok karesubb és legyesebb mint a rendes cincgéknél: általíban mesterségesb fészket készítenek. Szinte csak egy van nálunk.

(') A mi cinkéink szinte leábrízoltattak Roux munhájában, cxvil-cxxrv. lapig. A. hozzá: Parus bicolor. Catesb. 1.57; - P. cyanus, Nov. Comm. Petrop., XIV. XIr. rl.1. k. és 23, 2. kép, - P. saelbyensis. Sparm. M. Carls., Xxv. rl.) mellyeket Bechstein ugyan azon faj két nöménck tart, Vieill. Gal. 68. Naum. 95. 6 ; $\boldsymbol{P}$. atricapillus. (Briss. III, xxıx. rl. 1. k.); P. sibiricus, enl. 708, 3. k; $\rightarrow$ P. palustris, B. enl. 502 , 1. közel fajok vagy 3 fajták; - P. atriceps, Horsf. col. 287., 2.

A parus malabaricus, (Sonner, 2dik utazása, cx. rl. 1.) s coccineus, (Sparm. Mus. Carls. 48, 49), P. furcatus, col. 287, 1 sziklabilok vagy gébicsek, közcliek az Oranor-hoz, Vaill.; a Mot。 ruticilla, L. turdus speciosus-hoz Lath. Azt megjegyezhetni, hogy valahányszor nem elég pontosan jeleltettek ki valamelly wadír bé byegei, azt a szerzok (auctorok) nembël nembe hinytik. 
A rendes csügecin. (Függömadcír, Remicz. F. Le Remiz Parus pendulinus. L. Die Beitelmeise.) Enl. 618, 3. Vieill. 70. Naum. 97. Brehm. xxry. 5.

Ilamras; szárnya, farka barna, homlokán fekete szalag. a himnél elterjedö egész a szemek mogé. Ezen apro madár Europa déén s keletén lakik, s híres azon esinos fészehert, mellyet erszényidomban a füz és nyárfa pelyheihol hieszít, belül tollakkal környez, s a vizi fák hajlékony ágaira fölfüggeszt. (1).

\section{A SÁRMÝNYOK.}

\section{(Les Bruants. Emberiza. Lin. Ammer.)}

Rendlivïl megkïlönbözteteu bélyegök van kípos, rövid, egyenes csorrukban, mellynek felsö lemeze keskenyebb s az alsóba béhat, s szájpadlatín kiálló s kemény gumó ritu. Magszem-erö madarak, rigyázallanok, minden elökbe vetett törbe rohanók.

1. A cilrom scirminy. F. (Le Bruant commun. Emberiza cutrinella. Lin. Die Goldammer. Der Hämmerling.) Enl. 30. 1. Naum. 102, 1. 2.

Ilíta barna súrga, fekete s teste egész ala súrga, farka két külsö tollának belszéle fehér. Grepuïken lészkel; lélen szimtalan csoportban közclí a likhelyelihez a verebekkel, pintyekkel stb. midön a füldet hri födi.

2. Az ostoba sármainy. (Le Bruant fou. Emb. cia. Lin. Die Zippammer.) Eul. 30, 2. Naum. 10.1, 1. 2.

Amattól abban különbözils, hogy alul verhenyes szür-

(') Parus narbonensis, (enl. 708, 1.) ugy látszik a pendulinus jérceje; A. h. Par. capensis, (Sonner. 2-dik utaz. cxirt. rl.) mellynek fészke palaczkidomu, s pamutból ugy csinált, hagy a nyak szélén egy his tiúca van, hogy a hím rajta ngugodhassck. 
he, feje oldalai fehéresek, háromszegletesen véve feketc vonalokkal körül. Hegyes tájakon lakik. $\left({ }^{1}\right)$.

3. A gyepüs sármainy. (Le Bruant des haies. Emb. cirlus. Lin. Die Zauncummer.) Enl. 653. Naum. 102, 3. 4.

'Torka fekete, fejoldalai sárgák. Bokmokban fészkel a mezök határain. $\left({ }^{2}\right)$.

4. A naidas scirmány. (Le Bruant des roseaux. Emb. schaeniclus, Lin. Die Rohıranmer.) Enl. 217, 2. Naum. 105.

Fején fekete sapka, fekete foltok a meléu, híta verhenyes. A bokrok aljára fészkel, a vizck hosszában, stb. $\left({ }^{3}\right)$.

5. A köleses särmány. (Sorclély. Kölesmadair. Földi. Die Grauammer. Der grosse Ortolan.) 101. 1. Emb. miliaria. L. Le Proyer. Enl. 233. Naum.

Barna-szürke, mindenfelé sölét barnával pettegetett. A füben és gabonában fészkel.

6. A kerti scirmány'. F. (L' Ortolan. Emb. hortulana. Lin.) Enl. 247. . 1. Naum. 103. Der Ortolan. Fettammer.

Háta olajzöldes-barna, torka sárgás, farka két kiilsó tolla belül fehér. Gyepúlkben fészliel; számos és igen kiövér ószszel. $\left(^{*}\right)$.

Déli Europában néha megfordul:

(') Az Emb. lotharingica, enl. 511. 1. nem különbözik töle.

$\left(^{2}\right)$ Ide számláltatik még: Emb. passerina; s tán az Emb. provincialis, enl. 656,1 . lesbia, uo. 2 , csak történetbeli fajtúi. L. Roux, 176 és 178. 1.

$\left({ }^{3}\right)$ Wolf véleménye szerint ide egyesitendő az Emb. chlorocephala, és ax Emb. badensis.

( $\left.{ }^{4}\right) \mathrm{Az}$ Emb. melbensis, Sparm. Mus. Carls. 1, 21. nem egyéb fiatal kerti sármánynál.

Mindazon kettős elnevezések levonta után, mellyeket hijeleltünk, kicsapandók még e nembiul: Emb. brumalis, mert = Fring. 
7. A fekete fejü-scirmainy. (The Br. ¿̀ tâle noire. Fmb. melanocephala. Scop. Naum. 101. 2. - Fring. rrocer, Vieill. Ois. tab. 27.

Fölül barnább sárga, alul súrga: feje felicte.

8. Afenveres scirmainy. (Le Bruant des pins. Fmb. pilhyornis. Pall. Die Fichtenammer). Natum. 104. 3.

'Torlsa s leje oldalán egy ronat, sötét rerhenye's.

\section{SÁRMIÁ. SARKAMÁNYOK}

nevit lordhatjál azon simmingok, mellyeket Meyer Plectrophancs (Spornammer) nevezeltel megkülönböztete. medyehneh hüelykiome megnyult, mint a pacsirtáke.

Illyen:

1. A lararasi scirma. (Hómadur, havasi scirmainy. T. l.e Bruant de neige, Emb. nivalis. Lin. Die Schneeammer). Enl. 50. Naum 106, 107.

Megismerhelö egy fehér sziles hosz-szalagrul a szár-

citrinella, enl. 658, 2; - Emb. rubra, mert = Fring. erythrocephala, enl. $665,1,2$; minden $\ddot{z} z e^{y}$ pinty, mint alábh mondandom; Emb. quadricolor, enl. 101, 2; Emb. cyanopis, Briss. IIl, viI. rl. 4. k. - Emb. caerulea, ua. uo. XIV, 2, = cyanella, Sparn. Carls. 1I. 42, 43, - mert ezek (3) loxia-k; - Emb. quelea, enl. 225, 1; - Emb. capensis, enl. 158 és 564: - Emb. borbonica, enl. 321.2; - Emb. brasiliensis, uo. 1.'ezek pintyek; Fimb. ciris. enl. 158, melly kenderike; végre Emb. oryzizora, enl. ies, mellynek csorra mint a kenderikeé, nen számlálva ide azon iajokat, mellyeket meg nem vizsgálhattam. De valúban a sármányokhoz Lartozók: A kurmányzó sárm. (Le Br. commandeur. Emb. gubernator. T. col. 63.) $=($ Emb. cristatella Br. huppé. Fieill. Galer. 67.); Emb. striolata (vonatos s.) Ruppel. Av., 10. 11. a; - Emb. caesia, ua. uо. b; a Tanagra cristatella, graminea, ruficollis, Spix. 53, szinte sármányok.

Tem. EuberızoInfs-ci, col. 114. hosszú szélcdt farku pintyek, mellyckuck, csorra kissé a pintychéhez közelit. 
nyán. Ez éjszaki madár, télen majd egészen megfehéredö. (1).

Ide adandó még:

2. A laphoni sárma. (Le Bruant de Laponie, ou, grand Montain Buff. Fring. laponica Gm. vagy Calcarata, Pall. Lásd a francz. ford. III, 1. rl. 1.) Naum. 108.

Barna-sárga alapon fekete foltokkal; a himnél a torok s a mel fölseje fekelék. Az elöbbivel egy vidéken lakik, s hozzánl csak télen jö, és jól ritkán.

\section{A PINTYEK. F.}

\section{(Les Moineaux. Fringilla. Lin.)}

Csorrok kúpos, alapján többé kevesebbé vastag; öszbucsa (eresztéke) nem szegletes: általában szemmel élnek s. nagyrészint torkos, ártalmas madarak.

Mi következöleg osztjuk óket föl :

\section{A FONÁROK, (SZÖVÉLYEK.) \\ (Ploceus. Cuv.) ${ }^{2}{ }^{2}$.}

Csorrok elég nagy, hogy részint a csoportályok közé tetettek; de egyenes eresztéke meglkülönbözteti azoktól. Azon fölül felső csorrlemezök könyủden boltos.

A két világrészen találıatnak. Az ó száraziak nagyobb része nagy mesterséggel ralkja fészkét, füszálakat fonva üszsze; ezért neveztetuek fonárok-nak.

Illyen :

A Fulïpszigeti fonair. (Toucnam-Courvi des Philippines. Loxia Philippina, Lin.) Enl. 135.

Sárga, barna foltokkil, torka fekete. Fészke föl-

(3) Az Emb. montana, \& Emb. mustelina, csak különbözð korai a havas sármának.

(') Пhокєu૬, szövo, takács. Vieillot vette föl e nemet és nevet. Gal. Lxxxiv, rl. 
akaszlotl, gokjóképui, liiggóleges hasadíssal, alul mill. melly oldalrást fïgg azon üreggel ësze, hol aprai vannak. ( $\left.{ }^{1}\right)$.

Némellyek nagy menuyiségben rakják össze f'szkpiket, abbul egy sok rekeszü tömeget liépezve.

Illyen :

1. A tarsas foncir. (Le Républicain. Loxia socia. Lath. Palers. Voy, xix. rl.

Olajzöleles barna, alul súrgás, feje s tollai barmáli ragy fekelések.

Az új világbelick közölt megjegyezhelö :

2. A riserö fondr. (I.e Mangeur de riz, petil Choucas de Surinam, de la Jamä̈que, Cassique noir. stb. Oriol. niger, Or, oryzivorus; Corv. surinamensis. Gim.) Enl. 534. Brown. Illustr. X. Wils. Am. III, $\mathrm{xxI}, 4$.

Melly regetlen esoportolitan pusztilja Amerika hevesebb) reszinck mogeil. Szine felicte, a simílott acél minden szincil ggängörï sugárlatokkal riblozlatra. $\left({ }^{2}\right)$.

(') A. 1. Capmore, Buff. (Oriolus textor, Gm.) eni. 375,376 ; Fring. erythrocephala, enl. 665. Vicill. Ois. ch. 28 ; a követelt Tang. de malimbe, Daud. An. mus. I, 128 , X. I. = Malimbe huppé, Vieill. Ois. ch. 42 s 43 ; - le Malimbe orange, uo. 44 ; - le malimbe à gorge noire, uo. 45; - Az aranyhomloku fonár. Ploc. aurifrons. Tem. col. 175 és 176; - a Baglafecht (Lox. abyssinica); a Nélicourai (Lox. pensilis.) Sonn. 2dik utaz cux. 1.; - a Worabee (Fring. abyssinica, Gin.) Vieill. Ois. ch. 28**; - Fring. erythrocephala. Gm. Vieill, uo. 28.

Az alecto szözélyt is. Tem. col. 446. meg lehet különböztetni, mellynek csorra alján földuzadás van.

$\left.{ }^{(2}\right)$ A nérosztók nem szehették mindeddig rendbe Amerikának, a csoportilyokhoz töhbé heveseblué hözeli fekete malarait, mivel ar utasok-adták leirások elégtelenek.

Azt vélem, helye lesz ilt a nevezetesebbeket kị̣elelni azzal, a mi synonymiájokban világosabl. 


\section{A VEREBEK.}

(Les Moineaux. propr. dits. Pyrgita ( $\left.{ }^{1}\right)$. Cuv. Eig. Sperlinge.

Csorrok kissé röridebh az elóbbiekénél, kupos, s hegye felé kissé boltos.

1. A haizi veréb. (Veréb. F. Le Moineau domestique. Fring. domestica. Der Haussperling). Enl. 6. 1. Naum. 115.

A falak lyukaiban fészkel; a lakott helyeket szemtelensége s torkossága miatt háborgatja. Tölül barna, feketés

1-ször. Le cassique noir à mantelet. Alább a csoportályoknál fölhozva.

2-szor. A fölebbi madár, jól rajzolva, de csillogás nélkül festve, enl. 534, s Oriolius niger név alatt fölhozva. Az Oriol. ludozicianus enl. 616. nem egyéb mint kakerlak-fajta. Világosan $=$ Corz。 surinamensis, Brown. III, x. rl. Az apró choucas de Jamä̈que, Sloane Jam. II, 299, ccLviI. rl., mellyet Pennant Grac. barita és quiscala alatt hoza fö!, szinte ez a madár. Más oldalrul nem kételkedhetni, hogy Latham szeme elött birta, midön az Oriolus oryziz'urust leirta.

3-szor. A valódi Carouge noir, violaszinbe játszó, kissé rövid de jỏl egyenes csorru, tangara gyanánt adva, enl. 710. s mellyböl a tanagra bonariensis csináltaték, de ezen ábra valódilag az apró fekete csapatályt (oriolus minor) mutatja. Ezen fajt rosszul mondják jércének, az enl. $600,-2$ kép alatti madár egészen különbözó.

4-szer. Valódi Troupial csapatály, sötét fekete, violaszin fénynyel, hegyes csorra kissé ivelt s melly farkát fölülrỏl csanakidomulag keresztezi. Ez a boat-tailed grakle Penn. és Lath., mellyet e két szerzỏ a gracula barita névazonának tartanak s mind a mellett, cz. valóban az a madár Catesb. 12. rl, mellybỏl Linné a gracula quiscala-t csinálta, de Catesby rosszul adta a csorrát.

5-ször. Egy fekete madár violaszin és zöld játszással, egy hissi elvágott farkkal, csapatály-csorral, de hegje fele jobban hajolttal. stb.

(') Pyrgita, a házi veréb hellen neve: 
foltokkal, alul szürke, fehéres szalag a szárnyám, a himnek verhenyes oldalsapkája, torka fekete.

Olaszhonban van egy faj ragy fajta, melly himének feje egészen gesztenyebarna.

2. Az olasz veréb. (Fr. cisalpina. 'I. Fring. Italiae.) Vieill. Gal. 63.

A torok feketesége néha a melig kiterjed; $\mathrm{e}$.

4. A mezei veréb. (Le Frinquet, Moineau de bois. Fring. montana.) Enl. 267. 1. Naum. 116, 1. 2.

A lakhelyektül tárolabb tartózkodik. Szárnyán két fehér szalag van, sapkája veres, fejoldala fehér, egy fekete folttal. $\left(^{1}\right)$.

\section{A PINTYEK.}

\section{(Les Pinsons. Fringilla. Cuv. Eigentliche Finken.)}

Csorrok valamiral kevesebbé ívelt, mint a verebeknél, kissé erösebb és hosszabb mint a kenderikéknél. Erkölcscik vidámabbak s dalok változatosb mint a verebeké.

Nálunk három faj van:

(') A hambouvreux. Buff. (Loxia hamburgica, Gm. nem egyéb mint Albin által elrontott mezei veréb, Ois. 111, 24. r1.

A rendes verebekhez számitandók még a természetvizsgálók által elszórt ezen madarak: Fring. arcuata. enl. 230. 1. k. hol igen veres; igazi szinei a verebéi; Fring. crucigera, Tem. 269; - Emb. capensis, c. enl. 389 , enl. 389, 2 és 9. enl. 664, 2; - T'anagra silens, enl. 742, nellybül Vieillot az Arremon nemet csinúlta, Gal. 78; - Fring. elegans, enl. 205, 1. Vieill. Gal. 64; - Emb. ciris, (le pape) enl. 159. melly = PAsserina, Vieill. Gal. 66; Loxia oryx. enl. 6, 2; - Loxia ignicolor, Vicill. Ois. chant. 59; - Lox. dominica, enl. 55, 2. s más faj, enl. 103 ; - Fring. cristata, enl. 181; - Emb. quelea, (le dioch), Vieill. Ois. ch., 23:le dioch rose, ua. 24; - Loxia capensis, Ez kezd egy kissé a vasorrokhoz közelíteni. 
1. Az erdei pinty. F. (Fring. celebs. Lin. Le Piņon ordinaire. Edelfink. Gartenfink. Buchfink.) Enl. 54, 1. Naum. 118.

Fölül barna, alul borverhenyes a hím, szürkés a nö; kél fehér folt a száruyán; fehérke a fark oldalán. Mindenféle magol eszik s mindennemü fín fészkel. A mezöséget leginkább vidámító madár.

2. A fenyö pinty. F. Le Pinçon de montagne. Fring. montifringilla. L. Der Buchfink. Bergfink.) Enl. 54, 2. Naum. 119. Br. Xvir. 3.

Fölül fekete, barnasárgával árnyalt, mele sárga, szárny-ala szép citromszin. Ezen sokat változó madár, a legsúrübb exdökben fészkel, s a sikokra csak télen jö.

3. A hó pinty. F. (Le Pinçon de neige ou. Niverolle. Fring. nivalis. L. Der Schneefink.) Briss. III, xv. 1.

Naum. 117.

Fölül barna világosabbal árnyolva, alul fehéres, feje hamvas, szárnyfedöi s majd minden másod rangu tolla fehér. A hím torka fekete. A magas havasolk szikláin fészkel homnan csak az erös télen jö le az alsóbb hegyekre.

\section{A TengeliceK és (Kenderikék.) F.}

(Les Chardonnerettes. Carduelis. Cuv. Distelfinken).

Csorrok pontosan kúpos, sehol nem boltolt. Magrakkal élnek. A tengeliceknek csorra kissé hosszabb és hegyes.

A közünséges tengelic. (Le Chardonneret ordinaire. Fring. carduelis. Lin. Der gem. Stiglitz. Distelfink.) Enl. 4. Naum. 124. 1. 2. Br. xvir. 7.

Egyike az europai legvidorabb madaraknak, fülül barna, alul fehéres, szép veres álarccal, szép sárga folt a szárnyán, stb. Egyszersmind igen tanulékony madár, éne- 
kelni s kiilönféle mesterségeket megtanuló. Idegen neveit at kóritul kapta, mert a bogáeskoró magrait igen örimest eszi. ( ${ }^{1}$.

\section{A KENDERIKÉK.}

\section{(Les Linottes. Linaria. Bechst. Die Hünflinge.)}

Csorrok szinte szigoruan kípos, de röridebb és tompább mint a tengeliceké. Nörény magrakkal nerezetesen len-és kenderével élnek s kalickíban künnyen tarthatók.

Nálunk van nehány barna laj, verhenyes keveríkkel, mellyek kiulönösen lenitek-nek (L.rotTes) mondathatnak. A liatalok és jercés icren kïlönböznek a reres szin mennyisegere, vagy ammals egész hióral is vamnal. $A$ elsö faj csorra meg majel olly hegges mint a tengelicé. Ez $A$ kis lienderike. (Csicsürke. F. Lenike. Le Sisserin. ('a-

baret, r. petite Isinotte. Fr. linearia. L. Leinhänffling.) Enl. 485. 2. Vicill. gal. 65. Naum. 126.

Fölul barna, feketés foltokkal, szímyán keresztuil két feher szalag, torka fekete, fejföle veres ralamint a mel is a feluoilt himnél, neha még a faresik is. Fiszaki madát, mellynek, mint velilis, mostanábin egy lis és nagy fajtája ismerteték meg $\left({ }^{2}\right)$.

A nagy kenderike. (Kenderike. F. Ia grande Linolle. Fring. cannabina. L. Enl. 485. 1. Naum. 121.

Hita súrga-barna, szírny-és farktollai feketék, fehérrel szegre; alul fehéres, szép veres a fején s melén a vín himmek. Csorra szürie. Gyakran a szölöhegyeken

(') A. h. Fr.psitacea. Lath. Syn. II, 48. I ; - Fr. melba, Edw. 128 , s 272 ; - Fr. coccinea, Vieill. Ois. ch. Xxxı. rl ; - Fr. leucocephala, Lat. uo. 26; - Fr. magellanica, uo. 50.

$\left(^{2}\right)$ L. Vieillot. acad de de Turin, xxur. kör. 193. s höv. lapok. 
majd az erdövágásokban és bokrokban is fészkel. Egy k̈̈zép faj, melly azonban az utolsóhoz közelebb esilk.

3. Az éjszaki kenderike. (Fring. montium. Gm. Naum. 122. Brehm. XVII. 4.) néha ćjszakrul jö hozzánk. Cisorra sárga s a hím farcsilsa kissé verhenyes.

\section{CSIZEK. F. \\ (Serins. Tarins. Zeisige.)}

Azon fajok, mellyek többé kevesebbé zöldek.

1. A közönséges csiz. (Le Tarin. commun. Fring. spinus.

Lin. Der Zeisig. Erlfink. Enl. 485. 3. Naum. 125.

Csorra szinte jól hasonlít a tengelicéhez s különbféle tekintetben hasonlít a kis kenderikéhez. Fölül olajzöld, alul sárga, sapkája, szárnya, farka feketék, két sárga szalagg a szárnyán. Csak a fenyrek legmagasabb tetején fészkel.

A többi fajok csorra rövidebb, mint a nagy kenderikeé.

2. A citrom csiz. (Le Venturon. Fring. citrinella. Lin.

Der Zilronenzeisig.) Enl. 658, 2. Vicill. gal. 62. Naum. 124. 3. 4.

Fölül olajzöld, alul sárgás, feje s nyaka hátula hamvas.

3. A girli csiz. (Le Cini. Fring. serinus. Lin. Der Girlitz). Enl. 658, 1. Naum. 123.

Fölül olajzöld, alul sárgás; barna foltokkal, sárga szalag a szárnyán. Europa déli hegyeinek két madara, a közönséges csiz nagyságával.

4. A kanári csiz. (Kanári pinty F. Le Serin des Canaries. Fring. canaria. Lin. Der Canarienvogel.) Enl. 202. 1.

Nagyobb; künnyen szaporodván a fogságban s igen szépen énckelvén, mindenütt elterjesztetél, s annyira meg- 
változott szinében hogy az eredetit nehéz meghatározni. A nem többi fajainak nagyobb részével nószik; s azokkal többé kevesbbé termélieny korcsokat nemz ( $\left.{ }^{1}\right)$.

\section{AZ ÖZVEGYPINTYEK. \\ (Les Veuves, Viduc. Cuv. ( $\left.{ }^{2}\right)$.}

Afrikai s indiai madarak, csorrok mint a kenderikeé, nẻha kissé fỏlfúttabb alapú, az által még különböztethetöli, hogy némellyeknél farkok tollai vagy felsö takarói rendkivül hosszak. $\left({ }^{3}\right)$.

(') Azon idegen madarak közé, mellycket nömi bélyegekkel meg nem különböztethetni a kenderikéktül, Fringilla lepida; - Fr. tristis, enl. 202, 2; - Fr. ictera. enl. 564; - Fr. nitens, enl. 224; - Fr. senegalla, Vaill. Ois. ch. IX. rl.; - Fr. amandava, enl. 115, 2 és 5;-Fr. granatina, enl. 109, 3;-Fr. Bengalus; - Fr. angolensis, enl. 115, 1; - Carduelis cucullata, Swins. Zool. IIl. Több fajokat találni még, astril, bengalis és senegalis, név alatt, Vieillot illy cimii munkájában. Oiseaux chanteur dela zóne torride, mint: Fring. bicolor, xx. rl.; Fr. cinerea, 6 ; - caerulescens, 8 ; - melpoda , 7; - viridis, 4; - erythroneos, 14; - quinticolor, 15; - rubriventris, 13; - frontalis vasy loxia frontalis, L. 16; - Fr. guttata. 3; - a h. Fr. melanotis, Tem. col. 151, 1; - Fr. sangvinolenta, uo. 3; Fr. polyzona, uo 5; Fr.otoleucus, Tem. coll. 269, 2, 3; - Fr. simplex, Lichtenst. col. 358; - Fr. lutea. ua. Col. 565. Fr. ornata, Pr. Max. col. 208. A ráfogott emberiza oryzivora, cnl. 388, szinte hasonló csorru, hanem farkának durva s hegyes tollai megkülönböztetik.

Lásd szinte azon számos piutycket, mellyek Bonaparte Károly áttal leirattak, Lycée de New-York. II. déc. 1826. 106 s köv. lap.

$\left.{ }^{(2}\right)$ Nem tudni mért számlálta osket Linné s Gmelin a sármányokhoz illy név alatt: emberiza regia, (enl. 8, 1); - Emb. serena, (uo. 24; Emb. paradisea (enl. 194); - Emb. panayensis (en]. 647); - Emb. longicauda, (enl. 635); Add hozzá: Fr. superciliosa, Vieill. gal. 61. Ha az özvegy pintyeket a kersderikéknél nem bagyjuk, a kupályokhoz kell sket tenni.

( $\left.{ }^{*}\right)$ A vállas özvegypintyuél ( $\boldsymbol{V}$. longicauda) csak a takarók hoszszuk; másoknál a tollak. 
Fokonkénti menetel van minden elöállítható köz nélkül a kenderikéktül ( $\left.{ }^{1}\right)$

\section{A KUPÁLYOK-hoz. (VASORR-okhoz.)}

\section{(Les Gros-becs. Coccothraustes. Cuv. Kernbeisser.)}

Mellyek szigoruan kúpos csorra rendkivül nagy. 1. A vasorru kupály. (Vasorru-magnyitó. F. Le Grosbec. commun. Loxia Coccothraustes. Lin.) Enl. 99; 100. Naum. 114.

Nevét igen megérdemli. Iszonyú csorra sárgás; háta,

Jegyz. Az Emb. principalis (Edw. 270.) és Emb. vidua. (Aldrow. Ornith. II, 565.) ugyan azon madárnak látszanak, de különbözo tollazati állapotban. A Emb. psilacea, Seb. 1, Lxvi. rl. 5. k. nem valódi forrásbul jô, az angolensis, Salern. Orn. 277; La veuve chrysoptère, Vieill. Ois. ch. XII, és a Lox. macroura, enl. 285 , 1. melly alig különbözik tôle, nem özvegypintyek hanem rendes kupályok.

(1) Ezen átmenetel, a megvizsgálhattam fajokban, majdnem következơ rendben történik, a csorr egyre nólvén; Lox. quadricolor, (Emb. L.) 101, 2; - ugyan az mint le gros-bec longicone, Tem., Col.; - Lox. sanguinirostris, enl. 183, 2 ; - Lox. Molucca. enl. 159, 2; - Lox. Variegata, Vieill. 51; - Lox. punctulata, uo. 1; - L. Maja, enl. 109, 1; - L. striata, enl. 153, 1; - Lox. nitula, Vieill. 50 ; - L. malacca, enl. 139, 3; - L. astrild. enl. 157. 2 : - L. bella, Vieill. 55 ; - L. cantans, ua. 57 ; L. oryzivora, enl. 152, 1; - L. fuscata, Vieill. LXIr.; - L. cyanea, uа. 64; - L. atricapilla, ua. 53 ; - L. nigra, Catesb. 1, 68 ; Vieill. gal. 57 ; - Lox. brasiliana, enl. 309, 2, és Vieill. gal. 58 ; - Lnx. petronia. (Fring. petronia. L.) enl. 255 ; - L. chloris, enl. 267,2 ; - L. hoematina, Vieill. Lxvir. rl. a hol a csorr igen vékony; - Lox. guttata, ua. 68, amannak fajtája; L. quinticolor, ua. 54; - L. fasciata, Brown, Ill. xxvir, - L. madagascariensis, enI. 134, 2 ; - Lox. caerulea; - L. cardina. lis, enl. 37 ; - L. melanura: - L. coccothraustes, enl. 99 és 100 ; - L. ostrina, Vieill. Ois. ch., 48. gal. 60 ; - L. rosea, Vieill. LxIII. 
sapkája barna, cgyéb tollazata szürkés, torka s szirnytollai feketék, szárnyán fehér szalag. Hegyi erdökben lakik, bük és gyïmöleslákon fészkel, mindenféle gyümölcsöt s magvat megeszik.

Europában még két kisebb csorru faj van.

2. A zïldike kupaily. (Zïldike. F. Le Verdier. Lox. chloris. Lin. Der Grünling.) Enl. 672. 2. Naum. 120.

Fölül zöldes, alul sárgás, farka kïlszéle sárgat. Pagonyokban lakik s minden magot megeszik.

3. A kö̈i kupcily. (La Soulcie. Fring. petronia. Lin. Der Steinsperling, Graufink.) Enl. 225. Naum. 116. 3. 4.

Ezt a verebekhez rala szokás tenni, mert hasonló színii; de nagy csorrán kirül, azoktul könnyen megküilünbiiztethetni egy fehéres vonalrul feje liorölt s egy sárgás foltrul a mellén. ( $\left.{ }^{1}\right)$.

A kupályoktíl meg kell különböztetni némelly idegen fajokat. Ezek

\section{A MAGZuzárok. (MAGZUZóK). (Pitylus, Cuv.)}

Csolrok szinte nagy, kissé összenyomott, föluil irelt, s néha a felsö állkapea (lemez) szólének közepén egy kiálló szeglet van. $\left({ }^{2}\right)$.

Már régóta megkülönböztettek.

(') Könnyen litható hogy ezen harmadik faj nem keresebbé kupály mint a második.

$\left(^{2}\right)$ Illyenek: Lox. grossa, enl. 154; - L. canadanensis, enl. L52, 2, - L. erythromelas, Lath. II, LXVII, és Vieill. gal: 59; - L. portoricensis, Daud. Orn. II, XxIX. rl. vagy pyrrhula auranticollis, Vieill. gal, 55 . 
A РІRóKoK. F. SÜVöLTÉREK. (Les Bouvreuils. Pyrrhula. Gimpel.)

Csorrok görgeteg, föltútt s minden oldalra boltolt. Nílunk egy van

$A$ rendes pirók. (Süvöltö magnyito. Le Bouvreuil ordinaire.

Fölül hamvas, alul verhenyes, sipkája fekete; a jércén verhenyes szürke foglalja el a verhenyes helyét. Különbözö fákon, eserjeken fészkel, az nitak hosszábau. Természcti éneke kellemetes; könnyen szeliduil, dalolni, szólni meglauul. Van egy fijlája, melly egy harmaddal nagyobb ( $\left.{ }^{1}\right)$.

\section{A KERESZTORRÁLYOK. KERESZTORRUAK.}

(Les Becs-croisés. Loxia. Bris. $\left({ }^{2}\right)$. Kreuzschnabel.)

Csorrok összenyomott s két lemezök annyira görbe, hogy hegyeik majd egyik másik oldalrul keresztezik egymást, az egyénck szerint. Ezen rendkivïli csorr arra szolgál, hogy a fenyö tobozok pikkelyei alul kiszedjék vele a magvakat.

Az curopai faj mindcnüt számos, hol nagy fenyvesek vannak: ez

A rendes keresatorraly. (keresztorru magnyitó. F. Loxia curvirostra. Lin. Der Kreusschnabel. Enl. 218. Br. XVI. 1 .

A fiatal hím tollazata szép veres, szárnyai barnák, az

(') A. 1. Lox. lineola, cnl. 319, 1; - L. minuta, uo. 2; L. collaria, enl. 395, 3; - L. sibirica, Falk. Voy. III, Xxvir.; - Pyr. cinereola, Tem. col. 11, 1; - P. falcirostris, uo. 2;P. orthaginea, Tem. col. 400 ; - P. mysia, Vicill. Ois. ch. XLVI. 11. s Spisnél LIX és LX.

(2) Loxia $\lambda_{0}$ Łos-tol (sörbe) Gessner Conrad képzette neve ezen madárnak; Liuné álvilte miaden kupályohra.

CUVIER. I. K. 
idulté s a jércee fölil zöldes, alul sárgás. Szinte két fajLija ran, különbözö nagsyágu, sol a mint mondják. szavu s csorridomu is (Loxia surirostra Nanm. 110. és Loxia pytiopsittacus, Bechst. Naum. 109. (').

A pirokoktul is kereszlorilyoktul el nem tárolithatók:

\section{A KUPAIORGOK. (MAGNYITóK).}

\section{(Les Durbec's. (orrthus, Cur. (). Hakenkernbeisser.)}

Csorroli mindenfelinlröl boltos, és hegyel folülrö az alsú lemezre hajlítja.

Legismertebl, faj :

1 kisemelo kupahore. Iroxia enucleator. I.in. Der Makenfink.) Eul. 135, 1; vagy jobban, Edw. 123. 124; Vicill. gal. 53. Naum. 112.

Szinte a két világrész éjszaki tájain lakik s a keresztorr modjira di. lows vagy vereses, szirny-és farktollai fehéren szegre. $\left({ }^{3}\right)$.

Ejszakou szomszid lajok is rannak, szepszinuek, s

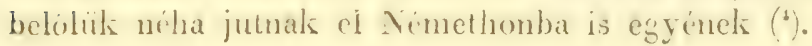

(1) A. h, Loxia leucoptera, Lath. Vicill. gal. 53. és Wils. Orn. Am.

$\left({ }^{2}\right)$ Corythus, egy ismeretlen madír görög neve. Vieillot e nevet STROBILIPHAGA-ra változtatá.

$\left({ }^{3}\right)$ Lox. flamengo, (Sparm. Mus. Carls. xvir. rl.) velenényem szerint csak a kiszemelö-nek fehér fajtája.

A loxia psittacea a Sandwich szigetekrül, Lath., Syn. II, LXIr. rl. vagy PSitTAcirostra icterocephala, Tem. CoI. 457, a kupahorcroktul nem litszik kulönbözui mint csorrának egy kissé hosszabitott zörbe hegye által.

(4) Lox. erythrina, Pal. v. fringilla flammea, Linn. Naum. 115, 1. 2; - Lox. rosea, Pall. Nanm. 113, 3 ; - Fr. purpurea, Wils. Air. I, VII. 4 ? 


\section{A HAJLAKÚPOK.}

\section{(Les Colious. Colius. Gm. $\left(^{1}\right)$.}

Még elég kïzel állanak az elóbbiekhez. Csorrok rövid, tömölt, kupas, kissé összenyomoll s liét lemeze meghajlott, de egymást keresztuil nem rágja; farktollaik elrágvák s igen hosszak, hürelykök, mint a föllengúké, a többi ujjakhoz elöre irányozhatú: finom és selvmes tollaik rendesen hamvas sziniick. Afrikai s indiai madarak, majd mint a papagílyok kúszuak, seregben élnek, söt még fészkeiket is azon cscrjére nagy számmal épitik össze, régre az ágakra fölakasztra lúggó fejjel, egymáshoz szorulkozva alszanak: gyümölesesel élnek. $\left({ }^{2}\right)$.

Ide helyezendóls még:

\section{A VÁGÁRoK (MARHAVÁGóK.)}

Les Pique-Boeufs. Buphaga. Bris. Ochsenhacker.

Apró nem, mellynek csorra kïzéphosszasígu, eicinte hengeríi, de hegye elótt mindenik lemezén foildagad, s elég tompa hegybe régzödik. Az ökör börének ässzenyomására szolgál ez nekik, hogy onnan az oll lalıi bi:gócs bábokat kiszorítsák, mellyekkel élnek.

Csak egy afrikai faj ismeretes, melly barmás, kïzţszerü, s tompa farku, huros-nagyságu. Ez As afrikai vágár. (Földinél: Amerikai marhavágó. Buphaga africana.) Enl. 293. Vaill. Afr. 97. rl. Vicill. gal.

(') Kohoıs, görög neve egry kis va!ju fajnak.

(2) Colius capensis, enl. 282, 1; Vaill. 258, s a fiatal, 256. Ezen fiatal $=$ Col. striatus és Col. panayensis; - Col. erythropus, Gm. leuconotus, Lath Vaill. 257; - Col. gularis, Vaill. 259.

Én a hajlakúpokhoz vezetendöknek vélem a Malurus textilis. Less. (Mlerion natté) és Mel. leucopterus, (Merion leucopteré) revŭ madarakat. Voy. dc Frevcinet. Zool, 25. rl. 


\section{A CSOPORTÁLYok. (Les Cassiques. Cassicus. Cuv.)}

Csorrok nagy pontosan kúpidomu, alapján vastag, s nagyon hegres vigui apro gömbölyü orrlyukai oldalvást nvilnak; a lemezels crösze tört vonalu, vagy szegletet liepzo mint a seregchelind. Amerikai madarak, ertsïleseik cleggé hasoulok seregélyeinkichez, seregekben éök, gyakran fészkeiket is közel rakik s néha nagy mestersiggel lieszitik azt. Bogarakkal s magrakkal duek s számos csapataik nagy kirt okommah a mirelt mezöségelien. Iúsok rosz.

Mi kövelkezöleg osztjuk fel öket:

\section{A tulajdonképi csoporTitчок. \\ (Les cassiques propr. dits. Cassicus. ( $\left.{ }^{1}\right)$.}

Hol a csore alapja a homlokra folmegy s ofl a Lollaliat egy széles, fëlliörü kimelszís állal körülveszi. Ezek közt talíltatuak a legnagyobb fajok. $\left({ }^{2}\right)$.

\section{A CSAPATÁTIYOK.}

(Les Troupiales. Icterus.) $\left(^{3}\right)$.

Mellyeknck csorra a homlok tollitil esak hegyes kimelszissel veszi körül; - s c'gész hosszábam hajolt. ( $\left.{ }^{4}\right)$.

(1) Vieillot fogadta el a nemet és nevet.

(') Cassicus bifasciatus, Spix. Ixr. a; - Cassic. angustifrons, แa. Lxı; - Cass. nigerrimus, ua. Lxu1. 1; - Oriolus cristaus, enl. 344; - r. 328; - Hemorrhous, 482; - Persicus, 184. Jegyz. melly nem Perciabul jỏ hanem Amerihibul, mint a többiek!. - Van ç̧y ércfinyü fehete faj, mellynek nyaktollai fölmereszthetök s némi takarófélit képezhetnek; ez a Grand. troupiale, Azz. Voy. III, 167.1.

$\left({ }^{3}\right)$ Vicillot ezen troupiale nevet carouge-ra víltoztatá, mig én a küretkezỏ osıtílynak adtam azt. A curouge-t pendulinus-sal forfordití, gal. 186. rl.

(4) Oriolus varius, 607, 1; - Or. cayanus, 555, 2; - Or. 


\section{A FALKÁROK.}

\section{(Les Carouges. Xanthornus.) (').}

A csapatályoktul esak egészen egyenes csorrokkal különböznek. $\left({ }^{2}\right)$.

A többek közt egy faj megkülönböztetendö, kissé rövidebb csorru, ez okbul a pintyekhez közelitő:

A csordai falkir. (Icterus pecoris. 'Tcm. Emberiza pecoris. Wils.) Am. II, xvmI. 1, 2. Enl. 606. 1.

Violaszin-fekete; feje, nyaka barna-szürke. E madár seregesen él a marhák között, de legbélyegzöbb tulajdon-

capensis, enl. 607, 2. (Jegyz. Louisianabul, j8 nem a Reményfoktul); - Or. crysocephalus, Merr. Beytr. I, III. Il. Vieill. gal. 86; - Or. dominicensis, enl. 5, 1; és egy játszó-fekete faj, mellynek farka mindenféle idomot fölvesz, az oldali tollak irányzása altal mind a többiekkel azon laptérben, majd hanyattfektetve sajkát képez. (Quisqualus versicolor, Vieill. gall. 108); Wils. III, XxI. 3. Ugy látszik hogy egyszersmind = Gracula quiscala, L. Catesb. xir. rl. s gracula barita, Lath. I, xvm., rl. vagy $=$ Jamaikai szarka. (Pie de la Jamaique); találtatik az Antillakon, Carulinában stb. A Ploceus niger-rel összezavartaték.

Elválasztatandó volna az Icterus sulcirostris, Spix. Lxiv, mellynek csorra, sokkal nagogobb s állkapesának alapja ferdén barázdás.

(') Vicillot az én Carouge-aimnak Baltimore és Yphantes nevet ad, galer. Lxxxvir. Némellyeket elválaszt tôlök, különösen troupiales vagy AGELAIUS név alatt, Lxxxvir. rl.

$\left({ }^{2}\right)$ Oriolus icterus, enl. 352 ; - Oriol. minor et tanagra bonariensis, enl. 710. Ezek ugyanazon madarak. - Oriolus citrinus, Spix, 76. - A Car. gasquet. Quoy et Gaym. Voy. de Freycin. xxiv. Il; - Oriol. phoeniceus, enl. 402; - Oriolus americanus, 236, 2 ; - Oriolus leucopterus, Lath. Syn. I, homl. 1; - Oriol. bonana, enl. 535, 1; - Oriolus cayenensis, uo. 2; - Or. icterocephalus, 543; - Or. xanthocephalus, Bonap. Kár. I, IV, 1, 2. - Or. mexicanus, enl. $533 ;$ - Or. xanthornus, 5,$1 ;-$ Oriol. baltimore, 506, 1, Vieill. gal. 87 , és Wils. 1, 1, 3;-- Or. sprs- 
siga az, hogy tojisait idegen lészekbe rakja, mint a kukuk. $\left({ }^{1}\right)$,

\section{A GYÜLÉREK.}

(Les Oxyrlinques. Oxyrhynchus. Tem.)

Csorrok kípos és hegyes mint a falkároké, de fejöknél xöridebb.

A lingfejü syuler. (Oxyrh. flammiceps. 'T. Ox. cristatus, Swains.) 1ll. 49. col. 125.

Eqy ismeretes fij, melly reressel regyitelt búbot hord, mint a többi zsaroly.

A CSORDÁLYYK, PITPITEK.

(Les Pit-pits. Buff. Dacnis. Cuv.)

Rie-iny ben a falhárohat ábirizolják kipos hegres csorrok allal, s azolial az ökörszonckhez liotil. Ismeretes laj: $A$ cayani csurdrily (.Mot. ca) ana. L.) Enl. 6699. Vicill. gal. 165, Apró, liéls és fekete madár.

\section{A SEREGÉLYEK. F.}

(Les Etourneaux. Sturnus. Lin. Der Staar.)

A falkíroktul csak lenyomolt s királt hegye felé ollyan csorrok által különböznek.

A kiörinseges seregely. F. (T; Litourneau commun. Sturnus. vulgaris. Lin.) Enl. 75. Naum. 62.

Fekete, viola is züldszinjaltszíssal, mindenü̈t fehés vagy sárga foltos. A fiatal hím barna-szürke.

rius, enI. 2, és Wils. I, IV. 1-4; -- Or. melancholicus, enl. 448, mellynek véne $=$ Or. guyanensis, enl. 536 ; Vieill.gal. 88. rl.

('). Gmelin a 606,1 ; képre hivatkozik az. Oriolus minor, alatt, de itt hiba van. 
Ezen madír igen szimos az egész régi viliggban, min-denféle bogarakat eszik, s a marhálinak jo szolgálator tesz, azokiul oklirt megszabadítrín. Nagy sürü csoportokban repül, könnyen szelidül, megtanul énekelni, söl szolani is. Husa rosz izủ. (1).

Nem látunk semmi elegendó bélyeget, mellynél fogva a kupcsorruaktól egészen megkülönbüziethetnók a holló család nemeit, mellyeknek azon belsö alkotása, azon kül müszereik vannak s csak nagyobb termetök által különböznek, melly öket néha az apróbb madarak üldözésére is segíti, erós csorrok gyakran össze vau oldalvási nyomva.

Ezen nemek száma három, nevök: hollók, paradizárok, szalakóták.

\section{A HOLLÓK. VARJUK.}

(Les Corbeaux. Corvis. Lin.)

Cisorrok erós, oldalrást többé kevesebbé lippitott: orrlyukaik elöre irányzott durva tollal fedvék. Finom

(1) A. h. Sturnus unicolor, déli Europábul, Tem. Col. 3 ; Vieill. gal. Xcr; - Sturn. capensis, enl. 280, mellytül St. contra, Albin. III, 21, nem különbözik, de a melly Indiábul s nem a Reményfoktul jo. - St. militaris, enl. 115; - St. ludovicianus, enl, 256, ugyanazon az Alauda magna, Gm. Catesb. 1, 33, vagy = Stournelle à collier, Vicill. gal. xc. rl. és Wils. Ill, xrx. 2; Az oriolus ruber, Gm. (Étourneau à camail rouge) Sonnert, nouv. g. Lxviı. vagy amblyramphus tricolor, Leach, Zool. miscell, Xxxvi. szép faj a Buenos-Ayresi pusztákbul, s nem Indiábul mint Sonnerat mondja.

Jegyz. A St. cinclus fölebb egy a rigókboz (húrikhoz) közel nemet képez. A St. sericeus, Brown. III, 21. inkább csacskár, a $S$ t. collaris, = havasi zenér (accentor). A st. rarunculatus, véleményem szerint a hurszikhoz jo. 
(ravasz) madarak, igen des szaglással, s általíban s\%okísok elviuni s elrejteni a nelik hasztalan dolgokal is, p. 11. a pénzdarabokat, stb.

hözclebbrïl HoLIók-nak és VARJAK-nak azon nagy fajok mondatnak, mellyeknck esorra arányilag crösebb, s a felsö lenłez crösze iveltebb. Farkok lierek vagy négyszegü.

1. I (fekete) hollo. F. (The Corbeau. Corvus corax. Lin. Der Kolkrabe, Rabe,) Namm. 53. 1. I aill. Afr. 51. 1l. $\left({ }^{1}\right)$.

Legnagyobb europai madár a verebüek oszlályábul. Nagysága föliti a kakasél. 'Tollazata egészen fekete, larka kerek, felsö lemezenck híla elöre ivelt. A többi lajoknal clromultabban il, jul is magasan repail, egy mérfoldnyiruil megérzi a dög szagail, kïlönben mindenféle gyümölcsöt és apró madarakat eszik, még az udvarbelieket is elragadja, magán lészlicel magas fäkon ragy meredek szilkán; könnycu szeliduil s még jol is meglanul beszéhni. Ugy látszik, a vilíg minden résziben lalitható. Éjszakon gyakran feherrel lievert tollu. (Iscan. Ic. Hat. vru. rl.) Ez alkior a Corvus leucophacus. 'Tem. Vicill. gal. 100. 2. A (Sekete) varju. F. (Le Corneille. Corv. corone. Lin. Die Krähe. Rabenkrähe.) Enl. 195, Naum. 53. 2. $\left({ }^{2}\right)$.

A hollónál egy negyedddel lisebb, fiuka négyszegúbb, esorra fölül kevesbbé ivelt.

Osbec. IIernandés stb. fajai kevescbbé hitclesck; a mi Pallaséit illeti, az bajus hogy nincsenck rajzai. Daudiu seregélyei a hurikkal vagy hurszikkal tartoznah egybe, yuiscales-ci pedig részint a csacskárokboz, részint a csoportílyokhoz. Általíban. Daudin e nemet az elödei által rosszul magyarázottat, még tovább zavará.

(') Jegyz. Enl. 595. egyszerú varjunak látszik, és 483. fiatal vetési varju. Temmink azt hiszi, hogy a Vaillant-idézte ábrázolat, tulajulon faj, Afrikában lakó, mellynek Cort' montanus, nevet adott.

(2) Temmink azt hiszi, hogy a mi varjunkat meghölönböztet- 
3. A vetési varju. F. Vetély. (Le Freux. Corv. frugilegus. Liu. Die Saatkrähe.) Enl. 484. Naum. 55.

Még valamivel kisebb; egyenesb és hegyescbb csorru, mint a virju. Elsö fiatalságát kivéve, csorrlapjának kïrc tollul fosztott, hihetö: mirel sokat turkílja a földe九 vele, eledelét keresve ott.

E két faj nagy csapatokban él, még fészkelés réget is összegyülnek; bogarakat szintugy esznek mint magrat. Egész Europában találtatik, de télre esak a kevesbbé hideg tartományokban marad meg.

1. A hamvas varju. (közönséges V. F. La Corneille mantelée. Corv cornix. Lin. Die Nebelkrähe.) Eul. 76. Naum. 54.

Hamvas; feje, szárnyai, farka feketék. Kevesbbé magevö; a tengerpartokat keresi, ott csigákkal él, stb. Naumann erósíti, hogy a fekete varjuval gyakran párosodik s vele termékeny korcsokat nemz.

5. A csóka. F. (Cory. monedula, Lin. Le Choncas, petite Corneille de clochers. Die Dohle.) Eu!. 525. Naum. 56. 1.

Az elóbbieknél még egy negyeddel kiscbb, majd galambnagyságu, vilígosb fekete, melly szin még hamvasba is hajlik nyakin s hasa alatt, ncha egészen is fekete; tornyakon, ó falakon fészkel, csapalosan él, kzülönben varju-szokásu s azokkal gyakran repül. A ragadozó madaraknak nincs vigyázóbb ellenségök. (1).

lieti a reményfokitul. (Vaill. 52); mellynek e nevet adja: C. segetum.

(') A csókák bevégzik a ralódi hollók törzsökét mivel fölsó álkapcsok alig jobban görbült az alsónál. Ada $e$ törzsökhöz: Corv. jamaicensis; - Cor». dauricus, enl. 327 ; - 


\section{A sZARKÁK. F. \\ (Les Pies. Pica. Cuv. Elster.)}

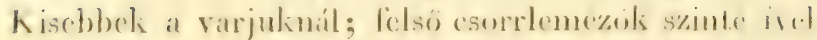
ıcbb a másiknál, farkok hosszú, vígotl.

1. As europui saurka. (lee Pie d' Tiurope. Corn' piect.

Lin.) Enl. 488, Naum. 56. 2.

Sxip matir, selyemfekele, biborlönsii a kekben is

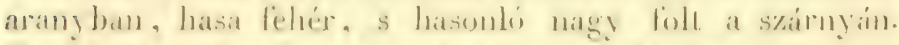

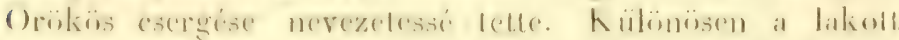

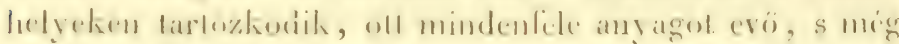
a majorságbeli apró madarakat is megtámadó. ( $\left.{ }^{1}\right)$

\section{А sұлако́к. F. \\ (Les Geais. Garmulus. Cuv. Haher.)}

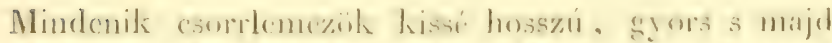
egrenlo gördoulesbe regzodo: midon liurhok vigoll, keressi

Corv. scapulatus, Daud. Vaill. 55, mellyet Tenmink az ciobbituil küönbözo̊nck hisz; C. albicoll's, Lath. vagy Corbizau, melly ery mellehes alnemet kiprezletur, onszenyomott folemelt des metszó hátánál fogva. Vaill. 50; - A Corv. splendens, Indiábul, Vieill. col. 425, nevezetes azon ösztöncért, hogy a chaugoun keselyú alatt a tetrcket kikeresi, melly azt örömest eltïri; $\Lambda$ Corv. columbianus. Wils. III, xx, f. 2; - a Corve nasicus, 'Tenm. col. 413; - a Corz ossifragus, Wils. V. xxxvır. 2. k. ha csak ugyan különbözik a mi varjunktul.

(') A. h. Corn. senegalensis, enl. 558; - Corw. ventralis, Sh. Vaill. Afr. 55; - Corz. erythrorhynchos, enl. 622, és jobban, Vaill. Afr. 57; - Corv. cayanus, enl. 373; - C. peruvianus, enl. 625 ; - C. cyaneus, Pall. Vaill. Afr. 58, 2; - C. rufus, Vaill. Afr. 59; - Az, Acahe' Azz. Corz. pileatus, Ill.) col. 58, vagy (Pica crysops,) Vieill. gal. 101, - A garr. gubernatrix. T'. (Garrule commandeur). col. 436; - a Corv. azureus. (Pie bleue de ciel.) Col. 168; - Corr. cyanopogun, Pr. Max. (la pie geng.) Col. 169. 


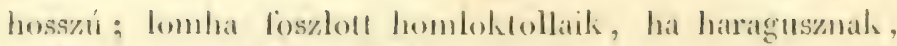
löblé kevescbbé fölmerednek.

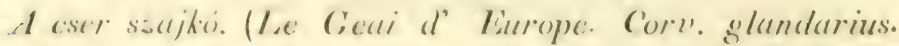
Liin. Der Holzhïher.) Ful. 181. Naum. 58, 1.

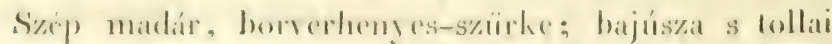

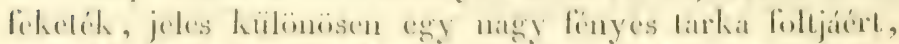

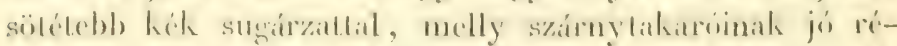

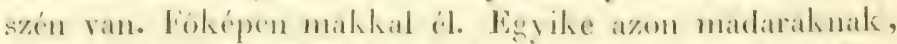
mellsek leghajlandebbak minden hang ulánozísára. Min-

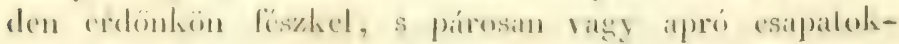
banı él. (').

А DIótönók. (иАGтӧпöк. F.)

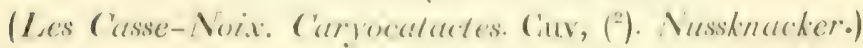

hil esorrlemezol egyculien hegyes. egyenes, görbüléstelen.

Csak egy ismeretes laj ran.

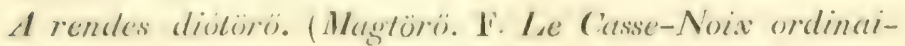
re. Corv. caryocalactes. Lin. (Enl. 50. Naum. 58.

2. Vieill. gal. 105.

Barua, egész testén fehér foltos. Fa odvakban fész-

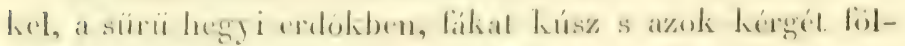
vágia mint a harlsily, mindentéle gytimölesiet, bogara-

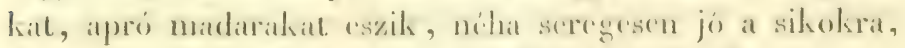
de rend nidhuil. Hires a heréssio lílenksigriil. ( $\left.{ }^{3}\right)$.

(') Ah. h. Cormus cristatus, cul. 529. Vicill. gal. 102 ; - Corn. Stelleri, Vaill. Ois. de Par. etc. I, Corw sibiricus, enl. 608; Corm. canadensis, enl. 530; s egy fajta, Vaill. 48; Corn.cristatellus, vagy C. cyanoleucos, Pr. M. col. 193; - Corw. ultramarinus, T. col. 159; Cor». torquatus, 'T., col. 44; - Corv. floridanus, Bonap. K. 1, хин. 1.

$\left(^{2}\right)$ Vicillot e nevet emezacl cserélte fül: NUCifragA.

(3) Jegyz. A Corz. hottentotus, enl. 226, ugy látszik küzel all a zsarolyokhoz; - A Corr. balicassius, bogárkapó; a Cor». 


\section{A HoLtánoK.}

\section{(Les Temia. Vaill.) ( $\left.{ }^{1}\right)$.}

A szarkik idoma s larka mellett esorrok emelt, felsó lemeze boltos, s ennck alapja bibor tollakkal szegett majd mint a paradizárolknál.

Legrégibben ismeretes:

A tarka hollir. (Corv. varians. Lah. Vaill. Afr. 56; Vieill. galer: 106.

Bronz-zöld. Indiában s Afrikában talállatik. $\left({ }^{2}\right)$.

\section{A HARJÚK.}

\section{(Les Glaucopis. Forster:) $\left({ }^{3}\right)$.}

Csorrok, idomok ugyanaz, de csorrok alapja alatt két husos torongy csüng.

calvus, enl. 521, zsarcsup, - A Corn. novae Guineae, cnl. 629, s Cor\% papuensis, ent. 650, hollógebicsek: - Corn speciosus, Sh. = Rollier de la Chine, enl. 620, s a fogcsorruak-hoz tartozik. Temmink loriót csinál belole, col, enl. 401. - Cor. flaviventris, zsaroly, enl. 249; a Corz. mexicanus, hilsctöicg csoportily vagy fonár, de a Corz. argirophtalmus valoban ollyan, Brown. III. 10; Corn. rufipennis, enl. 199, rigó, = turd. morio; - Corv. cyanurus, enl. 355, C. brachyurus, enl. 257,258 s a C. grallarius, Schaw, enl. 702. hangyazuzok és hansyörölÿï, a Corz. carunculatus, Daud. hurszi.

A rigókhoz tétettck a Cor2\% pyrrhocorax, enl. 531. a babutíkhoz Cor.graculus, cnl. 255. Én azt hiszem, hogy a C. eremita, nem létez. C. cariboeus, Aldror. I, 788, gyurgyalag, mellynek Dutertre adta leirását, de csak rosz cmlékezete szerint, végre a $C$. gymnocephalus. T. (La pie chauve) véleményem szerint a fogcsorruakhoz tartozik.

(') Vieillot e nevet CrIPsirina-ra változtatá, gal. 106 ; Horsfield PyENotrix-ra. Temmink a hollárokat, a varjukkal egyesíti.

$\left({ }^{2}\right)$ A. h. Glaucopis leucoptera, T. col. 285; - G. temnura ua. col. 537 .

$\left({ }^{3}\right)$ Bechstein Glaucopis, helyett CALLAEAS-t használ. 
$\mathrm{A} z$ ismeretes faj.

A hamvas harju. (Glaucopis cinerea.) Lath. Syn. I, xiv. rl.

Uj Hollandbul, bogyơval él; fán ritkán ül. Husa jelesnek mondatik.

A SZALAKótÁK.

(Les Rolliers. Coracias. Lin. ( ${ }^{1}$ ). Rake.

Csorrok erös, hegye felé összenyomott, hegye kissé görbe; orrlyukai hosszúdadok, a tollak szćlén ülnek, azoktul nem födve; lúbaik rövidek, erôsek. Ó világi madarak, a szajkókhoz igen hasonlitók szokísaikra s homlokuk lomha tollaira nézve; élénk de ritkán öszhangzó szinück. Bonctanuk olly különösségeket mutatja, mellyek miatt a jegérekhez és harkílyokhoz közelítenek: két kimetszés ran mellesontukon, csak egy pár izom az algégén, s hártyás gyomor. $\left({ }^{2}\right)$.

A tulajdonképi szALAKóTÁK.

(Les Rolliers propr. dits. Eig. Raken.)

Csorrok egyenes, mindenütl ınagasb, mint széles. Europában egy van:

A karicsa szalakóta. F. (Le Rollier commun. Coracias garrula. L. Die Mandelkrïhe.) Enl. 486.

Tengerzöld, háta, válla súrgák; tiszta liék a szárny töve; majd szajkó nagyságu. Igen rad madár, noha társai közt igen nyájas, kiáltozó, fa odrakban fészkel az erdökïn, télen elhagy minket. Férgekkel, bogarakkal, apró békákkal él.

(') Ezen, Linné auctoritása illal megszentelt nevet Vieillot GALGulus-ra változtatí, melly a régi latinokuál a Lon ró neve volt.

(2): Nitsch. Naumannál, 11, 156. 1. 
Némelly idegen szalakibúknál négyszegü a lark, misl a mienknel $\left({ }^{1}\right)$ : azonban amnak külsö tollai már emnek himjenel himyulnak cgy kissé, a mi elsó jele a többi fajols nagy számánáli nagy kihosszúlásnak. $\left({ }^{2}\right)$.

\section{A SZELEKÖTÉK. \\ (Les Rolliers, Coracias. Cuv.) $\left(^{3}\right)$.}

A szaliklintiklu! rivilubb, iveltebb s kiblïnösen ala-

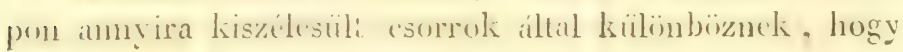
az olt kevesebbé magas mint széles. (").

a PARADIZÁROK. (PARAdICSMAdARAK. F.) (Les O)isecun de: Paralis. Paradisaea Lin. Paradiesvogel.

Conrok, mint a hollihe. egrones isszenyomoll eros.

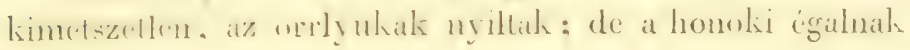

(1) Coracias benghalensis, enl. 285, ugyanaz, mi az indica, Edw. 526, s mellyet Albin caudata, néven emlit, 1, 17. k; Coracias viridis, Cnv ; Vaill. 1, 51. Vieill. gal. 110.-Cor. Teminkii, Vaill. G. r.

$\left({ }^{2}\right)$ Cor. abyssinica, enl. 606, s fajtája, Cor. senegala, enl. 526, Edw. 527. - A C. caudata, nem egyéb eliclomitlanitott egyénnél, a benghalensis fejével. (Vaill. loc. cit. p. 105.) - Cor. cyanogaster, Vieill., idézett helyett xxvı. 1.

Jegyz. Cor. caffra, hol Shaw. Edw. 320. idézi, nem egyéb lesz rigónál (turdus nitens; - C. sinensis, enl. 620, kivágott csorra altal szinte vagy a rigúkhoz ragy a gebicsekhez közelit. Már mondók, hogy Temmink loriónć tette. Schaw. azt véli, hogy viridis, Lath. jegér; - C. strepera, C. varia Lath. varjugebicsek; $-C$. militaris et Cor. scutata, Shaw. piohók; - Cor. mexicana, Seb. 1. Lxiv. rl. 5. k. Canadai szajkó; C. cayana, enl. G16, tangara.

$\left.{ }^{3}\right)$ Colaris, görög neve egy ismerelen madárnak. Vieillot ezt iltváltoztatá EURYSTOMUs-ra.

(') Corarias orientalis, enl. 619; - Cor. madagascariensis, enl. 501; - Cor. afra, Math. Vaill. az id. helyen. xxxv. rl. 
befolyása, a még több nemckre is kiterjedö, az orrlyulaakal betakaró tollaknak biborszövetet ada s nćha ércfünyt is a mellett hogy testök több részeinek tollait különösen kifejté. E madarak Uj-gvincábul erednek s a szomszéd szigetekbül. Nem egy könnyen kaphatni ölket músokiul mint e vidékek igen rad lakosaitul, kik öket tollbokrétávi líszitik s ez olkbul lábaikat és szárnvaikat kiszagrgalják. Innét hitték cleinte az curopaiak, hogy az clsö faj lábai hibáznak, melly mindig a levegóben élne, nag̨ oldaltollain tartózkodra fön. Azonban némelly utasok némelly fajok teljes egyéncit tudták megszerezui, s ma ludjuk, hogy lábaik és szárnyok azon helyet kivánják, mellyre öket tettük. Az moudatik, hogy gyümölcsöl esznek s kivált a fǘszereseket keresilk.

Némcllyeknél az oldaltollak foszlottak s különösen kinyultak a testnél hosszabb pamatokba, mellyck olly fogatćkot adnak a szćlnck, hogy az által e madarak igen gyakran torább vitemek akaratlanul; ran még liét szakállatlan csolijok is a farcsikon, mellyck szinte olly-ragy még inkább hosszan elnyulnak, munt oldal tollai. $\left(^{1}\right)$.

1. A smaragd paradizar. Aagy paradicsmadár. F. Li oiseau de Paradis émeraude, Paradisaea apoda. Enl. 254. Vaill. Ois. de Par. 1. rl. Vieill. Ois. de Par. 1. rl.

Huri-nagyságu, gesztenyeszin, fej és nyakföle sárga, csorx és torok-köre smaragdzöld. Ezen fajnak hime hordja azon tollpamagokat, mellybül az asszonyok ékszert csinálnak. Van egy kissé apróbb fajtája.

2. A veres paradizar. (Parad. rubra. L' oiseau de Paradis rouge.) Vaill. 6. rl. Vieill. 3. rl.

Oldal pamagai szép veresek, s csökeik szélesebbek, cgg oldalrul homoruak.

(') Vieillot az én elsó fölosztásombul nemet csinált s azt sAMaLia névvel ajáudékorá meg 
Mis paradizírolnál megramak mieg a tollescilioik, de az oldaltollats, noha eggy kissé husszats, nem haladjảls meg a farkat.

3. A kiratyi paradizar. (Le Manucode. ('). Paradisaea regia. Enl. 496. Vaill. 7. Vieill. 5. galer. 96.

I erib nagy sigu, bibur-gesztenyeszinü, hasa fehér, egy szalagr lieresztul a melin, oldaltullainak rége s azon szatkillyuk, mellyek a kiet hosszú csök régét kiszélesitik, smaragdzüldek.

1. 1 pompás paradizar. (Le Magnifique. Par. magnifica.) Sommerat. 98. Enl. 631. Vaill. 9. Vicill. 4.

Fiblil gesztenyeszin, alul és oldalvíst zöld, szírnyIollai sirgaik. egy toll-pamag a nyak mindeuik oldalin halvány szalmasárga egy másik sárguabb a szárnyhajlatmak ellenében.

Misoknak migg foszlott de rövid tollaik rannak oldalaikon, s farcsikokon hibázók a csölsszúlak.

5. Az arany paradizar. (Te Siflet. Par. aurea. Gim. Par. sexsetacea. Shaw.) Sonnerat. 97. rl. Enl. 635. Vaill. 12. Vieill. 6. és Galer. 97.

Rigin nagysign, felsele, torkín arimyziold vietees, mindenik fülenck lárom tolla szailba nyúl, mellyet egy kis szakállkög végez be, aranyzöld. ().

Másolinál régre sem csijkszárak sem kinyujlás nines az oldaltollakon.

A kevely paradizar. (Le Superbe. Par. superba.) Son-

(') Manucodewata, azt mondják, anuyit tesz a moluki szigeteben, mint Istenmadár. Fz minden paradizár hözös neve. Vicillot czen fajbul csinálta a cixcinsurus nomet.

(2) Vieillot e fajbul a paroris, gal. 97. - nemet csinálta. 
nerat. 96. enl, 601. 632. Vaill. 14. Vieill. 7. galer. 98. (1).

Válltollai mind a mcllett némi liöpönyeggé nyúltak ki s a szárnyakat be tudják takarni, a melltollak pedig némi ruhaujj-idomu villás csomagba gyültek. Minden tollazata fekete, kivévén a mellcsomagot, melly fénylö acélzöld. A narancsos paradizár. (Le Orangé. Par. aurea. Sh. Oriolus aureus. Gm.) Edw. 112. Vaill. 18. Viell. 11.

Tollazatán semmi rendkivüli kifejlés, s nem ismerhetó másrul meg, mint az orrlyukait takaró tollak biborságárul. A him legridámabb narancs színü, torka s szárnyának elsö rangu tollai feketék, a nönél szürke foglalja el narancsszín helyett. $\left({ }^{2}\right)$.

A verebek negyedik családa.

A VÉKONYCSORRUAK.

Az elsö felosztásbcli maradék-madarakat foglalja magában, mellyeknek csorra vékony, hosszú s majd egyenes, majd többé kevesebbé ívelt, kimetszés nélkül. Ugy vannak majd a kupcsorruakhoz mint a billegetók a többi fogcsorruakhoz.

(') Vieillot e fajbul a Lophonrs nemet csinálta, gal. 98.

(2) Én a rigókhoz szúmlálom ezcket Paradisaea gularis, Lath. v. nigra, Gm. Vaill. 20 és 21. Vieill. 8. 9. leucoptera, Iath. A varjugebicsekhez teendo̊k: Par. chalybaea, enl. 633, Sonn., 97; Vaill. 23; Vieill., 10; - le Cirrhatu, Aldrov. 814, igen el van csonkitva s le nem irható, a furcata Lath. ugy látszik, hogy a superba-nak tökéletlen egyéne.

CUVIER I. $k$. 


\section{A FavágároK. (FAVÁgók. F.)}

(Les Sittelles. Torchepots. Silla. Lin. Spechtmeise.)

Az clsö helyre tehetök; csorrok egyenes, hengerí, hegyes, vége felé öszenyomout, mellyet ugy hašnálnak, mint a harkályok a kéreg fölvágására, hogy alúl a férgeket kiszedhessék, de nyelrök nem nyul ki s roha mindenféle módon kúsznak a fákon, hátul csak egy ujjok van, de igen erös. Farkok nem szolgál támaszul, mint a harkályoké s a valódi kúszóké.

Nálunk (Franciahonban) csak egy van :

A küzönséges favoigcir. (Kurlakalapcics favigón. Földi.

Le Torchepot commun. Silta europaea. L. Der Kleiber.) Enl.623.1. Naum.139.

Föliil kékes hamuszín, alul verhenyes, egy feketís szalag szál szeme mögöll le; alikora mint egy reres begyï dalár. $\left({ }^{1}\right)$.

Ugy vélem, elválasztandók a favágároktul:

\section{A VÁGCSÁROK.}

\section{(Les Sittines. Xenops. Iliger.) $\left({ }^{2}\right)$.}

Amazoktul caka jobban össenyomott esorral különböznek, mellỵnck alsi erösze domboríbb. ( $\left.{ }^{3}\right)$

(8) A. h. S. canadensis, (S. à sourcil blanc.) Briss. Enl. 623, 2. - A fekete fejü farágály. S. melanocephala. Gm.) Catesb. I, xxxı. Vicill. gal. 171, Sitta frontalis, Swains, Zool.; Ill. 2: vagy Sitt. velata Temm., col. 72, 3 vagy orthorynchus frontalis, Horsf. jav.; - Sit. crhrysoptera, Lath. 3 pót. 327 ; - S. pusilla. ua.

(2) Vieillot e nevet Neops-ra változtatá.

(3) Xenops rutilus, Licht. col. 72, 2. v. neops ruficauda, Vieill. gal. 170; Xen. Hofmanseggii. col. 150, 1. Vaill. prom. 31, 2. - Xenops anabatö̈des, col. 150. 2. 
A. VERGÉLYEK.

\section{(Les Anabates. Anabates. Temm.)}

Mellyeknél ellenkezóleg a csorr felsö erösze domború, mintegy kimetszéstelen rigó-esorr. Vamnak hosszú ikfarkuak, sót kopott farkuak is, a mi azt bizonyítja hogy kúszás közben tartózkodnak vele. ( ${ }^{1}$ ).

\section{A KOPOGÁROK.}

(Les Synallexes. Synalexis. Vicill.)

Csorrok egyenes, kissé nyult, igen összenyomott, karesu, hegyes; farkok rendesen hosszú hegyes. $\left({ }^{2}\right)$.

Vannak ollyak is, mellyeknél a toll-csökök a szakállakon túl is kinyulnak. $\left.{ }^{3}\right)$.

\section{A FAKÚSZoK. F.}

\section{(Grimpereaux. Certhia. Lin. Baumlïufer.)}

Cisorrok hajolt, de majdnem esak ez egyben egyez-nek meg.

Megkülönböztetjük köztök elöször is :

(') Anabates cristatus, Spix, 84; - Anab. rufifrons, ua. 85, 1 ; - Philydor ruficollis, uа. 75; - Phil. albogularis, ua. 74; Phil. superciliaris, ua. 73 ; talám $=$ Anabates amaurotis, Tem. col. 238, 2; - Sphenura striolata, Spix. 83, 2. anabates striolatus, Tem. col. 23.1 .

$\left({ }^{2}\right)$ Synallaxis ruficapilla, Vicill. gal. 174. v. Parulus ruficejs, Spix. 86 ; mellyektiil fajilag alig különböznek a Syn. albescens, Tem. col. 227,2 és cinerascens, uo. 3 ; - syn. rutilans, col. 227; 1; - Syn. tesselata, col. 311, 1; Syn. setaria, wo. 2; - Prinia familiaris, Horsf. Jav.? - le Flúteur, Vaill. Afr., 112; v. Malurus africanus, Swains. Illig. 170, esak csorra magasabb kevéssé.

( $\left.{ }^{3}\right)$ Dendrocalaptes sylivillus, Tem. col. 72, 1. Vaill. prom. 31, 2. 30 * 


\section{A valódi FAKÚszoK-at. \\ (Les vrais Gimperaux. Certhia. Cuv. Die achten Baumbläufer.)}

Igy nevezteluck azon szokásokért, hogy fákon kúsznak mint a harkílyok, farkokat támasz gyanánt hasznúlva; megismerhetök kopott farklollaikról, mellyek durva hegr be végzödnek, mint a harkályoknál.

Nílunk egy van.

A küzönséges fakuss. F. (T,e grimperau d' Europe. (erlh. familiaris, L. Der Baumreiter.) Enl. 681.1. Naum. 140.

Apri madír, fehéres ruhával, fölül barna foltog, faresikín és farkin verhenyes. Talyukakban fészkel s gyorsau kísz, bogaralsal is bíbokal keresö a kérgek repedésciben, a moh alatt stb. $\left(^{1}\right)$.

Amerikában nehán! vatudi fakrisz van, nagy tcrmetii, mellyelinek nere:

\section{Y.LCSÚSZOK.}

(Picucules. Dendrocolaptes. Herm. ( $\left.{ }^{2}\right)$. Grimpars. Vaill. Kletlerschwanz.)

Farkink hisonló, de csorruk sokkal crösebb s átmeszöleg szélesbb $\left({ }^{3}\right)$.

(1) A. A. C. cinnamomea, Vicill. Ois. dor. 62, és gal. 173; Motacilla spiricauda, Lath. Sio. II, pl. 52 ?

$\left.{ }^{2}\right)$ Dendrocaloptes, a harkily görög neve. Vieillot DEndrocopcs-ra viltozlatá, gal, $1 \% 5$, s mús osztílyra alkalmaztalí.

(') Le ficucule, Buff. (Gracula cayennensis. Gm. Grac. scandens, Lath. et Sh.) enl. 621. Vieill. Ois. dor., 76. mellyhez igen közel állók: a Dendroc. decumanus, Spix. 87, és falcirostris, 88. A. h. le grand Grimpart, Vaill. 42; - Dondr. Wagleri, 90, 2; - le Gr.mailléc, Vaill. 29, 2 ; - le Grimpart flambé, Vaill. proinér, 30. v. Dendroc. platyrostris, spix, 89 ? - le Grimp. enfuxie, Vaill. 29. 
Egy még ollyan is van, melly egészen egyenes és összenyomott csorra által a favágárokhoz közelít, s kopott farku favágár gyanánt tekinthető ( $\left.{ }^{1}\right)$.

Egy másiknak csorra kétszer loszabb a fejénél s csak a hegyén hajolt. $\left({ }^{2}\right)$.

Egy másiké hosszú vékony s annyira ívelt, mint a mézszipoknail. ( ${ }^{3}$ ).

\section{A FALKúszoK.}

(Tes Echelettes. Grimp. de muraille. Tichodroma. Illig. Mauerlïufer. ( $\left.{ }^{4}\right)$.

Farkok nem kopott, noha a falakon és sziklíkon ugy kúsznak mint a fakúszok a fúkon, de igen nagy körmeikkel ragaszkodnak. Csorrok háromszeglelii s lcnyomott az alapjún, igen hosszú, igen vékony.

Csak egy ismeretes, melly déli Europában lakik. $A$ rendes falkusz (Falmászó fakúsz. F. Certh. muraria.

Lin.) Enl. 372. Naum. 141.

Csinos madár, világos hamúszinü, vidám veressel a száıny-takaróin s evezöinek egy részén. ( $\left.{ }^{5}\right)$.

\section{AZ ÉDSZIPOL.}

(Les Sucriers. Nectarinia. Lin. Zuckervogel.)

Farkok nem kopolt, nem kúsznak, de küzépszerüen

(') Le talapiot, Buff. (Oriolus picus, Gm. et Latl. Gracula picoides, Sh. enl. 605, v. Dendrocaleptes gruttatus, Spix.91. 1.)

(') Le Nasican, Vaill. promer. etc. 2 .

(') Le Grimpart promerops (Dendrocalejtes procurius, Tem.) col. 28, v. Dendrocapus falcularius, Vieill. gal. 175.

(†) Echelette neve van a falkúsznak némelly francia tarlományban. Vieillot Picchion-ra változtatá s Illigerét pedig PÉTODnOMA-ra.

(3) Certhia fusca, Lath. Vieil. 65, szinte véleményem szerint ezen alnemher tartozik. 
hosszú, ivelt, hegyes es üsszenyomolt esorrok hasonlit az álkúszokéhoz.

Még különösebben Guitguit (szıpÁn) nevet lordanak bizonyos apró fijok, mellyeknck hímjei vidor szinück. Nyelvök kétszer szclt és fonálidomu. $\left({ }^{1}\right)$.

Etrálaszllatik imen a nagyobb és lievesebbé szép fajok, mellyeknek nyelve rövid és porcos.

1 veres édszip). (Le F'ournier. Merops rufus. Gm. Der

'L̈̈p) fervgel.) Ënl. 739. Figulus albogularis, Spix. 78.

Déli Ancrika madara, alikora mint egy nádi zenér, fibliil rereses, torkán fchéres, - a löldön rak a bokrok alá kemence idomulag födött fészket, $\left({ }^{2}\right)$.

\section{A KUSZIANOK.}

(Les Dicèes. Dicaeum. Cuv. (3).

Szinte nem krisznak, farkuk nem kopolt; csorruk

(') certhia cyanea, enl. 85, 2. Vieill. 41, 42, 43, gal. 176; coerulea, Edw. 21. Vicill. 44, 45, 46. Két amerikai faj, mellyekhez hihetoleg adandik némelly kelcti, töblonyire veres fajok, mint C. sanguinca, Vieill. 66 ; C. cardinalis, ua. 54, 58; - C. burbonica, enl. 681, 2; - Vieill. gal. 167, czen madarahnak Conrebs nevet adott.

Jegyz. C. armillata. Sparm. 56; - C. cayana, 682, 2. stb. nem egyebek mint a Cyanea v. coerulea, fajtái.

$\left({ }^{2}\right)$ Ezen madár ada typust Temmink e nemének Opnif v. Opetiorlyynchos; Furnarıus, Vieillotnál, gn!. 182. Nem különbözik tơle Spix. Figulus neme. A. h. Pichion baillon, Vieill. gal. 172; Pomacorhinus montanus, Horsf, jav.; - Pomat. turdinus, T. col. 411 ; - Pom. trizirgatus, T. col. 443; - Climacteris picumnus. Tem. col. 281, 1; - Clim. scandens, uo. 2; - Certhia flaveola, Edw. 122, 36.2. Vieill. 51.; C. varia, (mot. varia. Lin.) Edw. 30, 2 ; Vieill 56; - Promerops olivâtrè, Vaill. Huppes Promerops. pl.v. (Mer. olivaceus, Sh.) - Azt hiszem, logy ilt van a C.virens, Vieill. 57 és 58 ; és sannio, ua. 64 helye, mellyeket nem láttam, de melylyek kevessé villás farkok által különböznck.

${ }^{(3)}$ Dicaeum, egy igen kis indiai markár neve; Aelianus sze- 
hegyes, hajolt, fejöknćl nem hosszabb, alapján lenyomott és szélesített.

Keletindábul jönek, igen aprók s rendesen skarlat szin van tollaikon.

\section{A MÉzszípoK.}

\section{(Les Héorotaires. Melithreptus. Vieill. Honigsauger.)}

Farkok nem kopolt, csorruk rendkivül nyult s majdnem félkörbe hajlotl. A déli tengerek szigeteibül jönek. A ruhcizó mézszip. (Certhia Vestiaria. Sh.) Vieill. Ois. dorés, II, 53. rl. gal. 181.

Skarlát tullakkal takart, mellyek a Sandwich szigeti lakosoknak az ezen szinü szép s nagyon becsülı köpünyegek készitésére szolgálnak. $\left({ }^{1}\right)$.

\section{$\Lambda$ DIszKúsz-ok. (Les Soui-Mangas. Cinnyris. Cuv.) $\left({ }^{2}\right)$.}

Farkok szinte nem kopotl: esorrok hosszú s igen karesu, ké lemezének szélci linom fürészfognak; a csorrokbul kinyujtható nyelv kissin villába végzödik; apró madarak, hímcik szcrelem idején érefényü szinüek s a

rint. Ide tartozok: Certh. erythronotos, Vicill. 11, 35. C. cruentata, Edw. 81. melly hihetöleg amattul csak életkora nézve különbözik. - C. rubra, Vieill. Lıv. s ennek a C. erythropygia, Lath. 2. pótl. hilietơleg jércéje; s a Necturinia rubricosa, Temm. Col. 108. f. 2. 3. nem látszik tole különbözni. - C. taeniata, Sonn. II. Voy. pl. cv11., 3. k; - C. cantillans, uo. 2; - Motac. hirundinacea, Sh. Nat, Misc. 114. sz.

I (') A. h. Certh. obscura, Vieill. Ois. dor. II, LII, rl. - C. pacifica, uo. Lxirr, de a többi méz-szipok ezen szerzótül, különbözó nemekbe tartoznak fókép a húrszikhoz s kuszlanokhoz.

$\left({ }^{2}\right)$ Cinnyris, görög neve egy igen kis ösmeretlen madarnak. Souimangat, mondják madagasrari nép nyelven cukor-erö-t jelent. Vicill. elfogadta c cınNyris nevet, gal. 177. 
pompályok ragyogásához Jiozclílnck, czeket némileg kipólolva az ó világhan, mert leginkább Afrikában s az indiai szigetsokon találtatnak. lirágokon ćluck, s azok nedvét szivják, módjok vidor, éuckök szép. Számosan hozatnak tárainkba szépségökért; de mivel a nö ruházata s a himé is az coôs érszakban cgészen különbözik ragyogo tollazatoktul, igen bajos a fajukat megbilyegezni.

Legnagyobb számnál egyenlö a fark. $\left({ }^{1}\right)$.

Némollyeknél a him käzepsö két tolla iggen kinyult. $\left({ }^{2}\right)$.

Megkiilönbözlethetök még az igen ragy majd egyenes csorruak. $\left({ }^{3}\right)$.

(') Certhia splendida, Sh. Vicill. Vicil!. 82 ; - C. affra, Edw. 347 ; - C. superba, Vieill. 22 ; - C. lotenia, enl. 575, 2.3; Vieill. 43; - Ametystina, Vieill. 5, 6; Calybaea, enl. 246, 3 ; Vieill. 10, 13, 18, 24, 34, 80. Omnicolor, Seb. I, 69, 5; Cuprea, Vieill. 25; - Purpurata, Edw. 265; Vicill. 11. Cyanocephala, Vieill. 7; - Zeilonica, enl. 576, 4, Vicill. 29. 30 ; Dubia, Vicill. 81 ; Senegalensis, Vicill. 8; - Sperata, cnl. 246, 1. 2. Vieill. 16, 32, mellynek nöje a lepida, Sparm. $35 ;-M a-$ dagascariensis, Vicill. 18; Currucaria, enl. 576;- 3. Vieill. 31 ; - Rubro fusca, Vieill. 27; - Fuliginosa, Vieill. 20; Maculata, Vicill. 21; - Venusta, Vieill. 79; - Gutturalis, enl. 578, 3; Nectarinia solaris, Temm. col. 311, 3; - Eximia, Tem. col. 138, 1. 2; - Pectoralis, uа. col. 158. 3; - Lepida, Latb. col. 126, 1. Vieill. gal. 177, 2; - Hasselti, T. col. 376, 3; - coccinogaster, T. col. 388, 5. - Cinn. Eques, Less. et Garn. Voy. de la Coquille xxxr. f. 1. - Javanica, zool. ill; 121. - Ezen marlarak némellyike hihetōleg a másikak fajtája.

(') Certhia famosa, L. enl. 83, 1; - C. pulchella, enl. 670, 1 ; - C. violacea, enl. 670,2 ; - Le Sucrier cardinal, Vaill. Afi. 291; - Le sucrier figuier ua. 293, f. 2. - - Nectarinia metallica, Licht. Ruppel ; vil. rl. col. 347 ; - Nect. mystacalis, T. col. 126,$5 ;-N$. Kuhlii, T. col. $376,1.2$.

( $\left.{ }^{3}\right)$ Cinnyris elegans, Vieill. gal, 177. v. Certl. rectirostris, ua. Ois. dor., Il, LXXv. 


\section{A PókFAIÁROK.}

\section{(Les Arachnothères. 'Tem. Spinnenfresser.)}

Csorrok hosszú s hajolt mint a diszkúszoké, de erösebb s fogallan: nyclvök hosszú, porcos: csak India szigetsokárul jönck, s pókokat esznek. (1).

\section{А РомРа́цток. (Vircigmadar. Kolibri. F.) (Les Colibris. Trochilus. Limé.)}

Ezen apró madarak, olly hiresck tollaik iref'nyećrt s föképen azon dríga köragyogísu helyckír, mellyeket torkokon vagy fejükön képzenek a különös alkotísu, pikkelyidomú tollak; hosszú vékony csorruak, olly nyelvet birók, melly, majd mint a harkályoké, kinyujtható s hasonló mechanismus (kézmúkïdés) által, — s melly majd alapjáig lsét fonálra (szálra) osztatik, mellyeket a madár a virígok édének szivására használ. Azonban a pompályok apró bogarakkal is élnck, s mi gyomrukat illyenekkel telve találtuk. Igen apró lábaik, széles farkok, rendkivül hosszú és keskeny szárnyaik (evezöik igen hamar rövidülvén); kurta válcsontaik, igen nagy s limetszetlen mellcsontuk, a föllengüliéhez igen hasonló repülési rendszert képeznck, és a pompályok a levegöben majd olly liöny-

(1) Arachnothera lonfirostra, Tem. col. 84, 1; - Arachn. inornata, ua., 2.

Jegyz. Mind ezen megkülönböztetésck utín a nagy fakisz nemtül elválasztandók: C. lunata, Vieill. 61; ('. Novae Hollandiae, J. White New. S. W. pl. xvr. és Lxv. Vieill. 57 , 71; C. australasiana, Vieill. 55 ; - carunculata, Vieill. 69,70 ; - C. auriculata, Vieill. 85 ; - C, cocincinica, enl. 643. Vieil. 77, 78, - C. spiza, enl. 578, 2. Edw. 25. - C. seniculus, Vieill. 50 ; - C. graculina, Vieill. 87; - C. goruck, Vieill. 88:- C. caerula, Vieill. 83; C. xanthotis, Vieill. 81 ; C. mellivora, Vieill. 86 , mellyek mind húrszik kivágolt csorjok 8 ecsetes nyelvök miatt. 
nyen súlyegyengetik magokat, mint bizonyos legyek. Illy módon dongjak a virágyó növényeket és fákat körïl, s arányilag scbesebben repülnck minden más madírnál. Zuzájok igen kiesin, a mi ıgen hasonkókká teszi öket a harkílyokhoz. Magánosan élnek, fészkeiket bátran védik s cgymást közt dühvel harcolnals.

A Ponpáli. (Colibri, Trochilus, Lac.) nevet azon fajok számíra lartjuk meg, mellyek csorra hajlott; némellyek fartiok körep tollainak hosszasága által jelesek.

Kizuilïk egyik legnagyobbat és legszebbet hozom föl. A topaiz pompily. (Le Colibri topaze. Trochilus pella.) Enl. 599.

Bıborbarna: feje fejekcte, Lorka legszebl, ragyogó topázsirga, zöldet jútszó. felsetérel körilzölt. (').

Másoknál az oldal farktollak igen hosszúl $\left({ }^{2}\right)$; lïbbeknél középszerien villás a fark $\left({ }^{3}\right)$. A legnagyobb számnál kerek ragy négyszegủ. (s).

(') A. h. Tr. superciliosus, enl. 600, 3; Vicill. gal. 17, 18, 19 ; - Tr. leucurus, enl. 600, 3; - Tr. squalidus, Natterer, col. 120 , f. i, - Tr. brasiliensis, Lath. col. 120. f. 20.

( $\left.{ }^{2}\right)$ Tr. forficatus, Edw. 33; Vieill. 30; - Polithmus, Edw., 51, Vicill. 67, s fohépen a Perui fölséges faj, aranylényü farkával ('T'r. chrysurus. N.)

( $\left.{ }^{3}\right)$ Tr. elegans, Vieill. 14.

(4) Tr. mango, 1. enl. 680, 2 és 5 ; - Vicill. 7 ; - Tr. naevius, Dumont, col. 120.f. 5 ; - Tr. gutturalis, enl. 671; Tr. Taumantias, enl. 600,1 ; - Troch. violaceus, cul. 600, 2; - T. cinereus, Vieill. 5; - Tr. melanogaster, Vieill. 75; Tr. jugularis, Sh. Edw. 266; 1; Vieill. 4; - Tr. holosericeus, Sh. Vicill. 6, 65; Tr. punctatus, lentus, Sh. Vieill. 12; - Tr. aureoviridis, Sh. Vieill. 15: - Tr. hirsutus, Gm. vagy brasiliensis, Sh. Vieill. 20; - Tr. albus, - Vieili. 11; - Tr. viridis, Vieill. 15; - Tr. margaritaceus, enl. 680, 1, Vieill. 16: - Tr. multicolor, Gm. harlequin humingbird, Lath. pótl. cxI. 11; Vicill. 79 ; - T'r. lazulus, Vieill. gal. 179. 
Diszcsének. (Oiseau mouches. Orthorhynchus. Lac.) nevet azok kapnak, mellyek' csorra egyenes; - liöztök búbos fejüek is vannak. (1).

Másokuál a bubok vagy tollak még a fejoldalakon is kinyujlvák $\left({ }^{2}\right)$. s ezek közölt rannak hegyes és igen hoszszú farkuak. $\left.{ }^{3}\right)$.

Másoknál a szárny első tollainak csöke különös módon szélesült. ( $\left.{ }^{4}\right)$ s azok között, mellyeknél nines meg czen ékesség, megkülönböztethetök a villásfarku fajok $\left(^{5}\right)$, s ezek közt vannak, mellyeknek igen hosszúlt oldaltollai végen igen szélesek. ( $\left.{ }^{6}\right)$.

A négyszeg- vagy kissé kimetszelt farkuak kïzölt rendkivüli kicsiségeért megjegyzendö

Az apró diszcsér. (Kolilri Virágmadcir. F. Le Plus petit des Oiseaux Mouches. Troch. minimus. Der kleinste Fliegenvogel.) Enl. 276. 1. Edw. 105. Vieill. 64. Viola-szürke. Méh nagyságu.

(1) Tr. cristatus, Eew. 37, enl 227, 1; Vieill. 47, 48; Tr. pilatus, (puniceus Gm.) Vieill. 63: - Tr. Lalandii, Vieill. 18. f. 1, 2; Orthor. stephanioides, Less et Garn. Voy. de la Coquille, pl. $x x x ı$. nro. 2.

(2) Tr. ornatus, enl. 640, 3, Vicill. 49, 50; - Tr. chalybeus, Vieill. 66, 2, k; - Tr. petasophorus, Pr. Max. col. 203. 3 ; Tr. scutatus, Natterer, col. 299, 3; - Tr. magnificus, Ilig. Col. 299, 2; - Tr. mesoleucos, Tem. col. 317.

( $\left.{ }^{3}\right)$ Tr. bilophus, Tem.

(4) Tr. latipennis, enl. 672, 2; Vieill. 21 ; - Tr. ensipennis, Swains. Zool. ill. 107 ; - Tr. falcatus, ио. 82.

$\left(^{5}\right)$ Tr. mellivorus, enl. 640, Edw. 35, Vicill. 23, 24; Tr. amethystinus, Gm. enl. 672, 1; - Tr. furcatus, enl. 509, 1; Vicill. 34; - Tr. forficatus, Vicill. 36, 60; - Tr. smaragdo-saphirinus Vieill. 40; - Tr. colubris, Edw. 38; Catesb. 65; Vieill. 31, 52, 55; - Tr. maugeanus, Vicill. 37, 38; - T. Langsdorfï, Vieill. 66, 1; Tr. enicurus, Vicill. 66, 5; - Tr. mediastinus, Tem. col. 317 ; -- Orthor. cora. Less. et Garn. 31, 4.

(6) Tr. glaturus, Vieill. 52. 
Egy másile ellenben nagyságra az egész nemet fölülmulja :

Az óricis diszcsér. (L' Osieau-Wunche géant. Troch. gigas.) Vicill. gal. 180.

Majd akkora mint a föllerigü. $\left.{ }^{2}\right)$.

a вавтта́, (Les Huppes. Epupa. Lin. Mriedehoff: Közöltök elölre teendük:

\section{A BANKÁK. (Bankavarjak.) \\ (Les Craves. Fregilus. Cuv. $\left({ }^{2}\right)$.}

Orrlyukai elöre irányzott tollakkal fedvék, miokbul tïbb szerzó által a hollókhoz tétettek, mellyekhez némileg erköleseik álıal is hasonlítanak: Csorruk fejölinel valamivel hosszabb.

Az árva bankavarj. (Árva szajkó. Havasi holló, svaitzi varju. F. Le Crave d' Europe. Corv. graculus. Lin. Die Steindohle.) Enl. 255. Naum. 57. 2. Vieill. gal. 163.

Varju nagysága, fekele, csorra lábai veresck; szár-

(') Mís négyszegü ragy kivágott farku fajok: Tr. mosquitus, L. enl. 227, 2: - Tr. carbunculus, Vicill. 54; - Tr. ourissia, enl. 227, 5; - Tr. mellisugus, L. enl. 640, 2; - Tr. rubineus, Gm.

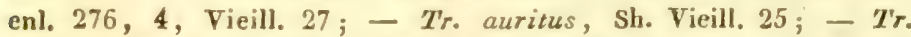
ccllaris, Vieill. 61, 62; - Tr. superbus, Sh., longirostris, Vieill. 59 , col. 299,1 ; - Tr. mellivorus, L. enl. 640,2 ; - Tr. leucogaster, Gm. Vieill. 43; - Tr. imbricatus, Gm. Vicill. 221 ; Tr. albirostris, Vieill. 45; - Tr. viridis, Vicill. 41; Tr. maculatus, Vieill. 44; Tr. saphyrinus, Sh. Vicill. 55, 57, 2; Tr sqamosus, Temm. col. 203, 1. - Tr. albicolis, L. col. 205, 2; - Orthor. Amasili, Less. et Garn. Voy, de la Coquille. 31, 3.

(') Vieillot ès nevet Coracras-ra változtatá, melly Linnénél a Szclakotákat jegyzi. 
nyai elérik vagy fülümulják farka hegyét. A havasok és Pyrenéek legmagasb hegyein lakik, hol sziklarepedékekben fészkel mint a havasi zajgár, de kevesebbé szapora, s ritkríbban gyül csoportra. A gyümölcs és bogarak egyenlön szolgálnak neki élkuil. Mikor völgyekre száll le, havat és rosz idöt jelent. (').

\section{А ВАвUтА́к, tulajdonképen. (Les Huppes propr. dits. Upupa.)}

Fejükün ékesség van, két sor hosszú toll által kępzett, mellyet a madár kénnye szerint fölmereszhthet. $\left({ }^{2}\right)$. Europában egy van:

A bubos babuta (Babuk, bubos Banka. F. La Huppe commune. Upupa epops. Lin. Der Wiedehopf) enl.

52. Naum 142.

Bor-verhenyes, szárnyai farka feketék, két fehér szalıg a takaróin keresztül s négy a szárnytollakon. Nedves földben keresi a bogarakat, fa ragy fal-lyukakba tojik, télre elmegy. $\left({ }^{3}\right)$.

A foki babula (Lei Huppe du Cap. Lipupa capensis. Enl. 697.

Mćg külünösebben közclít a bankavarjakhoz, nivel bubjának elsö tollai, rövidek is Teszesck, clöre irányzottak s az orrlyukakat fedik.

(') Nem tudni, miképen zavautaték össze ezen bauka leirás más libás képekkel, talán némelly ngaralyokéval, hony a bubos bankiavarj, (C'oz'. eremita. Lin.) szïlethessék elo, egy állitásilag sveizi madár, de mellyet Gesner után senki $11 \mathrm{~cm}$ látott. De a Cor\%. affinis, Lath. ugy látszik, valódi banka: van egy egészen fekete faj is Ujj hollandiában.

$\left({ }^{2}\right)$ A huppe $=$ név a babuta hialtásálul számaztatek fianciảul s azon bulnak lett nevévé, mellyet ez fején hordoz, s átviteték çyéb madirak búbjára is.

$\left({ }^{2}\right)$ A. H. Upupa minor, (Ifrihai babuta) Vieill. promerops, pl. 11, és gal. 18\%. Vaill. prom., 23. 


\section{A GYURGYÁK.}

\section{(Les Promerops. Briss.)}

Niucs fejbúbjok, farkok igen hosszú; kinyujthato s villís nyelviok által képesck, mint mondják, a virágnedvekbül élni, mint a diszkniszok és pompályok. $\left({ }^{1}\right)$.

\section{A BANKARAGYOK.}

\section{(Les Épimaques. Épimachus. Cuv.) ( $\left.{ }^{2}\right)$.}

A babutik és gyurgyáli csorra mellett, pikkelyes ís bibor tollaik rannak, mellyck orrlyukaik egy részét befüdik mint a pompályoknál; szinte azon vidékrül jönck és szinte ragyogi tollakkal ékeskedik. Oldaltollaik a hímekuél szinte többé kevesebbé kinyultak.

A bodros bankaragy. L' ípimaque à parements frisé:s.

Upupa magna. Gm. (Tpupa superba. Lath.) Enl. 639. Vaill. Prom. 13.

Fekele vágolt farku, testénél háromszorta hosszab);

(') Vieillot, galeriá-jiban, crxxxy, rl. a promerops nevet falcinellus-ra változtatí. Jól csak az Upupa promerops, ismertetik vagy Merops caffer, enl. 637, melly $=$ Sucrier de protea, Vaill. Afr. 139. - Vaillant azt hiszi, hogy az Up. fusca, Gm. v. papuensis, Lath. enl 6.38, hodros bankaragy jércéje, enl. 639. - Vp.paradisaea, Seb. I, xxx. rl.8, nem cgyéb, mint Mluscicapa paradisi, roszul rajzolt csorral; - Az. Upupa aurantia, egész jloma szerint csoportálv. A Mexicana, Seb. I, xLv, 3, nem Mexicobul való, mint Seba akarja, Nierenberg egy helyét idézve $e$ végre ( $X$. könyr. 44 szakasz) hol csak egy részérül van słó. Kétlem, hat vajon ide teendo-e a Promerops coeruleus, Shaw.; Promerops bleu, Vieill. Upupa indiea, Lath., vagy inkáhb közelit az Upupa erythrorluynchos-hoz (Merops moqueur.)

${ }^{(2)}$ Epimachus, egy igen szćp indiai madárnak neve, határozatlan fajé. 
oldaltollai hoszak, cmeltek, bodrosak, ragyogó szélüek, acél kék, melly szinte a fején és hasán is fénylik. (1).

Mcgkülönböztetnek a négyszegü farku fajok (PRILoRIS Swainson), millyenek:

A Sehér bankaragy. ( $L$ ' Épimaque à douze filets. Ep. albus. Paradisaea alba. Blumenbach. Abb. 96. Vaill. Ois. de Par. 16. és 17. rl. jobban. Promer. 17. Vieill. 13. rl. jobban Galer. 185.

Igen soká a paradizárok közé tetettek, oldalaikat fedö hosszú fehér tollpamagaikért, mellyeknek csölsei kinyulva 6 fonalszálat adnak mindenik oldalon. Teste rendesen viola-fekete, melle aljának tollain smaragdzöld szegély van; de ugy látszik, van egészen fehér fajta is. Szárnya első tollai röridek és sokkal kevesebbek mint rendesen a madaraknál.

$A$ dicsö bankaragy. L' Épimaque proméfil. Epimachus magnificus. Cuv. Vaill. Prom. 16.

Bibor-fekete, középszerü farka kissé villás, feje melle legszebb acél-kék rágyogásu, oldal-tollai hosszak, foszlottak, feketék.

A kirailyi bankaragy. (L' Épimaque royal. Epimachus regius. Less. et Garn.) Voy. da Duperrey. 28. rl.

Ptiloris paradisceus, Swains.

Bársony fekete; fejföle s mel-magasa szép ragyogó zöld. Oldaltollai kerekültck, zöld szélyüek.

A verebek második és legkissebb osztálya azokat foglalja magában, hol a külsö uj majd olly

(') Nem tudom, ide vagy a Merops moqueur-hoz teendö a Promerar, Vaill. 8,9 ; - a Promerup, Vaill. 11 és 12 , és Promerops sifleur, 10. uggyan tỏle. - Általában ezen uj Gvineai szép madarak ritkik gyuijteményeinhbrn, s gyakran megnfosztvák lábaiktul, s ez okbul biztosan nem igen helyeztethetni el óket. 
hosszú mint a középső s avval egész az elsö-elölti izesülésig egyesült.

Mi csak egy csoportot csinálunk belölük.

\author{
AZ ÖSZ-UJUAK.
}

Már régóta öt nemre osztatlak, mellyeket mi megtartunk.

A GYURGYALAGOK. F.

(Les Guépiers. Merops. Lin. Bienenfresser.)

Csorrok hosszúlı, alapján háromszegrletú, könuyüd’’n hajolt, hagyesen végzödio. Mellesontuk hátulról minclenik oldalon kimetszett. llosszú hegyes színyaik és rövid líbirk a fecskélséhez ingen hasonlo repuilést szereznek nekik. Jagy csapatban üldüzik a bogarakat s föképen a mélehel, darízsokat, poszméhelet; és a mi elég nevezetes, nem szuratnak meg tólük.

Van egy liaj, deli Enropiban lïzönséges, de a mi (mildirati) szélességünk alalt elég rilka. (Brchm s a tajats\%talís szerinl egyik lajlájal Magyarországban számos).

A közönséges gyurgyalag. (Piripió sy. F. Merops. apiaster, Lin. Le (Guépier commun.) Enl. 938. Naun. 143. Vaill. Guep. 1 és 2. ( 1 merops. Hungariae.) Brehm, mint fajta. XI. 1.

Szép madir, sárga hitu, homloka s hasa tengeryöldes kék, torka sárga !eketérel szegett; lyukakban fëszliel, mollyeket partokba ás, négy öt lábnyi mélyen. A fialalok oll soláig tartozkohnals nemzoikkel, melly okbul azt gondoláls a régick, hogy a gyurgyalag gondot visel elaggrolt szülöire.

Farka két közcpsö tolla kissć meghosszult, melly elsö 
jele a sokkal naçobb hosszulísnak a külföldi fajok nagyobb részénél. ${ }^{(1)}$.

Mindazílal sok fajnak farka majdnem négyszegletü $\left(^{2}\right)$. ragy kissé villás $\left(^{3}\right)$, de ez ućha azon ćletszaktul függ, mellyben leöleték.

A gyurgyalogokhoz lï̈zel kellene tenni némelly hoszszú farkú, ćrcfény-tollazatu, s eddig a gyurgyák közé helyezett madarakat, de mellyeknek két külsó ujja majdnem annyira egyesült, mint a gyurgyalagoké $\left({ }^{*}\right)$.

Ugy látszik a gyurgyalagok hibáznak Amerikáhan, de ott kipótolják óket

(') Illyenck: Mierops viridis, enl. 740, Vaill. 4; - Ornatus, Lath. - Superbus, Nat. Misc. 78; - Senegalensis, enl. 314, és badius, 252, Vaill. 12, 13; - superciliosus, 259, Vaill. 19 ; M. nubicus, Vaill. 5, enl 649; ezen egyén meg volt hoszú tollaitul fosztva. - MT. Savignii, Vaill. 6; - MT. Cuvieri, Vaill. 9. et Swains: 11l. 76. Savigny neve alatt. - $7 l$. Lamark, Vaill. 10.

$\left({ }^{2}\right)$ Merops philippinus, enl. 57 ; - 11. cayennensis, 454. (Jegyz. De nem Cayennebul valú). - $M$. nubicus, 549 ; - $M$. crythropterus, 318 ; - IT. malimbicus, Sh. v. bicolor, Daud. Annal. du Mus. I, LxIr. és 5 , Vieill. gal. 186 ; - MT. gularis, Nat. Misc. 357 ; - MI. amictus, T. col. 310; MT. Daudin, Vaill. 14. - $M T$. Coromandus, Lath. Sonnerat, 2. Voy. 105 v. G. cytrin, Vaill 11 ; - M. quinticolor, Vaill. 15; M. minulus, Vaill. 17; - M. Lechenaud, Vaill. 18; - M. Bullock, Vaill. 20.

$\left({ }^{3}\right)$ M. Taiza, Vaill. 8; - Mr. urica, Swains. Ill. zool 8.

Jegyz. A Merops congener, Aldr. I, 876, nem valódi; a Cafer, $\mathrm{Gm} .=$ Upupa promerops; - a brasiliensis, Seb. I. LXVI, 1. hiheto̊leg valami csapatály; - a Mer. monachus, corniculatus, cyanops lóricsupok, a MTer. phrygius, cincinnatus, cucullatus, cyanops, garulus, fasciculatus, carunculatus, Lath. ugy látszik hurszik; au. M. cinereus, Seba, XXXI, ro. hosszúfarku diszkuszok.

(') Promerops moqueur; Vaill. prom. 1, 2 s 4. Upupa erythrorhynchos, Lath.) A fiatal csorra fekete. - A Prom. namaquois, Vaill. 5 is 6 vagy Falcin. cyanornelas, Vicill.

CUVIER I. K. 


\section{A GYÜRGYELEGEK.}

\section{(Les Motmols. Prionites. Jlig.)}

Az clöbbiek lábat és szokísát birjak, de kïlönbriznck rrish esorruk allal, mellynek szólei mindenik lemezen fiirészcsek, s lollak modjaira szakállas nycly által, mint a borsailyoknail. Ezck szip madarak, szarka nagyságuak, fejök tollazata lomha mint a szajkókníl, hosszú farkok elvígott, s két liözépsö tolla megszakíllatlanodik az idültn'l egy kis téren nem messze régétül, a mi farkolinak rgészcn lïlönös idomot ád. Rosszul repülnek, magánosan inck, lyukakban fészlichek, bogárerök s apró madarakat is üldözók. ( $\left.{ }^{1}\right)$.

\section{A JEGÉREK. (JÉGMADARAK. F.)}

(Les Martins-Pécheuri. Alcedo. Lin. Eisvogel.)

Lábaik rövidebbek mint a gyurgyalagé, csomk joival hosszabb, egyenes, szegletes, hegres; nyelvok, farkok igen kurla. Mellesontuk kiel kimelszóst bir mint a gy turgalagoli es szalakintílí. A pro halakkal élnek, mellyeLiet a vizbe rohanra fognak meg némelly ágrul, hol ülve lesték a zsílimány. (Gyomruk hárlyás zseb. Mint a gyurgyalagok parti lyulakban fészkclnck. A kél szárazon találtatnak.

(') A kétfejü gyürsyeleg (le IIoutou de la Guyane, Brasiliában fuira guannumby, Margrave szerint, Rumphastos momota, Gm. 1'rionites brasiliensis. 1lig.) enl. 370. Vaill. Ois. de Par. I. Xxxvil. és xxxviI; - a zeresfejü gyürgýeleg, vagy pérui; Motmot dombey, Vaill. az id. hely. xxxix. Vieill. gal. cxc; - Pr. Marcii, Spix. 9 ; a Tutre du Paruguay, Azz. 52-sz. legalábl, igen közelítenek azokhoz.

Motmot az elsonek neve Mexicóban, Fernandes szerint. Prionifes, røí(t)-tul (fürćsz) jó, Illiger csinálta. Vieillot ezt átcserélte Bมนиนоกับ- 
Az europai filj,

A közünséges jegér. (Közünséges jégmaddr. F. Alcedo ispida.) Enl. 77. Naum. 144. Brehm. xI, 2.

Veréb nagyságu, fólül zöldes, felielés hullámzattal; egész híta hosszában széles, legszebb tengerzöld-kék szalag nyulik el; alja s mindenik oldalín egy ronat verhenyes.

$\mathrm{Az}$ idegen fajoknál majd mind mint a micnknél, foszlott tollazat van s különbözö kék és züld festéssel tarkázott. ( $\left.{ }^{1}\right)$.

Egymástul megkülönböztethetök csorruk szerint, melly majd egyszerüen egyenes és hegyes, mint a ksözönséges fajnál, majd alsó csorrlemeze fölfútt. $\left({ }^{2}\right)$.

Vannak némellyek Uj-hollandiában, s a szomszéd földeken, horgos végü esorrokkal. $\left({ }^{3}\right)$. Ezek közt többek-

(') Alc. (Afr. Sh.) maxima, enl. 679; - Alcyon, 715 és 593, és Wils. Amér. III , xxxır. 1; - Torquata, 284; - Rudis, 62. és 716 ; - Bicolor, 592; - Americana, 591; - Benghalensis, Elw. 11; - Coeruleo-cephala, enl. 356, 2; - Cristata, 756, 1 ; - Madagascariensis, 778, 1; - Purpurea, 778, 2; - Supercilinsa, 756, 1 és 2; - Cinerifrons, Vieill. gal. 187; - Biru, Horsf. Jav. és T., col. 239, 1; - Semitorquata, Swains. ill. 154; - Asiatica, uo. 50.

$\left.{ }^{2}\right)$ Alc. capensis, 599 ; Atricapilla, 673; - Smirnensis, 252 és 894; egyile az Aristoles alul följegyzett két fajnak; - Dea, 116 , mellybül Vigors a TANysiptera nemet csinálta; Cloroceplala, 783, 2; - Coromanda, Sonn. 218; - Leucocephala, (Javanica, Sh.) 757 ; - Senegalensis, 594 és 356 ; - Cancrophaga, Sh. 334; - Melanorhyncha, T. col. 391; - Omnicolor, T. col. 135; Diops. ua. col. 212; - Dacelo-Concreta, ua col. 346; - Dacelo cinnamominus, Sw. ill. 67.

Ezen alosztásbul csinálta Leach a DACELO nemet.

Jegyz. A szinzett képek többjénél a csor nem eléggé fölfújt.

$\left({ }^{3}\right)$ Ale. fusca (gigantea, Sh.) enl. 663; Vieill. gal. 188; Dacelo pulchella, Horfs. Jav. és Tem. col. 277; - Dac. cyanctis, 
ned, a szürlics is nem foszlott toll kijeleli már, hogy a vizeket nem igen licresik meg; s valoban bogaralikal élnek, mi olibul (halcisz füllengük helyett) vadcisz föllensük nevel kapmak franciául, azaz Martin-chasseur-t.

\section{AZ UJHIJAROK. \\ (Les Ceyx. Lacép.) (1).}

Rendes csorru jegérek, de liözépsö ujjok hibázik. Indiakban három faja van.

\section{A TóDok. F. \\ (Les Todiers. Todus. Lin.)}

Amerikai apró madirak, általínos idomokban iggen hasonlitanak a jegérelihez, mellycknel lábait s hosszitull csorrát birjáls. de c\%en csorr vizszinitegr lapositott, tompa végü, lábuk ancltebb, farkoli hosszabb. Légyerök s földön költök. ( $\left.{ }^{1}\right)$.

Ezen rend-leirist egy a legkïlinüisebb nemmel végezzuils be, mellynel a löbbi iszoujualihal ammi hasonlatossága smes, mint mag̨a fajanali cgymás kïzotl, s melly egy különös esaládot tehetne kiszakasztottan. Ezek

A SZARVÁTYK. (SZIRVASMADARAK. F.)

(Les Calaos. Buceros. L. Nashornvogel.)

Afrikai s indiai nagy madarak, mellyeket iszonyú s fogazott, neha, mint magok, olly nagas emelkedésekkel

'T. col. 262; - Dac. Gaudichaud, Quoy. et Gaym. Voy de Freyc. xxy 11.

(') Alc. tridactyla, Pall. és Gm.; Pall., Spic., VI. 11. rl. f. 2; Sonı. Xxxır. 1.; Alcedo tribrachys, Sh. Nat. misc. XVI, 681. ri; - Aleedo meninting, Horsf., col. 239, 2.

(') Todus viridis, enl. 585, 1, 2, Vieill, gal. 124; T. coeruleus, enl. $783,1$. 
biró, ragy legalább fólül jól dagadt csorrok, nevezetesekké tesz, s ïsszeköt a borsályokkal, mig tartásmódjuk és szokások által a bollókhoz közelítenek, lábaik pedig mint a gyurgyalag-és jegéréi. Csorruk kinövésének idoma nagyon víllozik a korral, söt az igen fiataloknál az nem is tün föl; belseje reudeseu sejtes. Nellcsontukon hátul csak egy, mindenik oldalrul könnyiuden behajló is van. Nyelvök apró, a torok fenekén; mindenfélit esznck, gyönge grümölcsöt: egeret, apró madarakat, mászólkat radásznak s még a dögöl scm velik meg. (1).

Igen rosszul tétettek a tódok neméhe némelly igazi légykupók. kivínott csorrak s szabad külsö ujjuak, millyenek: Todus regius, enl. 289; - Paradisaeus, uo 254; Leucocephalus, Pall., Spic., VI. III., 2: - Desmarets két Platyrirnques-e, mellyek $=$ Tod. rostratus, et nasutus, Shaw., v. Tod. platyrhinchos et macrorhynchos, Gm. Vieillot elsőt adja, gal. 126.

(') szarvílyok elödudorodíssal. Buc. rhinocerus, enl. 931 , Vaill. Calaos, 1 és 2 ; B. africanus, Vaill. pl. 17, f. 2. csak amannak kor okozta fajtája lchet; Niger, Vaill. 13. Temmink szerint csak 'gy rosszul megtartott egész; - Monoceros, Sh. enl. 873 ; Vaill. $9,10,11,12 ;-$ Cassidix, Tem. col. 210; - Malabaricus, Lath. V1, II, vagy albirostris, Sh. Vaill. col. 15; - Buccinator, T. col. 284; - Gingianus, Sonn, 2. Voy. cxx.r. rl. Vaill. 15; Bicornis, Vaill. 7, vén jérce; Cavatus, ua. 4, középkorbeli him. A 5 és 5 xl. megváltozott egyének; - B. hidrocorax, enl. 282, fiatal, col. 283, az id8lt; - Violaceus, ua. 19; Abyssinicus, enl. 779, középkoru; Vaill. Afr. 230, 231. a vén madár; Vieill. gal. 191 ; - Sulcatus, T. col. 69; - Panayensis, en]. 780, a jérec, f. 781. a vén him; Vaill. col.16,17,18; Manillensis, enl. 891 , a fiatal lesz; - Fasciatus, Vaill. Afr. 235; - Exaratus, T. col. 211. 
A HADARAK H.MUMUIK RFIDE.

$v$ at $5 y$

\section{A KÚSZÓK-E; ( $\left.{ }^{1}\right)$.}

(IISS GRIMPRLRS. SCANSORES. KLETTERVÖGEL.)

Olly madarakbul all, mellyeknek külsö ujja hitja irányzot, mint a hüvelyk, homnan számokra eröschb támasz származik, mellyet némelly nemek a fatörsök megonászására s bekúszására használnak.

Ennck következésében kaptúk a kiliszó, nevet, noha, szigornan véve, az nem mindnyáajokat illeti, s több madár kúszó valódilag, noha ujjainak alkotására nézve nem tartozik e rendhez, valamint mát láltuk a fakúszoknál s favígároknal.

A kúszík rendebeli madarak reudesen a vén fäk odvaiban f'észkelnek, repülésök középszerü; táp-

(') Elódvdoratlin szarvályok. B. javanicus, Vaill. gal. 22. a fiatal him; Afr. 239, a vén hím, = Cal. de Waidjiou, Labill. Voy. Buc. undulatus, Vaill. col. 20, 21, a jércék; B. erythrorhynchos, enl. 260; Vaill. Afr. 238, a fiatal. - Hastatus, Cuv. enl. 890, Vaill. 236, 237; - Coronatus, Vaill. Afr., 234, 235 ; Bengalensis, Yaill. gal. 23.

Jegyz. A. B. galeatus, mellynek csak feje ismeretes, enl. 955. (Hardwicke aeneral azonban ijalhan az éész madarat megismertete, Y. Yaillanttul hibásan tartaték vizi madárnak, mert igazi szarvály, mellynek dúdora rendkivül vastag szaríval takart, foképen mclülsơ részén.

Lásd a szarvályokrul T'emminh cihkelyét a szinezett ábrák tarpalmáhan. 
lilatuk, mint a verebeknél, bogarak vagy gyümölcs, a mint csorruk többé vagy kevesebbé erös; némellyek, mint a harkályok különös készületet birnak annak megnyerésére.

A nemek nagyobb részénél két hátsó kimetszés van a mellcsonton, de a papagályoknál csak egy lyuk van rajta, s gyakran egészen teljes.

\section{A KАРASZOK, (DSAKÁK). \\ (Les Jacamars. Gabula. Briss.)}

Igen közel állanak a jegérekhez hosszú, hegyes csorruk által, mcllynek felsö erösze kitủnö, s rövid lábaik miatt, mellyeken az elsö ujjak nagy részén összenóltck; azonban ezen ujjals nem a jegérekéi; tovább, a kapaszok tollazata kevesbbé foszlott s mindig ércfényü. Magánosan szoktak leuni a nedves erdölsön, bogarakkal élnek, alacson ágakon fészkelnek.

Az anerikai fajok csorra hosszabb s egészen egyenes. $\left({ }^{1}\right)$.

De ramnik az indiai szigetsokban ollyanok, mellyelict a röridebb, nagyobb, s kissé meghajlott csorr a gyurgyaloghoz vezetnek közel. Elsö ujjaik jobban elválasztvák; Ezek:

Le vaillant (GYURGYAKUSZAI) JACAMEROPS-ai. (').

Ezen természetvizsgáló egy ollyant is ad hozzájok, mellynek fölül nincs cṣorr-erösze. $\left({ }^{3}\right)$.

(') Alcedo paradisaea (Calbula paradisaea, Lath.) enl. 271; Alcedo galbula, Lin. Galb. viridis, Lath.) enl. 238; - Galb. ruficauda, Cuv. Vaill. Ois. de Par. II, L. rl. vagy Galb. macroura, Vieill. gal. 29. Galb. albirostris, Lath. Faill. pl. LI., Vieill. Ois, dorés, I, IV. rl. - Galb. albiventris, Vaill. xuvr.

(i) Alcedo grandis, Gm. Galbula grandis). Lath. Vaill. pl. L.iv.

( $\left.{ }^{3}\right)$ Le grad Jacamar, Vaill: az id. h. Lut, xl. 
Vigre rannak ollyanok is, mellyeknck esak hírom njjok ran, p.o. Jacamar-Alevon -; ezek Braziliában élnek. ( $\left.{ }^{1}\right)$.

\section{A JARKÁLYOK. F.}

\section{(Les lics. Picus. Lin. Spechte. $\left(^{2}\right)$.}

Igen jöl bilyrgzelt madarak hosszii, egrenes, szegletes s rigén ididomuan összenyomoll s a filiereg foilrepesztésere allialmazlaloll cosorok által: ide jirul móg hátra

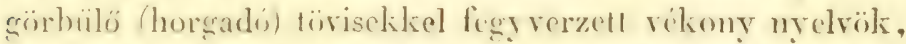
melly a szahesont hosszú poreszarvatul nyomatra igen

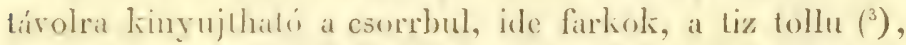
durva rugikony csiikiolikel, mellyck öket támaszkint tarl-

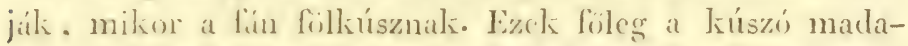
rak: mindenfike irúu ban forognak a fik kírgín, molylyet csorrokkal ragclahnak, s mellynek repediscibe s lyukaiba bedugjak nyclvöket, vele megfogandok a táplálatukra szolgáli bogárbáboliat. Nyclvoik, a fegyrerin kiviil, még ragates necliurel is boriloll, mellyet nagy nyalnirriggei aduak; hálrahuzalísa két izom allal történik, mellyck szalaglint tekerledlek a gowsipra: ezen vissza-

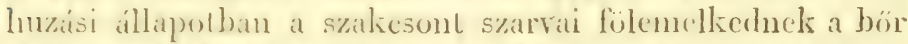

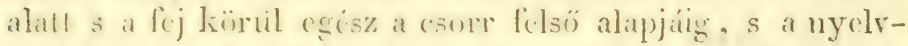

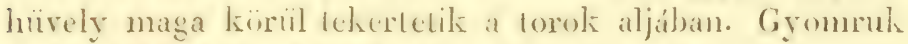

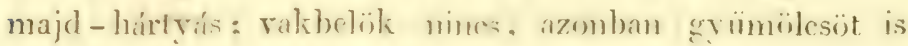

Jacamaciri, ezen madarak neve Brasiliában, Margrave szerint. Galoula, ugy litszik, a s latinolnál a Invicit (sárgarigót) jelenté: MTocring vitte ált e neret a kapaszokı́a.

(') Vaill., jac. suppl., f. L, Spix. 57, 2, czen név alatt: Alcyon. tridactyla.

(2) Picus, czen madarali latin neve, azt mondjúk egy latiumi Királytul jo.

$\left({ }^{3}\right)$ Tulajulonképen lizenhét tollu a fark; de az igen hicsin oldaliak nem számláltattak oda. 
esznck. Félékenyeli és ravaszok lévén, tübbnyire magánosan chuck. Szerelmeskedéskor a nót hívni akarók gyorsan kopogtalják a száraz ágat. Évenként egyszer fészkelmek falyukakban. A két nöm fölváltva ül.

Europában öt vagy hat faj van:

1. A fckete harkíly. F. (Le grand Pic noir. Picus martius. I. Der Schwarzspecht.) Enl. 596. Naum. 131.

Majdnem varjunagyságu, egészen fekete; a hímnél szép piros saplia van, melly a nónél csak egy folt a fejhátulán. Különösen az éjszalsi fenyresekben lakik.

2. A zsolna, züld harkály. F. (Le Pic vert. Picus viridis. Der Grünspecht.) Enl. 371. Naum. 132.

Gerle-nagyságu, fülül zöld, alul fehéres; saplsája veres, farcsika sárga; egyike legszebb madarainknak. A fiatal alul fekete foltos, köpönyege fehér foltos. A siki ritlaúbb erdóket bükkösöket szilasokat szereti, s eledelét a földön is keresi.

Szomszéd de valamivel kisebb faj

3. A szürke harkíly. (Picus canus. Gm. Der Grauspecht.) Edw. 65. Naum. 133.

Hamrasabb színú, csorra vékonyabb s fekete bajuszu. A himnél is csak a fejtetó veres, a nönél az sem. Ritkábban jố le délre s Franciahonban ritkább az elóbbinél, mellynek erkölcseit birja különben. Hangyákkal sze . ret fóképen élni.

4. A nagyobb (tarka) harkily. F. (L' Epeiche ou grand Pic varié. Picus major. Der grosse Buntspechs.) Enl. 196. a him, 595, a jérce, Naum. 134.

Huri nagyságu, fölül feketével és fehérrel tarka, háta s farcsika feketék, alul fehér, seggtájélsa veres, valamint egy folt a him fejluátulán. A fiatalnál majd az egész sapka veres; a mindig zöld fálkat szereti, gyaliran közelít a lakhelyelshez, de egészen a földre soha sem megy. 
i. A hües, kuzip tarkic harkily. I. (Te moyen Ejeiche. Picus medius. IF eiss-specht.) Enl. 611. Nitum. 136. 1,2 .

Valamircl kischb, saplsijal mindemk nömnch reres. faresika fekete, farkalja reres. Mérsciklett s déli Europában.

6. A hücsit, kisebb tarka karkilly. I. ( Le perit Tipeiche.

Picus minor. ('rasspecht.) Enl. 598. Naum. 136. 2, 3.

Verób nags sígu, fülül fekete- s feherrel tarka, alul szürki's fehér, veres e'sak a him fejen van. Azt mondják, hogy foldere is szall hangrakat lieresni, s czért neveztetik fü-harkúlynak, de Nitumamn szerint ezen vélemény hamis.

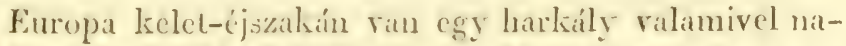
gyobb a mieink hïzuil az elsoncl (a nagy tarkínál), s hozzi hasonlit is, rsak hogy hita ala s faresika fehér, s a him saphaija reres. Noha Némehonigg is eljö. Ez a

7. Ieherhatu harkicily. (Picus leuconolos, Bechst. Der Elsterspecht.) Naum. 135.

$\mathrm{Az}$ idegen harkityok igen saimosak, s nagyon hasonlitmak egymishoz, mign mimi szin-closzlísban is, poldaul a fej verességében (1).

(1) A fekete harkályokhoz rokon fajok: P. pileatus, L. enl. 718 ; - P. lineatus, L. enl. 717 ; - P. principalis, L. enl. 690 ; P. galeatus, Natter. col. 171, iģen közel esõ négy faj, mellyek egyikéhez hihetỏles tartozik a B. melanoleucus, Gm. Latl. Syn. 1, 2. t. $\mathrm{XXV}$; $-P$. rubricollis, Gm. enl. 612 ; $-P$. robustus, Spix. 44; - P. albirostris, ua. 45; - P. validus, Tem. col. 378. és a jérce, 402 ; - P. erythrocephalus, L. enl. 117 ; - P. pulverulentus, T. col. $389 ;-P$. concretus, Reinw. col. $90 ;-P$. chilensis, Voy. de la Coq.; - P. torquatus, Wils. Am. III, Xx, 3 ; P. dominicanus, Spix, 50.

A zöld harkályhoz rokon fajok: - P. percussus. Tem. col. 590 és 424 a jérce; - P. benghalensis, L. enl. 695, mellynek a 


\section{PICOTDES-(HARKÁLYCSA.) nek.)}

Nerezte Lacépede azon harkály-fajokit, mellyeknck nincs külsö ujjok, s küvetkezóleg elül kél s hátul egy ujjok ran. Különben egészen hasonlitanak a reudes harkúlyokhoz.

Egy van belólük Europa éjszakán és keletén:

P. aurantius, Gm. Briss. IV. Vi. rl. f. 1. hihę 8 leg csak fajtája; $\boldsymbol{P}$. goensis, Gm. enl. 696; - P. aurulentus, Illig. col. 39 , f. 1. v. macrocephalus, Spix. 53, 2; - P. puniceus, Horsf. col. 423; P. mentalis, 'T., col. 384; $-\boldsymbol{P}$. ceylonus, N. Nat. Forsch. 14, 1. rl.; - P. goertan, Gm. enl. 320 ; - P. manillensis, Gm. Sonn., pl. xxxvr, - P. senegalensis, Gm. enl. 345 , f. 2 ; - $\boldsymbol{P}^{\prime}$ passerinus, Gm. Briss. IV. t. IV. f. 2.; - P. luzonicus, Cuy.; Sonn. Xxxvir. rl.; - P. miniatus, Gm. Ind. zool. VI. k.; - P. chlorocephalus, Gm. enl. 784; - P. exalbidus, Gm., 509; - P. cinamomeus, Gm., enl. 524; - Palalaca, Cuv. enl. 691; P. jumana, Spix, 47 ; - $\boldsymbol{P}$. ochraceus és $\boldsymbol{P}$. flavicans, ua. 51.

A nagyobb (tarka) harkályhoz rokon fajok: $P$. rubriventris, Vieill. gal. 27; - P. hirundinaceus, L. enl. 694; - P. varius, Gm. enl. 785 ; $-P$. canadensis, Gm. enl. 345 , f. 1 ; $-P$. villosus, Gm. enl. 754, Wils. I, IX, 3; - P. undosus, N. enl. 553; - P. pubescens, Gm. Catesb. 31, 11; Wils. I, IX, 4.

Keresztben csikolt hátu fajok: $P$. moluccensis, Gm. enl. 748 , f. 2 ; - P. bicolor, uo. f. $1 . ;-$ rufus, Gm. enl. 694, f. 1. igen közel állók a $P$. undatus-hoz, Gm., Edw. 332 ; $-P$. carolinus, Gm. enl. 597 és 692 ; - P. cayennensis, Gm. enl. 613 ; - P. melanochloris, Gm. enl. 719; - P. striatus, Gm. enl. 281 és 614 ; - P. superciliaris, T. col. 435 ; - P. flavescens, Gm., Brown. II. xrr. rl. és Spix, $49 ;-P$. cardinalis, Sonn. xxxy, rl.; $-P$. querulus, Wils. Am. II, xv, 1 ; $-P$. campestris, Spix. $46 ;-I$. Mlacei, T. col. $59,2$.

Végre megjegyzends, hogy ezen hasonlatossági megrkïlönböztetések, leginkább a szinektül vetetvéu le, kevés becsüek, s meglehet hogy faj egyik a másikába fog tartozni. 
A fekete harke. (Picus tridactylus) Edw. 114. Naum. 137. (Hoiromuju harkily).

Nagrsagra közipet tart a nagy is kis tarka harkály közïlt; lishil fekele, fehér follokkal, alnl feher; a him sapkája narancsszinü, a nöé fehér.

Szinle rgy aluemel lehelue képezni azon fajokbul,

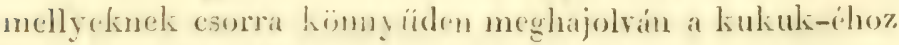
kezd közclíteni. $\left({ }^{1}\right)$.

Egrikiole csali a foildrin jírra lecesi eledelét, noha farka a többiekéhez hasonló. $\left({ }^{2}\right)$.

\section{A NYAKTEKERCSEK. F.}

\section{(Les Torcols. Yunx. Lin. Wendeltals). (').}

Nyelvok kingujthatio mint a harkilyoké, s ugyan azon múkï̈dés íltal, de töristelen; különben csorruk egyeurs, hegyes, majdnem görgeteg s szeglettelen; farkokbau esak rendes tollak vamuik. Cisaknem usy éluck mint. a harkályok, kivéve hogy keveset kusznak.

Europában egy van:

A künsïnséges nyaktekers. F. (Yunx torquilla. Lin.) Ful 698. Natum. 138.

Pacsirla-nagýságu, föluil batrua, apró feketés hullimokkal, is likete súrga hosszronatokkal esinosan tarkizva, alul fehéres, feketés kereszt-sugárzattal.

(') Millyenek: Picus auratus (Cuculus auratus, a 10. kiadában) enl. 695 és Wils. Am. I, 111; - A picus cafer, Lath. v. promépic., Vaill., prom. 32; - P. poicilophos, Tem. col. 197, f. i.

(2) Le Pic, laboureur, (Picus arator. Cuv.) Vaill. Afr. ccLv. 11. és cCrvir.

Kiilönlıen a harkály nemtiil semmit el nem veszïnk mint az egy Picus minutus-t, Lath. Yunx minutissima, Gm. enl. 7S6, 1, Vieill. gal. 28), melly valóban nyaktekercs.

( ${ }^{3}$ Yonx, görög, Torquilla, latin neve e madárnak. 


\section{A TEKERÜCSÖK.}

\section{(Picumnes. Temm. Picumnus.)}

A nyaktekerescktül csak igen rövid fark által kulönbëznck. Apró madarak. ('). Vannak csak háromujjuak is, mint a harkák. $\left({ }^{2}\right)$.

A KAKUK-ok. F.

(Les Coucos. Cuculus. Lin. Kukuk.) ().

Csorruk középszerii, eléggé szelt. összenyomolt, könyüden hajolt; farkok hosszú. Bogarakkal élnek, s vándorlanak. Mi következóleg osztjuk föl :

\section{A valódi KAKUKor.}

Csorrok középszerüien erös, lábaik rövidek, farkok tiz tollu. Híresck azon különös tulajdonságokért, hogy tojásaikat más bogárevő madarak fészkébe tojják; s a mi nem kevesebbé különös, az idegen nemzóli, gyakran igen apró fajak, annyira gondját viselik a fiatal kukuknak, mint tulajdon fijaiknak, még akkor is, ha a betojáskor tulajdon tojásaik eltörtek is. Ezen, a madarak természelleirásában egyetlen tüneménynck oka mind eddig ösmeretlen. Herissant azt a gyomor helyezetének tulajdonitá, melly valóban a hasban hátra fekszik s a mellesont által kevesebbé védetik, mint más madaraknát. Ezeknek vakbele elég hosszú, s al-gégéjelien csak egy tulajdon izom van.

(1) P. minule, T. (Yunx minutissima) Gm. enl. 78f, 1; P. à toupet. (Picumnus cirrhatus, T.) col. 571, 1. Vicill. gal. 28; - P. mignon. (P. exilis, T.) col. 571. 2.

(') Picumne abnorme, (P. abnormis, 'T. col. 371. 3.

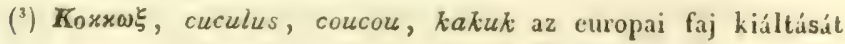
fejezi ki. 
Europában egy általánosan elterjedt faj van:

1. A hangos kakuk. F. (Cuculus canorus. Lin. Der gemeine Kukuk.) Enl. 811.

Hamras szürke, hasa fehér, fekete keresztcsikozattal, furka orlalvást fehéc foltu, a fiatalon verhenyes van a szürke helyett.

Néha egy mís faj is meglátngat benuünkel, melly tarka is búbos, hangosabban kiailtó az elöbbinél. Ez

2. A tollagos kakuk. (Cucul. glandarius. Edw. 57.) Naum. 130. a hím. Col. 114, a nóstén. ( $\left.{ }^{1}\right)$.

A két világ forró részciben töb) más találtalik. (²).

Kiváltiépen pedig Afrikában nehány szép faj van, többé herescbbé aranyos zöld; csorrok a micnkénél kissé lenyomottabb. $\left.{ }^{3}\right)$.

Más fajok lübbnyire tarkás tollazatuak, fügróleg magasb csorrot birnak. ( $\left.{ }^{+}\right)$.

(') Cuculus pisunus, Gm. a fiatala.

(2) Cuc. capensis, Yaill. Afr. 200, r. hihetỏleg a hangos fajtảja ; Solitarius, Cuv. Vaill. 206 ; - Radiatus, Sonn. 1. Voy. 79. rl; - Clamosus, Cuv. Vaill. 204, 205; - Edelius, Cuv. Vaill. 207, 208, Jegyz. Cuc. serratus, Sparm. Mus Carls. 5, a híme; Melanoleucos, enl. 272, a jérce; - Coromandus, enl. 274, 2, s egy fajta, Vaill. 215; - Americanus, enl. 816, ragy Carolinensis, Wils. III, xxvir, 1; - Erythrophtalmus, uo. 2? - Flarus, onl. 814.

(3) Cuc. auratus, enl. 657, Vaill. 211;-Clasii, Vaill. 210; -; Lucidus, Lath., Syn. I., xxirı. rl.col. 102. f. 1; - Cupreus, иа. supl 154, Vieill. gal. 42 ; - Chalcites, T. col. 102; f. 2. a é rce.

( $\left.{ }^{4}\right)$ Cuc. punctatus, enl. 771 , és scoluspaceo, 586, s talán még a maculatus, 764. is, csak fajták; Honoratus, enl. 294, Vaill. 216: - Taltentis, Sparm. Mus. Ca!ls., 52; Mindancnsis, enl. 377 ; 


\section{A KŮ́LYOK.}

\section{(Les Couas. - Coua. Vaill.)}

A kakukoktul csak emelt szárok által különböznek (1). Falyukakban fészkelnek s idegen fészekbe nem tojuak; cz legalább azon fajokrul igaz, mellycknek szaporodása ismeretes.

Elválasztható imnen cgy amerikai faj; hosszú s esak vége felé görbült csorru. $\left({ }^{2}\right)$.

Levaillant már régóta elválasztá, s olsosan, a többi kukukoktul.

\section{A KUKÄLYOK-at.}

\section{(Les Coucals. $\left.{ }^{3}\right)$. Centropus. Ilig.)}

Afrikai s indiai fajok; hürelyk-körmök hosszú, egyenes, mint a pacsirtáknál. Az ismertek mind ó világiak. Szinte faodvakban fészkelnek ( $\left.{ }^{4}\right)$.

- Gaira, Vieill. gal. 44; Freycinet; Voy. zool. 26. Nem tudni mint csinálhatá Vieillott ani-vá (nyth'észszé).

(') Ezen fölosztásból csinálta Vieillot Coccyzus nemét, gal. 41. Ezek Spix. Macropus-ai. Cuc. madagascariensis, enl. 825 ; - Cuc. Lalandii, T. col. 440;- Cristatus, enl. 589 ; Vaill., 217; - Coeruleus, 29.5, 2 ; Vaill. 218; - Naevius, enl. 812; - Cayanus, enl. 211; - Cuc. brachypterus, T. v. macropus, caixana, Spix, 43; - C. seniculus, enl. 813; - Macropus phasianellus, Spix, 42.

${ }^{2}$ ) Cuc. vetula, 772. Ezen megkülönböztetésre alap̧itá Vieillot SAurothera nevét, gal. 38 .

$\left({ }^{3}\right)$ Covcal, a coucou-s alouette-bül összetett szó, Centropus, tüskés láb. Vicillot Carydonie-re változtatta, Leach pedig PoDophrLUS-ra.

( ${ }^{4}$ Cuculus aegyptius el senegalensis, cnl. 552; Vaill. Afr. 219 ; - Philippensis, Cuv. enl. 824, vagy Cuc. bubutus, Horsf. Java; Nigrorufus, Cuv. Vaill. Afr. 220; - Tolu, enl. 295; Vaill. 210; - Benghalensis, Brown. Il., XIII ; - Rufinus, Cuv. Vaill., 221 ; - Aethiops. Cuv. Vaill. 222 ; - Gigas, Cuy. Vaill. 225; - Atralbus, Voy. de la Coq. Zool. 34. 
Azon természetvizsgáló szerint, szinle megkülönböztetendólk:

\section{A KUROLYOK.}

(Les Courols. ('). ou. I'ouroudrious de Madagascur.)

Csorrok nagy, hegyes, ösznyomolt, alig egy kissé hajlott, felsö csorrlemeze végénél orrlyukiti ferdén átfurlak közepén mindenik oldalon. Farkok tizenkét tollu. Mint az elöbbick ugy fészkelnek, az erdöliben tartizkodnak. liöIsépen gyümölcsesel élni mondatnak. $\left({ }^{2}\right)$.

A MÉZKALAUZOK. F.

\section{(Les Indzcatentr. Vaill. Indicator.)}

Mís kél afrikai faj, azért híresek hogy mézol ilvén, kalauz gyanínt szolgáhnak a lakosolinak a rad-

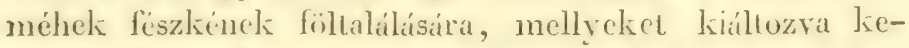
resnek. Csorruk rürid, magas, majdnem kippidomu mint a pintyeké. Tizenkét tollu farkok egyszersmind kissé elvágott és kissé villís. Kïlönösen lienény bürük megrédi óliet a méhek szurísitul; de a sziuncllenül háborgatott méhek szemölinel támarljík megg öket s néha meg is ölik $\left({ }^{3}\right)$.

\section{A SZAKÁLKUKUKOK.}

(Les Barbacous. Vaill. ( $\left.{ }^{4}\right)$.

Csorrok liúpos, hosszúlt, lissé összenyomolt, köny-

(1) Courol, Goucou, s rollier szavakbul összetett. Vicillot ezen osztásbul csinálta a LEPTososus nemet, gal. 29.

(2) Cuculus afer, cnI. 387, a hím, mellynek csorra rosszúl adva, s 558 a jérce, melly jobb, Vaill. 226, 227.

( $\left.{ }^{3}\right)$ Cuculus indicator, Vaill. Afr. 241; Minor, Cuv. ua. 24; Albirostris, T. col. 367 . Vicillot vette foll e nemet és nevet, gal. 54 .

(4) Barbacou, a barbu s coucou szavakbul van össze téve. Vieillot. Monasa, nemét csinálta belöle, gal. 36 . 
"yviden hajlott végü, alapján foszlott tollakikal körülvett vagy durra szörökkel, melly óket hasonlókki teszik a szakállárokhoz, $\left.{ }^{1}\right)$.

\section{A HAJLAKÚSZOK. (Les Malcohas, Malcoha. Vaill.) (2).}

Csorrok igen nagy, görbe alapu, vége felé hajlott, szemci körül széles csupasz tér. Némellyeknél gömbölyüek az orrlyukak a csorr vége lélé ( ${ }^{3}$ ); másokníl keskenyek a szélhez kïzel $\left({ }^{4}\right)$. Ezen ceylani madarals, mint mondják, fóképen gyümölesesel élnel.

Hihetöleg meg lehetne különböztetni a kisebb csorru fajokat, s mellyeknél a szen körúl alig van csupasz tér $\left({ }^{5}\right)$.

\section{A BORSAKÚSZOK.}

\section{(Les Scythrops. Scythrops. Lath.)}

Csorrok még hosszabb s még nagyobb a liajlakúszokénál, mindenik oldalon két hosszanti, keressé mély barázdával metszett; szemkörök csupasz, orrlyukaik ke-

(1) Cuculus tranquillus, cnl. 512, Spix, 41, 2;-Cuc. tenebrosus, enl. 505 , et col. 523, 2; - C. rufalbinus, 'Г. col. 523; Monasa personata, Vieill. gal. 36, v. Bucco albifrons., Spix, 41.

Jegyz. Megjegyzendo hogy a Cuc. paradisaeus, Briss. IV., xıv. 1. A. 1, nem egyéb mint Drongo de paradis (Lanius malabaricus), és a Cuc. sinensis, ua. uo. A., 2, = Pie bleu (kék harkály, Cor». erythrorhynchos). Ezen két jegyzék Levaillanttul van, ki a kakukok leirását legjobban fölvilágosította.

(2) Vieillotnál phoEnicopnaeus nevet hordanak, gal. 37.

$\left({ }^{3}\right)$ Le Malcoha Rouverdin, Vaill. Afr. 223.

(') Le Malcoha, ua. 221; vagy Coc. pyrrocephalus, Forster, ว. Vicill. gal. 37.

(') Le Malcoha d bec peint (Phoenicophoeus calyorhynchus T.) col. 549; - Phoenicophaeus javanicus, Horsf. Jav.

CUVIER. I. K. 
rekek. Csorruh állat a borsilyokhoz közehieneh, de nem szemszörüs nyelviili clviliszlja oket azolitil. Csah egy fijok ismerctes $\mathrm{Lj-Hollam(l)ul;} \mathrm{varjunagyságu,} \mathrm{lehéres,}$ szürkés köpönyegî́. (').

\section{A POFÓKKUSZOK. SZAKÁLLÁROK.}

(Les Barbus. Bucco. Lin. Bartvogel. $\left({ }^{2}\right)$.

Cosomol nagy hiipos, alipja oldalain dagadt s durva

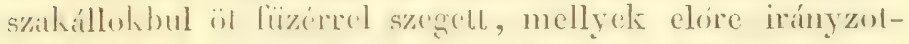

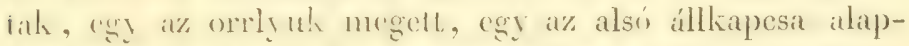

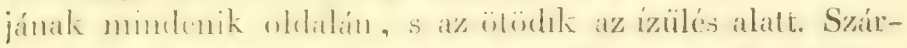

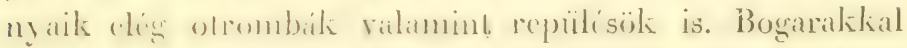

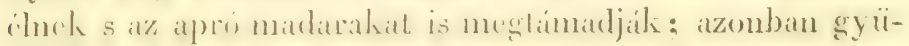
mölesöt is esznek. Fa-odrakban fészkelnck.

Három alnemre oszthatók,

\section{A SZAKÁT,T,NAGYOK.}

(Les Barbicans. Buff. Pogonias. Ilig.) ( ${ }^{3}$ ).

A telsö csurrlemez mindenik oldalon egy vagy kin crös fogat bir, s a csorr crösze tompa, ívelt; szakálLok igen erös. Alikikan tidiltatnak. 'Tübb gyümölesöl esznck mint a többi fajok $\left(\begin{array}{l}4 \\ 1\end{array}\right)$.

(1) Scythrops Norae Ilollandiae, Lath.; v. Scyth. Australasiue, Sh., Phillip. 165 és John White, 142, 1.; kész kép. Jobbak col. 290. Vicill. gal. 59.

$\left.{ }^{2}\right)$ Bucco, Brisson által adott név, mivel csurrlemezénck alapja folfitt, bucca, (pof, arc) latin szótul.

$\left(^{5}\right)$ BARBICANs, a barbus és toucans szavakbul, mert azoknak idomát egyesitik. Pogonras a tóranv (szakáll) szótul jő, de a nevet Lacép. már régóta egy halnemnek adta.

$\left(^{4}\right)$ Bucco dubius, Gm. (Pogon. sulcirostris) Leach. Zool. Misc. 11, 76, enl. 602; Vaill. Ois. de par. etc. II, xrx. rl.; - Pog. eryeliromelas, Vieill. gal. 32 ; $-P$. levirostris, Leach. 77 ; Vaill k. \., A barbe à ventre rose, Vaill. az id. helyen, A. rl. a fiatal; - 


\section{A tulajdonképi szakáltárok. (Роѓ́кKuszok).} (Les Barbus, proprem. dits. Bucco. Cuv. (1).

Csorrok egyszerüen kúpos, kïnnyüden összenyomolt, erösze tompa, küzépen kissé emelt. Vamak mind a két. szárazon, s többen közúlök vidor szinckkel festrék. Menyelszókor párosak, külöuben apró csoportokban jir nak. $\left({ }^{2}\right)$.

\section{A SZAKÁLLKÚSZOK. \\ (Les Tamottas. Tamatia. Cuv.) ( ${ }^{3}$ ).}

Csorrok liissé nyultabb és összenyomotlabb, felsó c sorrlemezök végén alára görbült. Fejök vastag, farkok rövid, csorrok nagy s innét idomuk ostoba. Mind az ismerete-

Pog. personatus, T. col. 201;- Pog. niger, T. enl.688, 1; Vaill. 29, 50, 31; - Pug. rubicon, Vaill. D. rI.

(') Vieillot e nevel CAPI'SO-ra változtatá.

$\left.{ }^{2}\right)$ Bucco grandis, enl. 871; - Viridis, enl. 870; - Flavifrons, Cuv. Vaill. id. hely. 55; - Cyanops. Cuv. ua. uo., 21, vagy Capito cyanocollis, Vieill. gal. 35; - Lathami, Lalh. Syn. I, xxıI: rl.; - Phillippensis, enl. 335 ; Rubricapillus, Brown. III. xiv; - Rubricolis, Cuv. Vaill. 55, ha ezek nem három fajták; Torquatus, C. Vaill. 37; - Roseus, C. Viill. 33;-Niger, enl. 688, 1; Vieill. gal. 53; - Maynanensis, Lath.; - Elegans, Gm. enl. 688; - Barbiculus, Cuv. Vaill. 56; - Parrus, him. Vaill. 32. a no̊ enl. 746, 2; - Erythromotos, Cuv. Vaill. 57 ; - Zeylanicus, Brown. III, XV; - Cayanensis, enl. 206; - Peruvianus, Cuv. Vaill. 27, ezek szinte három fajtát tehetnek; - Fuscus, Vaill. 45; - Armillaris. 'T. col. 89, 1; - Gularis, ua. uo., 2 ; Chrysopogon, T. cul. 285; - Versicolor, T. col. 309; - Mrystacophanes; T. col. 515 ; Vaill. C. rl; - Aurovirens, Cuv. Vaill. E. rI.

$\left({ }^{3}\right)$ Tamatia, Margrave szerint, ezen madarak egyikénck neve Brasiliában. Paraguayban nevök chacurus, Azzara szerint. Temmink ezekre ruházta a CAPITO nevet. 
sek Amerihibul jonck. S csak bogírevoli. Modjoh szomorú, magános. ( $\left.{ }^{1}\right)$.

\section{A KURUKURUK.}

\section{(Les Couroucous. Trogon. L.) $\left({ }^{2}\right)$.}

1 pofikkuszoli szöresomói mellelt esorrok rörid, szelesb mint magas, alatpjatul kezdve görbuill, felsö eröste ivelt, tompa. Apro lábaik, tollakkal az ujjakigg fedvek, hosszui szeles litkok, finom hïmmii, sürii tollaza-

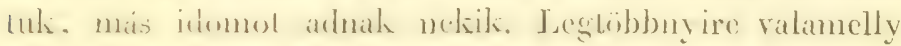

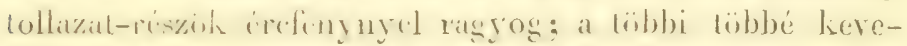

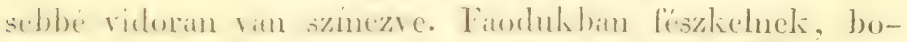

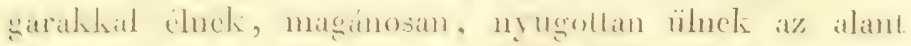

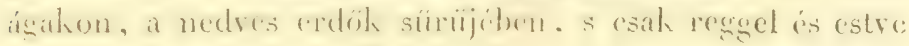
repülnek.

Találtatnak mind a kél szírazon:

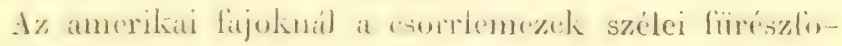
Elith. $i^{3}:$

Az ó világbelieknél az sokkal épebb. ( $\left.{ }^{+}\right)$.

(1) Bucco macrorhynchos, enl. 689; - Melanoleucos, enl. 688,2 ; - Collaris, enl. 595; Tamatia, cnl. 716, 1; Vieill. gal. 34. (Tamatia maculata, Cuv.); - Capito melanotis, Temm. col. 94; - Cyplos macrodactylus, spix, 39, 2.

$\left({ }^{2}\right)$ Kuruǩ, kialltozások kifejezése, s nevök is Brasiliában; a Tromon nevet Mochring adta nehik.

( $\left.{ }^{3}\right)$ Amcrikában : Trogon curucui, enl. 452; Vaill. Courouc, 1, 2: - Trogon rosalba, Vaill. 6. vagy variegatus, Spix, 38; Viridis, enl. 195, Vaill. 5, 4, Spix, 36; - Violaccus, Nov. comn. petı. X1, xvI, f. 8; - Strigilatus, enl. 765; - Rufus, enl. 736, Vaill. 9; - Trog. atricollis, Vicill. gal. 31, vagy Oranga, Vaill. 7, 8, 15, vaøy sulfuraceü, spix, 3S; - Tr. domicellus, Vaill. 13 ; - Tr. albiventer, Vaill. 5.

(4) Asiában, Trogon fasciatus, Ind. zool. V.rl.; - Trog. oreskios, T. col. 181; - Trog. Reinwartii, 'T. col. 124; - Trog. Duzreucelii, 'I. col. 291 ; Vaill., 14; - Trog. condea, T., col. a221; 
Egy faj nevezctes farkának elkurtultságaért; ez. A csipelt farku kurukuru. ('Tr. temnurus. T.) col. 326.

Egy másiknál pedig a farktakarók majd-nem olly hosszak, mint a teste, ez

A pávarokon kurukuru. (Fr. pavoninus. 'T.) col. 272;

Spix. 35.

Hires a mexicriak mythologiájábin, és a benföldiekhül kerestetik ékesség végett.

\section{A NYÜVÉSZEK. F.}

(Les Anis. Crotophaga. Lin. Madenfresser. (1).

Nagy, összenyomott, hajolt, fogazatlan csorrokrul megismerhetök, melly fölemelt és fïggö s metszö tarajt liordoz.

Két fajok ismerctes, mindenik Amerika forrú nedres lájairul, erös emelt lábuak, hosszúkerek-farkuak s fekete tolluak:

1. A nagyobb nyüvész (Crotophaga major) és

2. Az ani nyürész (Crotoph. ani.) enl. 102. 1, 2. k.; Vieill. gal. 43.

E madarak bogarakat és szemet esznek, seregesen röpuilnck, több pár cgriutt tojik és köll cey az ágakra s az egyült költendö párok számának megfelelelö nagyságura épitelt fészekben. Könnyen megszelidiilnek, szólni is megtanulnak, de husok rosz-szagu.

- Trog. Temminkii, Vaill,, 12; - Afrikában. Trogon narina, Vaill. Afr. 228, 229 és Cour. 10, 11.

Kételkedni szabad, hogy a Trogon maculatus, Brown, III. XIII, valódi kurukuru.

(') Ani, anno ezen madarak neve Guianáhan, Brasiliában. CroTOPHAGUS-t Brown gondolta ki (Hist. nat. Jam.), mivel e szigetben a madír a marhákra repul, ott hagoescrkat is kollancsokat fogdosó. Kisotor, = musca canina. 
A BorsáLYoK. BorsevöK. F. (Les Toucans. Ramphastos. L.) ( $\left.{ }^{1}\right)$.

Minden madarak kïzölt megismerhetók iszonyú csorrokrul, melly majd olly nagy és olly hosszú mint testök, beliil sejtes, kimny ü, víge felé hajolt, szélein rendetlenul fogas, s mychrökriil, melly hosszú, keskeny, minWomk oldahon stakállas mint valami toll. Csak Amerika hér reseriben talíltatuak, hol apró esapatoliban élnek, symmileviol is bogarakat esznek, Költés idejében magok megeszik lojánaikat s at most helt li apró madarakat. Csorrok alhutása az cledelnek elnyelésere kinyszeriti obet megrágis melliul. Mikor azt megloglak, a levegübe retik, hogy kenyclmeschben duyclhessik. Lábaik röridek, szárnyaik keresse terjeduck ki, farkok clég hosszu. Fatözsökrihben feszlichek.

a. A tulajdonképi Borsár.yor.

(Les Toucans. propr. dits.)

Csorrok nagyobb a fejuilsnel: általában feketék, torkokon vidim szinckkel, valamint mellökön és faresikokon. Tollazaluk ezen riszeit hijdanában ruhaszegélyekhe\% használták. $\left({ }^{2}\right)$.

(') Toucan ezen braziliai nevöktül, tucá. Ramphastos-t Linné sondoláki, a gapqos, csorr, szótul származtatva, e rész iszonyú nagysága miatt.

( $\left.{ }^{2}\right)$ Ramphastos toco, enl. 82 , Vaill. 2; - Carinatus, Wagler, Edw. 329 ; - Tucanus, enl. 507; - Piscivorus, L. v. Callorhynchus, Wagl. Edw. 64; - Maximus, Cuv. Vaill. Touc. vi. rl; - Pectoralis, Sh. v. Tucai, Lichtenst. enl. 269; - Aldrozandi, Sh. Alb., 1I, 25; - Erythrorhynchos, Sh. enl. 262, Vaill., 5; Vaillantii, Wagler, Vaill. 4; - Tocurd, Vaill. 9; -Vitęlinus, แa. Vaill. 17, Swains. Zool., 11., 56; Dicolorus, Waglex, v. Chlororhynchos, Tem. Vaill. 8. 


\section{b. A CSORRÁL,YOK.}

(Les Aracari. Buff. Pleroglossus. Ilig.)

Csorrok kiscbb a fejöknél s szilárdabb szarr-anyagu: termetök lissebb s tollazatok alipja rendesen zöld, némi reressel ragy pedig sárgával torkokon és mellökön. ( ${ }^{1}$ ).

\section{A PAPAGÁLYOK.}

\section{(Les Perroquets. Psitacus. Lin. Papagei.)}

Csorrok nagy, kemény, mindenfelül gömbölyú, alapján hártyával kerítel, hova az orrlyukak befurrák, nyelrök vastag, húsos, kerek: két olly kürülmény, melly öket igen alkalmasakká teszi az emberi szó ntánozísálra. Al-gégéjöl cléggé bonyolt, s minden oldalrul három tulajdon izmot birván, elösegiti e liönyüséget. Erös állkapesaik több izmok által tételnek mozgésba, mint más madaraknál. Beleik igen hosszík, vakbelök hibázik. 'Táplálatuk mindenféle gyümölesbül áll. Az áģalion kúsznak, csorrokkal liormányozva magokat, faodvaliban fiszkehek; természeli szarok kemény és kiáltó, s majdnem mindnyája élénk szinü; s nem egy könnyen találtatnak máshol, mint a hév ör alatt; de vannak mind a két szárazon, jol érve, hogy mindenikben kiilonbözöli a fajok; minden nagy szigeten lulajdon fajok vamuak, rövid szairnyaik meg nem engedvén nckik hogy nagyobb tengerterülcten ált repülnénck. A papagályoli tehát igen szai-

(') Ramphastos viridis, enl. 727, 728. Vaill., 16, 17; - Aracari, enl. 166, Vaill. gal. 50; - Piperivorus, L. v. Culik, Wagler enl. 577, 729, Vaill. 13, 14; Pterogl. sulcatus, Swains. Zool., I1l., 44, col. 356 ; - Picatus, Albin. 11, 25; - Azarae, Vaill. Supl. A; Inscriptus, Swains. Zool., III., 90 ; Bailloni, Vaill. 18; - Maculostris, Vaili.; 15. és Suppl. AA. 
mosak: furkaik idoma s némi más bilyeg szerint oiztatnak föl.

A hosszú farknak kïzält clöször megkülönbëztctuck.

\section{A PAPARÁK.}

(Les Aras. Ara. Kuhl.)

Arcok tollatlan csupasz: Amerikai fajok, nagyobb részint igen nagyok s igen ragyogo tolluak, mi okbul számosan hozatnak elerenen Europába. ${ }^{1}$ ).

Mís hosszú farkuaknak közös neve:

$$
\begin{gathered}
\text { PAPA-KÚSzoK. } \\
\text { (Perruches. Conurus. Kuhl.) }
\end{gathered}
$$

Mellyck Le Vaillant példäjakint fölosmthatók:

a. pipicsepojra. (Perruches-Aras. Taill.)

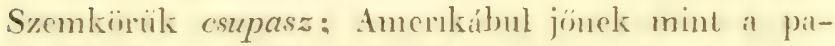
parák. $\left(^{2}\right)$.

h. рАРАNYгоо-ra. (nyil-farku papagailyok,) (Perruches à queue en fleche. Palaeornis. el Vigors. Horsf.)

(1) Psitt. macao, L. Vaill. 1; - Ps. aracanga, enl. 12, Vaill. 2 ; -- Ps. tricolor, Vaill. 5; - Ps. hyacinthinus, I.ath., $\mathbf{v}$. anodorhynchos, Maximiliani, Spix, xi; - Ps. ararauna, enl. 36; - Ps. militaris, Vaill., 4; - Ps. severus, Vaill, 8, 9, 10 ; Ps. macawuanna, enl. 864, Vaill. 7; - Arara purpureo-dorsalis, Spix, XxIv.

(2) Ps. guyannensis, eni. 167, 407, Vaill, 14, 15; - Ps. squamosus. Shaw. Misc. 1061; - Ps. vittatus, Vaill. 17; - Ps. versicolor, enl. 144. Vaill. 16; - Ps. solstitialis, Vaill. 16, - 19, v. aratinga chryso-cephalus, Spix. xiv. Az Aratinga luteus, Xiv, $a$, amannak fajtája. 
hét kïzípsö farktolluk a többickei solkal fülül haladják. $\left({ }^{1}\right)$.

Illyen, pétdául azon fiij, melly elóször láttatck Europában s nagy Síndor által hozatéls-be:

A saindor papanyila. Psittacus Alevandri. L. Nyakravalós Papagáj. Földi.) enl. 642.

Szép zöld; takoiján veres nyakkörv van s torka alalt fekete folt.

c. А PАРАTERJEK-re, (kiterjedt farkvégü papakilszok.)

(Perruches à queue élargie v. l. bout. Platycerus. $\left({ }^{2}\right)$.

(1) Ezen fölosztatbul csinálák Vigors és Horsfield a PALAeornis sernet. Ide helyezendök:

Ps. torquatus, Briss. enl. 551; Ps. Alexandri, L. enl. 642, Vaill, 50. Edw. 292, mellynek fiatala, Kulıl szerint, = Ps. eupatria, L. Vaill. 73. Enl. 259; - Ps. annulatus, Bechst. Vaill. 75. 76 ; - Ps. erythrocephalus, L. gingianus, Lath, Vaill. 45. Edw. 253; - Ps. malaccensis, Gm.; - Ps. Barrabandi, Swains. III, 59 ; v. barbulatus, Bechst. enl. 888. Vaill. 72 ; - Ps. bengalensis Gm. enl. 888, Vaill., 74; - Ps. papuensis, Sonn., Nouv. Guin. III; - Ps. rufirostris, enl. 580 ; - Ps. haematodus, enl. 61 , v. cyanocephalus, enl. 192 , v. moluccanus, enl. 743 , v. cyanogaster, Schaw. Gen. zool. VIII. LIx. rl. és White J. 140. 1. Mind életkor miatti fajták. Vigors és Horsfield urak azon megjegyzést tették, hogy ezen utolsó papanyil nyelvének hegye alatt selymes ször van, s Trichoglossus nemi nevet adtak neki. Érdekletes volna megvizs gálni, valljon nincs e több papakúsznak hasonló bélyege.

${ }^{(2)}$ Ps. niger, enI. 500, Edw. 5; Psit. vasa, Vaill. 51; - Ps. mascarinus, 5, cnl. 5, Vaill. 139; - Ps. erythropterus, Sh. Nat. misc. 653 ; - Ps. eximius, Vaill. 28, 29, Sh. Misc. 93; - Ps. Pennantii, Lath., J. White, p. 174 és 175, v. elegans, Gm. Vaill. 78, 79, v. gloriosus, Shaw. 53; - Ps. Brownii, Kuhl Vaill., 80; Ps. scapulatus, Bechst. Vaill. 55, 56, enl. 240; - Ps. tabuensis. 


\section{d. Rendes РАрАкÚSZOK-ra.}

Farkok majduem egyenlöen elvágott. $\left({ }^{1}\right)$.

Ide mellekezendök a négrszegfarliu lajak, mellyelinél a kít kirzepsö toll elnyulik, de a nyult résznck esak hegyén van szakáll. $\left.{ }^{2}\right)$.

A rörid eg̣ enlö farkin papagály nk között megkiülönböztetnek :

\section{A PAPADÚK. (CSACSOGÁLYOK.) (Les Cacatoes. Cacadú.) ( $\left.{ }^{3}\right)$.}

Búbot hordoznak, hosszú lieskeny s kit sorba helye-

Lath. v. atropurpureus, Sh., Lev., Mus., 34. - 13s. amboinensis, Gm., enl. 210, White J. 168 és 169.1.

Vigors is Horsfield ezen fülosztatbul csinúltíi a PLATYcerces nemet.

(') Ps. guaruba, Kuhl, lutens, Lath, Vaill. 20, vo Aratinga Carolinae, Spix, XII; - Ps. guyanensis, Gm. v. macrognathos, Spix, $\mathrm{xxv}$; - Ps. ludoricianus, enl. 499, vo carolinensis, Wils. III, xxvr. 1.; - Ps. pertinax, enl. 528, Vaill. $34-57$; - Ps. aureus, L. Vaill. 41; Edw. 235; - I's. canicularis, enl. 767, Vaill. 40; - Ps. aeruginosus, Edw. 177; - Ps. buccalis, Vaill. 67; - Ps. virescens, cnl. 359; - Vaill. 59; - Ps. sosova, enl. 456, 2, Vaill, 58, 59 és Ps. tori, cnl. 190, 1; - Ps. marinus, enl. 768, Vaill. 58; $\boldsymbol{N}$ s. ponticerianus, cnl. 517, Vaill., 31 ; $\boldsymbol{P}$ s. xanthosomus, Beckst., Vaill. 61; - I's. capistratus, Bechst. Edw. 232, Vaill. 47 ; - Ps. ornatus, enl. 552, Vaill., 52, Edw. 174 ; I's. marginatus, Vaill. 60, vagy olivaceus, enl. 287; - Ps. macrorhynchus, enl. ?15, Vaill. 83; P'sitt. grandis, enl. 518, és 685: jobban Vaill. 126, 127, 128; - Ps. incarnatus, Vaill. 46; - I's. borneus, Vaill.44; - P's. Novae Guineac, Vaill. 19 ; Ps. concinnus, Vaill. 48; - Ps. pusillus, Vaill. 65; - $\boldsymbol{P}_{\text {s. hume- }}$ ralis, Vaill. 50 ; - P's. discolor, V. 62 ; - P's. undulatus, Sh. 673 ; - Ps. chrysostomus, Kuhl, pl. 1, - Ps. pulchellus, Vaill. 68 ; - I's. zonarius, Sh. 657.

$\left({ }^{2}\right)$ Ps. setarius, Tem. col. 15.

$\left({ }^{3}\right)$ Vicillot ur ezen fölosztatot PLyCToropros-nak nevezé. 
zett tollakbul képzcttet, melly az állat liénye szerint lesimul vagy fólberzed. India legtávolabb részében élnek: a nagyobb rész tollazala fehér; legtantilékonyabb fajok, leginkább a mocsáros földeket szeretik. $\left.{ }^{1}\right)$.

Némelly, nem rég Új-Hollaudban filtalált fajok egyszcrübb, kevesebbé mozgékony, és széles, középszerúleg hosszú tollakbul álló búbot burnak. Täbbnyire gyökerekkel élnek. $\left({ }^{2}\right)$.

Másoluál az egész búb belyett néhány csüngö, s foszlott szakíllakit csak vége felé biró toll vagyon, mellyek némükép a tolltaraj helyet foglalják el. ( $\left.{ }^{3}\right)$.

De a legnagyobls szám fején semmi ékesség nincs; a tanulás- és szólásbeli ügyeségrül legismcrtebb faj

A hamuszin papadu, hamusz. csacsogcily. (hamuszin papagai, F. Le Perroquet gris. Jaco. Psitt. erythracus.) enl. 311. Edw. 163. Vaill. 99-103.

Egészen hamvas; farka veres. Afrikábul jö.

A zöld ruhás fajok legszámosabbak. $\left({ }^{*}\right)$.

(') Ps. cristatus, enl. 265; - Ps. Philippinarum, enl. 191; - Ps. malaccensis, enl. 498; - Ps. sulfureus, enl. 14; - Ps. galeritus, White. 237; - Ps. nasicus, Temm. col. 331.

$\left({ }^{2}\right)$ Ps. Banskil. Lat syn. Suppl. 109, Shaw. Misc. 50; - Ps. funereus, Sh. Misc. 186 ; 1 s. Cookii, Tem. v. Leachii, Kuhl. III, rl.; - Ps. roseus, Kuhl. col. 81.

Ezen fölosztat lön a CaLyptorhynchus nem Vigors és Horsfield-nél.

$\left({ }^{3}\right)$ Ps. galeatus, Lath., Suppl.

(') I's. melanocephalus, enl. 527; Vaill. 119, 120 ; - I's. signatus, Vaill. 105; - Ps.menstruus, enl. 384; Vaill. 114, V.flavirostris, Spix. xxxI; Ps. purpureus, enl. 408; Vaill. 115; - Ps. sordidus, Vaill. 104; - I's. amazonicus, enl. 13, 120, 312 ; Vaill. 98, 99; - Ps. aestivus, enl. 545, 879; Vaill. 110 és 110 kétszer; - Ps. coerulifrons, Sh. Edw. 330; Vaill. 135; - Ps. cyanotis, T. v. brasiliensis, Lin. Edw. 161; - Vaill. 106; Ps.dominicensis, 


\section{PAPAGÁK - (LORIS),}

nevet azon fajok hordanak, mellyeknil a tollazat alapjia reres, s a fark kisse dk-idomu, s mellyek igen liozelitenck némelly papakiszolkhoz. Csak Keletindiában talíltatnak. ( $\left.{ }^{1}\right)$.

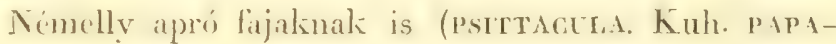
GÁlCSA. perruches) név adalék, de hamisan. ( $\left.{ }^{2}\right)$.

Azonban mind ezen szin is nagg sigbeli kiobubstig alig jogosíthat nemi megkülönböztclésre.

Csak

enl. 972, v. vinaceus, Pr. Max, v. columbinus, Spix. xxvı; 1's. dufresnianus, Kuhl, Vaill. 91; - P's. autumnalis, Edw. 164; Vaill, III; - I's. havanensis, enl. 360 ; Vaill. 122; - I's. leucocephalus, L. cnl. 535, 518, 519; Vaill. 107, 105' 109. kétszer, 109, - I's. albifrons, MIus. Carl. 52; - P's. pulverulentus, cnl. 861; Vaill. 92 ; - 1's. festivus, enl. 840 ; Vaill., 129;-P's. accipitrinus, enl. 520. és Spix. xxxu. a ; - Ps. senegrallus, enl. 288; Vaill. 116, 11S; - Ps. Levaillantis, Lath. V. infuscatus, Sh. Vaill. 150, 151; - Ps. gramineus, enli. 862; Vaill. 121; - Ps. sinensis, Edw 231, enl. 514; - I's. Geoffroii, Vaill. 112, 113, v. personatus, Sh.; - Ps. Xanthops, Spix. xxvi; - Ps。 mitratus, Pr. Max. col. 207, จ. maïtaca, Spix. Xxix, $\mathrm{xxx}$; - I's. diadema, Spix, xxxil.

(') I's. unicolor, Vaill 125; - I's. domicella, enl. 119; Vaill. 94, 95; - I's. lori, enl. 158. Vaill. 123, 124; - I's. garulus, enl. 216; Vaill. 96 ; - Ps. cyanus, Sh. Vaill. 97.

$\left({ }^{2}\right) \boldsymbol{P}^{3}$ s. passerinus, enl. 455, 1, Shaw. Misc. 893, és Spix, xxxı1; - P's. tui, enl. 456, 1; Vaill. 70; - Ps. melanopterus, cnl. 591, 1; Vaill. 69; Sh. 132; - Ps. pilealus, enl. 744; Vaill. 155; - I's. Berrabandi, Vaill. 134; - Ps. canus, enl. 791, 2 ; Sh. 425; Ps. swindernianus, Kuhl, II, 1l.; - Ps. galgulus, enl. 190, 2; - Ps. philippensis, enl. 120; - Ps. vernalis, Mus. Carls. 29 ; - Ps.indicus, Edw. 6; - Ps. torquatus, Sonn., Nouv. Gvin., 393 ; - Ps. stmplex, Kuhl, Sonn. uo. 38, 1; Ps. pullarius, enl. $60 ;-P s$. micropterus, Sonneret, 41; - Ps.taitianus, Gm. enl. 


\section{A. PAPATÁr-ok}

(Perroquets à trompe. Vaill. Rüsselpageien.), hiruak jó behregeket a többeketüli elválaszthatísra. Rövid n'grgsegii farkok, hosszú keskeny tollakbul álló bubjok a papadúlioz leszili öket hasonlókká. Arcok csupas\% mint a paparálinál; de felsö csorrtemezök iszonyu, az alsin iggen rörid, s igy szájok tátolt, lárt, nyelvök hengerui. egy a regén beszelt szarvnenui kis maklkba végzödö s a staijbul messze kinyujtható, száraik a bokán kissé fölïl esupanzok, régre rövid és lapos lábok (lábtövök) melyIreke járískor savakan nehezkednek, minden papagályrul meghilönböztehk öket. Csak liét faj ismeretes Keletindiábul. ( $\left.{ }^{1}\right)$.

Talán alnemmé emelhetöls még:

\section{A PAPAJÁROK.}

(Perruches ingambes. Vaill. Pezoporus. Ilig. Frdpapageien.)

Csorrok göngébb, lábaik, emeltebbek s körmeik "gyenesebbek mint a többi papagályolinál. A földön járuak, s eledelöket a füben keresil. $\left({ }^{2}\right)$.

455; 2; Vaill. 27; Vaill. 66; - Ps. fringillaceus, Vaill. 71, v. porphyrocephalus, Sh. Misc. 1; - Ps. phigy, Vaill. 64; - Ps. xanthopterigius, Spix. xxxiv, 12; - Ps. gregarius, Spix, xxxiv, $3,4$.

(') Ps. aterrimus, Gm. v. Ps. gigas, Lath. Edw. 3, 15; Ps. goliath, Kuhl, v. I' Ara noire à trompe, Vaill.: per I, xIı. rl. és xrII; Az Ara gris à trompe, ua. uo. II, rl. csak fajta lesz. Különben is a ,trompe“ (ormány) kevesbbé pontos. Ezen nyelv nem csőves, sőt nyeivnek is csak azon kicsin szarvnemá darab mondható melly ezen henger véget takarja. Lásd: Geoffr. Saint Hilar. ap. VI. ga). 4 .

Vicillot ezen osztat)ul csinálta a Migroglosse nemet. gal. L. Jap.

(?) Ps.formosus, Vaill. 1, 52 ; Sh. Misc. 228; - Novae Zee. 
Rendesen a kúszók közé tétetik két egymashoz igen közeli madár, mellyek a tyukaikhoz is némileg hasonlítani látszanak, - nevezetesen a hokkókhoz.

Szárnyaik és larkok mint a hokkóké,s azok módjára fákon tartózodnak; csorrok rövid, felsó lemeze boltos; lábaikon a melülsó ujjak közöth rövid hár ya van; de a külsö ujj gyakran hátra irányzódik mint a hulolyoknál. Orrlyukitik szinte eggrszeriëen nyilnak a csorr szarvanyagába, a lemezek szélei fogacsosak, s a mellesont (legalíbb a turakusznál) nem birja a tyukiak-nál közönséges nagy kimetszéseket.

Ezen madarakbul két nemet csináltak, mint jö:

A TURムKÚSZOK.

(Les Touracos. Corythaix. Ilig.) (1).

Mellycknek esorra nem emelketik foil a homblira, s tejök fölmereszthetó tolltarajjal ékesílett.

Legismeretesebb laj:

A foki turakuss. (C'uculus persa. Lin.) cnl. (601. Vicill.

Prom. elc. 16, 17.

A Remeny-fok kiorrül lakik, szép zöld, számytollainak egy része liamazsin reres. Fa odvakban löszkel, gy ümölcsölskel él. $\left({ }^{2}\right)$.

landiae, Lath., Mus. Carls., 28; - Ps. comutus, Lath. Syn. Suppl. III, VIII. rl.

(1) Vieillot e nevet opethus-ra változtatá.

$\left.{ }^{2}\right)$ A. h. Touraco géant, Vaill. Promér. et guép. 19. ri; Touraco paulins. Temm., col. 25, v. opoethus erythrolophus, Vicill. 
A HƯVELYKÜSZÖK.

Les Musophages. Musophaga. Isert.)

Francia, latmnevét onnan kapta, hogy a banana gyümölcsüt Cökép kedveli, a magyart pedig, mivel csorrának alapja kögöt képez, melly homloka egy részét hürely gyanánt veszi körül.

Ismert faj:

A violaszin huvelyküsz. (Musop)haga violacea. Vieill. gal.

47. Touraco violet. Vaill. Promer., stb. 18. rl.)

Szcmköre csupasz, veres, tollazata violaszin, kútfeje s evezöi karmaszin veresek, egy fehér vonás megy el csupasz szemköre alatt. Gvineál)an s a Senegalnál lakik.

A MAD.ARAK NEGYEDIK RENDE.

\section{A TYUKFÉLIEK.}

(LES GALLINACÉES. GALLINAE. Lin.)

Igy neveztetnek a házi tyukkali atyafiságokért, - $s$ általíban, mint azoknál, felsó csorrlemezök boltos, orrlyukaik egy nagy hártyás téren vannak a csorr alapján, egy porcnemü pikkelylyel takarva; idomuk otromiba, szárnyaik rövidek, mellcsontuk szi-

gal. 49 ; - Touracobrun, (Phasianus africanus, Lath.) Vaill. 20, v. musophage narié, Vieill. galer 48 。 
lírd (csontos) és két, akkora s olly mély kimetszés által kisebbült, hogy azok majd egész oldalait elfoglaljak: tiraja elül ferdén elvágott, olly módon, hogy a villacsont hegyes rége csak szalag által egyesült vele; melly hörilmćmyek nagyon gyöngitve a mellizmokal, nehézzé teszik repillé öket. Farkok többnyire lizennegg s néha egész tizennyole tollu. Algüigioli igen egıszeru. nines köztök egy kelleme sen ćncklii. I pulgógat kivévén, a földre tojnak s ott kölenek, durvin rakott szalma vagy füfészekben. Minden hímnek rendesen több jércéje van, melly sem a fészkelispe sem a fiak tartására nem fordit gondor, mellyek rendesen számosak s legtöbbuyire a tojáshul kibujra már funni képesek.

Ficn rend föképen exy igen természeli családbul képezletik, s arrul nevezetes, hogy majorságunkba madaraink legnagyobbs számát adva, sok és der’ék valat szolgáltat; elsó ujjai alapjoknál összenóltck eggy rövid hárlyával s szélök hosszában fogacsozottak, - s melly nemekre csak igen kevessé fontos jelek szerint oszlhatí fö!, mellyek a fej némi toldalćkairul retettek. De, hoģy a lényeket ne igen szaporítsuk, mi azon nemeket is ide mellékelendjük, mollyeknek lábain nines meg azon hártya, s mellyeknek egy része (a galambok) a tyukiakat a verebïekhez kötik, a másikak (ujjváltyukok) a turakúszokhoz közelítenek. 


\section{A PULYGóK.}

\section{(Les Alectors. Crax.) (').}

Amcrikai nagy tyukféle madarak, igen hasonlók a mi pulykáinkhoz, széles kerek farkkal, nagy durva tollakbul összetéve. Köztök többeknek különös alkalmaztatúsuk van a gögsipban. Erdökben laknak, bimbót s gyümölcsöt esznek, fákon fészkelnek, ágon ülnck, igen nyájasak, a húziasságra hajlandók. Gmelin és Latham által noccos és JAGous-okra osztatlak föl, de kissé-határozott bélyegek szerint. Mi következóleg osztjuk öket föl.

\section{Tulajdonképi нокко́к. (но́ко́к. F.)}

(Les Hogcos-propr. dits. MITU-k Braziliában. Crax. Lin.)

Csorrok erös, alapja börrel bevont, néha élénk szinüvel, hova orrlyukai is nyilnak; fejökön búb van fölberzedt, hosszú, keskeny, s bodrosvégü tollakbul.

'Termetök mint a pulykáé, s mint az fákra mennek. Amerikában készakarva neveltetnek, s ezen lájakról olly különbözö szinủ egyének jönek hozzánk, hogy fajaikat kétkedve határozzuk meg.

Legközönségesebb faj.

1. A kuraszszó. F. fekete hokkó. (Mitou-Poranga, Margr.

Crax. alector. L.) Buff. Ois. II, xuI. rl. Vieill. galer. 199.

Feketék, hasok fehér, csorrok viaszhártyája sárga. Gögsipjok csak könnyü hajlást csinál mielött a mellbe hatna.

Egy másiknál:

(') Alector, görög ncve a kakasnak。 
(A golyós hokkó. (rax. globicera. Lin.) enl. 86. Edw.. $295,1$.

A csorr alapján egy golyor dudor ran, többé kevesebbé nagy.

Egriliek és a másikak között is vamuak, mellycknél a test liülöbözökípen van lehérrel es sárgával tarliázra (Albin, II, 32.) ( ${ }^{1}$ ).

Néha az egész al sárga. $\left({ }^{2}\right)$.

A peru-belinek: (Crax. rubra. Lin.) enl. 125.

vidám gesztenyeszine van; feje s nyaka pedig kïlönbözóleg tarkítra fehérrel és feketérel. $\left({ }^{3}\right)$.

\section{A POKSZI.}

(Les Pauxi. Ourax. Cuv.) ( $\left.{ }^{4}\right)$.

Csorrok rövidebb, és nagyobb, s alapjának hártyája, valamint fejök legnagyobb része rövid és bibor-lömöt lollakkal födve.

Legközönségesb faj:

A gumós pokszi. (Pierre. Oisenu à pierre. Crax pauxi. Lin. Enl. 78. Vieill. gal. 200.

Csorra alapján tojásidomu gumoil hordoz, majd akkorait mint feje, vilígos kék szinüt s kökeményet. Ezen madár f́ckete, hasa ala s farka fehérek. A földre tojik. N̉em ismerni egészen eredeli honát. Gögsipja kivül, a jobb

(') Ugy látszik ez Fernandez valódi mexikói hoazin-ja.

$\left({ }^{2}\right)$ Illyen a jérce, leirva Azzaratul, Voy. Iv. p. 169. Ugy látszik még más utazók szerint, hogy a jércek sárgák is.

( ${ }^{3}$ Lásd még: Crax fasciolata, Spix, LxII, a; - Crax Blumenbachii, ua. Lxiv. - A. h. Crax. globulosa ua. LXX és LXVI; Crax rubrirostris ua. LXVII.

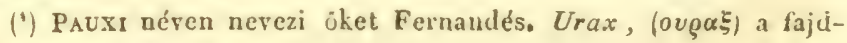
tyuk görög (athénei) neve. 
oldal hosszában szál le a mellcsont mögé; a bal oldalra hajlik s elöre jö hogy a villacsonton által a mellbe jusson. Minden gyủrüi összenyomottak.

Van egy másik faj, melly a gumók helyett cgy clöálló tarét bir csorrán, melly veres. Hasa és farka hegye gesztenyeszínüek. Ez Margrave valódi mitu-ja. Ourax mitu, Temm. col. 153. Crax galeata, Lath. Crax tomentosa, Spix. Lxirr. $\left.{ }^{1}\right)$.

\section{A JAKUK.}

(Les Gouans ou Yacous. Penelope. Merem.) ( ${ }^{2}$ ).

Csorrok vékonyabb mint a hokkkóké, szembörük csupasz, szinte mint torkok ala, melly legtübbnyire fölfúható.

'Többféle fajtákat ismérni belölök, szmre különbözöket, de mellyek között a faji határokat nehéz letüzni; a búbosak kiváltképen majd különbözó barnák, bronzosok (Penel. Jacupema, Merr. II, XI.) néha follos mellü (Pen. cristata, Lin.) Edw., 13, ( $\left.{ }^{3}\right)$ ugyan azon foltokkal s több kevesebb foltokkal bubján, s szárnytakaröin. (Pen.

(1) A h Crax tuberosa, Spix, LXvIr, a ; - Crax uramutum, ua. LXIr.

Jegyz. A. chacamcl, Buff. (Crax wociferans), melly Fernandes ingatag tudósitására alapitott, XLı. szak., semmi hitelességet nem bir. Sonnini még azt is hiszi, hozy = Falco zulturinus, Buffon Caracara-ja (és Dutertreé.,) = Psophia (Agami.)

${ }^{(2)}$ Gouan és Pacou, ezen madarak nevei Gvianában és Brasiliában. A Penelope, mellyel Merem ajándékozá meg 8ket, a Görögöknél egy réccfajt tön, melly, mint mondatik, Ulysses nejét gyermekségében a vizbiil kiszabadítá.

${ }^{(3)}$ A P. jacuaza, jacucaca, jacubemba, guttata et arracuan, Spix, Lxvirl - Lxxv. igen közclitenek a $P$. cristata-lioz, ha annak nern csupa fajtái. A P. marail, Vieill. gal. 198, föképen merofclel a jacubebanak. 
leucolophos. Nerr. II, xIr, vagy Pen. cumanensis. Gm.) Jacr. Beytr. 10. rl. Bajon, Cay. 5. rl. vagy Pen. jacutinsa, Spix, Lxx. rl. Vannak közbülsök is ezen két végsök között: Pen. pipile, Jacq. Beytr. XI. r].

A gögsip, legalább az elsóknćl, a bör alatt messze a mellcsont hálulsó széle mögé megy le, azután emelkedik, s lejö, hogy ismét felgörbülhessen s a villacsonthoz jusson föl, honan szokás szerint a tüdókbe jut.

Egy búbtalan faj :

A simult fejü jaku. (Penelope marail.) enl. 338. Vieill. gal. 198.

Zöldes fekete, sárga hasu, - jól különbözöttnek látszik. Gögsipja, mind a két nömnél, egy kis hurkot képez a mellesont magasán, mi elött a mellüregbe hatna.

\section{A JAKUTÁRSAK.}

\section{(Les Parraquas. Ortalida. Merrem.)}

A jakuktól csak abban különböznek, hogy semmi csupasz nines torkokon és szemeik körül.

Csak egy ismeretes, fólül bronz-barna, alul fehéres szürke, fején veres. $\mathrm{Ez}$

A parraka jakutcirs. (Catraca. Buff., Phasianus motmot.

Gm. Phas. parraqua. Lath.), Eul. 146. ('). Bayon. Cay., 1. rl.

Ezen madár szara igen erös s nevét nyomja (fejezi) ki. A him gögsípja a bör alatt egész a has felé lemegy, azutín ismét fülemelkedik a mellbe jutandó.

Ezen különbözö pulygókhoz szokás még adni

(') Jegyz. Az enl-beli rl. annyiban hijányos, mivel a farkat hegyesnek mutatja. 


\section{AZ UJVÁLTYUKOK-at.}

\section{(L' Hoazin. Buff. ('). Opisthocomus, Hoffinansegg.)}

Amerikai madár, hasonló idomu, rövid nagy csorrı, annak szarvanyagába nyiló orrlyukakkal, hártya nélkül; fején, hosszu igen vékony foszlout tollakbul bub van, - melly minden igazi tyukuaktul különbözik, mert ujainak alapjai között nem renni hártyát észre. Ez a

Tarajos ujvailtyuk. (Phasianus cristatus. Lin.) enl. 337.

Vieill. galer. 193.

Zöldes barna, fölül fehérrel tarka, nyaka elött s farka végén sárga, hasa alatt gesztenyeszin. Gvianában találtatik, az eláradt vidékek hosszában fákon ülve, hol a kontyvirág egyik fajának leveleıvel s magvával él. Húsa nagy hódonyszagu s csak mint csaló cledel használható némelly halak számára.

\section{A PÁVÁK. F.}

\section{(Les Paons. Pavo. Lin. Pfau.)}

Kiáltások szerint nevezteltek el; bélyegül egy bub vagy tollag van fejökön, a hím farktakarói hosszabbak tollainál s fölmereszthetók a kerék-verésre. Kiki tudja minö ragyogók ezen tollak lomha, selymes szakállai s azon szemfoltok, mellyek a mi fajtánkéinak végét diszesítik.

1. A búbos páva. F. (Paon domestique. Pavo cristatus. Lin.) Enl. 433. 434.

Azon faj, mellynek feje fölemelt, kiszélesült-végü

(') A Hoazin név bebizonyítás nélkül adaték e madárnak Buffon által Fernandès, utasítása szerint, Mex., 320 , ch. x.

Vieillot, gal., 193, Sasa cristata-nak nevezi, s rosszul ábrázolja, csorrát az összeereszkerlés felé, mintegy fogacsosnak mutatván. Igen különbözö nemet képez a többi tyukuaktul, s melly tulajdon család typus-ává lehet, ha bonctudománya megismertetik. 
tollak pamagával ckess. - E kevély madár India éjszaki részébuil ered, s Europúba Súndor által hozaték. A rad egyének ragyogásak által még fölümulják a szelídeket. Hítakon és száryokon a kék uralkodik az arany-züld loclyett, farkok még gazdagabb.

2. A züld nyaku púva. (Paon spicifère, Porv. spicifer. (1). Vieill. gal. 202. Shaw. Nat. miscell. 641.

Linné rosszul nevezé muticus-nak, mert vamnak sarkantyúi; - külön faj; tollagában hosszú keskenyeli a tollak; nyaka nem kik, hanem zöld, hullámos, aranyos; farka majd olly szép mint az elsóé.

Egy másik faj,

3. A ketsarkantyus pava. L' Éperonnier, Chinquis. Pav. bicalcaratus, thibelanus, Gm.) cnl. 492, 493. Vieill. gal. 203. 1 .

Sokkal kisebb: fejon csak rïvid tömötl bub van; a him mindenik sarka két törissel fegyrerzett; farktakaroi kevesebbé hosszak, kettós foltosak, a válltollak egyfoltuak, mind tükrözók. $\left({ }^{2}\right)$.

Egy közel faj :

1. A fehérszemï pava. (Pavo albocellatus. Polypl. albocellatum. 'Tem.

Csak egyszerü, kék, feheres körrel keritett foltokai bir.

5. A vonatolt piva. (Polyplectron chialcurum. T.)

Tollar kékek, de a takarókon csak súrga és fekete keresztvonatok vannak.

(') Sokáig csak egy rosz kép után ismerteték melly a xvr. században Japanbul hozaték (Aldrov., II, av. 33, 54), de Duvaucel és Diard több madarat hoztak Sumatrabul, mellyek szerint csinálta Vieillot az ábrázolatot.

$\left({ }^{2}\right)$ Temmink egy Polyplectrum nevü nemet csinált belßle, Vieillat pedig e nevet DIPLECTRON-ra változtatá. 


\section{A. PÁvACsoK.}

\section{(Les Lophophores. Lophophorus. Tem.)}

Fcjöliön tollag mint a pávákén; farkok is egészen hasonlít azékhoz, de takarói nem nyulnak el: különben a lim szineinek érc-ragyogísa által a pávához hasonlók, Szemkörük sót arcok is csupasz mint a fícánnúl, sarkaikon erös sarkantyuk.

Egyet ismerünk India éjszaki hegyeibül, ez

A ragyosó pávacs. (Lophophorus refulgens. Phasianus impeyanus, Lath. Synops. supl. 114. 1. Monaul.

Sonnin. Vieill. gal. 208.

Pulyka nagyságu, fekete; tollaga s háta tollai különbözóleg játszák az arany- réz-zafir-és smaragd színeket; farka tollai veresek. A fiatal s a nö barnák srïrǩe és sárga lángakkal. (1).

\section{A PULYKÁK.}

(Les Dindons. Meleagris. Lin, Truthahn.) ( ${ }^{2}$ ).

Fejök és nyakok föle tollatlan s egészen bibiresos börrel takart; torka alatt egy függelék van az egész nyak hosszában lecsüngó, s homlokín egy másik kúpidomú toldalék, melly a himnél földuzasztható s az indulat idején kinyúló, annyira logy csorra hegyérül lecsüng. A vén him nyak-alárul egy ecset durva ször csüng le; farka

(') Ugy látszik, Aelianus ismerte már s leirta. Hist. an. L. XV1, C. 2 .

A. h. Lophophore, Cuv. Tem., col., 1. rl., (Cuvier pávacsa), csüngo búbu, fekete testü, hát-tollainak szélei fehérek; Duvaucel találta föl. Ez tán Lath. Phasianus leucomelanos-a. A nỏ barna, melltollainak széle fehéres.

( $\left.{ }^{2}\right)$ Meleagris, a gyöngytyuk görög neve, Linnetül rosszul alkalmaztatva a pulykákra. 
tákaröi, a röridebbek és durvábbak mint a párać, szinte fölmeredre kereket képzenck. A himeknek gyönge sarkantyúi rannak.

Régóta csak egy faj ismeretes.

A küzünséges pulyka. F. (Le Dindon commun. Meleagris gallopavo. Lin.) Enl. 97.

Amerikíbul a 16 században hozaték s ma egész Europában clterjedt, husának jó izeért: nagyságaért és könnyú szaporodásaért. A virginiai rad pulykák (Vieill. gales. 201.) zöldes barnák, rézfényléssel.

$\mathrm{K}$ is ideje hogy egy másik faj is leiraték, A szemes pulyka. (Mel. ocellata.) Cur. Mém. mus. vi. 1. rl. cul. 112.

Majdnem olly szép mint a pára, szineinek ragyogásat által, s kiváltképen zalfir szinü tükrei által, mellyek arany és rubin körölkel keritrék, pulyka-idomu farkát ékesitve. A Honduras öbölnél fogaték.

\section{A GYÖNGYTYUKOK. ( $\left.{ }^{1}\right)$.}

(Les Peintades. Numida. Lin.)

Fejök csupasz, arcaik alán hus-karélyok, farkok rövid, s kaponyájok fölölt legtöbbnyire havadályos tarạ van. Lábaikon nincs sarkantya; rörid s csüngö farkok s farcsikok súrü tollai, testöknek boltos idomot adnak.

Ismeretes faj:

1. A küzünséges gyöngytyuk. (Numida meleagris. Lin.) enl. 108.

Afrilsábul eredt, palaszinï, mindenütt betakarva göm-

(') A régi görögök a gyöngytyuitokat NIeleagris-nak hivták, s azt hivék, hogy Meleagris, testvéreinck átváltozásábul eredtek. Zollazatuk foltjait a könyñk nyomainak vallák. A rómaik öket afrikai, numidiai sth. tyukoknak hívták. Ma csak Gvineálıan találtattak föl îjra. 
bölyü fehér foltokkal. Ezen madarat a majorságokban igen alkalmatlanná teszi kiáltozó s nyugtalan módja, noha húsa igen jeles. Vad állapotban igen nagy seregesen él s különösen a mocsárok közelén tartózkodik.

Még egy faj ismeretes, mellynek fején tollbúb van; $\mathrm{ez}$ :

2. A tarajos gyöngytyuk. (Num. cristata),

És egy másik, hol e faj kúpidomu sisakkal fegy. verzett, ez

3. A sapkís gyöngytyuk. (Num. mitrata.) Pal. Spic. IV.

I. s III. rl. I. kép. Vieill. gal. caLx. rl.

Kevés idö óta egy faj találtaték föl, mellynck sisaka igen kicsin, s melly csorra alapján egy kis csomól bir rövid csökökbül, majd minden szakáll nélkül, ez

4. A pamagos gyöngytyuk. (Num. ptylorhynca. Licht.

\section{A FÁCÁNOK}

\section{(Les Faisans. Phasianus. Lin.)}

Nagy neme bélyegül birja a részint tollaktul fosztott és veres börrel fedelt arcokat, s farkának kölöubözóképen födél-idomulag elrendelt tollait.

Itt elöször megkülönböztetnek,

\section{A КАKАSOK. \\ (Les Coqs. Gallus.)}

Fejök a mondottakon fölül husos és függóleges tarajjal szaporitott, alsó csorrlemezök pedig mindenik oldalrul husos cafattal biró. Farktollaik számra tizennégyen, Két függóleges sikra emelkednek föl, mellyek egymást hátolják; a hím takarói iv-idomulag nyulnak ki a tulajdoképi farkon túlra.

Az udvarainkban annyira elterjedt 
1. Rendes kakas és tyuk. (Le Coq, la Poule ordinaires Phasianus Gallus. Lin.) Enl; 1, 49.

Végetlenül ráltozik szinére néze: nagysága igen különbïzó; ramak fajok, hol a taraj fölberzedt tollpamag által pótoltatik ki; némellyek tollat birnak lábakon és ujaikon is; másolinal taraja, lebentyüi s egész vízbeli esonthúrtyája feketék; némelly szürnyeges fajtáknál több nemzetségen által öt sót hat ujj is láttatik.

Ma több faja ismeretes a vad kakasnak; Sonnerat

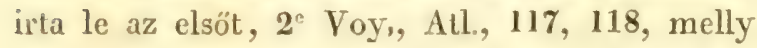

1. Sonnerati-kakas. (Gallus Sonneratii. Tem.) col, 232 és 233.

Igen jeles a hím nyakinak tollairul, mellynek csïkei alap felé három egrmásutáni, s szarvanyagu köggé terjeduck ki. A him taraja logazolt. Az indestani Gathegyekben találtatuk.

Lechenaud más kettót hoza Javarul; az egyik

3. A törzsük kakas. (Gallus bankiva. 'Temm.)

Taraja fogazott mint azclöbbić, s nyakín szép aranyveres lelriggó tollalsat hord. Ez, wgy liitszik, legininább hasonlít a mi rendes kakasunkhoz. - A másik

1. 1 tarka kakas. Ploces. varius. Shaw. Nat. misc. 353:

Ajamalas; Gall. furcatus. Temm. Col. 374.)

Fekete: nyaka réz-züld, feketével tarkís, taraja nem fogas, torka alatt pici lebeny, oldal-cafatok néllkïl.

\section{A tulajdonképi FÁcánok.}

(Les Faisans propr. dits. Eigentl. Fasane.)

Farkok hosszú, vágott, tollok mind két sikra redïlt s fơdelek gyanánt takarjál egymást.

Legközönségesb 
1. Az igazi fácain, F. (Phasianus colchicus. L.)

Ugy mondják, Phasisbul hozaték az Argonauták által, s ma egész Europában tartatik, de nagy gondot kiván. A him feje s nyaka sötétzöld, két apró búbbal fejhátulán; többi toliai aranysárgák, zülddel tarkítra; a jérce barnás, sötétebb barnával vegyítve s tarkítva.

Maibb idökben China három más fajlát vagy fajt ada nekünk, mellyek a pávával együtt majoraink ékességét teszik:

2. Az örves fácán. (Le Faisan à collier. Pll. torquatus.)

Az igazitul nem különbözik másban, mint villogó fehér folttal nyaka mindenik oldalán.

3. Az ezüst fácin. F. Le Faisan d' argent. Phas. nycthemerus. L.) Enl. 123.

Fehér, minden tollán igen finom fekete vonatokkal; hasa egészen fekete. Végre:

4. Az arany fácín. (Le Faisan doré. Phas. pictus. Lin.) Enl. 217.

Szép tollazatárul igen jeles; hasa tüzpiros; fejérül szép aranyszinü tollag csüng; nyaka feketével kevert narancsszinü körvvel födözölt; háta cleje zöld, hátulja s farcsilsa sárga, szárnyai veresek egy szép lkék folttal, farlka igen hosszú, barna, szürkével foltos. stb. Ugy látszik, hogy Plinius leirása a Phoenixnek (lib. X. cap. 2.) ezen szép madárrul veteték.

Ezen fácámok jércejének farka rövidebb mint a hímeké, s tollazatuk különbféle módon tarkís szürkével és barnával. ( ${ }^{1}$ ).

Egyilse a legkülönöscbb madárfajaknak:

(') A. b. Faisan versicolor (Phas. Diardi, Temm.) Diard és Duvaucel által találtatva föl. Vieill. gal. ccv. rl. 
5. A szemes fícín. (L'Argus. ou. Luen. Plıas. Argus.) Vieill. galer. Gair.

Nagy facín Ásia déliröl, feje s nyaka majd esupaszok, lába sarkantyullan, a him farlia igen hosszú s fökípen szárnyának másod tollai rendkivïl hosszúk, szélesck és egész hosszuságokban szemidomá foltokkal taJart, mellyek kiterjesztre, egészen különös nézetet adnak a madámak. Sumatra hegyein lakik s némelly más tartományokban Ásia délkeleli részén. (Ez $=$ Argus. $11 \mathrm{~cm}$. 'I'emm., Gallin.)

Ugy látszik van China belsejében egy madár, mellynek farktollai még hosszabbak s egész négy lábnyiak, fehérek, széleik felé reresbe raltozók, számos feketés vagy gesztenyeszín lieresztronatokkal. Azt hiszik, hogy számos chinai papirosokon ábrázoltatik. Ez

A kevély fácin, (Phasianus superbus), 'Temmink. Gall. II, 336,1 .

\section{A BóBITÁR-ok.}

(Les Houppifères. Temm. Spicifer. Federbuschtrüger.)

Arcok csupasz mint az egész nemuél, farkok függöleges és takaroi ireltek mint a kiakasnál, fölmereszthetö tollak a fejekiön s olly tollagot képezni tudók, mint a páraé. Arcok csupasz börénel alsó clöilló széle a leppentyük helyét pótolja ki. Erös sarkantyúsak.

Még csak egy faj ismeretes; a Sunda szigetekbül, kakias nagyságu, fényes arany veres farcsikkal, - farkok liél felsö takaroja sárgás vagy fehéres, oldalai fehér vagy sárga foltosak, ez

A lángszin bóbitár. (Phasianus ignitus. Sh.) Nat. misc. 321. Vieill. gal. Gcvir.

Nösténye barna, fölül barnával finoman tarkitva, alul fehérrel árnyalva. Szinte bóbitás. 


\section{A LEPCÉR. \\ (Les Tragopan, Tragopan.) Cuv.}

Egy azon madarak közül, mellyek feje legfurcsábban van a himnél ékesítve. Majdnem csupasz, mindenik szeme mögölt egy kis vékony szarv; torka alatt egy kitágitható lebbentyü (cafat). Mindenik neınnek lábán rövid sarkiuntyuk.

Csak egy faj ismeretes, India éjszaki részérül eredett, neve:

A szarvas lepcér. (Le Nepaul. Faisan cornu. Buff. Penelope satyra. Gm. Meleagris satyrus. Lath.) Edw. 116. Vieill. Gal. 206

Kakas nagyságu, fénylö veres, apró fehér könyökkel. A fiatal s a jérce különbözö barnák. $\left({ }^{1}\right)$.

A fácánoktul elválasztandók:

\section{A KAROMHIJÁROK. \\ (Les Cryptonix. Temm.) ( $\left.{ }^{2}\right)$.}

Mellyeknél csak a szem köre csupasz, farkok középszerú, sík, lábaik sarkatlanok; de az nálok igen tulajdon bélyeg, hogy hüvelykökön hibázik a köröm.

Csak egy fajok ismeretes, hol a hím veres foszlott tollakbul hord hosszú tarajt (bóbitát), s szemöldökein hosszú szakáltalan szőrszálakat. Ez:

$A$ bóbitcis karomhijár. (Rouloul de Malacca. Sonnerat. $\mathrm{II}^{\mathrm{e}}$ Voy. 100. rl. Cript. coronatus, Temm. Col. 350.

(') Hihetơ ezen madír szerint képzelteték a Tragopan, mellyrül Plinius szól, Lib. xc. 49.

${ }^{(2)}$ Vieillot e Criptonix nevel Liponix-ra változtatá.

Malaccában van egy fekete karomhijár, búb és szem nélkül, Dussumier hozta hozzánk. ' 
351. Columla cristata, Gm. ct Lath. Phasianus cristatus, Sparm. Mus. Carls. III, 64.

A nöstény, mellynél a bóbitának semmi nyoma, a Tetrao viridis, Lath. Syn. II. 67. rl. (1).

\section{A FAJDOK.}

\section{(Les Tétras 'T'etrao. Lin.)}

Szinte meg egy nagy nem, mellynek bélyege egy ('supasz s többnyire veres szalagban all a szemöldökök helyén.

Alnemekre következöleg osztatnak :

\section{ERDÖSZFAJDOK.}

\section{(Les Coqs de Bruyères. Tatrao. Lath.)}

Mellyeknck szárai tollal fedvók és sarkantyútlanok.

Nemellyek, az ezen neret különösebben megtartók, kerek vagy villís farkuak, ujjaik esupaszok.

Két nagy faj van belölük nálunk:

A nagy erdöszfajd. (A fajdlyuk F. Le grand Coq de bruyères. Tetrao urogallus. Lin. Der Auerhahn.) Enl. 73. 74.

Legnagyobb a tyúkuak közölt; nagyobb a pulykáuál, tollazata palaszinü, finom feketés keresztronatokkal; a nö súrga, barıa ragy feketés lieresztvonalokkal. A magas hegyck nagy erdeiben tartozkodik, a fenyérelien vagy új rágásoliban fészkel, s bimbokkal, magvakkisal él. Husa jeles, gögsipipa liél görbúletet csinál mielött a tüdöbe menne.

(') A Columba cristata, B., Gm., Lath., Syn. II, LVIr, igen közel áll; de a kép igen nagy hüvelykörmöt ad ncki. Ez lán hiba, mint Vieillot galeriájában 11 köt., ccx. rl. 
2. A nyir fajd. F. (Le Coq de Bruyère à queue fourchue. Coq. de Bouleau. Tetrao tetrix. Der Birkhałn.) Enl. 172 s 173. Frisch. 109. Naum. 1-sö kiad. 18, 37 s 38 liép.

A hím többé kevesebbé fekete, fehérrel a szárnytakarókion s a fark alán, mellyek két villája kifelé hajlik. A jérce súrga, feketés és fehéres keresztronatokkal. Nagysígok mint a liakasé s tyuké. Szinte hegyi erdökben találtatik.

Ugy lítszils van még Europa éjszakán egy közép faj is :

3. A közép fajd. (T'etrao intermedius) Langsdorf. Péterv. évl. III. köt. xIv. rl.; Sparn., M. Carls., xv. rl.

$\mathrm{Az}$ elöbbinél nagyobb, farka lkisebbé villás, melle fehér foltos. Courland s Ingria mocsáros helyein. stb. ( $\left.{ }^{1}\right)$.

Minden mérsékclt tartományaink erdeiben találtatik:

4. A császair fajd. (csaiszairmadár. F. La Gelinotte. Poule des Condriers. Tetr. bonasia. Lin. ${ }^{2}$ ). Das Haselhuhn.) Enl. 474, 475. Frisch. 112. Naum. 20. 39. k.

A fogolynál csak kissé nagyobb, kellemesen tarkítva barnával, fehérrel, szürkével és veressel, széles fekete szalag a fark végéhez közel; a hím torka fekete; feje kissé búbos. ( $\left.{ }^{3}\right)$.

(') Ugy látszik hogy ez egyszersmind = Tétras à plumage z'ariable, és T'étras à queue plein. Buff.

$\left({ }^{2}\right)$ Bonasia v. Bonasa, a császárfajd neve Albert le Grand-nál s egyéb középkorbeli iróknál.

( $\left.{ }^{3}\right)$ Az attagas, Buff, attagen, Aldrov. Ornithl. II, 75. 1.; Gelinotte huppée, Briss., sok, még Olaszhonban is tett, vizsgálatok után csak fiatal- vagy jérce császármadárnak látszik. Ugyanazon madár $\delta$, melly le van festve Frisch által, cxir. rl. A tetrao canus, Gm. (Sparm, Mus, Carls, 16. 1.) ncm egyćb a császárfajd fehér faj- 
Amerika nchány, a mi erdösz fajdainkhoz közcli fajokat táplál :

5. A kanadai erdöszfajd. (La Gelinotte noire d'Amerique. Tetrao canadensis et canace. Lin.) Enl. 131, 132. Edw. 118, 71.

'Többé kevesebbé fckete barna; farka vége veres.

E számban ollyak is rannak, mellyek himei nyakok mindenik oldalín fölemelik a tollakat, mint kis köpönyeget, ragy számyacsliát; módjok mint a pulykátié. Illyenek:

6. A bodros erdöszfajd. (Le Coq de bruyère it fraise. T'etr. umbellus et togratus. Gm.) Enl. 104. Edw. 248. Wils. xurx. rl.

Pensylvaniában fácán, új Angliában fogoly nevel hord.

Veres szürlie és fekete szinckkel tarka; nyaka alának mindenik oldalán egy nagy fekete folt; egy fekete szalag farka régén, melly lehérel stegett, a líbtók alja csupasz. Ilegyi erdökben tartizkodik; szerelemkor a hím szava vert dob csergéséhez hasonló.

7. A siki erdöszfajd. (La Coq de bruyère à ailerons. Grous, az egyesült tartományokban. Tetr. cupido. Gm. Catesb. Supl. I. Wils. xxrr. rl. Vieill. galer. 219.)

Sárgáral is barnával tarka. Farka barna, lábai az ujjakig tollasak; a hím nyak-alának tollai két hegyes szárnyacskába cmelkednek. Sikon tartózkodils; a hím nyaka majd szárnyai alatl csupasz bört bir, mellyet szerelmesliedéslior, mint ralami hólyagot fơlfú. Szava mint

tájánál. Szinte nem hiszem a Tetrao nemesianus és Tetrao betulinus, Scopoli, valódiságát. Ezek vagy jérce vagy fatal nyirfajdok, v. elrontott császárfajdképek. 
les rad; megtartására némelly tartományokban törvények hozattak.

Nagyobb megkülönböztetéssel

\section{HÓFAJDOK \\ (Lagopèdes, ou Perdrix de neige.)}

neve alalt azon fajok értetnek, mellyeknck farka kerek vagy négyszegü, ujjaik tollakkal fedvék mint lábaik. A legelterjedtebbek télen fehérek lesznek.

1. A rendes hófajd. (Le Lagopède ordinaire Perdrix des Pyrénées. Tetr. lagopus. Lin. $\left({ }^{1}\right)$. Enl. 120. 494. Brit. Zool. Pl. M. 4. M. 4. Naum. I-só kiadás. pótl. 61. - 115. - 116. k.

Nyáron sárga tollazatu, apró fekete vonatokkal jegyzett. $\left({ }^{2}\right)$. Minden magas hegveken, hol télen a hóba ásott lyukakban tartózkodik.

2. A fehérhasu hófajd. (Le Lagopède des saules, dit de la baie de Hudson. Tetr. albus. Gm. T. saliceti, Tem.) Edw. 72. Frisch. 110, 111.

Egész éjszakon; nagyobb, nyári ruházata veresebb; hasa fehér marad. $\left({ }^{3}\right)$.

Azonban van Skóthonban egy hófajd, melly télen nem változtatja el szinét, ez

3. A mocsciri hófajd. (Le Poule de marais. Grous. etc. T'etr. scuticus. Lath.) Albin. I, 23, 23. Brit. Zool. Pl. M. 3, Vieill. galer. 221.

Fölül sárga, barna s fekete szincklkel tarka, alul sölét reres, fekeléssel vonatolt; szárai hamvasok, ujjai jobban takartak.

Elválaszhatók még:

(1) LAgopus, nyullább, takart láb, régi neve czen madárnak.

$\left(^{2}\right)$ Ezen tollazatban $=$ Tetr, rupestris. Lath:

(3) Nyári ölözetben = Tetrao lapponicus, Lath.

CUVIER I. K. 


\section{CSUPFAJDOK. (GANGÁK, Khaták.)}

(Ganga ou Attagen. $\left({ }^{1}\right)$. Pterocles. 'Tem.)

Nere alatt a hegres farliu, csupasz ujju fajok. Cisals szemliöruk meztelen, de nem reres színü, hürelyliök igen kicsin:

$A$ rendes cosupfajd. (Le Ganga uu Gelinotle des Pyrénés. Tetr. alchata. L.) Enl 105, 106. Edw. 249. $\left({ }^{2}\right)$.

Foguly nagysign, follzata súrgat-s baruival pilikelyes: furlat hit linzeposn lollai igen himpultats heggesen, a him Inrka lécle. Talailatik Franciahon deli részén s a Középlenger liörén mindenüll. $\left(^{3}\right)$.

\section{A FOGLYOK. F. \\ (Les Perdrix. Perdix. Briss.)}

Lúbaik csupaszok mint ujjaik.

Köztök

A NOGOLYSZIK.

(Les Francolins. Tem. Francolinus.

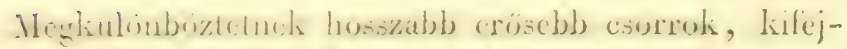

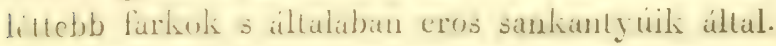

(1) Attagen, görög neve egy nelıéz madárnak, kissé nagyobl a a fogolynál, lebenke tollazatu, s hihetöleg a gangát jeleli.

$\left({ }^{2}\right)$ A ganga cataluni, alchata, vagy inkább chata, arab neve.

${ }^{3}$ ) A. h. a kinyujtott farktollú fajokat: Tetrao senegallus, v。 Pterocles guttatus, 'Temm. enl. 150, s a jérce 515; - Pter. exustus, Tem. col. 351 és 360 : - az egyszerüen hegyes farkuak közül: T'etr. arenarius, Pall. Nov, com. petrop. xix, vitr. il. v. Pterocl. arenarius, col. 52, 53, = Perdix arragonica, Lath.; - Pter. Lichtenstennii, T. col. 55.5 és 561. A him, 3.55, leqalább igen közel áll a Tetrao indicus-lıoz, Lath.; Sonneral., Ill: 96 ; - Pterocles coronatus, T., col. 539 és 540 ; - P'terocl. quadricinctus, 
Déli Europában egy van:

$A$ déli fogolyszi (Tetrao francolinus. L.) ('). Enl. 147 148. Edw. 246.

Lábai veresek; a hím nyaka és hasa fekete kerek és fehér foltokkal; vidám veres nyakkörvvel. $\left({ }^{2}\right)$.

Némelly idegen fogolyszik-nak kettôs sarkantyujok van $\left({ }^{3}\right)$, vagy torkok böre csupasz $\left(^{(}\right)$; Egynćhánynál mindenike e bélyegeknek látható $\left.{ }^{5}\right)$; némelly igen nagy csorru fajoknál egészen hibáznak a sarkantyuk. $\left.{ }^{6}\right)$.

\section{A rendes FOGLYOK.}

(Les Perdrix ordinaires. Perdix. Feldhühner.)

Csorrok kissé gyöngébb; hímeiknél rövid sarkantyuk vagy egyszerú gumók, a nóknél az hibázik.

Mindenki elótt ismeretes :

1. A szürke fogoly. Fogoly. F. Perdrix grise. T'etrco

Temm., v. Oenas bicinctus, Vieill gal. 240 ; - végre a legnagyobb faj, Tetrao phasianellus, Gm., vagy Hudson öbli, hosszú farku császármadár ; Edwv, 117.

(') Francolino, (tilos) azon madarakra alkalmaztatott név, melylycket megölni tiltva van; jele tartozók a jó csemegehúsuak, p. u. a császárfajd, és ezen madár.

(2) A. h. Tetrao ponticerianus, Sonnerat. II. Voy. II, 165, 'Tomm., col. 213; - Pcrlatus, Briss.' xxvil. rl A.f. 1, Vieill., galer. 213 ; = Madagascariensis, Sonn., 11; 169; Xcvir. rl.

( $\left.{ }^{3}\right)$ Tetr. bicalcaratus, L' enl. 137; - Perdr. Clappertonii, Rupp., Ix. rl. alig különbözik to̊le; - Spadiceus, Sonn., 11, 169 ; - Zeilonensis, Ind. zool., pl. XIv. - A veres fogolyszi (Le Francolin ensanglanté de Napaul, Perlix cruenta, T.) col. 532, három sôt négy sarkantyuval s ? többieknél hibázó élénk szinekkel.

(') Tetr. rubricollis, enl. 180.

$\left.{ }^{5}\right)$ Tetr. nudicollis.

( $\left.{ }^{6}\right)$ Tetrao javanicus, Brown, Ill., XVII. (rosz ábrázolat.) Van jobb col. 148, neve Perdix ajanham, Temm. 
cinereus. Lin. Das l'eldhuhn, Rebhuhn.) Enl. $2 \%$ Frisch. 114. Naum. 1-sö kiadás. 3. rl. 3. k.

Csorra s lábai hamvasok, feje sárga, tollazata különbözó szürkével tarkitott: a him mellén egy gesztenyeszinü folt. Ezen szapora vad aszlalaink gyönyörüsége, a mezóségèen fészlsel és lakik.

2. A veres fogoly. F. (La Perdrix. rouge. Tetrao. rufus. L.) enl. 150.

Csorra s lábai veresek, fölül barna, oldalai veressel es hamuszimuel kevervék, torka fehér feketével keritve; nkíbb halmokion és emelt helycken seregel. Husa feliérebb és szírazabb.

Déli tarlományainkban lakik még:

3. A sziklís fogoly. (La Barlavelle ou Perdrix grecque. Perdix groeca. Briss. Perd. saxatilis. Meyer.) Enl. 231. Frisch. 116.

Melly a veres fogolylul csak nagyobb termete s hamvas tollazata által lisilonbrizili. A nagy hegylíncols hoszszíban tarlózkodik. ( ${ }^{1}$.

\section{$\Lambda$ FÜRJEK. \\ (Les Cailles. Coturnix. Wachtel.)}

hiscbbrek a fogolynál, csorrok vékonyabb, fiackols rividebb, reres szemöldök ís sarkantyu nélkül.

Mindenki ismeri

(1) A. h. a berberi veres fogoly. (Tetrao petrosus, Gm.) Edw., 70, - igen különböz8 faj; - A hegyi fogoly', (Tetr. montanus, enl. 156, Frisch, 114, B. Bonnelli szerint nem ezyéb a szürke fogoly fajtájánál; - Perd. de Haye, T., col. 328 és 329; - Perd. personata, Horsf. jav.; - Perdr. à gorge rousse ( $\boldsymbol{P}$. gularis, Temm.) - Perd. oculea, ua.; - Perdr. fusca Vieill. gal. 212. 
A küzönséges fürj-ct. (La Caille commune. Tetrao coturnix. L.) Enl. 170. Frișch. 117. Naum. 4. 4. k.

Háta barna, feketével hullámozva . minden tollán hegyes fehér csökronat; torka barna, szemöldölie fehéres; mezöinken él, vándorlásairul hires; ezen vehéz madár módot talál a Közép-tengeren általszállani. $\left(^{1}\right)$.

\section{A FürejeK. Amerikai fürjek és foglyok.}

\section{(Les Colins.)}

Csorrok nagyobb, rövidebb boltosabb; farkok kissé kifejlcttebb $\left({ }^{2}\right)$. Cserjéken ülnck, s üzetve, fákra menekednek. Solsan, mint a fürj, vándorlanak.

Nem lehet a fajdok fóncmétül el nem választani

(1) A. L. Tetr. chinensis, L. (la petit Caille de la Chine)', enl. 126, f. 2. mellynek nơje a Tetr. manilensis, Gm., Sonn. 1-er Voy. xxıv. rl.; Perd. australis. T. La Caille australe) Vieill. gal. 215.; - Perd. textilis, (la cille nattée), col.35; - Tetr. Coromandelicus, Sonn. II., 172; - T'. striatus, Sonner. II. Xcxvin. (?) és Temm. col. 82, igen különböző a Lath. syn., II, LxVI : - Perdrix gingi (Tetr. gingicus), Sonn. II, 167. 1. szinte ez alnemhez látszik tartozni.

( $\left.{ }^{2}\right)$ A fogoly-nagyságuak közül megemlíthetỏk : a Tocro ou Perdr. de la Guiane, Buff. (Tetr. Guyanensis, Gm.) v. Perd. dentata, Temm. v. Odontophorus rufus, Vieill. gal. ccxr. rl. melly nem farklan, mint Gmelin állítá.

A fürjnagyságuak közül: Tetr. mexicanus, enl. 149, Frisch. 11, = Marylandus, Albin. 1, xxvi1, és Virginianus, v. Perd. borealis, Vieill. gal. 214; - Tetr. falclandicus, enl. 222 ; - Tetr. cristatus, enl. 126, f. 1; - Colin, Sonnini, (Perd. Sonnini, T.) col. 75, Journ. de Phys. II, 217, 2 rl.; - Colin à aigrette de Californie, Tetr. californius, Sh. Nar. misc. IX, 345, Atl. du Voy. de la Peyrouse, XXXVI. rl.; - Perdr. rousse-gorge (Perd. cambayensis, Tem). col. 447;-Perd. australis, Vicill. gal. 215. 
A HÁRMUJЈAK-at. (hcirmujjtyukokal.)

(Les Trydactyles. Lacép. Hempodius. Tem.)

Hürelylï̈ hibazik, csorrok összenyomoll, s alsí lcmeze alatt eş lis kidagadást képez. Nem oszlílyozhatni ölict jól elöbb, mint bonctanuk ismeretes lesz. 'Tübbnösségben élnek homoksos vidékeken.

Némellyek:

\section{A FÉLLÁBTYUKOK.}

(Les Turnix. Bonnat. Ortygis. Iliger.)

Még fürj-idomuak; ujjaili jol elválasztvák egész alapjokig, apró hártyák nélkül.

Van egy faja, mellyel Java szigetén viaskodtatnak mulatságbul, mint Angliában a kakasokkal, ez

A viaskodó féllcibryuk. (Hemip. pugnax. T.) col. 602. (1).

Mísols.

\section{A TÁVOZTYUKAK.}

\section{(Les Syrrhaptes. Ilig. Syrrhaptes.)}

Ammira cltároznak a tyukuak általámos mintájátul, hogy kitchednünk kell, bejöjenck-e ezen remdbe.

Rövid lábaik tollakkal fädvék, szinte mint ujjaik, mellyek iggen liurtik s hoszasigok egy részén egyesuilvék, számyaik rendkivïl hosszuak és hegyesek.

$\left({ }^{2}\right)$ A. h. Tetr. nigricollis, enl. 171 ; - Tetr. undalusicus, Lath. Syn. II, r. 2. homlokkép; - Tetr. luzoniensis, Sonn., 1. Voy., xxu1. xlt; - Hemipodius nigrifrons, Temm. III, 610; Vieil. gal. 218; Hemip.thoracicus, Tenm. III, 622, vagy Turnix maculatus, Vieill, gal. 217: rl.; Hemip. Meiffrenii, T. Col. 60 ; 1. mellybül Vi. cillot, sal. 500, a Torticelle nemet csinálja, mellyet a' gázlóhboz tesz, mivel a sipcsont alja tollatlan. A Hemip. nivosus, Sirains. zool. ill., 163, szinte ide tartozó; - a' Tetr. suscitator, (Réveil-maıin de Jaz'a) szinte féllábtyuk. L. Bontius, Méd. ind. p. 65. 
Csak egy fajok ismeretes Asia küzcpének pusztáirul, ez

A kétes távoztyu. (Tetrao paradoxus. Pall. Utazás. a fr. kiadás III köt. 1. rl. 18. 1.) Vieill. gal. 222. rl. $t$ ' heteroclile. Tem. col., 95. rl.

A fajdoktul szinte elválasztandók

\section{A FARKLANOK. FARKTALANTYUKOK.}

(Les Tinamous. Tinamus. Lath. Crypturus. Ilig. Ynambus. Azzara. $\left({ }^{1}\right)$.

Igen jeles amerikai nem; nyaka vékony, elég hosszú (noha lábai rövidek), tollal fedett, mellyek szakállainak hegye foszlott s kissé bodros, mi olsbul tollazatuk ezen részének különös tekintete van. Csorrok hosszu vékony, tompa hegyü, kissé boltos mindenik oldalon apró barázdával, orrlyukai mindenik oldal közepén nyilnak s ferdén hátra felé mennek. Szárnyaik rövidek, farkok alig van. Ujjaik alapjának talpazata igen rörid Szeme körül van egy kevés csupasz.

Ezen madarak az alanti ígakon ülnek, vagy a magas fübe bújuak el; bogarakkal és gyümölescsel élnek; husok igen jó. Nagyságok a fajok szerint a fácánétul a fürjéig megy és alább is :

Némellyek (pezus. Spix. csiklár, csikzártyuk,) még birnak egy kis farkat, a far-csik tollai alá rejtettet. $\left({ }^{2}\right)$.

(') Vedd ki onnau a Choro-t, melly vizityuk, 's az Uru-t, melly = a foglyoknál emlitett T'ocro-val.

$\left({ }^{2}\right)$ Tetrao major, Gm., Tin. brasiliensis, Lath., v. Tin. magoua, Tem.; Buff. enl. 476, és sokkal jobban, Hist. des ois, IV. 4.rét. xxıv. rl. melly $=$ Spezus serratus, Spix; - Tetr. cinereus; - Tetr. variegatus, enl. 528, mellytül kissć különböznek a Tin. undalatus, T., v. Cryptura sylaicola, T., Vieill. gal. 216; - Tin. apequia ( $T$. obsoletus, T.) col. 196; - Tin. tutaupa, Swains. 111. 19, v. Tin. plumbeus, T. col. 196, v. Pezus niamba, Spix, 78, 
Másoknak (Tromús, Spix. FAßKLAN-ok, FARKLANTYUk-ok) épen semmi farkok nines. $\left.{ }^{1}\right)$. Orrlyukaik kissé hátrább állanak.

Megkü̈̈nböztetendöls méğ a FAnkcSÁROK, FARKCSÁkTYukok, (Rhynnocoszes. Spix.) mellyeknek csorra cröscbb, csalornátlan, kissé hajlolt és lenyomoll, orrlyukai az alap felé nyilók. $\left({ }^{2}\right)$.

\section{¿ GALAMBOK.}

\section{(Lies Pigeons. Columba. Lin. Taube.)}

ligy képzelhetök mint hidul szolgálik a tyukféle madaraktul a recébelihez. Mint az clsöknél, csorrok dombos, orrlyukaik egy szóles hirtyatéren nyilnak meg, s porcléle pikkelylyel fedrék, melly a csorr alapján dagadást is lićpez; mellesontuli csontosult, mólyen s keltesével kivágott, noha rgy kissé külïnbüzö hajlambau, besyök, föképen kilígult, al gégejök esak egy tulajdon izmot biró, de ujjaik alipja közïlt nines más hárlya, mint melly a szólek folytatisábul ercel. Farkok tizcukét tollu. Jól repülnck. Mindig egy nössígben éhnek, läkon vagy sziklarepedéliekben fészkrlnek; kevés tojást tojnak, rendesen kettöt; ámbár iga\%, hogy gyakran költenek. A hím ugy ül mint a jérce. Fijaikat ugy típláljáls, hogy a begyükben megáztatolt magrakat adják ált nekik. Csak egy nemet csináltak belölüli, mellyet három alnemre föl-

a; - Tin. noctivagus, Pr. Max. v. Pezus zabele, Sp. 77;-Tin. macaco, ou verniculé, (T. adlspersus T.), col. 369 , v. Pezus yapura, Spix, 78; - Tetr. sovi, Gm. v. Tinam sovi, Lath. Buff., enl. 829:

(') Tin. inambui, Azz. (Tin. maculosus, I.) v. Tyn. major, Spix, 80; - Tin. medius, Sp., 81; - (Tin. boraquira, Sp. 79; - Tin. carape, (T. paroninus, T.) mellynek no̊sténye a Tin. minor, Sp., 81. Ezen három faj igen hasonló.

$\left(^{2}\right)$ Tin. isabelle (Tin. rufescens, T.) col. 412 ; vagy Rhinocotus fasciarns, Spix. 76. 
oszlani kisértenck, a mint csorrok többé kevesebbé crös, s a millyen a lábail viszonya.

\section{A TUBATYUKOK.}

(Les Columbi-Gallines. Vaill. Columbi-gallina.)

Inkább közelítnek a tyúkuakhoz mint a többi alnemek, emeltebb lábaik s csoportosan élni szeretèsök miatt, cledelöket a földön keresve, fára nem ülve. Csorrok vékony, hajlékony.

Egyik faj a tyúkuakhoz szít, fejének csupasz részei s torongyai miatt. Ez

1. A torongyos tubatyuk. (Columba carunculata, Tem.

II. rl. Collumbi-calline, Vaill. 278.

Egy másils oda szít legalább nagysága által, melly majd a pulykáét fölüti, ez

2. A koroncis tubatyuk. (Le pigeon couronné, az indiai szigetsolson, Goura. 'Tem. Columbihocco; Vaill. Columba coronata, Gm.) Sonnerat, 104; enl. 118, 'Temm. pigeons. 1. rl. Vieill. gal. 197.

Egészen palaszürke, szárnyán geszlenyeszinnel és fehérrel, feje ékesítve van függöleges bubbal hosszú foszlott tollakbul. Majorságban tartatik, Javáu. stb. De Europában még nem akart szaporodni. $\left({ }^{1}\right)$.

Egy harmadik ide tartozik még hosszú s csüngö tollai miatt, mellyek nyakát mint a kakasét ékesítik. Ez

3. A nikobari tubatyuk. (Le pigeo de Ninconbar. Col. nincobarica. Lin.) Enl. 491.

Legesillogóbb aranyzöld. India több részében találtatik: $\left({ }^{2}\right)$.

(') Vieillot ezen koronás nagy galambbul csinálta a Goura vagy Lopuirus nemet Gal. 197. rl.

$\left({ }^{2}\right)$ Ezen alnembe rendelt fajok, melly talán nem eléggé mea- 


\section{A rendes gaLAmBoK.}

(Les Columbes ou Pigeons ordinaires. Gewöhnl. Tauben.)

Lábok röridebb mint az clóbbické de csorrok vékony és hajlékony mint azoké.

Nálunk négy vad faj van.

1. Az ïrves galamb, Széliács. F. (Le Ramier. Col. palumbus. Lin. Die Ringeltaube.) Enl. 316.

Legnagyobb. Erdökben lakils, leginkább az örökén zöldekben; hamras, tübbé keresebbé kéklös; hasa borverhenyes, s megkiüünböztetik fehér foltai által nyaka oldalán s szárnyán.

2. A vad galamb. F. (Te Colombin ou petit Ramier. Col. oenas. Lin. DieHolzlaube.) Friscli. 139.

Pala-szürke, mele borveres, nyakoldalai játszó zöld; ez clöbbincl valanivel lisebb, de hasonló életnemúi.

3. A sziklis galamb, türzsük g. (Le Biset on Pigeon de rocke. Col. livia. Briss.) Enl. $510 .=H a \approx i \cdot g a-$ lamb. F.

Palaszourke, nyakliörve változi zöld, szírnyán kettös fekete szalag, farcsika fehér.

Ezen lajtol származnak házi galambjaink, s a mint látszils, a házi lajtíls legnagyobb része, mellyeknek elöhozísíra némi szomiszed lajok összekeveredése is befolyhatott.

El nom mellörhetönck rélte itt a maggar fordíti a

határozott: Col. cyanocephala, enl. 171, Vaill. 281; Temm, 3; C. montana, Edw. 119; Tem. 4, Col. martinica, enl. 141, 162, Vaill. 282 ; T. 5,6 ; - C. erythrothorax, Temm. 7, - cruenta, Sonn. 20, 21; T. 8, 9; - jamaicensis, T. 10; Col.talpacoti, T. 12 ; - Col. passerina, enl. 243, 2, Catesb. 26; - Col. minuta, enl. 245, 1; - Col. hottentota, Tenm., Vaill. 285; - Col. cobocola, és Col. griseola. Spix, Lxxv, 2. 
házi galambok fajtåinak fölhozását Temmingk leirása szerint.

a. A házi galamb. F. Columba Livia domestica. Die gemeine Haustaube. Enl. 466.

Tarka; fehér farcsikkal.

b. A spanyol galamb. F. (C. L. Tispanica. Die spanische (türkische) Taube Enl. 110.)

Még egyszer akkora mint a házi g•; 17 ujnyit szárnyölel; különben mindenféle szinü, bubos is, gatyás is van, stb.

c. A gatyás galamb. F. (C. L. Dasypus. Trommeltaube, Latschtaube.) Frisch. 'Г. 145.

Egész az ujjakig tollas lábakkal.

d. A tarajos galamb. (C. L. cristata.) Frisch. T. 144.

Szinte gatyús, egyszersmind még búbos is.

e. A norvegiai galamb. (C. L. norwegica.)

Hófehér; különben búbos, s ujjain tollas. Norregiában.

f. Berberi galamb. (C. L. barbarica.)

Szemei korül csupasz beporzott husszömőcsökkel s szárnyain kettös fekete folttal. Bubos és bubatlan. Berberiábul.

g. A csuklás galamb. F. (C. L. cucullata. Die Schleiertaube. Frisch.

Fejtetején a tollak fülmeredvék, elöre állók, igen rövid csorral. Legszebbek a fekcték, fehér fövel és szárnyakksal:

h. A borzas galamb. F. (C. L. hispida.) diában.

Apró, fölálló tollakkal a hátán és szárnyain. In- 
i. A fodrosbegyii galamb. F. (C. L. turbida.) Frisch. 147.

Kurta csorru, lapos fejletörel, a melltollakbul egy csomag oldalvást fölfelé irányzott. Gerlice-nagyságn.

k. A szélesfarku g. F. páva g. (C. L. laticauda. P'auentaube.) Frisch. 151.

hiterjeszteu, sokitollu farkkal, mellyet kéuyére foilmereszlbet. S ekkor ugy áll az mint a pulykánál. Sokszor 34 farktolla is van.

1. A keringö galamb. F. (C'. L. gyratrix. Die Purzeltanbe.) Frisch. 148.

Egrike a legkisebbeknck: repülve mindig bukforgúsokat csinál. Mindenek lsözt legmagasbra emelkedik; szárnyai is leghosszabbak.

m. A sisakos galamb. (C. L. galeata. Die Helmuaube.)

Csak abban kïlönbözik, hogy feje, szírnyai s farka a többitöl külïnbözö de eggmáshoz hasonló szinück.

11. A törïk galamb. F. (C'. I. turcica. Die türkische Taube.) Frisch. 159.

Veres, biboresos viaszhárlyáral, melly néha olly nagy lehel, hogy a csorrot és a szemcket is eltakarhatja. Csorra sárga. Persiában honol.

o. A pósta galamb. T. (C. I. tabellaria. Die Brieftaube.)

Az elöbbitül csak fehéres riaszhártya s csupasz szemhéjak által lrülönbözik.

p. A begyes galamb. (C. I. guthurosa. Die Kropftaube.) Frisch. 146.

Néha begyét akkorára fölliija, mint az egész teste.

*. A lovag galamb. (C. L. eques. Die Reiterlaube.)

A kiét clöbbitül kores; fölfútt begygyel s bibircsos viaszháryáral. I. Sommini, Buff. vir. 63. rl. Albin. 151. 
\%. A csallogó galamb. (C.L. percussor. Die Schlaglaube.)

Körben repül, s a közben szárnyait nagy csattogva veri össze, ugy hogy néha azok eltörvén, nem repülhet tovább.

r. A sürény'es galamb. (C. L. jubata. Die Mähnentaube.) Sörény idomulag fölmeredt nyaktollakkal.

\section{$\Lambda$ Gerte. (Gentice. F.)}

\section{(La Tourterelle. Col. turtur. Lin. Die Turteltaube.)}

Köpönyege sárga, barna foltos, nyaka kékes, mindenik oldalán fehérrel és feketével kevert foltot mulató. Ez a legkisebb rad fajunk. Erdókben lakik inint a vad galamb.

Mulatság kedveért zárokban neveltetik:

A kacagó galamb. F, (Le Tourtelle ì collier ou Rieuse.

Col. risoria. Lin.) enl. 244. Frisch. 44. 'Temm. 44. Die Lachtaube.

Afrikábul látszik eredni; szóke, alul halaványabb; tarkóján fekete nyakkörv. ( $\left.{ }^{1}\right)$.

( $\left.{ }^{1}\right)$ Más négyszeg v. kerek farku galambok: Col. spadicea, Temm. 1 ; - Col. oenea, enl. 164, Temm., 3 és 4;.Voy. de Fraycinet, 29, mellynck a Col. pacifica, hímje Temm. szerint; - A Col. océanique, Les et Garn. Voy. de Duperry. 41, hozzá közclit; Col. arcuatrix, Vaill. Afi.; Temm. 5, - C. armillaris, T. 6;Col. littoralis, Sonner. 103; Temm. 17; - C. chalcoptera, Temm. 8; - C. cristata, Temm. 9; C. caribaea, Tem. 10;-C. leucocephala, Catesb. 65 ; Tem. 13; - Col. speciosa, enl. 213, Temm. 14; - C.corensis, Tem. 15; - C. guinea, Edw. 75; Vaill. Afr. 265 ; Temm. 16; - C. madagascariensis, enl. 11, Vaill. Afr. 266 ; Temm. 17; - C. Eymnophtalmos, Temm. 18; - C. Franciae, Sonner. 101; Tem. 19; - C. rubricapilla, Sonn. 57; Temm. 20; - C. elegans, Temm. $22 ;-C$. cincta, Temm. 23; - C. rufina, Tem. 24; - C. leucoptera, Edw. 76, Temm. 25; - C. javanica, enl. 177, Temm. 26; Sonner. 66; - C. jamboo, Temm. 27 és 25 ; 
Ezen osztás fajai számosak, s még torább föloszthatók, a mint lábaik igen vagy nem födvék tollakkal, s azon csupaszág szerint, melly némellyek szemkörén találtatik. $\left.{ }^{1}\right)$.

Taunak ollyak is, mellycknél torongyok és más csupasz részek találtatnak a fejen. Illyen :

A füles galamb. (C'ol. auricou. Col. auricularis. Tem., 21).

Ha akarjuk, clrálaszthatni még a többiektól nehány hegyes farku fajokat. $\left({ }^{2}\right)$.

De a legjobb osztás a galambok nemében, a

- C. violacea, Temm 29; - C. melanocephala, enl. 214, Temm. 30; - C. larvata, Vaill. Afr. 269; Temm 51; - C. holosericea, T. 32 ; - C. sinica, Albin III, 46 ; - C. viridis, enl. 142;C. erythroptera, 'T. 55 ; - C. mystacea, T. 56 ; - C. superba, T. 35; - C.tympanistria, Vaill. 272, T. 36; - C. coerulea, T. 37 ; - C. afra, enl. 160; Vaill. 271; T. 38 és 39; - C. Geofroii, Temm. 57 ; - C. cinerea, 'T. 58 és a jérce, col. $260 ;-C$. bitorquata, T. 40 ; C. vinacea, 'T. 41 ; - C. tigrina, Sonn. 102 ; C. cambayensis, Vaill. 270 ; T. 45 ; C. malabarica, col. brame; T. 46; - C. squamosa, T. 59; - C. malaccensis, Mus. carls. 67; Edw. 16; T. 47; - C. macroura, enl. 329; - C. porphyrea, Temm. col. 106; - C. dilopha, T. col. 162; - C. magnifica, T. col. 165 ; C. lacernulata, Tem. col. 164 ; - Col. capistrata, T. col. 165; - C. locutrix, Pr. Max, col. 166;-C. leucomela, T., col. 186 ; - C. scripta, T. col. 187; - C. Dussumieri, T. col. 188; - C. leucotis, T. col. 189; - C. xanthura, Cuv. col. 190 ; - C. picturata, Temm. col. 242 ; - C. perspicillata, col. $246 ;-C$. luctuosa, Reinw. col. 247 ; - C. hyogastra, Reinw. col. 252; C. monacha, R., col. 253 ; - C. humilis; T. col. 258 ; - C. pinon, Quoy et Gaym. Voy. de Freyc. 28; - C. pampusan, uo. 30; - C. araucana, Less. és Gayn. Voy. de Duperrey, $40 ;-$ C. cyanovirens, uo. 42 ; - C. Zoae, uo. 29.

(') Swains. Ptilinopus nevet adott a tullas lábtőú fajoknak, millyen a $C$. purpurata, T. col. 34, stb.

$\left({ }^{3}\right)$ Col. migratoria, enl. 176; Frisch. 142; Temm. 48'és 49; - C. carolinensis, uo. 175; T. 50 ; Catesb. 24 ; Edw. 15; - Col. Reinuartii, Temm. col. 248; - C. humeralis, иo. 191; - C: am- 
A GÁZIIÓK.

\section{TUBÁK- é.}

(1)es Colombars. Vieill. Vinago. Cuv.) (1).

Megismerhetók szilárd anyagú, nagyobb esorrokrul melly oldalvást összenyomott, lábtöik rövidek lábaik szélesek és jól szegettek. Mind gyümölesesel élnck és nagy erdökön. Csak nehány fajok ismereles, mind a régi száraz forró éghajlata alul. $\left({ }^{2}\right)$.

Vannak hegyes farkuak is közöttök. $\left({ }^{3}\right)$.

\section{A MADARAK ÖTÖDIK RENDE.}

\section{A. GÁZLÓK. (GóRLẢBÙ்̃.) F. v a g y}

\section{PARTI MADARAK.}

(LES ĖCHASSIERS. GRALLAE. Lin. STELZVÖGEL.)

Nevök szokásaiktul s az azt okozó alkotástul van. Megismerhetők alszáraik csupaszságárul s leg-

boinensis, uо. 100 ; - C. lophotes, no. 140 ; C. venusta, uo. 341, 1. v. C. strepitan's, Spix, Lxxv, 1 ; - C. dominicensis, uo. 487 ; T. 51 ; $-C$. capensis; uo. 140 stb. Vaill. 273, 274; Temm. 53, 54;-C. Maugei, T. 52 ; - C.macquaria, Quoy et Gaym., Voy. de Freycinet. 31.

(') Vinago latin neve a sziklás galambnak. Vicillot Treron-ra változtatá.

$\left({ }^{2}\right)$ Col. abyssinica, v. Wallia de Bruce, Vaill. 276, 277; Temm. 8 és 9 ; - Col. australis, enl. 3. Temm. 3 ; - Col aromatica, enl. 163; T. 57 ; Brown., IIl. Zool. 20 ; - Col.vernans, enl. 158; T. 10 és 11 ; - Col. militaris, T. 1 és 2 - Col. psistacea, Temm., 4; - Col. calva, Temm., 7; - C. olax, T. col. 241 ; - C. Capellei, uo. 45.

$\left({ }^{3}\right)$ Col: oxyura, T. col. 240. 
többnyire lábaik magasságárul, két olly körülmény, melly megendi, hogy bizonyos mélységig a vizbe bémehessenek, tollokat meg nem nedvesítve, ott kedvök szerint járjanak és halászszanak nyakok és csorrok segedelmével, mellyek hosszasága általában arányt tart a lábokéval. Mellyek csorra erös, halakkal vagy mászókkal élnek; mellyeké gyönge, férgekkel és bogarakkal. Igen kevesen érik be részint szemekkel ragy füvel s csak ezek élnek vizektül távol. Legtöbbnyire a külsö ujj, alapja által, egyesítve van a közepső́vel, egy rövid hártyával; néha két illy hártya van jelen, máskor az egészen hibázik s az ujjak egészen elválaszlvák; az is meglörténik, de nagy ritkán, hogy egrész hosszában szegettek vagy egész az ujjak hegyiig hártyásak; végre a hüvelyk több nemnél hibazik, mind olly körülmények, mellyek többé kevesebbé vizi életökre befolynak. Majd mind ezen madarak, kivéve a strucot és kazoárt, hosszú szárnyuak és jól repülnek. Száraikat hátra nyujtják, mikor repülnek, mások ellenére, mellyek azokat hasok alá huzzák.

Mi ezen rendben öt fö családot álitunk föl s néhány elvált nemet.

Azonban:

\section{A RövIDSZÁRNYUAK}

családa, noha általában hasonlít a többi gázlókhoz, egy ponthan igen különbözik tölök, t. i. szárnyai rövidségében, melly öket a repüléstül tilija: 
csorra s életmódja különben számos hasonlatosságot ad neki a tyukuakkal.

Ugy látszik, hogy az izomerö, mellyet a természet kioszthata, nem volt volna elegendó olly kiterjedt szárnyali mozgatúsára, millyeneket ezen madarak tömege a légbeni tartózkodásra megkivánt volna; mellcsontuk egyszerü vérthépü, s azon taraj hijával van, melly minden más madaraknál láttatik; mellizmaik nagyon vékonyak; de hítulsú végtagjaik megkapták azon eröt, mellyet a szárnyok elvesztettek. Combjaik s fơképen száraik izmai iszonyú vastagok.

Egynek sincs köztök hürelyke. ('). Két nemet csinálnak belölük.

\section{A STRUCOK. F. (SZALADÁRoK.) \\ (Les Autruches. Struthio. Strauss.)}

Lomha hajlckony tollakat biró szíruyok elegendó hosszú még fulásole elösegitésére. Kiki ïsmeri azon vékony csökii lollakibul kíszüli csomagok ékességél, melly tollaknak szakílai, ámbár szakíllesákkal cllátvits de nem tapadnak össze, mint a madarak ngyobb részénél. A strucok csorra vizszintileg Icuyomolt, hözopszerün hosszú, tompa régü; nyelvök rörid és gömbölyitell mint a lëlhold; szemüls nagy, szembejaik szcmszörösels, szátriik s lábtöik igen cmeltek. Iszonyu begyök van, s meglelelös gyomrok a begy is zuzal közöll, terjedelmes beleih,

(') Perceik száma illyea, mint hövetkezik, a belsỏ ujjon kezdve. A struznil 4,5 .

A kis szaladár nál és kazuámál, 5, 4, 5.

Melly a madarak rendes szímálıoz visszatér.

CUVIER l. K. 
hosszi vakbelesh s igy ök egyeduil a hugyozó madarak. Vesszejök igen nagy s néha kilátszó (1).

Csalk liét faj ismeretes, akár két nemre változtalható.

1. It vilugi struc. Vagy säuladar. (Küzönségess strue.

F. I' Autruche d l' ancien continent. Struthio Camelus. Lin. Der Strauss. Enl. 457. $\left({ }^{2}\right)$.

Csak ké ujju, a kiilsö léllel kisebb a másiknál s kürnucllen. Ezen az ó régiségben híres madár nagyon számos Arabia s egés\% Afirka homoli pusztáin, hat is uyole lábny i magas lesz. Nagy seregehben de majd három fontos tojisoliat tojik, mellycket (a legmelegebb tarlományokban) (sak a nap hevenck tes\% ki a homokan, de a forro igovion innen és túl äli azokill, gondot risel rájoks bótoran rédi öket.

A strue fürel és maggal él, izlése pedig olly tompa,

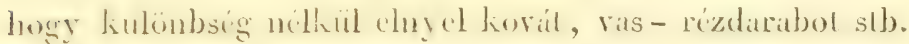

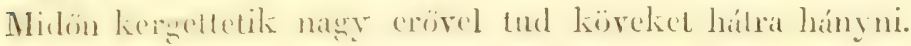
Futásban semmi állat nem éri el.

2. Az amerikai struc. Kis szaladar. (T' Mntruche d' smerique, Nandu, (hurlo. Strulhio rhea. Lin.) Hanmer. Ann. Ilus. XII., xxxrx. Vicill gal. 229.

Majd felemgi kicsm, hoveseblé tollazoll, reg idomu

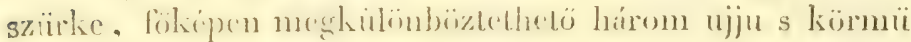

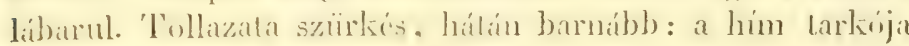

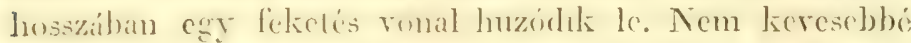
szimos deli Ameriha deli rezoin mint Afrihúban a nagy szaladar. 'Tollait csak seprihöz használják. Fiatalan fogal-

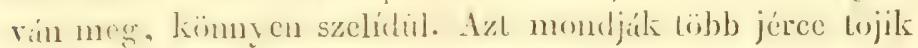

(') A madarak nemzési s hugyozísi muiszereikrül, különösen a strucérul, kérdezd Geoffi. - Sto-Hilaire munkáját a Mem. du Mus, Xv. kötetben.

${ }^{(2)}$ Lásd még azon szćp képet, mellyet Maréchal rajzolt Lacépècic és Cuvier Ménagerie du IIuseum-ában, lemúsolva Vicill. gal., 225. 1. 
cgy fészckbe ragy inkább azon gödörbe, súrgás tojásokat, mellyeket egy hím költ ki. Csak fiatal korában eszik meğ.

\section{A KAzUÁr-ok. Földi. (Szalagriz-ok.)}

(Les Casoars. Casuarius. Briss.) (').

Szálnyaik még rövidebbek mint a strucoké s a futísra egészen haszlalanok; lábaikon három ujj vats, nindenik körmös; tollaik szakállai olly kevessé birnak szakíllcsákat hogy tárolrul lecsüngö hajaknak vagy szörnek látszanak.

Szinle két fajok ismereles, de mindenik tulajdon nemet képezhetne.

1. A sisakos kazuar. (Sisakos szalagá. (Le Casoar d casque ou Emen. $\left({ }^{2}\right)$. Struthio-Casuarius. Lin.) Enl. 313. jobban Frisch. 105. $\left({ }^{3}\right)$.

Csorrok oldalrást összcuyomott, fejökön csontos döduzadás, melly szarranyaggal födelék; fejböre s nyaka magasa csupaszok, égkékek és tüzpirosak, csüngö lorongyokkal, természetre a pulykaéihoz hasonlítra; a szárnyban nchány durva, szahállıalan csök ran, mellycket a madár fegyverként használ a vitában; a belsö uji körme sokkal eröscbb. Ez leguagyobb madár, a struc ulín, mellytïl bonelanára nézre cleget különbözik; mert belei rövidek, vakbelci lisek; közép-gyomra hibázik a begy és zúza közölt, s ürszéke (cloaca) arányilag nen mulja fölïl a többi madarakét. Gyümölesöt eszik és tojásokat, de

(1) Brisson és Buffon, Barrére után, rosszul alkalmaztaták reá a 'Touyou, vagy inkább Touiouiou nevet a Jabiru-t illetöt. Ez Brissomnál a Rhea nem. A brasiliai portugálok az Emeu nevet rulázák rá, melly tulajdonképen a szalagúzt illeti.

$\left({ }^{2}\right)$ Cassuwaris, malaji neve e madárnak. Clusius szerint eme vagy émeu nevet hord különösen Bandaban.

$\left({ }^{3}\right)$ Maréchal ennek is szép lépét adta a, Menagerie du Mu scumb"ban, ucllyet Vicillot lemásoliata a gal. 225. lapjä. 
szemet nem. Kevés számu zöld tojíst tojik, mellyeket a struckint a termézel melogre biz. Az indiai szigctsols kilönbüzö szigetein fogalik.

2. Az iijhollandi kazuar. (Le Casuar de la Nourelle Míllande. ('asuar. Norae-Hollandiae. Lath.) Toy. de Péron. All, 1. rész. xxxyi. rl. Vieill. gal. 226. rl. $\left(^{1}\right)$. Csorra lenyomoll, feje sisaktalan, csupasz csak a fül

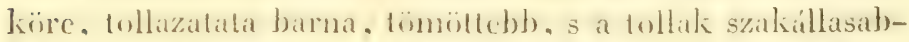
bak; ninestorongyal. sem szárnyarkan!y ui: ujjan a kör-

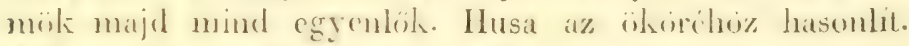
A lecjobb agarnat glorsabban fut. Az aprok barna s fehirrel tarkásak. $\left(^{2}\right)$.

\section{Mésodik család}

\section{A NTOMOTT CSORRUAK-é, (Les Pressirostres. Pressirostres.)}

A magas sziru, hüvelyktelen nemeket foglalja magában, vagy mellyekn'l az xövidebb minthogy a földre íne; - csorrok hözépszerü, elég erös a fold folvágusára hogy ou férgeket keressenck; a leggyöngébbet birú fajok pedig a réteket és rijdonan szintott mezóket futjik be, ottan ezen eledelt keresve. Az erösh csorvuak, szinte magvat és fúvel is esznek, stb.

\section{A TúzoK-ok. F.}

(Les Outardes. Otis. Lin. Trappe.)

A tyuhnemüek otromba idoma mellett nyakok és líbols chy husszu, csorrok középszerú, felsö csorrleme-

(') Vicillot belōle csinálta az EMou vagy Drostarus nemet.

(2) Jegyz. Ezen sorozitba nem tehetem az olly kevessé ismert sôt hevesse hiteles fajokat, mint mellyek Liunć DıDus nemét képzik. 
zök könnyiden irelt es boltos, - ez is njjaik alapjai kriziitt az igen apró hártyák, még a tyukuakra emlékeztelnek; de szíraik aljának csupaszsíga, egész bonctanok s mig húsok ize is a gázlok kïrí leszik öket, s hüvelykök hibázxán, a kisebb fajok iggen es rigetlenül küzclítenek a lilékhez. Lábtöjök háiozolt, számyaik röridek; kereset repülnck, nem igen ğ akran használják szárnyaikat másra, it strucokkint, mint fulúsuk elöseģ́lesére, szinte szemeket, füvet, férgeket, hogarakat esznek.

Az elsö vagy a lepcses dudu, F. (Le Dronte. Didus ineptus) csak egy az első holIandus hajósok leirása szerint ismeretes, föntartva Clusiustol, Exot. 99. I. és egy olajfestében ugyanazon korbul, Edwardstul lemásolva, 294. $\%$, mert Herbert leirása gyermekes, minden többi pedig Clusius és Edward után van. Ugy látszik hogy az egész faj elveszett, s ma csak egy lába látható, a brit muzcum bistokában. (Shaw. Nat. miscell. pl. 143, s egy elíg rossz korbeli fej Oxfordban a, ,Muséum Asmoléen"-ben (ua, uo. 166. rl.) Csorra nem látszik minden hasonlatosság nélkül az alkákéhoz, s a láb, ha uszóhártyás volna, a reptelenébez hasonlitana.

A második faj, magános dudu (Le Solitaire, Didus solitarius.) csak Leguat tanubizonyságán alapul, Voy. 1, p. 98 , ki azonban a legismertebb állatokat is elidomtalanítá, po u. a vizilovat és kézcetet.

Végre a harmadik, a nazareni dudu (Didus nazarenus) csak Cauche Ferencz után ismeretes, melly ót az elsỏ dudínak tekinti, uoha csak három ujjat tulajdonit neki; mig a töbhiek mind négy ujjıul beszélnek.

Ezen utazók óta senki nem láthatá e madarakat uijra.

Minden madarak között leginkább csupa nyomdokát mutatják a szárnynak, az Apterix neviek, Shaw. által mutatvák. (Nat. misc., 1056 és 1057.) Általános idoma mint a reptelené, nagysága a ludé. Lábai szinte a reptelenéi lennének, ha rajtok nem hibáznának az uszó-hártyák. Csorra igen hosszú, karcsu, mindenik oldalrul hoszanti barázdás, s alapján hártyával szegett. Színya egy kis csonkbul âll, horogba végzodve. Új-Zelandban lakik. 
1. A lomha tusot. (Ta grande Outardr. Olis tarda. Lin. Der grosse 'liappe) Bnl. 245.

'Tollazala a hálán vidim sírga, sok fekele vonatal

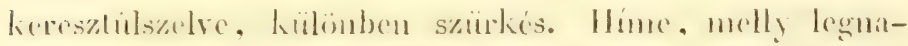
syoble anopai maditr. Losszífuleked bir. mellyek kit oldulrul nemileg nagg bajusal kipezuck. Ezen faj vadaink regik legjobbika, a nagr siki videked gyaliorolja s a ve. tésekben lészkel, a földön.

2. I kis luzok. (Reznek. F. (Ta petile oularde, on. Cannepiliere. Olis letrax. Lin. Der lawergtrappe.) Enl. $25 \mathrm{~s} 10$.

Fil ahkoráníl hiseble minl a misils, nem olly elter--

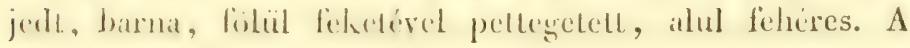
hím nyaka fekete, liét fehér nyakzattal.

Az idegen fajok naggubl részend vikonyabb a csorr mint a mi fajainlaníl. Ezek liözöl megjegy ezhcto

3. Az öres tuzok. (T.e Houbura. ()is houbara. (im. D)a. Kragentrappe.) Desfontaines. Acad. des Sc. 1787, x. rl. Vieill. gal. caxrvir.

Afrika-s Arabiabul; nyaka hét oldalín hossá tollakbul egy örv ragyon. $\left.{ }^{1}\right)$.

\section{A III,EK.}

(Les Pinviers. (Waradrius. Lin. ( $\left.{ }^{2}\right)$. Der Regenpfeiffer.)

Szinle hïvelylitelenek, csorcok kïzépszerü, ̈̈szenyomott, végén dagadt. Két alnemre osztható:

(') A tuzokok körött hagyom Latham minden fajait, mint $O$. afra, Lath., Syn. II, Lxxix; - Benghalensis, Edw., 250;Arabs, ua. 12; de elveszen az Oedicnemus-t, melly a következ $\delta$ nemet kezdi, összenyomott s végén duzadt csorráért! A. h. Otis nuচ̆a, Rupp., 1. rl.; - Ot. denhami; - Ot. torquata, Cuv. esp. llouv. du Cap.

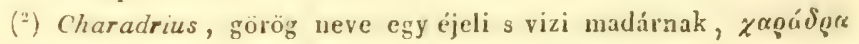
(part-repedék) szótul jō. Gaza HıAticula névvel adja. 


\section{A I Í́TÖMÉREK. (TÖMLÁBAK.)}

(Le's Oedicnemes. Oedicnemus. 'Tem. ( ${ }^{1}$ ). Dickfuss.)

Csorrok hegye alul ugy dagadt mint fölül, s az orrlyukak esatornája annak csak fele hoszaig terjedt ki. Ezek nagyobb lajok, fokipen szíraz is sziklís foildön élök, oll csigákal, bogarakal, stb. Cogok. Hasonlílanak a tuzok kisebb lajaihoz. Lábaik háluzotlak, s három ujjaik közén rövid hártya van.

A rendes láblömér. (I' Oedicnène ordinaire. Courlis de terre. Charadrius. Lin. Oedic. crepilans. 'Tem.) EnI. 919. Frisch. 215. Natum. 1-kiad. 9. 13. k.

Lcbenke (snef) nagyságu, sárgás saürke, minden tolla közepén egy barna láng, hasa fehér; szeme alall egy barna vonat. $\left({ }^{2}\right)$.

\section{A tulajdonképi LILÉK.}

(Les Pluviers propr. dits. Charadrius. Eigenll. Regenpfeiffer).

Csorrok csak fölül dagadt, hosszasíga két harmadát elfoglalja mindenili oldalon az orresalorna, mi olsbul az gyöngébb lesz. Szímos csapatban élnek, nedves fïldet szeretve, s azt lábaikkal megrerve, hogy mozgásba indítsák a golisztákat (férgeket) mellyekkel élnek.

(') Oedicnemus, (dagadt-láb), Bélon csinálta név, a szárazi ugarályok számára.

$\left(^{2}\right)$ A. h. Oed. maculosus, Cuv. (Oedicnème tachard), col. 292; - Oed. longipes. Geofr. Oed. à longs pieds.) Vieill. gal. 228. vagy Oedicn. echase. Temm, col. 386; - Oed. magnirostris, Geoff. (Oed. à gros bec.), col. 587 , melly csorra idománál fogva tulajdon sort kezdhetne, mellyhez csatoltatnék egy igen hözel faj, kissé görbült fölso csorrlemezzel: Oed. recurvirostris, Cuv.; - Char. crassirostris, Spix. 
A nálunk mulatkozó fajak esak vándorlók, taraszszal is oszzel: a tenger melled maradnak az erois lagnig.

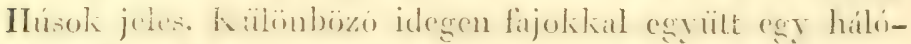

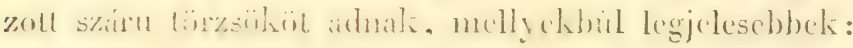

1. As arany lile. (P'luvier doré. Char. pluvialis. Lin.

Der Condregent? feiffer.) Enl. 9i)4. Frisch. 216. Vilum.

1. (. i). 14. k. II il. Am. III. I.1. 5.

Fekciés, tollai oldalín sárgíral pontolt; hasa fehér.

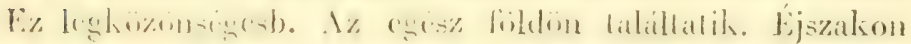
van egy liij, clliil csak felccle torka által különbözó. (Charadr. apricarius.) Edw., 140 : Naum II, 15. k. Wils. Am. VIl. urI. 4. Nimcllyek ata mondják hogy cz a fiatal.

2. A morinell. F. (Le Guingnark' Char. morinellus. Lin. Der Morinell). Enl. 852. Naum. 12. 16 - 17. k.

Szürke vagy feketés, tollii sárgás szürkérel szegrék. szeme liblïl feher vonat. melle s hasfölc vidim veres, has-ala felicer.

3. A vizi lile, (Le Pluvier à collier. Char. Tiaticula.

I.11. Der Halnhandregenpleiffer.) Eul. 920. Frisch.

214. Briss. Zool. P. P. Mils. Anı. V. xxxvm. 2.

Föliil szörke. alul fehér, nyaka alján fekete körr, melly eluil igen szúles; foje fehérel és feketérel tarka; csorra sárga es fekete. Nálumk kiét vagy három fajtája

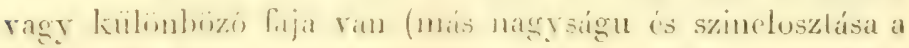

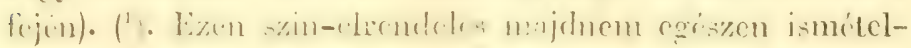
telik tïbb jưnen fạnil. $\left(^{2}\right)$.

(') Ch. minor. Meyer, enl. 921; Wils., VII. L1x, 5 ; Naum. 15, f. 19. vagy Ch. curonicus, Latl. egészen fekete csorru; - Ch. cantianus, Lath. vặy albifrons. Meyer, mellynek jércéje lehet a Ch. aegyptius, - Nyakkörve megszakadt.

$\left(^{2}\right)$ Char. vociferus, enl. 286; Wils. VII, I.Ix, 6; - Ch. indicus, Lath.; - (har. Azarai, T., col. 181; Char. melanops, Vieill. 
Sok idegen fajnak szárai paizsosak; ezck egy kis osztást képeznek, mellyben a fajok nagyobb része tövist hord a szamyakon ragy bús leffenyeliet a fejöliön; némellyek a két bélyeget összekötik. ( ${ }^{1}$.

\section{A LIBUCOK. F.}

(Les Tanneaux. Tanellus. Bechst. Tringa. Lin. $\left(^{2}\right)$. Kiebitz.)

Csorrok mint a liléké s azoktul csak létezó hürelykök illal különböznck; de melly rörideb]s minthogy a földet megérné.

Az elsö osztatbeliek:

А ві́вісек. (НIÚвісок, libuc-lilék.)

(Les Vanneaux-Pluviers. Squatarola.)

Alig ćszrevehetö hürelykkel. Negkülönböztetik alul dagadt csorrárul, mellynck orr-csalornája rövid mint a lábtöméreknél. Lábai hálósak: a honiaknak farka mind fe-

gal. 235 vagy Char. nigrifrons, Cuv. col. 47, 1; - Char. Wilsonii, Wils. Am., IX, LxIr , 5; - A. h. ezen közel fajokat, nyakkörvteleneket: Ch. pecuarius, T., col. 183.; - Ch. nivifrons, Cuv.; Char. ruficapillus, T., col. 47, 2; - Ch. monachus, T.; - Ch. griseus, Lath.

(') Paizsos nem fegyveres lábu fajok: Char. coronatus, enl. 800 ; Ch. melanocephalus, enl. 918, Savign. Egypt. Ois. vr. rl. 4. k. mellybül Vieillot a Pluvianus nemet csinálta, gal, xxir. r. Csorra valamivel nagyobb a többiekénél. - Fegyveres fajok: Char. spinosus, enl. 801; - Char. cayanus, enl. 833 ; Cafatos fajok: Char. pileatus, eni. 834; - Ch. bilobus, enl. 880 .

A Char. cristatus, Edw. 47, azonosnak látszik a spinosus-sal.

$\left(^{2}\right)$ Tringa, vagy inkább trynga, görög neve egy rigó nagyságu madárnak, melly a vizek széleit szereti s farkát mozgatja. Arist. Ugy látszik, Linné tette ez alkalmaztatást, de Tringa nemébe sok más madarakat bevett, mellyek nem libucok, fơképen partiramokat. 


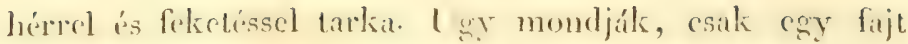
képzenck, de toll-változísai miatl az megszaporittaték. 'Tírsaságot tart a likékkel.

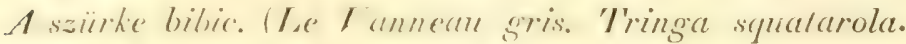
Der geflectle Kiebic.) Enl. 854.

Fölül szürtsés, alul fechéres, szürkés foltokkal; - cz a vedletlen fialal. A tarka bibic. (Le Vanneau varié,

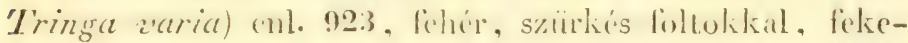

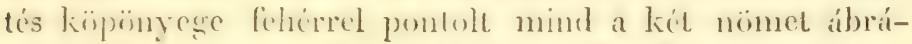
zolja tili ruhában. A szeizi bibic. (Le I'annean suisse. I'ringa helvetica.) cnl. 853. Naum. 1. Kiad. 62. 117. k.

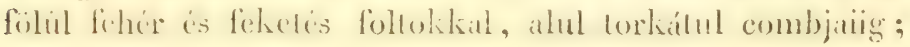
ez a hím lakodalmi rulsíjában.

\section{A tulajdonképi mmoucuk.}

(Les Vawealx, propr. dils. Vinelucs. Cur. Figen/l.

$$
\text { Kiebitze.) }
$$

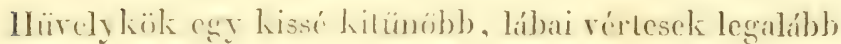
cgy részint, az orr-csatoma a csorr két harmadára megy. Módjok a férgek meglogísánál az, mi a liléké.

$\mathrm{Az}$ europar faj:

A kïzänseges libuc. F. (Der getüubte Kiebilz. 'T'ringa vanellus. Lin.) Enl. 240. Irisch. 213. Naum. 11. 18. k.

Módos madír, galamb-nagyságu, broncos lekete, husszí foszlott búbbal. 'Taraszszal ćrezik meg, mezókön is réteken lakili, ott f'́szkel, s üszszel elmegy. 'Tojásait fölségeselnnek mondják. $\left({ }^{1}\right)$.

A heres tartományokban vamak olly libucfajok is, mellycknck szárnyán cgy vagy két töris (sarkantyu) van,

( $\left.{ }^{1}\right)$ A. h. Tan. cinctus. (Le Vanneau à écharpe). Less, et Garn. Voy. de Duperrey, XLII. rl.; - Van. flaripes, (Le Vann. à pieds jaunes.) Savign., Égypte, Ois. C. rl. 3. k. 
s mísok, csorrok alapjin torongyokat ragy hus cafatokat hordozók: líbaik rértesek. E madarak minden legkiscbh nesze ballató liáltozásaili miatl alkalmatlanok; a ragadozó madarak ellen bátran védik magokat. ( ${ }^{1}$ ).

A vérlábuak. F.

(Les Huitriers. Haematopus. L.

Csormok egy lissé hosszabb, mint a liléké és libucoké, egyenes, hegyes, ílimódra összenyomolt, s eléggé erös hogy a liél telicnyú csigákal crószakkal fölnyissa, belölük az állatot kiszedendö: azonban a földet is ássa, abban férgeket keresve. Az orresalorna jgen mély s a csorr felét foglalja el, a csorrlyukak ott középen állanak, mint kis repedékek. Száraik középnagysíguak, lábtöik hálósak, lábaik csak lárom ujra usztvák.

Az curopai faj:

1. A csigcisz vérlcibu. F. Haematopus ostralegus. Lin. Der Austerdieb). Eul. 929. Briss. Zool. D. rl.; Catesb., 85. 1.

'Tengeri szarkának is mondatik fekete tollazatáért, mig hasa, lorka szárny-és farkiöre szép fehér. Nyáron torka fehére eltün. Ruca nagyságu; lábai, csorra veresek.

Braziliában találtatik egy faj, hosszabb csorru, s torLka alatt semmi fehérrel, ez

$\left({ }^{3}\right)$ Exek Gmelin parra-inak 9 elso fajai, névszerint: $P$. cayennensis, enl. 362, vazy jobban Fanel. albicollis, Vieill. gal. 236; - P. ludoviciance, enl. 835, mellytïl a: Van. gallinaceus, Tem. tán fajra nem különbözik stb., erkölcseik, száraik, csorrok, idomok, szineik closztasa hasonlít a libucokéhoz és lilékéhez; nincs nkunk óket a parákhoz számitani, mellyek majd minden tekintetben mis bélyegïek.

A. h. Tr. macroptera, Új faj. Java szigetérül, szürke, fejehasa feketék, feggyeres s cafatos, - szirnyai sokkal meghaladják farkát. 
2. A palcistos vérlíbu. (Haematopus palliatus. Tem.). mellyed Wils. VIII. Lxiv. 2. a esigússzal összezavar.

A Mialuin szigetelien ran egy faj, mellynil a fekete szin a mellen mélyebbre ereszkedik, ez

2. A gycisz vérlib. (Haematopus luctuosus. Cuw.)

Mign az egísz déli lilkügön degy rgíszen fekete tollazatu faj, ez,

4. A fekale neirlib. (Maemalopus niger. Cur. Haemal.

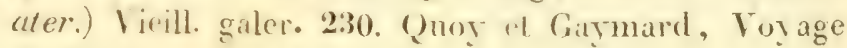
de Freycinel, xxryy. $r$.

A liblihez es rérlabualioz hïzel helyezendiok:

\section{AZ ÜGETÉREK.}

(Tes Coure-vile. Cursorius. Lac. 'I'achydromus. I1. Taufer).

Csorruk véhonvalbb, egyenlöen kiupos, hajoll, barizdítlan, középszeriileg szelt: száruyiak rörideblek, sziraik magasabbak s hairmm ujj állal régoödök, uszhárlya s hüvelyk nélkül.

Littaték már, de igen ritkín, Franciahonban, cgy. ijszak-afrikai faj, rilúgos súrgai, fehéres hasu, melly

1. A scirga ügetér (Char. gallicus. Cuv. Cursorius isabellinus. Neyer.) Enl. 795.;

is egyet Indiábul hoztak, melly barna-szürke, hasa veres; $\mathrm{ez}$

2. A koromandeli ügetér. (Ch. coromandelicus Curs. asiaticus. Lath.) Vieill. gal. 232. enl. 892.

Mindenilinél egy fehér és egy fekete ronat ran a szem mögött. Nevöket szaladásbeli gyorsaságokért kapták. Különben erkölescik egészen ismeretlenck. ( $\left.{ }^{1}\right)$.

(1) A. h. a violaszin szárnyu ügetér. (Curs. chalcopterus. T.). col. 298; - a két örves ügetér. (Curs. bicinctus, T.) Man' orn.; - Curs. Teminkii, Swains., Zool. Ill., 106. 
A mennyire a külsörül ilélhetui, ide legjobban helyezendók :

\section{A BUBAPÁROK.}

(Les Cariama. Briss. Microdactylus. Geoffr. Dicolophus. Ilig. ( $\left.{ }^{1}\right)$.

Csorrok hoszabb, horgosabb s egész a szemök aljaig szelt, a mi rémileg a ragadozó madarakhoz hasonlítja öket természetre s physiognomiára nézre s a gémekhez viszi közel. Veres és igen magas száraik igen rövid ujjakba régzödnek, kissé hártyás alappal, s füldre nem érö hüvelykkel.

Csak egy faj ismeretes déli Amerikábul:

1 tarajos bubapár. (Microd. cristatus, Geoffr. Palamedea cristata, Gm. Saria. Azz.) Ann. Mus. d' Hist. nal. XIII. 26. rl. col. 237. Vieill. Gal. 259.

Nagyságra fölül mulja a gémet, gyikokat és bogarakat eszik, mellyeket emelt helyeken s erdószéleken üldöz. 'Tollazata súrga-szürke, barna hullámu; csorra alapjin foszlott tollak, ott könnyüded s elöre nyúló csomagot liépezre. Rosszul és ritkán repül; erós szava a fiatal pulykaéhoz hasonlit. Husa kedveltetvén, sokfelé házi madárrá tételék.

Harmadik család a gázlóknál.

A KÉSCSORRUAK. (Les Cultrirostres. Cultrirostres.)

Csorrok nagy, hosszú, erös, legtöbbnyire metszö is és hegyes, s majdnem egészen Linné-

(2) IItcrodactylus, kis ujju. Dicolophus, kétsoru taraj. IIaematopus, vérszinláb. Vieillot e barbar nevet fogadta el cariama, melylyet igy kell kimondani, cariama. 
nek , АвDEA ${ }^{66}$ nevï nemében összeállított madarakbul all. Fajainak nagy számánál a hím gơgosípja kïlönbféleképen hajtogatott, vak beleik rövidek, s a tulajdonképi gémeknél is csak egy vau.

Mi öket harom törzsökre oszıjuk, a darukérat, gémekére és hattyukéra.

Az elsó törzsökben csak egy nagy nem van:

\section{A DATUKE.}

\section{(Les Grues. Grus. Cur. Kranich.)}

Csorrok egyenes, licressé szell, rajla az orrlyukak hiirlyís csatorníja szicles, homoru s a hosszasigr majd fe-

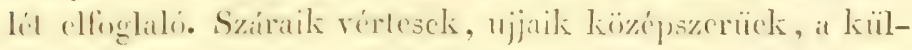
sök keressé hártyásak s a hürelyk alig ér a földhöz. Majd mindnyájinail a lej és nuak tribbé lesesbbé jeles rísze tollatlan. Szolkitsails inhaib) sziraziak s eledeliok nö-

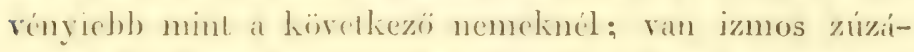
jok s eling hosszu vakbeleik is. Al-griggök esals egy izmol bir mindenik oldalon.

Vilemenyem szcrint, mint Pallas tön ('), czen trïzsük clején hagyhatók

A KORGÁLYOK. (Korgó. F.)

(Les Agamis. Psophica. Lin.)

Cacmrok riovidebb mint täbbi fajoknál, frjök nyakok

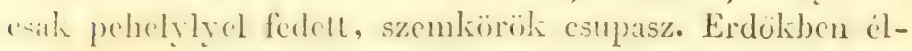
nck magrakkkal és gyümölescsel.

Legismerelesebb, dél-amerikai faj:

(') Spicil. Zool. IV, 3. 
1. A has-szavue korgály. (has szarvu kargó. T. L' Oiseau-lrompelle. Psoplia crepilans. Lin.) enl. 169.

Igy nereztctik mivel tompa mély hangot tud hallatni, melly scgébul látszik jöni. Kappan nagysígu; tollazata fekclés, mellén ragyogó violaszin jálszíssal, liöönyege hamvas, fölfclé suirgísan fölhözre. Ezen madának ismerete ran: mint valami kutya (eb) megszokik, s mint mondják ammyira szelidílhetö hogy a lübbi majorságbeli madarakat vezérli. Rosszul repül, de gyorsan szalad. Földön fészkel a fák tövénél. Húsa jó izúi $\left({ }^{1}\right)$.

Némelly idegen darrak (korgályok) ilt kürclkczendók, mellyeknek csorra rövidebb mint a mienké.

2. A koronás korgcily. (L' Oiseau royal, Grue couronnée. Ardea pavonia. Lin.) Enl. 265. s a fialal Vicill 257.

Igen karesu termetü, négylábnyi magas, hamvas, fekete hasu, sirrga farcsiku, fehér szírnyu; csupasz arcai fehérrel s ridám rózsával festrék, hátfeje koronázva ran egy csomó sárga foszloll tollal, mollynek hangja a trombita recsegó hangjához hasonló, Afrika nyugoli partjairul jö, hol ggakran háznál tartatik, magrakkal táplállatra. Vad állapotban az eláradt helyeket keresi ott apró halakat fogdosva.

3. A szüz Korgcily. (La Demoiselle de N'umidie (Ardea virgo.) Enl. 246.

Az elöbbihez közelít idomára s majd nagyságára is, hanvas, nyaka fekete, két szép fehéres tollaggal, melylyeket a füleit fedezó foszlott tollak kinyulása képez. A

(2) Nevök Agami Cayenncban, Barrère szerint, caracara az Antillakion Dutertre szcrint. Mivel cgy szarvály is Oiseau trompettenek neveztetik Afrikában, Fermin (Descript. de Surin.) nevetségesen átviszi a korgályra a két egymásfölötti csorr bélyegét. Az agami sohiig osszezavartaték Margrave macucagua-jával, melly farklantyuk P'sophia Barrère csinálta szó yopeo (korgok'-tul.

A. i. Psophia viridis, Spis, 83, és Psophia leucoptera, wo 81. 
rabszolgasígban lítottak, tettetett és furcsa mozgísols s majmolások által föltünóls. $\left.{ }^{1}\right)$.

\section{$A$ rendes darvaK.}

(Grus. Les Grues. Gewöhnliche Kriniche.)

Csorrok akkora vagy hosszabb mint fejök:

1. A küzunsérges Darn. Г. (La Grue commune. Ardea grus. L. Grus, cinerea. Bcchst.) Enl. 769. Frisch. 194. Naum. 1. kiad. 2. 2. k.

Négy és több lábnyi magas, hamvas, torka fekele, fejleloje csupasz és reres; firresika liosszú, fulílli, bodrostollakkal ékesilett, részint felectiked; hires minden idöben azon rándorlisirul, mellyet taraszszal délril ijszakra s özzzel megationditra tesz, olly nagy mint jol rendelt esatpatoliban. Magrakal eszili a mezóliön, de jobbe szereti a bogarakat is forecket. millyeneliet a moesáros videkek adnak neki. A regiek soliat beszéltek ezen madárul, mi-

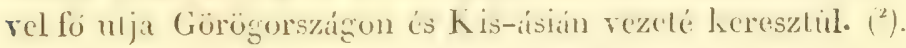

Csak a darvak s gémek liözött hozandók föl:

2. A lebenkés daru (1)e ('ourlan. ou. Cuurliri. Ard. scolopacea. (in. Der Silnepfenreiher.) Enl. 848. ( $\left.{ }^{3}\right)$.

Csorra vélsonyabb s hissé szeltebb mint a darraké,

(') Az academia bonctudósai ezen madarat, helyzet cserciért scops, otus, asio néven ncrezék, de ugy a régick a mi suholyainhat hivtáh. Buffon, ki e hilhit jül megfejté a sulolyoknil, még is abba vissza esik, feledékenységbül, a szïz korgálynál.

$\left({ }^{2}\right)$ Ezen nemhez tartoznak még: Ard. canadensis, Edw. 133. (Grue de Canada); La Grue à collier, cnl. 865 és la La Grue des Indes, Edw. 45 ; (Ard. antigone.); Vieill. gal. 256; (Ard. americana), et la Grue géant. Pall. It. II., no 30 , t. I. (Ard. gigantea), melly nem látszik semmiben kiilönbozni a fehértul; végre a torongyos daru, (la Grue caronculée, Art. carunculata), melly nem gém, mit Gmelin hitte.

(') Ezen madírbul csinálta Vieillot az. Aranus nemet, gal. 252; Spix, 31 , 1. - on Rallus ardeoides, nevet ad neki. 
hosszasága ulolsóharmadán duzadt, - ujjai clég hosszúk, de hártyátlanok. Erkölcse, nagysága mint a gémeké, tollazata, Jarna, nyakán fehér csomókkal.

\section{A NAPÁLY.}

\section{(Eurypyga. Ilig.) (1).}

2. A pillés napaily, pillés daru. (Le Caurale. Pelit Paon de roses. Oisecu du Soleil. Ard. Helias. Lin. Der Sonnenvogel. Enl. 702.)

Csorra rékonyabb a darvakénál de hasonló orresatornát biró, s egész a szem aláig szelt mint a gémeknél, de nincs csupasz böre az alapján. Fogolynagyságu ez a madír, s mellyet hosszu vékony nyaka, széles kiterjedt farka s cmeltebb szárai egészen különbözö idomuvá tesznek a többi gázlókétul. Tollazata barna sárga, veres szürke és fekete szalngokkal s vonalokkal vállozva a legszebb éji pillékre emlékeztet. Guiana vizei hosszában találtalik.

A második lörzsök húsevöbb s megismerhetö eröscbb csorrárul, s nagyobb ujjairul: clöl bocsáthatók.

\section{A RÁKÁSZOK Vagy CSÓNAKORRUAK.}

\section{(Les Savacous. Cancroma. Lin.)}

A gémekhez egészen közelítenek crös esorrok s az onnét számazó táplálali mód állal, ha ugyanazon esorr olly különös idomu nem volna, de tovább vizsgálva azt lelendjük, hogy ez nem egyéb, igen szétnyomott gém vagy nádi-bika csorrnál, melly valóban igen széles jobrul balra, s mintegy két kanálbul képzelt, a homoru részek fordítlatrán össze. Állkapesai crösck, metszök, a felsónck mindenik oldalán a hegyénél egy hegyes fog van; az orrlyukak az alaphoz közel nyihak meg, de kél egyenkö-

(') Vicillot c nevel IIelias-ra változtatla.

CUVIER I. K. 
zios barizdában nyulnak el majd a hegyig. Lábakon negy vij ran, mind hosszil, s majd semmi hárlya; szinte folyórizek partján fákon tartózkodnak e madarak, homuan a haliktra lecsapnak, mint rendes cledelïkre. Magok riseInte kïlönben szomoru s helyzetök összehúzoll mint a gémeké.

Ismereles fiij:

A halanos rakisz. F. KCancroma Cochlearia. L. Der Löffelreiher.) Enl. 38 és 369. Vieill. gal. 249.

'Tyuk-nagyságu, fehéres, hála szürke vagy barna, hasia reres, homloka feher, egy fekele sapkítul követve, melly a vin himmél hosszú bribitává változik; déli Ancrika forró s nedres részein lakik.

\section{Ezután következnek:}

\section{$\Lambda$ GÉEHE.}

\section{(Lıe's Mérons. Ardea. Reiher.)}

Csorruk egész a szem alúig szclt; egy kis orr-gödör mint barizda igen hïzele a coore hegyédg elnyul; megje-

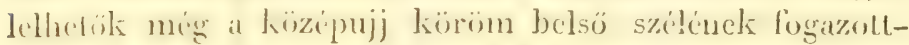

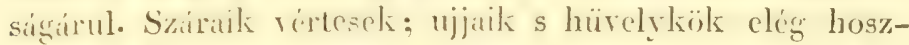
szuak, a huilsö uszhárlya joikora, szemeik a csorrigg kiterjedi esmpas\% börbe lelyezvils. Gyomrok igen nagy zseb, licressé izmos, valibelök jgen kicsin. Szomorí madarak, a folyok partjain fészkelok és ïlok, hol sok halit elpusztitanak. Ganajok elégeti a fákat. Mind a két szárazon számos fajoli van, mellyckel mísrul nem oszthatni föl, mint tollazatuk némi különösségérül.

A valódi gémek nyaka igen véliony, alapja felé hoszszú csüngő tollakkal szegett.

1. A hék-szurke gém. (Kék gém. F. Le Héron rommun. Ardea major et cinerea. Lin. Der Fisch-rciher.) 
Enl. 755. 757. Frisch. 198. 199. Naum. 1. kiad. 25. 33 s 34. kép.

Kékes hamuszin, feje hátulán egy fekcle búbita, nyaka cleje fehér behintve fekele könyükkel; nagy madár, folyöinknak igen ártalmas; hajdanában híres volt azon mulatságért, mellyet a nagyok általa szereztek magokuak, öt sólymokkal vadásztatva.

Nálunk van még egy szürke és reres vagy biborszinzi gém :

2. A bibor gém. (Arclea purpurea. Der Purpurreiher.)

Enl. 788. Naum. 1. kiad. Pól. 45. 89-60 k. (1).

A rövidebb lábu apróbb gémeket franciául ,Crabiers", néven nevezilk; mi gémcse szóval adhatnók azt.

Franciahon hegyes tartományaiban legközönségesebb) :

3. Az apró gém. (gémcse). - (Le Blongios. Ard. minuta et danubialis. G:n.) Enl. 323. Frisch. 207. Naum.

1. kiad. 28. 37. k.

Surga, sapkiija, hála, tollai feketék; alig nagyobb cgy guratnál; pocsolyák körött tartózkodik.

A larakgémek (UNonés) gémesék szokásaival a raliodi gém termetét s a dobgém szincit kötik össze. $\left({ }^{2}\right)$.

A кócsıgok. (Les Aigrettes. Fedterbuschreither.

(') Meyer szerint az Ard. purpurea, purpurata, rufa, Gm. Africana, Lath. csak fajtái a bibor gémnck.

A. h. Ard. herodias, Gm. Wils. VIlI, Lxy, 2, mellynek fiatala lehet az enl. 858 ; - A. cocoi, Lath. Spix, xc; czen hamis név alatt: Ard. maquare. A. sibilatrix, Temm. col. 271 ; - A. ludoviciana, Gm. enl. 99, mellytül az A. virescens, enl. 908, 912, nem különbözik fajra nézve; - Ard. Novae Guineae, Lath. enl. 926 , csorrára nézve közelit a lebenkegémhez.

$\left({ }^{2}\right)$ A. lineate, Gm., enl. 860 ; - A. tigrina, ua. enl. 790, melly az Arel. flava fiatalának Ienni látszik. 
Olly gémek, mellyelinél a hit-al tollai bizonyos idöben hosszúk és foszlottak.

Iegszebb fajok, mellyekuck tollait azon ismeretes használatra fordílják, melly et már nerok kifejez:

1. A kis kócsag. (Fehér kócsag. F. Ardea Garzetta. Straussreiher.) Enl. 901. La petite Aigrette.

Fél akkora mint a gém; egészen lehér, foszlott tollai nem haladják meg farkát.

2. A nagy kiocsag. (Fehér gém. F. La grande Aigrelte. Ardea alba, Der grosse Silberreiher.) Enl. 886.

Szinte fehér, de nagyobb.

E két faj Europában talíltatik. ( $\left.{ }^{2}\right)$.

Van egy harmadils is, rövidebb lábu, foszlott tollai solikal meghaladják a farkat. Ez

3. Az amerikai kócsag. (Ard. egretta. enl. 925.

Ide vagy jól közel helyezendök:

4. A hajas kivisag. E. (I.e Cralier de Mathon. Ard. comata. Gm. Der Rallenreiher.) Enl. 3.18. Naum. Isï kiad. $22,45.1$.

Délemopai madár, háta verhenyes barna, stáruya hasa farkia foherels. A vén nyalia sárgás, lejhátulán egry hoszszú tollag. $\left({ }^{3}\right)$.

DoBgéseK : (Butors. Rohrdommeln.)

Nyakok tollai lomhák, széledvék, mi okbul nagyobbaknak látszanak. Rendesen foltosak vagy vonatoliak.

$\left({ }^{2}\right)$ Temmink véii hogy az A. alba, az egrettá-nak Gatala, s hogy az cnl. 30 i. rl. nem az earopai apró hócsagot mutatja, Lanem az amerikait.

$\left({ }^{3}\right)$ Mreyer poutos vizsgálatai szerint az Ard. castanea, Gm., v. ralloides, Scopol., - Ard. squaiotta; - A. Marsiglii., - A. pumila s még az A. erythropus, s A. malaccensis, Gm. cnl. 911, nem

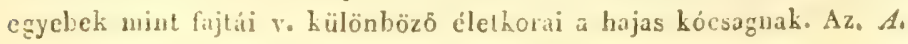


Az europai dobgém. (Dobos. g. F. T'uszkag. F. núdi bika. Le Butor d' Europe. Ard. stellaris. L. Rolırdommel.) Enl. 789. Frisch. 205. Naum. 1. kiad. 27. 36. k. Aranysárga, feketés foll-és pontokkal, csorra s lábai zöldesek, a kákásban tarlózkodik, s ott irtózatos hangon kiált, s ez okbul neveztetéls nádibikának. (Bostaurus franciaul). Nyugodt állapolban különös idomú, csorra égfelé emelt. ( ${ }^{1}$ ).

Az éjgémek. (Les Bihoreaux. Nycticorax. Nachtraben.)

$\Lambda$ dobgémek idomai mellett aránylag, nagyobb csorruak, s a vénnck fejhátulán nehány vékony toll van,

Nálunk csak egy találtatik:

A rendes éjgém, közönségesen : Vak varju. (Le Bihoreaux d' Europe. Ard. nycticorax. Lin. Der Nachtreiher.) Enl. 758. Frisch. 203. Naum. 1. kiad. 25. 25. h. $\left({ }^{2}\right)$.

A hím fehér, sapkíja, hála fekcték; a fiatal (Enl. 759.) szürke, köpönyege barna, sapkajja fekelés. $\left(^{3}\right)$.

senegalensis, enl. 315 , szinte annak fiatala. Meg lehet hogy ez Plinius valódi baleari daruja, $\mathbf{x} \mathbf{1}, 57$.

A. h. Ard. candidissima, Wils. Lxı. 4; - Garde-bocuf, A. bubulcus, Savign., Eg. Ois. pl. vir; - A leucocephala, Gm. enl. 910; - Ard. jugularis, Forst. v. gularis, Bosc. Actes de la Soc. d' hist. natur. félrét, Ir. rl. v. albicollis, Vicill. gal. 253; - A. coerulea, enl. 349 , mellyuck hihetö fialala az $A$. aequinoctialis. Catesb., 77, a szin különbsége mellett is; - A rufescens, Gm. enl. 902; - Ard. leucocaster, enl. 550 ; - A. agami, enl. 859.

(1) A. b. A. minor, Wils. VIII, Lxv, 3. v. A. siellaris, B., Gm., Edw. 155; - A. undulata, Gm., enl. 768; - A. philippensis, Gm. enl. 908.

$\left({ }^{2}\right)$ Meyer szerint, kit követünk, az A.grisea, A. maculata, és az A. badia, Gm. az éj gémek különbözơ életkorait illetik.

$\left(^{3}\right)$ A. h. A-pileata, Lath., v. $A$. alba, $\beta$; Gm., enl. 907 ; A. caledonica, Lath.; - A. cayennensis, cnl. 899, v. violacea, 
Végre azt jegyezhetni meg, hogy a gémmemnek alosztályai nem fontosak, s nem igen élesek.

A harmadik törzsöknél a nağyobb és simább csorron kivül, mint millyen a másodiké, az uszhárlyák majd egjenlök s elég erösck az ujjak alapjai között

\section{A Gólyák. F.}

\section{(Les Cigognes. Ciconia. Cuv. Storch.)}

Csorrok nagy, középszerüleg szelt, gödör vagy barízda nélkiil, mellyen az orrlyukak a hát felé léteznek, kïzel az alaphoz, s mellynek alapjál eg! rendkirül rövid nyelv foglalja el. Szárati hálósak, elsö ujjaik eléggé rrösen hairly ás-alapuak, kivílt a külsok. Csorrok kïmnyu is széles lemezei egymáshoz verefrén az ugg nevezell kerepelest teremtik clö, majhem egyellen hangot e madaraknál. Zúzíjols egy lissé izmos, vakbelök olly kicsi hogy alig vehetni eszre; algregejönck nincs lulajdon izma; lingesoiveik hosszabbak s egriszebb gyüriisek mint rendesen lemmi szokolt.

Két faj honol belöle itt:

1. A feher goilya. (Ja Cigogne blanche. Ardea ciconia. 1.in.) Enl. s66, Frisch. 196. Naum. 1. kiad. 22. 31. kép.

Fehér, szím!lollai leketek, csorra lábai reresek, nagg madár, melì iránt a nép nagy tiszlelettel viseltetik, kétségkiviil azon épülttel, hogy a kigyokat és mús árlalmas állatokat pusztilja. Fészkét leginkább tornyakon (híztelókön, kïrtokön) kisziti, oda minden tavassszal megjö.

Wils. VIII, Lxv, 1, mellynek fiatala az A. jamaicensis, Gm.; A. sibilatrix, T., col. 271 ; - Pouacre, Buff. (A. Gardeni, Gw.) enl. 509, fiatala, mint listszik, egy bronz-fekcte sapkaju hamyas éjsémnek. Ez = A. maculata; Frisch. 202. 
miutín a telet Afrika külünbözó tartományaiban tölté s ott másodszor fészkelt.

2. A fekete gólya. (La Cicogne noire. Ardea nigra. Lin.) Eul. 399. s a fiatal Frisch. 197. Naum. 23. 32. kép.

Fehéres biborcsillogással, hasa lehér, távol mocsírokat keres meg; erdókben fészkel. $\left(^{1}\right)$.

Az idegen fajok kïzzött megkülönböztelendök :

$$
\text { L csupasz nyaku goilyaik. }
$$

Mellyeknek csorra még nagyobb mint más fajoknál, hanem köunyủ anyagu; - s ezek közt

A begyes gólycik. (Les Cicognes is sacs. Ardea dubia.)

Gm. Lath.

Mellyeknél a nyakközép alatt valami kolbász-fúle függeszték van, s mellynck szárnyalatli Lollai a Marabou nevezetü kömnyú tollpamagokat adják. Ezek legnagyobb madarak a nembül; hasok fehér, köpönyegük ércfényü fekete. Két fajok van :

1. A marabu gólya; (Ciconia marabu. Tem.) col. 300,

Egy szinü köpönyeggel. A Senegaltul.

2. A szegélyes gólya. (Cic. argala. Tem.) col. 301.

Indiábul. Száruylakarói fehérel szegettek. - Szíles csorraikkal madarakat fognak a levegóben repülice. $\left({ }^{2}\right)$.

(') Ezen nemhez tartozók még a Maguari, v. amerikai gólya, (A. maguari,) Vieill. gal. 254; Spix. Lxxxıx, e hamis név alatt Ciconia jubura, melly kevessé különhözik a mi fehér gólyánktul ha csak nem hamvas csorra áital; az aptró nubiai fekete gólya (Cic. abdinii, Lichtensein), Ruppel, 8; - A violaszin gólya (C. leucocephala, Gm.) enl. 906.

${ }^{2}$ ) A. h. C. capillata, 'T. (C. chevelue, ) col. 312. 


\section{AZ ORRONDIK.}

\section{(Les Jabirus. Mycteria. Lin.)}

Linné czcket clválaszlá az Ardea-ktul, de a gólyálshoz igen kïzel állanak, is liözclebben, mint ezek a tulajdonkiepi gémekhez; csorrok középszerí tálja, orrlyukaik, lábtöik hálós takarózata, s jókora úszhártyájok azok, millyck a goilyákéi; detmodjok is hasonló.

Egyellen tulajdon bélyegök a rége felé könyüden hajló csorr.

Legismereleseblo faj:

Az amerikai orrondi. (Mycteria americana. Lin.) ${ }^{1}{ }^{1}$. Enl. 817.

Igen nagy, fether, feje, nyakit tollatlan, fekete börii, alá felé veres; a fiejhálulán nehány fehér toll; csorra lábai feketék. Déli Amcrikában el, pocsolák és mocsárok szélein mászókat és halakat vadász. $\left({ }^{2}\right)$.

A NYOMGóLYAK. (NYYonACSORROK.) (Les Ombrelles. Scopus. Briss. $\left({ }^{3}\right)$.

A grilyáktcil csak összenyomolt csorrok által különbuznck, mellynek metszó crósze az alap felé duzadt, s

(1) Tuyuyu, Cayenneben, aiaiai Paraguayban, collier rouge, ctc. Barrére összezavarta az anerikai szaladárral, melly okbul exen madárra (szaladirra) Brisson és Buffon átvitték a touyouyou vagy touyou nevet.

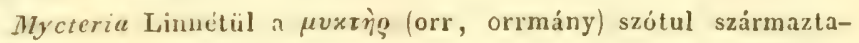
ték, mivel csorra igen nagy.

$\left({ }^{2}\right)$ A. h. IIyceria senegalensis, Lath,; Vieill, gal. 255, mellytul a ('ce. ephlippirhyncha, Ruppel., av., 5. nem látszik kïlönbözni, csak hogy újdon júldány után rajzoltaték s csorr-alapján két csüggöny van.

(') Scopus a \$rozos-(ör) szótul jỏ. 
orxlyukai egy barízdába nyulnak el, melly az cröszszel cgész a hegyig egyenközileg fut, melly egy lkissé görbült. Csak egy fajok ismeretes:

$A$ buibos nyomgólya. (Scopus umbretta.) Enl. 796. Vieill. gal. 250.

Varjunagysága, fekclés földszínï, himének Lollag ran a fejhátulán. Egész Afrikában elterjedt.

\section{A HIUcsorRok. (Csorratát-ok.)}

(Les Becs-ouverts. Hians. Lacép. Anastomus. Ilig. Klaffschnabel.

A gólyáktuli elválasztatásra nem birnak talán egyéb bélyeget, mint az orrondik erósségét. Csorrok két lemeze csak alapján csukódik és hegyén, középen pedig hiu tért hagy, melly azonban részint az elkopás sükerének látszik, mert látni ottan a szarvanyag rostjait, mellyek elhasznált szint mutatnak.

Keletindiai madarak ezek, s az egyik fehéres, ez

1. A pondiceri hiucsorr. (Ard. ponticeriana. Gm.) Enl. 932. Vieill. gal 251.

A másilk barna szürke, ez

2. A koromandeli csorratát. (Ard. coromandeliana. Sonner. It. II, 219.

Mindeniknek szárny-és farktollai teketék. Lehet hogy ezen utolsó csak fiatal. A harmadil szivárványzó fekete: 3. A lemezes csorratát. (Anas. lanelliger. Tem.) col. 236.

Arrul nevezetes, hogy mindenik tollának csöke szarvlapocba végzödik, keskenybe s a zászlót (szakállakat) fölülmulóba.

\section{A KEREPORRAK.}

(Les Dromes. Dromas. Pajkull.)

Igen hasonlitanak a csorratáthoz, mellyeknek majd- 
nem szokásait ís lábail birjáli ; de ässzenyumotl s alapján alul kissé duzadt csorrokon tojásdadoli a\% ortlyukak, - a szélek jól összeillúk.

Csak egy faj ismereles a Verestenger partjairul s a Senegaltul:

A gémecske kereporr. (Dromas ardeola. Payk.) Stokh. érkönyv. 1805. 8. rl. Col. 362.

Ruhízata fehér; kïpönyege s szárnya egy része feketél. $\left({ }^{1}\right)$.

$\Lambda$ TANTAL-ok, F. (FENEKLENEK.)

(Les Tantales. Tantalus. Lin. Nimmersatt.)

Lábaik, orrlyukaik s csorrok mint a gólyánál; de csorrok hála gömbölyäi, s hegye alí görbült s mindenik oldalín kissé kimelszetl: fejük egy része s néha nyakoké is, tollaktul cupasz.

1. Az amerikii feneklen. (Le 'T'antale d' Amerique. T'antalus loculator. Lin.) Enl. S68. Wils. VII. Lxvi. 1.

Gólya nagyságu, de vélionyabb; felér, szírny és farktollai feketék, esorra s libiti fekctések valamint feje s nyalia esupasz böre is. Mind a liét Amerikában él s minden tartomingba a\% esös ćrszak idcjére megy, hol az iszapos vizeliet vílogatja ki, hol föliép ligyükat keres. Járása lassú, természete ostoba.

2. Az afrikai feneklen. (Le Tantal d' Afrique. Tantalus ibis. Lin.) Enl. 339.

Fehér, szárnyain könyüden árnyalra biborral, csorra súrga, arca böre csupasz és sárga, sokáig ugy tekintetél a természetrizsgálók által, mint a régi egyiptomiaktul ,Ibis ${ }^{66}$ név alatt annyira tiszteltetell; de ujjabb vizzgálódások bc-

(') Dupont, Ann. des. sc. natur. IX. xLv. rl. Ez az Erodia amphilensis, Salt., Voy et Abyss., a tlas pl. XXXI. 
bizonyitak, hogy az Ibis egy sokkal kisebb faj, mellyrül alább szólandunk. Ezen fencklen közönségesen nem is találtatik Egyiptomban; hozzánk a Senegaltul hozatik. A ceylani feneklen. (Le Tantale de Ceylan. Tantalus leucocephalus.) Encyc. méth. Ornith. 66. rl. 1. k. Vieill. gal. 247.

Mindnyája között legnagyobb, csorrot is legnagyobbat bir. Arcbóre s csorra sárgák, tollazata fehér, mellén egy ör s tollai feketék, farcsikában hosszú rózsaszín tollak, mellyeket az érszakban elveszl. $\left({ }^{1}\right)$.

\section{A KALÁNOSAK. F. (KANÁLGÁZOK.)}

(Les Spatules on Pallettes. Platalea. Lin. Lüffler.) (²).

Egész alkatokban küzclitenck a haltyukhoz, de csorrok, honnan nevöket vették, hosszú, lapos, mındenütt szćles, de kivált vége felé kanál-idomu kerek liöggé szélesül és lapul ki; alapjátul két esekély, egyenközös barázda indul el, a végig terjedó, pontosan nem maradva a szélekkel közegyenes. Orrlyukai petésck, s mindenik barázda credetétül nem messze nyilnak meg; apró nyelvök, hálózott száraik, eléggé nagy uszhártyáik, két igen kis valibelök, kevessé izmos zúzájok, tulajdon izom hijányu algégejök, azok mellyek a haltyunál, de csorroktul a kiszélesbülés minden eröt elvesz és másra alkalmatlanná teszi óket, mint az iszapban turkálni s vizi bogarakat és apró halakat halúszni.

1. A feliér kalános. F. (La Spatule blanche huppée. Pla-

(') A. h. a tejes feneklen (Tantale lacté, Tant. lacteus. T.) col. 352 .

$\left(^{2}\right)$ Platalea, vagy platea, latin nevck, néha azon jelentésüek a pelikånnal. 
talea leucordia. Gm. Der 14eisse Lüfler. Eul. 10.5. Naum. Pot. 44. 87. k.

Egészen fehér szinii, fojhítulín bubbal, eltcrjedt az egísz a rilígban, magats lákion fészkel. A bubatlan kanálgciz. Bufl. Hist. des Ois. VII. kül. 21. rl. Bail szerint csak amamnak fiatala. Bubliján kivial még arrul ismerhető hogy szárny tollai feketével szegvék:

2. A rózsaszinü kancilgaiz. (Le Spatule rose. Platalea aiaia. Enl. 165. Vieill gal. 248.

Arca csupasz, lollazatán kïlönbözö árnyóklatu vidím rúzsitféstéseh, idörel sütétebbé lecndök. Dél-anerikábul.

\section{Negyedik család.}

A HOSSZCSORRUAK.

(Longirostres. Langschnäbler.)

Számos parti (gázló) madarakbul áll, s ezeknek nagyobb száma Linnének Scolopax nemét képzé, mig músok a Tringa nemben voltak összezavarva, részint annak bélyege ellenére, - az igen rövid hüvelyknek t. i., melly a földet nem éri meg. Végre kevés szám a lilék közé téteték, mivel hüvelyke egészen hibázik. Mindezen madaraknak majdnem azon idomuk van, azon szokások, s gyakran még azon színelosztások is, mi okbul igen nehéz óket egymástul megkülönböztetni. Általában bélyegezik óket vékony, hosszú, gyönge csorr, melly mást nem igen enged meg nekik mint az iszapban vájni, ott férgeket és apró madarakat keresve; ezen 
csorr idomának különböző változtásai a nemek és alnemek fölállítására szolgálnak.

Limné elvei szerint ezen madarak nagyobb száma egyesítendö volna

A LEBENKe, LABonka; (sNef. F.) nemben.

(Scolopax. Bécasse. Schnepfe.)

Mcllyet mi csorra különbségei szerint igy osztunk föl, mint köretkezık:

\section{A BATLÁK. (IBISZ CIBIK. F.) (Les Ibis. Ibis. Cuv)'. (').}

Gmelin tantalusaitul elválasztjuk öket, mivel csorrok, noha hajolt, mınt a feneklencké, de solkkal gyöngébb, kimetszéstelen a hegyén, az orrlyukak alapjának híta felé nyılıak, s mindenik egy barázdíba folytatódile, melly egísz a hegyig megy. Különben czen csorr elég vastag, alapján majd négyszögủ, feje vagy még nyaka egy része is mindig csupasz. A külsö ujjak alapon igen hártyásak s a hüvelyk elég hosszú, hogy jól támaszkodjék földre.

Vaunak rövid, hálós száruak, ezek az legerösebb és legnagyobb csorruak:

1. Az ilisis batla. ( $L$ ' Ibis sacré. Ibis religiosa. Nob. Abou-Hannes. Bruce. It. 35. rl. Tant. aethiopicus. Lath. A vén, Cur. Rech. sur les. Oss. foss. I. köt. s a fiatal. Sarign. Descr. de l' Egypte. Hist. Nat. des Ois. 7. rl.

Leghíresebb faj. E madár Eegyptom templomában

(') Ime ismét egy megkülönböztetés, mellyet Vieillot (gal. 246.) forrás megnevezés nélkül vett, noha az én Mémoire-om az Ibistül, hol azt alapitám, tizenöt évvel van elöbb irva, mint a mi a madarak rendszerériil iraték. 
tartaték, egész vallásosságig hatíros tisztelettel; holla után bel)alzsamozák, némellyek szerint, mivel kigyúkat evék, mellyek azon tartományokban igen veszedelmesek lehellek volna, misols szerint, mivel nemi viszony mutalkozik tollazata s a hold phasisai közölt; egyebek szerint régre, mivel megjelcnése a Nilus nevekedését jelenté. ( ${ }^{1}$ ). Sokáig azt hiték, hogy ezen Ibis az afrikai feneklen; most már tudjuk hogy szóbeli nemünkhöz tartozik, tyuknagyságu, fehér tollazatu, kivévén szírnytollai végut, nuclly fekele, a régsö takarók zászlója kinyult, foszlott, violist csillogó felete s a számy és fark végét betakarok Csorra lábai fekcték valamint feje s nyaka egész esuprasz rósze: ezen rísz a fiatalnál, legalább felsö részćn, apró feketés tollakkal fedett. Ezen faj egész Afrika kiterjedésébeu találtatik. $\left.{ }^{2}\right)$.

A mís ibiszck szárai vértezctlck : csorrok clégr állanosan vékonyabb.

2. 1 veres batla. (I' Ibis rouge. Scol. rubra. Lin. Tantalus. ruber. Gm.) Enl. 80, 81. Wils. VIII, Lxvi. 2.

Amerita minden részeincli madara, jeles szép piros szinciril, mis színytollai vége fekete. Aprai eleinte feketis pelyhück, majd hamvasok, utobb repühni kezdestior feheresck leszach: a reess szin esak liet ér mulva jö clö s idovel rgyre fonyestil. Ezon faj nem ntaz, csapatonként il a folyamok kiömlisei mellett a mocsáros helyeken. Könnyen szclidithetö.

3. I magyar bata. (L' Ibis ver\%. Courlis. vert. Scol. falcinellus. Lin.) Enl. 819. Naum. 1. kiad. Pót. 28. Sav. Eg. Ois. vir. rl. 2. k.

Teste bibor-veresbarna, köpönyege sötétzöld, a fia-

(1) Savigny, Mém. sur l' lbis.

() A Moluccai szigeteken egy közel faj van, hosszabb esorru, bevescblé foszlott s részint felıérrel tarka fölöskkel; melle fölének 
talok feje s nyaka fehéresen pontozott. Szép madár déli Europában s éjszaki Afrikában, s cgész hilietöséggel azon faj, melly a régiektül fekete ibisznek, mondaték. ( $\left.{ }^{1}\right)$.

AZ UGARÁLYOK. KURLTK.

(Les Courlis. Numenius. Cuv. Brachvogel.) ().

Csorrok hajolt mint batláké, de vékonyabb, egész hosszában görgeteg: a felsö lemze vége túlhaladja az alsó lemezét, s cgy kissé elöbbén alá nyul. Ujjalapjai között hártyák vannak.

1. A kurli ugaraily. (Póling snef. Földi. Le Courlis d' Europe. Scol. arcuata. Lin. 818. Frisch. 224. Naum. 5. 5. k.

Kappan nagyságu, barma, minden tollainak széle fehéres; farcsika fehér, farka fehér és barra szalagu. Közép izü vad, a parlok hosszáthan közönséges, s szárazra is jól bemenö. Kurli nevét kiáltozásátul kapta. ( $\left.{ }^{2}\right)$.

tollai hosszuik és hegyesck (Ibis molucca, Cuv. Molukkai Ibisz), s Bengalában egy másik, kissé foszlott és hamras takarókkal (bengalai batla, Ibis bengala, Cuv.)

A. h. Ib. papillosa, Temm., Col 504; - Tant. calvus, Gm. enl. 867 ; - Ib. nudifrons, Spix, 86; - Ib. oxycercus, uo., 87 ; - T. albicollis, Gm., v. Couricaca, Margr. enl. 976; - Tant. cayennensis, Gm., enl. 820 ; - Ib. plumbeus, Temm., col. 235; - Tant. melanopis, Gm. Lath. III, LxxIx. rl.; - Ibis chalcoptera, Vieill. gal. 246 , v. Tant. hogedash. Lath.

(') A. h. Tant. albus, et T. coco, Gm., enl. $915 ;-T$. cristatus, ua. enl. 811; - Ibis. leucopygus, Spix, 88, hogyha nem egyez, meg a veressel; Tant. leucocephalus, Lat. III, Lxxx, 2.

(') Numenius, a nèoménie, új hold, szótul származik, mivel csoría új holdidomu.

( ${ }^{3}$ A. h. Num. virgatus. Cuv. (Courli à méches etroites) a ReményfoktuI, enl. 198; - Num. lineatus (Courl. à m. étr. de I' Inde); - Num. longirostris, Wils. (hosszúcsorru amerikai ugarály.) Am. II, XXIV, 4 ; - Num. borcalis, ua. VII, LVI, 1. 
2. A kis kurli. (Esö snef. F. Le Corlieu d' Europe. Petit courlis. Scol. Phoeopus. Lin.) Enl. 842. Edw. 307. Frisch. 225. Naum. 10. 10. k. ${ }^{1}{ }^{1}$.

Amamál felényivel kisebb, de majd hasonló tollazatu $\left({ }^{2}\right)$

A tulajdonképi ц.евеNкÉK. (snef-ek. F.), labonkcik. (Les Bécasses propr. dits. Scolopax. Cuv. (3). Eig. Schnepfe.)

Csorrok egyenes, orrlyuk-barízdáil igen kïzelre hatnak a véghez, melly egy kissé elöreduzad, hogy az alsó esorrlemezt meghaladja s mellynck kïzepén egy egyszerü barázda van. Ezen rég lígy s igen érzékeny; holta utín kiszáradrán, pontolt fülíletet laap. Lábaikon nincs hártya. Különös bélyeg ezen madaraknál az összenyomoli fö, s az igen hátra helyezetl nagy-szemek, mi okbul igen ostuba tekintelök van, mellyct szokásaik által sem hazudtolnak meg.

1. Az erdei lebenke. (Lrdei snef. F. La Bécasse. Scol. rusticola. Lin. Die grosse WValdsnepfe.) Enl. 885. Frisch. 126. 127. Naum. 1. kiad. I. 1. k.

Mindenki ösmeri; ruházata folül tarkízoth szürke, veres és fikete lütokkal és szalagolkial; alul szürke, feketés lieresztronalokkal. Afegkülünbüztetö bélyege négy fe-

(') Phaeopus, hamvasláb, Gesner csinálta szó.

(2) A. h. A karcsorru ugarály. (Num. tenuirostris, Bonap. k.); - A vereses farcsiku, ug. (Num rufus, Vieill. gal. 245 ; - A félcsorru ug. (Num. brevirostris, T.) col. 381.

Jegyz. A csorr e nemben s majd az egész csalídban idővel egyre hosszabbul.

(3) Scolopax, görög neve a lebenkének, a vxoגò tul, mivel csorrok egyenes, heģyes. Vieillot Rusticoli-ra változtatá. (Lebenke, a lebegve repüléstül.) 
kete széles kereszt szalagban áll, mellyek feje hátulán egymást követik. A lebenke nyáron a magas hegyeket lakja, s octoberben erdeinkbe száll alá. Magán vagy párosan jár, kivált hotnályosodáskor (szürkületkor); férgeket és bogarakat keres a földben. Nyáron csak kevés marad hátra a sikon. $\left({ }^{1}\right)$.

2. A szalonka. F. Vizköri lebenke. (La Becassine. Scolopax gallinago. L.) Enl. 883. Frisch. 229. Naum. 3. 3. k. (Herrschnepfe.

Kiscbb, de csorra amazénál hosszubb, megkülönböztctik liét széles hosszanti feketés szalag által a fején, barna-és sárga foltos nyak, feketés köpönyeg által két sárga hosz-szalaggal, szürke hullámu barna szárnyak, s fehéres has által, oldalvást barnás hullámzattal stb.

Mocsárolban, folyók partjain, forrísok körúl tartózkodik; láthatlan magasságra emelkedik, és a látmatgason túl igen messzirül hallatja keeskééhez hasonló éles szózatát.

Majd változás nélkül találtatik a földgolyó minden részében.

3. A nagyobb lebenke (nagy sacilonka. Le double Bécassine. Scol. major. Gm.) Frisch. 228. Naum. 2. 2. k. Die grosse Sumpfschnepfe.

Egy harmadával nagyobb termetï az elóbbinél, mellytiil még abban is különbözik hogy fölülső szürke és sárga hullámai kisebbek, az alulsó barnák pedig nagyobbak és számosabbak.

4. A kis lebenke. (Kis szalonki. La petite Beccassine. la

(') A. L. egy igen közel fajt éjszaki Amerikábul. (Scolominor, Gm.) Arct. Zool. II, xıx, rl.; Vieill. gal. 242 ; Wils., VI, XLVrir, 2 ; - Scol. sabini, vig. Trans. lin. XIV, xxı. rl. ha ez állandó faj.

CUVIEIi I. K. 
Sourde. Scol. gallimula. Gm. Gyepi csirke. F. Die Moorschnepfe.) Enl. 88. Frish. 231. Naum. 4. 4. k. Majd felényirel kiscbb mint a rendes szalonka, s fején csak egy fekete szalag van, köpönyege alapja ércfényú zöld szint játszik. 'Tarkroját szürke félkörr foglalja el, oldalai mint melle barna foltosak. Mocsárainkban majd egész évben megmarad.

Mind ezen madarak jeles eledelt adnak s télen elég közönségesek asztalainkon. $\left.{ }^{1}\right)$.

A többi lebenkéktuil megkiulönböztetendö:

5. A szürke lebenke, szïrke szalonka. La Bécassine grise. Sc. grisea. Gm.) Wils, VII. Lvin. 1. Scolopax Paykuli, Nils. Orn. svec. II, 2. rl. s nyári öltözetben. Scol. noveboracensis. Lath.

A tübbicktiil abban kïlönbözö, hogy iggen kitünö fél-hárlyás a külsö ujjai köze; Télen hamvasabb, verhenyebb nyáron, faresika mindig fehér és fekete foltos. Szinte láttalik Europában. $\left({ }^{2}\right)$.

\section{A SZENTENKÉK. (SZÁRNYASZEMESEK.)} (Les Rhinchées. Rhynchaea. Cuv.) ( ${ }^{3}$ ).

Afrikai s indiai madarak, mellyeknek majdnem egyenlö liét csorrlemeze kömnyüden meghajlott régü, orrlyuk-ba-

(') A. 1. Scol. Brehmii, Kaup., (la Béccassin muette. d'Eur.) Isis, 1825; - Scol. puludosa, Gm. eul. 895, melly $=$ Scol. gallinago, Wils. VI, XLVII. 1; - Scol. gigantea, Temm., col. 403.

Buffon Brunette-je, Scol. pusilla, Az angolok Dunlin-a, nem egyéb rniut az örves árpacsirta, vagy a szürke partiram nyári öltözetben.

(") Ugy látszik, Vicillot ezen osztatnak tartja fön a scolopax nevet, legalább, mint hiszem, ha 211. xl.-ja ezen madarat ábrázolja; de az kevessé pontos. Leach ebbuil csinálta a Macroramphus nemet.

(3) Vieillot fogadta el e nemet és nevet, gal, 240. rl. 
rázdái eljönck a felsỏ csorr végeig, mellyen páratlan barázda nines. Ujjaikon nines uszhártya. Lebenke idomuk mellett vidámabb színüek s leginkáhb jelesek szárny és farktollaiknak szép szemfoltairul.

Különbféle szinkeveréküeket ismerni belólük, melylyeket Gmelin mint fajtákat egyesít a Scolop. capensis (reményfoki szemenke) név alatt s mellyeket Temmink valóban csak különbözö lioruaknak állit. (').

AZ ISŻAPGÁZAK. (MOCSÁRGÁZAK).

(Les Barges. Limosa. Bechst. Sumpfwader.) $\left({ }^{2}\right)$.

Csorrok egyenes, néha könnyüden fölfelé is hajolt, s még hosszabb, mint a lebenkéké. Az orrlyukbarázda egész az elöszélig megy, melly egy kissélenyomott, tompa, páratlan barázdája nincs, sem pontozata. Külsó ujjaik alapja között van hártya. Termetök sokkal karcsubb s száraik emeltebbek mint a lebenkélsé; a sós mocsárokat s tengerpartokat szeretik.

1. A küllös farku zszapgáz. (La Barge aboyeuse ou d̀ queue rayée. Scol. leucophaea, Lath. laponica. Gm.) a fiatal. Brit. Zool. XIII. rl. Briss. v.; rl. xxıv. k. 2. A vén nyári ruhában. Enl. 900. ( $\left.{ }^{3}\right)$.

Télen, sötét barna-szürke, tollai fehéressel szegvék,

(1) Scol. capensis, $\delta$ Gm. enl. 922, a vén lesz; Scol. capensis

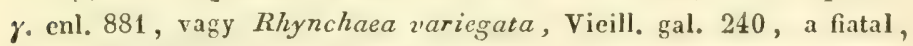
s enl. 270, közép-kor. A chevalier vert, Briss. és Buff. (Rallus benghalensis, Gm.) Albin., III, 90, még e nembül van, s nem látszik különbözui az enl. 922. - ábrázolt fajtátul. - Jegryz. Csak ezen utolsó rajzolat mutatja jól ezen apró alnem csorrát. A. b. még egy brasiliai jól kïlönbözơ fajt: Rhynchaca hilarea, Val., Bullet. des sc. de Ferussac, 2e cah.

$\left.{ }^{2}\right)$ Vieillot e nevet Limcula-ra változtatá, gal. 243.

(3) Gmelin e madár fiatalát a következơ faj fajtájảvá csinálta, és Brisson ábráját idézi, Scol. glottis alatt, melly víziram. A véu 
furcsika fehér barnával liülözve, stb. Nyáron verhenyes, barna híltal. Farka mindig fehéres és feketéssel szalagolt.

2. A fekete farku iszapgíz. (La Barge à queue noire. Scolopax aegocephala, et belgica. Gm. Limosa melanura. Leisler.) Téli ruhában Enl. 874. nyáriban no. 916.

Télen hamras szürtie, hátán barnább, hasa fehér; nyáron feje, nyaka, melle veres, köpünyege barna, veres foltokkal, alul harna veres és fehér szalagokkal, farka mindig fekete, végén fehérrel szegre.

Ezcn hét madár még egyszer olly magas mint a lebenke. 'Toll-ráltozísaik adtak okot a fajok nagy szaporitísára. Az utolsi nyáron Ifolland éjszaki sikjait lepi el. Kiáltása éles mint a kecskcé. $\left({ }^{2}\right)$.

\section{A pattiramok. (PARTJgázoK.)}

(Les Mauberhes. Calidris. Cur. Tringa. Temm. Strandliiufer.)

Csorrok rige lenyomoth, orrtyuk-barázdaja igen hosszú mint az iszapgázoknál; dr a csorr állalában nem hosszabl) a fejnél; könyiiden szegett ujjaik nen birnak luírlyál alapjokon, s hüvclykök alig elég nagy megérinthetui a földet; középszerúleg magas stáraik s rövidült

- Scol. laponica. A Limosa Meyeri, Leisl. és Temm., ezen tulajolon faj téli rubájában, - a Lim. rufa, azon tulajdon, "yári öltözethen.

(') A. 1. Scol. fedoa, Lin.; Wils., Am. VIJ. Lvı. rl. 4, vagy la Barge marbré; - Limicula marmorata, Vieill. gal. 243. -Mlegkülönbözlptheto a Scol. terek, Sc. cinerea, Gm.; Guldenstein, Nov. act. petrop. XIX, Xıx. rl., mellynek csorra fölfelé hajolt, lábai fél-úszhártyásak. A kardorrokhoz vezet.

(2) Calidris, hamvas, foltos madít, folyókat és erdozket kereso̊. Arist. Brisson a nagyobb partiramra alkalmaztatá. 
termetök otrombább idomot adnak nekik mint a mocsárgázoké. Szinte sokkal kisebbek is.

1. A nagyolb partiram. (La Maubèche; Sandpiper és

Canut az Angoloknál. Tringa grisea, Tr. cinerea. Tr. canutus. Gm.) Enl. 366. Edw. 276. Wils. VII.

LVII. 2.

'Téli ruhájában fölül hamvas, alul fehér, nyakelején mellén feketés foltokkal. Nyíri tollazata: ( $T r$ r islandica. Gm. Tr. rufa. Wils. VII, LviI. 5.) fölül sárgával és felietéssel follos, alul verhenyes. A Tr. naevia. enl. 365. közép évszakbeli. Farktakaróji mindig fehérek, feketével küllözven, tollai szürkék. Majdnem szalonka-termetü.

A kisebb (feketés) partiram. (La Maubèche noiratre.

'Tringa maritima. Brün. Tr. nigricans. Montag. 'Tr. lin. IV. rl. 2. k. 1.

Az elóbbinél kevéssel kisebb, szürke, köpönyege feketés, szárnyain fehér hullámzatu, hasán fehéres. Franciahonban ritkább, de Holland partjain közönséges. Csak köveken nyugszilk meg. $\left({ }^{1}\right)$.

\section{A НОMOKGÁZOK. HOMONKÁK.}

(Les Sanderlings. Arenaria. Bechst. Calidris. Vigors.)

Mindenben hasonlítnak a partiramokhoz, azon egyet kivéve, hogy hüvelykök egészen hibázik, mint a liléké. $A$ rendes homolgciz. (Charadrius calidris. Gm.) Briss. V. Xx. rl. 2. $\$$; Vieill. gal. 234.

Egy ismeretes faj. Télen : fölüI szürlsés, alul és hom-

(') A. h. ezen europai fajokat: Tr. Temminkii, Leisler, col. 41. 1; - Tr. minuta, Leisl., Naum., 21. f. 50. s ez idegen fajokat: Tr. leucoptera, Gm., Lath. Syn. 111, Lxxxu. rl.;-Tr. albescens, Temm., col. 41, 1; - Tr. maculosa, Vieill. Dict.; - Tr. pusillu, wils. xxxvrr, 4 . 
lokín fehér, szírnyai feketések, fehérrel tarkázva. Wils. VIII, LIX., 4. Nyáron: háta sárga s fekete foltos, melle feketís pontozással. (Charadrius. rubidus.) Wils. VII. LxmI. 3. $\left({ }^{1}\right)$.

Az ÁRPAcsinták. (tengeri pacsirták.)

(Les Alouettes de mer. Pelidna. Cuv.)

Nem egyebek mint apró partiramok, fejöknél egy kissé hosszabb nyakkal. Lábaik szegúlyét észre sem vehetni.

$A$ kis cirpacsirta. ( $L$ ' Aloulte de mer. ou petit Maubeche. 'Tringa cinclus et alpina.)

Egy harmaddal kisebb) a nagy partiramnál s mint az, télen foilül haunvas, alul fehér, melle szïrkével felhös, (Wils. VIII, LviI. 3.); nyáron fölül sárga tollazatot kap, fekete foltokkal; apró fékete foltokal nyakelöjén és melén, s egy fekete paizst a hasa alalt. Ez az örves cirpacsirta, vagy 'Ir. alpina. Gm. vagy 'Tr. cinclus. B., cul. 552 : Wils. VII, Lvr. 2. - 1 rendes árpacsirta ( $L$ ' Alouette de mer ordinaire 'T'r. cinclus. L.) enl. cnl. 851. küzép ívszaki állapotban. $\left({ }^{2}\right)$.

\section{A HAJLÁRAK. (Les Cocorlis.)}

Az árpacsirtáktul csak abban kiulimbüznck, hogy esorrok kissé hajlott.

Ismereles faj:

(') A téli öltözetbeli kis árpacsirtá-val összezavartaték, melly petit Maubiche, s Tringa arenaria nevet is hord. Brisson, nevezetesen, egy madár leirását adja s egy másiknak ábráját. $A$ calidris tringoides, Vieill. gal. 25t, ezen nyár-ruházalu madár rosz ábrájának látszik.

${ }^{2}$ ) Ide jö hihetỏleg a $T$. macroptera, Spix, xcir. 
A közönséges hajlárcsirta. (Scolopax subarcuata. Gm.

Numenius africanıs.) Naum. 21. 28. k. - és 20. 27. k.

Télen fölül fekelés, szürkésen hullámozva, alul fehéres; nyáron a háta feketével és sárgával foltos, szárnyai szürkék, nyaka s test-ala veres. Mindenütt találtatik de elég ritkán.

\section{A KASZACSORRUAK.}

(Les Falcinelles. Falcinellus. (').

Csak egy fajok ismeretes:

A törpe kaszacsorr. (Scol. pygmaea. L.) Afrikában honi, de néha Europában is láttatik.

\section{A víbic-ok.}

(Les Combattans. Machetes. Cuv. Kampflahhn). ( $\left.{ }^{2}\right)$.

Valódi partiramok idomra s csorra nézve; csak külsö ujjaik között van majd akkora hárlya, mint a viziramoknál és iszapgázoknál.

Csak egy fajok ismeretes:

A bajnok vibic, (bajnok libuc. F. Tring. pugnax. L.) Enl. 305. 306.

Kissé kisebb a szalonkánál, jeles azon dühös harcrul, mellyel a hímek a nö birtokaért tavaszszal megküzdenek. Ezen évszakban fejök részint veres bibircsokkal takart, nyakok sürü tollpamaggal van körülvéve, olly változólag rendelve el és színezve s olly furcsán düledve ki, hogy két hasonló egyént soha nem találtak; — söt még: ezen idó elött és után is olly tarkaság van tollazatukban

(') Vieillot e nevet Erolia-val váltá föl. Igaztalanul állittaték, hogy e madárnak hüvelyke hibázik.

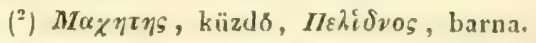


hogy a természetvizsgálók több képzelt fajt csináltak belölük. $\left(^{1}\right)$. Lábaik mindig sárgásak, $\mathrm{s} \mathrm{ez}$, valamint csorrok s külsö félúsz-hártyájok jó ismertetó jelek. Ezen egész Europa éjszakín liözönséges madár, a mi partjainlira is eljö, kivált tavaszszal, de ilt nem lészliel.

Ancrikában rammak a parliramokhoz hasonli apri madarak.

\section{AZ IRAMÚSZOK.}

(Hemipalcma. Ch. Bonap.)

Mcllychnck lábai clül fël-úsz-hárlyások. - Fajok a Tringa semipalmata, Wils. VII. Lxin. Tringa brevirostris. Spix. xcIII.

A partiramokhoz lï̈zel helyezendönck látszik

\section{A I APÁTGÁz, (lapátcsorr.)}

(L' Eurinoringue. Eurinorhynchus. Wilson.)

Melly amazoktul lenyomott, (lapitidomulag) kiszelesült végü csorráral, a línúlgázéhoz hasonlóval, különbözils, s mellynek egy ismeretes faja

A törpe lapcitcsorr. (Platalea pygmaea. L. Eurinorhynchus griseus.) Wils. 'Thunb. Acad. svec. 1816. vi. rl.

Legrilkább a létezók kiözött, mert csak egy cgyéne ismereles, fülül szürlic, alul fehér, alig ezy árpacsirlanagyságu.

(') A Chevalier varie, Buf,, Esp. IV; Briss., V, xvı, 2. (Tr. littorea, Lin., T'r. ochropus, B; Littorea, Gm.); a Chevalier, proprement dit, Buff., esp. 11.; Briss., V, xvir. rl. f. 1. Gmelintiil idézve Scol. calidris, alatt; a Maubèche propr, dite, Briss. V. xx. Il. 1. k. (Tring. calidris, Gın.); Frisch madara a 238. rlapon, nem egyebek különböző ruházatbeli zibucoknal, - $s$ még több fajtákat is lehetne igy összeállitani.

Meyer szerint a Tringa grenowicensis, I,ath., szinte fiatal vibuc. 


\section{SZÁRCSIRAMOK.}

\section{(Les Plialaropes. Phalaropus. Briss.) (1).}

Apró madarak; esorrok laposabb a partiramokénál, de különben azon arányuak s azon barázdákat birók; lábaikon az ujjak igen széles hírtyáral szegrék, mint a szárcsáké.

Ismeretes faj:

A feketés-szcirnyu szárcsiram. (Tringa lobata. Tr. fulicaria. Lin). ( $\left.{ }^{2}\right)$. Fhalar. fulicarius. C. Banap.

Csorra erös mint ezen családé. 'Télen fölül hamvas, alus s fején fehéres, tarkóján fekete szalag, = Tring. lobata, Phal. gris. Edw. 308; nyáron fekete lesz fölül sárgával lángolt, alul verhenyes; mindig pedig feliér szalagg van fekete szányán. Ez a Phalarope rouge. Phalar. rufus, Bechst. et Meyer; Tringa fulicaria. Lin. Edw. 142. $\left({ }^{3}\right)$. Crymophile roux, Vicill. gal., 270. Ezcn madúl Europában ingen rilká.

\section{A KöIIENGÉREK (hengérek).}

(Les Tourne-pierres. Strepsilas. Ilig. Steinwäler). ( ${ }^{b}$ ).

Lábaik kissé alacsonyabbak, csorrok rövid, ujjails mindeu hártya nélkül mint a valódi partiramok; de a csorr kúpos, hegyes, le- vagy össze nem nyomolt, nem duzadt, s az orrbarízda nem ér feléig. Hürelykök igen kissé ér a földhöz. Egy kissé az clöbbiekénél erösebb és

(') Vieillot e nevet Crymophila-vel cserélte föl.

(2) Meyer rosszul zavarja össze ezen madarat, Edw, 308 a Tringa hyperboreá-val és T'r. fusca-val, mellyek coorra mint a zizira. moḱe s mellyekbül mi a karély lábua-kat csináltuk.

$\left({ }^{3}\right)$ Gmelin második zavart okoza, e madarat ugy idézve, mint fajıit a hyperborea, alatt.

(') Vieillot e nevet át változtatá Arenaria-ra, gal. pl. 237. 
aránylag durvább esorrokat köhengeritésre használják, azok alatt férgeket keresve.

Egyik faj:

A tolmaics köhengér. (Tringa interpres. Enl. L. 856.)

Köpönyege feketérel s reressel regyes, feje hasa fehér, melle s arca fekete, kiterjedt a liétszírazon, - mig egy másik barnáral és szurkérel tarka, talán csak kormiatti liülönbség. Enl. 340, 85̃7; Vieill. gal. 237. $\left({ }^{1}\right)$.

\section{A VIZ-IRAMOK.}

\section{(Les Chevaliers. 'Totanus. Cuv. IV asserläufer). ( ${ }^{2}$ ).}

Csorrok vékony, gömbölyủ hegyes, szilárd, - orrlyukírka nem haladja meg felét, felsö lemeze pedig vége felé egy kereset meghajlik. 'Termelök könnyü, száraik emeltek; hüvelykök igen kissé éri meg a földel, szélsö hárlyájok eléggé fejlett. Mindenik faj az egész földön találtatik.

1. A söldlibu viziram. (Züldlibu snef. F. Le Chevalier it pieds z'erts. Scol. glollis. L.) Albin. II, 69. Aldrov. Ornith. III, 535. Britt. Zool. rl.c. 1.?

Iszapgáz nagyságu, csorra nagy és crös, fölül és oldalríst hamvas barna, tolla szegései barna pontozatokkial, hasa farcsilia lichérck, farka keskeny, rendellen, szürke s fehér küllökkel küllözre, hábai zöldek. Nyáron nyakián és mellén barna foltukat kap, télen egész teste fehér. Europai víz-iramaink liözült legnagyobb.

(1) Lásd még Edw., 141; Naum., pótl., 62. f. 118; Wils., Am. VII, Lvı. 2. A Chevalier varié, enl. 500, mellyet Mejer a kóhengérekhez számít, nem eģéb víbucnál.

(2) Totano, relencei neve egyik mocsárgáznak víz-iramnak. 
2. A felele viz-iram. (Te Chevalier noire. Barge brune. Buff. enl. 875.) Sbolopax fusca. L. Frisch. 236. $\left({ }^{1}\right)$.

Karcsu mint valami iszapgáz, nyáron fölül feketés barna, alul palaszin, tollai fehéressel szegve vagy kiharapálva (szegletezve); farcsilsa fehér, farka barnával és fehérrel küllözve, melly két bélyeg többé kevesebbé minden víz-iramunkban föltaláltatik; lábai vereses barnák. Télen mele s hasa fehér lesz, fölül majd hamvas lábai veresek. Ekkor a veres lábu nagy viziram. (Piroslábu snef. F. Scol. Calidris Lin.) Enl. 876. $\left({ }^{2}\right)$.

3. A veres libu viziram. (Le Chevalier aux. pieds. rouges ou Gambette. Tringa gambetta. Gm.) Enl. 845. Frisch. 240. Naum. 9. 9. k.

Nyáron: fölül barna, fekete foltokkal és nehány fehérrel tollai szélén, alul fehèr, barna foltos, kiválı nyaKán és mellén, lába veres, farkán számos barna s fehér küllö. Télen foltjai majd elenyésztek, köpönyege majdnem egyidomú barna szürke; ez az Enl. 827. képe. De termete egy negyeddel kisebb.

4. A tavi viziram. (Le Chevalier à longs pieds. Bonelli. Totanus stagnatilis. Bechst.

Az elöbbinél valamivel kisebb, de lába még vékonyabb és magasabb; nyáron hála barna, reudellen fekete foltokkal, hasa fehér; nyaka s melle alatt barna foltok. Télen köpönyege egyidomulag szürke, teste ala fehér. Farka küllózele rendetlen s szélek közegyenes.

5. A folyami viz-iram. (Le Becasseau. on Cul-blanc de rivière. Tringa ochropus. Lin.) Enl. 843.

Fölül bronz-fekelés, tolla-szélei fehćresen pontolva,

(1) Meyer szerint a Scol. curonica et cantabrigiensis, és a Tringa atra, Gm., e madárhoz tartozók. A két elsó fiatal.

$\left.{ }^{2}\right)$ A barge gris, hamis név alatt. 
alul fehér, nyaka clött s oldalain szürke foltos; három fekete szalag esak farka alfelén, lábai zöldesek; a két elöbbinél még kisebb. Jó husu vad, folyöink szélein közönséges, noha ott elég szomoruan él.

6. Az erdei viz-iram. (La Bécassean des bois. Tringa glareola. Gm.)

A folyamitul leginkább abban különbözik, hogy hét vagy nyole felictés szalag ran farka egész hosszában. Háta halavány foltai szélesebbek. Télen nyaka s melle foltai majd egészen eltünnck.

7. Az apri viz-iram. (La Guignette. T'ringa hypoleucos.

L.) Enl. \$50. 'Totanus macularius. Wils. VII, LIX.

1. 2.?

Leghiscbl) viz-iramaink kïzött; cirpacsirta-nagyságu, bronz-zöldes-barna fülül, szárnyán sírga s felcete lieresztvonatokkal, clül s alul fehér, - faresika s farka középsö tollai a háta színcivel megegyezók, csak az oldaliak vannak, mint a tübb viz-iramoknál, fehér és feketével küllözve. Fiatal korában világos sárgával vannak háta tollai s szárnya kis talkaroji szegve. Életmódja s honolása mint a folyami víz-iramé.

Az idegen riz-iramok között föképen egy nagy csorru s félig úszhirtyás lábu faj megjegyzendö Éjszak Amerikábul: 8. Az úszós viz-iram. (Scolopax semipalmata. Lin.) Encycl. méth., pl. d' orn. Lxxi. rl. - 1. k. Wils., VII, I.VI, 3 .

Majd akkora mint a mi elsö fajunk, csorra rövidebb és nagyobb, tollazata fölül barna szürke, alul fehéres, nyakán s mellén barnás foltokkal, ujjai jól szegettek, úszhártyái jólsorák s majd egyenlök. ( ${ }^{1}$ ).

(1) Bonaparte ezen bélyegrc épité a CAToptrophorus alnemet. A rendes viz-iramhoz adandók: Tot. speculiferus, igen hasonlitó a Semipalmatus-hoz, de „magasabb száru, hosszabb csorru, rendes lá- 


\section{A KARÉLYLÁB-ak.}

\section{(Les Lobipèdes. Lobipes. Cuv.) ( ${ }^{1}$ ).}

Mellycket a szárcsiramoktul clválasztandóknak hittünk, noha azoknak lábait birják; - de csorrok mint a víz-iramokć. Illyen :

A nagy kürves karélyláb. (Le Lobipède à hausse-col.

Tringa hyperborea. L.) Enl. 766. Kinek. ,Tringa

fusca"6ja, Edw. 46, hihetóleg a jérce vagy fiatal.

Ezen kis madár fölül szürke, alul fehér, válla veressel befútva, fehér torka körül egy széles verhenyes örv. $\left({ }^{(}\right)$.

\section{A SZÍJLÁBAK. (GYÖNGYVÉREK. Földi.)}

(Les Échasses. Himantopus. ${ }^{3}$ ). Briss. Strandreiter.)

Csorrok gömbölyú, vékony, hegyes, még nagyobban

bu; Tot. vociferus, Wils., VII, Lvur, 5., vagy Toi. melanoleue cos, Ord. uo; - Tot, flavipes, Wils, LVIII., 4; - Toto solitarius, (Tot. glareolus, Wils.) Wils. VII, Lvm., 5.

A Tot. bartramizs, Wils. VII, LIX, 2 , aránylag a többi fajokénál rövidebb csorru, de különben mind azon bélyegü.

Jegyz. Ezen víz-iramok neme, Buffon által sok víbuc fajtákbul rakva össze, Linné által minden ok nélkül elszóraték a Scolopax és Tringa nemekbe. Ezen zavar nincs is még egészen elháritva, mert minden idegen fajt nem vissgálhattam meg. Látható azonban hogy meghatározísaim szerint Illiger ATrtes neme meg, nein állhatott.

Megjegyzendö még hogy a legpontusabb leirisok szerint sem határozhatni meg biztosan a fajohat, mig nem föncbb hiję̧zett csorridomok szcriut elrálasztattak az én viz-iramain a partiramoktul s moesírgázaimful. Ez gåtolt meg, hogy teljesen adjam Beclistein és Meyer synonymiáját.

(') Vieillot, csak hogy változlatliasson, ezeknél a I'Halaropus nevet hagyta meg.

(2) A. h. Phalaropus frenatus, Vieill., gal., pl. 271. v. Phalarope liseré, Temm., col. 270 ; Wils., Am., IX, Lxır., f. J. ? Ez o Holopodrus alnem Bonap. K.

( $\left.{ }^{3}\right)$ Himaniopus, szij-láb, fyöngescige tniatt; ezen madár neve Pliniusnal. 
mint a viz-iramoknál; orrlyulibarázdáik csak félig terjed. Az mi öket megkülönbözteti s nevöket adá, igen magas és rendkirül vékony lábok, hálós és hüvelytelen, s olly gyönge csontokkal, hogy alig tudnak járni.

Europában csak egy faj ismeretes:

A töcs szijlab; (rendes) (Gyöngyvér. F. Charadrius himantopus. L.) Enl. 878.

Fehér, sapkája, köpönyege feketék, lábai veresck; elég ritka, erkölcseit kevessé ösmerjük. ${ }^{1}$ ).

Máshova nem könnyen tehetók, mint ide:

\section{A Kardorruak. Földi.}

(Les Avocelles. Rocurvirostra. Lin. Säbelschnäbler).

Noha majd ujjaik hegyéig hárlyás lábaik mialt csaknem úszó madarak gyanánt tekinthetök; de emelt láb)aik, félig csupasz szírails, hosszú vékony, hegyes, sima és rugékony csorrok s ezen alkotísbul credı életmód egyszerüen oda törekesznek, hogy öket a lebenkékhez közelitsék. De legjobban bélyegzi óket s minden madárlul is megkülünbözteli magasra nagyon meghajló esorrok. Száraik hálúzottak, s hüvelyliök igen nagyon rövid, a földre nem érö.

Ismeretes fajok:

1. Az europai kardorru: (Avozetta K. F. a népnél: Cstutor-orr. Recurvirostra avocelta. Lin.) Enl. 353.

Fehér, sapkája s szárnyán három szalag feketék, lábai ónszinüek. Csinos madár, karesu temetü; télen a tenger partjain lakó.

2. Az amerikai kardorr. (Rec. americana.) Wils. VII. LxiIr. 2. Leach, Zoolog. Misc. 101. rl. Amatul reres sapka által különbözik.

(4) A. h. Him. nigricollis, Wils., Amér, VII, LVır. rl. 2., Vieill. gal. 229. 
Van még az Indiai-tenger parljain egy harmadik, egészen fehér, szárnyai egészen feketék, lábai veresek; ez 3. A keleti kardorr. (Recurv. orientalis. Nob). ( $\left.{ }^{1}\right)$.

\section{Ötödik család.}

\section{A NAGYUJJUAK. \\ (Macrodactyles.)}

Lábujjai igen hosszúk s a mocsári füveken való járásra söt uszásra is alkalmasok, kivált azon számos fajoknál, mellyeknél be van szegve. Azonban ujjok alapja között nincs hártya, még a külsőknél sem. Oldalvást többé kevesebbé összenyomott csorrok hosszú vagy rövid lesz a nemek szerint, de el nem érve az utolsó családbeliekének vékonyságát, gyöngeségét. E madarak teste is különösen összenyomott, melly alkotást a mellcsont keskenysége okozza; szárnyok középszerú vagy rövid, repülésök gyönge. Mindnyájának hüvelyke elég hosszú.

Két törzsökre osztattak föl, a mint szárnyok fegyveres vagy nem; de e bélyeg kivételt szenved.

\section{A parrák. F. (nagyujjgáz-ok.) (Les Jacanus. Briss. Parra. Lin). $\left({ }^{2}\right)$.}

A többi gázlóktul sokat külöuböznek négv igen hoszszú s cgész gyökerig elvált ujjaik által; körmeik, kivált a

(') Vieillot e nevet átváltoztatá Recurz. leucocephala-ra, gal., $272, \mathrm{rl}$.

(2) Jacana v. Jahana, Brasiliában a nádfúk neve. A parrákat ott aquapuazos, névvel tisztelik, mivel az aquape nevü vizi növé. 
huivelylié, szinte igen hosszú s hegyes, a mi okot ada rí logy fianciául chirurgien (sebész, borbély) neret kapjanak. Csorrok igcen hasonlit a libucokéhoz középszerí lıoszszasága s hegyénck lsonnyui dagadtsíga által, szárnyok sarkantruval fedezetl. Ezek igen kííltozó s panaszos madarak, a forró tartományok mocsúraiban élók, s ott a füreken diönnyen járók hosszú ujjaik segedelmércl.

Amerikában olly fajok vamnak, mellycknek csorralipjín egy esupasz hártya fekszik s a homlok egy részét is betakarja.

1. A közünsiges parra. (The Jacana commun. Parra jacana. L.) Enl 322.

Feliete, liöpönyege veres, szárnya elsö tollai zöldek, esorria alatt húscafitok. Ez legközönségesb Amerika minden forro részében. Igen hegges szárnytöviseket bir (1).

Szinte illyen nehiny $\Lambda$ siában is van:

2. Az ércényü hosszujgegciz. (Le Jacana bronzé. Parra aenea. $\left({ }^{2}\right)$.

'Teste felsete, kek-s violaszinbe jálszó, köpönyege érezöld, farcsika és farkia vérpiros, szírnya elsö tollai zöllek: szeme mögält egy lehér szalag. Szárnytövisei tompák, kicsinck.

ujeken járnak. Lehet lıogy a leiró hibájảbul történve nevezlelck egyikök aguapeccaca-nak Margrave-tól.

Parra latin neve egy ismeretlen madárnak.

(') A. P. variabilis, (Le J. varié) enl. 846, csak a kózönséges fiatal fajtaja. A $P$. brasiliensis és $P$. nigra crak Margrave egy kissé gyanís hitele szerint léteznck. A $P$. ziridlis, melly csak Margrave leirásán alapul, ezen leirás szerint biborfü-nak látszik. A $P$. africana, alig különbüzik valamit. A $P$. chavaria-ra nézve nézd a Pálméd cikkelyt.

(2) Vieillot ezen faji nevet Melanochloris-ra változtatá, gal. 264. Ez egyszersmind Parra superciliosa, Horsf. Jav. 
Keleten talíltattak föl, mellyeknél hibázilk ezen hártya, másképen pedig tollaik viszonyainak különössége által föltünók.

3. A hosszú farku parra. (Le Jacana à longue queue. Parra chinensis.) Encicl. Méth. Orn. 61. 1. 1.. Vieill. gal. 265.

Barna, feje, tarka, nyakeleje s szárnytakarói fehérek, nyakhátula aranysárga selymes tollakat bir, egy lis nyeles függelék néhány szárnylollain; farktollai közuil négy fekete s testénél hosszabb. A "Parra luzoniensis" (Le Chirurgien de Lucon. Sounerat) csals fiatala. Némelly szinküülönbségen kivül még farka scm hosszú.

Keleten tanyáz még :

A tarajos parra (Parra gallinacea.) Tem. 464.

Tarajt visel, de szárnytövise nincs.

\section{A PÁlmÉD-ok Földi.}

(Les Kamichi. Palamedea. Lin.)

Solfćle tekintetben a parrákat ábrázolják, de igen nagyban, két erös szárny-sarkantyujok, hosszú ujjaik, erös körmeik által, kivált a hürelyken lévő által, melly hosszú s egyenes mint a pacsirtáknál. De kevessé szelt csorrok, kissé összenyomott, nem duzadt, felsö lemeze könyủden hajolt. Száraik hálósak.

Ismeretes faj :

A szarvas pálmèd. F. (Palamedea cornuta. Lin.) Enl. 451.

Vieill. gal. 261. Brasiliában Antima, Cayenneben.

Camouche stb.

Nagyobb a luduál, feketés veres folttal a vúlán; fejtetcje különös ékességgel bir, hosszú, vélsony, mozgékony szarr-csölkkel. Ujjai hártyátlanok. E madár déli Amerika eláradt helyein tartózkodik, s már távolrul hallatja igen erös szava csattogásait. Párosan él nagy hüségben. Azt CUVIER I. $K$. 
mondák, mászókat radász, de noha gyomıa kevessé izmos, nem igen eszils mást vizi növényelinel és magvalinál. ( $\left.{ }^{1}\right)$. Különbözö nemmé emelteték:

\section{AZ öRGÁZ.}

(Chaia. Azz, Chauna. Ill). ( $\left.{ }^{2}\right)$.

$S$ mint faja:

A nyügüs örgáz. (Nyügös parra. F. Chaüa du Paraguai. Azz. Parra chavaria. L.) col. 219. Vicill. gal. 267.

Fejtetején nines szar, fejhálulit fülberzeszthetö tollkörrel chesítre. Feje s nyakföle csak pehelylycl lakart, van fekete örre. Egyeb) tollazata ólomszin és fekelés, fehér foltul stárnya-izín, s egy másiklial némelly nagy toll alapján. Külsö ujjai közö̈t jókora úszhártya. Föképen vizi fürekkel él, s Carthagéna liörúl az Indusok nehányat a lud-és csirkecsoport közötl nevelnek föl kïzülök, mirel igen bátorak s a keselyúl is képesek elüzni. Különös tïnemeny az, hogy böre, míg a szárín is fölútl, közle s a hús között levegö levén, s az ujj alalt pattog.

A pílmédokioz kïzel tcendök, noha száraikon alig van csupaszság $\left({ }^{3}\right)$ :

\section{A IÁBNAGYOK.}

\section{(Les Megapodes. Megapodius.)}

Ez ujjonan föltalált nem Új-grincában; csorra bol. los, kissé üsszenyomott, mellynek majdnem felét clfoglalják a hártyás orrlyukak, szárai erösek, elég magasak, vertesck, hosszú ujja s hürelylei kissé lapos de nagy liörmükJe végzödnek, farkok lkurta, szemköröli esupasz-

(1) Bajon, Mém. sur Cayenne, 1l, 284.

(2) Vieillol e nevel Opistoloprus-ra változtatá.

(3) A haris lábain is alig van valami csupasz. 
kís, szálnyizesuilésöl egy lis gumót mulat, a pálmédok sarkantyujảnak clsô csekély jelensíge. Uszhártyájok igen sövid a külsö ujjak között, a belsólinél valamivel nagyobb. Ezen madarak nagyságokhoz képest igen nagy tojásokat tojnak.

Van egy bóbitás faj, majd mint az órgáz:

1. A búbos lcibnagy. (Megap). Duperrey-i. Less. et Garn. Voy. de Duperr., Zool., 37. rl.) Tavon, Manilla szigetén.

Alig nagyobb a fogolynál, mégis majd akkorák tojísai, mint a ludé. Dussumiernel köszönjülk ez észrevételt.

Más kettónel nincs bubja:

2. Freycinet libnagya. (Megap. Freycinetii). s

3. Lapeyrouse liubnagya. (Legap. de Lapeyrouse.) Quoy és Gaym., Voy. de Freyc. 28 és 27. rl. Col. 220. ( $\left.{ }^{2}\right)$.

Ezen negyedil (Alectelie de Durville.) Voy. de Dup. 38. rl. - kisebb s farkatlannak látszik.

A fegyvertelen szárnyuak törzsökében Linné a fulica nem alatt azokat érti, mellyeknek csorra némi vértbe, a homlokat fedezőbe, folytattatik; a rallus nem alatt, mellyeknél ezen különösség nem találtatik.

\section{A GUVATok. F.}

(Lies Rales. Rallus. Lin. Ralle.)

Mellyek különben igen hasonlítanak egymáshoz s igen különböző arányú csorrokat mulatnak.

A hosszabb csorruakhoz (Rallus, Bechts.) számláltatnak:

1. A vizi guvat. F. (Le Rale d' eau d' Europe. Rallus

$\left({ }^{2}\right)$ A. h. A vereslabul libnagy (Meg. it pieds rouges), Col. 411. 
aquaticus Lin. Die Wasserralle.) Enl. 740. Naum. 20. 11. k.

Sírga barna, fölül feketés foltokkal, alul kékes hamuszin, oldalai feketével és fehérrel küllósek, vizeinken s pocsolíinkon kïzönséges, jöl úszik, s könnyüden fut a vizi fürek levelein, apró (ollótlan) rákokkal él, húsán mocsárszag érezhètô. ( ${ }^{1}$ ).

A tübbi fajok (Harisok. Crex. Bechstcin.) csorra rövidebb. Ide jönek:

2. A haris. F. Fürjanya, fürjkirály. (Le Rale de genêts. Roidles. Cailles. Rallus crex. L. Der Viesenknarrer.) Enl. 750. Friseh 212. 13. Naum. 5. 5. k.

Sárga barna, fölül feketés foltokkal, alul szürkés, oldalai feketés szalagokkal, sź́rnyai veresck. Mezókön lakik es fészkel, a füben nagy gyorsan fut. Magyar s latin neve kiáltásátul szúmmazotl. Tiüjlkirálynak neveztetik, mivel a fürjekliel érkezik és megy el, magánosán ugyanazon rideken lakik, s cz okból azt hivék, hogy amazokat vezérli. Szemelkkel szintugy él mint bogaraklial és férgekkel.

3. A bukio guvat. (La Marouetle ou petit Rale tacheté. Rallus porzana. L.) Eul. 751. Frisch. 211. Naum. 31. 42. $\mathrm{k}$.

Sötét barna, fehér pontozatu, oldalai fehér küllösck; a mocsárok közclén él, a kálsábul csónakidomu fészket

(') A Foknál egy faj vagy fajta van, Rall. coerulescens, Cuv. mellynek hasín a fehér és fekete csikok kiterjedtebbek. Add a vizi guvatokhoz: Rallus virginianus; Edw., 729 ; Wils. LxI. 1; - Crepitans, uo. 2; - Longirostris, enl. 849; - Variegatus, enl. 775; - Torquatus; - Striatus; a Fulica cayennensis, melly igazi guvat, enl. 552 ; olly jol mint a Gallinula gigas, Spix, xcrx; - Sarracura, ua. xcvir ; - Mangle, ua. xсvı; - Ruficeps. ua. xcvi, és Cacria; ua. xcv. - A Rallus fuscus-nál kezdo̊dve a csorr rovidebb lesz. 
csinál, mellyet nádszálhoz köt, igen jól úszik és bukik, s vidékeinket csak igen erós télen hagyja el. (1).

A Fü-k. F. HódẢK. F.

(Fulica. L. Wasserhuhn.)

Ezen nem fölosztható mint következik, csorridoma $s$ lábszegései szerint:

\section{A NÁDFúk. (Vizi tyukok.)}

(Les Poules d’ eau. Gallinula. Briss, et Lath. Rohırhuhn.)

Csorrok majd mint a harisé, mellytül homlokpaizs, és igen hosszú s nagyon lreskeny szegésü ujjak által különböznek.

1. A rendes naidfú. (La Poule d' eau commune. Fulica chloropus. Lin.)

(Zöldlábu), fölül sötét barna, alul palaszürke, combjain fehér, valamint alhasa közepén végig és szárnya külső szélén. A fiatalok (fulica fusca. Gm. vizi csirke. Poulettes d' eau. Buff.) világosabbak, s homlokvértök nagyobb. $\left({ }^{2}\right)$.

\section{A BIBoRFúk.}

(Les Talòves ou Poules sultanes. Porphyrio. Briss. Purpurhuhn.

Csorrok hosszaságához képest magasabb; ujjai igen

(') Europában nég két guvatunk van, rövid csorru, kisebbek a bukónál, R. Baillioni, Vieill.; Dict. és R. pusillus, Naum. 32 . f. 43. A rövid csorru guvatok közé helyezhetendosk: Rallus cayennensis, Enl. 755 és 368; - Minutus, enl. 847 ; - Jamaicensis, Elw. 278; - Noreboracensis, Vieill. gal. 266; - Nigrolateralis, Lichtenst.; - Carolinus, Edw. 144; Wils. 48, 2; - Gallinula eurizona, T., col. 417; - G. rubiginosa, ua. col. 387.

A Rallus benghalensis, Gm. szemenke.

$\left({ }^{2}\right)$ A Poule d' eau ardoiséc de l'Inde, Vicill. gal. 268, a ren- 
hosszúk, majd észrevehetö szegés néllkiil : a homlokpaizs jókiora, majl gömbölyü majd fơn négyszegú. Egy lábon állva, a másiklsal szijoliba viszils az cledelt. Szineik általában szíp viola, kék és tengerzöld olvadatok. Illyen:

A rende's biborfü. (La Poule sultane ordinaire. Fulica porphyrio. Lin.) Edw. 87.

Afrikai szép madír, ma már sol parljín és szigetén a Középtengernek meghonosult. Szćpsége miatl parkjaink diszévé lehelne ${ }^{(1)}$.

végre.

\section{A tulajdonképi szárcsík.}

(Te's T'oulyues propr. dits. Morelles. Fulica. Briss. It'asserhuthn.)

Csorrok rövil, homlokvértük jóliora, ujjaik erösek, lanyaru szegís által szélesek s egveszersmind jó úszók; éltöket mind is pocsolyákon es mocsírolion töltik. Sikos tollazatuk nines is kevesebbé alkialmaztatva ezen életmódra, mint alkatísuk, - sök természetes kapesolatol tesznek a gázlók és úsztalpas madarak kiözött.

Nálunk csak egy van :

$A$ (fetiete) szárcsa F. (La Foulque ou Morelle al' Euro-

des nadfútól alig különbüzik; - A Poule d' eau tachetće, v. grinette, Fulca naezia, Alb. II, 73, nem egyéb mint a fürjkirály A. h. P. d' eau des Indes, Rallus phoenicurus enl. 896.

(') A Fulica maculata, flanipes et fistulans eredetileg csak Gessner adta rosz képeken alapszik, mellyek néki beküldettek. De a Ful. marinica et flavirostris valódi biborfúk. A martinica látható Vicill. gal. 267. A. h. a zöld köpünyesrii biborfüt, (Porph. smaragnotus, enl. 910 ; - T. à manteau noir, (Porph. melanotos, T; - a T. meunier, (Porph. pulverulentus, T.), col. 405; - a T. émeraudine (Porph. smaragdinus T.), col. 421; - T. blanche (Porph.albus, L.) Philip., Voy. 'a' Bot. Bay, p. 273 ; J. White, p. 238. 
pe. Fulica atra. F. aterrima. F. aethiops. Gm.) Enl. 197. Frisch. 208. Naum. 30. 40. k.

Sötét palaszinü, homlokvérte s szárnyszélei fehérek; szerelem idején a vért veres lesz. A mocsárolkban mindenütt közönséges. ( $\left.{ }^{1}\right)$.

A gázlók ezen sorát három, a többiekhez nehezen adható nemmel fejezzük be, mellyek külön, apró családokat képezve gondolhatók.

A HÜVELYÉREK, TOK-GÁZOK.

(Les Vaginales. Chionis. Forst. Vaginalis. Lath. Scheidenvogel.)

Száraik rövidek, majd mint a tyuknemüeknél, lábtöik vértesek, csorrok nagy kúpos, s alapján kemény anyaggal van belakarva, a mi cmelkedni s lefeküdni képesnek látszilk.

Egy faj ismeretes csak:

A feliér tokgaiz. (Chionis. Lath. III, 89. rl. Chionis necrophaga, Vieill. gal 258.)

Ujhollandból; fogolynagyságu; cgészen fehér. A tengerpartokon tartózkodik, hol halt állatokkal ćl, mellyeket a hullámok partra vetnek.

\section{A Porondályor. (Porondlakó F.)}

(Les Giaroles. Glareola. Gm. Sandhuhn. Perdrix de mer.)

Csorrok rövid, kúpos, egészen hajolt, eléggé szelt, s tyukéhoz hasonlít. Szárnyaik rendkiviil hosszúk, hegyesck, farkok véha villás, a fecskék repülésére emlékeztet-

(') A h. Foulque de MIadacascar, (Ful. cristata, Gm.) cnl; 797 ; Vieill gal. 269. 
nek $\left.{ }^{(}\right)$, vagy a nagy tenger uszlalpuiéra; száraik középmagasak, lábtöik vértesek, külsó ujjaik kissé hártyásak, hüvelykük földre ér. Serengenkínt repülnek s kiáltozva a vizek szélén. Vizi bogarakkal és férgekkel élnek.

Europai faj:

Az austriai porondily. (Austriai porondlatió. F. Glareola austriaca. Gm. Glar. pratincola. Leach. 'Trans. lin. xIII. rl. XII. Naum. 29. - k. 59.

Fölül barna, alul és faresikín fehér; torka fekete liörel keritett, csorra alapja és lábai veresek. Ugy látszik, hogy a rigi rilíg egész éjszaki részében talúltatik. ( $\left.{ }^{2}\right)$.

Utolsó nemünk gyanánt állanak:

A LÁNGÁLYOK. (Lángmadár. F.)

(Flamants. Phoenicopterus. L. Flamingo.)

Legkülönösbck és elválasztottabbak minden madarak lküzött. Rendkivül magas lábaikon az elsö három ujj hegyig hártyás, a hátulsó ujj pedig végtelenül rövid; láboknál nem kevesbbé vékony s nem kevesbbé hosszú nyakok s apró fejök egy olly csorrt emelnek, mellynek alsó kapesa tojásidomu s hosszában fëlhengerú esatornában hajtott, mig a felsö, hosszúdad és lapos, keresztbe hajtott középett, hogy a músikat pontosan zárja. Az orrlyukak hártyás árlsa azon rész majd egéš oldalát elfoglalja, melly a kereszthajlís mögült van; s magok az orlyukak hoszszas repedékek az árok alapján. A két esorrlemez szćlei igen finom licresallemezeklkel szegeltek; a mi nyelvök hú-

(2) Linné (XII. kiad.) czen fajt a fecske nembe tette, a Hirundo pratincola, név alatt.

(') Glareola naevia, Gm., a rendes fajnak fiatala. L. Leach, Trans. linn., XIIl, pl. xII. f. 2. A. h. Glareola australis, Leach, az id. helyen, XIv. rl. vagy Glar. Isabella, Vieill., gal. 263; Glar. orientalis, Lcach. XIII; - Gl. lactea, Tomm., col. 3999. 
sos vastagságával együtt, némileg a récélkhez teszi e madarakat hasonlókká. A lángályokat az úszlábosak közé is lehetne tenni, ha lábaik olly magasak és csupaszok nem volnának. Csigákkal, bogarakkal, halikrával élnek, mellycket hosszú nyakokkal halásznak s megfordítra fejöket, hogy felsö lemezök görbülésének hasznát vegyék. A mocsárokban fölemelt földre raknak fészket, hol nyergesen ülve költenek, mivel hosszú lábaik nem engedik meg a másképen ülést. Közönséges faj

A piros lángály (Piros lángmadár. F. Phoenicopterus ruber.) enl. 68. Brehm. címkép.

Három négy lábnyi magas. Hamvas az első évben, barna foltokkal, második évben rózsaszint kap szárnyain, harmadikban örökre veres szint kap hátán, rózsásat a szárnyain. Szárnytollai feketék; csorra sárgás fekete vévégü, lábai barnák.

Ezen faj az egész ó világban elterjedt, a $40^{\circ}$ alul. Számos csapataikat láthatni déli partainkon; néha egész a Rajnáig fölmennek.

Az amerikai lingály. (Le Flammant d' Amerique.) Wils. Am., VIII, 66. Catesb. 73.

Temmink véleménye szcrint különbözik az $\delta$ világitul, Egészen vidor veres. ( $\left.{ }^{1}\right)$.

(1) A. h. Apró lángály Amerikábul, Geoffi.; Phoenic. minor, Vicill. gal. 273. H. a fiatal; vagy Flam. pygmée. Temm col. 419. jduilt. 
A MADARAK HATODIK RENDE.

\section{AZ ÚSZHÁRTYÁSAK.}

USzlábuak. USzótAlpuak. F.

(LES PALMIPEDES. PALMIPEDES. SCHWIMMVÖGEL.)

Bélyégeik: uszásra készuilt lábak, azaz testök hátulán létezők, rövid üsszenyomott lábtơktül hordva, s ujjaik között hártyásodva. Sürü, fényes, olajos nedvel megitatotı, a börhöz közel tömött pehelylyel toldott tollazatuk megóvja öket a viztül, mellyen élnek. Ezek szinte azon madirak, mellyeknél a nyak hosszasága, meghaladja s néha igen is a lábakét, mivel a fölszínen úszya, gyakran a mélyen kell keresgelödniek. Mellcsontok igen hosszú, beleık legniagyobb részét oltalmazó, s mindenik oldalín csak egy kimetszést vagy egy petés lyukat bir, hártyákkal takartat. Ziizájok rendesen izmos, vakbeleik hosszuik, algégejök egyszerü, egy családnál porcos tokcsává duzad.

Ezen rend igen szépen fölosztható négy családra.

Nálunk elöl állanak:

A BUKÁRoK. (RöVIDSZÁRNYUAK.) (T.es Plongeurs ou Brachypteres. Taucher. Brachypteri.)

Részint külidomokban hasonlítanak a nádfuk- 
hoz; száraik hátrábban köttettek egybe mint akármelly más madárnál, s ez okbul nehezen járnak s testöket függölegesen kell tartaniok. Valamint különben is a nagyobb rész rosz repülö, sőt sok épen nem tud repülni, ugy tekinthetók, mint majd kizárolag a viz szinére kötöttek, ehez képest tollazatuk is igen sürü; néha pedig sima fölületet s ezüst szinü csillogást is mutat. A viz alatt is úsznak, szárnyaikkal kormányozva majd mint úszszárnyokkal. Zúzájok elég izmos; vakbeleik középszerüek; algégejök mindenik oldalán egy tulajdon izom van.

Ezen családban első nem lehet:

\section{A HosszanbuKóK-é.}

(Les Plongeors. Colymbus. Lin. Seetaucher.) ( ${ }^{1}$ ).

Különös bélyégkint mondható róluk, hogy csorrok sima, egyenes, összenyomolt, hegyes, orrlyukaik vonaluak, - de lábkiülönbségöliért fölosztattak, mint következik:

A vöcsöKöK. F.

(Les Grèbes Brıss. Podiceps. Lath. Colympus. Briss.

et Ilig.) Steissfuss.

Igazi íszóhártyák helyett esals ujjaik terjedtek ki mint a szárcsáknál, s cz clsól vék hártyálk által. A kzözépujj körmei laposak, a lábtö erösen összenyomott. Tollazatok fólćrcfényủ s ez okbul gyakran haszuáltalék szücsmunkálkhoz. Sipcsontok, valamint

( $\left.{ }^{1}\right)$ Colymbus, görög neve ezen madaraknak: Földinél: Karakatnák, de hibásan véve át a néptül, melly e nevel a karamúsz$n a k$ adja. 
a következö alnemé is, fülfelé hegybe nyulik ki, melly a szár kiterjesztó izmanak hatalmasabb támaszpontokat ad.

Ezen madarak tavakon és mocsárokon élnek s a kákásaliban fészlielnek. Ugy látszik, hogy bizonyos liörülményckben szárnyaik alatt hordjális fiaikat. Termetük s tollazatuk ammyira ríltoznak életszakaikkal, hogy fajaikat ez okbul igen megszaporitaik a természetvizsgálúk. Meyer az europaiakat négyre teszi.

1. A búbos vöcsük. (Le Grëbe. Tuppée. Col. cristatus.) Gm. enl. 400. és 944. Frisch. 183. Naum. 69. 106. k. Col. urinator. Gm. Enl. 941. Edw. 36.

Réce nagyságu, fölül fekete barna, alul ezüst fehér, szúrnyán fehér szalag; idövel kettös fekete búbot kap, s a rénck nyakfülén még széles veres körr ran, feketével szegve.

2. A szarvas vörsük. (Le Grèbe cornu. Col. cornutus. Enl. 402, 2. Col. obscurus. Enl. 942. et Col. caspicus. Gm.) Vicill. gal. 281. Edw. 145.

Idomra az clsöhöz hasonli, de a vén nyakörve fekete, bubjai s nyal eleje rerhenyes. Nagyságra különben jơval alább áll.

3. Az alig bubos vḯsü̈. (Le Grèbe à joues grises. Col. subcristatus. s a fiatala: parotis. et rubricollis. Enl. 931.) - Lath. Supl. I. 118.

Nyakeleje szinte rerhenyes, de a vén bubjai aprók, feketék, nyakkürre igen rövid és szürke. Nagyságra a két elöbbi között-áll.

4. Az apró vǘsìk. (Le petit Grèbe ou Castagneux. Col. minor.) Enl. 905.

Fürj nagyságu, soha nincs bubja, sem nyakkïrve; Inllazata barna. lïbbé kevesebhé veressel árnyalva, ki- 
vévén mellén $s$ hasán, hol ezüst szürke. A fiatalok torka fehér. ( $\left.{ }^{2}\right)$.

5. A füles (rendes) vöcsök (Vöcsük. F. Podiceps auritus. Der geöhrte Steissfuss.) Naum. 70. 108. Edw. 96, 2. $\left({ }^{2}\right)$.

Feje, torka, nyaka fénylö felrete valamint egész föle, szemei mögött, fül gyanánt foszlott rozsdaszinü tollcsomag, alteste ezüstfehér, oldalain rozsdaszinü.

\section{A szárcsa vöcs-ök (Farcsiklábak).}

(Les Grèlifoulques. Buff, Heliornis. Bonnaterre. Podoa. Iliger.)

Lábaik karélyosals mint a szárcsáké s vöcsöké, de farkok kifejlettebb mint mindeniké, körmelk is hegyesebbek $\left({ }^{3}\right)$.

A BUKDÁroK; tulajdonképi нosszanвuKóк. (Les Plongeons. propr. dits. Mergus. Briss. ( $\left.{ }^{\star}\right)$. Colymbus. Lath. Eudytes. Iliger.)

A vöcsök egész idoma mellett rendes úszólábails vannak, azaz elsö ujjaik egész végölkig egyesitték hártyákkal, s hegyes körmölkbe végzódök. Ezek éjszalki madarak,

(') A. b. a karolinai vöcsök. (Pod. carolinensis. Lath.) Catesb. 1, 91. enl. $943 ;-a$ szép arcu vöcsök (P. kaliparcus, Less. et Garn.) Voyage de la Coq., Zool. 45. sz. - Rolland vöcsöke ( $P$. Rollandi. Quoy et Gaym. Voy. de Freye. Zool., xxxvi. rl.

( ${ }^{2}$ Ezen madarat Cuvier kihagyta (hihetö, feledékenységbül), én beigtatám mivel hazánkban is találtatik, s Földinél és Voigtnál is a többek közt le van irva.

$V$.

(3) Plotus surinamensis, Gm. enl. 893; - Heliomis senegalensis, Vieill. gal. 280. Bonap. Károly, valamint Gmelin is, ezen nemet a nyurganyakok-hoz számitandónak véli.

(4) Mergus (buvár) egy nehezen meghatározandó madár latin neve; Liuné, Gesner szerint. 
nálunk ritkín fészkelók s hozzánk csak télen jövök. Néha partjainkon látható:

1. A nagy bukckir. (Le grand Plongeon. Col. glacialis. Lin. (Der grosse Eistaucher.) Enl. 952. és Col. immer. Gm. Wils. Am. IX. Lxxiv. 3. Naum. 66. 103. k.

Az idült két s féllúbnyi hosszí, feje nyaka feketék, zöldbe jálszúk, fehéres nyakkiorrrel, háta fehéres pontokkal, alul fehér. Fgy kissé fólfelé görbült alcsorrlemezén alul barizala ran. A fiatal, Col. immer. Gm. Briss. IV, x. 1. melly ides vizeinlire gvalirabban jö, lï̈ünbüzils röbbé lierescbbé fekete nyalsíval szürlic vagy barna hátíval, s ez olibul s kisebb termete miatt tulajdon fajnak véteték.

Megkülönböztetik tóle

2. Az éjszaki bukclár (Kijszaki karakatna F. Le Lumme.

Col. arcticus L. Der Polartaucher.) Edw. 146. Naum.

Sup. 30. 60. k. s a fiatal. enl. 914.

Valmivel lisebb, ny ahala hamras, alsó csorrlemeze cgyenes és barázdállan. A fiatal iggen hasonlít az elöbbi fajéhoz.

3. Az apró bukdcir. (Le petit Plongeon. Col. septentrionalis. Lin. Enl. 308. Edw. 97. Naum. 67. 94. k. Vieill. gal. 282. is Col. stellatus, Gm. Bulf. VIII. xxI. Enl. 992. Naum. supl. 32. 62. k.

Az idölt hím fölül barna, alul fehér, arca s nyak. oldalai hamvasak, nyakeleje rerhenyes. A nö s a fiatalok barnák, fehiér foltolikal fülül, egész fchérek alul.

А вUКјо́к. (КАRАKÁK).

(Les Guillemots. Uria. Briss. et Il. Lumme). (').

Csorrok általános idoma mint az clóbbické, tollaik

(1) Uriı görög vagy inkább latin neve egy vizi madárnak, melly 
cgész az orrlyukakig, - az egy kissé meghajlott csorrvégen kimetszés van. Fö bélyegölk a hüvelykhijány. A bukdárokénál is rövidebb szílnyaik a repdezésre is aligg elegendók. Halakat, rákokat esznek, meredek sziklákon tartózkodnak és ott tojnak.

A nagy faj mellynek neve:

1. Nagy bukjó. Troil. Földi. Grand Guillemot. Colymb. troile. L.) Enl. 983. Brit. zool. H. rl. Edw. 359. 1. Frisch. 185.

Réce nagyságu, feje nyaka barna, háta, szárnyai feketések, hasa fehér, szárnyán egy fehér vonal, a másodrangu tollak hegyei által képezve. Mély éjszakon lakik; azonban Anglia s Scotia sziklás partjain is fészkel $s$ erôs télen hozzánk is eljö.

E Van egy kisebb faj is:

2. A kisebb bukjó. (Grönlandiai karakatna. Földi. Col. grylle. Lin.) Viell. gal. 294. Choris., Voy. aut. du M. isles Alent. xxir. $x$.

Fekete, szárnyeleje fchér. Néha mindenütt fehérrel márványozolt, (Colymb. marmoratus.) Frisoh. Supl. B., 185. rl. Edw. 50. et Penn. Arct. zool. II, xxir, 2. Láthatni egészen fehér egyéncket is. Col. lacteolus. Pall. (').

Ezen alnemtül elválaszthatók

\section{$\Lambda$ BUKDACSOK.}

(Les Cephus. Colombes de Groenland. Krablentaucher. (').

- Csorrok rövidebb, hajlottabb hátu s kimetszéstelen.

bukdár-nak vagy vöcsöknek lenni látszik. Guillemot, angol neve, $\mathrm{s}$ ostobaságát jelenti ki.

(') A. h. G. à gros bec, (Uria Brunnichii, Sabine), Choris, Voy aut. du m., pl. xxi; - Uria lacrymans, Lapil. ua. xxirr, s nézd meg azon cikkelyt, mellyet Valenciennes e nemrül adott.

(i) Cephuss, egy tengeri madár neve, melly gyakran emlittetik 
Alsó csorrlemezök izesülése rendkivül rövid. Szárnyaik erôsebbek s úszó hártyáik kimetszvék.

Legismeretesebb faj

A törpe bukdacs. (Petit Guillemot, Pigeon de Groenland. Colymb. minor. Gm.) Enl. 917. Mergulus alle. Vieill. gal. 295. Brit. zool. H. rl. 4. 1. k. Edw. 91.

Naum. 1. kiad. 65. 102. k. Die Zwergblumme.

Jokora galamb nagyságu, fölül fekete, alul fehér, szárnyán egy fehér rouallal, mint a bukjó. Csorra fekete, lábai veresek. Az egész éjszak partjain lakik, föld alatt fészlkel. Télen néha $\mathrm{mi}$ is látjuk.

Következö nem:

\section{AZ ALKর́K-é. Földi.}

(Les Pingouins. Alca. Lin. Alk.)

Csorra igen összenyomott, fügcoóleg emelt, hátín metszö, rendesen lieresztben barázdás lábai egészen hártyásak s hüvelyktelenek mint a bukjóknál. Mind e madarak az éjszalki tengereken laknak.

Még lzét alnemre oszthatók tovább:

\section{A BÁBUSZOK.}

(Les Macareux. Fratercula. Briss. Mormon. Ilig.)

Csorrok röridebb a fejnél, s alapján olly vagy még inkább emelt mint hosszú, s ennél fogva rendlkivüli idomu; redös börrel van rendesen beszegve az alapja. A szél lrözelén lévö orrlyukak nem egyebek keskeny hasadékoknál. Apró szárnyails által még föl tudnak egy lsissé emel-

a görögöktül, s hojsza vagy csïlls. Moering és utána Pallas a bukdárok-ra és bukjók-ra alkalmaztaták. Vieillot MErgulus-ra változtatá, gal. 295. 
kedni; tengeren élnek mint a kiarakák s sziklíkon fés\%kclnek.

Közönséges faj :

Az éjszaki bábusz. Északi alka. F. Alka arctiea $\mathrm{L}$. et labradoria. Gm. Mormon. fralercula, Tem.) Eul. 27.5. Brit. zool. H. xl. Edw. 358, 1. Frisch. 192. Narm. 65. 101. k.

Galambnagysígu, sapkíja, köpönyege feketék, alul cgészen fehér. Néha Angolhon meredek part szikláin fészkel, télen a francia partokon bövelkedik. ( ${ }^{1}$ ).

Temmink staryques (PIALERIS) név alatt a kiscbbé emelt csorruakat külöubözteti meg. $\left({ }^{2}\right)$.

\section{$\Lambda$ tulajdonképi ALKák.}

(Les Pingouins. propr. dits. Alca. Cur. Alken. $\left({ }^{3}\right)$.

Csorrok nyultabb és késlap-idomu; alapját egész az orrlyukakig füdik a tollak; szárnyaik épen kisebbek, minthogy rolek cmclkedui tudnának, épen nem repülnek.

Néha télen partjainkon látható:

A torda. F. (Rendes alka. Le Pingouin. commun. Alca torda et pica. Gm.) Enl. 1004. a vén, 1003. nyári ruhában. Edw. 358, 2. Briss. VI. vir. 2. Brit. Zool. H. il. 1.

Fölül fekete, alul fchér; szárnyán cggy fehér vonal, csorráa cgy rag̨ lieltö. A him torka még azon fölül fe-

(1) A. h. A. cirrhata, Pall. Spic., V. I. 1., ; Vicill. gal. 299.

$\left(^{2}\right)$ Alca cristatella, Vicill. gal. 297, vagy Starique cristatelle, T. col. 200. et Pall. Spic. zool. V. rl. I. mellynek az A. pygmaea, fiatala; A psittacula, Pall. Spic. V. rl. 2, s ennek az A. tetracula, uo. 4. k. fiatala.

(3) Alka, alk, «uk, a Plıerö szigeten divatozó nevek, valamint éjszahi scotiäban. P'inguvin, nevet adtak a Hollandusok a déli repCUVIER I. K. 
kete, s szemétuil esorráig egy fehér vonal rin. Nagyságra majd akkora mint a ruca.

A nagy alka. (Le grand Pingouin. Alea impennis. L.) Butr. IX, xxix. Eul. 367. Edw. 147.

A ludhoz közclít nagyságra; szinei mint az clöbbinél, de csorra rgészen fekete, nyolc vagy tiz barázdís, csorra is szeme kïzïll egy fehér foltja van: szárnyai aránylag rörd,bbek mint e nem akírmellyik fajánál. Azt mondjali hogy esak egy tojást tojik, nagyot bibor foltosat.

Kövelkezó nem

\section{A REPTELENEK-é.}

(Des Manchots. Aptenodytes. Forst. Fiettgans, Pingvin.)

Az alkáknál is kevescbbé repülhet; apró szárnyain csilk nyomai vanmak a tollnak, elsö pillanatra pikkclyckhe\% hasonlitok; libai hálrább allok, mint bármelly más madírnál, öt csak a lábtöre timaszkodra tarlják, melly ngy terjedt ki, mint valami emlös állat talpa, s mellynek belsejüben hírom, üszclorrt végï esontot lelni. E madaraknal hülouben van egy hátra irányzoll hüvelyk, három clsö ujjaik hártyáral egészen egyesítvék.

Csak a déli hideg égör tengerein találtahnak, hol csak fészkehii jönck a żárazra. Fészkeikhez csak hasaikon nehezen csúszva jutnak.

Csorrolnál fogra három alnemre oszthatók föl:

A tulajdonképi RePteLENEK.

(Tes Manchots propr. dits. Aptenodytes. Cuv.)

Corrok vékony, hosszú, hegyes; vége felé hajloll a

tcleucknck, olajos zsiradétok miatt. Lásd, Clusius, Exot. 101. Buffon vilte kizálólag at ac ejjszaki dlkikra. 
felsö csorr, s hosszasága harmadaíg tollakkal ledett, hol az orrlyuk van s hol egy barázda kezdödik egész a hegyig menó.

A patagoni reptelen. F. (Le grand Manchot. dpt. patagonica.) Enl. 975.

Lud nagyságu, fölül palaszürke; alul fehér, álarca fckete, citromsárga körrvel. Igen nagy csapatokban lakik Magellan szorosa körül egész uij Grincaig. Húsa, noha fekete, megehetö.

\section{A REPLENÚSZOK.}

(Les Gorfous. Catarrhactes. Briss). (').

Csorrok erös, kissé összenyomott, hegyes, gömbölyü háltal, hegye kissé hajolt; az orrlyukítul eredö barízda ferdén végzödik a szél alsó harmadánál.

Az ugró replenúsz. (Le Gorfou sauteur. Apt. chrysocoma. Gm.) Enl. 984. Vieill. gal. 298.

Jó réce nagyságú, fölül fekete, alul fehér, s fejháta mindenik oldalán egy fehér vagy sárga tollagol hord. A Maluiuok s Új-holland vidékein találtatik. Úszva néha fölugrik a vizbül, lojásait földalatı vizbe rakja lc. $\left({ }^{2}\right)$.

\section{А CSAKÚSZOK.}

(Les Sphoenisques. Spheniscus. Briss. ( $\left.{ }^{3}\right)$.

Csorrok összenyomolt, egyenes, alapján rendellenül

(') Gorfou a goir fugel-bul clrontva, uncllyen a nagy alka nevertetik a Ferỏi szigeteken. Lásd Clusius, Exot., 567. - Catarrhactes, egy igen különbözó inadia neve, nelly ijen jól repül, s magastul csap a zsákmányra le. Ez lihets egyik csüllö vagy sirúly volt.

$\left({ }^{2}\right)$ A. I. Apt. catarrhactes, Edw., 49; - Apt. papua, Sonn. 1-er Voy. pl. 115 ; Vieill. gal. 299; - Apt. minor, Latham, Syn. III, 103.

(') Sphocniscus nevet Moehring elósıor a bábuszoknak adott, Brisson a reptelencknck; cttül Iqỳv, ék (ik). 
barízdás, fölsó lemezének rége hajolt az alsóé csonka, nyilt orrlyukai a közepén vannak.

A foki csakiusz (Le sphienisque du Cap. Apt. demersa. Gm.) Enl. 382. és 1005 .

Fölil feliete, alul fehér, csorra barna, középen egy fehér szalaggal: a himnél azon fölül fehér szcmöldök van, torka fekete, mellén fekete ronal, melly mindenik oldala hosszában folytatódik. Föképen a Reményfok körén lakik, hol sziklákban fészkel (').

Második esalád.

A TÁVOLREPÜLÖK (IIOSSZÚSZÁRNYUAK).

(Longipennes. Grands voliers.)

A tág tenger madarait foglalja magában, melylyek nagy szárnyaik segedelmével mindenfelé elterjedtek, s a hajósoktul minden vidékeken talíltatnak. Ismertetö jegyök, szabad vagy semmi hüvelyk, igen hosszú szárny, fogazallan de az elsö nemekben horgadt a többieknél egyszerúen hegyes végü csorral. Al-göggök mindenik oldalán egy tulajdou izom van; zúzájok húsos, vakbelek rövidek.

\section{A HoJszák. F.}

(Les Pelrels. Procellaria. Sturmvogel.)

Csorrok rége hajlott s mintegy beizesült, darabuak látszik a többi részbe; orrlyukaik egy, a felsö lenezen fekvö csübe egyesültek; lábolion hüvelyk helyelt csak egy körön van a sarkson. Ezek minden úszó talpuak kö-

(1) Aptenod. corquata, Sunn. 1-cl. Voy. 114. melly, mint látszik, as Apt. demersa júrcéjc. 
zölt legtarlósabban tartózkodnak távol a száraztul: de midön szélvész közelít, gyakran a sziklákion és hajókon kénytelenck menedéket keresni, mi okbul szélvész madarak-nak is mondatnak. Péterke (Petrel) nevöket onnan kapták, mivel szárnyaik segedelmével járkálni szoktak a vizen. Fészkeiket sziklalyukakba rakják, s az öket megtámadúkra olajos nedvet lükdösuck, mellyel gyonmok mindig telmek látszik. A fajok nagyubb száma a déli hideg égöv fclé lakik a tengeren.

Közelebbrül

\section{Hossza (Procellaria, Pétrels)}

nevel kapnak azok, mellyeknek alsó állkapesa suta (csonkitolt). Legnagyobb faj:

1. Az óriás hojsza. (Pétrel géant. Quebranta huessos ou Briseur d' os. Procellaria gigantea, Gm.) Lath. Syn. III, 100. rl.

Csak a Déli-tengereken lakik s nagysigra fölülmulja a ludat. Tollazata feketés. Vannak töhbé kevesebbé fehér fajtak.

Ugyan azon tengerben találtatnak:

2. A foki hojsza. (Le Damier. Pélrel du Cap. Pinlado etc. Procell. capensis.) Enl. 964.

$\mathrm{K}$ is réce nagyságu, hálín fehér s fekcte foltos, alul lehér. A hajósok solsszor emlegetik.

Néha partjainkon látható:

3. A jeges hojsza. (Lee Pétrel gris-blane on Fulmar, Pétrel de Saint-Kilda. Proc. glacialis.) Enl. 59. Brit. Zool. M. rl. 1. k.

Fehér, köpönyege hamvas, jó réce nagyságu. A britamiai s minden éjszaki meredek partokon fészlkel. ( $\left.{ }^{1}\right)$.

(1) A. h. Petrel hartie, Temm, col.416; - le Petrel bérarard 
A Vészjósok. (T'halassictroma. Vigors).

Apró fajak, lissé röridebb csorral, kissé emellebb szárakkal, s fekete tollazaltal. Ezeliet tarlják leginkább) szélvészhirdetóknek.

Legközönségesebb fiaj :

A lengeri vészjös (lengeri hojsza. F. Procellaria pelagica. L.) Briss. VI, xm, I; Wils. Am. VII, LIx, 6 ; Edw. 90.

Alig nagyobb a pacsirtínil, magas száru, egészen barna, kirérén faresikát, melly fehér, s egy fehér vonalt számyai nagy takaroinak hegyén. Midön a hajókon menedéket keres, beköretkezö szélvész jele. ( $\left.{ }^{1}\right)$.

Brisson szerint még elválasztaudók:

a széltírsak. (hojhák). (Les Puffins. Puffinius.) ${ }^{2}$ ).

Alsó csorrlemezök víge a felsóvel rgyüit alá gürbül, orrlyukaik pedig, noha esöresek, nem liöznyilisuak, hanem két különbözö lyukuak. Csorrok aráuylag hoszszabb.

1. A hamvas széltcirs. (Le Puffin cendré. Proc. puffnus, Gm.) Enl. 962.

Fölül hamvas, alul fehéres, szárnyai, farka feketék;

Freycin, 37 ; - Proc. cinerea Lath.; - Proc. desolata, id.; Proc. turtur. Forst.

(') Az enl. 935-ki kép igen közel faj a Déli-tengerekhez (Proc. oceanica, Forst.) - A. h. Procell. Leachii, 'I'emrn., Ac. de phil, VI, pl. 9. f. 1; - Proc. Wilsonii, Ch. Bonap.; Wils. Am. VII, LXX, 6. u. a. Ac. de phil. VJ. pl. 9. f. 2 ; Proc. fregatta, Latham, Rochef., Antill., p. 152; - Proc. marina, Vieill., gal. 292.

$\left.{ }^{2}\right)$ Puffin, a mi 2oik fajunk neve a skot partokou. 
a fratal sölétebl) szinü. Holló nagyságu. Majd minden tengerben talíltatik. ( $\left.{ }^{1}\right)$.

Ezen fajjal igen soká összezararłalćk egy másik, csıpán lebenke nagyságu, fölül fekete, alul fehér, Scotia ¿jszaki partjain s a szomszéd szigetekru végetlen számban lakozó, mellyeket a lakosok téli cledeluck besúznak, neve: 2. A skót hojha. (Procellaria Anglorum, 'Tem.) Edw. 359.

A hajósok néha, hojsza név alall, beszélıck olly déli sarktengeri madarakrul, mellyek két különbözö nemet alkothatnak.

A TENGERóRöK (TENGörök). (Ler Pélécanoïdes, Lacép. Halodroma. Ilig.)

Idomok mint a hojszáké vagy hojháké, de torkok kiszéleszthetö mint a kormoránnál, hürelykök pedig egészen hibázik, mint a diomédeknél. (Procellaria urinatrix Gm.), és

\section{$\Lambda$ нолнúszoк.}

(Les Prions. Lacép. Pachyptila. Ilig.

Különben a hojszákhoz hasonlik, de orrlyukaik clrálasztvák mint a szćltársaknál, csorrok tág az alapjín, széle pedig belül függó lemezcsélihel szegett (fogas), mint a rucáknál. Ezek az ugy nevezelt lék hojszcik (Procellaria villata et coerulea. Forst.)

\section{A DIOMÉDEK.}

(Les All;atrosses. Diomedea, Lin. Albatros.) ( $\left.{ }^{2}\right)$.

Legtömegesebbek minden vizi madarak között. Csor-

(') A. h. Proc. obscura, Vieill. gal. 301 ; - Proc pacifica v. fuliginosa, White 252, melly talán nem különbözik a Procell. aequinoctialis-tul, Edw. 89 .

$\left(^{2}\right)$ Diomedea, végi neve a Diomed szigete körül Tałcutohoz kö- 
rok nagy, crös és melszö, lijelelı varrinyokkal, nagy horogba régzödö, melly oda izesülınek látszik. Orrlyukaik rövid gombolyidomnak, a csorr oldalai felé fékïrök le, lábaikon nincs hüvelyk, sem a hojszálnuál mutatkozó kis köröm nines meg. Minden déli tengeren laknak; halikrával, puhángokkal stb. élnek.

A hajósok clölt legismerètesebb faj :

A repülö dionéd' F. (Diomedea exulans, Lin.) Enl. 237. Vicill. gal. 293.

A franciáktul mouton due Cap. (foki ïrü) nagysága s fehér tollai okúért, (mig szúrnyai feketék), s mivel a déli napfordítón túl föképen bövelkedik. Az Angolok hadi hajo-nak is nerezik öket. A repülö halaknak iggen nagy ellensége. Fészket fölemelt földre rak s ide számos és jó izü tojást tojik. Szavál olly erösnek mondjúk, mint a szamáré.

Még sok tïbbe kevesbé barna ragy felictés diomédek ismertetnek, de még eddig nem lehele meghatírozni, mennyire képzenek fajlákat vagy fajokat. (').

\section{A csüLtők. F.}

(Les Goelands, Manves, Monettes. Larus, Lin. Möve). $\left({ }^{2}\right)$.

Csorrok összenyomott, nyúlt, hegyes, felsö lemeze

zel tanyázó némelly madaraknak, mellyeh a görögöhet idvezelve, a barbarokat, monda szerint, megtámadva fogadík. Mi az clbatro-t illeti, az elsö portugali hajósok az otrombokat más tengeri madarakkal együtt alcatros-vagy alcatras-nak nevezék. Dampierre e nevet a jelen nemre alkalmaztatá; Grew Albitros-1a, Edw. Albatros-ra változtatá.

(') Illyen a Diom. spadicea, - A. h. D. brachyura, Temm. enl. 963; - D. melanophris, T., col. 456; - D. chlororhynchos, Lath., V. pl. xcrv, col. 468; - D. fuliginosa, col. 469.

$\left(^{3}\right)$ Larus . e madár görög neve: Gavia latin, s innét a proven- 
hajlott végï, az alsó alul clöálló szögletel képez. Küzzéptíjon fckvö orrlyukaik hosszúk keskenyek s elötünöls; lirkok teljes, száraik clég emeltck, hüvelykök rövid. Gyára, falekony madarak, a leuger partjain pesgök, mindenféle halakkal, döghussal stb. ćnck. A homokban vagy sziklarepedékckben fészkelnek, csak kereset tojnak. Mikor a szárazra mennck, rosz idö jele. Parljainkon több faj találtatik; s mivel életkoruk szerint kül̈̈nbözö tollazaluak, fajaik még többre szaporiltatıak. Álialíban mint fiatalok, szürke foltosak.

Buffon Goelands-nak nevezi a nagyobb fajokat, ezck nálunk maradhatnak:

\section{A CSỨLLőK.}

Mellyek nagyságra a récét fölül mulják.

Egy a legnagyobb közül,

1. A fekete (köpönyegú) csüllï. (Te Goëland à manteau noir. Larus marinus et naevius. Gm.) Enl. 990 és 226.

Eleinte fehér és szürke foltokkal, utóbb egészen fehér lesz, csak köpönyege fekete; csorra sárga, alul egy veres folttal; lábai verhenyesck.

2. A szürke (köpünyegü) csüllö. (közönségesen a polgármester, Le Goèland à manteau gris. Larus glaucus. Gm.) Naum. 1. kiad. 36.

Alig kisebb nála: töle csak világos hamvas köpönyegére különbözils. A fiatal szinte foltos. ( $\left.{ }^{1}\right)$.

cali Gabian; a francia Mauves, vagy Mouettes a német Möve-tül jô; Goeland, mellyet Feuillée használt elöszorr, az angol Gull, vagy Gull-ent-bül van clrontva.

(1) Temmink megkülönbözteti a Lar. argentatus-t, Lath., enl. 255; - A. h. Goëland leucomele, Vieill. 61. s. Goüland à tîte noire du Bengale. 
A SIRÁLYOK. F. (Les Mauves. ou Mowelles.)

Kiscbb fajok.

1. A scirga (labu) sircily. (La Monelle i pieds jaunes. farus Juscus. L. flavipes. Meyer.) Frisch. 218. Naum. 1. hiad. j1. K. B.

Fekete köpönyegén livïl egészen fehér: lábai sárgaik. 2 A feher sircily. (La Mouette blanche. Larus eburneus, Gm.) Enl. 994.

Egészen fuhér: lábai feketék ; Grönland és Spizbergában. Néha Europába is alátéred.

3. A kiklábu sircily. (La Mouette à pieds bleues. Lar. (yanorhynchus. Meyer.) Enl. 977. Briss. II. xvr. 2.

Kísö korában szćp fehér, lïpönyege vilígos hamvas; szárnya elsö tollai részint feketék, régökön fehér foltokkal; csorra, lábai domkékek. Sokat el csigákkal.

4. A nevetö sircily (veres libu sircily. Ia Mouette is pieds rouges. Lar. ridibundus. Lar. hybernus, el Iar. erythropus. Gm.) Enl. 969. is 970. Briss. VI. xvĩ. 1.

Majdnem hasonlio az elïbbiliez, kiverén hoge elsé korában, farka vege felicte, szímyán pedig fekete s barna szin is találtatik; az idciltuck feje tavasszal barna les\% s exész nyáron illyen marad (Enl. 970): csorra s lábai (iib)be kevesebbé veresek. Nerelös kiállísa ran. $\left({ }^{1}\right)$.

(') A. h. Larus atricilla, Pall. Nov. com. pefrop., XV, ххи, 2 ; Catesb. 1, 89; Wils. Am. 1X, Lxxıv. 4, - Ridibundus név alatt; - Lar. leucopterus ; Lar. cirrhocephalus, Vieill. gal. 289, v. poliocephalus, Licht.; - L. leucophtalmus, Licht col. 566 ; L. Sabini, Leach; - L. minutus, Falk., Voy. III, xxıv; - Lar. melanurus, T. col. 459, és Tiles, Voy. de Krüsenst. LVI. rl. 
5. A háromujju sircily. F. (Ta Mouette à troi cloights. Tarus tridactylus. Lar. rissa. Gm.) Briss. VI. xvI. I és XVII. 2.

Egyre igen hasonló az elöbbickhez, de igen rövid s tökélyetlen hürelyke által különbözik. Fialalságában többé kevesebbé barna foltos.

Méltán válaszlatuak el a czüllök- és sirílyoktul.

\section{A GANÁLYOK.}

(Les Stercoraires. Briss. Lables. Buff. Lestris. Ilig. Raubmöve). ( $\left.{ }^{1}\right)$.

Csorrlyukaik hártyásak, naggobbak mint a többicknél, következöleg nyilások a csorr hegyéhez és széléhez közelebb esik; farkok hegyes. Dühösen kergetik az apróbb sirályokal, elragadandók azoktul az eledelt, söt mint mondatik, azoknak ganaját (emésztetét) tölfalandók. Innét nevök.

1. A hosszi farku gancily. (Le Labbe à longue queue.

Larus parasiticus. Gm.) Enl. 762. Edw. 148.

Fölül sötét barna, alul fehér; farka két középsö tolla a többinél még egyszer hosszabb. Nálunk igen rilka. Fiatalságában egészen barna. Ekkor = Larus crepidalus, Gm. Enl. 991. vagy jobban Edw. 149.

Az éjszaki földsark vidékcin találtatik egy faj, csüllö nagyságu, barna szárnytollainak alapja fehér, ez a

2. Nagyobb ganaly. (Larus cataractes, Gm.) Brit. Zool. L. rl. 6.

Van egy másik is, sirály nagyságu, fölül barua, alul fehér, mellén barna örüvel, ez az

3. Örves ganaily. (Lestris pumurinus, 'Tem.) ( $\left.{ }^{2}\right)$.

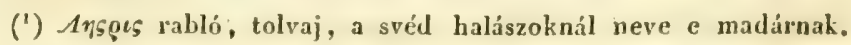
Vieillot STORCOREUS-ra változtatá.

$\left({ }^{2}\right)$ Nem merem a Lestr. Catarrhactes, Freyc. 38, és Stercoreus pomarinus, Vieill. gal. 288 azonosságát vitatni a fölebbi fajokkal. 


\section{A HALÁszkík. (IAтÁszMAdír. F.)}

(T.es Hirondelles de mer. Sterna. Lin. Setschataben). (').

A francials és némelek arért nevezik ölict tengeri fecsheknek, mirel szirnyaik rendkirül hosszuak, farkok villás, libaik röridek, melly okokbul idonra s repülesse néze a fecskikhez hasolitanak. Csorrok hegyes, összenyomoll, egrenes, hajlís s elöduzadís nélkil; orrlyuhaik az alap lélé, hosszádadok s résziust át furtak; a lábaikit egyesitö hártyák igren kiszeltek; kereset is usznak. Mindenfele mod replichluels s igen gyorsan a tongereken, nagyon kiáltozva, s ügyesen fölkapliodra a vizck szinćriil it puhányokiat és apró halikliat, mellyekkel ćlnek. A szárazta is elmennels a tarakra és folyólkba.

lides vizeinken tavaszszal legliözönségesebb,

1. Az europai halaiszka. (Luropai halciszmadar. F. Lie

Pierre-Garin, ou. Hir. de mer à bec rouge. Sterna hirundo. Lin.) Enl. 987., Frisch. 219; Naum. 37.

52 k. Wils. VII, LX, 1.

Idölt korában fehér, köpönyege vilígos hamuszin, sitpliaja fekete, lúbai veresek, csorra veres fekete viggel; egy lábnyi hosszu; de legalább kettöig terpeszkedik.

2. Az apró halciszka. (La petit Tirondelle de mer. Sterna minuta. Lin. Die Vwergseeschwalbe.) Enl. 996. Wils. Am. V. Lx, 2. Naum. 38, 55. k.

Az clsötuil esak ey harmaddal kisebb termetere ne\%ve különbözik, homloka is lehér.

3. A fekete cisorru haliszka. (Hir. de mer à bec noir.

St. cantiaca. Albiu.) II, Lxxxvin.

Az clsöt meghaladja; félete csorránals rége súrga; i fiatal = Sterna striala, Gm. Lath. VI. 98. Il.

(') Sterna angol nevok, Stern vagy T'ern, Turner által latinizálva s Gesnertül fölvéve. 
4. A honi halíszka. (Sterna Caspia, Pall.) Sparm. Mus., Carls., Lxrr, Meyer, Némethon mad., II, vi. Sav. Egypt. Oıs. rs. rl. 1. k.

Fehér, köpönyege hamras, fejhíta feketével fehćrrel vegyes, csorra veres, lábai feketék.

5. A fekete halciszka. (L' Hir. de mer noire. St. nigra. St. fissipes. el St. naevia.) Enl. 338, és 924. Frisch. 220.

Farka kevescbbé mélyen villás. A fiatal köpönyege fekcte foltos. Az idölt majd egészen feketés hamvas.

Az idegen fajok között megjegyzendö:

6. A tollagos halciszka. (L' Hir. de mer a nigrettes. St.

inca. Less el Garn.) Peru partjairul. Voy. de la Coq., Zool. 47. rl.

Fekete, czorra-lába veres, arcín cgy szalag s fülénck csüngö tollai fehérek. ( $\left.{ }^{1}\right)$.

A többi halászkátitul megkülönböztetendök:

\section{А ВАNGóK. F. (LES NODDIs.)}

Farkok nem rillás s majd a szárnyokat üti föl. Csorrokou szinte egy csekóly elöduzzadás ran, elsö jelensíge a sirályokénak. Csak egy faj ismeretes

A fekete bangó. (Le Noddi noir, oisean fou, elc. S'terna stolida, L.) Enl. 997.

Feketés barna; feje föle felréres, a hajósoknál azon ostobaságaért hires, mellyben a hajókra rohan. $\left({ }^{2}\right)$

(1) A. L. czen curopai fajokat: Sterna Dougali, Monlag.; Vicill: sal. 290 ; - St. angelica, ua., vagy aranea, Wils. Am., VIII, IxxıI, 6; - St. arctica, T.; - St. leucopareia, Natter. St. leucoptera, Temm. Schinz., Vögel der Schweiz, homl.

Az idegen fajokbul: St. cayana, enl. 988 ; - St. melanauchen, T., col. 427; - St. melanogaster, ua. col. 434; - St. fulisinosa, Wils.

(2) St. philippensis, Sonn. 1'cr. Voy. Lxxxy. rl.) nem lítsiik 


\section{A GÓLICOK.}

(Less Coupeus-d' eau oul Bees-en-ciseaux. Rhynchops. L. S(heerenschnabler.)

A halászkákhoz hasonlitanak apró lábaik, hosszí szaitnyaik s villás larkok által; de minden madártól különbäznek rondkirili csorrok altal, mellynek folsö lemeze rövidebb az alsónál, mind a kettö pedig egyszerü leme\%ekke lipult, mellyek szclei megregyeznck (összérnek) be nem kulcsolidra. Csak azzal típlálhaljík magokal, a mil a va föszinerial repulve cmelnek föl also állkapcsokkal.

Föképen egy laj ismeretes:

A felete goilic. F. (Rhyncops nigra. Lin.) Enl. 357.

Fehér, sapkija s kïpönyege feketek, szírnyán egg szaliag s farka kiilsö tollai kifelé lehérek. Csorra líbai veresek: mintegy galambnagysagu. $\mathrm{A}$ \% antilli szigeteken latkik. (1).

\section{Harmadik család.}

A TELE'TALPUAK-É.

\section{(Totipalmes. Totipalmali.)}

A r. rajta nevezetes, hogy hüvelykök a többi ujjakkal egyetlen egy hártyába egyesült, s ezen müszeresség dacáa is, melly legjobb evezókké teszi óket, az uszótalpuak között egyediil ïlnek föl a fíkra. Mind jó repü̈lök s rövid lábuak. Limné s

hülönbözni a stolida-tul; - a St. fuscata, Latham, Briss. VI, XXI, 1, srinte ezen aluemliez litszik tartozni, valamint a St.tenuirostris, T. col. 202.

(') A. h. Rhynch. flavirostris, Vieill. gal. 291; Rh. cinerascens Spix, сII; - Rhynch. brezirostris, ua. cill. 
hrírom nemre osztja föl óket, de ezek közül az clsü tovább fölosztandó.

\section{A PELLTKÁNOK. F. (TOLKATÁG-ok.) (Les Pélicans. Pelecanus.)}

Mindazok ide tartozók, mellyeknél a csorr alapjánál némi tolltul csupasz hely vau. Orrlyukaik alig észrevelietö nyilásu repedékek. Torok-börük többé kevescbbé kinyujtható, nyelvök igen kicsm. Zúzíjok a többi gyomrokkal együtl nagy zsebet képez. Középszerủ vagy apró vakbeleik vimnak.

A GödÉNYEK (vagy tulajdonképi PELLIKÁNOK)

$$
\text { (TORKATÁGOK). }
$$

(Les Pelicans propr. dits. Onocrotalus, Briss. Pelecanus, Ilig). ( $\left.{ }^{1}\right)$.

Csorrok igen nevezetes nagy hosszasága, egyenes igen széles és vizszinüleg lelapitott idoma által, s horogba régzödilí régre alsö álkapesúnak hajlékony ágai csupasz s clég nagy zsebbo kitcrjeszthetö hárlyát tarlanak. Hosszában kél barázdija vau s cbbe elrejtrék az orrlyukak. Szcmkörúk csupasz mint torkuk. Farkok kerek.

$A$ rendes gödény (kïzönséges torkatág. Le Pélican ordinaire. P'elecanus onocrolalus.) Enl. S7. Edw. 92. Frisch 186.

Hatlyu-nagysígu, egészcu fehér, könnyúden befutva hús-szinuel; csorra horga veres miut cseresnye; többé kevesebbé cltcrjedl az cgész ó vilígban, mocsárokban fészkel, csak eleven halakat eszilk. Ugy mondják, élelmet és vizet hord torokzsebében. Az életkor-miatti változísokat

(') Pelecanus és Onocrotalus, hét latinizált görög neve c madirnat. 
nen cléggé határozák meg e madárnál, hogy lajait biztosan számlílhatnók el. $\left({ }^{1}\right)$.

\section{A KOROMÚSZOK.}

(Les Cormorans. ("). Phalacrocorax, Briss. Carbo, Mcyer; Haliens, llig. Scharbe.)

Cisorrok liusszult: összenyomott, a felsö esorteme\% vége görbült a\% alsio elvígoll; nyelvök igen kicsin, lorokböre kevesebbé tígulo; orrlyukai mint apro ronals nyiluak nem lítszok. A kïzipuij körme fürészes-logáas.

\section{a) A tulajdonképi коnoмúszok.}

\section{(Les Cormorans propr. dils. Eigentliche Scharben.)}

Farkok kereli, 14 tollu. Nálunk esak cgy laláltatik: 1. A nagy koromisz. (Kormorán, Füldi. A népnci: karakatna; kira kalonaja. The Cormoran. Pelecanus.

(1) Nem látok scmmi kïlöubséget a rendes gődény s Pelic. roseus, közótt, Somn., 1-er Voy., LIV. 11. A Pelec, manillensis, ua. LII, már Sonnerat véleménye szerint nem egyéb fiatal roseus-nál. Szinte nem látok különbséget a Fuscus, Elw. 93, s az enl. 965 képe közt, melly Roseus, néven idéztetik, de inkább hasonlit a Manillensis-hez. Temmink e képet a rendes faj fiatalanak álítja. A Philippensis, Buiss. VI, L.r. rl. ugyanazon eryén, melly mintául szolgált az enl. 96.5 képnek. Igy mindenik fiatal gölény. - A 9.57 rlapon, szinte Fuscus néveu idćzett, valóban fajnak látszik, megegyezö Vicillotéval, gal. 276. - A. H. P. perspicillatus, 'T. (szemiiz'eges göllény,) col. 276.

$\left.{ }^{2}\right)$ Cormoran, a Corbeau marin, clrontott összetétele, hollónak mondaték fekete szinećrt: Ez valoban Aristoteles vizi hollaja. Pholacrocorax (Kopas holló) görög neve egy madámak, Pliniustul emlitett, de Aristotelestiil nem használt. A Carbo-t Albert adta neki, talúm a német scharbe szerint. Mint e nevekhez Vieillot is oda adta a magaét, Hydrowcorax-ot, gal. 275. 
Carbo. L. Die Scharbe.) Eul. 927. A fiatal, Frisch. 187 s 188, s Brit. Zool. L. rl. 1.

Fekete barna, hátán sötét felzete hullámzattal, csorra hegye felé s nyakelején fehérrel vegyítve, a torokkör s az arcok fehérek a himnél, feje pedig búbos. Lud nagyságu. Sziklalyukakban vagy fákson fészkel; hármat vagy négyet tojils.

2. A kis koromiesz. (Lie petit Cormoran. Pelecanus graculus. Gm.) Enl. 974. a fialal.

Jegyz. Graba újabb tapasztalásai szerint ezen faj megegyez a cristatus-(búbos)sal; szemcsillaga hamisan van barnára festve.)

Valamivel kisebb, sölélebb lekete, jobban bronc szinü; semmi fehér a nyakelejún; haita tollai hegyesebbek, az elöbbinél ritkább. ${ }^{1}$ ).

\section{b. A LENGÉK. LE்NGÖRÖKÖK. \\ (Les Fregattes. Fregatvogel.) ( ${ }^{2}$ ).}

A koromúszoklul villás fark, rövid lábak, - mellynek úszhártyái mélyen kiszeltek, iszonyu terjengés és ollyan csorr álial, mellynek mindenik lemeze meghajlik a végén, különböznek.

Szárnyaik olly hatalmasak, hogy végetlen távolságra repülnek a szálaz földtül, kivíltképen a napforditók között, a repülö halakra csapva le s az otrombokat, zsákmányuk kiadására kényszerítök.

Jól csak egy faj ismeretes:

(') A. h. Cormoran longup., Temm. (Pel. cristatus, Olafs.) Voy. ou Isl. franc. ford. xuIv. rl. col. 322 , Vieil. gal. 276 ; - Pel. africanus, Lath.; Sparn., Mus. carls., III, 61.; -- Pel. nuevius, Lath., Syn. IIl, 104. rl. Sparm., Mus. Carls. I, 10 ; - Pel. pygmaeus, Pall., Voy. App., pl. 1.

() Vieillot wirnal nevök: 'T'uchýpeces, pl. 274.

CUVIEIR 1. $K$. 
A kesely lenge (kesely pellikin, F. Pelecanus aquilus, L. Der Fregatvogel.) Enl. 961. Vieill. gal 274. rl.

Tollazatia fekete, torka s nyaka alatt többé kevesebbé felérrel keverve, csorra veres. Kiterjeszlett szírnya, mint mondjak, néha tiz söt tizenkét lábnyit ölel. $\left({ }^{2}\right)$.

\section{c. AZ OTROMBOK.}

(Les Ious. ou Boubies. Sula, Briss.; Dysporus, Ilig. Der Tölpel.) $\left({ }^{2}\right)$.

Csorrok egyenes, künnyüden összenyomolt, hegyes, hegye gürbuilt, szúlei lürész-fogasak, fogai hátra irányozvák; orrlyukai egy majdnem a hegrig nyulo vomalba mennek át: toliok, mint szemliörök is esupasz, lievessé nyúlékony, a küzépujj korme fürészes; szirnyok sokkal kisebb mint a lengeé, farkok kissé íkes. Otromboknak néveztetnek azon ostobaságert hogy emberek is madarak, legrinkább a lengè által, iildöztetni hagyják magokat, melly utolsoik megrerik öket, hogy halászolt halaik átadására kényszeritsék.

Legközönségesebb :

-1 feher utromb. (Le l'ou de Bassan. Pelecanus bassanus. L.) Enl. 278. Vicill. Brit. Zool. L. rl. Naum. pótl. 56. 105. k.

Fehér; elsö szárnytollai s lábai feketel, csorra zöldes, - majd lud nagyságu. Bassan-i nevét egy kis szigettuil kapta az Edinburgi öbölben, hol igen szaporodik noha egyszerre csak egy tojást kült. 'Télen gyakran eljö

(1) Kissé önkényuileg emelteték faji rangra a Pelec. minor. Edw. 309, s a leucocephalus, Buff. Ois. V1II., xxx. rl. talán = Pelec. Palmerstoni, Lath.

$\left(^{2}\right)$ Sula, Koyer szerint a fehér otromb. neve a Ferói szigete. ken, Clavius, Exot. 36. Boubie, angol, nevök, a booby-tul, melly ostobát, ostrombát jelent. 
partjainkra. A fiatal barna, fehér pontozattal (Enl. 986.) $A z$ utrombok többi fajai nincsenek elég szigoruan meghatározva. ( $\left.{ }^{1}\right)$.

\section{A NYURGANYAKOK. F.}

(Les Anchinga. Plotus. Lin.) ${ }^{2}$ ).

A koromúszéhoz hasonlító testen és lábakon hosszú nyakat, kicsin fejet egyenes, karesu s hegyes csorrot mutatuak, ez utolsónak szélei fogasak; szemeik és arcok csupaszsága kïlönben ollyan mint a torkatágnál, mellynek a nyurganyak szinte szokásait birja, ö is mint azok, tákon fészkelve.

Néhány fajok ismeretes vagy lajlájok a két világ forró tájairul. A ruca nagyságát nem mulják föl, de nyakok hosszabb. $\left({ }^{3}\right)$.

\section{A FÉTONOK. F. HÉHONÁROK.}

(Les Paille-en-queue. Oiseaux du tropique. Phaelon. L. T'ropikvogel).

Megismerhetök két keskeny, igen hosszu, s távolrul szalmaszálhoz hasonlító tollrul farkokban. Fejökön semmi csupasz nincs. Csorrok egyenes, hegyes, fogas, középszerúleg erôs, lábaik rövidek, szárnyaik hosszúk: ennél fogva igen messze is repülnek a mély tengerek fölé, s ritkán hagyván el a forró égall, megjelenésök a heves

(') A. h. a barna otromb., (Pelec. sula, L.) enl. 973. Catesb. I, 87. Vieill. gal. 277.

$\left({ }^{2}\right)$ Anhinga ezen madarak neve a Topinambusoknál, Margrav szerint. Plotus vagy plautus latin, s laposlábat jelent. Klein az hártyás lábu-cs̊aládjainak egyikére ruházta, Linnné a nyurganyakokra.

$\left({ }^{3}\right)$ Plotus melanogaster, cnl. 959 és 960 ; Vicill. gal. 278; Wils. IX, LXXıv, 1, 2; - eul. 107; - Latham, Syn. VI; 96; - Anh. Levaillant, T., col. 380. 
is hïzeletét hirdeti a hajósoknak. A szárazra jobban esak fészkelni jöneks sákra ülnek le.

Csals nehány fiej vaçy fajta ismeretes, fehér tollaza111, tribbé kevesebbe fekeléssel tarka, galambnagyságát fölül nem muló. $\left.{ }^{1}\right)$.

\section{Negyedik család.}

A LEMEZ-CSORRUAK.

(Lamellirustres),

Csorrok vastağ, inkább lágy börrel mint valúságos szaruval takart; szélei lemezekkel vagy apró fogakkal szegrvék; nyelvök széles, husos, fogazott szélü. Száirnyok középszerúen hosszí. Inkább édes vizeken élnek mint tengeren. A legnagyobb számnál a him gögsípja, ketté szakadásánál különbözó idomu tokcákra van földuzadva. Zuzájok nagy, igen izmos, vakbeleik hosszuak.

Elsó nagy nem

A RÉCÉKÉ.

(Les Canardis. Anas. Lin.)

Azou uszhályásokat froglalva magrában, mellyek

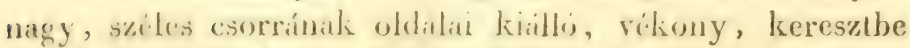
helyezell lemezekled borilvak, arra szantaknak lílszva, hogy a vizet lis hagyjak folyni, mikor zsákmányát megfogta a madár. Hírom aluemre oszlatuak föl, de ezek haLárai mindeddıg nem szigoruak.

(') A repülö fétou. Földi (Phacton aetherchs,) Enl. 36\%,, és 998; - Ph. phoenıcurus, Enl 979. Vicill. gal. 279. 1. 


\section{A HATTYÚk. F.}

\section{(Les Cignes. Cygnus. Meyer. Die Schwäne.)}

Csorrok elül olly széles mint hátul, alapjánál magasabb mint széles; az orrlyukak majd hosszasíga közepén; nyaka igen hosszú. Legnagyobb madarak a nemben. Fökép' a vizi növények magraival s gyökeivel élnek. És igy beleik s királtképen a rakols igen hosszúk. Gégejök nem dagadt:

Europában két faj van

1. A néma hattyu. (Le Cigne à bec rouge. Anas olor. Gm.) Enl. 913.

Csorra veres, feketévcl szegve, alapján gömbölyủ puppal; tollazata hófehér. A fiatal csorra olomszinü, tollazata szürke. Ezen faj teszi megszelidítve tavaink és csatornáink diszét. Mozgásainak gyöugédsége, idomainak kelleme, tollainak ragyogó fehérsége, a szépség és ártatlanság példaképévé tették. Egyenlöen él halakkal és növénvekkel, igen magasan és gyorsan repül, sebesen úszik, szárnyaival a szelet fólfogva, mellyek különben hatalmas fegyver gyanánt szolgáluak neki a megtámadók elleu. Tavakon, uádasokban fészkel, hat vagy nyolc zöldes-szürke tojást tojik.

2. Az énekes hattyu. (Le Cigne à bec noir. Anas Cygnus. Gm.) Edw. 150. Brit. Zool. Q. rl. Naum. 1. kiad. 13. rl. 27. k.

Csorra fekete, sárga alappal, teste fehér, sárgás szürKrével árnyazva, fiatalságában egészen szürke. Ezen faj külsejére igen hasonlít az elóbbihez de belsóleg teljesen különbözils attul gögsípja által, melly visszagörbül és nagy részint behat a mellcsont gerincének egy üregébe, melly különösség mind a két nömmel közös de a házi (néma) hattyunál nem létez. Ezen hattyu vad hatt,yu nevet is vi- 
sel, noha nem eltaláltan. A haldokló hattyunak inclilése mese.

3. A fekete hattyu. (Le Cigne noir. Anas plutonia. Sil. An. atrata. Lath.) Natur. misc. 108. rl. Vicill. gal. 286.

Nem rég úta talúltaték föl Ĺjhollandban; akliora mint a rendes haltyu, de kevesebbé kellemes; egészen fekete, clsö tollait kivére, mellyek fehérek, mig csorra s annak alapján a csupasz bör veresek. $\left({ }^{1}\right)$.

Nem kömyen vílaszhatm el a hallyulíbl bizonyos fajokat; valóban kevesebbé csinosakat, de mellyeknek csorra ugyan ollyan.

Közúlök többeknck csorr-alapjin púp van. A legismeretesbnek neve

4. Spanyol hattyu. F. (Khinai haltyu. I. L' Oie de Gvinée. Anas Cygnoides. L.) Enl. 347.

Udvarainkban neveltetik, hol ludainkkal könnyen tenyészik. Fehéres szürke, köpönyege barna szürke: a hím megismerhetó azon tollas lebbenyrül melly csorra alant csüng, s a csorr alapján lévó nagy pupról.

Egy másik ritkább fajt leirói elsúbben gambiai ludnak neveztek, nálunk illy nerü :

5. A gambiar hattyu. (L' Oie de Gambie. Anas gambensis. L.) Lath. Syn. IIl, p. 2. 1. 102. rl.

Kitünik nagysága, magas szárai, homlokának pupja s azon két sarkantyu által, mellyel szárnyizesülése fölfegyverzell. Tollazata biborfekete. Torka, teste eleje s alja s szárnyai fehérek $\left({ }^{2}\right)$.

(') A kanadai hattyu ( $L$ ' Oie à cravatte. Anas canadensis, L.) Enl. 346 , Wils. Am., Lxvı, 4, szinte valódi hattyunak látszik:

$\left({ }^{2}\right)$ Buffon e madarat összezavarta az egyptusi lud egy fajtájával, enl. 982. Latham úbrázolata hiányos, csak egy sarkantyut mutatván, s a sisak nem elöálló. 


\section{A LUDAK.}

(Les Oies. Anser. Briss. Gänse.)

Csorrok középszerú vagy rövid, elül keskenyebb mint hátul, alapján magasabb mint széles; száraik emeltebbek mint a récéknél, s közelebb állván a test közepéhez, járások könnyebb. Sokan élnek füvel és maggal. A gége egy ismert fajnál sem képez áthajlást.

\section{Tulajdonképi LUDAK.}

Csorrok olly hosszú mint fejök; szélét lemez-hegyek szegik be, hegyes fogaknak látszók.

1. A rendes lud. (L' Oie ordinaire. An. anser. L. Die gemeine Gans.)

Udvarainkban mindenféle szineket kapott, - egy vad fajtul ered, melly szürke, küpönyege barna de szürkével hullámzott, csorra egészen uarancssárga $=$ Anser cinereus, Meyer Albin 90. Naum. I. kiad. 41. rl. 60. k. De van egy igen közel faj, öszszel érkezö meg, farkánál hosszabb szárnyai s homlokának nchány fehér foltja által megismerhetö; csorra narancsszínü, alapjản és végén fekete = Anas segetum, Meyer. Enl. 985. Frisch. 155. Naum. 1. c. 42. fo 61 .

Télen elég gyakran látható:

2. A piszegö lud ( $L$ ' Oie rieuse. Anas. albifrons. Die Bläsggcns.) Edw. 153. Naum. 1. kiad. 43.62. k.

Szürke, hasa fékete, homloka fehér.

A két világrész éjszakán van egy negyedik faj is

3. A hó-lud ( $L$ ' Oie de neige. Anas hyperborea. Lin.) Wils. Am. VIII. LxxiIr. 5. s a fiatal LxIX. 5. Naum.

1. kiad. pótl. 23. rl. 46. k.

Fehér; csorra, lábai veresek, szárnytollainak vége fekete: néha a téli nagy zivatarokban a mi mérsékelt vi- 
dékeinkre is elvetödik. A fiatal többé kevesebbé saürkérel kevert. Ez iz Anas coerulescens, Gm. Edw. 152.

\section{A GUNÁK.}

\section{(Les Bernaches ('). Barnakelgänse.)}

A rendes ludaktul röridebb), vékonyabb esorr által kulinbriznok, mellynek szélein nem láthatik ki a lemezek végei.

E.jszali Europábol hozzánk jö télen azon faj, melly a mese szerint gyümölcsként nöl a fákon, ez

1. A feher arcu lud. (Anas erythropus, (im. vagy job)ban Anas leucopsis. Bechst.) Eul. 85.5; Frisch. 189; Naum. 1. c. 39. f. 77.

Köpönyege hamras, nyatia fekete, homloka, areai. torka s husa fehérek, esorra lekete, lábai szürkék.

2. Az ürves gruna. (Örvüs lud, F. The C'ravant $\left({ }^{2}\right)$. Inas bernicla. (Gm. Die Ringelgans.) Enl. 312. s jobban Frisch. 156. Naum. 1. c. 39. 78. k. Wils. VIII, Lxxı. 1.

Ugyan azon vidékrul. Feje, nyaka, šírnylollai felietèk, köpönyege barna-szïrke, nyaka magasának mindenik odalán egy folt s farka-ala fehérek, esorra fekete, lábai barnák.

3. A fegyveres guna. (La Bernache armée, Oie d' Afrique, du Cap, de Egypte, etc. An. aegyptiaca Gm.) Enl. 379, 982. és 983.

Szineinek ragyogása és stárnyainak kis sarkantyuja

Ide jönek még a csorrturaju bronzos lud, Ipecati apoa. Margr. (Anas melanotos), Enl. 937• Vieill. 235.

(') Barnacle, skot neve az anser leucopsis-nak. Klake ludat jelent skot nyelven.

( $\left.{ }^{3}\right)$ Crawane, elroutya a graue Ente-biil. 
által jeles; ezen alnemhez tartozó még; szelidítve is tenyészthetö, de mindig hajlandó a megszökésre

Ez a Chenalopex, vagy rókalud, a régi aegyptusiaktol amyira tiszlelt, mivel fiaihoz igen ragaszkodik. (1).

\section{A LÜDÉR (Cereopsis. Lath.)}

Ujhollandi madár, igen hasonlitó a gunához; csorra még kisebb, de hírlyája solikal szćlesebb s kissé a homlokri is emellzedik.

Csak egy faj ismeretes

A hamvas lüclér. (Cer. cinereus. Lath.) col. 206. Vieill. gal. 284. Szürke, lud nagyságu.

\section{A RUCÁK, tulajdonképi RÉCÉK.}

Cisorrok kevesebbé magas mint széles az alapnál, s annyira vagy még inkábls széles a vég mint feje felé; orrlyukai a hátához és alaphoz állanak közelebb. Száraik rövidebbek $\mathrm{s}$ hátrább is állván, járásokat a ludakénál nehezebbé teszik; nyakok is rövidebb; gögsipjok âz elágozásnál porc-tokcákká dagad, s ezek közül a balsó rendesen nagyobb.

Az elsö osztatbeli fajok, azaz mellyelnnek hüvelyke hártyával szegett nagyobb fejet, rövidebb nyakat, hátrábbi lábakat, kissebb szárnyokat, durvább farkot, öszszenyomottabb lábtôt, hosszab ujakat s egészebb uszhár-

(') Geoffroy-Saint-Hilaire, a ,Menagerie du Museum d' histoire naturelle"-ben, Aegyptus cikkel alatt.

A. h. An. magellanica, enl. 1006 ; An. antarctica, melly amahoz igen közeli, Mus. Carls. 37. és Voy. de la Coquille, Zool. 50; - An. leucoptera, Brown., 11., 40; An. ruficollis, et torquata, Pall. Spicill., VI. Iv. rl. melly Némethonba is jôni mondatik; An. coromandelica, enl. 949 s 950 ; - An. madagascariensis, enl. 770 . 
tyát birnak. Rosszabbul jírnak, kizáróbban halakat is bogarakat esznek, gyakrabban búknak. ( ${ }^{1}$ ).

Köztök megkülönböztethetök:

\section{A BUKRUCÁK.}

\section{(Les Macreuses. ${ }^{(2}$ ). Tauchenten.)}

Csorrok szélessége s földuzadása últal.

1. A küzünsigges bukruca. (Le Macreuse commune. Anas nigra. Lin. Die 'Traurente.) Eul. 972. Naum. póll. 14; 28 s 29. k. Bril. Zool. Q. rl. 6. Wils. Am. VIII. LXXII. 2.

Egészen fekete, fiatalságában szürkés, csorra igen tereb, s alapján pupol hordi. Nagy csapatokban él, partjaink hosszában, leginkább esigálkkal. A fiatal nöstény = An. cineraceus. Naum. 1. c. 60, f. 91-92.

2. A nagyobb bukruca (Biborruca. La double Macreuse. Anas fusca. Lin. Die Sammetente.) Enl. 956, Frisch. 165. Naum. 1. c. supl. f. 15. 16. Wils. Lxxir. 3.

Amatlul nagyobb termele, szírnyán egy feliér folt és szeme alatt egy fehér ronat által kiilönbözik. Gégeje közepén egy kerekided duzadis van, vizszinüleg meglapitott.

3. A szemkörves bukruca. (La Macreuse à large bec. Anas. perspicillata. Lin. Die Brillenente.) Enl. 995. Edw. 155. Wils. Am. VIII. LXvir. 1.

Fej-hátán s nyaka mögött fehér szint bir, csorra alapjánal csupasz, sárgaböre a szemekel és körvezi.

Ujholland is ad egy lajt, ez

(1) Ezen osztály teszi Brehm Platypus nemét, melly $=\mathrm{HY}$ DRoBates, Temm. vagy Fulica, Ch. Bonap.

$\left({ }^{2}\right)$ A macreuse név talám a manger maigre-tuil jö, mivel sovány ćtelt ad. Flemingnél neve OrDEMIA. 
4. A torongyos bukruca. (Anas lobata. Nat. misc. VIII. 255. 1. Col. 406. ( $\left.{ }^{1}\right)$.

Hullámos, nagy torongy (lebbeny csüng a csorra alatt.)

Külön választhatók :

\section{A KERCÉK (kercerucák.) (Les Garrots. $\left({ }^{2}\right)$. Die Schellenten.)}

Csorrok rövid s elófelé keskenyebb; ezek küzött elölbocsáthatok azon fajok, mellyeknek farrkában a közepsö tollak hosszabbak, s igy a fark hegyes.

Ide tartozók:

1. A jeges kerce. (Le Canard de Terre-neuve. An. glacialis. Lin.) Enl. 1008. Edw. 280. Naum. 52. 76. k. Wils. VIII. Lxx. 1. 2. A fiatal hím. Enl. 999. Naum. 52. 76. k. B. a vén, menyegzöi ruhában, Edw. 156.

Feliér, arcán s nyak-oldalán egy sárga folt; melle, háta, farka, szárnyának egy része feketék. Minden rucáink közötl neki van legrövidebb csorra. Gégéje aláfelé csontosulı, s egyik oldalán mintegy $\mathbf{5}$ négyszegü üveg van, egyszerüleg hártyás, mellyek alatt csontos tokcába duzad.

2. A bohóc. kerce. (Le Canard Arlequin. Anas histrionica. L. Die Kragenente.) Enl. 798. Wils. Am., VIII, LXXII. 4. Edw. 99. Naum. 1. c. 52, f. 77. s a nó (Anas minuta.) 799. Edw. 197.

Hamvas, a hím furcsán tarkítva fehérrel; szemöldö-

(') A. h. An. mersa et leucocephala Voy. de Pallos, franc. ford. v. VI. rl. Naum. pótl. 40. f. 79. 80; - An. brachytera, Lath. Voy. de Freyc. xxxix. rl.

(2) Leach óket Clangula neven nevezi. 
kei, olılalai reresek. Télen mindenik elvetüdik hozzínk de távol idöközökben.

A rendes kercék farka kerels vagy négyszegü.

3. A valudi kerce. (Le Garrot proprement dit. Anas clansulu Lin. Die eigentliche Schellente.) Enl. 802. A liatal (An glancion Lin. (1). Frisch. 181, 182. Nanm. 1. c. 55. f. 81. 82. Wils. Am. VIII. Lxvir. 6.

Foher; fi.je, háta, farka feketék; egr kis folt a szeme cloll s liet szalag a számyán fehérek; esorra feketés. A nö hamvas, feje barna. Seregesen jö éjszakrul téleu, s ntha tavainkon fészkel. Gégéje közepén nagy kitásnlás ran, mellỵek irei meglartják inozgékonyságukat. Kette szaliadísa felé külünösen nỵulik ki. $\left({ }^{2}\right)$.

\section{A DUNNÁK. F.}

\section{(Somateria. Leach. Les Eiders. Die Eidergänse.)}

Csorrok hosszabb mint a kerceke s magasabban menö a homlokra, hol egy lollszeglet által kivígottnak látszik; de elöre szinte keskenyebb.

A lágy dunna. (Dunna lud. F. I' Eider. Anas mollissisima Lin. Die Eiderente.) Eul. 208 és 209. (mind a két nömbeli vén.) Mus. Carls. 39. (3-éves hím.) Továbbí Edw. 98. Wils. Am.. VIII, Xcr, 2. 3. Naum. 64. f. $7 y, 80$.

Fehieres; sapkája, hasa, farka feketék; a nöstény szürke, barnával hullímzoll. Hires madár azon drága pehelyért, mellyet ad, s mellyet a franciák édredon, a né-

(') Glaucion, görög neve egy rucának, szemei szineért neveztetve ugy.

$\left({ }^{2}\right)$ A. h. Anas albeola, enl. 948, = An. bucephala, Catesb. 1, 95; - An. brachyptera, Voy. de Freyc. Xxxıx. rl. 
melek Eiderdune néven neveznek, mi pedig dunna-pehelynek mondhatunk. $\left({ }^{2}\right)$.

\section{AZ INGARUCÁK (INGOVÁROK.) \\ (Les Milouins. Die Moorenten.) $\left({ }^{2}\right)$.}

Széles lapos csorrokon kivül nincs egyéb kitünö jelök. Nálunk több faj van közuilök, s ugy látszik, ezeknek gégéjik najdnem hasonló tágulatokba végzödnek, balrul egy tokcát képezve némi hártyás részben, egy beszegés (cadre) és csont-elágozatok által föntartottat.

1. A közönséges ingaruca. (Le Millonin commun. Anas ferina. L. An rufa, Gm. Die Tafelente.) Enl. 803. Naum. 1. c. 58. f. 87, 88. Wils. An. VIII. XG. 6.

Hanvas, feketével finoman vonalt, feje s nyakmagasa veres: nyakala és melle barnák; csorra vilígos ólom szin. Néha tavaink nádasaiban fészkel. Gégeje majdnem egyenlö átmérót bir.

2. A tollagos ingaruca. (La Millouin huppé. An. rufina.

L. Die Kolbenente.) Enl. 928. Naum. l. c. 32. f. 63. 64.

Fekete, háta barna, oldalain és szárnyain fehér, feje veres, fejtetején a tollak bubbá emelkedtek; csorra veres. Ezen faj a Kaspi-tenger szélein lakik, s néha a szelektül hoztánk is elhozatik. Gégején két cgymásutáni tágulat van, egy tokcán, kivül a ketté ágozásnál.

3. Az éjszaki ingaruca. (Le Millouinan. An. marila. L. Die Bergente.) Enl. 1002. Brit. zool. Q. Wils. Am., VIII. Lxix. 3. Naum. 59. f. 90. A nö (An. froenata.) Mus. Carls. 38. Naum. 59. f. 90. B.

Hamvas, fekelés vonalokkal; feje, nyaka felieték, ha-

(') A. I. An. spectabilis, Sparn. Mus. carls. I1, xxxvı. rl. Edw. 154. Naum., 40 , f. 58,59 .

$\left({ }^{2}\right)$ Leach Fuligula, néven köszönti sket. 
sa s szárnyfoltai fehérek, csorra olomszinii: télen apro csapatokban jö Sibcria nélyébül hozzánk. Eleinte igen vastag gégeje utóbb megvékonyul.

4. Az apró ingaruca. (Le petit Millouin. An. nyroca. Gm. An. leucophtalmos. Bechst. A nöstény, An. africana, Gm.) Enl. 1000. Naum. J. e. 39, f. 89.

Barna; feje, nyaka veres, szírnyán egy fehér folt, hasa fehéres; a him uyak-alán barna kïrr. Némethon ajszaki részében fészliel; hozzunk rilkin jö. Gégeje küzípen hasas.

5. A bubos ingaruca. (Bubos ruca. F. Le Morillon. Anas fuligula. L. Die Reiherente.) Enl. 1001. Frisch. 171. Naum. 1. c. 56. f. 83. 84. Wils Am. VIII. LxVII, 5. $\Lambda$. fialal cnl. 1007. An. scandiaca. Frisch VI. xxxvi. 1. 2.

Fekete; a fejhát tollai bubbá hosszúltak, hasa és szárnyiun egy folt fehórek, csorra ilomszín. Éjszakrul telenként rendesen eljó hozzák. ( $\left.{ }^{1}\right)$.

A második föloszlúsbeli RtCák $\left({ }^{2}\right)$ hürelỵe nincs hárlyáral szegre, fejök kisebb, vekonyabb, lábaik kevesbbe szílesck, nyaliok hasszabb, esorrok egyenlöbb, testök kevesbbe tönölt; jobban is járnak; vizi növényeket és azok magrail eszik, szinte mint halakat s más állatokat. Ligy látszik, logy gégejük tígulatai azonnemü csontos és porcos anyagbul állanak.

Ezck liözt is némi föloszatásokat állithatni föl.

(1) A. h. ezen idegen fajokat: An. spinosa, enl. 967, 968; An. Stelleri, Pall. Spic., VI. V. rI. - An labradora, Wils. VII. Lxix, 6. - An. valisneria, uo. Lxx, 5. - An. rubida, uo. Lxxi, 5, 6. mellybol Bonap. K. az OxYuna alıemet csinálta, hecyes faika miatt.

$\left({ }^{2}\right)$ Bonap، K. eze fölosztisuak adva az ANAs nevet. 
A KANÁLRUCÁK. ( ${ }^{1}$ ).

\section{(Les Souchets. Löffelenten.)}

Igen jelesek csorrok miatt, mellynek felsö lemeze tökélyesen félhengerbe lıjıva végén kiszélesült. Lemezei olly hosszuik és vékonyak, hogy inkább szemszörökhöz hasonlitanak. E madarak férgekkel élnck, mellyeket az iszapbul szednck ki a csermelyek partjain.

1. A küzönséges kanálruca. (Kalcinos ruca. F. Le Souchet commun. An. clypeata. Lin. Die gem. Löffelente.) Enl. 971. 972. Frisch. 161. 162. 163. Wils. Am, VIII, LXVII. 7. Naum 49. f. 70. 71.

Igen szép ruca, feje nyaka zöld, melle fehér, hasa veres, háta barna, szárnyai fehérrel, hamvassal, zölddel és barnával tarkák. Hozzánk tavaszszal jö. Húsa jeles. Gégeje aljának tágulísa igen csekély. Ez Pliniusnál a Chenerotes.

Új-Hollandban találtatik egy faj

2. A szegélyes kancilruca. (Anas fasciata.) Sh. Natur. miscell. 697. rl.

Felsö csorrlemezének szélei mindenik oldalról hártyás toldalékba nyulnak el.

\section{A KÁCSARUCÁK. (KÁCSÁK.) (Les Tadornes. Brandenten.)}

Csorrok vége felé igen lapítolt, alapján dagadt puppá emelkedik.

1. A közönséges kácsaruca. (Le Tadorne commun. $\left({ }^{2}\right)$.

(') Leachnél ezeknek neve: RryncAspis.

(2) T'adorne ezen madár neve Bélon-nál. Buffon, Turner szerint, azt hivé, de hibásan, hogy ez a régiek Chenalopex-e vagy $V u l p a n s e-e . L$. fülcbb az aegyptusi ludat (fegyzeres guinát.) 
Die Brandenten.) Enl. 53. Frisch. 166. Naum. 1. 55. f. 103. 104.

Minden rucáink käzzötl legvidámabb szinzetü: Cehér, feje zöld; fahéj-veres kürr a mellín, szárnyai, feketével, fehérrel, zöld-és veressel tarkák. Közönséges az Éjszaki s Balti-tenger partjain, hol a förnypartokban s az elhagyott tengeri nyul-lyukakbau lészkel. Kettégzása két kevessé különbözö csontos tokcává tágul.

Másoli ezen másodili löloszlásbeli rucálibril esupas\% helyeket birnak fejökin s gyakran pripot is csorrok alapján.

2. A pezsmás kicicsa. (Pésma rura F. Le Canard musqué

Anas muschata. I. Die Bisamente.) cul. 989, rendesen, de rosszul, berber vagy török ruca.

Amerikíbol eredt, hol vadon ma is találtatik, hol läkon ül: naggsága miall igen szaporittatik majorságainkban. Kömyen párosodik a rendes kácsával. 'Tokcája igen nagy, körekded, vizszinüley lapiloll s egészen baloldali.

Némellycknek farka hegyes.

3. A hegyes kcicsa. (Le Pilet. In. acula. Die Spiesente. Enl. 95.1. Wils. Am., VIII, Lxvin. 3. Frisch. 160. 168. Naum. 51. f. $74,75$.

Fölül s oldalríst hamvas, finom fekete sugárzallal, alul feher, feje cserszinü, stb.; gége-lokcája kicsiny.

Másoknál legalább a him néhány fökukorodott tollat bir a farkíban.

4. A rendes (haizi) kciesa (Kricsa. ruca. F. Le C'anard. ordinaire. An. boschas. L. (1). Die gemeine Einte.) Enl. 776, 777. Wils. Am., VIII, LXx. 7. Frisch. 158. és 159 .

Ismertetó jelci: hajnalsárga lábak, sárga csurr. frje s

(') Boưas, görög neve a kácskámak. 
larcsika a himmck szép játszéliony zöld stb. Udvarainkban ugy változlalja színét mint többi házi állataink. A vadkáesa, közönséges mocsárainkbau, nádasainkbau vén füztörzsökökben néha fálion fészkel. Gégeje alaut nagy csontos tokcába végzódik.

Különös fajta

A görbecsorru kácsa. (Le Canard à bec courbe. An. adunca L. Die krummschnüblige Ente.)

Vannak bubos fejü, s elül kissć keskenyebb csorru kácsák is, idegegen honbul jövök, de majd minden nagyobb állat-tárakban láthatók.

5. A khinai kácsa. (Le Canard de la Chine. An. galericulata. L. Enl. 805. 806. Vieil. gal. 287. Die chinesische Kragenente.

Himének még szélesült és függóleg fölemelt szárnytollai vannak.

6. A kíroliniai kcicsa. (Le Canard de Caroline. An. sponsa. Lin.) Enl. 980. 981. Wils. VIII, Lxxvir. 3.

'Tokcái középszerüek, kerekdedek. (Legszebb minden rucák közölt; érc-zöld fejü, lecsüngö búbbal, háta s farka is zöld; torka fehér, melle s fejháta sötét violaszin barna, melly alatt oldalvást egy fehér és fekete félhold; szárnyain szép violakék tükör, stb.)

Más szinte idegen fajoknál a kácsa-csorr mellet a szárak hosszabbak még a ludénál is; fákon ïlnck és fészliclnek. ( $\left.{ }^{1}\right)$.

Ezen számban van egy, mellynek talpa csak félig úszhártyás. $\left({ }^{2}\right)$.

(') An. arborca; cnl. 804; - An. autumnalis, 826; - An. viduata, enl. 808.

() An. semipalmata, Lath.; Cuv. Mém. du Mus. (V11.) köt.; (XIX) $\mathrm{rl}$.

CUVIER I. K. 
Vérre még a semmi liülönösséget nem mutatek kozul találtatik nálunk, kivált télen

7. I csörgö kicsa. (Csörgö ruca. F. Le Chipean ou Ridenne. An. streperc Lin. Die Schnatterente.) Enl. 958. Naum. 1. c. 45. f. 65. Wils. Am., VIII, Lxx. 1.

Felictésscl hullímolt és finoman sugárzolt; szárnya veres, egy zöld is egy fehér folttal. Gégetokja kiesin.

¿. I sipus kicicsu. (Tie Siffleur. Anas Penelope. Linné.

Die Pfeifente.) Enl. 825. Frisch. 164. 169. Naum. £. 7.2. 73. $\left({ }^{3}\right)$.

Feletéssel linoman sugarolt, melle borrerhenyes, feje veres, homloka lialaviny, szírnyán fehér, zöld és fekete szin van: grégetokja kerelided, középszerï s igen csontos. (4).

\section{A КА́CSKÁK, КАCSOGÁK.}

(Les Sarcelles.)

A kácsák alneméhez tartozó apró fajak.

1. Arendes kicicsuga. (La Sarcelle ordinaire. An. querquedula. Dic Knäkente. F'elelö ruca. F.) Enl. 916. s a rén hím (An. circia.) Frisch 176. Naum. 47. f. 66. 67 .

Szztrie alipjon felietével hullámzott, szeme koruls mogolt egy feher vonal, stb. Közonséges a tuvakon, mocsúrokon, stb. Gégctokja livirteképü csont-lágulat.

2. Az apró kacsogar. (La petit Sarcelle. An. crecua. L.

(') Penelops, görög neve egy veres fejü récénck, $=\mathbf{a}$ sipos $k \dot{a}$ csa v. ingaruca.

$\left({ }^{2}\right)$ A. h. An. rutila, Pall, Nov, comm, petrop. XIV. Xxil.; An. cana et casarca, Brown. Ill. 41. 42 ; - An. paecilorhyncha, Ind. Zool. xıv. rl.; - An. americana, (le Jensen) enl. 955. Wils. VIII, Lxix, 4; - An. bahamensis, (le Marec.) Catesb. 93; - An. cbscura. Wils. VIII, Lxxir. 5; - An. arcuata, Gm. (paturi) Spix. C. 
Die Krikente.) Enl. 947. Frisch. 114. Naum. 48 f. 68. 69. Wils. Am. VIII. Lxx. 4. Brit. Zool. Q. rl.

Finoman feketésen sugarozva, feje veres, egy zöld szalag szeme mögött, két fehér vonallal szegve stb. A tokca, mint egy borsó. ( $\left.{ }^{1}\right)$.

Utolsó nem

\section{A BUVÁroK-é.}

\section{(Les Harles Mergus. Lin. Der Säger.)}

Azon fajokat foglalja magában, mellyeknek csorra véksonyabb, s hengerübb a récekénél, s mindenik lemezének egész hosszában apró hegyes fogakkal fegyverzett, fürész idomuakkal s hátra irányozva, a felsó lemez vége görbe. Idornuk sót tollazatuk is majd mint a tulajdonképi récéké; de zúzájok kevesebbé izmos, beleik s vakbelök rövidebbek.

A hímek al-gégéjének tágulata igen nagy s részint hártyås. Tavakon és pocsolyúlkon élnek, hol sols kárt tesznek a halakban.

Franciaországba télen három faj szokott jöni, de ezels tollazatok változása mialt megszaporíttattak a vizsgálók által. Azt mondják, éjszakon fészlkelnek sziklúk között vagy nádasokban, és sokat tojnak.

1. A lïzönséges buvair. F. (Le Harle vulgaire. Mergus merganser. L. Der Gänsesüger.) Enl. 951. Naum l. c. 61. f. 93. Brit, zool. N. rl. Frisch 190. Wils. Am., VIII, LxVIII. 1.

Ruca nagyságu; csorra, lábai vercsck. A vén hím feje sötét zöld, s annak tetején a tollak fölemelkedve némi

(1) A. h. An. discors, cnl, 966. és 403.; - An. manillensis, Sonn, 1-er Voy., LV. rl.

Sarcelle, vagy cercelli a qucrqucdula, nćvtïl jo, melly a maJár kiáltásátul cred. 
ustököt képeznck; köpönyege fekctés, lehér folthal a szairnyán; nyaka alul fehé, rózsaszinnel könnyen befillatva. A lialal s a nöstćny (Mergus custor, Enl. 953. Frisch. 191. Naum. 61. f. 93. B.) szürkék, fcjök veres.

2. A bubos buvar. F. (Le Ilurle huppé. Merg. serralor. L.) Enl. 207. Edw. 95. Naum. I. c. 61. f. 90. Wils. An. VIII, LXIX. 2.

Csorra, Jábai veresck, tesie litilönbözöleg tarhítra leLete-fchér-és barnával, feje fécte-züld, csïngö bub a lijhálon. A fialahnál és jércénćl (Hlarles noirs, H. à manteau noir. Naum. 62.95. k.) barna a fej.

3. Az apró buvior. (La P'ielle; Nonnelle; pelil Marle. Merg. allellus. Lin.) Enl. 119. Frisch. 172. Naum. 63 f. 97. Brit. Zool. N. r. 1. Wils. An. VIII. xgí. 9.

Csorra, lábai kéliek, maga fehér, kïpönyegén ku-

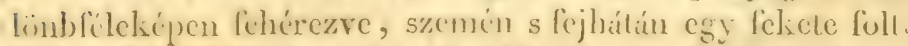

A fialal himeks a jercók (Merg minulus, muslelinus. ctc. cul. 150. Bril. zool. N. rl. 2. Naum. 63. 98. k.) szürkék, veres fejück. ( $\left.{ }^{1}\right)$.

(') Az ielesen huvárol hozill alïg van tobl, jól megállapilva,

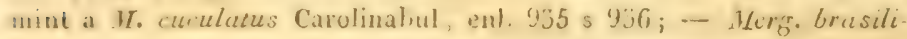
ensis. Vicll, gal. 283. 





SMITHSONIAN INSTITUTION LIBRARIES

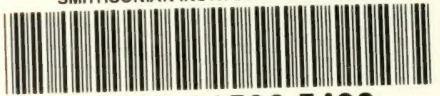

39088015065493 